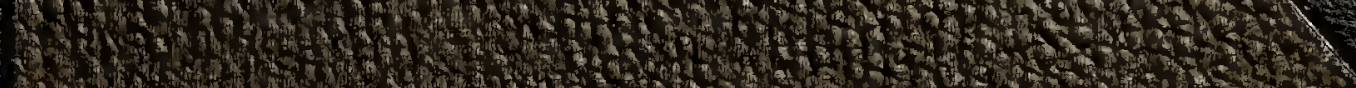

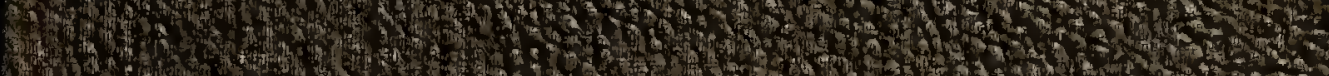

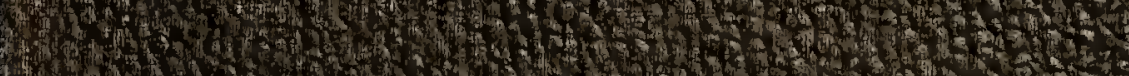

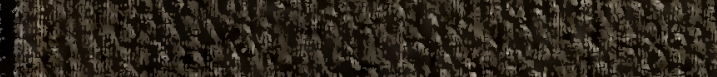

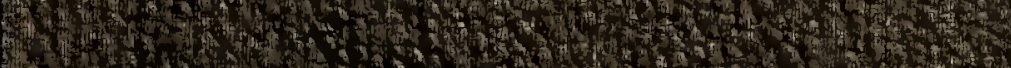

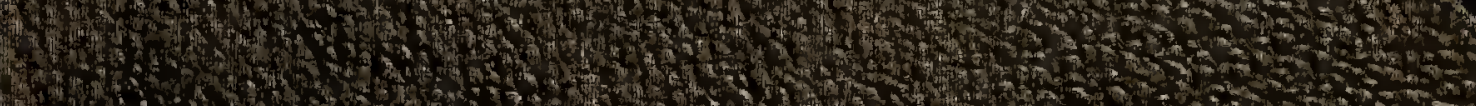

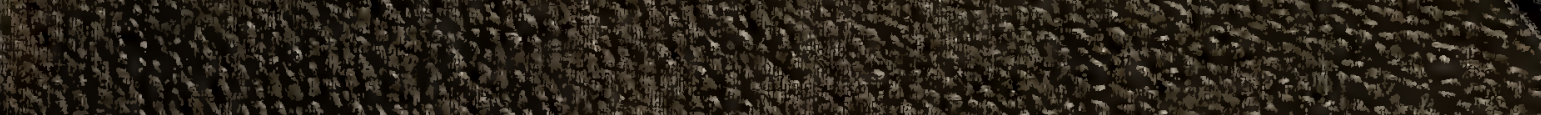

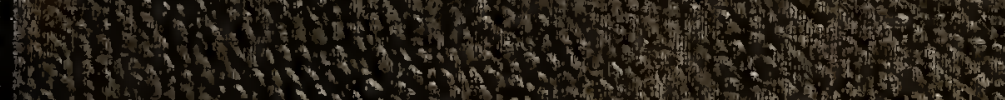

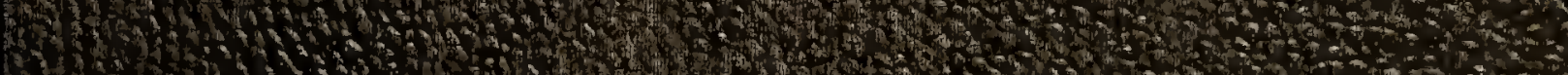

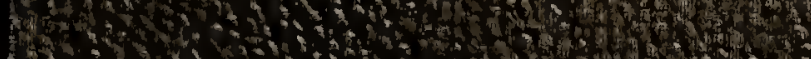

3
3
1

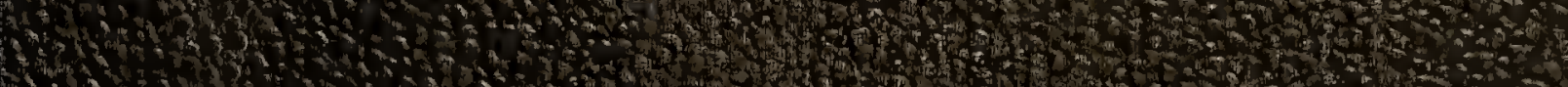

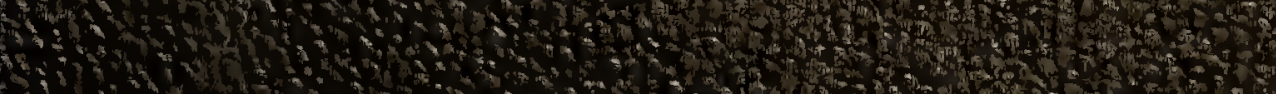

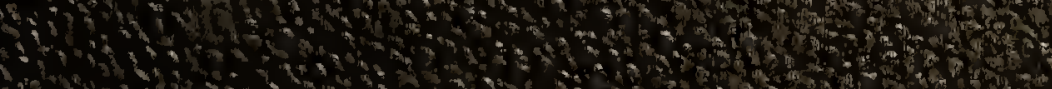

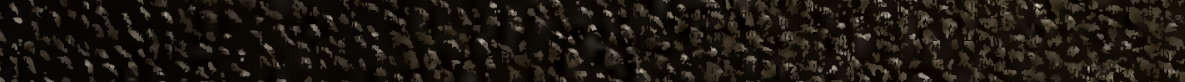

(1)

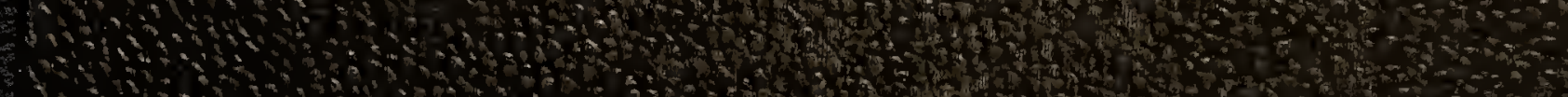

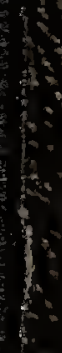

a

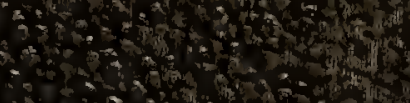

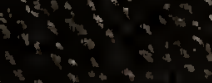




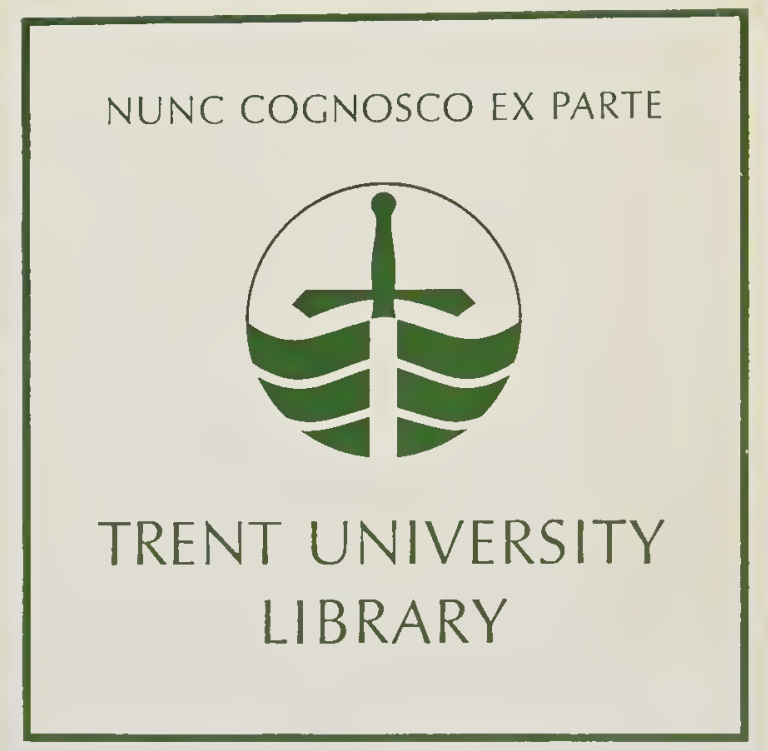

PRESENTED BY

Mrs. H.H. Graham 
Mitt of Mrs. K.A. Houkan 
Digitized by the Internet Archive in 2019 with funding from Kahle/Austin Foundation 




\title{
THE
}

\section{BRITISH MOSS-FLORA.}

BY

R. BRAITHWAITE, M.D., F.L.S., \&c.,

SOCIO CORRISY. DELLA SOCIETÁ CRITTOGAM. ITALIANA.

VOL. II.

\section{ACROCARPOUS MOSSES.}

\author{
"The means therefore which unto us are leut, \\ Him to behold, is on His workes to looke, \\ Which He hath made in beautie excellent: \\ And in the same, as in a brazen booke, \\ To read enregister'd in every nooke \\ His goodnesse." \\ Spenser.
}

EOHDon:

PUBLISHED BY THE AUTHHOR, AT 303, CLAPHAM ROAD.

All Rights Reserved. 



\title{
BRITISH MOSS-FLORA.
}

\author{
VOL. II. \\ A C ROCARPI II.
}

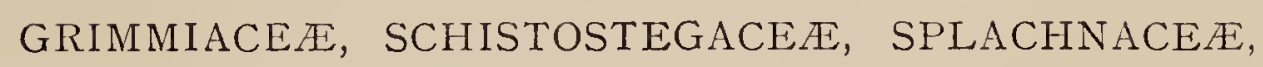
OEDIPODIACEÆ, FUNARIACE⿸, BRYACEÆ, BARTRAMIACEÆ， MEESEACEÆ， MNIACEÆ.

R. BRAITHWAITE, M.D., F.L.S., \&c.

(SOC. CRITTOG. ITAL.-SOC. PRO FAUNA ET FL. FENN,-SOC. NAT. DES SCIEN. NAT. DE CHERB. SOC. CORRESP.)

\section{LONDON :}

L. REEVE \& CO., 5, HENRIETTA STREET, COVENT GARDEN. I $888-1895$. 
QK $=43 . K 81887$ v.R 
G R I M M I A C E A. 
GRIMMIA EHRH.

1. Grimmia conferta Funck.

2. ——apocarpa (L.) Hedw.

3. - maritina Turn.

4. anodon Br. Sch.

5. crinita Brid.

6. - incurva Schwaeg.

7. __ funalis (Schzeacg.) Schp.

8. - torquata $H s c h$.

9. —— Stirtoni Schimb.

10. __ Muehlenbeckii Schimp.

11. — pulvinata (L.) Sm.

12. —— orbicularis Bruch.

13. —— trichophylla Grev.

14. - Hartmani Schimp.

15. — subsquarrosa Wits.

16. - decipiens (Schultz) Lindb.

17. _ _ elatior Bruch.

18. Donii Sm.

19. - alpestris Schleich.

20. - montana Br. Sch.

21. - ovata Wcb. Mohr.

22. —— ovalis (Hcdw.) Lindb.

23. - elongata Kaulf.

24. —— microcarpa (Ginct.) Lindb.

25. - campestris Burch.

26. - atrata Mielich.

2\%. unicolor Hsch.

28. —— elliptica (Turn.) Arn.

29. - patens (Dicks.) Br. Sch.

30. — acicularis (L.) C. Mucll.

31. aquatica (Brid.) C. Mucll.

32. —_ obtusa (Sm.) Lindb.

33. - affinis (Schlcich.) Lindb.

34. - heterosticha (Hed.) C. Mucll.

35. - ramulosa Linclb.

36. —— fascicularis (Schrat.) C. Mucll.

37. hypuoides (L.) Lindb.

38. _- canescens (Timm) C. Mucll.

COSCINODON SPRENG.

1. Coscinodon cribrosus (Hcd.) Sprucc.

GLYPHOMITRIUM BRID。

8. Glyph. Daviesii (Dicks.) Brid.

2. - polyphyllum (Dicks.) Mitt.

3. - saxicola ( $W c b . M o h r)$ Mitt.
ANCETANGIUM HEDW.

1. Anœet. Lapponicum Hcdw.

2. Mougeotii (Bruch) Lindb.

PLEUROZYGODON LINDI.

1. Pleuroz. æstivus (Hed.) Lindb.

ZYGODON HOOK. TAYL.

1. Zygodon Stirtoni Schimp.

2. - viridissimus (Dicks.) $\mathrm{Br}$.

3. conoideus (Dicks.) H.T.

4. —— Forsteri (Dicks.) Wits. -

5. gracilis Wits.

ORTHOTRICHUM HEDW.

1. Orth. obtusifolium Schrad.

2. - - rupestre Schleich.

3. -... Shawii Wils.

4. —— affine Schrod.

5. —— speciosum Nics.

6. - striatum $(L$.

\%. L_— Lyellii Hook, Tayl.

8. - diaphanum Sclirad.

9. —— cupuiatum Hoffm.

10. - anomalum $H c d w$.

11. rivulare Turn.

12. - Sprucei Mont.

13. - stramineum $\mathrm{Hsch}$.

14. - Schimperi Hamm.

15. —— pallens Bruch.

16. — tenellum Bruch.

17. _... pulchellum Brunt.

WEISSIA EHRH.

1. Weissia Americana ( $P . B e a w d$.$) Lindb.$

2. —— coaretata (P. Bcauv.) Lindb.

3. - Drummondii ( $H k, G r e v)$ Lindb.

4. __ Bruchii (Hurnsch.) Lindb.

5. —u ulophylla Ehrler.

6. vittata (Mitt.) Brotithe.

\%. __ phyllantha (Brid.) Lindo. 


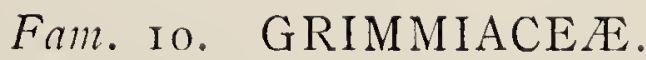

Plants tufted in small cushions, or in large lax mats, the stems repeatedly dichotomous. Leaves pluriseriate, ovato-lanceolate, dull green, opake, lower cells hexagonal or linear, frequently with the inner wall sinuate, upper minute quadrato-rotundate, highly chlorophyllose. Capsule on a straight or arcuate seta, erect, usually equal. Calyptra mitræform, enclosing the whole or part of capsule, rarely cucullate, smooth or sulcate, often pilose. Peristome rarely none, single or double, teeth plane, rarely filiform. Male infl. gemmiform. Inlabiting rocks and stones or the bark of trees.

This great family, including about 700 species, falls naturally into tro groups, of which Grimmia and Orthotrichnnn are the types; and as in both genera considerable uniformity exists in the leaves, we require to have good fruiting specimens for their satisfactory determination, as the calyptra and seta in Grimmia, and the peristome and stomata on the wall of the capsule in Orthotyichum are of prinary importance.

The species of Grimmia have a distinctive aspect in their grey tufts, very often hoary with the white hairpoints terminating the leaves, or they form black fragile patches on the exposed rocks of the higher mountain regions. I have followed C. Mueller, Mitten and Lindberg in uniting Rhacomitrium with Grimmia, as the linear crenulate leaf-cells regarded as characteristic of the former genus, will be found appearing in many species of the latter.

Orthotrichum also has a peculiar habit which is soon recognized, though the Schistillium section of Grimmia closely resembles it. The stems are pulvinate or crowded into depressed tufts, dichotomonsly fastigiate-brancled, short and erect, or longer and decumbent or creeping, as is more especially the case in the vast exotic genus Macromitrinm (which comprises one-third of the whole family), and also in Schlotheimia and Drummondia. The leaves are often cirrhato-crispate when dry, patent or squarrose when moist, hardly ever hoary at point, oblonglanceolate, entire and papillose, the vaginula ochreate and often pilose, the calyptra mitræform or subcylindric, longitudinally plicate, rarely smooth, the capsule erect, immersed or somewhat exserted, with a tapering neck, costate or striate; peristome very rarely none, simple, of 8 bigeminate or 6 geminate broadly lanc. teeth, very often with an endostome of 8 or I 6 cilia alternating with them. The great variability of the peristome has struck all writers, and shows how insufficient this organ is of itself to afford generic characters. 
In both divisions transverse sections of the leaves are of the greatest importance in showing their structure, and it will thus be seen that the margin is often thickened by the cells being in two layers, though, in some cases, it is only a single row of cells which is double. Chalubinski's "Grimmiex Tatrenses" is a splendid monograph of the species found in that part of the Carpathians.

Subf. I. GRIMMIEAE. Densely tufted, pulvinate, or taller and cæspitose, dichotomous ; leaves ovato-lanc., opake, often hair-pointed, upper cells minute, rounded or hexagonal, smooth or weakly papillose, lower elongated or linear and sinuose. Calyptra mitræform, rarely cucullate, smooth or sometimes plicate. Caps. erect, on a straight or arcuate seta; peristome simple, very rarely none; teeth lanceolate, papillose, entire or lacerate or lacunose or in filiform segments.

\section{GRIMMIA Ehrh.}

Beitr. i, $\mathrm{r}_{7} 6 .\left(\mathrm{r}_{7} 8 \mathrm{I}\right)$.

Mosses growing in small cushions or tufts, generally rooting only at base, innovating below the fertile apex. Leaves crowded in $5-S$ rows, patent, lanceolate, usually passing into a white hair, teretenerved, with the margin narrowly incrassate-limbate, entire, very rarely eroso-denticulate at point, minutely papillose, toward apex quadratoor hexagono-areolate, opake and often bistratose, at base wider, hexagono-rectangular, linear, sinuoso- or tuberculoso-linear, towards margin rectangular. Calyptra small conic lobate, covering only the operculum, or larger mitræform and lacerate at base, lobato-cucullate or cucullate, smooth or with a rough beak. Capsule erect, cernuous or pendulous, peristome very rarely none, simple, teeth $\mathbf{r} 6$, transversely articulated, lanceolate, entire, cribrose, cleft or with filiform legs, papillose, purple, hygroscopic. Inhabiting rocks and stones.-Der. after J. F. C. Grimm, a pliysician of Gotha.

This genus comprises about I 50 species, varying greatly in size from little dense cushions one-third of an inch high, to the great mats of G. hypnoides, whose stems attain a length of 8 inches. The dingy colour of the leaves, tipped with long or short white hairs is their most striking feature, and it will be noticed the latter is not due to the excurrent nerve, but to absence of chlorophyl from the leaf point.

\section{Clavis to the Species.}

Sect. I. SCHISTIDIUM. Capsule immersed, wide mouthed; lid falling with the columella attached.

Upper leaves hyaline at point, margins revolute.

In small dense cushions, soft, lurid green.

In laxer cushions, more robust, coarse, fuscescent.

All leaves muticous, margins plane.

conferta. apocarpa. maritima. 
Sect. 2. EUGRIMMiA. Plants short, in rounded cushions, capsule exserted, small-mouthed; teeth lanceolate, cleft or perforated. Leaf cells rounded-quadrate above, elongate or rectangular at base.

Capsule ventricose on one side, immersed, on a very short curved seta.

Capsule symmetric, exserted.

Seta curved.

Seta straight.

Calyptra mitræeform, capsule gymnostomous.

$$
\text { cucullate, capsule peristomate. }
$$

Leaves curled and incurved when dry, subulate.

Leaves spirally twisted when dry.

Hair point long, lower cells sinuose.

short, lower cells elongate oval.

Autoicous.

Tall, laxly tufted, leaves gradually ending in a longish hair.

Short, densely pulvinate, leaves suddenly hair-pointed. Calyptra mitræform.

Dioicous. cucullate.

Leaf-margin plane.

Leaves not narrowed at base, hair nearly smooth. narrowed at base, hair rough.

Leaf-margin recurved.

Tall, robust, naked at base.

Leaves distant, hair point very short.

- dense, hair point longer.

Short, slender, leafy to base.

Basal cells rectangular, not sinuose. Basal cells short, hair rough. longer, hair smooth.

anodon.

crinita.

incurva.

funalis.

torquata.

decipiens.

pulvinata. orbicularis.

Stirtoni.

Muehlcnbcckï.

Hartmani.

elatior.

subsquarrosa. trichapliylla.

alpestris.

montana.

ovata.

Taller, laxly tufted.

Leaves substriate at base, lid conic, obtuse

alyptra nitræform.

Very short, densely pulvinate, capsule pale.

Taller, laxly tufted, capsule brown.

Hair nearly smooth.

Grey-green, hoary, hair long.

Basal cells narrowly rectangular.

Fuscous-black, hair very short.

Hair rough and spinulose.
Donï.

ovalis.

microcirpa.

elongata.

campestris.

Sect. 3. DRYPTODON. Plants tall, regularly dichotomously branched and fastigiate; teeth more deeply cleft, lower leaf-cells often sinuoso-crenulate.

Caly ptra cucullate.

Leaves lanceolate, rather acute.

- lineal-ligulate, obtuse.

atrata.

unicolor.

Calyptra mitræform.

Short, seta straight.
Taller, seta arcuate.

elliptica.

patens.

Sect. 4. TRICHOSTOMUM. Plants tall, robust, with numerous short lateral often fasciculate ramuli ; lower leaf-cells narrow, sinuose-crenulate; teeth cleft into two filiform legs.

Leaves muticous.

Leaves short, broad, very obtuse.

acicularis.

Tall and robust, lower cells long, nodulose. Upper cells quadrate.

aquatica.

hort, lower cells short, sinuose.

fascicularis.

obtusa. 
Leaves with hyaline points.

Hyaline point very short.

Upper cells rotundate-quadrate.

Hyaline point sinuose.

Leaves smooth.

Hair point denticulate.

Leaves papillose on both sides.

affinis.

ramitilos $\alpha$.

heterostiche.

hypnoides.

canescens.

Sect. I. SCHISTIDIUM (Brid.) Capsule smooth, wide-mouthed, on a very short straight seta, immersed in the perichætium; lid cupulate, rostellate, falling with the columella attached; calyptra small, mitræform, lobed, scarce covering lid.

\section{GRIMMIA CONFERTA Funck.}

Autoicous; dwarf, densely tufted. Leaves ovato-lanc., very densely areolate, uppermost with short hair points, margin recurved below. Caps. ovato-globose, leptodermous, fuscous ; teeth broadly lanc., orange-red, rimoso-cribrose. (T. XLVI, A.) Syn.-Grimmia pulvinata Swartz Summ. veg. scand. 39 p.p. (I8I4). Hartm. Skand. fl.
I-4 edd.

Grimmia conferta Funck Moostasch. I8, t. I2 (I82I). NeEs Hornsch, Bry. germ. ii, P. I. I 5 , t. I9, f. 5 (I827). Hueben. Musc. germ. I69 (I833). De Not. Syllab. 239 (I838). Hartm. Skand. fl. 7 ed. 37 I (I858). Schimp. Synops. I99 (I860), 2 ed. 239. ZetTerst. Rev. Grimm. scand. 48 (I86I). MILdE Bry. siles. I43 (I869). HoBk. Syn. br. m. 77 (I873). Juratz. Laubm. oester-ung. I5 I (1882). LesQ. James Mosses N. Amer. I35 (I884).

Grimmia apocarpa var. conferta SpReng. (L.) Syst. veg. I6 ed. iv, P. I, 153 (IS27). C. Muell. Synops. i, 777 (I8+9). Chalub. Grimm. Tatr. 23 (I882). Husn. musc. gall. 124 (I886). Bovlay Musc. Fr. 392 (I884).

Grimmia cribrosa Funck MSS.

Grimmia glacialis NeES Hsch. op. c. II8, t. I9, f. 6.

Grimmia fusca NeEs Hsch. op. c. I20, t. I9, f. 7 .

Schistidium confertum BR. Scr. Bry. eur. fasc. $25-28$, p. 7, t. 2 (I845). Aosgst. in Fries Summ. veg. scand. 93 (1846). Rabenh. Deutsch. kr.fi. ii, s. 3, I5t (I84S). Wils. Bry. br. I49, t. $44\left(I_{55}\right)$. BERL. Handb. br. m. 244 (IS63). DE Not. Epil. Bri. ital. 7 I 3 (1869).

Autoicous; pulvinate or in dense small tufts, readily falling apart, dull dark green above, brown or blackislı below, radiculose. Leaves when dry erect, appressed, when wet suddenly recurved, then erectopatent, ovato- or oblongo-lanc., margin recurved below, nerve ending before or at the point, or in the upper leaves excurrent as a short broad liair, areolation very dense, upper cells minute, quadrate, opake at a pex, the basal rectangular; perich. bracts larger, broader, liair-pointed. Calyptra mitræform, lobed, covering lid only. Caps. immersed, leptodermous, fuscous, ovato-subhemispheric, lid convex, acutely apiculate, of same colour as capsule, annulus indistinct, teetl of per. 
[Grimmia.

broad, lanceolate, orange, papillose, rimoso-cribrose. Male infl.small, gemmaceous, in the axils of comal leaves.

HAB.- Trap or sandstone rocks; rare. Fr. 3-4.

Arthur's Seat, Edinburgh (Greville I847)!!

VAR. $\beta$. pruinosa (Wils.)

More rohust, in blackish tufts. Leaves broader, the upper gradually ending in long smoothish hairs; perich. bracts larger, distinctly papillose. Teeth of per. rufolis-orange, more lanceolate, often reflexed against the capsule.

Syn.-Grimmia prininosa Wils. MSS. Schimp. Synops. 2 ed. 24I.

Grimmia conferta Var. incala Braithw. in Journ. Bot. I872, p. I95. HobK. Syn. 77.

Grimmia apocarpa Var. pruinosa Huss. musc. gall. 123.

HAB,-Bowling, Glasgow (McKimlay I865)!! Largo Law and Dunbarnie Links, Fife (Howie 1863)!! Downe, Perth (McKinlay). Cavehill, Belfast, and Rathlin Isi. (Stewart I882)!! Mourne Mtns. (Lett I883).

As will be noticed several good bryologists unite $G$. conferta with $G$. apocarpa, and with some reason as the differences are not very important, still there are several which induce us to keep them apart. These are in $G$. conferta the sniall size and densely pulvinate habit of growth, dark green leaves, with the apex plane and more minute reticulation, and nerve more prominent at back, the orange rimoso-cribrose teeth, which are more fragile and fugacious.

Schimper's var. obtusifolia is only a form with blunt-pointed leaves, and $G$. primosa may perhaps be regarded as the transition to the next species.

\section{GRIMMIA APOCARPA (L.) Hedw.}

Autoicous; laxly cxespitose, free from radicles. Leaves broadly lanc., with short hair-points or muticous, the margin strongly revolute. Caps. pachydermous, rufous, teeth deep red, subentire. (T. XLVI, B.)

Syn.-Muscus trichoides, capitulis apodibus, foliis angustioribus Doodï RAY Synops. 2 ed. 339 (I696), Hist. iii, 39, n. 3 (I 704 ).

Muscus apocarpos hirsutus saxis adnascens, capitulis obscup rubris Ray Hist. ii, 40, 11. Io. Sphagnmm canliforum et ramosum saxatile lirsntum virescens, capitulis obscure rubris Dill. Cat. Giss. 229 (I 7 I9), in Ray Synops. 3 ed. IO4 (I724).

Sphagnum subliirsutum obscure zirens capsulis rubellis Dill. Hist. musc. 245, t. 32, f. 4 (I 74I) et Herb.

Bryum a pocarpum L. Sp. pl. III5 (I753), Syst. nat. ii, 70I. Huds. Hl. angl. 403 (I762). Oeder Fl. dan. t. 480 (I 769$)$. Weiss Crypt. Goett. I79 (I770). Neck. Meth. musc. I 99 (I 77 I). With. Bot. arr. br. veg. ii, 670 (I 776). Lightr. Fl. scot. ii, 716 (I777). ReLhan Fl. cant. 402 (I785). VILl. Pl. Dauph. (I786). Schmid. Ic. pl. rar. Man. II. t. 57 , f. I (I795). Hoffm. Deutsch. fl. ii, 30 (I795). AвbotT Fl. bedf. 236 (I798). Hull Br. f. P. II, 253 (I799).

Bryum apocarpum Var. virens EHRH. Hann. mag. I780, p. 236.

Fontinalis apocarpa Web. Spic. fl. gott. 38 (1778). SWARTz Meth. musc. 366 (178r).

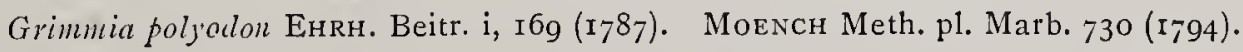


Grimmia apocarpa Hedw. Musc. fr. i, 104, t. 39 (i787), Sp. musc. 76 . Roth Tent. fl. germ. i, 455 (I788). Timm Fl. megap. n. 729 (I 788). SibTh. Fl. oxon. 276 (i 794$)$. Swartz Musc. suec. 27 (I 799). Brid. Musc. rec. ii, P. I, 57 (I798), Sp. musc. I, 96 (I806), Mant. 33 (I8I9), Bry. univ. i, I67 (1826). Roenl. Moosg. deutsch. I 5 (1800), Deutsch. fi. iii, 46 (I813), Ann. Wett. ges. iii, 95. SмIтн Fl. brit. I 200 (I804), Eng. Bot. t, I I34. Turn. Musc. hib. 20 (1804). P. Beauv. Prodr. 58 (I805). Schultz Fl. starg. 283 (I806). Web. Mohr Bot. Tasch. I 29 (1807). Schkuhr Deutsch. kr. gew. P. II, 47, t. 2I (I8Io). Schwaeg. Suppl. I, P. I, 96 (I8I I). Voit Musc. herbip. 27 (I8I2). Wahlenb. Fl. lapp. 3I9 (I8I2). MarT. Fl. cr. erl. iI4 (I8I7). Hook. Tayl. Musc. br. 36, t. I3 (I8r 8). Hook. Fl. scot. P. 2, I28 (I821), Br.fl. ii, 24 (I833). Funck Moost. I8, t. I2 (I82I). Gray Nat. arr. Br. pl. i, 726 (I82I). NeEs Hornsch. Bry. germ. ii, P. I, 86, t. I4, f. 4 (I827). Hueben. Musc. germ. I63 (I833). Mack. F1. hib. P. 2, I6 (1836). De Not. Syllab. 236 (1838). C. Muell. Synops. i, 776 (1849). Schimp. Synops. 200 (I860), 2 ed. 242. ZetT. Rev. Grinm. scand. 50 (I86r). Milde Bry. siles. I42 (I869). Hoвk. Syn. br. m. 78 (1873). Husn. Mouss. Nurd-ouest 90 (I873), Musc. gall. I23, t. 35 (I886). JURAtz. Laubm. oester-ung. I52(I882). Chalub. Grimm. Tatr. I7 (1882). Boulay Musc. Fr. 39I (I884). LesQ. James Mosses N. Amer. I36 (1884).

Grimmia apocaulos LAmk. CAND. Fl. Franc. 3 ed. i, 458 (I805).

Schistidium apocarpum BR. Sch. Bry, eur. fasc. 25-28, p. 7, t. 3 (1845). Aongst. in Fries Summ. veg. scand. 96 (I846). Rabenh. Deutsch. kr. fl. ii, s. 3, I 54 (I848). Wils. Bry. brit. I 5o, t. I3 (I855). Berk. Handb. br.m. 243, t. 2 I, f. 6 (1863). DE NOT. Epil. bri. ital. 7 I I (1869).

Autoicous; robust, crowded in lax fuscescent, olivaceous-green or blackish tufts, dichotomously branched, free from radicles. Leaves from an erect base, patent, erect when dry, ovato-lanc. and elongate lanc., concave at base, thence deeply carinate, the margin adpresso-recurved, toothed at the usually hyaline apex, or entire, upper prolonged into a short rough hair ; nerve rough above, continued to the hair or vanishing below apex, 5-stratose below; lowest basal cells rectang., then narrow and sinuose, upper rounded. Perich. bracts broader, thinner, with a narrower nerve, hair point shorter or none. Caps. ovate, pachydermous, less concealed in the perichætium, solid, rufous, lid bright red, mucronato-rostellate, annulus $3-4$ rows of small cells; teeth of per. arising below orifice, large, purple red, but little perforated or entire, radiately spreading when dry. Male infl. lateral, gemmiform, bracts ovate, subcucullate.

HAB.-Rocks and stone walls; not uncommon. Fr. I2-3.

Var. $\beta$. alpicola $(S w$.$) .$

Short, more densely tufted, suberect; leaves shorter, broader, ovateoblong, green, muticous, obtuse, entire, nerve shorter, basal cells laxer ; caps. more emergent, calyptra often cucullate, lid long-beaked.

Syn.-Grimmia alpicola Swar'sz Musc. suec. 27 et $8 \mathrm{I}$, t. I, f. I. Hedw. Sp. musc. 77, t. I 5 f. I-5. Sm. Fl. brit. I I99, Eng. Bot. t. 2226. Turn. Musc. hib. 22. Brid. Sp. musc. I, 98 ; Mant. 32 , Bry. un. i, I65. Schwaeg. Suppl. I, P. I, 95. WAHL. Fl. lapp. 320 ,
excl. syn. Hueben. Musc. germ. I62. Grimmia apocarpa var. alpicola Hook. TArl. Musc. br. 87. Nees Hsch. Bry. germ. ii,
P. I, t. I 8, f. $4 \mathrm{~m}$.

HAB.-Stones in alpine streams.

Bridge of Achallater (Gardincr I844)!! Ben Lawers (Hunt 1872)! Monsal dale
(Holt 1886)! 
Var. $\gamma$. rivularis (Bvid.) W. $M$.

Laxly cæspitose, naked at base, fasciculate branched, $2-3$ in. long, lurid or blackish-green. Leaves ovato-lanceolate, rather obtuse; caps. shorter, when dry and empty turbinate, wide-mouthed.

SrN.-Grimmia rizularis BrID. in Schrad. Bot. Journ. iii, 276. Sp. musc. I, 97; Mant. 33; Bry. un. i, I66. Turn. Musc. hib. 2 I, t. 2, f. 2. Sm. Fl. brit. I200; Eng. Bot. t. I345. SchwaEg. Suppl. I, P. I, 96, t. 23.

Grimmia apocarpa var. rivularis Weв. M. Bot. Tasch. I29. SchkunR Deutsch. kr. g. 47, t. 2 I. Hook. T. Musc. br. 37. NeEs Hsch. Bry. germ. ii, t. I8, f. 4 .

G. alpicola $\beta$. rivularis WAHLEN. F1. lapp. $320 ;$ Fl. carp. 339.

Schistidium apocarpum var. rivulare Br. Sch. Bry, eur. Wils. Bry. br.

HAB.-On stones in streams.

Brandon Mountain, Ireland (Wilson I829)! Ben Lawers and Campsie, Glasgow (Gardiner)!! In Meavey and the Teign (Holmes). Romiley, Cheshire (Whitchcad I862) !! Aber (Wilson) !! Ingleton (Wcst I862)!! Bradshaw Clough, Bolton (Roger's I868)! The Hodder and Mitton, Clitheroe (Holt I885)! Belfast (Stereart).

Var. ò. gracilis (Schleich.) W. M.

Stem longer, more slender, decumbent; leaves patent or homomallous, serrate at apex, often black; caps. secund, teeth long and slender.

Srx.-Grimmia gracilis Schleich. Cr. helv. cent. 3, n. I4. SchwaEg. Suppl. I, P. I, 98, t. 20. Brid. Mant. 33, Bry. univ. I7o. Schultz Suppl. Fl. Starg. 67.

Grimmia stricta Turn. Musc. hib. 20, t. 2. f. I. BrID. Mant. 34, Bry. univ. i, I72.

Grimmia Schlcicheri SpREng. Einleit. in d. Stud. kr. g. 277, t. 7, f. 5, 9 .

Grimmia apocarpa $\beta$. gracilis Web. MoHr Moost. I3I. SchkUHR 47, t. 2 I, f. 3. Roenl. Deutsch. fl. ii, 47. Hook. Tayl. Musc. br. 37. Nees Hsch. Bry. germ. ii, P. I, t. I7, f. 4 .

Grimmia trichodon BRID. Bry. un. i. I 7 I.

Schistidium apocarpum $\beta$. gracile Bry. eur. 7, t. 4. WrLs. Bry. br. I50.

$\mathrm{HAB}$ - Stones in streams.

Crow Road, Campsie (Hunt I866)! Glen Dole, Canlochan and Sidlaw Hills (Gardiuer)!! Ben Lawers. Killarney (Moorc). Ptarmigan m. (Holt 1880)! Hampton Lucy and Earlswood, Warwick (Bagnall).

Var. $\epsilon$. pumila Schimp.

Plants very small and slender; leaves narrower, imbricated when dry, uppermost only with hyaline points; caps. small, concealed in the perichætium.

Syn.-Grimmia apocarpa var. є. pumila Schimp. Synops. 2 ed. 243.

HAB.-Alpine rocks.

Glaslyn (Holt $\left.\mathrm{I}_{38}\right)$ ! Miller's dale $\left(H_{0}\right.$ lt 1879$)$ ! Black Force, Lowgill Fells, Yorks. (Binstcad I886)!! Borrabank Fell, Loweswater (Watcrfall I $88_{5}$ ) !!

So variable is this moss, that it is difficult to know where to stop in our series of varieties, which might be extended beyond the number given in Bryol. germ. and yet not include all the forms, which again are connected by intermediate states. Sometimes the leaves are all muticous, broad and obtuse, entire or bluntly serrate at apex, sometimes they run out into longish hairs-the Var. incana NeEs Hsch.-while the colour varies from green. to fuscous or black. The Var. pumila is an elegant little plant, scarcely separable from $G$. conferta but by the stouter build and coarser areolation. 


\section{GRIMMIA MARITIMA Tum.}

Autoicous; densely pulvinate. Leaves narrowly linear-lanc., nuticous, curved and subtortuose when dry; perich. bracts longer, acuminate. Caps, truncate, obovate, lid yellow, convex, rostellate. (T. XLVI, C.)

Srn.-Grimmia maritima TuRn. Musc. hib. 23, t. 3, f. 2 (1804). SM. Fl. brit. I I99 (I804). Eng. Bot. t. I645. Brin. Sp. musc. I, 96 (I8j6); Mant. 32 (I8Ig); Bry. univ. i, I6t (1826). Schwaeg. Suppl. I.P. I, 95, t. 22 (I8I I). HоoK. TaYl. Musc. br. 27, t. I3 (1818). Gray Nat. arr. b-. pl. i, 726 (I82I). Nees Hsch. Bry. germ. ii, P. I, I05, t. I8, f. 4 ว (1827). Hook. Fl. scot. P. 2, I29 (I82r), Br. f. ii, 24 (1833). Hueben. Musc. germ. I6o (I833), MACK. Fl. hib. P. 2, I6 (I836). C. Muell. Synops. i, 78 I (I849). Fl. dan. t. 2496 (I8+9). Schimp. Synops. 20 i (1860), 2 ed. 244. ZetT. Rev. Grimm. scand. 55 (I86r). MILde Bry. siles. I 43 (I869). Hовк. Syn. br. m. 78 (1873). Husn. Mouss. nord-ouest go (1873), Musc. gall. r22, t. 35 (1886). Boulay Musc. Fr. 394 (1884). Lesq. James Moss. N. Amer. I37 (1884).

Grimmia rigida BrID. Bry. univ. i. 768 (1827).

Schistidiun maritimum Br. Sch. Bry. eur. fasc. $25-28$, p. Io, t. 5 (I845). Aongst. in Fr. Summ. Veg. scand. 93 (I846). Rabenh. Deutsch. kr. fi. ii, S. 3, I55 (I848). Wils. Bry. br. I5I, t. I3 (1855). BERk. Handb. br. m. 243 (1863).

Autoicous; in short densely pulvinate tufts, lurid or blackish green or sometimes yellowish above, fuscous black and interworen with rufous radicles at base. Leaves densely crowded, erecto-patent when moist, curved and subtortuose when dry, narrowly linear-lanc., muticous, canaliculate-concave, with plane margins; nerve thick, fuscous, vanishing at apex or excurrent in a strong mucro; cells lax and narrowly rectangular at base, minute, indistinct, in $2-3$ strata above. Perich. bracts longer, broader, falcate when dry, subpilifero-acuminate. Caps. pale brown, leptodermous, truncate ovate, when dry and empty broadly turbinate; lid yellow, large, convex, suddenly prolonged into a curved beak; teetl ferruginous, broadly lanceolate, remotely articulate, minutely cribrose. Male infl. near the female, gemmiform, bracts broadly ovate, shortly acuminate.

$\mathrm{H}_{\mathrm{AB}}$. - Rocks by the sea. West coast of England, Ireland, and Scotland; less frequent on the east side. Fr. I I-I2.

This moss grows in dense cushioned mats, and is much more rigid than G. apocarpa, with a more prominent perichatium, and all the leaves muticous. It is found all along the coast from Penzance to Orkney.

Sect. 2. EUGRIMMiA C. Muell. Pulvinate or cæspitose. Caps. on a short, straight, or curved seta, more or less exserted, plicate or smooth, rentricose at base or regular.; calyptra small mitraform or cucullate. 
Curvisete.

\section{GRIMMIA ANODON Br. Sih.}

Autoicous; in small hoary cuslions. Lower leaves ovate, muticous, upper ovato-acuminate with long hair-points, concave. Caps. immersed, ventricose at base, gymnostomous. (T. XLVI, D.)

Syn.-Grimmia anodon Br. Sch. Bry. eur. fasc. $25-28$, p. 8, t. I (I 845 ). C. Muell. Synops. i, 780 (I849). Schimp. Synops. 202 (I860), 2 ed. 245. Zetr. Rev. Grimm. scand. 57 (186r). Milde Bry. siles. I44 (1869). Braithw. in Journ. Bot. 1872, p. 195. Hobk. Syn. br. m. 78 (I873). JuRATz. Laubm. oester..ung. I53 (1882). Chalub. Grimm. tatr.30 (I882). Boulay Musc. Fr. 389 (1884). Lese. James Moss. N. Amer. I38 (I884). Husn. Musc. gall. I24, t. 35 (1886).

Anodon ventricosus Rabenh. Deutsch. kr. fl. ii, S. 3, $\mathrm{r}_{54}$ (1848).

Autoicous; in small fragile cushioned tufts, hoary with hairs; fuscous or black at base, with ferruginous radicles. Lower leaves minute, laxly imbricated, ovato-lanc., muticous, upper and perich. bracts much larger, patent, broadly oblongo-lanc., concave with plane margins, prolonged into an obtuse point with a longish serrate hair ; cells at base gradually wider, longish rectangular, scarce thickened, hyaline at margin, above small, incrassate; nerve vanishing in the apex. Caps. immersed, on a short arcuate pedicel, subglobose, ventricose on one side at base, leptodermous, pale brown, gymnostomous, gaping widely when dry; calyptra 5-lobed, annulus simple, operc. large, plano-convex, umbonate, yellow. Male infl. gemmiform, at end of short branches, bracts oblong, acuminate.

НАв.-Dry rocks ; very rare. Fr. 4.

Arthur's Seat, Edinburgh. (Bell I869)!!

This lias been confused by Bridel and others with G. Haccida (DE Not.) (Gymn. pulvinatum How m. Grimmia spherica Schimp.), but the latter has a symmetric capsule with a straight seta, and larger leaves with smaller basal cells; it is a species which will probably be found here. Another European moss, Gr. plagiopodia HEDiv, is also closely allied.

\section{GRIMMIA CRINITA Brid.}

Autoicous; short, densely cæespitose, hoary. Lower leaves ovate, obtuse, upper obovate, suddenly narrowed into a long smootli hair. Calyptra cucullate. Caps. subimmersed, ovate, slightly ventricose, teeth purple, rimose. (T. XLVII, A.)

Syn.-Grimmia crinita BrID. Sp. musc. I, 95 (I806), Mant. 32 (I8I9), Bry. univ. i, I63 (I826). Web. Morr Bot. Tasch. 456 et 480 (1807). SchkunR Deutsch. kr. gew. P. II, 5 I, t. 22, figg. b, d, g. (1810). Schwaeg. Suppl. I, P. I, 92, t. 26 (1811). Voit Musc. herb. 8 (I8I2) ROEHL. Deutsch. fl. iii, 45 (I8I3), Ann. Wett. ges. iii, 9I. FuncK Moost. I8, t. I2 (I821). NeEs Hornsch. Bry. germ. ii, P. I, 77, t. I6, f. I (I827). Hueben. 
Musc. germ. I72 (1833). DE NoT. Syllab. 240, excl. syn. (I838), Epil. bri. ital. 706 Musc. germ. I72 (I833). Deur. fasc. 25.28 , p. Io, t. 2 (I 845 ). Schimp. Synops. 204 (1860), ed. 246. Zett. Rev. Grimm. scand. 59 (I86I). Milde Bry. siles. I44 (1869). Braithw. in Journ. Bot. 1872, p. 195. HoBk. Syn. br. m. 79 (1873). Husn. Mouss. nord.ouest go (1873), Musc. gall. I25, t. 36 (1886). JuRATz. Laubm. oester-ung. I 54 (1882). Boulay Musc. Fr. 387 (1884).

Guembelia crinita Hampe Bot. zeit. I846, p. I24. RaвENh. Deutsch. kr. fl. ii, S. 3, I67 (I848). C. Muell. Synops. i, 77 I (1849.)

Autoicous; very dwarf, in small flat silky grey tufts, wliite witl depressed hairs. Leaves gradually accrescent upward, lower imbricated, lanceolate, upper obovate oblong, piliferous, very concave, with plane margins, cells at base wide, quadrate, above irregularly roundish quadrate; perich. bracts broadly obovate oblong, deeply concave, the membranous apex with a long smooth hair. Caps. on a longer curved pedicel, cernuous, emergent, ovate, less ventricose, reddish-brown, lightly striate, when dry costate, rugose at base ; calyptra cucullate, lid small, obtusely conical; teeth purple, lanceolate, rimulose or nearly entire.

HAB.-On the dry plaster of walls; very rare. Fr. 4-5.

Wall of a canal bridge near Hatton, Warwick (Bagnall 1872 )!!

This moss is not at home with us, and to see it in perfection we must visit Spain or Italy, where it forms extensive patches, the silky hairs giving it a resemblance to a mouse-skin.

\section{GRIMMIA INCURVA Schwaegr.}

Dioicous; densely tufted. Leaves very long, from a broader base, attenuato-subulate, lower mucronate, upper with very short hair-points, all with plane margins and strongly curled wlien dry. Caps. minute, cernuous, oval, on a subarcuate pedicel; teeth bifid. (T. XLVII, B.)

Syx.-Grimmia incurva Schwakg. Suppl. I, P. I, go (I8I I), et II, t. 97 (IS16). Roehl. Deutscls. fl. iii, 46 (I8r3). Brid. Mant. 37 (I8I9), Bry. un. i, I85 (I826). Funck. Moost. I7, I. I 2 (I821). NeEs Hsch. Bry. germ. ii, P. I, I68, t. 23, f. 2 I (I827). De Not. Syllab. 24I (I838). C. Muell. Synops. i, 788 (18+9). JURAT\%. Laubm. oester-ung. I59 (I882). Boulay Musc. Fr. 380 (I884). Husn. Musc. gall. 136, t. 39 (I887).

Dicramum contortum WAHLENB. FI. carpat. $346, \mathrm{t} .4$ ( $\left.18 \mathrm{I}_{4}\right)$.

'Camtylopus contortus BRID. mant. 74 (I8I9).

Dryptodon contortus Brid. Bry. un. i, I99 (1826).

Grimmia uncinata KAULF. in Sturm. Deutsch. H. 2, fasc. I5 (I8I5). Hueben. Musc. germ. I89 (I833). BR. Sch. Bry. eur. fasc. 25-28, p. I9, t. I2 (I845). RABENH. Deutsch. kr. fl. ii, S. 3, I63 (1848).

Grimmia contorta Schimp. Synops. 209 (I860), 2 ed. 252. ZetTerst. Rev. Grimm. scand. 66 (I86r). DE Not. Epil. bri. ital. 700 (I869). Milde Bry. siles. I47 (I869). Hoвk. Syn. br. m. 81 (1873). Chalub. Grimm. Tatr. 37, t. 5 (1882). Lesq. James Moss. N. Amer. 139 (1884).

Dioicous ; in small soft rounded tufts, dark lurid green above, black below, with fine radicles. Leaves patenti-incurved, strongly curled when 
dry, from lanceolate, lineal-subulate, diaphanous or with a short hair at point, at base carinate-concave with recurved margins, thence subcomplicate, cells larger, elongate and hexagono-rectangular at base, sinuoso-quadrate at apex, partly chloroplyllose, partly diaphanous. Perichætium exserted, bracts from an erect, oblong longly slieathing base, subulate and patent, longer than the capsule.

Caps. on a subarcuate pedicel, cernuous, erect when dry, small, oval, smooth, leptodermous, yellowish ; lid convex-conic, obtuse, erose at base, orange-red; calyptra mitrate-subulate, annulus broad of 3 rows of cells; teeth orange-rufous, reflexed when dry, cleft below middle and lacunose. Male infl. terminal, bracts broadly ovate, shortly acuminate.

HАB.-Shady crevices of siliceous rocks; rare. Fr. 4-5.

Bellyside hill and Henhole and in the Bizzle c. fr., Cheviots (Hardy 1867)!! Cloch-naBen, Kincardine (Sim I868)!! Bach-na-Gairn and Glen Callater (Fergusson). Glyders, N. Wales (Holmes 1878 )!!

The fruit of this moss is very rare, and the plant is very like Dicranoweissia cirrata; it may be recognised by the subulate leaves with short hyaline points, and the curly black cushions in which it grows.

\section{GRIMMIA FUNALIS (Schwaeg.) Schimp.}

Dioicous; slender, densely cæspitose. Leaves lanc. spirally twisted when dry, upper attenuated into a hair; margins plane. Caps. minute, on a short arcuate seta, ovate, lid conic. (T. XLVII, D.)

Syn.-Trichostomum funale SchwaEg. Suppl. I, P. I, I50, t. 37 (I8II). Roent. Deutsch. fl. iii, 62 (1813). Funck Moost. 26, t. I8.

Grimmia spiralis Hook. Tayl. in Drumm. Musc. Scot. ii, n. 29. Musc. br. 2 ed. 69, t. 2 (1827). Grev. Scott. cr. f. iv, t. 203 (1827). Hook. Br. fl. ii, 26 (I833). Br. Sch, Bry. eur. fasc. $25-28$, p. $\mathrm{r}_{4}$, t. 7 (1845). AonGST. in FRiES Summ. veg. scand. 93 $(1846)$. Rabenh. Deutsch. kr. fl. ii, S. 3 , I62 (I848). C. Muell. Synops. 789 (1849). Wils. Bry. br. I 54, t. $32(1855)$. HARTM. Skand. H. 7 ed. $37^{2}$ (I 858$)$. Berk. Handb. br. m. 24 I (1863). DE NOT. Epil. Bri. ital. 687 (1869).

(irimmia funalis Schimp. Synops. 21 I (1860), 2 ed. 254. ZETTERST. Rev. Grimm. Scand. 72 (I86I). Milde Bry. siles. I48 (1869). HobK. Syn. br. m. 8I (I873). JURA'Tz. Laubm. oester.-ung. I60 (I882). Chalub. Grimm. Tatr. 45 (I882). Boulay Musc. Fr. 382 (1884). Husn. Musc. gall. I32, t. 38 (1887).

Campylopus funalis Brid. Mant. 75 (1819).

Dryptodon funalis BrID. Bry. un. i, I93 (1826).

Dryptodon spiralis BRID. Bry. un. i, 77 I (I827).

Grimmia cermua NeEs Hsch. Bry. germ. ii, P. I, I74, t. 24 (I827).

Racomitrium funale HUEBEN. Musc. germ. 200 (1833).

Dioicous; densely cæspitose, readily falling asunder, grey-green or yellowish-green above, reddish brown or fuscous below. Stems $\mathrm{I}-2$ in. high, slender, erect, subdichotomous, free from radicles. Leaves when 
dry erect and spirally incumbent, when wet erecto-patent, small, lanceolate, upper with lyyaline points, or extended into a smooth hair, the margin a little recurved, nerve narrow, vanishing at apex; cells at base narrowly rectangular, quadrate and hyaline at margin, above quadrate and sinuose, upper in two strata, minute, quadrate. Pericl. bracts broader at base, concave, piliferous; seta shorter than pericl., curved, pale yellow, cal. conico-mitriform, 5 -lobed, caps. small, ovate, pale reddish-brown, 8-striate; ann. broad of 3 - + rows of cells, lid from a convex base, short-pointed; teeth rufous purple, lacunose or torn at apex. Male plants taller and more slender; infl. terminal, inner bracts oblong acute.

HAB.-Dry alpine rocks; not common. Fr. 9-10.

Ben Lawers (Greville)!! Clova (Drummond)! Slemish mountain, Antrim, Sillagh braes, Larne, Upper Lough Bray and Kylemore (Moore). Snowdon (IVilson)!! Glen Callater (Gardincr I 844)!! Craigailleach (Hunt I872)!! Trefriew, N. Wales (Dr. Wood)! Llanberis Pass (Holt I880)!! Ptarmigan Mtn. (Holt I880)!! Helvellyn, Red Screes, and Ingleboro' (Buswell I858). Slieve Donard and Slieve Dermot (Lett).

This moss is readily known in the dry state by the spiral twisting of the leaves, when moist it has much resemblance to G. trichophylla and Muchlenbeckii, but the leaves are narrower, with the base more elongated, a narrower nerve and nearly smooth liair.

\section{GRIMMIA TORQUATA Hornsch.}

Dioicous; densely tufted. Leaves elongato-lanceolate, acute, spirally contorted when dry, lower muticous, upper very shortly piliferous, margin plane. (T. XLVII, E.)

SYn.-Grimmia torquata Hornsch. MSS. Grev. Scott. cr. fl. iv, t. Ig9 (IS26). Drumm. Musc. scot. II, n. 28. Hook. Tayl. Musc. br. 2 ed. 70, t. 32 (I827). Hueben. Musc. germ. ig7 (1833). Aongst. in Fries Summ. veg. scand. 93 (1846). Schimp. Synops. 2 Io (I860), 2 ed. 253. ZeTT. Rev. Grimm. scand. 69 (IS6I). Milde Bry. siles. I48 (1869). Hoßk. Syn. br. m. 8I (1873). JuRAtz. Laubm. oester.-ung. i6o (ISSz). Chalub. Grimm. Tatr. 42 (I882). Boulay Musc. Fr. $3 S_{1}\left(I_{4} S_{4}\right)$. Lesq. James. Moss. N. Amer. I 40 (1884). Husn. Musc. Gall. 132, t. 38 (1887).

Dryptodon torquatus BrID. Bry. univ, i, 772 (1827.)

Grimmia torta NeEs Hscu. Bry. germ. ii, P. I, I79, t. 24, f. $24($ I\$27). Hook. Br. fl. ii, 26 (1833). Rabenh. Deutsch. kr. A. ii, S. 3, I6 I (1848). Wils. Bry, br. I56, t. 32 (I855). BERK. Handb. br. m. 24I (I863).

Zjgodon torquatus Liebm. in Wickström Jahresb. I839-1842, p. 430. C. MU£Ll. Synops. i, 682, excl. descr. fr. (1849). HarTm. Skand. fl. 7 ed. 367 (1858).

Dioicous; densely pulvinate, the tufts very convex, soft, fragile, readily falling apart, fine green above, black or rufescent below. Plants erect, slender, $\mathrm{I} \frac{1}{2}$ in. high, repeatedly dichotomous, rooting only at base. Leaves erecto-patent, when dry spirally curved round the stem, oblonglanceolate, lower muticous, upper with a slort hair, carinate, the margin straight, erect, nerve thin and channelled, vanishing in the apex, upper 
cells punctiform, lower elongate-linear, yellow, the walls incrassate, green, median quadrate, all unistratose. Short jointed filaments, producing globose propagula at upper end, are frequent upon the leaves.

Haв.-Alpine rucks. Fruit unknown.

Ben Lawers, Craig Chailleach, \&c: (Hooker, Grevilie)!! Clova mountains. Snowdon (Wilson)!! Most of the Irish mountains above $\mathrm{I}, 000 \mathrm{ft}$. Falcon clints, Teesdale (Nowell)!! White Force and Mazebeck Scarrs (Baker 1856)! Hillbell, Westmoreland (Stabler 1868)! Cheviots (Hardy). Helvellyn (Boswell I 858). Glen Shee (Ezing I884).

This beautiful moss has never been found in fruit, and the supposed fertile specimen of Leibman was due to capsules of $A$. lapponicum growing intermixed. The cable-like twisting of the leaves is still more pronounced than in $G$. funalis, and in the upper part of them they are also curiously inflexed, and then reflexed, but when moist the whole plant is exceedingly soft and flaccid. $G$. streptophylla Kindi. from Kongsvold differs in its wider areolation.

\section{GRIMMIA STIRTONI Schimp.}

Dioicous; in short black tufts. Leaves dense erecto-patent, small, narrowly lanc. upper with smooth longish hair points, margin plane, cells but little incrassate, quadrate, minute and opake toward apex. (T. XLVII, F.)

Syn.-Grinmia Stirtoni Sснімp. Synops. 2 ed. 270 (1876). Новк. Syn. br. m. 2 ed. I24 (1884).

Dioicous; laxly tufted, $\frac{1}{2}$ in. high, dull black, lurid green at apex, fuscous and radiculose at base. Stems dense leaved, dichotomous and fastigiate branched. Leaves erecto-appressed when dry, erectopatent and incurved in upper part when moist, small and narrow, concave, the lower lanceolate, muticous, the upper longer, from a more elongate base, lanceolate, ending in a terete nearly smooth hair, one-third lengtl of leaf; margin plane and erect below, thickened above ; nerve terete, vanishing at apex; cells at base close, rectangular, soon becoming quadrate, not sinuose, towards apex more incrassate, minute, opake.

HAB.-Basaltic rocks near Glasgow. (Dv. Stivton I866)!

This moss resembles a small state of $G$. elongata, but its structure is more that of $G$. pulvinata, from which however it differs by its much smaller, narrower leaves, with firmer quadrate basal areolation, from the former the non-sinuose areolation and form of leaf-base sufficiently distinguish it.

\section{GRIMMIA MUEHLENBECKII Schimp.}

Dioicous; laxly pulvinate, hoary. L. dense, patulous ; elongato-lanc., nerve thick, channelled at back, the hair-point very rough. Caps. 
minute, subpendulous, oval, very smooth, lid shortly rostrate, teeth nearly entire. (T. XLVIII, A.)

Sys.--Brym pulvinatum, Dicranum pulvinatum, Fissidens pulvinatus and Grimmia pulvinata of most Swedish authors.

Campylopus pulvinatus var. $\beta$ tenuis WAHLENB. Fl. suec. ii, 748 (1826).

Dryptodon Schultzii (non BRID.) HARTM. Skand. fl. 4 ed. 373 (1843).

Grimmia ineurva (non Schwaeg.) BR. Sch. Bry. eur. fasc. 25-28, Mon. I5, t. 8 (I 845 ). HaRTm. op. c. 5 ed. Schimp. Coroll. $47(+$ G. Hartmani), 1855 .

Grimmia rugulosa LiNdgr. MSS. et in Bot. not. 1845 , p. 88.

Grimmia trichophylla Bry. eur. 1. c. p. I6 p.p. ZETT. Rev. Grimm. scand. 75 p.p. (I86r). HARTM. op. c. 6-9 edd.

- var. $\beta$. septentrionalis Schiмp. Coroll. 47. Synops. 2 r3.

Grimmia Muchlenbeckii Schimp. Synops. 212 (1860), 2 ed. 255. Linds. in Hedwigia vi, r I6 (1867), et in Not. ur sälls. Fl. Fn. fenn. foer. ix, 262 (I868). DE Not. Epil. bri. ital. 689 (1869). Milde Bry. siles. I49 (1869). BRAITHw. in Journ. Bot. 1872, p. r97. HoBk. Syn. br. m. 8I (1873). JuRAtz. Laubm. oester.-ung. r6i (1882). Boulay Musc. Fr. $37^{8}$ (r884). LesQ. James Moss. N. Amer. I40 (r8I4).

Grimmia triehophylla var. Muehlenbeckii HusN. Musc. gall. I35 (1887).

Dioicous; laxly pulvinate and vaguely cæspitose, olive-green and hoary above, soft. Stems $\frac{1}{2}-\mathrm{I}$ in. high, erect or procumbent, rooting at base, repeatedly dichotomous. I. densely crowded, erect and incumbent when dry, patulous when moist and bending upwards from the middle, from a longish ovate base, lanceolate, gradually narrowed into a longer or shorter rough hair, concave below, carinate at apex, the margin plane or slightly recurved at the middle, nerve strong, channelled, very prominent above and with two ridges at back; cells above small, roundish-quadrate, obscure, in 2 strata, at base elongate and somewhat sinuose, $\mathrm{I}-3$ rows at margin short and hyaline. Caps. on a short yellow subarcuate seta, very small, oval, leptodermous, smooth, brownish-yellow, rugulose when dry, annulus very narow of $2-3$ rows of cells; lid yellow-red with a short beak, teeth red, lanceolate, nearly entire; calyptra 4 -lobed.

HAB.-Granite and sandstone rocks in mountains. Fr, $5-7$.

Wet rocks near Ballater (Fergusson r87o). Stone in the stream, Kynance Cove, c. fr. (Holmes I882)!

This moss is very close to $G$. trichoplylla, but that species is more robust, the nerve thinner and less prominent at back, with a nearly smooth hair, the cells internally scarce nodulose, the seta longer, capsule twice larger, oblong, subopaque, plicate, firmer, lid rostrate; from G. pulvinatı it is still more distinct by its dioicous infl., lax olivaceous tufts, taper-pointed leaves and firmer subsinuose areolation. It will probably be detected in many more localities. 


\section{I. GRIMMIA PULVINATA (L.) Smith.}

Autoicous; glaucous-green, hoary. L. lanceolate with long hairs, recurved at margin. Caps. on an arcuate seta, ovate, striate, rostellate; calyptra mitræform. (T. XLVIII, C.)

SrN.-Muscus trichoidcs, hirsutus, capitulis oblongis reflexis, pediculis brevibus insidentibus, Doody. Ray Synops. 243 (169o).

Muscus trichoides, hirsutic canescens, capitulis subrotundis refexis, in perbrevibus pediculis Ray Syn. 2 ed. 34 (I696).

Bry'um trichoides, \&c. Dill. Cat. Giss. 226 (I7I9), et in Ray Syn. 3 ed. Ion, n. 46 (I724).

Bry'um orbicularc pulvinatum, hirsntic canesccns, capsulis immorsis DiLL. Hist. musc. 395 , t. 50, f. $65 \mathrm{~A}-\mathrm{C}(\mathrm{I} 74 \mathrm{I})$ et Herb.

Bryum pulvinatum L. Sp. pl. II2I (1753), Syst. nat. ii, 702. Huds. F1. angl. $4 \mathbf{I} 3$ (I 762 ). Weiss Cr. goett. 26I (I770). NECK. Meth. musc. 200 (I77I). WiTh. Bot. arr. br. veg. ii, 678 (I776). LightF. Fl. scot. ii, 735 (I777). WEB. Spic. H. goett. II2 (I778). RelH. Fl. cant. 406 (I785). HoFfm. Deutsch. H. ii, 3 I (I795). AвBOT Fl. bedf. 243 (I798). Hull Br. fl. P. 2, 267 (1799).

Leersia palvinata Hedw. Fund. I, t. Io, f. 65, II, 88 (I782). Roth Fl. germ. i, 454 (I788). Schrank Baiers. fl. ii, 442 (I 789$)$.

Afzclia pulvinata EнRн. P1. crypt. n. I63.

Encalyptu pulvinata Siвtн. Fl. oxon. 278 (I794).

Fissidens pulvinatus Timm Fl. megap. n. 778 (I788). Brid. Musc. rec. II, P. I, I49 (I798). Roenl. Moosg. deutsch. 300 (1800). Hedw. Sp. musc. 158, t. 40 (I801).

Dicranum pulvinatum Swartz. Musc. suec. 32 (1799). Roth Fl. germ. iii, P. I, I79 (I800). SM. Fl. brit. I2I4 (1804). Turn. Musc. hib. 78 (1804). Lam. Cand. Fl. franc. i, 478 (I805). P. Beauv. Prodr. 55 (I805). BRID. Sp. musc. I, 2 II (I806). Schultz Fl. starg. 295 (I806). Schwaeg. Suppl. I, P. I, I89 (I8I I).

Trichostomum pulvinatum Sturm Deutsch. fl. II, 7 (1805). Web. Mohr Bot. Tasch. rog (1807). Schkunr Deutsch. kr. gew. P. II, 69, t. 3 I (I8Io). Voit Musc. herb. 23 (I8I2). Roenl. Deutsch. f. iii, 6I (I8I3).

Grimmia pulvinata SM. Eng. Bot. t. I728 (I807). MART. F1. cr. erl. II4 (I8I7). Hook. TAYl. Musc. br. 38, t. I3 (I8I8). Funck Moost. I7, t. I2 (182 I). Hook. Fl. scot. P. 2, I 29 (I82I), Br. f.. ii, 25 (I833). Gray Nat. arr. br. pl. i, 727 (I82I). HuEben. Musc. germ. I93 (I833). Mack. Fl. hib. P. 2, I6 (I836). DE Not. Syllab. 249 (I838), Epil. bri. ital. 691 (1869). Br. Sch. Bry. eur. fasc. $25-28$, p. I2, t. $4(18+5)$. Aongst. in Fries Summ. veg. sc. 93 (I846). Rabenh. Deutsch. kr. fl. ii, s. 3, I60 (1848). C. Muell. Synops. i, 783 (I849). Wils. Bry. br. I53, t. I3 (I855). HARTM. Skand. f. 7 ed. 372 (1858). Schimp. Synops. 206 (I860), 2 ed. 248. BerK. Handb. br. m. 242, t. 7 ed. 372 (I858). SCHTS. Rev. Grimm. scand. 6I (I86I). Milde Bry. siles, I45 (I869). HoBK. Syn. br. m. 79 (I873). YUuss. Mouss. nord-ouest 92 (1873), Musc. gall. I34, t. 38 (I887). Juratz. Laubm. oester.-ung. 156 (1882). Chalub. Grimm. Tatr. 33, t. 4 (I882). Lesq. James Mosses N. Amer. I38(1884). Boulay Musc. Fr. 385 (1884).

Campylopus pulvinatus Brid. Mant. 75 (I819). Wahlenb. F1. suec. ii, 747 (I826).

Dryptodon pulvinatus Brid. Bry. univ. i, I96 (I826).

Autoicous; in small convex hoary glaucous-green cushions; stems fastigiate-branched, radiculose at base, more dense-leaved toward apex. Leaves appressed when dry, gently recurved when moist, erectopatulous, lower lanc., acute, muticous, upper oblong-lanc., rather obtuse and carinate, suddenly ending in a long flexuose, serrated liair; margin recurved at base, erect and incrassate above; cells shortly rectangular at base, quadrato-hexagonal above and in $2-3$ strata at margin. Seta stramineo-fuscescent, arcuato-deflexed when moist; caps. pendulous, 
often depressed among the comal leaves, ovate, leptodermous, brown, distinctly striate, 8 -costate when dry, calyptra small, mitræform, lid purple, from a convex base, crenulate at margin, rostellate; annulus of 4 rows of cells, revoluble; teeth dark red, longer, slightly perforated, unequally bifid at apex. Male infl. gemmaceous, bracts ovate, concave, muticous.

HAB.-On walls, roofs and rocks; common. Fr. 3-4.

Var. $\beta$. obtusa (Brid.) Hueben.

Capsule smaller, on a shorter seta, ovato-globose, the lid obtuse, with a very short blunt point.

Syn.-Fissidens pulvinatus var. $\beta$. africanus Hedw. Sp. musc. 159 , t. 4o, f. 4-6.

Dryptodon obtusals Brid. Bry. univ. i, rg8 p.p.

Grimmia puluinata var. $\beta$. obtusa HuEben. Musc. germ. I94. Schimp. Synops.

HAP.--Exposed rocks.

St. Vincent's rocks (Thwaitcs). Conway castle (Wilson). Tickwall, Derby (Hunt r853) !!

This species is generally distributed, and frequent on garden walls, and a form also occurs on dry limestone rocks, with hairs longer than the leaves. The var. $\beta$. has been confounded with $G$. orbicularis, but that species differs in the calyptra, the large depressed tufts, and leaves with cells uni-stratose at margin.

\section{I2. GRIMMIA ORBICULARIS Bruch.}

Autoicous; widely pulvinate, grey, hoary. L. lanceolate, carinate, with long hairs, the margin erect, not incrassate. Caps. on an arcuate seta, subglobose, nearly smooth, with a mammillate lid; calyptra cucullate. (T. XLVIII, D.)

Syn.-Dryptudon obtusus Brid. Bry. univ. i, rg\& p.p.

Grimmia africana ARN. DE Not. Syllab. 248 (1838).

Grimmia orbicularis Bruch. Wils. in Eng. Bot. Suppl. t. 2858 (I $8_{44}$ ). Bry. br. I54, t. 44 (I855). Br. Scr. Bry. eur. fasc. 25-2S, p. 13, t. 5 (r845). Schimp. Synops. 205 (I860), 2 ed. 247. BERk. Handb. br. m. 24I (I863). Milde Bry. Siles. I+5 (IS69). De Not. Epil. bri. ital. 692 (IS69). Hobk. Syn. br. m. 79 (I873). Husn. Mouss. nord.-ouest 9I (1873), Musc. gall. I34, t. 38 (I887). JuRatz. Laubm, oester.-ung. I55 (1882).

Guembelia orbicularis Hampe Bot. zeit. I846, p. I24. Rabenh. Deutsch. kr. fl. ii, S. 3, I67 (1848). C. Muell. Synops. i, 775 (I849).

Grimmia mammillaris POEcH in musc. bohem. 11.29.

Autoicous; in larger compact swollen hemispherical cushions, falling in pieces when removed, brown at base, olive-green and hoary above. Leaves imbricated when dry, when moist recurved and then erecto-patent, lower small lanc., muticous or with a short hair, upper lanceolate, deeply carinate, running out into a long smoothish hair 
which is rather broad at base, nerve thin vanishing at apex, margin slightly recurved, unistratose, cells small roundish-quadrate, at base rectangular, hyaline, becoming quadrate at margin. Perich. bracts narrower, longer, sheathing. Seta short, yellow, arcuato-deflexed when moist, flexuoso-erect when dry. Caps. small, subglobose, faintly striate, bright orange, finally reddish-brown and plicate; calyptra small, cucullate, annulus simple, breaking up, lid small, purple, convex, obsoletely mammillate; teeth pale red, broad and trabeculate below, 3-4 fid at apex. Male infl. gemmaceous, terminal, bracts ovate.

Нав.-Limestone rocks and walls; not common. Fr. 2-3.

Ormeshead and Conway (Wilson 1826)!! St. Vincent's rocks, Bristol (Thwaites I 843 )!! Arthur's seat (Bevan I864). Catdown, Plymstock and Laira (Brent). TamertonFoliot (Holmes). Durdham Downs (Boswcll i 863). Near Cork (Dr. Wood 1859). Between Dublin and Stillorgan (Moore). Buckland, Faringdon (Mrs. Milne I863). Milnthorpe (Barnes I865)! ! Kinnoul hill (Dr. B. White 1866). Paignton, Devon (Mrs. Holmes 1885)!! Spelga Min., Co. Down (Lctt).

Growing in much larger patches than the last, and of a darker color, the leaves smaller, narrower, with the margin not incrassate, the capsules smaller, globose, bright red and nearly smooth, and the cucullate calyptra sufficiently distinguish it from G. pulvinata.

\section{I3. GRIMIMIA TRICHOPHYLLA Grev.}

Dioicous; laxly pulvinate, yellowish-green. Leaves erecto-patent, narrowly curvato-lanc., with a nearly smooth hair, margin slightly revolute. Caps. on a yellow curved seta, oval angulato-plicate when dry; annulus broad, lid subulato-rostrate. (T. XLVIII, E.)

SyN.-Dicramum pulvinatum $\beta$. argentatum TuRn. Musc. hib. 78, t. 3, f. I (1804).

Grimmia trichophylla GREv. F1. edin. 235 (I824), Scott. Crypt. F1. t. Ioo (IS25). BRID. Bry. univ. i, 188 (1826). Hook. Tayl. Musc. br. 2 ed. 68, Supp. t. 2 (I827). Ноок. Br. f. ii, 25 (1833). MACK. Fl. hib. P. 2, I7 (1836). BR. Sch. Bry. eur. fasc. 25-28, p. I6, t. $9(1845)$. RABENH. Deutsch. kr. H. ii, S. 3, I62 (1848). C. Muell. Synops. i, 785 (1849). Wils. Bry. br. 156, t. 32 (1855). Schimp. Synops. 213 (1850), 2 ed. 256. BERK. Handb. br. m. 240 ( 1863 ). MiLDE Bry. siles. I49 (1860). HoBk. Syn. br. m. 82 (1873). Husn. Mouss. nord-ouest 92 (1873), Musc. gall. 135, t. 38 (1887). JuRATz. Laubm. oester.-ung. I62 (1882). Boulay Musc. Fr. 378 (1884). Lesq. James Moss. N. Amer. I4I (I884).

Campylopus affiuis HoRnsch. MSS.

Dryptodon trichophyllus BRID. Bry. univ. i, $77 \mathbf{I}$.

Grimmia Schultzii p. p. Hueben. Musc. germ. I95 (I\$33).

Dioicous; laxly pulvinato-cæespitose, soft, bright or yellow-green above, fuscous at base, $\frac{1}{2}-\mathrm{I}$ in. high. Leaves accrescent upward, when moist recurved, then patulous and ascending at point, lower lanc., shortly aristate, upper oblongo-lanc., gradually narrowed into a rather short smoothish or slightly denticulate hair, concave below, carinate above, margin plane above, recurved below but sometimes 
only in one wing; cells slortly quadrate above, rectangular and faintly sinuose at mid-base, quadrate at margin. Perich. bracts sheathing to the middle, then suddenly lanceolate, subulate and recurved. Caps. on a longish cygneous pale seta, obliquely decurved, ovate or oblong, 8 -costate, pale yellow, finally brown, annulus broad of $4-5$ rows of large cells; lid yellow-red, with a short straight beak; teeth longish, red, connivent when moist, erecto-patent when dry, cleft to middle or lanceolate and rimose in the median line. Male plants more slender and simple, infl. terminal, bracts broadly ovate, obtusely pointed.

HAB.-Sandstone and calcareous rocks and walls. Fr. 5-6.

Dunkeld and Blair Athol (Greville)! Arthur's seat, Trossachs (MiKinlay 1864)!! Wemys Bay (Hunt I865) !! Campsie and Bridge of Lochay (Hunt I866) !! Ballater.

Barrowfield (Barnes 1866) ! Frodsham, Cheshire (Robinson 1865)! Wales (Wilson) !:

Sussex (Mitten). Dublin and Luggielaw (Moore). Slieve Donard (Lett I864) !

Bryansford, Down (Waddell I 883)! Penzance (Curnow)! Malham, Cheedale, and

I. of Man (Holt I885) !! Hatton, Staveley, and Windermere (Binstead I886, named

G. anoma!a)!! Devon (Holmes). Rowsley (Boswell i 874). Stoneleigh and Lapworth (Bagnall).

A widely distributed and very variable species, known from $G$. pulvinata by its large lax tufts, narrower tapering leaves, and costate capsule, while $G$. Muehlenbeckii differs by the shorter smooth capsule and spinulose hairs, and $G$. decipiens by its autoicous infl., more robust habit and denser foliage. A form occurs on exposed mountain rocks, in dense stunted dark brown tufts, in which most of the leaves are muticous, the upper only having very short hair-points. G. anomala Schump. has shorter non-sinuose areolation, with the margin bistratose in $2-7$ rows of cells.

\section{I4. GRIMMIA HARTMANI Schimp.}

Dioicous; in tall lax yellowish-green tufts, naked at base. Leaves somerwat secund, oblong-lanceolate, with short smooth or toothed hairpoints, carinate, revolute at margin ; basal cells rectangular, becoming quadrate at margin, upper rounded-quadrate. (T. XLVIII, F.)

SYN.-Grimmia incurva (non Schwaegr.) HARTm. Skand. A. 5 ed. 376 (I849).

Grimmia Hartmani Schimp. Synops. 2 I4 (i 460 ), 2 ed. 258. Zetterst. Rev. Grinm. scand. 77 (I86I). JuRATz. in Bot. Zeit. I 866, p. I77, Laubm. oester.-ung. I63 (I882). BERK. Handb. br. m. 240 (I863). Milde Bry. siles. I50 (I869). Braithw. in Journ. Bot. I872, p. 197, t. 124. Hobk. Syn. br. m. 82 (1873). Chaluis. Grimm. Tatr. 49, t. 6 (1882). Boulay Musc. Fr. 376 (1884). Husn. Musc. gall. 135, t. 39 (1887). Philib. in Rev. bryol. $1887,1.49$.

Grimmia sphcerocarpa Stinton in Sicott. nat. ix, 36 (188;).

Dioicous; in large lax dense-leaved tufts, fuscous below, yellowislgreen above, blackish at base and deep green above when growing in wet places. Stems procumbent, naked at base, elongate, $2-3 \mathrm{in.}$ long, arcuato-ascending, rigid, with few branclies. Leaves when dry loosely incumbent, crisped and incurved, when moist recurved, then divergent and ascending at point, from a small ovate base, elongato-lanceolate, 
usually subfalcato-secund, ending in a very short smoothish or bluntly tootlied hair-point, carinato-concave at base with the margin more or less reflexed, towards apex acutely carinate with the margin curved outward and $2-3$ stratose ; nerve smaller at base, irregularly $2-4$ ridged at back, running up to the apiculus, bistratose above, 5 -stratose towards base, in the young terminal leaves often tipped with globose propagula (I-I5), each composed of numerous chlorophyllose cells; cells all incrassate, unistratose, with $\mathrm{I}-2$ marginal rows bistratose, above small, roundish and opake, below roundish quadrate and sinuose, at base elongate near the nerve, roundish-quadrate and hyaline in several rows at margin. Perich. bracts shorter, from a longish concave base, lanceolate, pointed, with laxer more transparent cells ; caps. on acurved, but finally erect seta, longish oval-oblong, smooth, pale brown with a red mouth, annulus of $3-4$ rows of small cells, calyptra mitræform, lobed; teeth lanceolate entire or slightly perforated, orange-red, smooth at base; lid conical, subulate, slightly oblique.

Male plants like the female, infl. terminal, inner bracts oval, muticous, antheridia numerous, orange, without paraphyses.

HAB.-Granite rocks and stones in mountain districts.

Doigelly (Wilson 1840). Cardross and Blairgowrie (Stirton). Near Conway and Cwm Bychan (Wilson I 860) ! ! Rannoch, Perthshire (Dr. B. White 1867). Bridge of Lochay Hunt I868)!! Blackhall, Banchory (Sim I869). Aber and Llanberis (Hunt I87I). S.' side of Loch Tay (Howse 1872)!! Ben Ledi (Stirton 1864)! By R. Ken, New Galloway (McAndrew i 885 )! Barmouth (Whitehead 1879)!! Wall between Cong and Moytura, Galway (Moore 1872). Rydal, Thirlmere, \&c., Westmoreland and Cumberland (Binstead 1886)!! Honister Crag (Boswall 1858).

This fine moss has only twice been found with fruit, first by Hazsiinszky on M. Czerbo in Hungary, and recently by Philibert in Corsica; it comes nearest to $G$. microcarpa, but it is at once distinguished by the areolation, as it is also from $G$. trichophylla, as well as by the extremely short hair points.

\section{I5. GRIMMIA SUBSQUARROSA Wils.}

Dioicous; laxly tufted, fuscous and dull green. Leaves patent and subsquarrose when moist, ovato-lanceolate, with a denticulate hair-point, margin recurved, basal cells quadrate hyaline, elongate at margin, upper minute. (T. XLIX, A.)

Syn.-Grimmin subsquarrosa Wils. MSS. B. White in Trans. Bot. soc. Edin. ix, I42 (I868). Braithw. in Journ. Bot. I872, p. I96, t. I24, f. I. Hobk. Syn. br. m. 8o (1873). Schimp. Synops. 2 ed. $27^{\circ}(1876)$.

Dioicous; in small lax cushioned tufts, fuscous-green above, black at base. Stems $\frac{1}{3}-\frac{3}{4}$ in. high, erect, dense-leaved, dichotomous, the branches short, turgid, a little curved. Leaves erect and appressed when dry, patent, subarcuato-incurved and subsquarrose when moist, 
lower lanceolate, submuticous, upper longer and extended into a roughish hair $\frac{1}{3}-\frac{1}{2}$ length of lamina, erect and concave at base with margin recurved, complicato-carinate above, with margin incrassate and erect; nerve solid, semiterete, canaliculate; cells at base hyaline, quadrate, narrow elongate and bistratose in $\mathrm{I}-6$ rows at margin, above distinct, minute, rotundate-quadrate. Minute globose gonidia, in clusters of $2-5$, often occur on the surface of the leaves. Male infl. gemmiform, axillary, outer bracts ovato-lanc., acuminate, inner ovate, concave, acute, paraphyses none.

$\mathrm{H}_{\mathrm{AB}}$.-Basaltic rocks.

Moncrieff and Kinnoul hills, Perth (Dr. B. Whit' I864)!! Stenton rocks and Balthayock, Perth (Dr. B. Whitc I 865)! Crow road, Campsie (Hunt I 866)! Arthur's Seat and

Braid hills, Edinburgh. Dumbuck, Bowling c. fr. (Dr. Stirton). Stanner rocks, Radnor (Rev. F. F. Crouch and Boswcll 1873)!!

Var. $\beta$. Edinensis (Ferg.)

In very short black densely pulvinate tufts; the leaves shorter, less concavo-carinate, less recurved.

Нав.-Arthur's seat (Rev. F. Fergusson I 869)!!

The fruit of this moss is reported to resemble that of $G$. trichophylla, but the plant differs from that species in the leaves which are crowded at the apex of the branches, and are more rigid, with rougher hairs and all the basal cells shorter, more quadrate and not at all sinuose, and in the areolation it differs in the same way from $G$. Muehlenbeckii, as well as in the terete, rounded nerve. Perhaps it comes nearest to $G$. Hartmani, but is far more diminutive, and with different areolation.

\section{GRIMMIA DECIPIENS (Schultz) Lindb.}

Autoicous; robust, laxly tufted, yellow-green, hoary. Leaves elongate-lanc. witl rough hairs, carinate, patulous, revolute at margin. Caps. nutant, elliptic, 8 -striate, lid rostrate, cal. mitræform. (T. XLIX, B.)

Syn.-Trichostoman dicipicns Schulтz Suppl. F1. starg. 7o (ISI7).

Dryptodon Schultzii BRID. Bry. univ. i, I99 (IS26).

Trichostomum patens $\beta$. piliforum Hook. TAYL. Musc. brit. 2 ed. 105 (I827).

Trichostomum funalc (non Schwaegr.) Hook. Br. fl. ii, 32 (I833).

Grimmia funalis Br. Sch. Bry. eur. fasc. $25-28$, p. I7, t. II, (IS 45$)$. RABEnh. Deutsch. kr. fl. ii, S. 3, I6I (I $8+8)$. Aongstr. in Fries summ. veg. scand. 93 (I846). C. Muell. Synops. i, 799 (I849). HARTM. Skand. fl. 7 ed. 372 (I85S).

Grimmia Schultzii Wils. Bry. brit. I57, t. 44 (1855). Schimp. Synops. 20 S (1860), 2 ed. 25 I. ZETTERST. Rev. Grimm. scand. 65 (I86I). BERK. Handb. br. m. 240 (I863). MILDE Bry. siles. I46 (I869). DE Not. Epil. bri. ital. 687 (I869). HobK. Syn. br. m. 8o (1873). Husn. Mouss. nord-ouest 92 (I873), Musc. gall. I36, t. 39 (I887).

Grimmia dccipicns Lindi. in Hartm. Skand. fl. 8 ed. 386 (r86r). JuRATz. Laubm. oester.ung. ${ }_{5} 8$ (I882). Boulay Musc. Fr. $384($ I 884$)$. 
Autoicous; laxly and irregularly pulvinate or sub-crespitose, robust, the plants readily falling asunder, dark brown or black at base, yellowish-green passing to gray above. Stems shorter, suberect, or longer, ascending from a procumbent base, repeatedly dicliotomous, dense-leaved, with hardly any radicles. Leaves when moist recurved, then patulous and curved uprard at point, fuscous-green, long, from an oblong concave base, elongato-lanceolate, carinate above, gradually passing into a very rough hair, the margin here and there reflexed, the perich. bracts sheathing to middle; cells at base linear elongated, rectangular at angles, with $3-4$ rows at margin quadrate and hyaline, median longish, apical small, opake, roundislı-quadrate, all more or less sinuose; nerve broad, channelled, bistratose. Caps. on a yellowish cygneous pedicel, elliptic and obovate, 8-plicate, pale fuscescent witl a red mouth; lid $\frac{1}{3}$ length of caps., purple, with a straight beak ; calyptra small, many-lobed, annulus broad, revoluble; teeth purple, bifid, the legs unequal, erecto-patent when dry. Male infl. gemmaceous, axillar, bracts ovate, acute.

HaB.-Siliceous rocks. Not uncommon. Fr. 4-5.

Clova (Drummond). Argyleshire (Carmichael). Plymouth and Penzance (Tozer). Anglesea, Conway and Breiddin hills (Wilson I833)!! Stenton rocks and Dunsinane (Dr. B. White I865)! By river Cad, Shaugh bridge and Dewerstone rocks (Holmes I866)!! Robin Hood's Bay, Yorks. (Massee)! Cader Idris (Whitchead I879)! Ben Aan, New Galloway (McAndrewo). The Scalp, Dublin $(O r r)$. Luggielaw, Fairhead and Connemara (Moore). Mourne Mtns. (Lett I887)!! Slieve Donard (Lett I884).

Var. $\beta$. robusta $(F e r g$.

Stems straight, dichotomous, little branched. Leaves shorter, narrower, with a narrowed yellowish base, the basal cells shorter, firmer, the upperless sinuose smaller and more opake, the hair-point nearly smootl.

Syn.-Grimmia robusta Ferg. Mss. Braithw. in Journ. Bot. I872, p. I96, t. I24. Новк. Ss n. br. m. 80 (1873).

НАВ.-Limestone and granite rocks.

Glen Callater and Glen Phee, Clova (Fergusson I 868)!! Gairloch head (Hunt)! Near Cardross and Bowling (Stirton 1864). Ballater (Dickie 1869). Connemara (Moore 1863). Dean and Start point, Devon (Holncs). Slieve-na-Maddy, Down (Løtt $\mathrm{r} 885$ ).

This species is readily known by its robust habit and very dense long leaves with long rough silky points, it is nearly allied to $G$. elatior and also to $G$. trichophylla, but differs from both by the autoicous inflorescence. The Var. robusta is a more slender plant, with shorter hair-points, and differs somewhat in the areolation, but this varies considerably, especially in the degree of sinuosity of the cell-walls.

\section{GRIMMIA ELATIOR Bruch.}

Dioicous; robust, laxly cæspitose. Leaves elongato-lanceolate, from a broader base, deeply canaliculate-concave, with the margin revolute below, gradually attenuated into a smoothish hair. Caps. on a short arcuate seta, oval, Io-striate, lid rostellate. (T. XLIX, C.) 
Si'n.-Trichostomum incurvum Hornsch. in Bot. Zeit. I8Ig, p. 89 .

Dryptodon incurvus BrID. Bry. univ. i, I94 (1826).

Rhacomitrium incurvn HUEBEN. Musc. germ. 201 (1833).

Grimmia funalis $\beta$. robusta De Not. Syllab. 25I (1838).

Grimmia elatior Br. Sch. Bry. eur. fasc. 25-28, p. ${ }^{17}$, t. Io (1845). Aongstr. in Fries Summ. veg. sc. 93 (I846). Rabenh. Deutsch. kr. fl. ii, S. 3, I62 (I848). C. Muell. Synops. i, 798 (1849). HarTM. Skand. fl. 7 ed. 372 (1858). Schimp. Synops. $2 I_{j}$ (I860), 2 ed. 258. ZetTerst. Rev. Grimm. sc. 78 (I86I). MiLde Bry. siles. I5I (1869). De Not. Epil. bri. ital. 685 (1869). BRAITHW. in Journ. Bot. I872, p. I97. Hobk. Syn. br. m. 82 (i873). Juratz. Laubm. oester.-ung. I64 (1882). Chalub. Grimm. Tatr. 5I, t. 6 (I882). Bovlay Musc. Fr. 377 (I884). Huss. Musc. gall. I37, t. 39 $(1887)$.

Grimmia funalis * elatior HARTM. Skand. fl. 5. ed. 376 (1849).

Dioicous; robust, in broad lax incoherent tufts, black at base, fuscous-green above, canescent; stems dichotomous $\mathrm{I}-3$ in. high, naked at base, sparingly branched. Leaves subequal, erecto-appressed, when moist strongly recurved, then erecto-patent, very long, from all erect oblong carinate-concave plicate base, with revolute margins, longly lanceolate, subcomplicate-carinate, prolonged into a smoothish hair; cells at base I-stratose, linear rectangular, dilated towards margin, upper rounded-quadrate, 2-4-stratose at apex, more or less papillose, all slightly sinuose; nerve strong, canaliculate, rounded at back. Perich. bracts larger, erect, laxly areolate. Caps. on a short pale arcuate seta, ovate, Io-striate, when dry oblong and deeply sulcate, pale brown, leptodermous; cal. 5-lobed, annulus of 3 rows of cells, lid rostellate, straight or subacicular; teeth broadly subulate, purple, densely articulated, irregularly cleft and perforated. Male plant more branched, infl. terminal, bracts ovate, shortly acuminate.

HAB.-Quartzose rocks in mountains; very rare. Fr. $3-4$.

Clova mountains (Fergusson $\mathbf{1} 868$ ster.)!!

Resembles $G$. decipiens, but is more robust and of a more obscure tint the leaves longer with nearly smooth hairs, the nerve channelled ahove, 5-stratose. From G. trichophylla it differs by the robust habit, upper cells more opake and bistratose, lower longer and narrower. The branches in $G$. elatior are generally more or less incurved.

**: Rectiseta.

\section{GRIMMIA DONII Smith.}

Autoicous; in small green cushions. Leaves elongato-lanc., gradually attenuated into a longish hair, the margins plane. Caps. erect, subexserted, oval-oblong, smootli; lid conical, obtuse, annulus small, teeth nearly entire or perforated. (T. XLIX, D.) 
Syn.-Grimmia Doniana Smitu Fl. brit. iii, I Ig8 (I $8 \mathbf{O}_{4}$ ), Eng. Bot. t. I259. Brıd. Ṡp. musc. I., Ioo (I806), Mant. 35 (I819), Bry. univ. i, I75 (1826). Web. Mohr Bot. Tasch. I3I (I807). Roenl. Deutsch. fl. iii, 46 (I8I3). Ноок Tayl. Musc. brit. 40, t. I3 (I8I8). Hook. Fl. scot. P. 2, I29 (I82I), Br. f. ii, 27 (I833). GRAY Nat. arr. br. pl. i, 728 (I821). Nees Hsch. Bry. germ., ii, P. I, I28, t. 20, f. Io (I827). Hueben. Musc. germ. I 75 (I833). W1L.s. Bry. br. I59, t. I3 (1855). Schimp. Synops. 2 I6 (1860), 2 ed. 259. BERK. Handb. br.m. 239 (I863). MiLde Bry. siles. I5 I (I869). De Not. Epil. br. ital. 704 (I 869). Hobk. Syn. br. 1n. 83 (I 873 ). JURatz Laubm. oester.-ung. I66 (I882). Chalub. Grimm. Tatr. 54, t. 7 (1882). Boulay Musc. Fr. 372 (I884). HusN. Musc. gall. I28, t. 36 (I 886 ).

Dicranum ovale SM. Eng. Bot. t. 2165 p.p.

Grimmia obtusa Schwaeg. Suppl. I, P. I, 88, t. 25 (I8I I). Roehl. Deutsch. fl. iii, 46. Brid. Mant. 35, Bry. univ. i, I74. NeEs Hornsch. Bry. germ. ii, P. I, p. I35, t. 20, f. I I. De Not. Syllab. 243 (i 838 ). Br. Schimp. Bry. eur. fasc. 25-28, p. 20, t. I3 (i 845 ). Aongstr. in Fries Summ. veg. sc. 93 (I846). Rabenh. Deutsch. kr. A. ii, S. 3, I63 (1848). C. Muell. Synops. i, 796 (I849). Hartm. Skand. fl. 7 ed. 373 (1858).

Grimmia alpestris (non Schlejch.) Sommerf. Suppl. fl. lapp. 49 (1826).

Autoicous; in small round green cushions, canescent, lurid green above, brownish-black at base, densely cæspitose, very short. Leaves soft pale green, when dry fuscescent or blackish, appressed, when moist erecto-patent, lower very small, muticous, upper much larger, narrowly elongato-lanc., running out into a long smoothish hair, at base concave, thin, with narrow rectangular cells, 6-- Io rows at margin quadrate and hyaline, toward apex carinate, with minute roundish-quadrate cells in two strata, margin plane erect, slightly thickened at apex; nerve semiterete, vanishing in apex. Perich. bracts broader, the hair as long as the leaf. Caps. exserted or not reaching above the hairs of perich. bracts, on a pale seta, sniall oval-oblong, erect, yellow-brown, leptodermous, smootl ; calyptra mitræform, lobed, annulus of 3 rows of small cells, lid orange, convexo-conic, obtuse, teeth entire, or perforated at apex, rufous, papillose, reflexed when dry. Male infl. terminal or axillar, bracts broadly oblong, sheathing, apiculate.

HAB.-Siliceous rocks in mountain districts. Fr. $3-4$.

Common in the mountains of scotland and Wales. Cheviots (Hardy). Cronkley fell, Teesdale (Spruce). Kinder Scout and Buxton, Derby (Whitchead)!! Kentmere (Stabler 5869)! Slieve-na-Brock, Mourne mtns. Down (Rev. H. W. Lett i 884$)$ !! Axe Edge, Derby (Holmes I 874) !! Lydford (Holmes I 887) !! Brecon Beacon (Boswell I 883).

Var. $\beta$. sudetica (Spreng.)

Taller; leaves with longer hair-points; capsule immersed, elliptic, lid conico-acuminate.

Syn.-Grimmia sudetica Spreng. in Ludw. Crypt. gew. Schruhr Deutsch. kr. gew. II, 48 , t. 22 (I810). SchWaeg. Suppl. I, P. I, 87, t. 24 (I8II). Wahlenb. Fl, carp. 339. Funck Moost. I7, t. i II. NeEs Hsch. Bry. germ. ii, P. I, I28, t. 20, f. Io6.

G. Doniana Var. $\beta$. sudetica. Wiss. Bry. brit. Schimp. Synops.

Hab.-Sidlaw Hills (Gardiner). Braedownie, Clova (Fergusson).

A very pretty moss, especially abundant in the Clova district, and easily recognized by its soft pale capsules with an obtuse lid, which are produced in profusion, and by the plane margins to the leaves. 


\section{Ig. GRIMMIA ALPESTRIS. Schleich.}

Dioicous or autoicous; in large olive-ureen or blackish tufts, shortly canescent. Leaves lanc. with a smooth liair, lower muticouś, margin plane; perich. bracts larger, broad. Caps. on a short seta, erect, oval or oblong, smooth, brown; calyptra cucullate, lid conic, obtusely rostellate, annulus indistinct; teeth red, subentire. (T. XLIX, E.)

Srx.-Grimmia alpistris Schle1ch. Pl. Helv. exsic. NeEs Hsch. Bry. Germ. ii, P. I, I39, t. 21, f. I2 (1827). DE Nor. Syllab. 244 (I833), Epil. bri. ital.702 (I869). BR. ScH. Bry. eur. fasc. $25-28$, p. 27, t. I5 (I 845$)$. Aongstr. in Fr. Summ. veg. sc. 93 (I846). Hartu. scand. fl. 7 ed. 374 (I858). Schimp. Synops. 221 (I860), 2 ed. 265. ZetTerst. Rev. Grimm. scand. 93 (I86I). Milde Bry. siles. I55 (I869). Juratz. Laubm. oester.-ung. I72 (I882). Chalun. Grimm. Tatr. 65, t. 9 (I882). Boulay Musc. Fr. $37^{\circ}\left(188_{4}\right)$. Husn. Musc. gall. I29, t. 37 (1887). Lesq. James Moss. N. Amer. 146 (1884).

Guembelia alpestris Hampe Bot. Zeit. 1846, p. I 24. Rabenh. Deutsch. kr. fl. ii, S. 3, I68 (1848). C. Muell. Synops. i, 772 (1849).

Grimmia lamellosa C. Muelz. Bot. Zeit. I 554 , p. 3 IS.

Grimmia Ungeri Juratz. in Ung. Kotchy Die insel Cypern 169 (1865); Laubm. oester.-ung. I67 (1882). Braithw. in Journ. Bot. 1872 , p. Ig8, t. I24. Hobk. Syn. br. m. 83 (i 873 ). Schimp. Synops. 2 ed. 853 (I 876 ).

Grimmia intermedia FERG. MSS.

Dioicous or autoicous; in compact cushioned tufts, $2-3 \mathrm{in}$. diameter, glaucescent or dark olive-or blackish-green, more or less canescent, radiculose at base. Leaves erecto-patulous, lower smaller, muticous, comal larger, from an ovate base, lanceolate, gradually or suddenly passing into a smootl decurrent liair, margin plane, slightly incrassate above; cells at base shortly rectangular, with $2-4$ rows at margin quadrate and lyaline, the transverse walls more thickened, upper bistratose, opake, roundish quadrate; nerve narrow, sulcate in front, prominent at back; perich. bracts broader, elongated, semi-vaginant, internal shorter, very narrow. Caps. on an erect straw-colored seta, scarce elevated above the liairs, small, oval or oblong-cylindric, smooth, pachydermous, ferrug.-brown ; annulus narrow, of 3 series of cells, variable in distinctness; calyptra large, cucullate, lid conic, subobtuse, rufous, teetl orange-red, conicosubulate, entire or sparingly perforated or cleft at apex. Male infl. terminal or lateral, bracts broadly ovate, obtuse, muticous. $\mathrm{H}_{\mathrm{AB}}$. - On earth in crevices of roclis, very rare. Iir. 4.

Near Ballater (Rov. F. Firgusson 1870$)$ !!

Chalubinski's acute observations on this species are quite sufficient to satisfy us that $G$. Ungeri is not specifically distinct from $G$. alpestris, which is truly polyoicous, and the annulus most variable according to the amount and direction of the incrassation of its individual cells; he is also of opinion that liybrids form between $G$, alpestris and $G$. Donii. 
Our species closely resembles $G$. montanu but that has a larger capsule with acute rostellate lid, and the perich. bracts scarce differ from the comal leaves; the leaves also are more linear towards point, and the hair is longer and roughish. G. Donii differs by its small round tufts, small pale capsule and mitreform calyptra.

20. GRIMMIA MONTANA $B r$. Sch.

Dioicous; in very dense blackish cushions. Leaves erecto-patent, oblongo-lanc., with a long smoothish hair, margin flat, not incrassate. Caps. shortly exserted, erect, small ovate smooth fuscous, lid obliquely rostrate, calyptra large dimidiate. (T. XLIX, F.)

Syn.-Grimmia montana Br. Sch. Bry. eur. fasc. 25-28, p. 26, t. It (I845). Aongst. in Fries Summ. veg. sc. 93 (1846). HARTM. Skand. fl. 7 ed. 374 (I858). Schimp. Synops. 220 (I860), 2 ed. 264. ZetTerst. Rev. Grimm, scand. 9i (I86I). Milde Bry. siles. r54 (1869). Hoвк. Syn. br. m. 84 (I873). Husn. Mouss. nord-ouest 94 (I873), Musc. gall. I 29, t. 37 (I887). JuRatz. Laubm. oester-ung. i7 I (I882). Chalub. Grimm. Tatr. 63, t. 8 (I882). Boulay Musc. Fr. 369 (1884). Lissq. James Moss. N. Amer. I 45 (I884).

Gucmbelia montana Hampe Bot. Zeit. I845, p. I24. Rabenh. Deutsch. kr. fl. ii, S. 3, I68 (I848). C. Muell. Synops. i, 774 (I $8+9$ ).

Dioicous; densely pulvinate, blackish, or dull dark green and canescent at top, fuscous and radiculose at base. Leaves recurved when moist, then erecto-patent, lorver small lanceolate muticous, upper oblongo-lanceolate, carinate, flat and erect at margin, running out into a long slightly toothed, decurrent hair; cells above very small, roundishquadrate, bistratose, opake, at base hyaline quadrato-hexagonal, with 4-6 rows at margin broader and shorter; nerve thick, prominent at back, acutely channelled in front. Perich. bracts larger, sheathing at base, long-haired. Caps. on a short yellow seta, erect oval-oblong, smooth, orange-brown, calyptra cucullate, long-beaked, covering most of caps., annulus of 3 rows of small cells, lid rostrate, $\frac{1}{3}$ length of caps., teeth irregular, often erose at margin, and fisso-cribrose toward point, when dry recurvo-patulous. Male plants more slender, in separate tufts, bracts broadly ovate, acuminate.

НАв.-Porphyry and granite roclis; rare. Fr. 3-4.

Dee-side, Aberdeen (Barker Ev Ray I869). Fingle bridge, Devon. c. fr. (Holmcs 1877).

Distinguished from $G$. ovalis by the infl, the erect margin of leaf, more prominent nerve, cells opake above, bistratose in middle and longer hair. From $G$. alpestris by the denser more opake areolation of apex, leaves more patent and subulate, short capsule and rostrate lid. 


\section{I. GRIMMIA OVATA Web. Mohr.}

Dioicous; deep green, taller, laxly tufted. Leaves lax, erectopatulous, from an ovate base, lanceolate, with a long hair, cells minute, opake. Caps. large, turgid, ovate, calyptra cucullate, lid obliquely rostrate, teeth broad, trifid. (T. L, A.)

SYn.-Dieramm oratum Swartz Disp. musc. fr. suec. 35 p.p. (I798). BRID. Sp. musc. p. p.

Dieranum ovale Hedw. Sp. musc. I40, p. p. (I80I). Wahlenb. Fl. upsal. 752 (1820).

Grimmia ovata Weв. Moнr Naturhist. reise durch Schweden I32, t. 2, f. 4 (1804).

Triehostomum ovatum WeB. Mohr Bot. Tasch. III p. p. (I807). Swartz Summ. veg. sc. 39 p. p. (I8I4).

Grimmia elliptiea Funck Moost. I6, t. I I (I82 I).

Dryptodon ovatus Brid. Bry. univ. i, 202 p. p. (I826).

Grimmia commutata Hueben. Musc. germ. I8j (1833). De Not. Syll. 246 (I838), Epil. bri. ital. 699 (1869). BR. Sch. Bry. eur. fasc. 25-28, p. 25, t. I9 (1845). Aongst. in Fries Summ. veg. sc. 93 (I846). HARTM. Skand. fl. 7 ed. 373 (I858). Schimp. Synops. 2 Ig (I860), 2 ed. 263. ZetTerst. Rev. Grimm. sc. 88 (I86r). Milde Bry. siles. I54 (I869). Hoвk. Syn. br. m. 84 (I873). Husn. Mouss. nord.ouest 94 (I873), Musc. gall. Izo, t. 37 (1887). JuRATZ. Laubm. oester.-ung. I 70 (1882). Boulay Musc. Fr. $3^{67}$ (I384). Lesq. James Moss. N. Amer. I45 (I884).

Dryptodon ellipticus HARTM. Skand. fl. 3 ed. 27 I ( 1838 ), forma epiliferc.

Guembelia elliptiea Hampe Bot. Zeit. i846, p. i24. Rabenh. Deutsch. kr. fl. ii, Sect. 3. I 68 (I848).

Guembelia ovata C. Muell. Synops. i, 774 (1849).

Dioicous; in blackish-green incolierent tufts. Stem slender, erect. when old decumbent, flexuose, naked below. Leaves when moist strongly recurved, then erecto-patent, when dry laxly imbricated, lower very small, lanceolate muticous, upper much longer, patulous, bending upward from the middle, from a broadly ovate sheathing base, lanceolate, acuminate, concave, gradually running into a short finely denticulate hair, margin flat, erect or a little inflexed, not incrassate; cells above bistratose, small roundish, at base narrowly rectangular and chlorophyllose, with Io-I5 rows at margin quadrate and partly hyaline; nerve flattened. Perich. bracts broader, palish, the 3 inner erect, longly sheathing, with long hairs. Caps. exserted on a pale red seta, oval or oval-globose, contracted at mouth, erect, smooth, pachydermous, brown ; calyptra cucullate, reaching middle of caps; annulus of 4 rows of large cells, lid small obliquely-beaked, half length of caps., teeth $2-3$ fid to the middle, and cribrose, rarely sub-entire and lacunose only at apex, dull red, patulous when dry. Male plant smaller, bracts broadly ovate, shortly acuminate.

HAB. -Quartzose and porphyry rocks. Fr. 4.

Moncrieff hill, Perth (Dr. Stirton I864)! Stenton rocks, Dunkeld c. fr. (Dr. B. White I865)! Clova c. fr. (Rev. F. Fergusson 1868)!! Craig Chailleach c. fr. (Whitehead and Ashton 1882)!! Tiled roof at Wickham Bishops, Essex (H. N. Dixon I886)!! Kirkcudbright (McAndrets). Rydal, Westmoreland (Binstad I 887)! 
The greatest confusion exists among the older authors between this species and the next, and even Huebener, C. Mueller and others who adopt G. commutata quote Hedwig's Dicranum ovale as a synonym of it, in spite of the beautiful 5-lobed calyptra figured on his plate. It is clear that $G$. ovalis (Hedw.) must stand for $G$. ovata of most modern authors, and that G.ovata IVer. Morr-collected by them at Carlbergs Allee, Stockholm, although they do not appear to have seen the calyptra-is not the same as Hedwig's ovalis, hut the type of G. commutata Hueren. as was suspected by Zetterstedt, and more expressly indicated by Lindberg, who remarks that $G$. commutata is abundant about Stockholm, but G. ovalis is scarcely found there, and Weber and Mohr's description of their G. ovata "capsula ovata, pedunculo brevi insidente, operenlo oblique rostrato, per. dentes 16 , latiusculi," is far more applicable to G. commutata than to Hedwig's $G$. ovalis. It is evident then that the criginal names of the two species, characterized clearly enough when they were established, should be restored, and all the cross references of one to the other had better be avoided. G.ovata is distinguished by the dioicous infl., taller stem with more distant leaves, opake in the upper part, and with very narrow elongated cells near the basal part of the nerve, inflated caps. with long oblique acute beak, cucullate calyptra, and broad trifid teeth of peristome.

\section{GRIMMIA OVALIS (Hedr.) Lindb.}

Autoicous; robust, laxly pulvinate, blackish green, hoary. Leaves erecto-patent, from an oblong-ovate base, narrowly lanceolate, with a short hair. Caps. erect oval, fuscous, calyptra mitræform, lid short, rostellate, teeth narrow, bifid, cribrose. (T. L, B.)

Srn.-Dicranum ovale Hedw. Musc. frond. iii, 8I, t. 34 A. (I792), Sp. Musc. I4o p. p. Roth Fl. germ. iii, P. I, I 72 (I 800 ). TURn. Musc. hib. 77 p. p. (I804). SM. Fl. brit. I 214 (I804), Eng. Bot. t. 2 I65 p. p.

Dicranum ovatum SwarTz Musc. suec. 35, p. p. (I798).

Bryum ovalc Hoffm. Deutsch. fl. ii, I72 (I795). Dicks. Pl. crypt. Fasc. IV, I3 (I8oi).

Trichostomum ovatum WEB. MoHR Bot. Tasch. II I p. p. (I807).

Grimmia ovata Schwaeg. Suppl. I, P. I, p. 85, t. 24 (181 I). Hook. Tayl. Musc. br. 39, t. I3 (I8I8). Brid. Mant. 36 (18Ig), Bry. univ. i, I76 (I826). Gray Nat. arr. br. pl. 1, 727 (I82I). SOMmerf. Suppl. H. lapp. 50 (I826). NeEs Hsch. Bry. germ. ii, P. I, I5 I, t. 2 I, f. I5 (I827). HuEBEN. Musc. germ. I 82 (I833). DE Not. Syllab. 245 (i838), Epil. bri. ital. 700 (I 869 ). Aongstr. in Fries Summ. veg. sc. 93 (1846). BR. Sch. Bry. eur. fasc 25-28, p. 2 I, t. I7-I8 (I845). RaBenH. Deutsch. kr. fl. ii, S. 3 , I64 (I848). C. Mufll. Synops. i, 796 (I849). Wils. Bry. brit. I60, t. I3 (I855). HarTm. Skand. fl. 7 ed. 373 (1858). Schimp. Synops. 217 (I86o), 2 ed. 260. Zetterst. Rev. Grimm. sc. 83 (I86I). Berk. Handb. br. m. 239 (I863). Milde Bry. siles. I52 (1869). Hobk. Sjn. br. m.83 (1873). Husn. Mouss. nord-ouest 93 (I873), Musc. gall. 130, t. 37 (1887). JURATZ. Laubm. oester.-ung. I66 (1882). Chalub. Grimm. Tatr. 57, t. 7 (1882). Bovlay Musc. Fr. 368 (1884). LesQ. James Moss. N. Amer. I43 (I884).

Grimmia affnis, patens, obliqua ct sciuroidcs Hsch. Brid. Bry. univ. NeEs Hsch. Bry. germ. ii, P. I.

Grimmia ovalis Lindb. Act. soc. sc. fenn. X, 75 (I87I).

Autoicous; robust, pulvinate and subcæspitose, $\frac{3}{4}-I_{\frac{1}{2}}$ in. high, radiculose, from blackish or olive-green becoming grey. Leaves when 
moist slightly recurved, then erecto-patent, when dry incumbent, lower small, lanceolate, upper much longer, from an oblong narrow concave base, with the margin reflexed, lanceolate, acutely carinate, continued into a longish nearly smooth hair, upper margin erect, lightly incrassate, bistratose; nerve narrow, semiterete canaliculate, very thin towards base; cells above roundish-quadrate opake and sinuose, at base thin elongate, rectangular and hyaline at margin. Perich. bracts larger, broader, subvaginant. Caps. exserted on a yellow seta, ovate or longisli oval, pachydermous, light-brown; calyptra lobate mitræform, covering $\frac{1}{3}$ caps., sometimes subcucullate; lid rufo-fuscous, with a short straight beak, sometimes oblique, rarely obtuse, annulus broad of $3-4$ rows; teeth cleft to middle in two unequal legs or perforated, narrow, deep red, papillose, patulous when dry. Male infl. terminal and lateral, bracts short, broadly ovate, pointed.

HAB.-Alpine rocks; not common. Fr. IO-3.

Breadalbane and Clova mtns. Snowdon. Swithland slate pits, Charnwood forest (Bloxam)! Kyloe crags, Northumberland (Boyd and Ferdon). Howth and Killirey (D. Orr.) Loch Coruisk, Skye (Dixon I883)!!

Var. $\beta$. cylindrica (Hsch.) Hueben.

Stem erect, with fasciculate branches. Leaves broadly lanceolate, more acuminate, with weaker hair points. Caps. longer, subcylindric.

Syn.-Grimmia cylindrica NeEs Hsch. Bry. germ. ii, P. I, r6r, t. 23, f. I8.

Grimmia ovata $\epsilon$. cylindrica Hueben. Musc. germ. 183 .

Haв. - Near Cherrytrees; Northumberland $(B o y d)$ !

Perhaps G. oralis most resembles $G$. Donii, but is much more robust, with broader more rigid leaves, the seta longer, with larger and darker capsules. Its difference from $G$. ovata is indicated under that species.

\section{GRIMMIA ELONGATA Kaulf.}

Dioicous; laxly tufted, brown or black. Leaves patent, elongate lanceolate, lower muticous, upper with a hyaline point. Caps. on a short erect seta, small, ovate; lid conic, obtuse; calyptra with several lobes. (T. XLVII, C.)

Syn.-Grimmia elongata Kavlf. in Sturm Deutsch. fl. II, I5 (1815). Funck Moost. I6, t. II (I82J). Brid. Bry. un. i, I79 (1826). NeEs Hsch. Bry. germ. ii, P. I, r66, t. 23, f. 20 (1827). Hueren. musc. germ. r79 (r833). BR. Sсн. Bry. eur. fasc. 25-28, p. 28, t. 22 (1845). Aongstr. in Fries Summ. veg. scand. 93 (I846). Rabenh. Deutsch. kr. A. ii, S. 3, r66 (r848). C. Muell. Synops. i, 792 (r849). Hartm. Skand. fl. 7 ed. 353 (1858). Schimp. Synops. i, 223 (r860), 2 ed. 267. Zetт. Rev. Grimm. scand. 97 (r86r). DE Not. Epil. br. ital. 696 (r869). Braithw. in Journ. Bot. 1872, p. I99. Hовк. Syn. br. m. 85 (r873). JuRATz. Laubm. oester.-ung. I 74 (r882). Chalub. Grimm. Tatr. 78 , t. ro (r882). Boular Musc. Fr. 365 (r884). Husnot Musc. gall. r3r, t. 37 (1887). 
Dioicous ; in lax pulvinate tufts, fuscous or black below, olivaceousgreen and shortly canescent at apex. Stems slender, elongate, dicliotomous, sparingly branched, $\frac{3}{4}-2$ in. high, naked and decumbent at base. Leaves from an erect oblong base, divergent, rather rigid, elongate-lanceolate, lightly recurved at margin, subcomplicate-carinate, muticous, the wings asymmetric, nerve stout excurrent, uppermost with short hyaline points; basal cells linear-rectangular; dilated towards margin, upper quadrate, sinuose, apical minute, bistratose, I-2 rows at margin 3-4 stratose. Perich. bracts oblongo-lanceolate-acuminate, with short hair points. Caps. exserted on a short straight yellowish seta, small ovate, pale fuscescent, smooth, lid conic, obtuse, annulus of 2 -3 rows of small cells; calyptra cucullate, lobate, teeth yellow, broadish, cleft or perforated only at apex.

HAB.-Wet alpine rocks; rare and sterile.

Glen Callater and Glen Phee, Clova (Fergusson I868)!

Most of our native specimens are in short dense tufts, largely impregnated with earth and resembling Andrexa petrophila in colour.

\section{GRIMMIA MICROCARPA (Gmel.) Lindb.}

Dioicous; in lax olivaceous tufts. Leaves crowded, patent, ovato-acuminate carinate, with very short serrate hair points, the margins recurved. Caps. minute, elliptic, exserted on a straight seta, cal. mitræform, lid conic, acutely rostrate. (T. XLVIII, B.)

Syn.- Bryum hypnoides alpinum, setis et capsulis exiguis DulL. Hist. musc. 37o, t. 47, f. 29 (I74I) et Herb.

Bryum hypnoides Var. S. microcarpum and $\epsilon$.obtusum RETz. Fl. scand. prod. ii, $2 \mathrm{I} 4$ (1779).

Bryum microcarpon GmeL. (L.) Syst. nat. I3 ed. ii, P. 2, I332 (I79I). Hofrm. Deutsch. f. ii, 42 (1796).

Dicranmm microcarpan Schrad. Samm. kr. gew. i, I I (I796). Ro'rh Tent. fl. germ. iii, P. I, I77 (1800).

Trichostomum obtusum BRID. Musc. rec. II, P. I, 125 (1798), Sp. musc. I, 237 (1806).

Trichostomum microcarpon BRID. Musc. rec. II, P. I, I27; et Sp. musc. I, 237, max. p. Henw. Sp. musc. II2, t. 23, f. 8-I2 (I80I). Turn. Musc. hib. 40 (I804). SMith Fil. brit. 1243 (1804); Eng. Bot. t. I $44^{0}$. De Cand. (Lam.) Fl. franc. 3 ed. ii, 469 p.p. (1805). Web. Mohr Bot. Tasch. II3 (1807). Schkuhr Deutsch. kr. gew. P. II, 7o, t. 3 I (I8Io). Hook. TAYl. Musc. br. 6I, t. I9 (I8I8). Hook. Fl. scot. P. 2, I34 (182I), Br.f. ii, 33 (1833). W. Arn. Mem. soc. Linn. Par. ii,270 (1825). Duby Bot. gall. ii, 573 (1830). WaLlR. Fl. cr. germ. i, i76 (1831). W. ARN. HOOK. in HOOK. J. Bot. i, 95 (1834). TAY'L. in MAck. F1. hib. 2, p. 20 excl. var. $\beta$. (1836).

Trichostomum heterostichum Schleich. P1. cr. helv. I cent. n. I3 (I804), Cat. pl. helv. 2 ed. 3 I $(1807)$ ?

T. patens var. $\beta$. Schwaeg. Suppl. I, P. I, I52, t. 37 , f. Ia, 7,8 ?

Rhacomitrium obtusum BRID. Mant. 79 (1819), Bry. univ. i, 213 (1826).

Rhac. microcarpon BRiD. op. c. max. parte.

Trichostomum sudeticum Funck Moost. 26, t. I8 (1821), Cr. gew. ficht. n. $57^{\circ}$ (I822). 
Dryptodon sudeticus Brin. Bry. un. i, I95. WaLLk. Fl. cr. germ. i, 136 (I831).

Rhacomitrium microcarpon $\beta$. sudeticum Hueben. Musc. germ. 202 (I833). HaRTM. Skand. fl. 4 ed. 389 (1843).

Trichostomum gracile Hornsch. MSS. HUeben. 1. c. ut synon.

Grimmia proccra DE Nor. in Mem. acc. Torin. xl. 339 (1838), Syllab. $25^{2}$ (1838), Epil. bri. it. 695 (1869).

Rhacomitrizm sudeticum BR. Sch. Bry. eur. fasc. $25-28$; p. 7 , t. I (1845). RAbenh. Deutsch. kr. fl. ii, S. 3, I57 (1848). Wils. Bry. brit. I66, t. I9 (1855). Sснimp. Synops. 230 (I860), 2 ed. 276 . Zetterst. Rev. Grimm. scand. II5 (I86i). Berk. Handb. br. m. 235 (I863). Milde Bry. siles. 157 (1869). Hoвk. Syn. br. m. 87 (1873). Juratz. Laubm. oester.-ung. I78 (1882). Chalub. Grimm. Tatr. 92, t. I3 (I882). Boulay Musc. Fr. 36i (I884). Lese. James Moss. N. Amer. I49 (1884). HuSN. Musc. gall. I39, t. 40 (1887).

Grimmia microcarpa forma procera C. Muell. Synops. i, 805 (I849).

Grimmia microcarpa LindB. Act. soc. sc. fenn. X, $55^{8}$ (1875).

Dioicous; laxly cæspitose, plane, olivaceous or squalid-green, slightly canescent at tips. Stems slender, somewhat elongated, naked below, sparingly fastigiate-branched. Leaves erect when dry, divaricate and patulous when moist, longly lanc., acuminate with acute hoary dentate points, lower muticous, towards base carinate-concave with reflexed margins, above subcomplicate; cells in one stratum, at base sinuoso-rectangular, with a row of broader quadrate ones at margin, above roundish-quadrate with $\mathrm{I}-3$ rows at margin bistratose, the nerve stout, flattish at back. Perich. bracts sheathing, more laxly areolate, with the nerve vanishing. Capsule on a short yellowish seta, erect, very small, elliptic, light brown, olivaceous when young, leptodermous; calyptra mitræform, nearly smooth at apex, lid acutely rostrate, $\frac{2}{3}$ length of caps., annulus broad, of 4 rows of cells, rolling back, teeth more or less bipartite, red, erecto-patent when dry. Male plant more slender, bracts ovate, acute.

HaB.-Moist alpine rocks. Fr. 4-5.

Ben Lawers (Grevillc)!! Mountains of Connemara and Wicklow (Moure). Dartmoor (Holmcs). Cheesewring, Cornwall (Brcnt). Ingleboro' and Clapdale, Cheviots (Winch). Ben Laoigh (Ewing). Glen Torridon (Hunt).

This species as well as $G$. clongata having straight setae are removed from the G.trichophylla group, to which in their sterile state they would undoubtedly be referred, for $G$. microcarpa has in no form the peculiar ramification of Trichostomum, though its sinuose-crenulate cells represent those of that section. Griminia affinis has the greatest resemblance to it, but in G. microcarpa the leaves have much narrower points, and the lower cells are shorter and wider.

\section{GRIMMIA CAMPESTRIS Burchell.}

Dioicous; short laxly tufted, canescent. Leaves broadly oblongolanc., suddenly running into long rough hairs. Caps. on a straight 
seta, elliptic, smooth, lid conic, rostellate, calyptra mitræform. (T. L, C.)

SrN.-Bryum orbiculare pulvinatum, hirsutie canescens, capsulis immersis, var. capsulis erectis pradita Dillen. Hist. musc. 395 , t. 50, fig. 65 D-E (I74I) et Herbar.

Grimmia campestris BUrchell MSS. Hook. Musc. exot. ii, 9, t. I29 (I820). Steun. Nom. cr. I88 (I82I).

Campylopus levigatus BRID. Mant. 76 (I8I9).

Grimmia larigata Brid. Bry. univ. i, I83 (1826).

Grimmia leucophaa GREv. in Wern. Trans. iv, 87, t. 6 (I822), Scott. Cr. f. v, t. 284 (I828). Hook. Tayl. Musc. br. 2 ed. 70 , Suppl. t. 3 (I827). Hook. Br. fl. ii, 26 (1833). Hueben. Musc. germ. I87 (I833). DE Not. Syllab. 248 (I838), Epil. bri. ital. 708 (I869). Schwaeg. Suppl. IV, t. 306 (I8+2). Br. Sch. Bry. eur. fasc. $25-28$, p. 23 , t. 20 (I845). Rabenh. Deutsch. kr. f. ii, S. 3, I65 (I 848 ). C. Muell. Synops. 794 (I849). Wils. Bry. br. I6I, t. 33 (i855). Schimi. Synops. 218 (1860), 2. ed. 26I. Berk. Handb. br. m. 238 (I 863 ). MILDE Bry. siles. I52 (I869). HoRK. Syn. br. m. 84 (1873). Husn. Mouss. nord-ouest 93 (I873), Musc. gall. 127, t. 36 (I886). Juratz. Laubm. oester.-ung. I68 (I882). Boulay Musc. Fr. 373 (I884). Lesq. Jamfs Moss. N. Amer. I 44 (1884).

Dryptodon leucothaus Brid. Bry. un. i, Suppl. 773 (1827).

Dioicous; in wide very laxly coherent tufts, dull green, silvery grey above. Stem erect, simple or dichotomous, the branches erect, dense-leaved, subclavate at apex. Lowest leaves minute, triangularovate, muticous, thence gradually larger, erecto-patulous, from a broad oblong base, ovato-lanc., suddenly running out into a long very rough hair, decurrent at sides, cymbiform-concave, the margin flat and erect; cells soft, green, roundish-quadrate, opake, bistratose in upper part, at base next the nerve with $2-6$ rows elongate, faintly hyaline, the rest quadrate; nerve thin and flat. Perich. bracts larger, semivaginant, with lax, rectang. cells, several rows at margin hyaline. Caps. on a pale straight seta, scarce elevated above the hairs, erect, elliptic or tumid-oblong, reddish-brown, rather large, smooth, pachydermous; calyptra mitræform, lobed, annulus of 3 rows of cells, lid conic, subulate or bluntly rostellate, straight, $\frac{1}{3}$ length of caps., teeth $2-3$-fid to middle, cribrose below, rarely subentire, purple. Male plants mixed with female, infl. gemmiform, bracts broadly ovate, with short hairs.

Haв.-Dry granite and basaltic rocks. Fr. 4.

Arthur's Seat, Edinburgh (R. Brown)!! Fairhead, Fife (Arnott). Penzance (Curnow I878)! The Chasms, I. of Man (Holt I884)! The Gannel, Newquay, Bolt head and Whitsand Bay (Holmes 1884)!! Abbey craig, Stirling (Lyle). Salcombe (Mrs. Griffiths). Giant's Causeway and Rathlin Island (Moorc I837). Dartmoor (Marquand I884). Largo Lav (Howie I864).

Readily known by the broad leaves with very rough hair-points, and by the solid rufous capsule, just emergent above the leaf-hairs.

Sect. 3. DRYPTODON (Bvid.) Plants taller, in very lax irregular tufts, dichotomously branched, fastigiate. Leaf cells incrassate, their walls more or less crenulate or sinuate. Caps. on a curved or straight seta, smooth; teeth more or less deeply cleft ; calyptra mitræform. 


\section{GRIMMIA ATRATA Mielichh.}

Dioicous; tall, lurid green, dense-leaved. Leaves solid, lineallanc., muticous, broadly acute; cells quadrate with crenulate walls. Caps. on a short thick seta, oblong-ovate, witlı a very short neck; lid obtusely rostellate, calyptra cucullato-mitræform. (T. L, D.)

Sir.-Grimmia atrata MrerıchH. in Flora I8I9, P. I, 85. Hook. Musc. exot. ii, 9, t. Ioo (I820). Funck Moost. i7, t. I2 (1821). SchwaEg. Suppl. II, P. I, 59, t. II6 (I823). Brid. Bry. univ, i, I84 (I826). NeEs Hsch. Bry. germ. ii, P. I, I63, t. 23, f. I9 (I827). Hueben. Musc. germ. I80 (1833). Hook. Br. fl. ii, 27 (1833). Wils, in Eng. Bot. Suppl.t. 277 I (I833), Bry. br. I62, t. 44 (I855). Br. Sch. Bry. eur. fasc. 25 -28, p. 30, t. 23 (1845). Aongst. in Fries Summ. veg. scand. 92 (1846). Rarenh. Deutsch. $\mathrm{kr}$. fl. ii, S. 3, I67 (I 848 ). C. Muell. Synops. i, 803 (I849). Hartm. Skand. fl. 7 ed. 374 (I858). Schimp. Synops. 224 ( I860), 2 ed. 269 . ZetT. Rev. Grimm. scand. Ioo (1861). Berk. Handb. br. m. 237 (I863). Hobk. Syn. br. m. 85 (I873). JURAtz. Laubm. oester.-ung. I75 (I 882). Boulay Musc. Fr. 365 (1884). Husn. Musc. gall. I3 I, t. 38 (I 887 ).

Dioicous; tall, robust, densely pulvinato-cæspitose, deep black and subtomentose below, lurid green or yellowish at apex; plants erect, densely and uniformly leaved, the branches elongated. Leaves solid, erectopatent, when dry curved and subcontorted, longly lineal-lanc., straight, carinate-concave, widely acute, muticous, margin here and there reflexed, bistratose in 2 rows, nerve broad, canaliculate, vanishing at apex; cells minute, quadrate, strongly incrassate, the walls punctulato-crenulate, the basal laxer, more elongated, with some pellucid at margin. Perich. bracts semiamplexicaul, cymbiform-concave; caps. on a thick yellow seta, erect or suboblique, ovate-oblong with a very short neck, pachydermous, pale ferruginous, black when old, annulus broad of $3-4$ series of cells ; lid orange, shortly and obtusely rostellate; teeth with crowded articulations, perforated at apex or cleft to middle, pale ferruginous, recurved when dry. Male plants similar, short, infl. terminal, bracts ovate.

HAB.-Alpine rocks, rare. Fr. IO-II.

Clogwyn-y-Garnedd, Snowdon (Wilson, I826)!! Clogwyn-du-Arddu (Ralfs). Glen Callater (Greville, I830)!! Loch Kandor (Hunt). Canlochan (Eving I886).

Differs from $G$. clongata by the absence of hyaline points to the leaves, the incrassate margin and crenulate cell walls, and from G. clliptica by the shorter leaves and different lid and calyptra.

\section{GRIMMIA UNICOLOR Hook.}

Dioicous; tall, fuscous. Leáves erecto-patent, from an obovate base, linear-lanc., obtuse, muticous, incurved at margin, basal cells rectangular, pellucid at margin. Caps. ovate, lid rostrate, calyptra cucullato-mitræform. (T. L, E.) 
Syn.-Grimmia miculur Hook. in Grev. Scott. cr. fl. iii, t. I23 (1825), Br. fl. ii, 27 (1833).

Brid. Bry. univ. i, I82 (1826). Hook. TAYL. Musc. br. 2 ed. 72 , Suppl. t. 3 (1827).

Wrls. in Eng. Bot. Suppl. t. 277 I (1833), Bry. br. I62, t. 33 (I855). Br. Sch. Bry. eur.

fasc. $25-28$, p. 29, t. 23 (1845). AONGST. in Fries Summ. Veg. Sc. 93 (1846).

Rabenh. Deutsch. kr. H. ii, S. 3 , I66 (I848). C. Muell. Synops. i, 793, (I849). Hartm. Skand. fl. 7 ed. 374 (I858). Schimp. Synops. 224 (i860), 2 ed. 268. ZetT. Rev. Grimm. scand. 99 (I86I). Berk. Handb. br. m. 238 (I863). Milde Bry. siles. I55 (I869). DE Not. Epil. bri. ital. 693 (I869). Hовк. syn. br. m. 85 (I873). Lindb. in Act. soc. sc. fenn. X, 557 (I 875 ). JuRatz. Laubm. oester.-ung. I 75 (I882). Boulay Musc. Fr. 366 (1884). Lesq. James Moss. N. Amer. I46 (I884). Husn. Musc. gall. I3I, t. 37 (1887). Grimmia atrata Spreng. (L.) Syst. veg. I6 ed. iv, P. I, I54, p.p. (I827).

Dioicous; in large flat laxly coherent tufts, purple-black below, dull green above. Stems slender, decumbent, naked at base, fastigiatebranched, often with filiform small-leaved ramuli. Leaves patent and erecto-patent, when dry densely imbricated, from an ovate-oblong base, narrowly lineal-lingulate, obtuse, canaliculate-concave, margin erect, nerve scarce prominent at back, dilated at base, vanishing in the apex, cells at base rectang., 2-4 rows at margin quadrate and pellucid, above in 2 strata, gradually minute, quadrate, firm, incrassate, at apex in $2-3$ strata, rather fleshy and opake; ramuline leaves obovate, shortly and obtusely acuminate. Perich. bracts broader, sheathing. Calyptra cucullate-mitriform, long-beaked; caps. much exserted, erect or suboblique, oblong or ovate, leptodermous, yellow-brown; annulus broad of 3 rows of cells, lid orange, long-beaked; teetl orange, longish, cleft to middle and lacerate, very densely articulate, erect when dry. Male plants more slender, infl. terminal, bracts ovate.

HAB.-Alpine rocks, rare. Fr, II-I2. Bachnagairn, Clova (Drtmmond)!!

Readily known by the obtuse leaves with incurved margins after the fashion of Mollia crispula. The areolation resembles that of G.ovata, and is less dryptodontoid than the other species of this section, its affinity to $G$. atrata is however greater than to any other species.

\section{GRIMMIA ELLIPTICA (Twm.) Am.}

Dioicous; in rigid blackish depressed tufts. Leaves oblongolanceolate, suberect, muticous, margin plane incrassate, cells all sinuose, basal very narrow and elongate. Capsule on a thick seta, subglobose, castaneous, hard, lid conico-subulate. (T. L, F.)

Syn.-Dicranum ellipticum Turn. Musc. hib. 76 , excl. syn. Dill. t. 6, f. 2 (180 4 ). Smith Fl. brit. I2I3, excl. syn. Dill. (I804), Eng. Bot. t. Igor. BRid. Sp. musc. I, 2 I5 (I806). Schwaeg. Suppl. I, P. I, I 84 , t. 47 (I8II).

Trichostomum ellipticum Hook. TAYL. Musc. br. 62, t. I9 (I8I8). Gray Nat. arr. br. pl. i, 74I (I82I). Hook. Br. fl. ii, 34 (I833). TAYL. in MACK. Fl. hib. P. 2, 20 (I836).

Campylopus ellipticus Brid. Mant. 76 (18I9).

Grimmia elliptica W. ArN. in Mem. soc. hist. nat. Par. ii, 269 (1825). C. Muell. Synops. i, 799 (1849). LiNdB. in Act. soc. sc. fenn. X, 557 (1875).

Dryptodon cllipticus BRID. Bry. un. i, 204 (I826). 
Rhacomitrium ellipticum BR. Sch. Bry. eur. fasc. $25-28$, p. 5, t. $2+$ (I $8+5)$. Wils. Bry. br. I64, t. I9 (I855). Schimp. Synops. 228 (1860), 2 ed. 273. Zетt. Rev. Grimm. sc. Iog (I86I). Berk. Handb. br. m. 236 (1863). Новк. Syn. br. m. 86 (1873). Huss. Musc. gall. I38, t. 39 (1887).

Dioicous; in blackish rigid fragile depressed tufts, luteo-fuscous at top. Stems I in. long, erect or decumbent at the naked base. Leaves from an erect base, patent, when dry suberect and incurved, shortly oblongo-lanceolate, rather obtuse, solid, carinate-concave, lightly incrassate and of $2-+$ strata at the erect margin, upper cells bistratose, minute, sinuoso-quadrate, lower elongated, linear, crenulato-sinuose, all strongly pachydermous, smooth; nerve brownish, ill-defined above, ending at or below apex. Perich. bracts similar, shorter. Caps. erect on a thick rigid yellow seta, small, ovato-globose, smooth, pachydermous, rufo-fuscous, black when old; annulus broad, double, lid acicular, straight, long as caps., teeth narrowly lanc. bi-trifid to the middle, rufous-purple, smooth, when dry radiately patent; calyptra scabrous at apex.

Нав.-Damp schistose alpine rocks. Fr. I I-2.

Bantry (Miss Hutchins). Fairhead, Antrim; Brandon, Kerry; Lugnaquillia, Wicklow; Maam-torc, Galway; Giant's-stairs, Monkstown (Carroll). Snowdon (Wilson 1826)! ! Ben Arthur and Crianlarich (Hunt). Clova (Bcll). Ben Laoigh (Ewing). Ben Nevis (Whitchcad I875)! Tyndrum (Kidstor)! Ptarmigan Mtns. (Holt I880)!! Slieve Donard and Slieve-na-Maddy, Down (Lct) !! Skye, Clova, and Ben Macdhui (Hunt I868).

Distinguished by its small size and dark color from G. aquatica.

\section{GRIMMIA PATENS (Dicks.) Br. Sch.}

Dioicous; in large olivaceous fragile tufts, repeatedly dichotomous, with curved branches. Leaves patent, lanceolate, acuminate, muticous, margin revolute in lower half, nerve with $2-+$ lamellre at back, cells very minute and rounded above. Caps. oval, on a cygneous seta. (T. LI, A.)

SYN.-Bryum patens Dicks. Pl. crypt. Fasc. II, p. 6, t. 4, f. 8 (1790).

Pterygynandrum? patens Hedw. Sp. musc. 87 (I80I). BRID. Sp. musc. I, I 36 (1806).

Dicranum patens SM. Fl. brit. 1212 (1804), Eng. bot. t. 1990. BRID. Sp. musc. I, IgI.

Pterygynandrum Ramondi DE CAND. Fl. franc. 3 ed. iii, 462 (1805).

Trichostomum nudum Schleich. Pl. cr. helv. cent. 3, n. I9 (I805) ? Web. Mohr Bot. Tasch. 127 in obs. (1807).

Tortula? patens P. Beauv. Prodr. 48 (1805).

Trichostmum patchs Web. Mohr Bot. Tasch. 125 (1507). Bland. Musc. fr. exs. fasc. 5, n. 219 (1808). Schiuhr Deutsch. kr. gew. P. II, 77, t. 3+ (I8Io). Schwaeg. Suppl. I, P. I, I5I, t. 37, excl. figg. 1a, 7, 8 (I8II). RoeHL. Deutsch. fl. iii, 62 (1813). Hook. Tayl. Musc. br. 6o, t. I9 (1818). Gray Nat. arr. br. pl. i, 739 (1821). Hook. Fl. Scot. P. 2, 134 (1821), Br. fl. ii, 32 (1833).

Fissidens patens Wahlenb. Fl. lapp. 334 (I $\mathrm{I}_{12}$ ), Fl. carpat. 3 to (18If).

Campylopus patens Brin. Mant. 73 (I819). 
Leucodon Ramondi Brid. Mant. 135.

Dryptodon patchis Brid. Bry. un. i, I92 (I826).

Orthotrichum? curvatum BRID. Bry. un. i, 79 I.

Rhacomitrium patcns Hueben. Musc. germ. I98 (1833). Schimp. Synops. 226 (I860), 2 ed. 272. ZETT. Rev. grimm. sc. Io6 (I86I). BERK. Handb. br. m. 236 (I863). Milde Bry. siles. i56 (i869). Hobk. Syn. br. m. 86 (i873). Chalub. Grimm. Tatr. 84 , t. 12 (I882). Husn. Musc. gall. I38, t. 39 (I887). Lesq. James Moss. N. Amer. I48 (I 884 ).

Grimmia arcuata DE NoT, in Mem, acc. Torin, xxxviii, 250 (I836), Syllab. 252 (I 838 ).

(ivimmia patens Br. Sch. Bry. eur, fasc. 25-28, p. 18, t. Io (I845). Rabenh. Deutsch. kr. fl. ii, S. 3, p. I63 (I848). C. Muell. Synops. i, 797 (i849). Wils. Bry. br. I58, t. I9 (I855). DE Not. Epil. bri. ital. 692 (I869). LindB. in Act. soc. sc. fenn. $x, 556$ (1875). Juratz. Laubm. oester.-ung. I6 4 (I882). Boulay Musc. Fr. 375 (I884).

Dioicous; in tall flat fragile olivaceous or fuscous green tufts, blackish and nearly naked at base, $\mathrm{I}_{2}-4 \mathrm{in}$. high, repeatedly dichotomous, with curved branches. Leaves densely crowded, when dry suberect, when moist suddenly recurved, then patent and curved upward, rarely subsecund, elongate lanceolate-acuminate, muticous, carinate-concave below, with the margin revolute up to middle, apex generally subserrate, narrorvly carinate, the margin with two rows of cells bistratose; nerve vanishing in the apex, bilamellate at back, the lamellæ bistratose; cells very minute, rounded, the basal angular and yellowish, those next the nerve linear, with several rows next the margin quadrate. Perich. bracts shorter, lanceolate. Caps. bent down on a short yellow cygneous pedicel, elevated a little above perichætium, oval, smooth, pale fuscous with a red moutl, 8-sulcate when old; calyptra short, smooth, many-lobed ; lid red, conico-subulate, straight, annulus 2-seriate, broad, revoluble; teeth on an orange basal membrane, divided into two subulate papillose legs cohering here and there, purple, patent-incurved when dry. Male plant more slender and simpler, infl. terminal, bracts convolute, ovate, shortly acuminate.

\section{HAB.- Moist quartzose rocks in mountains. Fr. $4-5$.}

Frequent in Scotland. Slemish mtn., Antrin, and Yowerscourt, Connemara (Moure). Galtee-more and Gougaunbarra, Cork (Carroll). Brown Willy, Bodmin (H. N. Diron 1886) !! Scandale Glen, Windermere (C. Barton 1888) !! Sheepstor (Brent).

The wings vanish towards the apex and base of the nerve, but their presence is quite sufficient to distinguish this species from G. aquatica, obtusa, elliptica or fascicularis, which have all muticous leaves, while G. Hartmani, elatior and decipiens, which also more or less resemble it, may be known by the hyaline leaf-points.

Sect. 4. TRICHOSTOMUM (Hedw.) Taller, dichotomous or irregularly branched, with numerous short lateral ramuli. Leaf-cells towards base longer, with strongly sinuose-nodulose walls. Caps. smooth, on a straight seta; teeth elongate, cleft nearly to base into two filiform legs. 


\section{GRIMMIA ACICULARIS (L.) C. Muell.}

Dioicous; robust, rigrid, in lax dark green tufts. Leaves broadly ovate, obtuse, muticous, obsoletely denticulate at apex, recurved at margin. Capsule ovate or subcylindric, lid acicular; teeth cleft nearly to base in $2-3$ unequal legs. (T. LI, C.)

Syn.-Muscus aquaticus pileis acutis Merr. Pinax 74 (I667). Ray Synops. 2 ed. 323 (I696).

Bryum hypuoidcs, crcctum montanum, crectis capitulis acutis Dill. in RAy Synops. 3 ed. 94 , n. I2 (I724).

Bryum hypnoides repens aquaticum, erectis capitulis acutis DILL. in RAX Synops. 3 ed. 94, n. I3.

Brymm montanmm hemiheterophyllum, operculis acutis Dill. Hist. musc. 366, t. 46, f. 25 (I74I) et Herb.

Brymm hypnoides aquaticum calyptris nigris acntis Dill. Hist. musc. $367 \cdot$ n. 26, t. 46, f. 26 A-B. Et Herb.

Bryum aciculare L. Sp. pl. III8 (I753), Syst. nat. ii, 702. Huds. Fl. angl. 407 (I762). With. Bot. arr. br. veg. ii, 674 (I776). Lightr. Fl. scot. ii, 725 (I777). Ehrh. Hann. mag. I7 82, p. 364. Roth Tent. f. germ. i, 473 (I788). HoFfm. Deutsch. fl. ii, 37 (I796). Hull Br. fl. Part 2, 26i (т 799).

Hypnum aciculare Scop. Fl. carn. 2 ed. ii, 335 (1772).

Dicranum aciculare Hedw. Fund. II, 92 (I 782 ), Stirp. cr. iii, 79, t. 33 (I 792), Sp. musc. I35 (I801). Brid. Musc. rec. II, P. I, I62 (I798), Sp. musc. I, I39 (I806). Swartz Musc. suec. 35 (I798). Roth Tent. fl. germ. iii, 164 (I800). Roehl. Moosg. Deutsch. 344 (ז80o). Smith Fl. brit. I2I2 (I804), Eng. Bot. t. I978. Turn. Musc. hib. 67 (ISo4).

Bry'nm nigrescens Vizl. Hist. pl. Dauph. iii, P. 2, 88I, t. 54 ( $\left.\mathrm{I}_{7} 89\right)$.

Mnimm aciculare GMel. (L.) Syst. nat. I3 ed. ii, P. 2, 1328 (I79I).

Bryum rivulare HoFfm. Deutsch. fl. ii, 37 , in obs. (ז796)?

Trichostomum aciculare P. Beauv. Prodr. 9o (1805). Web. Mohr Bot. Tasch. I 9 (1807). Schkuhr Deutsch. kr. gew. P. II, 74, t. 35 (I81o). Schwaegr. Suppl. I, P. I, 157 (18II). Vort Musc. herb. 26 (I8I2). RoeHL. Deutsch. fl. iii, 64 (I8I3). Hook. Tayl. Musc. br. 62, t. 19 (I8I8). Funck Moost. 27, t. I8 (I82I). Gray Nat. arr. br. pl. i, 740 (I82I). Ноок. Fl. scot. P. 2, I35 (I82I), Br. fl. ii, 34 (I833). МАск. Fl. hibern. P. $2,20(1836)$.

Trichustomum aciculare a. obtusifolium W. ARN. in Mem. soc. d'hist. nat. Par. ii, 27I (I 825 ).

Trichostonum obtusifolizm P. BEAuv. Prodr. 9I. BRID. Sp. musc. 289.

Rhacomitrium obtusifolium BrID. Mant. 8o (I8Ig), Bry. un. i, 221.

Rhacomitrium aciculare BrID. Mant. 80; Bry. univ. i, 2I9. DE NoT. Syllab. 257 (I838), Epil. bri. ital. 677 (1869). Hueben. Musc. germ. 2 I I (I833). Br. Sch. Bry. eur. fasc. 25-28 p. 5, t. I (I845). RABENH. Deutsch. kr. fl. ii, S. $3, \mathrm{I} 56(\mathrm{I} 848)$. AONGST. in Fries Summ. veg. sc. 92 (I846). Hartm. Skand. fl. Wils. Bry. br. I65, t. I9 (I855). Schimp. Synops. 228 (I860), 2 ed. 274. ZetTer. Rev. Grimm. scand. i Io (I86T). Berk. Handb. br. m. 236 (1863). Mirde Bry. siles. I57 (is69). Hobk. Syn. br. m. S6 (1873). Husn. mouss. nord-ouest 95 (1873), Musc. gall. I39 t. 40 (I887). Linde. in Act. soc. sc. fenn. X, 555 (I875). Juratz. Laubm. oester.-ung. I76 (I882). Chalub. Grimm. Tatr. 87 , t. 13 (I882). Boular Musc. Fr. 363 (I $88_{4}$ ). Lese. James Moss. N. Amer. 147 (1884).

Campylopus acicularis WAHLEN. Fl. suec. ii, 749 (1826).

Grimmia acicularis C. MUell. Synops. i, 801 (1849).

Dioicous; in lax robust dark green incolerent tufts, blackislı at base. Plants $\mathrm{I}-3$ in. high, rigid, decumbent and naked at base. Leaves appressed when dry, erecto-patent when moist, subsecund at apex, broadly ovate-oblong, canaliculate-complicate, here and there 
undulato-plicate, the margin revolute, apex lingulate-obtuse, entire or usually remotely hyalino-dentate; nerve broad, thin, vanishing below apex, cells very small, in one stratum, double at upper margin, roundish at apex, the lower linear, strongly sinuose, at angles laxer, quadrate. Perich. bracts smaller, sheathing. Caps. on a dull red seta, erect, oblong or oblongo-cylindric, short-necked, small-mouthed, dull brown, when old black, annulus broad, lid acicular, half length of caps.; teeth dark red, cleft $\frac{2}{3}$ to base, legs unequal, subulate, connivent when dry. Male infl. terminal, bracts ovate, pointed.

$\mathrm{H}_{\mathrm{AB}}$.- On stones by streams in alpine and subalpine districts. Fr. 3-4.

Common in Scotland, Wales, N. of England, and Ireland.

Var. $\beta$. denticulata $B r$. Sch.

Plants more slender, the leaves laxer, yellowish green, more laxly areolate, more distinctly toothed at apex.

Har.-Sandy detritus by streams, occasionally in the lowlands.

\section{I. GRIMMIA AQUATICA (Brid.) C. Muell.}

Dioicous; rigid, in lax yellow-green mats. Leaves from an ovate base, gradually lanceolate, obtuse, muticous, quite entire at apex, recurved at margin. Capsule ovato-cylindric, pale fuscous, lid acicular ; teeth cleft nearly to base into two legs. (T. LI, B.)

SYN.-Trichostomum aquaticum BrID. Musc. rec. II, P. I, I32, excl. syn. (I798) ?

Dicranum aciculare $\gamma \cdot$ gracile Turn. Musc. hib. 67 (I804).

Dicranum aquaticum BRID. Sp. musc. I, Igo, excl. syn. (I806) ?

Trichostomum aciculare $\beta$. aquaticum WeB. MoHR Bot. Tasch. 192 (1807).

Trichostomum fasciculare (non Schrad.) Movg. Nestu. Stirp. cr. Vog.-rhen. fasc. 3, n. 215 (I8I2).

Rhacomitrium aquaticum Brid. Mant. 8o, excl. syn. (I8I9) ? Bry. univ. i, 222, excl. syn. (1826). LindB. Acta soc. sc. fenn. X. 554 (1875).

Trichostomum aciculare $\beta$. acutifolium W. ARN. in Mem. soc. d'hist. nat. Par. ii, $27 \mathrm{r}$ (1825).

Rhacomitrium cataractarum BRID. Bry. univ. i, 776 (I827). DE NoT. Syllab. 258 (I838). HuEBex. musc. germ. 2 I I (1833). Aongst. in Fries Summ. veg. sc. 92 (1846).

Trichostomum obtusum Schultz in Syll. ratisb. ii, I44, excl. syn. (1828). Wallr. Fl. cr. germ. i, I 76 (I83I)?

Trichostommm protensum BRAUN MSS. Schultz in Syll. ratisb. ii, I45, in obs. (I 828 ). Duby Bot. gall. ii, 573 ( 1830$)$.

irichostomum fusciculare $\beta$. protensum HARTM. Skand. A. 2 ed. 32 I ( $18_{32}$ ).

Rhacomitrium protensum BraUn MSS. HUEBEN. Musc. germ. 2r T, ut synon. (I833). BR. Sch. Bry. eur. fasc. 25-28, p. 6, t. 2 (r 845$)$. RabenH. Deutsch. kr. fl. ii, S. 3, 156 (1848). Wils. Bry. brit. 166, t. 45 (1855). HARTM. Skand. fl. 7 ed. 375 (1858). Schimu. Synops, 229 (1860), 2 ed. 274. ZETT. Rev. Grimm. scand. II3 (1861). BERk. Handb. br. m. 235 (1863). DE Not. Epil. bri. ital. 676 (r869). MILdE Bry. siles. 156 (I869). Hobk. Syn. br.m. 87 (1873). Husn. Mouss. nord-ouest 95 (I873), Musc. gall. I39, t. 40 (1887). Lindi. in Act, soc. sc. fenn. X, 554 (I875). JuRATZ. Laubm. oester.-ung. i77 (1882). Chalub. Grimm. Tatr. 90, t. I3 (I882). Boulay Musc. Fr. 363 (I884). 
Trichostomum cataractarum HARTM. Skand. fl. 3 ed. 283 (1838).

Grimmia aquatica C. Muell. Synops. i, 800, excl. syn. (1849.)

Dioicous; in lax wide depressed mats, dull or yellow-green above, ferruginous below. Stems elongated, more slender, I-4 in. high, ascending, repeatedly dichotomous, less rigid, dense-leaved. Leaves when dry laxly incumbent, when moist suddenly recurved, then erectopatent on all sides, or subsecund, from an oval-oblong base, gradually lanceolate, obtuse, muticous, quite entire, canaliculate, unequally recurved and not incrassate at margin, unistratose; nerve strong, reddish brown, ending in the apex; cells at base long, very narrow. above minute, incrassate, yellow, strongly punctulato-crenulate at margin. Perich. bracts sleathing, thin, nerve shorter. Caps. pseudolateral, on a longish pale brown seta, elongato-elliptic, erect, leptodermous, ferruginous, often scarce overtopping the elongated innovations; calyptra 5-lobed, acicular; lid acicular, straight, red $\frac{2}{3}$ length of caps.; annulus broad; teeth rufous, bipartite, the legs free, entire or partly cohering, perforated. Male infl. terminal, bracts ovate, shortly acuminate.

HAB.-Dripping rocks and waterfalls. Fr. 3-4.

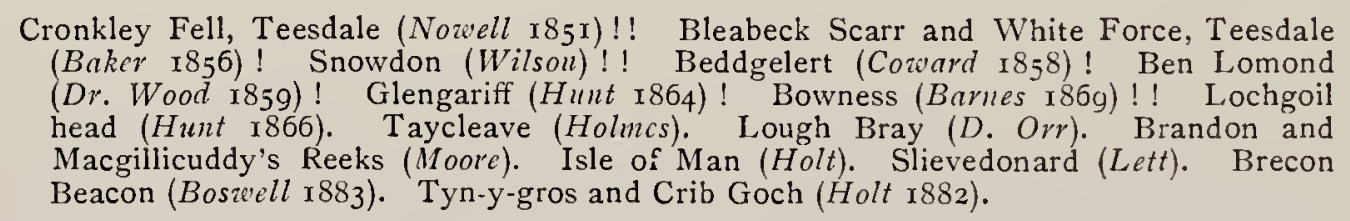

In appearance this much resembles $G$. patens, but apart from the wings on the nerve of that species, the leaves in $G$. aquatica are obtuse, quite entire, with the basal areolation much more sinuose; from $G$. acicularis it differs in the slender stems and narrower lanc. leaves, and the basal areolation is much coarser.

32. GRIMMIA OBTUSA (Sm.) Lindl.

Dioicous; short, densely pulvinate. Leaves quite beardless, ovateoblong, gradually acuminate, obtuse at point, nerve lost far below apex, margin narrowly revolute. Caps. oblong, narrowed at mouth, lid acicular, peristome fugacious, irregular, teetl with 2 unequal legs. (T. LI, E.)

Sre.-Bryum hypuoidcs alpinum, opcrculis obtusis DilL. Hist. musc. $37 \mathrm{I}$, p.p. t. 47, f. 30 (i74x) et Herb.

Bryun hypnoidcs $\delta$. Huds. Fl. angl. $41 \mathrm{x}$ (1762).

Trichostomum obtusum SM. Fl. brit. 1244, excl. syn. BRID. ( $\left.\mathrm{ISO}_{+}\right)$, Comp. fl, brit. 2 ed. $\mathrm{x}_{7 \mathrm{x}}(\mathrm{1} 8 \mathrm{x} \mathrm{x})$.

Dicranum acicularc $\delta$. pumilum TurN. Fl. hib. 67 (180.4) ?

Trichostomum pratcns W.-ARN. H. in Hook. J. Bot. i, 95 (1834). 
Rhacomitriun heterostichum Var. $\gamma$. gracilescens Br. ScH. Bry. eur. fasc. 25-28, p. 9 , p.p. (1845). Wils. Bry. brit. I68 (I855). Schimp. Synops. 232, p.p. (I860), 2 ed. 277.

Grimmia heterosticha Var. $\gamma \cdot$ gracilesccns C. Mueld. Synops. i, 808, p.p. (I849), Deutsch. moos. 368 , p.p. (I853).

Rhaconitrium obtusum LiNdB. in Act. soc. sc. fenn. X, 542 et 553 (I875).

Grimmia obtusa Linds. Musc. scand. 29 (1879).

Dioicous; short, densely pulvinate, $\frac{1}{2}-\mathrm{I}_{2}^{\frac{1}{2}}$ in. high, yellow green above, fuscous at base, with straight erect branches, very shortly ramulose. Leaves erecto-patent, straight, ovate-oblong, gradually very acute, with the tip obtuse and always quite free from a hyaline point, deeply carinate, margin narrowly revolute, not incrassate, nerve flat and ill-defined, channelled in front, vanishing below apex; cells very smooth unistratose, nearly all rectangular, strongly sinuose and crenate, narrow, a few at basal angles quadrate. Seta short, pale fuscous, caps. oblong, narrowed at the mouth, glossy, fuscous, annulus thick, triple, lid half length of caps., erect, acicular, straw-colour, purple at base; calyptra mitræform with a papillose beak; peristome pale red, minute, irregular, fugacious, teeth with two unequal legs, filiform, not trabeculate. Male plant more slender and branched, infl. gemmaceous, bracts obtuse, apiculate.

HAB. -Damp granite rocks and walls. Fr. 3-5.

Snowdon (Dillenius). Llanberis, Dolbadarn castle (Hunt I 865). Tyn-y-Groes and Dolgelly (Holt 1885)!! Luggielaw and near Dublin (Orr, 1855). Lough Bray (Lirdberg I873) !! Shanslieve, Slieve Donard, Slieve.na-Maddy and Slieve Bignian, Co. Down

(Lett I884)!! Ben Lawers (Holt I880)!! Ullock, Keswick (Rev. F. Kidsun I888) !!

Var. $\beta$. subsimplex $L$ indb.

Stems slender arcuate, ascending, naked below, with a few simple arcuate, comose-leaved branches. Leaves shorter, more obtuse, with the margins more widely revolute.

Syn.-Rhacomitrium obtusmn $\beta$. subsimplex LINDB. op. c. 543 .

$\mathrm{H}_{\mathrm{AB}}$. - Glendough (Orr 1870, named R. lamginosum).

This moss seems quite distinct in the rounded obtuse points to the leaves, which do not show any trace of a hyaline tip, even in the youngest leaves. It may be known from G. aquatica and fascicularis by its small size, independent of other characters. M. Corbiere finds it also at Cherbourg.

$G$. affinis comes nearest to $G$. obtusa, but has always some leaves with hyaline points, and they are also narrower and more acute at upper part, and the cells smaller and less crenate.

\section{GRIMMIA AFFINIS (Schleich.) Lindb.}

Dioicous; yellowish-green, scarcely hoary. Stems slender elongate, fasciculate-branched. Leaves lanceolate-acuminate, acute with a short 
or obsolete hair-point. Caps. elliptic-oblong, narrow at mouth; lid conico-rostrate; teeth short, pale, cleft to base. (T. LI, D.)

Syn.-Trichostomumn affine Schleich. Pl. crypt. helv. 3 cent. n. 18 (1805), Cat. pl. helv. 2 ed. 3I (1807). Web. MoHr Bot. Tasch. 127 in obs. (1807).

Trichostomum alopccurum Schкuнr Deutsch. kr. gew. 77, t. 35 (I810).

Trichostomum hctcrostichum SchwaEgr. Suppl. I, P. I, I49 p.p. (I8II). DE CAN. Fl. franc. v, 217 p.p. (I8I5). W.-ARs. in Mem. soc. d'hist. nat. Paris ii, 270 p.p. (1825).

Rhacomitrium alopecurum Brid. Mant. 79 (18I9), Bry. un. i, 215 (I826).

Trichostomum fastigiatum WALLR. Fl. cr. germ. i, I75 (183I)?

Rhacomitrinn hcterostichun Var. $\beta$. alopccurum HUEBN. Musc. germ. 208 (I833). BR. Sch. Bry. eur. fasc. 25-28, p. 9 (I845). RABENH. Deutsch. kr. H. ii, S. 3, I57 (I848). Wils. Bry. br. I68 (I855). Schimp. Synops. 23I (1860), 2 ed. 277. JURAtz. Laubm. oester..ung. I80 (1882).

Trichostomn fasciculare Var. TAYL. in Mack. F1. hib. 2, p. 20 in obs. (1836).

Trichostomum saxatile TAYL. in Trans. bot. soc. Ed. ii, P. I, I (1845).

Grimnia hetcrosticha Var. $\beta$. alopecura C. Muell. Synops. i, 808 (I849).

Rhacomitrium affinc LindB. Act. soc. sc. fenn. X, 552 (1875).

Grimmia affinis LINDB. Musc. scand. 29 (1879).

Grimmia sublurida StiRTon in Scott. Nat. ix, 36 (1887). A dwarf starved form.

Dioicous ; slender, elongated, ascending or trailing, fusco-lutescent, with many fasciculate branches, scarcely incano-pilose. Leaves never secund, accrescent, lanceolate-acuminate, very narrow at apex, much more narrowly revolute at the bistratose margin, but flat at the short narrow hair; nerve well-defined, rather thick, very prominent at back, lost in the hair; leaf-cells rectangular, narrow and elongated at base, roundish-quadrate and crenulate above, externally at the connate longitudinal walls minutely crested. Caps. shorter, elliptic-oblong, narrower at mouth, very pachydermous, formed of longer incrassate cells; peristome short, paler, teeth more or less connate at base.

$\mathrm{H}_{\mathrm{AB}}$. - Rocks and walls in subalpine places. Fr. 3.

Frequent in the Snowdon district and Ireland.

VAR. $\beta$. gracilescens (B.S.) Lindb.

Stems more slender, elongated, with few branches or almost simple. Leaves with very short hair points; caps. small, on a shorter seta.

Syn.-Rhacomitrium hotcrostichum $\gamma \cdot$ gracilesccns Br. Sch. p.p. Wils. Bry. br. p.p. Schimp. Synops. p.p.

Grimmia hatcrosticha $\gamma$. gracilescons C. MUeLL. Synops. i, 8o8, p.p.

HAB.-Damp shady rocks.

Killarney (Wilson) !! Shanslieve (Rcv.Mr. Lctt 1884) I! High Force, Teesdale (Bakcr $1856)$ ! 
I have followed Prof. Lindberg in keeping this distinct, though more inclined to retain it as a Var. of G. hetevosticha. The leaves are longer, with narrower acuminate points, acute and more or less hyaline at tip, and thus it may be known from $G$. obtusa, but the almost obsolete hair-point seems to be the chief difference from $G$. hetevosticha, and this may be distinct as a short hair, or it may be reduced to a few hyaline cells.

\section{GRIMMIA HETEROSTICHA (Hedre.) C. Muell.}

Dioicous; in lax depressed rather rigid, dull-green hoary tufts. Leaves lanceolate, gradually attenuated, piliferous; revolute but not incrassate at margin ; nerve flat, well defined. Caps. on a straight seta, subcylindric, fuscous ; teeth purple, lanceolate bipartite ; calyptra rough at apex. (T. LII, A.)

Syn.-Bryum hypnoides, hirsutie canescens, vulgare Dill. Hist. musc. 368, t. 47, f. 27 $\mathrm{A}, \mathrm{B}, \mathrm{F}, \mathrm{G}(\mathrm{I} 74 \mathrm{I})$, et herb.

Trichostomum heterostichum HeDw. MSS. Timm Fl. megap. 2 I5 (I788); Stirp. cr. ii, 70, t. 25 (I789); Sp. musc. I39 (I80I). Schrad. Spic. fl. germ. 64 (I794). BRID. Musc. rec. II, P. I, I28, t. 2, f. I6 (I798), Sp. musc. I, 238 (I806). SWARTZ Musc. suec. 30 (I798), Summ. Veg. sc. 92 (I8I4). Roenl. Moosg. Deutsch. 263 (I8oo), Deutsch. fl. iii, 62 (I8I3). Roth Fl. germ. iii, P. I, I92 (I80o). SMith Fl. brit. I239 (ISo4), Eng. Bot. t. I347. Turn. Musc. hib. 37 (I804). Schultz Fl. starg. 290 (I806). Web. Мohr Bot. Tasch. II3, t. 7 , f. 5 (I807). Schkuhr Deutsch. kr. gew. P. II, 70, t. 3 I (I8IO). Schwaeg. Suppl. I, P. I, I49 (I8II). Voit Musc. herb. 2I (I8I2). Wahlend. Fl. lapp. 33I (I8I2), Fl. carp. 34I (I8I4). Hook. Tayl. Musc. br. 6I, t. I9 (I8I8). Funck Moost. 26, t. I7 (I82I). GRAy Nat. arr. br. pl. i, 740 (I82I). Hook. F1. Scot. P. 2, I34 (I82I), Br. fl. ii, 33 (I833). Mack. Fl. hib. P. 2, I9 (I836). Hornem. Fl. dan. t. 2307 f. I (I840).

Bryum sccundum GMEL. (L.) Syst. nat. I3 ed. ii, P. 2, I333 (I79I).

Bryum heterostichum Hoffm. Deutsch. fl. ii, 40 (I796). Dicks. P1. crypt. IV, I4 (I80r).

Rhacomitritm heterostichum BRID. Mant. 79 (I8I9), Bry. univ. i, 2I4 (I826). Hueben. Musc. germ. 207 (I833). DE Not. Syllab. 256 (I838), Epil. bri. it. 673 (I869). BR. Sch. Bry. eur. fasc. $25-28$, p. 9, t. 2 (1845). Rabenh. Deutsch. kr. fl. ii, S. 3, I57 (I848). Wils. Bry. br. I68, t. I9 (I855). HARTM. Skand. fl. 7 ed. 375 (I858), Schimp. Synops. 23 I (I860), 2 ed. 277. ZetTERST. Rev. grimm. scand. II8 (I86I). Berk. Handb. br. m. 234, T. 2I, f. 4 (I863). Milde Bry. siles. I58 (I869). Hobk. Syn. br. m. 87 (I873). Husn. Mouss. nord-ouest 96 (I873), Musc. gall. 140, t. 40 (I887). Lindb. in Act. soc. sc. fenn. X, 55 I (I875). JURATZ. Laubm. oester.-ung. I79 (1882). Chalub. Grim. Tatr. 96, t. I4 (I882). Boulay Musc. Fr. 359 (I884). Lesq. James Moss. N. Amer. 149 (I884).

Grimmia hetcrosticha C. MuELL. Synops. i, 807, excl. varr. (I869).

Dioicous; tufts at first circular, afterwards extended and irregular, blackish-brown at base, above dingy green, grey and loary; plants in the middle of tuft erect, at margin prostrate and creeping, stiffish, dichotomously branched, sparingly fasciculato-ramulose. Leaves appressed when dry, when wet suddenly reflexed, then erecto-patent or subsecund, from a broadly ovate base, lanceolate-acuminate, running out into an elongate broad decurrent remotely denticulate hair, deeply 
canaliculate, the margin revolute, not thickened, nerve flattened, sulcate, well-defined; cells at base obtusely sinuose, narrow and elongated, upper dense, quadrate, very smooth, plane. Perich. bracts shorter, sheathing, with shorter hairs, nerve vanishing above the middle. Calyptra $4-5$ lobed, rough at apex; lid conico-subulate, half length of capsule; annulus narrow, yellow; seta straight, reddishyellow; caps. oblongo-cylindraceous, small-mouthed, pachydermous, tawny-brown, fuscous when old; teeth red, lanceolate, in two unequal filiform papillose legs. Male plant resembling the female, inner bracts broadly ovate, obtuse, apiculate.

HaB.-Quartzose rocks, stones and walls in subalpine districts. Fr. 4 .

A frequent moss on moorlands and exposed rocks, and very variable in size, mode of branching and form of fruit, the latter however always more or less cylindric. In its rough rigid habit it much resembles $G$. apocarpa.

\section{GRIMMIA RAMULOSA. Lindd.}

Dioicous; in lax tufts, stems slender with numerous short branches. Leaves spreading, elongato-lanceolate, acute, with a short serrate hair, cells all elongated and sinuose. Caps. very small, elliptic, lid rostrate. (T. LI, F.)

Syn.-Bryum caule erecto, ramis latcralibus brevibus fertilibus L. Fl. lapp. 3 I $_{4}$ (I737).

Bryum hypnoides alpinum, setis et capsulis exiguis OEDER F1. dan. iii, 9, excl. syn. t. 476 (I 769$)$.

Trichostomnm microcarpon BRID. Musc. rec. II, P. I, I27 p.p. I798, Sp. musc. I, 237 p.p. (I806). De Can. (Lamk.) Fl. franc. 3 ed. ii, 469 p.p. (IS05). Wahlenb. Fl. lapp. 33 I excl. syn. (I8I 2). Swartz in LiLjebl. Svensk fl. 3 ed. 537 (I8I6). Harta. Skand. fl. 400 , excl. syn. (I820).

Bryum microcarpum Funck Cr. gew. ficht. fasc. 2, p. 3, n. 40 (I801). Hoppe in STURM Deutsch. fl. II, fasc. 7 (1805).

Rhacomitrium microcarpon BRID. Mant. 79 p.p. (I8I9), Bry. univ. i, 2II p.p. (I826). Hueben. Musc. germ. 202 excl. syn. et Var. $\beta$. (1833). De Not. Syll. 253 (I838). Epil. bri. ital. 674 (I869). Hartm. Skand. fl. 4 ed. 389 excl. Var. $\beta$. (I843). Br. Sch. Bry. eur. fasc. 25-28, p. Io, t. 5 (I845). AONGSTR. in Fries Summ. Veg. sc. 92 (I 846 ). RABENH. Deutsch. kr. fi. ii, S. 3 , I58 (I848). Wils. Bry. br. I69, t. 6i (I855). Schimp. Synops. 233 (I 860), 2 ed. 279. ZETTERst. Rev. Grimm. sc. I 24 (I86I). BERK. Handb. br. m. 234 (1863). MILde Bry. siles. I58 (I869). Hobk. Syn. bi. m. 88 (I873). HuSN. Mouss. nord-ouest 96 (i873). JuRatz. Laubm. oester.-ling. I80 (I882). Chalub. Grimm. Tatr. Io5, t. I5 (I882). LesQ. James Moss. N. Amer. I50 (I 884 ).

Trichostomum heterostichum Var. $\beta$. microcarpum WaHLEnB. Fl. suec. ii, 75 I excl. syn. Dill. (1826).

Grimmia ericoides BrID. Bry. univ. i, 768 (I 827 ).

Grimmia microcarpa C. Muell. Synops, i, 804 excl. forma procera (I849). 
Rhacomitrium ramulosum Linde. Act. soc. sc. fenn. X, 550 (1875).

Grimnia ramulosa LindB. Musc. scand. 29 (1879).

Rhacomitriunn heterostichum Var. microcarpun HusN. Musc. gall. I40 (1887).

Dioicous; in lax depressed tufts, dark brown at base, pale or yellowgreen above, lightly canescent ; more slender than $G$. fascicularis, flexuose, with short crowded fasciculate obtuse branches. Leaves densely crowded, patulous, variously curved and subsecund at apex, from a longish ovate base with a shallow plait on each side, lanceolate, gradually narrorved into a short toothed hoary point, margin revolute, not thickened at the carinate apex, nerve broad, flat bistratose; areolation of all lamina, sinuose, unistratose, nodulose-linear, very narrow at base, with $\mathrm{I}_{-2}$ marginal rows hyaline and quadrate. Perich. bracts shorter, sheathing, the nerve vanishing about the middle. Seta short, pale yellow; caps. ovate, elliptic or cylindraceous; very small, leptodermous, yellow, then fuscescent with a red mouth; calyptra mitrate, papilloso-scabrous at apex, annulus triple, lid conoid, subulate, $\frac{2}{3}$ length of caps., peristome orange, teeth linear, short, cleft to base into two filiform nodose legs, erecto-patent when dry. Male infl. numerous, inner bracts broadly ovate, shortly acuminate, muticous.

HAB.-Dry mountain rocks. Highlands (Herb. Hooker).

This moss still remains a doubtful native, its claims as such resting solely on the unlocalized specimens in the Hookerian herbarium.

Nearest to G. fascicularis, but in that species all the leaves are muticous and rather obtuse with the nerve vanishing below the apex, the capsule also is larger, fuscous and pachydermous. From G. heterosticha it is distinguished by the numerous lateral ramuli, diaphanous leaves with the cells of upper part elongated and sinuose, and of the lower elegantly nodulose, those of the margin being $\mathrm{I}$ and not 2-stratose, and the small pale capsule.

\section{GRIMMIA FASCICULARIS (Sclvad.) C. Muell.}

Dioicous; stems elongated, with fasciculate short ramuli. Leaves crowded, incurved or recurved, lanceolate, gradually narrowed, muticous, reflexed at margin. Caps. elliptic, lid long, acicular; teeth long, bipartite. (T, LII, B.)

SYN - Bryum hypnoides aquaticum, calyptris nigris acutis Var. C. strigosior cun setis brevioribus Dill. Hist. musc. 367 , t. 4 6, f. 26 C (I74I) et Herb.

Bryum hypnoides hirsutie virescens, fasciculare alpinum DiLl. op. c. 370, t. 47 , f. 28 , et Herb. 
Bryum hypnoides Var. $\beta$. L. Sp. plant. I I 20 (I753).

Bryum hypnoides Var. vircscens Retz. F1. scand. prodr. ii, 2I4 (I779). EHRH. Beitr. ii, I 46 (I 788 ).

Bryum fasciculare Schrad. in Grel. (L.) Syst. nat. I3 ed. ii, P. 2, p. I332 (I79I). Hoffm. Deutsch. fl. ii, 42 (I796).

Trichostomum fascicularc Schrad. Spic. fl. germ. 6I (I794). Brid. Musc. rec. II, P. I, I70 (I798), Sp. musc. I, 240 (I806). Swartz Musc. suec. 29 (I798), Summ. veg. scand. 39 (I8I4). Roenl. Moosg. deutsch. 275 (I800), Deutsch. fl. iii, 64 (I8I3). Hedw. Sp. musc. i io (I80I). Smith Fl. brit. I243 (I804), Eng. Bot. t. 2005. TURN. Musc. hib. 40 (I804). P. Beauv. Prodr. 9I (1805). Web. Mohr Bot. Tasch. II 8 (I807). Schkuhr Deutsch. kr. gew. P. 2, 75, t. 33 (I8ro). Schwaeg. Suppl. I, P. I, I55, t. 38 (I8II). Hook. Tayl. Musc. br.6o, t. I9 (I8I8). Funck Moost. 27, t. I8 (I82I). Hook. Fl. scot. P. 2, I35 (I82I), Br. fl. ii, 34 (1833). Gray Nat, arr. br. pl. i, 740 (I 821 ).

Bryum lutesccus Dicks. Fasc. pl. cr. IV, I4 (I80I).

Rhacomitrium fasciculare BrID. Mant. 80 (I819), Bry. univ. i, 2 I8 (I826). HueBeN. Musc. germ. 209 (I833). DE Not. Syllab. 258 (I838), Epil. bri. ital. 675 (I869). Br. Sch. Bry. eur. fasc. $25-28$, p. 8, t. 4 (I845). Aongst. in Fries Summ. Veg. sc. 92 (I846). Rabenh. Deutsch. kr. fl. ii, S. 3, I57 (I848). LiebM. Fl. dan. t. 2497 , f. I (I 849 ). Wils. Bry. br. I67, t. I9 (I855). HARTM. Skand. fl. 7 ed. 375 (I858). Schimp. Synops. 233 (I860), 2 ed. 278 . ZetTerst. Rev. Grimm. scand. I2 I (I86i). Berk. Handb. br. m. 234 (1863). Milde Bry. siles. r6o (1869). Hobk. Syn. br. m. 87 (I873). Husn. Mouss. nord-ouest 97 (I873), Musc. gall. I4I, t. 40 (I887). LiNDB. in Act. soc. sc. fenn. X, $55^{\circ}$ (I875). JURATZ. Laubm. oester.-ung. I8I (I882). Chalub. Grimm. Tatr. I02, t. I5 (I882). Boulay Musc. Fr. 356 (I884). Lesq. James Moss. N. Amer. I50 (1884).

Trichostomum maritimum BLytT MSS. HARTM. Skand. fl. 3 ed. 283 (I838).

Grimmia fascicularis C. Muell. Synops. i, 809 (1849).

Rhacomitrium virescens Linde. in Act. soc. sc. fenn. X, 68 (I87r).

Dioicous; in depressed subintricate tufts, lurid green or yellowish above, fuscous or ferruginous below, rather rigid. Plants often much elongated, prostrate and trailing, naked in the old parts, fasciculatebranched, densely nodoso-ramulose. Leaves densely crowded, patulous, curved upward and backward from an elongate ovate base, narrowly lineal-lanc. muticous, with the margin reflexed, plicate at base, faintly papillose, nerve weak, ill defined, vanishing below apex; cells all elongated and sinuose, $2-4$ rows at basal margin hyaline, quadrate. Seta brownish-yellow, thick, calyptra almost wholly papillose, multifid at base ; caps. oval or oblong, pachydermous, fuscous, black wlien old; lid acicular, shorter than caps., crenulate at base, annulus rather broad, teeth purple, long, cleft to base into two filiform nodose legs, erectopatent when dry. Male plant more slender, with shorter leaves, bracts of infl. broadly ovate, nerveless.

HaB.-Roclss in subalpine districts. Fr. 3 .

Readily distinguished by the numerous lateral ramuli, and the perfectly muticous leaves with thin nerve. It somewhat resembles $G$. aquatica, but that species wants the short lateral ramuli, is more rigid with a thicker nerve, and the upper cells of leaf are short and scarce sinuose. 


\section{GRIMMIA HYPNOIDES (L.) Lindb.}

Dioicous; in tall wide and lax tufts, black at base, hoary above. Leaves dense, erecto-patent, from an ovate base, long lanceolateacuminate, the points diaphanous, eroso-serrate. Caps. on a short rough seta, small, ovate, lid long acicular, teeth long with filiform legs. (T. LII, C.)

SYN.-Muscus terrestris vulgari similis, lanuginosus RAY Synops. I8 (I6go).

Bryum hypnoides, capitulis plurimis crectis lanuginosum DILL. in RaY Synops. 3 ed. 97 (1724).

Bryum hypnoides polycephalum, lannginosum, nontanum DiLl. Hist. musc. 373, t. 47, fig. 32 ( I 74 I), et Herb.

Bryum hypnoidcs L. Sp. plant. I II9, excl. varr. (I753), F1. suec. 2 ed. 392, excl, varr. (I755). Huds. Fl. angl. 4IO (I762). NEck. Meth. musc. 226 (I77I). With. Bot. ari. br. veg. ii, $676\left({ }_{177} 6\right)$. LightF. Fl. scot. ii, 732 (I777). Gmel. (L.) Syst. nat. I3 ed. ii, P. 2, I332 (I79I). Аввот Fl. Bedf. 242 (I798). Hull Br. A. P. 2, 258 (I799).

Hypnum canesccns a. hirsutun WeIss Crypt. gott. 2I I (I770). WEB. Spic. fl. goett. $82\left(177^{8}\right)$.

Bryum hypnoidcs $\alpha$. lanuginosum EнRн. Beitr. ii, pp. 95 et I86 (I788), et iii, II9 (I788).

Trichostomum hypnoides Willd. F1. berol. 307 (I787). BAUmG. F1. Lips. n. I242 (I790). Moench Pl. Marp. 736 (I794).

Trichostomum ramigerum T1мм F1. megap. 2 I5 (I788).

Triclostounum lanuginosum Hedw. Stirp. cr. iii, 3, t. 2 (I79I), Sp. musc. IOg (I8oI). Schrank Baiels. fl. ii, 450 (I789). Brid. Musc. rec. II, P. I, I28 (I798), Sp. musc. I, I38 (I806). Swartz Musc. suec. 29 (I798), Summ. veg. scand. 39 (I8I4). Roehl. Moosg. deutsch. 270 (ISoo), Deutsch. fl. iii, 63 (I8I3). RoTH Fl. germ. iii, P. I, I88 (I800). SMITh F1. brit. iii, I240 (I804), Eng. Bot. t. I348. Turn. Musc. hib. 38 (I804). P. Beauv, Prodr. 9 I (I805). Schultz Fl. starg. 290 (I806). Web. Mohr Bot. Tasch. I I 4 (I807). SchKUhR Deutsch. kr. gew. P. II, 7 I, t. 32 (I8Io). Schwaeg. Suppl. I, P. I, I50 (I8II). VoIT Musc. herb. 20 (I8I2). WAHLENb. F1. lapp. 329 (I8I2), F1. carp. 34 I (I8I4). MART. F1. cr. erl. 22 (I8I7). Hook. TAYl. Musc. br. 6o, t. I9 (I8I8). FUNCK Moost. 28, t. I7 (I82I). GRAY NaT. arr. br. pl. i, 739 (I82I). Hook. Fl. scot. P. II, I34 (I82I), Br. f. ii, 32 (I833). MAck. Fl. hib. P. 2, I9 (I836).

Trichostomun scrratum EнRн. Crypt. exs. n. 94, et Beitr. vii, I3 (I792).

Bryum lannginosum HoFfm. Deutsch. fl. ii, 40 (I796).

Rhacomitrium lanuginosum BRID. Mant. 79 (I8I9), Bry. univ. i, 215 (I826). HUEBEN. Musc. germ. 204 (1833). DE Not. Syllab. 254 (I838), Epil. bri. ital. 67 I (I869). Br. Sch. Bry. eur. fasc. 25-28, p. II, t. 6 (I845). AONGST. in Fries Summ. Veg. sc. 92 (1846). Rabenh. Deutsch. kr. fl. ii, S. 3, I58 (1848). Hartm. Skand. fl. 5 ed. 379 (I849). LiebM. Fl. dan. t. 256I (I852). Wils. Bry. br. I69, t. I9 (1855). Schimp. Synops. 234 (I860), 2 ed. 279. ZeTTERST. Rev. Grimm. scand. I26 (I86I). BERK. Handb. br. m. 233 (I863). C. MuEll. in Verh. z. b. ges. Wien. I869, p. 223. MILdE Bry. siles. I59 (1869). Новk. Syn. br. m. 88 (1873). HusN. Mouss. nord-ouest 9 (I873), Musc. gall. I4I, t. 4 I (r887). JuRATZ. Laubm. oester.-ung. I82 (I882). Chalub. Grimm. Tatr. Iog, t. I6 (I882). Boulay Musc. Fr. $35^{8}$ (I884). Lesq. James Moss. N. Amer. I5I (1884).

Grimmia lannginosa C. Muell. Synops. i, 806 (I 849).

Rhacomitrinm hypnoides LINDB. in Oefv, vet. ak. foerh. I866, p. 552. Act. soc. sc. fenn. X 548 (1875).

Grimnia hypnoides LindB. Musc. scand. 29 (1879).

Dioicous; in tall lax extended swelling grey tufts, with hoary points, brown or black at base. Stems slender, flexuose fragile, ramulose, the 
lateral branches longer. Leaves very densely crowded, long, erectopatent, incurved or secund, especially at apex; thin-nerved, from an ovate base, lanceolate acuminate, with one or more plaits at base, carinate-concave in the upper part, the margin revolute below, apex with a broadly membranous border, excurrent in a hair, its margin flattened, minutely papillose, eroso-subciliate-dentate; nerve bistratose, broad, thin, prominent at back; cells unistratose, quadrate at apex, elongate and very narrow at base, beautifully seriate, eroso-sinuose, walls incrassate, minutely crenulate, one row at the basal wings rectangular and hyaline. Pericl. bracts sheathing. Caps. many near the apex, rising from short lateral ramuli, on short rough reddish setæ, small ovato-elliptic, pachydermous, brown; calyptra rough at apex; lid subulate, $\frac{2}{3}$ length of caps.; annulus very broad, revoluble; teeth bifid, the legs long equal, filiform, erecto-connivent.

HAB.-Stony heaths, rocks and walls; common in mountain and subalpine districts. Fr. 5-6.

This fine moss is not met with frequently in fruit, which appears to be produced most freely on shaded walls and rocks in the lowlands. The erosodentate hair point, which is a most beautiful miscroscopic object, is quite sufficient to identify the species; Lindberg however has a var. subimberbis, where this part is almost wanting, it then approaches $G$. affinis, but the habit and areolation sufficiently distinguish it.

\section{GRIMMIA CANESCENS (Timm) C. Mull.}

Dioicous; in lax yellowisl-green hoary tufts. Leaves patulous, ovato-lanceolate, papillose on both sides, with a serrate liair. Caps. on a long smooth seta, ovate, lid long and subulate, teeth very long, with filiform nodulose legs. (T. LII, D.)

Syn.-Muscus capillaris lanugine cancscons, pediculis temibus oblongis, capitulis in mucroncs longos rccte sursum exporrectis. Vernon. RaY Synops. 2 ed. 3 I (I696).

Bryum trichoidcs ercctis capitulis, lanuginosum DILL. Cat. Giss. 224 (I7 IS).

Muscus trichoides montanus crica hirsuto folio, capitulis crcctis acutis D. Richardson. DILL. in RAY Synops. 3 ed. 97 (I724).

Bryum hypnoides hirsutic canesccns, vulgare DiLL. Hist. musc, 368, t. 47, f. $27 \mathrm{~A} \rightarrow \mathrm{C}$ (I74I), et Herb.

Bryum hypnoides Var. $\beta$. L. Fl. suec. 2 ed. 392 (I 755).

Hypum canesccns Var. pilosum WeIss Crypt. gott. 2r 3 (г770). WeBer Spic. Al. goett. 82 (I778).

Bryum hypnoides Schreb. Spic. f. lips. 77 (I 77 I).

Bryum hypnoides Var. $\beta$. pilosum RETz. Fl. scand. prodr. ii, 2 I 4 (I779).

Trichostomum hypnoides HEDw. Fund. II, gI, t. 8, fig. 43-44 (1782) 
Trichostomum canescons Tiмm F1. meg. prodr. 2I5 (I788). HeDw. St. crypt. iii, 5, t. 3 (I79I), Sp. musc, III (I80I). BRID. Musc. rec. II, P. I, I23 (I798), Sp. musc. I, 235 (I806). Swartz Musc. suec. 30 (I798), Summ. Veg. Scand. 39 (I8I4). Roth Tent. fl. germ. iii, P. I, I92 (I800). ROEHI. Moosg. deutsch. 266 (I800), Deutsch. Al. iii, 63 (I8I3). Smith Fl. brit. I242 (I804), Eng. Bot. t. 2534. Turn. Musc. hib. 39 (I804). P. Beauv. Prodr. go (I805). Schultz Fl. starg. 29o (I806). Web. Mohr Bot. Tasch. il6 (I807). Schiuhr Deutsch. kr. gew. P. II, 72, t. 32 (I8Io). Schwaeg. Suppl. I, P. I, I74, t. 38 (I8II). Voit Musc. herb. 22 (I8I2). Wahlenb. F1. lapp. 577 (I8I2). MarT. F1. cr. erl. 93 (I8I7). Hook. TAYl. Musc. br. 6I, t. I9 (I8I8). Hook. Fl. scot. P. II, I34 (I82I), Br. fl. ii, 33 (I833). Funck Moost. 26, t. I7 (I82I). Gray Nat.arr.br.pl.i, 739 (I 821 ).

Gymnostomum cancsccns Schrank Bayers. fl. ii, 436 (I789), Prim. fl. salisb. 22I (I792).

Bryum canescens Hoffm. Deutsch. A. ii, 4 I (I796).

Rhacomitriun cancscens Brid. Mant. 78 (I8I9), Bry. univ. i, 208 (I826). Hueben. Musc. germ. 206 (1833). DE Not. Syllab. 255 (I838), Epil. bri. ital. 67 I (I869). Hartm. Skand. fl. 4 ed. 389 (I843). BR. Sch. Bry. eur. fasc. 25-28, p. I2, t. 78 (I845). Aongstr. in Fries Summ. veg. scand. 92 (I846). RABENH. Deutsch. kr. fl. ii, S. 3, I59 (1848). Liebm. F1. dan. t. 256I (I852). Wils. Bry. br. I70, t. ig (I855). Schimp. Synops. 235 (I860), 2 ed. 280. Zetterst. Rev. Grimm. scand. I28 (I86r). Berk. Handb. br, m. 233 (1863). Milde Bry. siles. I59 (1869). Hobk. Syn. br. m. 88 (1873). Husn. Mouss. nord-ouest 97 (I 873 ), Musc. gall. I4I, t. 40 (I887). Juratz. Laubm. oester.-ung. I83 (I882). Chalub. Grimm. Tatr. II2, t. I7 (I882). Boulay Musc. Fr. 357 (I884). Lesq. James Moss. N. Amer. I5I (I884).

Grimmia canescens C. Muell. Synops. i, 807 (1849).

Rhacomitriun cricoides Var. $\beta$. canesccns Lindo. in Oefv. v. ak. foerh. xxiii, 553 (I866), Act. soc. sc. fenn. X, 547 (I875).

Grimmia cricoides var. $\beta$. cancscens LindB. Musc. scand. 29 (1879).

Dioicous; laxly cæspitose, the tufts large, plane, yellowish to dingy green, hoary at top, fuscous at base. Stems erect or spreading, 2-4 in. long, with few or many short obtuse branches. Leaves patulous, curved backward and forward, the terminal often secund, from an oblong decurrent concave subsulcate base, narrowly lanceolate, carinate, extended into a flat lanceolate subulate, toothed papillose hair, margin revolute, not incrassate, all surface of lamina densely papillose, nerve very thin, sulcate; vanishing below the hair; cells at base elongated, eroso-sinuose, with several rows at margin quadrate and hyaline, at apex rectangular, sinuose. Perich. bracts sheathing beyond middle, with a papillose nerve. Caps. on a long purple seta compressed when dry and twisted to the left, ovato-elliptic, small mouthed, angular when dry, coriaceous, brown; cal. longly subulate, rough at apex; lid subulate, as long or longer than caps., straight or oblique, annulus broad; teeth long as caps., on a more produced basal membrane, purple, filiform, cleft to base, papillose. Male plant more slender, sparingly branched; inner bracts oblong with a hyaline point.

HAB.-Sandy stony heaths and walls. Fr. 3 .

\section{Var. $\beta$. ericoides (Schrad.) C. Muell.}

Plants shorter, yellowish-grey, lateral ramuli very numerous, nearly equal, pinnately arranged. Leaves shorter squarrose, with shorter hairpoints. 
SyN.-Bryum hypnoides, capitulis plurimis erectis, non lanuginosum DiLL. in RAY Synops. 3 ed. $47^{8}$.

Bryum hypnoides, hirsutie cancsccns vulgare p.p. Dill. Hist. musc. 369, t. 47 , f. 27 D-E, et Herb.

Bryum hypnoides, Evica facie, capsulis barbatis, alpinum DilL. op. c. 37 I, t. 47, f. 3 I, et Herb.

Bryum hypuoides Var. $\gamma$. L. Sp. pl. ii, I 20.

Var. ऊ. L. Fl. suec. 2 ed. 392.

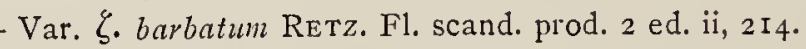

Bryum hypnoides Pollich Pl. palat. iii, го6.

Hypnum canescens Var. $\gamma$. cricoides WEB. Spic. fl. goett. 82.

Bryum ericoides Schrad. in Gmel. Syst. nat. I3 ed. ii, P. 2, I332 (I79r). Dicks. Pl. crypt. Fasc. IV, I4.

Trichostomum elongatum EHRH. Pl. exsic. n. 233.

Trichostomum canescens Var, ericoides HEDw, Stirp. iii, 7, in nota.

Trichostomum ericoides Schrad. Spic. fl. germ. 62. Roth Tent. fl. germ. iii, P. I, Igr. Sm. Fl. brit. I24I ; Eng. Bot. t. I99I. Turn. Musc. hib. 38. P. Beauv. Prodr. go. Web. Mohr Bot. Tasch. II7. Schkuhr Deutsch. kr. gew. P. II, 73, t. 32. Schwaeg. I, P. I, I47, t. 38. Voit Musc. herb. 22. Wahlenb. Fl. lapp. 329. Roehl. Deutsch. fl. iii, 363. Funck Moost. 26, t. I7.

Bryum clongatum Hoffm. Deutsch. fl. ii, 4I.

Rhacomitrium ericoides BrID. Mant. 78 ; Bry. univ. i, 2 IO. DE Not. Syllab. 255. LiNDB. in Oefv. V. ak. foerh. xxiii, 553, et Act. soc. sc. fenn. X, 546.

Rhacomitrium canescens forma localis, HUEB. Musc. germ. 206.

Rhacomitrium canescens Var. $\gamma$. ericoides Br. ScH. Bry. eur. fasc. 25-28, p. I2. WiLs. Bry. br. I7o, t. I9. Schimp. Synops. Milde Bry. siles. I6o. Husnot. Chalubinski. JURATZKA, \&c.

Grimmia canescens Var. $\beta$. ericoides C. Muell. Synops. i, 807.

Grimmia cricoides LindB. Musc. scand.

HAB.-Dry sandy places.

Both forms are equally frequent in subalpine districts and delight in the gravelly detritus about the margins of moorland streams. Schimper's Var. prolixa is an intermediate form, which with several others often have the hairpoint almost obsolete, but the papillose leaves are sufficient to indicate the species. Lindberg regards evicoides as the type of the species, and conescens as a variety.

\section{COSCINODON SPRENG.}

Einleit. in das Stud. kr. gew. 28r ( 1804$)$.

Small mosses, growing in dense cushioned tufts. Leaves hairpointed, resembling those of Grimmia. Calyptra large, campanulatemitræform, multifid at base, plicate, covering greater part of capsule. Caps. half immersed; peristome of 16 lanceolate teeth, arising below orifice, indistinctly articulate, minutely granulose, perforated like a 
sieve. Inhabiting rocks and walls.-Der. коккєоv a sieve and oóovs a tootl.

A small genus of some 6 species, separated from Grimmia on account of the orthotrichoid calyptra. A third European species-C. Patersoni-has been described by Rev. J. Fergusson in the Scottish Naturalist, iv, 62 (I877), of which I have seen no specimen.

\section{COSCINODON CRIBROSUS (Hedw.) Sprice.}

Dioicous; pulvinate, dull green, canescent. Leaves ovatolanceolate, deeply sulcate in each wing; nerved to apex, ending in a smoothish hair. Capsule half-immersed, ovate, lid with a short beak. (T. LIII, A.)

Syn.-Grimmia cribrosa Hedw. Stirp. iii, 73, t. 3I, A. (I792), Sp. musc. 76 (I80I). Brid. Musc. rec. II, P. I, 60 (I798), Sp. musc. I, Ioo (I806), Mant. 36 (I8I9), Bry. univ. i, I74 (I826). Roenl. Moosg. deutsch. I20 (I800), Deutsch. fl. iii, 45 (I8I3), Ann. Wett. ges. iii, 94. Lam. De Can. F1. franc. 3 ed. ii, 459 (1805). Web. Mohr Bot. Tasch. I32 (I807). Schruhr Deutsch. ki. gew. P. II, 30, t. 22 (I8Io). Schwaeg. Suppl. I, P. I, 94 (I8II). Funck Moost. I8, t. I2 (I82 I). NeEs. Hsch. Bry. germ. ii, P. I, So, t. I6, f. 2 (I827). Hueben. Musc. germ. I73 (I833). De Not. Syllab. 240 (I838). Hовк. Syn. br. m. 2 ed. I23 (1884).

Bryum cribrosum HoFfm. Deutsch. fl. ii, 3 I (1796).

Coscinodon pulvinatus Spreng. Einl. kr. gew. 372, t. 8, f. 75 (I804). Fuernr. in Flora I 827 , II, beil. p. 45. BR. Sch. Bry. eur. fasc. 2-3, p. 3, t. I (I837). Schimp. Synops. 242 (I860), 2 ed. 287. MILDE Bry. siles. I8o (I869). HusN. Mouss. nord-ouest 98 (1873). Juratz. Laubm. oester.-ung. I49 (I882). Lesq. James Moss. N. Amer. I54 (I884).

Coscinodon cribrosus Spruce Ann. Mag. N. H. 2 ser. iii, 49I (1849). C. Muell. Synops. i, 765 (1849). De Not. Epil. bri. ital. 720 (I869). Ferguss. in Naturalist I880, p. 83 . Boulay Musc. Fr. 354 (I884). Husn. Musc. gall. I44, t. 4I (1887).

Dioicous; in small dense cushions, dull or glaucous green and canescent above, fuscous at base. Leaves ovato- and oblongo-lanc., concave at base, thence deeply sulcate in the middle of each wing, crowded, patulous, nerved to apex, the margin incurved above; the upper ending in a smoothish hair ; cells above rounded-quadrate, minute incrassate opake, at base quadrate or rectangular, diaplianous, not incrassate; inner perich. bracts very thin, larger, broader. Caps. just emergent, on a very short straight seta, obovate, the neck defluent into the pedicel, smooth, leptodermous, pale brownish-yellow, when dry, wide-mouthed, cyathiform; ann. simple, persistent, lid cupulatoconic rostellate, red; cal. thin, ochraceous, covering $\frac{2}{3}$ capsule; teeth orange, reflexed when dry, perforated between the articulations with round or elongated ocelii. Male plant more slender, more branched. Infl. in the axils of the branches, bracts broadly ovate, shortly acuminate, paraphyses none. 
НАв.-Walls and rocks; rare. Fr. 5-6.

On walls, Coniston (Prof. Barker I867)!! Block of limestone in a bridge at Staveley, near Kendal (Binstcad I 886) !!

Closely resembling Grimmia anodon and crinita, but known at once by the plicate leaves, with rectangular leptodermous cells at base.

\section{GLYPHOMITRIUM Brid.}

Plants short, gregarious or pulvinate. Leaves long, narrow, crisped, opake, areolation minute and quadrate above, laxer and linear or rectangular at base. Capsule exserted. Calyptra mitræform, campanulate, deeply lobulate at base and longitudinally plicate or smooth; per. of I 6 lanceolate teeth, entire or bicrurous or approximate in pairs, papillose or densely trabeculate.-Der. $\gamma \lambda v \phi \omega$ to carve, $\mu \iota \tau \iota$ to the calyptra.

The three genera here united into one have the closest affinity in the form and structure of their leaves, which in the dry state assume a peculiar hooked position, and G. Daviesii only differs in the shorter and broader teeth of peristome, which have a narrow membranous border. About 36 species are known, the majority belonging to the section Brachysteleum, represented here by $B$. polyphyllun.

\section{Clavis to the Spec1es.}

Teeth lanceolate, with a hyaline border.

Davicsii.

- cleft into two papillose legs.

Plants robust, seta straight.

short, seta flexuose, cygneous.

polyphyllum. sa.ricola.

\section{GLYPHOMITRIUM DAVIESII (Dicks.) Brid.}

Autoicous; densely pulvinate. Leaves linear-lanceolate, incurved, entire. Perich. bracts large, convolute. Caps. on a short straight seta, subglobose; cal. covering all caps. contracted and laciniate at base; teeth 16 in pairs, broadly lanc. (T. LIII, B.)

Syn.-Bryum Daviesii Dicks. Pl. crypt. Fasc. II, p. 3, t. 7, f. 6 (I790). Wither. Bot. arr. Br. veg. 3 ed. iii, 835 (I 796). Hull Br. fl. P. 2, 264 (I 799).

Encalypta Daviesii Sмгтн Eng. Bot. t. I28I ; F1. brit. iii, I I83 (I804).

Grimmia Daviesii Brid. musc. rec. II, P. I, 6I (I798). Turn. Musc. hib. 24 (I804). Hook. TAYl. Musc. brit. 39, t. I3 (I8I8). Gray Nat. arr. br. pl. i, 727 (IS2I). Hook. Grev. in Edin. Journ. Sc. i, I 31 (1824).

Griffithia Daviesii R. BR. in Linn. Trans. xii, 575 (I8I9). 
Glyphomitrium Daviesii Brid. Mant. 3 I (I8Ig), Bry. univ, i, 268 (1826). SchwaEg. Suppl. II, P. I, 4I, t. II3 (I823). MACK. Fl. hibern. P. 2, 2I (I836). BR. Sch. Bry. eur. fasc. $2-3$, p. 3 , t. I (I837). C. Muell. Synops. i, 766 (I849). Wrls. Bry. br. I72, t. I3 (I855). Schimp. Synops. 246 (I860), 2 ed. 292. BERK. Handb. br. m. 232, t. 2 I (I863). HoBk. Syn. br. m. 88 (1873). HusN. Musc. gall. 146, t. 42 (1887).

Autoicous; short, in small dense obscure-green cushions. Leaves narrowly linear-lanceolate, incurved and crisped when dry, acute, carinate, margin entire, slightly incrassate, plane or somewhat reflexed below, nerve strong, continued to apex; cells above small, rotundatequadrate and angular, basal rectangular larger, hyaline. Perich. bracts large convolute, recurved at the suddenly narrowed apex. Calyptra pale yellowish-brown, large ventricose, covering all capsule, plicate, contracted at base, laciniate at margin. Caps. on a short thickish rufous seta, pale yellowish brown with a red mouth, subglobose when dry and empty, wide-mouthed and contracted below the orifice; lid rostrate, nearly as long as caps.; teeth $\mathbf{I} 6$, in pairs, inserted below mouth of caps., red, widely lanceolate, reflexed when dry, trabeculæ somewhat crowded, prominent at back, margin hyaline; spores large, green. Male infl. axillar, gemmiform, bracts ovate, acuminate.

Hab.-Crevices of basaltic and granite rocks. Fr. 6-7.

\footnotetext{
Snowdon (Davies). Llanberis and Anglesea (Wilson)!! Giant's Causeway, Fairhead, Antrim and Bantry (Moore)!! Kilpatrick (Sir F. D. Hooker). Bowling (B. Salt I864)! Aros, Mull (Hunt I859) !! Ardtun, Mull (D. Black I864)! Skye (Hunt). Campsie hills (Thompson and Galt). Cock's Tor, Devon (Brent 1868). Slieve Donard $($ Lett $)$.
}

\section{GLYPHOMITRIUM POLYPHYLLUM (Dicks.) Mitt.}

Autoicous; robust in soft yellow green tufts. Leaves patent, lanceolate-acuminate, remotely and coarsely toothed in upper part, plicate. Caps. on a tall seta, cylindrico-elliptic, lid subulate, teeth very long, with rough slender legs. (T. LIII, C.)

SYN.-Brynm trichodes, crectis sublongis capitulis, cxtrcmitatibus per siccitatem stellatis DiLL. in RAY Synops. 3 ed. 98 ( 1724 ).

Bryum cirratum, setis et capsulis brevioribus et pluribus Dill. Hist. musc. 378, t. 48 , fig. 4I (I 74I), et Herb.

Bryum cirratum Var. $\beta$. Huds. Fl. angl. 409 ( $\left.17^{62}\right)$.

Bryum polyphyllum Dicks. Pl. crypt. fasc. III, 7 (I793). Wiru. Bot. arr. br. veg. 3 ed. iii, 825 (I796). Hull Br. fi. P. 2, 260 (1799).

Dicranum polyphyllum Swartz in Schrad. Journ. iv, I78 (I80r). Sm. Fl. brit. iii, I225 (1804); Eng. Bot. t. I2I7. BRID. Sp. musc. I, 202 (I806).

Trichostomnum cirratum SM. F1. brit. I239.

Trichostomum polyphyllum TurN. Musc. hib. 85 , t. 7 (I804). SchwaEg. Suppl. I, P. I, I53, t. 39 (I8II). Hook. TAYL. Musc. brit. 62, t. I9 (I8I8). Funck Moostasch. 26, t. I8 (I82I). GRAY Nat. arr. br. pl. i, 74I (I82I). Hook. Fl. scot. P. 2, I35 (I82I), Br. fl, ii, 34 ( 1833$)$. 
Dicranum aggregatum BRID. Sp. musc. I, 203.

Muirm tortile BRID. Sp. musc. III, 64 (I8I7).

Racomitrium falcifolium BRID. Mant. 82 (I8Ig).

Racomitrium polyphyllum BRID. Mant. 82; Bry. univ. i, 225 (1826). Hueben. Musc. germ. 214 (1833).

Ptychomitrium polyphyllum Fuerne. in Flora xii, P. II, Erganz. I9 (1829). Br. Sch. Bry. eur. fasc. 2-3, p. 4, t. I (I837). DE Not. Syllab. 260 (I838), Epil. bri. ital. 722 (i869). Hartm. Skand. fl. Rabenh. Deutsch. kr. fl. ii, S. 3, I73 (I848). Wils. Bry. brit. I73, t. I9 (I849). Schimp. Synops. 244 (1860), 2 ed. 289. Berk. Handb. br. m. 23I, t. 2 I (I863). Milde Bry. siles. I62 (I869). Hobk. Syn. br. m. 89 (I873). HusN. Mouss. nord-ouest 99 (I873), Musc. gall. I45, t. 42 (I887). BoulaY Musc. Fr. 352 (1884). JuRAtz. Laubm. oester.-ung. I87 (1882).

Brachysteleum polyphyllum Hornsch. Linnœa XV, I27 (1848). C. Muell. Synops. i, 767 (I849).

Autoicous; plants $\frac{1}{2}-2$ in. high, erect, crowded in small soft yellow-green cushions, branched from the base. Leaves densely crowded, nearly equal throughout, crisped and spirally involute when dry, erectopatent when moist, from an oblong plicate base, gradually lineallanceolate, acutely carinate, remotely and coarsely serrate below apex or nearly entire, margin revolute up to middle, nerve channelled, vanishing in the apex; cells at base very narrow, elongated, at angles lax, broad, fuscescent, at apex small, quadrate. Caps. aggregated on an elongate straight red seta, longish elliptic, leptodermous, pale brown, lid reddish, subulate, half length of caps., annulus very broad, teeth long, red, cleft to base into two subulate rugulose legs; calyptra roughish at apex. Male infl. axillar, below the female minute, bracts broadly ovate, acuminate, very concave, entire.

Hab.-Siliceous rocks and old walls in subalpine districts. Fr. 3-4.

A common but very beautiful moss, usually fruiting in abundance, its pale red teeth fading a way into white at apex. Occasionally it occurs in rough squalid tufts of a black or lurid green colour.

\section{GLYPHOMITRIUM SAXICOLA (Web. Mohr) Mitt.}

Autoicous; very short. Leaves lanceolate-subulate, subcrispate, entire. Caps. on a geniculate seta, subcylindric, pale, calyptra subulate, 5-lobed, lid subulate, teeth lanc.-subulate, bicrurous. (T. LIII, D.)

Syn.-Dicrantmn saxicola Web. Mohr Bot. Tasch, I67 (1807). Funck Moostach. 3I, t. 22 (I82I).

Grimmia geniculata Schwaeg. Suppl. I, P. I, 82, t. 22 (I8II). Funck Moostach. I5, t. it. Kautz. in Sturm Deutsch. fl. II, I6 (I8I8). Brid. Bry. univ. i, I8g (I826).

Weissia geniculata Roehl. Deutsch. fl. iii, 48 (I8I3). Brid. Mant. 38 (I8I9). Hueben. Musc. germ. I39 (I833). 
Grimmia saxicola Hook. TAYL. Musc. br. 38 , t. I3 (I 8 I 8 ). GRAY Nat. arr. br. pl. i, 727 (1821). Hook. Br. fl. ii, 25 (1833). Hook. in Eng. Bot. Suppl. t. 2627 (1830).

Campylopus saxicola BRID. Mant. 72 (I8I9).

Dryptodon saxicola Brid. Bry. univ. i, 7\%o (I827).

Ptychomitrium geniculatum HAMPE Flora 1837 .

Campylostelium saxicola Br. ScH. Bry. eur. fasc. 29-30, p. 3, t. I (r846). Rabenh. Deutsch. kr. fl. ii, S. 3, I50 (I848). C. MuELl. Synops. i, 477 (1849). Wils. Bry. br. 52, t. I3 (I855). Schimp. Synops. 688 (r860), 2 ed. I33. BERK. Handb. br. m. 290 t. 24 (I863). DE Not. Epil. bri. ital. 666 (I869). Boulay. Musc. Fr. 54 I (I884). Milde Bry. siles. 135 (I869). Hobr. Syn. br.m. 36 (I873). JuRATz. Laubm. oester.ung. 7 I (I882). Leso. James Moss. N. Amer. 99 (1884). Husn. Musc. gall. 58, t. I7 (I 884$)$.

Autoicous ; very short, nearly simple, densely gregarious, radiculose at base. Leaves small and lanc. at base, upper densely crowded, from a lanceolate base, longly subulate-lineal, smooth, concave, lightly recurved when moist, subcrispate when dry, nerve thick, vanishing below apex, cells abovesmall, roundish-quadrate, opake, at base laxly hexagonorectang., hyaline. Perich. bracts shorter, narrower, more concave at base. Caps. decurved, on a longish slender pale cygneous seta, cylindraceous-oblong, leptodermous, pale with a red mouth; cal. 5-lobed, subulate; lid with a long straight or oblique subula; annulus of $2-3$ rows of cells; teeth lanc.-subulate, bicrurous, the legs alternately longer and shorter, punctulate, reddish at base, pale at apex. Male infl. gemmiform on a short radical branch.

HAB.-Sandstone and granite rocks; not common. Fr. I I-2.

Blackdown, Sussex (Borrer 1822). Near Crich and Rowsley, Derby (Wilson 1833)!! Ramsden clough, Todmorden (Nowell I838)!! Near York and Hackness (Spruce). Henley hill, Tillington, Whip's cross and Balcombe, Sussex (Mitten). Lough Bray, Wicklow (Taylor). Kelly's Glen (Moore). Arncliff wood, Eskdale (Slater 1884)!! Highcliff and Easington, Cleveland (Barnes I887)!!

A delicate little plant, perhaps often overlooked, and corresponding in distribution somewhat with Brachydontivm.

Subf. 2. ORTHOTRICHER. Pulvinate, dichotomous and fastigiate, or decumbent and creeping, with erect fertile branches. Leaves lanceolate or ligulate, upper cells rounded, obscure, with verruciform papillæ, lower elongate pellucid. Vaginula surmounted by a membranous tube. Caps. erect, immersed or exserted, often 8-costate, peristome double, outer of I 6 pale fleshy teeth, geminate, or 8 and bigeminate, endostome of 8 or 16 cilia alternate with the teeth, rarely gymnostomous. Cal, mitræform, usually pilose, rarely cucullate.

\section{ANCECTANGIUM Hedw.}

Sp. musc, 40 (r8or),

Growing in soft swelling yellow-green cushions, interwoven with radicles. Leaves lanceolate, finely papillose. "Calyptra cucullate, 
small, fugacious; caps. on a short seta, deeply $\delta$-striate, urn-shaped

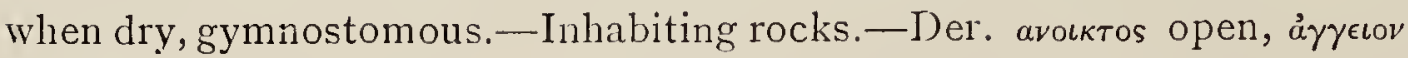
a capsule.

A small genus of 7 species, resembling in habit and foliage several of the Tortulaceæ, but differing considerably in the fruit, which has a wide mouth and 8 ribs.

\section{Clavis to the Species.}

Autoicous; leaves oblong-lanc, basal cells leptodermous.

Dioicous ; leaves lanceolate, acuminate, basal cells incrassate.

Lapponicum. Mougcotii.

\section{ANECTANGIUM LAPPONICUM Hed ${ }^{\prime}$.}

Autoicous; densely tufted olivaceous. Leaves oblong-lanc., erectopatent, basal cells subquadrate, pellucid. Caps. slightly exserted, oval with a swollen neck, contracted below mouth, lid conic, obliquely rostellate. (T. LIII, E.)

SYN.-Gymnostomim Lapponicum Henw. Musc. fr. iii, I2, t. 5 (I792). EHRH. Beitr. vii, I82 (I792). Schrad. Spic. fl. germ. 59 (I794). Hoffm. Deutsch. fl. ii, 29 (I796). Swartz Musc. suec. 20 (I798). Roth Fl. germ. iii, P. I, I82 (I800). SMith Fl. brit. II67 (I804). Eng. Bot. t. 22 I6 (I8I0). Web. Mohr Bot. Tasch. 77 (I807). Schkuhr Deutsch. kr. gew. P. II, I8, t. 8 (I8Io). Hook. TAYL. Musc. br. Io, t. 6 (I8I8). HarTm. Skand. fl. 38 I (I820). Gray Nat. arr. br. pl. i, 7I3 (I82I). Hook. Fl. scot. P. 2, I22 (I82I), Br. Fl. ii, 7 (I833). NeES Hsch. Bry. germ. i, I80, t. II, f. 27 (I823).

Hedwigia lapponica Brid. Musc. rec. II, P. I, 33 (I798). DE Not. Syllab. 93 ( 1838 ).

Bryum lapponicum Dicks. Pl. crypt. fasc. IV, Io (I80I).

Ancetangium lapponicum Hedw. Sp. musc. 40 (I80I). Schwaegr. Suppl. I, P. I, 36 (i8Ii). Wahlenb. Fl. lapp. 304 (I8I2). Funck Moost, 8, t. 5 (I82I). Hueben. Musc. germ. 60 (1833).

Anactangium striatum Brid. Sp. musc. I, 25 (I8o6). RoeHL. Ann. Wett. ges. ii, IIS.

Gy'mnostomum striatum RoEHL. Deutsch. fi. iii, 37 (I8I3). BRID. Bry. univ. i, 90 (I826).

Schistidium striatum BRID. Mant. 22 (18I9).

Hymenostylium lapponicum FUERNR. in Bot. Zeit. i, I837.

Zygodon lapponicus BR. Sch. Bry. eur. fasc. IV, p. 6, t. I (r839). Rabenh. Deutsch. kr. fl. ii, S. 3, I75 (I848). C. Muell. Synops. i, 680 (I849). IVIls. Bry. brit. I92, t. 6 (I855). Berk. Handb. br. m. 2I9, t. 20 (I863). HoBk. Syn. br. m. 97 (I873). Boulay Musc. Fr. 35 I (1884).

Amphidium lapponicum Schimp. Coroll. 39 (1855).

Amphoridium lapponicum Schimp. Synops. 247 (I860), 2 ed. 293. DE Not. Epil. bri. ital. 276 (I869). MILDE Bry. siles. I63 (I869). JuRATZ. Laubm. oester..ung. I88 (I882). Lesq. James Moss. N. Amer. I58 (I884). Husn. Musc. gall. I47, t. 42 (I887).

Cylicocarpus lapponicus Lindb. Oefv, vet. ak. foerh. I862, n. Io.

Autoicous; densely tufted, olive-green or brownish, blackish-brown at base ; stem fragile tomentose $\frac{1}{2}-\mathrm{I} \frac{1}{2} \mathrm{in}$. high. Lower leaves lanceolate, upper oblong-lanc., patent, curved upward and backward, when dry curled and twisted, keeled, finely papillose, entire, margins plane, the nerve vanishing below the point; cells at base subquadrate, pellucid, above very minute, opake, chlorophyllose. Perich. bracts narrorved at 
base, sheathing, short-pointed, smooth. Caps. on a short yellowish seta, a little exserted above the bracts, oval with a swelling neck rather shorter than the sporangium, fuscous-brown with rufous strix, when dry and empty strongly contracted below mouth; lid conic with a short oblique beak, calyptra fuscous. Male infl. axillary, gemmiform, often aggregate, bracts broadly ovate, shortly acuminate.

HAB.-Clefts of alpine roclis. Fr. 6-8.

Snowdon (IVilson)!! Skye (Prof, Lawson)!! Grayrigg forest, Westmoreland (Stabler, I 868)!

An elegant moss with beautiful striate capsules sometimes produced in great abundance, and ornamenting the crevices of rocks in most of the Scotch mountains; it is evidently closely allied to Zygodon differing principally in its subimmersed fruit.

\section{ANECTANGIUM MOUGEOTII (Bruch) Lindb.}

Dioicous; in large turgid mats. L.eaves long, lineal-lanceolate, acutely carinate, not opake. Caps. stouter on a longer seta, the lid with a subulate beak. (T. LIII, F.)

Syn.-Gymnostomum Mongcotii Bruch Mss. Hueben. Musc. germ. 59 (I833).

Zygodon Mongcotii Br. Sch. Bry. eur. fasc. 4, t. 2, p. 7 (I839). RabenH. Deutsch.kr.fl. ii, S. 3, I75 (1848). C. Muell. Synops. i, 68I (I849). Wils. Bry. brit. I92, t. 46 (I855). Berk. Handb. br. m. 2 I8 (I863). Boulay Fl. crypt. de l'Est 35I (I872). HoBk. Syn. br. m. 97 (1873). HusN. Mouss. nord-ouest I00 (1873).

Amphidium Mongeotii Schimp. Coroll. 40 (1855).

Amphorilium Mougcotii Schimp. Synops. 247 (I860), 2 ed. 294. De Not. Epil. bri. ital. 276 (I869). Milde Bry. siles. I63 (I869). JuRATz. Laubm. oester.-ung. I89 (I882).

Lesq. James Moss. N. Amer. 159 (1884). Husn. Musc. gall. I47, t. 42 (1887).

Cylicocarpus Mougeotii Lindi. Oefv. Vet. Ak. foerh. I862, п. го.

Barbula Woodii Schimp. Synops. 2 ed. 207 (1876).

Anoectangiam Mongeotii LindB. Musc. scand. 29 (1879).

Dioicous; in large soft turgid mats, yellow-green above, ferruginous below, interwoven with scattered radicles. Leaves erecto-patent, longer, lineal-lanc., narrower, acutely carinate, less crisp when dry, nerve stouter, vanishing at apex; cells incrassate throughout, not opake, quadrate, yellowish, nearly smooth, margin revolute at base, entire or with minute crenulations from projecting cells. Perich. bracts sheathing only at base, narrower, longer, gradually acuminate, with the nerve subexcurrent. Caps, on a longer seta, thicker, the neck elongated, lid with a long subulate beak, calyptra straw-coloured, long and narrow. Male infl. gemmiform, bracts ovato-lanceolate.

HAB.-Moist shady rocks. Fr. very rare, 8-9. 
Common in mountains. Teesdale (Spruce). With fruit, Clova mountains (Arnott). Dobb's Linn, Moffat (Bell I86I). Campsie (Stirton I863)! Glenballyeman, Cushendall, Antrim, I capsule (Moore 1863).

Taller than the last, and of a bright yellow-green colour, growing in large patches; the leaves also are much longer and more acuminate, and occasionally are obscurely serrulate towards apex; the capsule long and narrow, with the bands less distinct.

\section{PLEUROZYGODON Lindb.}

Utkast till en nat. grupp. Eur. bladm. 35 (1878).

Plants erect, densely pulvinate, cæspitose; leaves accrescent upward, lanceolate, densely papillose, the cells minute and opaque above. Perichætium lateral, of $9-\mathrm{I} 2$ sheathing bracts; seta elongated. Calyptra cucullate, subulate rostrate. Caps. ovate with a swollen neck, leptodermous, smooth, gymnostomous: lid obliquely rostrate.-Der. $\pi \lambda \in v p a$ the side, and $\xi v$ o $\delta o v$.

Besides the single European species, some it others have been described, about equally divided between the Andes and the Himalayas. Anact. Homschuchii Funck, and its Var. Sendtneri Br. Sch. belong to a distinct genus Molendoa LiNDB.

\section{PLEUROZYGODON ÆSTIVUS (Hedw.) Lindb.}

Dioicous; in dense matted tufts. Leaves accrescent upward, lanceolate, acute, carinate, papillose. Caps. lateral, leptodermous, ovate-oblong, smooth; lid obliquely rostrate. (T. LIV, A.)

Syn.-Gymnostomum astivun Hedw. Sp. musc. 32, t. 2, f. $4-7$ (r8or). Web. MoHr. Bot. Tasch. 89 (I807). Schkuhr Deutsch. kr. gew. P. II, 26, t. II (ISIO). SchwaEg. Suppl. I, P. I, 30 (I8II). Roenl. Deutsch. f. iii, 40 (I8I3). Hook. TAIL. Musc. br. Io, t. 6 (I818). GRaY Nat. arr. br. pl. i, 7 I4 (I82I). Hook. Fl. scot. P. 2, I22 (I821). NeEs Hsch. Bry. germ. i, I73, t. I I, f. 25 (I823). HARTM. Skand. fl. 38 I.

Gymnostomum compactum Schleich. Cr. helv. cent. II, n. 7 (I805). Brid. Bry. univ. i, $86(1826)$.

(?) Gymnostomnu luteolum SM. Eng. Bot. t, 220 I (I8Io).

Anactanginm compactum SchwaEg. Suppl. I, P. I, 36, t. II (ISII). BRID. Mant. 23 (I8Ig). Funck Moost. 8, t. 5 (I82I). Hueben. Musc. germ. 6I (I833). BR. Sch. Bry. eur. fasc. $29-30$, p. 5, t. I (I846). Rabenh. Deutsch. kr. fl. ii, S. 3, $2+3$ (I $8+8$ ). Wils Bry. brit. 3II, t. 6 (I855). Schimp. Synops. 46 (IS60), 2 ed. 47 . BERK. Handb. br. m. I55, t. I4 (I863). DE Not. Epil. bri. ital. 253 (I 869). Milde Bry. siles. Iog (I869). Hoвk. Syn. br. m. I 39 (I873). JuRATz. Laubm. oester..ung. I7 (I882). Boulay F1. cr. de l'Est 579 (I872). Husn. Musc. gall. Io, t. 3 (I884). Limpr, in RabeNh. kr. Al. 2 ed. band IV, 244 , fig. 92 (I886).

Gymnostomum tristichon WAHLENB. Fl. lapp. 303 (I8I2).

Hedrvigia restiva Hook. Br. fl. ii, 68 (1833). MAck. Fl. hib. P. 2, I I (1836). DE Not. Syllab. 93 (1 838 ).

Zygodon compactus C. Mueld. Synops. i, 633 (1849).

Ancetangium astivum MıтT, in Journ. Linn. soc. Bot. xi1, I75 (I869).

Pleurozygodon astivns LindB. Utkast, \&c. 35 (I878). 
Dioicous; in large soft swollen tufts, briglit yellow-green above, ferruginous below, radiculose. Stems slender, I-4 in. high, fragile, dichotomous, fastigiate. Leaves gradually accrescent and more crowded upward, from an erect base, patent, ascending at point, when dry obliquely incumbent and twisted at apex, lanceolate, acute, acutely carinate, very densely covered with short bipartite papillæ; margin plane, minutely crenulate, nerve vanisling below apex, subterete, very prominent at back; cells at base longisli rectangular, hyaline, above roundish-quadrate, small, opake. Periclı. bracts paler, subvaginant beyond the middle, acuminate, smooth; seta $\frac{1}{2}$-in. high, pale yellow, twisted to right when dry. Caps. erect, small ovate-oblong, with a swelling neck, leptodermous, pale ferruginous with a glossy rufous mouth, smooth when dry and empty; annulus narrow; lid as long or longer than capsule, obliquely rostrate, subulate. Male plants more slender, the infl. gemmiform, bracts ovate, acuminate, faintly nerved.

HAB.--Schistosc rocks about streams in mountains. Fr. 8.

Frequent in Scotland, Wales and N. of England. Rare in Ireland; Bantry and Galtee-more, Tipperary.

Var. $\beta$. pellucida (Wils.).

Plants more robust, densely compact and radiculose, pale yellow-green; leaves longer, broader flatter, with larger cells, which are pellucid and almost free from papillic.

SYN.-Ancctangium pellucidum WiLs. MSS.

\section{HAB,--Kilblane near Inverary: क (Wilson $188_{3} 6$ )!!}

This moss has taxed the powers of all bryologists to find a satisfactory position for it in our systems, combining as it does various characters pointing to widely different groups. Although the inflorescence proceeds from a lateral bud, it has nothing in common with pleurocarpous mosses, but its habit much resembles that of Barbula curvirostris, as also does the fruit, and the leaves are equally akin to those of Ancect. Mongeotii in structure. The var. pellucida is a larger plant in every way, with laxer leaves, and may bc distinct.

\section{ZYGODON Hook. Tayl.}

Musc. brit. 70 (1818).

Plants dichotomous, fastigiate branched, crowded and interwoven with radicles. Leaves spathulate-lanc., very chlorophyllose above, hyaline at base. Caps. on an elongated pedicel, oval-oblong, with a soft swelling neck, less distinctly striate; peristome single or double 
rarely none, the teeth resembling those of Orthotrichum. Calyptra smooth, cucullate. Inliabiting trees and rocks.-Der. Govos a yoke, ofovs a tooth.

Between 60 and 70 species of this genus have been described, about half of them being natives of S. America. The peristome agrees in structure with that of Orthotrichm, the lid differing in being obliquely rostrate, and the calyptra cucullate.

\section{Clavis to the Species.}

Nerve excurrent in a mucro.

Stirtoni.

vanishing below point.

Leaves entire, plants rather short. Peristome none.

- present.

Autoicous, in dense tufts with pale radicles.

Dioicous, in loose tufts with red radicles.

Leaves denticulate at apex, plants tall.

viridissintus.

Forsteri.

conoideus.

gracilis.

\section{ZYGODON STIRTONI. Schimp.}

Dioicous; leaves dense, erecto-patent, elongate lanceolate, the wings often unequal at apex; nerve thick, prominent at back, excurrent in a smooth-pointed mucro; cells at base ovali-rectangular smooth, above rounded, papillose. Caps. subglobose. (T. LIV, B.)

Syx.-Zygodon Inmilis Hunt MSS. 1867.

Zygodon Stirtoni Schimp. MSS. StiRTon in Trans. bot. soc. Edin. xi, 75 ( $187 \mathrm{I})$. Husx. Musc. gall. 148, t. 42 (I887).

Zygodon aristatus Lindb. Act. soc. sc. fenn. $x, 542$ (I875).

Dioicous ; in short dense tufts, dull yellow-green above, fuscous and radiculose at base, dicliotomous. Leaves dense, erecto-patent, straight, elongato-lanceolate, wings often terminating unequally at apex, the margin crenulate with minute papillæ; nerve yellow, thick, rounded and very prominent at back, excurrent as a very thick, subterete pungent fragile awn; cells strongly incrassate, basal ovali-rectang. or quadrate, smooth, the rest rounded, chlorophyllose, each with several minute acute papillæe on the surface. Perich. bracts like the leaves but with a shorter awn, and the cells in the lower half laxer and morc elongated; caps. on a yellowish elongated seta, erect, leptodermous, subglobose-pyriform with a small mouth, gymnostomous, faintly striate when dry; lid rostrate.

$\mathrm{H}_{\mathrm{AB}}$ - - Rocks and limestone walls, especially near the sea. Fr. rare, 4.

Roadside near Barmouth c. fr. (Wilson 1863)! Coast at Elie, Fife, c. fr. (Howie I864)!! Buxton (Hunt I867)!! Arbroath and Troup head, Forfar (Fergisson I864)!! Menmuir, c. fr. (Anderson). Bowling and Campsie (Stirton I865). Ben Lavers and Killin (Stirton I867). Limestone wall at Plymouth (Holmes I867) I! Cromaglown and 
Muckross on beech (Lindberg 1873). Derry, Ireland, on a sycamore c. fr. ( 7 . H. Davies I885)!! Kilroot and Rathlin island, Antrim (Stcwart I880)!! Gordale Scar and Malham fHolt I885)!! Chee Tor and Monksdale (Holt 1886)!! Rushen Abbey, I. of Man (Holt I884)!! Annalong, Co. Down (Rev. H. Lett). Penmaen Rhos, Colwyn (Holt I 889 ) !!

This is certainly distinct from the next species, being of much firmer texture, with sub-erect leaves and nerve excurrent to a variable extent, the lamina often ending unsymmetrically on each side of it; the capsule also is rounder with a small mouth. It occasionally grows intermixed with $Z$. viridissimus and its variety, and thus becomes an occupant of tree trunks.

\section{ZYGODON VIRIDISSIMUS (Dicks.) Brown.}

Dioicous; in small lax bright green tufts. Leaves patent, recurvosquarrose, lineal-lanc., acuminate, nerve narrow, vanishing below apex. Caps. on a longish seta, leptodermous, oval-oblong with a short neck, striate at mouth, lid rostrate. (T. LIV, C.)

Syn.-Bryum viridissimum Dicks. Fasc. pl. cr. IV, 9, t. Io, f. I8 (I80I). Brid. Musc. rec. II, P. III, 64, excl. syn. (ISo3).

Dicranumi viridissimum SM. Fl. br. I224 (I804). TURN. Musc. hib. 7I (I804). BRID. Sp. musc. I, I93 (1806).

Gymmostomum viridissimum SM. Eng. Bot. t. I583 (1805). Hook. TaYl. Musc. br. Io, t. 6, excl. syn. (I8I8). GRAY Nat. arr. br. pl. i, 7I4 (I82I). Hook. Fl. scot. P. 2, I22 (I82I); Br. fl. ii, 7 (I833). SchwaEg. Suppl. II, P. II, t. I77 (I826). MaCk. Fl. hib. P. 2,9 (1836).

Zygodon viridissimus Brown in Trans. Linn. Soc. xii, 575 (18rg). BrId. Bry. univ. i, 592 (1826). Huliben. Musc. germ. 388 (1833). DE Not. Syllab. I59 (1838). BR. Sch. Bry. eur. fasc. 4, p. 7, t. I, excl. syn. (I839). RABENH. Deutsch. kr. fl. ii, S. 3, I75 (I 848 ). C. Muell. Synops. i, 67 I (I849). Wils. Bry. brit. I93, t. 6 (I855). Schimp. Synops. 249 (1860), 2 ed. 295. Berk. Handb. Br. m. 218, t. 20 (I863). Milde Bry. siles. I64 (I869). Boulay Hi. crypt. de l'Est 349 (1872). HoBK. Syn. br. m. 97 (1873). Husn. Mouss. nord-ouest Ioo (I873), Musc. gall. I48, t. 42 (1887). Juratz. Laubm. oester.-ung. Igo (I882).

Amphoridium viridissimum DE NoT. Epil. 277 (I869).

Dioicous; in small cushioned tufts, bright green above, fuscous at base. Stems $\frac{1}{2}-1$ in. high, sparingly branched, fastigiate, with rufous radicles at base. Leaves dense, when moist recurvo-squarrose, when dry erecto-appressed or somewliat twisted, toward apex complicate, oblongo-or lineal-lanc., elongated, acutely acuminate, deeply carinate above, expanded below, minutely papillose, margins plane; nerve pellucid, ending abruptly below apex, cells at base thin, quadratohexagonal, above small hexagono-rotundate. Caps. on a longish pale seta, erect, oval-oblong witli a short neck, olivaceous, when dry pyriform, fuscescent with a narrow red mouth, obscurely 8-costate; calyptra fugacious, rostrate, lid orange, obliquely rostrate; peristome norre. Male plant more slender, in distinct tufts, infl. terminal gemmiform, bracts ovato-lanceolate.

HaB.-Trees, sometimes on walls, not rare. Fr. 3-4. 
This pretty moss flourishes best in mild moist localities, and with us attains its greatest perfection in Devonshire and at Killarney, where the fruit is abundant.

\section{Var. $\beta$ rupestris $L$ indb.}

Plants more robust, dark green; leaves twisted when dry, longer, narrower, apiculate, the nerve stronger, reaching nearly to point. Caps. pale brown, subcylindric, tapering at base, not contracted at mouth.

Syn.-Zygodon rutpestris Lindb. M. S. I861; Musc. scand. 29 (1879). Milde Bry. siles. I64 (I869).

Zygodon vividissimus $\beta$. rupestris HAR'TM. Handb. Skand. fl. Mossor, 9 ed. 52 (1864).

Zyg. viridissimus $\beta$. saxicola Molendo M. S. I862. Rabenh. Bryoth. eur. n. 626 (I863). LORENTZ Moos-studien 95 (1864).

HAB,-Rocks and walls; rare.

Old wall near Oxford (Bosweil I884)!! Wall at Barmouth with $Z$. Stivtoni (Holt I882) !! Limestone rocks at Castleton, Derby, and Rushen Abbey, I. of Man, with $Z$. Stirtoni (Holt I884)!! On sycamore, Derry ( $F$. H. Davies I885)!! Rocks at Pentreath, Anglesey, c. fr. (Rogers I 887)! Malham (Holt I885)! Miller's dale (Holt I884)!!

A stouter plant than the type and of a dull dark green colour, almost intermediate between $Z$. Stirtoni and $Z$. viridissimus.

\section{ZYGODON CONOIDEUS (Dicks.) Hook. Tayl.}

Dioicous; in small lax slightly branched tufts. Leaves less dense, patent, broadly lanc., flat, keeled; nerve vanishing. Caps. ovalpyriform, lid subulate, teetl I 6 , pale yellow, short, obtuse; endostome of 8 fugacious cilia. (T. LIV, D.)

Syn.-Bryum conoideun Dicks. Cr. Fasc. IV, t. II, f. 2 (r8or). Turn, Musc. hib. II2 (ISO4).

Mnium conoideum SM. Fl. brit. I345 (I804); Eng. Bot. t. I 239.

Zygodon conoideus Hook. TAyl. Musc. br. 7I, t. 2I excl. syn. (I8I8). Gray Nat. arr. Br. pl. i, 744 (I82I). Hook. Grev. in Breivst. Ed. J. sc. i, I 32 (I824), ut Var. minor. Ноок. Br. fl. ii, 52 (1833). Маск. Fl. hï. P. 2,29 (I836). WiLs. Bry. br. I93, t. 2 I (1855). Schimp. Synops. 250 (I860), 2 ed. 296. BERK. Handb. br. m. 217, t. 20 (I863). Boulay Fl. cr. de l'Est 350 (1872). Hobk. Syn. br. m. 98 (1873). Husn. Mouss. nord. ouest roo (I873), Musc. gall. I 48 , t. 42 (I887).

Zygodon Brebissoni Br. Sch, Bry. eur. Fasc. 4, p. 8, t. 2 (1839). C. Muedl. Synops. i, 673 (1849).

Dioicous; in small lax light yellow-green tufts. Stems nearly simple or sparingly branclied, slender, beset with ferruginous radicles at base. Leaves less dense, patent, curving upward, imbricated when dry, lineal-lanc., acuminate, flat and slightly keeled, more papillose, nerve narrow, vanishing below apex, more opaque; cells larger and more incrassate. Caps. on a longisl slender pale seta, oval, tapering downwards into a neck of equal lengtl, narrower, striate toward moutl, when dry and empty, leptodermous, pale fuscous; lid with a subulate beak; peristome of 8 bigeminate, pale yellowish teetl, reflexed when 
dry, truncate at apex, fugacious, endostome of 8 yellowish cilia, very fugacious, often abortive. Male plants intermixed with female, slender geniculate-flexuose, infl. terminal, gemmiform, bracts ovate, acuminate.

HaB.-Trunks of trees; not common. Fr. 5 .

Inverary (Dickson). Belfast (Tcmpleton). Mucruss, Killarney and near Beaumaris (Wilson I829)!! Manchester (Hobson). Mill pond at Arundel and Charlton forest (Borror). Oughterard, Ireland (Nowell I 860). Handcross $(7 \mathrm{~cm}$ (Nor). Lydford (Holmes I868)!! Dailly (Shaz'). Near Airth (Lyle r85r)! Appin (Carmichad). New Galloway (B. Syme r850). Glen Lochay (Hunt I868)! Tyn-y-Groes, N. Wales (Holt 1885) !! Baldwin, I. of Man (Holt $\left.\mathrm{I} 88_{3}\right)$ !! Dolgelly and Barmouth (Whitchead I876).

Much resembling $Z$. viridissimus, but with more erect straight leaves with larger, laxer cells; the caps. with a longer neck, and double peristome.

\section{ZYGODON FORSTERI (Dicks.) Wils.}

Autoicous; densely tufted. Leaves erecto-patent, subspathulate. Caps. pyriform, striated, lid with a curved beak, teeth of per. strongly recurved when dry. (T. LIV, E.)

Syn.-Bry lum Forsteri Dicks. Fasc. Pl. crypt. III, p. 4, t. 7, fig. 8 (I793). Brir. Miusc. rec. II, P. III, 56 (I803).

Grimmia Forsteri Smith Fl. brit, 1196 (I804), Eng. Bot. t. 2225. Schwaeg. Suppl. I, P. I, 66 (I8I I).

Weissia Forsteri Brid. Sp. musc. I, I24 (1806), Mant. 45 (I8I9), Bry. univ. i, ?57 (1826).

Gymnocephalus conoidcus SchivaEg. Suppl. I, P. II, 87 (1816).

Gymnostomun viridissimum p.p. Hook. Tayl. Musc. br. ro (r8I8).

Amplidium pulvinatum NeEs in Sturm Deutsch. Fl. II, I7 (I8Ig). Funck Moost. 33, t. 22.

Gagea compacta Raddi Nuova Raccolta Dec. II.

Zygodon conoideus Schwaeg. Suppl. II, P. I, r58, t. I36 (I823). Brid. Bry. un. i, 590 (1826). Hueben. Musc. germ. 386 (1833). De Not. Syllab. I58 (I838). Br. Sch. Bry. eur. fasc. 4 , p. 8, t. 2 (1839). C. Muell. Synops. i, 667 (1849).

Zygodon coniodeus $\beta$ succulentus Hook. Grev. in Brewst. Journ. Sc. i, 132 (I824).

Zygodon Forsteri WiLs. Bry. br. I94, t. 46 (I855). Schimp. Synops. 250 (I860), 2 ed. 298. De Not. Epil. bri. ital. 272 (I869). Berk. Handb. br. m. 2 I $_{7}$ (I863). Milde Bry. siles. I64 (1869). Hoвk. Syn. br. m. 98 (I873). Boulay Fl. cr. de l'Est 348 (I872). Husn. Mouss. nord.onest Ioo (1873), Musc. gall. I49, t. 43 (I887).

Autoicous; in compact dark green cushions, rufous at base, interwoven with whitish radicles, the stems with close adpressed branches. Leaves erecto-patent, broad, upper acuminato-spathulate, acute, subplane, with a stout nerve reaching apex, basal cells rectangular, hyaline, reddish at insertion, upper rounded-hexagonal, smooth, deep green and chlorophyllose. Caps. on a straight thick rufescent seta, pyriform with a long neck, from yellow, fuscescent, with 8 orange striæ, forming ribs when dry, solid, when dry and deoperculate slightly constricted below the mouth, brown and subcylindric, lid shortly conico- 
attenuate; teeth 8 , bigeminate, minutely rugose, yellow, broadly lanc., cleft at apex, when dry reflexed and appressed to the capsule, cilia lanceolate-subulate, rather shorter than teeth, hyaline, slightly incurved. Male infl. terminal on lateral ramuli, bracts ovate, acute.

HAB.-Trunks of trees, rare. Fr. 5 .

On a felled tree in a timber yard at Chapel End, Walthamstow, probably brought from Epping Forest (T.F. Forster)! Near Hastings (Fenner)! Minehead, Somerset (Miss Gifford). Epping Forest (Holmes I885)!!

Wilson first cleared up the uncertainty about this moss, which had been confounded with both $Z$. viridissimus and $Z$, conoides. It is of singular soft pulpy consistence, and quite reminds us of a species of Pottia.

\section{ZYGODON GRACILIS. Wils.}

Dioicous; taller, widely crespitose, fuscescent. Leaves subrecurved, oblong-lanc., irregularly serrulate at apex, nerve excurrent. Caps. on a short rufous seta, oblongo-cylindric, lid rostrate, peristome as in $Z_{y} g$. conoidens. (T. LIV, F.)

SYN.-Zygodon gracilis Wils. MSS. BERK. Handb. Br. m. 219 (I863). HuNt in Mem. Lit. Phil. Soc. Manch. 3 ser. iii, 237 (I867). Hobk. Syn. br. m. 98 (I873). Husx. Musc. gall. I49, t. 43 (I887). JURATz. Laubm, oester.-ung. I9o (I882).

Didymodon gracilis Schimp. in Molendo Musc. tirol. aust. n. I6.

Amphoridium gracile DE Not. Epil. bri. it. 278 (I869).

Zygodon Nowellii Schimp. Synops. 2 ed. 297 (1876). Hobk. Syn. br.m. 2 ed. 130 (1884).

Dioicous ; in wide crowded tufts, brownish or blackish-green above, reddish-brown at base. Stems I-3 in. high, rigid, repeatedly divided, with innovations at short intervals, and fuscous branched radicles at the lower leaf-axils. Leaves crowded, when moist subrecurvo-patent, when dry laxly incumbent, lower narrowly elliptic-lanc., upper from a concave oblong base, narrowly lanc, arclied backward, acutely carinate, the wings patent from the middle, waved, minutely papillose, at apex irregularly eroso-serrate or only with 3-6 irregular distant repand teeth, nerve semiterete, narrow, subcanaliculate in front, hispidulous at back, vanishing just below apex or slightly excurrent; upper cells very small, rounded and well-defined, more or less chloroplyyllose, basal oblongo and hexagono-rectangular, smaller towards margin, pachy'dermous, diaphanous. Perich. bracts similar; vaginula oblong, paraplysate, seta stout rufous, only 3 times length of capsule which is oblongo-cylindric, suberect, somewhat asymmetric, castaneous, 8 -striate, costulate when dry, lid conico-rostellate pale red, calyptra long, rostrate, annulus large, of 3 rows of cells; teeth pale, rather broad, 8 bigeminate, 
cleft at apex, like those of $Z$. conoideus, articulations numerous, minutely vermiculate, cilia 8 , partly adhering to the teeth. Male plants in separate tufts, more slender, infl. terminal, stoutly gemmiform, bracts ovate, acuminate, the nerve thin and vanishing, antheridia and paraphyses numerous.

Hab.-Calcareous rocks and walls rare. Fr. 5-6.

Middlehouse, near Malham Tarn (Novell r856)!! and c. fr. (Whiteheral i879). O1d limestone walls, Heselton gill, Litton dale c. fr. (Nowell I866)! Ingleboro, in the ascent from Clapham (West I876)!! Connemara, Ireland (Wilson).

This species has quite a different aspect from the other European forms, resembling most the Mexican $Z$. campylophyllus C. Muelu. The fruit is rare with us, but has been found in good condition in the Tyrol.

\title{
7. ORTHOTRICHUM HEDW.
}

\author{
Musc. frond. $\mathrm{ii}, 96\left(\mathrm{I}_{7} 88\right)$.
}

Growing in round cuslions on trees, rocks or walls. Leaves lanceolate, generally recurved at margin, not dilated at base, imbricated or twisted when dry, minutely papillose, cells punctiform and chloro. phyllose above, hyaline and elongate below. Capsule on a short pedicel, as long or longer than the ochreate vaginula, immersed or exserted above the leaves, 8-I6 striate, the striæ alternating with the teetl, prominent or forming ribs when dry, very rarely none. Teeth of peristome 32 , geminate or bigeminate, formed of one series of quadrate cells; endostome of 8 or $i \dot{6}$ cilia, filiform, articulated, alternate with the teeth, often rudimentary or abortive. Calyptra mitræform, lobed at base, conico-campanulate, plicate, naked or covered with straight filiform ramenta.-Der. optos straight, $\theta \rho \iota \xi$ lıair.

About I 20 species of Orthotrichum have been described, but judging by a study of our native species, it is to be feared that many of these must sink into synonyms. The great difficulty in dealing with the genus is the great uniformity in the habit of the species, and, with a few exceptions, the little variation to be met with in the form and structure of the leaves. These are more or less imbricated when dry, but when wetted, quickly become recurred from the base and then gradually erecto-patent, in shape oblongo-lanceolate, or sublinear, the point obtuse, acute or acuminate, very rarely piliferous, the margin usually revolute, the upper cells incrassate, usually bearing coarse or fine, cleft or conical papillæ. The vaginula is smooth or hairy and is crowned by a little membranous tube enclosing the pedicel, named the ochrea or vaginal tube, this pedicel is usually very short, so that the fruit is 
seldom exserted above the upper leaves; the caps. is symmetric, erect, oval or subcylindric, almost always striate with 8 or 16 vittæ or bands, which after sporing, produce on the ripe dry capsule as many ridges and furrows, these bands or ribs consist of darker and larger cells than the intermediate tissue, arranged in 2-5 vertical series, and their walls, especially the lateral, much and often irregularly thickened. The peristome is very rarely wanting, and is extremely variable, the teeth consist of 32 flat lanceolate processes, generally united in pairs (geminate), or in fours (bigeminate), and are covered with papilla, but sometimes with very minute sinuous lines, and when dry are erect, spreading horizontally, or reflexed against the capsule; very often an endostome is also present in the form of 8 or I 6 cilia, consisting of $\mathrm{I}$ or 2 rows of cells, opposite to the ribs of caps, and therefore alternate with the teeth; too much value however must not be fixed upon them, as they are sometimes imperfect or abortive. The calyptra is campanulate or conical, longitudinally plicate, more or less covered with straight hair-like processes, or sometimes quite smooth.

A very important character lias been discovered in the two forms of stomata found on the lower part of the capsule, and applied by Lindberg in I 866 to divide the genus into two sections; these are I. Superficial-(termed phaneropores by Milde, stomata normalia by De Notaris, stomata muda by Venturi), - which are seated in the cuticle only, and the two stomatic cells are thus nakeci and risible; 2. Immersed-(cryptopores of Milde, stomata sphincterifomina of De Notaris, stomata periphrasta of Venturi), - - these are sunk in the capsulewall and the two stomatic cells more or less covered by a circle of projecting cuticular cells. In order to obtain a proper knowledge of the form of the capsule, it should be soaked in water for some hours, and to observe the stomata the base of the caps. should be cut off, the fruit slit up on one side, the spore sac removed, and the pericarp with the cuticular side upward, spread out in water on a slide and covered with glass; a power of 300 will be required. Dr. Carrington added largely to the knowledge of our native species in the Phytologist for 1858 , and Dr. Venturi, of Trient, who has for years paid unremitting attention to the genus, first in Hedwigia for I87 I -3, and recently in Parts 5-6 of Husnot's Muscolugia gallica, lias given masterly descriptions of all the European spccies, which leave little to be desired.

\section{Clavis to the Siriciles.}

Stomata superficial.

Leaves obtuse, with plane margins.

- more or less acute, with recurved margins.

Peristome simple.

Peristome and endostome present.

Capsule without ridges

- with ridges and furrows.

Autoicous, cilia 8 .

Capsule striate nearly all its length.

Caps. short, brown; calyptra yellow. rufestre.

- long, narrow, pale; cal. pale greenish. affinc.

obtusifolium.

Sharii.

striatum. Capsule fainty striate at upper end.

speciosum.

Dioicous, cilia 16 .

Lyellii. 
Stomata immersed

Upper leaves with diaphanous hair-points.

without diaph. hair-points.

diathantum.

L,eaves obtuse.

Leaves round at point, with small crowded cells.

rivinlare. apiculate, with lax rounded cells.

Leaves more or less acute.

sprucei.

Teeth of per. striolate vertically, with short basal lamellx. Capsule inmersed or emerging.

\section{cupulatum.}

anomalum.

Teeth of per. papillose, without lamellie.

Neck of caps. shrivelling into a cup, enclosing the pedicel. Schimperi.

Vaginula hairy. defluent into the pedicel.

- - - smooth.

Capsule immersed.

Caps, oval-oblong, calyp. campanulate, naked.
cylindric, cal. conic, with few hairs.

Capsule exserted.

stramineum. tencllinm. pulchellum.

Sect. I. GYMNOPORUS Lindl. Stomata on wall of capsule superficial.

* Dioicous; leaves obtuse with plane margins.

\section{ORTHOTRICHUM OBTUSIFOLIUM (Schrad.)}

Dioicous; in small yellowish-green cushions, with short turgid branches. Leaves imbricated, broadly ovate with the margin erect, obtuse and hyaline at apex. Caps. immersed, oval-pyriform, with the neck longer than sporangium, and 8 weak bands; stomata superficial; teeth 8 , bigem. ; calyptra naked, covering the capsule. (T. LV, A.)

Srn.-Orthotrichmm obtusifolinm Schrad. Crypt. Gew. I4 (I796). Swartz Musc. suec. 42, t. 4, f. 9 (I7g8). Brid. Musc. rec. II, P. II, 23 (I80I). Sp. musc. II, 6 (I8I2), Mant. III (I819), Bry. univ. i, 287 (1826). Schultz Fl. starg. 308 (I806). Web. Mohr Bot. Tasch. 23 I (1807). Voit Musc. herb. 62 (I8I2). Wahlenb. Fl. lapp. 365 (I8I2), Fl. carp. 354 (I8I4). Roenl. Deutsch. fl. iii, 82 (I8I3). Schwaeg. Suppl. I, P. II, I4, t. 50 (1816). Funck Moost. 35, t. 23 (I821). Hook. Grev. in Edin. J. Sc. I824, p. I22. Hueben. Musc. germ. 355 (1833). BR. Sch. Bry. eur. fasc. 2-3, p. 13, t. I (1837). DE Noт. Syllab. I53 (I838), Epil. bri. ital. 306 (1869). Rabenh. Deutsch. kr. fl. ii, s. 3, I79 (1848). Hammar Orthot. suec. 2 ( 1852 ). C. Muell. Synops. 688 (I849). Carringt. in Trans. Bot. Soc. Edin. vi, 49, et in Phytol. 1858, p. 572. Schimp. Synops. 263 (I860), 2 ed. 320. BERK. Handb. br. m. 22 I (I863). MILDE Bry. siles. I72 (I869). Boulay Fl. cr. de 1'Est 6r7 (1872). Новк. Syn. br. m. 9o (1873). Husn. Mouss. nordouest to6 (1873). Juratz. Laubm. oester-ung. ig8 (1882). Lesq. James Moss. N. Amer. 177 (1884). Venturi in Musc. gall. 193, t. 52 (1888).

IV cissia obtusifolia Roth Tent. F1. germ. iii, I, 2 I8 (I80o).

Dorcadion obtusifolium Lindb. Musc. scand. 29 (I879).

Dioicous; in small dense cushioned tufts, pale or yellow-green above, fuscescent at base; stems $\frac{1}{2}-I$ in. high, with a few turgid branches. Leaves closely imbricated when dry, quickly spreading when wet and then becoming straight, ovate-oblong, concave-carinate, obtusely rounded, slightly hyaline and minutely serrulate at point, plane at margin, often bearing small oblong septate gemmæ on the 
surface, papillose at back; cells at base quadrate at margin, more elongated in the middle, gradually becoming rounded upward, with strongly incrassate walls and a large projecting papilla which is sometimes bifurcate; nerve vanishing below apex. Perich. bracts broader, thinner, subvaginant, sulcate. Caps. yellow, deep orange at mouth, just immersed, oval or pyriform with the neck longer than sporangium, abruptly narrowed at base into a very short pedicel, contracted below the mouth and furrowed when dry, bands 8 , not prominent, composed of two rows of quadrate cells; stomata superficial; calyptra coniccampanulate, naked, brown paler at margin, covering the sporangium, roughish at apex, lid conic with an orange point. Teeth of per. 8 bigeminate, orange, obtuse at point, more or less lacunose in the divisural line, densely and finely papillose; cilia \&, shorter than the peristome, yellow, of two rows of papillose cells. Male plants with the female or in separate tufts, more slender.

HAB.-On elms and oaks, rare and barren.

Near York (Wilson I8;6). Near Cheltenham (Beash 185I). Chipping Campden and Mickleton, Glos. (Kirk I857)!! Stratford-on-Avon and Harbury (Bagnall)!! Wytham wood, Oxon. (Bosteell). Near Buckingham (Holnes I884)!! Kettering (Dixon r885). Pencombe, Perrystone and Hentland, Hereford (Rev. A. Ley r886).

This moss has not been found with fruit here, but is readily known by the subclavate branches with broad obtuse leaves, erect at margin.

Another closely allied species (O.gvmnostomm BRUCH) is found with this on the continent and should be looked for here, especially as Dr. Venturi informs me that a specimen was sent to him by Jaeger from the collection of M. Sickenberger labelled, "England, Yorkshire." In this species the capsule is oblong and gymnostomus, the leaves ligulate, involute at margin, with rhomboidal cells.

* Endostome of 8 slender smooth or punctate cilia, sometimes wanting.

\section{ORTHOTRICHUM RUPESTRE. Schleich.}

Autoicous; laxly pulvinate, dichotomous. Leaves oblong-lanc., revolute at margin. Caps. immersed, oblong, S-striate, gradually defluent into the pedicel, teeth 8 , bigeminate, pale, papillose rugulose, cilia 8 ; calyptra campanulate, fuscous, hairy. (T. LV, B.)

Syn.-Orthotrichum rupestre Scleich. Crypt. helv. exs. Cent. III, n. 24 (i8o6). Schwaeg. Suppl. I, P. II, 27, t. 53 (I8I6). BRIn. Mant. Iro (I8Ig), Bry. univ. i, 279 (I826). Funck Moost. 35, t. 23 (I82 I). Hook. Grev. Edin. Journ. Sc. I824, p. I2I. WVallR. Fl. cr. germ. i, 209 (183I). Hartm. Skand. fl. 366. Hueben. Musc. germ. 369 (1833). Br. Sch. Bry. eur. fasc. $2-3$, p. Ig, t. 9 (I837). De Not. Syliab. I52 (I838), Epil. 304 (I869). Rabenh. Deutsch. kr. fl. ii, S. 3, I8 I (I848). C. Muell. Synops. i, 707 (I $8+9$ ). Hammar Mon. orthot. suec. 20 (1852). Wils. Bry. br. ISI, t. 34 (I855). Carringt. 
in Phytol. I858, p. 573. Schimp. Synops. 270 (1860), 2 ed. 3 I6. Berk. Handb. br. m. 223 (I863). Milde Bry. siles. I75 (I869). Boulay Fl. cr. de l'Est 607 (I872). Hobr. Syn. br. m, 92 (I873). Husn. Mo iss. nord-ouest Io6 (I873). Juratz. Laubm. oester.-ung. 200 (I882). Lese. James Moss. N. Amer. I67 (I884). Vent. in Musc. gall. I 55, t. 44 (I887).

Orthotriclium affine $\beta$. rupestre Brid. Sp. musc. II, 7 (I $8 \mathrm{I} 2)$.

Orth. flaccum DE NoT. Epil. $30 \mathrm{I}$.

Dorcadion mpestre LinnB. musc. scand. 29 (I879).

Autoicous; more or less densely tufted or pulvinate, fuscescent, olivaceous or yellowish-brown, rather rigid when dry; stems erect, I-2 in. high, sometimes longer and ascending, more or less branched. Leaves oblong-lanc., suddenly or gradually acuminate, straight, imbricated when dry, recurvo-patent when moist, carinate, the margin recurved or revolute to apex, nerve vanishing toward point, or reaching it; cells mostly unistratose, narrowly rectangular at base, rounded or angular above, papilla minute, simple or bifurcate. Caps. immersed or emergent, pale yellow, fuscous when old, oval or oblong, truncate when dry and empty, not contracted belor mouth, gradually defluent at base into the pedicel ; bands 8 , rarely with intermediate ones, stomata superficial, annulus persistent, of $2-3$ rows of depressed cells ; lid conic, apiculate: calyptra plicate, campanulate, ferruginous, with numerous yellow liairs. Teeth 8 , splitting into 16 , each half lacunose or cleft, pale yellow, erect when dry, surface papillose or with faint sinuous lines, cilia 8, yellowish, long as teeth, sometimes wanting. Vaginula naked or hairy, male infl. lateral, bracts ovate, rather obtuse.

HAB.-Rocks and walls in subalpine districts. Fr. 7 - 8 .

Var. B. rupincola (Funck.) Hueben.

Densely crowded, subpulvinate; leaves straighter, capsule smaller, emergent, calyptra less hairy.

Syn.-Orthotrichum rupincola FUnCK Moostasch. 35, t. 23. BrID. Bry. univ. i, 2S4. GREv. Scott. Cr. fl, ii, t. I05; F1. elin. 249. Hook. Grev. in Edin. J. Sc. i, I22. Hook. Taya. Musc. br. 2 ed. I 27, suppl. t. 4. Ноэк. Br. fl. ii, 5 t.

Orthotrichum rupestre Var. $\beta$. mpincola Hues. Musc. germ. 36g. Wrus. Bry. brit. Schimp. Synops. Milde, JuRatzka, \&c.

HAB.-On drier rocks in the Highlands.

This is rather the compact form of the species, just as O. Sellmeyeri Bruch, is a tall lax form.

Var. $\gamma$. Sturmii (Hornsch.) Fuvatz.

Plants darker and more slender, the leaves shorter and rougher, with the cells in the upper half mostly bistratose, some cells here and there occasionally forming a third series. Caps. less defluent at base and passing suddenly into a shorter pedicel, less distinctly striate, cilia almost obsolete or abortive. 
SYN.-Polytrichum capsulis sessilibus, foliis brevibus rectis carinatis DILL. Hist. musc. 432, t. 55 , f. Io et Herb.

Orthotrichum Sturmii Hornsch. in Flora I8I8, p. 34I et I8Ig, p. 89. Funck Moost. 35, t. 23. Hook. Grev. Edin. J. Sc. I824, p. TI2. Brin. Bry. univ. i, 277. Hueben. musc. germ. 383. BR. Sch. Bry. eur. Fasc. 2-3, p. 9, t. 2. DE Not. Syllab. I5o, Epil. 300. C. Muell. Synops. i, 708. Hammar Orthot. suec. rg. Schimp. Synops. 26i, 2 ed. 3i4. Berk. Handb. br. m. 22I. Milde Bry. siles. I7 I. Hobr. Syn. br. m. 8g. Boulay 6og. Lese. James Moss. N. Amer. 66 . Vent. in Musc, gall. I57, t. 44.

Dorcadion rupestre $\beta$. Sturmii Lindr. Musc. Scand. 29.

Orth rupcstrc $\delta$. Sturmii Juratz. Laubm. oester..ung. 20 I.

HAB,-Basaltic rocks.

Luggielaw, Wicklow, Fairhead and Seven Churches (Moorc 1857). Bowling (Hnnt 1865)!! Largo Law, Fife (Horic I 869)!! Knocklayd, Antrim (Stcr'art I882)!! On trees, Glen Ogle, Perth (Horn I 887$)$ !!

O. Stummii is certainly not separable from O. vupestre, for the bistratose cells in the upper part of leaves are by no means uniform, and we find numerous transition forms. The typical plant is plentiful about the bases of all the Highland mountains, perhaps nowhere finer than around Schiehallion.

\section{ORTHOTRICHUM SHAWII Wilson.}

Autoicous; in short green tufts. Leaves lanc.-acuminate, nerved to apex, the cells unistratose. Capsule oval-oblong, with 8 faint bands below the mouth; teeth 16 , reflexed when dry, white papillose, cilia none; calyptra hairy. (T. LV, C.)

SYN.-Orthotrichum orncum WrLs. MSS.

Orthotrichum Shazwii Wils. MSS. (non De Not,). Schimp. Bry. eur. Suppl. Fasc. I-2 (I864) ; Synops. 2 ed. $3{ }^{\mathrm{I}} 4$ (I876). Hunt in Mem. Lit. Phil. soc. of Manch. 3 Ser. ini, 236 (I867). Hoвk. Syn. br. m. $90(\mathrm{r} 873)$. Vent. in Husn. Musc. gall, I65, t. 46 (1887).

Autoicous; in small lax deep green tufts, $\frac{1}{2}-\mathrm{I}$ in. high. Leaves laxly incumbent when dry, spreading from an erect base when moist, lanceolate acuminate, deeply carinate, nerved nearly to apex, recurved at margin; cells small, rectangular and hyaline at base, denser and roundish quadrate above, unistratose, the papillæ not prominent. Vaginula naked, calyptra pale and glossy, with a reddish brown tip and a few thin hairs; caps. immersed, oval-oblong, leptodermous, pale yellow, with 8 scarcely conspicuous bands below the mouth where it is slightly contracted, rounded at base and passing abruptly into a very short pedicel; stomata superficial.

Peristome of 16 whitish lanceolate teeth, gaping in the divisural line, densely papillose, reflexed against the capsule, cilia none; lid conic, rostellate, with a red margin. Male infl. small, axillar, the bracts ovate, lingulate, obtuse. 
HAв.-Ash trees on the lawn of Kilkerran Castle, Dailly, Ayrshire. ( $f$. Slanw, June, I 860)!! -

This rare species has some resemblance in the capsule to $O$. striatum, but is much smaller, and the capsule always shows some traces of bands, but no cilia. Perhaps its natural position is near the var. Stuvmii of O. vupestre, and Venturi conjectures that it may be a hybrid between rupestre and striatum; the Italian specimens referred to it by De Notaris, belong according to Venturi, to O. mupestre var. Franzonii.

\section{ORTHOTRICHUM AFFINE Schrad.}

Autoicous ; tall, laxly pulvinate. Leaves lanceolate, acuminate, witl revolute margins, cells rounded, incrassate, with prominent papillæ. Caps. emergent, oblongo-elliptic, defluent into a longislı neck, 8-striate ; teeth 8 , bigeminate, cilia 8 , filiform. Calyptra conical. (T. LV, D.)

Syn.-Polytrichum Bryi ruralis facic, capsulis sessilibus majus Dill. Hist. musc. 430, t. 55, f. 8 (I74I), et Herb.

Orthotrichum affine Schrad. Spic. H. germ. 67 (I794). Hofrm. Deutsch, fl. ii, 26 (I796). BRID. Musc. rec. II, P. II, 22 (I8nI), Sp. musc. II, 7 (I8I2), Mant. IIo (I8Ig), Bry. univ. i, 282 (1826). Smith Fl. br. I 263 (I804), Eng. Bot. t. I323. Turn. Musc. hib. 96 (ISO4). Schultz Fl. starg. 308 (I806). Web. Mohr Bot. Tasch. 233 (I807). VolT Musc. herb. 63 (I8I2). Roehl. Deutsch. fl. iii, 82 (I8I3). Wahlenb. Fl. carp. 354 (I8I4). MarT. Fl. cr. erl. 77 (I8I7). Hook. TAYl. Musc. br. 74, t. 2I (I8I8). Kaulf. in Sturm Deutsch. fl. II, n. I6. Hook Fl. scot. P. 2, I37 (I82I), Br.fl. ii, 54 (I833). Gray Nat. arr. br. pl. i, 746 (I82I). Funck Moost. 34, t. 23 (I82I). Hook. Grev. in Edin. J. Sc. I824, p. I2I. Hueben. Musc. germ. 365 (I833). Mack. Fl. hib. P. 2, 30 (I836). BR. Sch. Bry. eur. fasc. 2-3, p. 17, t. 7 (I837). DE Not. Syllab. I52 (I838), Epil. bri. ital. 307 (I869). Rabenh. Deutsch. kr. fl. ii, S. 3, I80 (1848). C. Mulll. Syn. i, 705 (I849). Hammar Mon. Orthot. suec. 4 (I852). Wils. Bry. br. I6I, t. 2I (I855). Schimp. Synops. 265 (1860), 2 ed. 32 I. Berk. Handb. br. m. 222 (I863). Milde Bry. siles. I73. (I869). Boulay Fl. cr. de l'Est 609 (I872). Hobk. Sýn. br. m. 92 (I873). Husn. Mouss. nord.ouest 108 (1873). Juratz. Laubm. oester.-ung. 202 (I882). LeS(2. James Moss. N. Amer. I68 (I884). Venturi in Husn. Musc. gall. I7o t. 47 (1887).

bry lum affillc GMELIN Syst. nat. ii, I335 (r791.)

Wcissia affinis Rотн Fl. germ. iii, P. I, 2 I 7 (1800).

- octoblepharis Roti op. c. 2 I8.

Orthotrichum octoblcpharis BRID. Musc. rec. II, P. II, 24. umbonatum Brid. Bry. univ. i, 787 (I827).

Splachumm scmivacumm P. Beauv. Prodr. 89 (1805).

Dorcadion affinc Linde. Musc. scand. 28 (1879).

Autoicous; in loose pulvinate tufts, tall, yellowislı or dull green, repeatedly dichotomous. Leaves more or less strictly imbricated when dry, quickly recurved and patulous when wetted, coarse, lanceolate acuminate, acute, nerve vanishing at point, margin reflexed all the length; cells at base unequal, quadrangular-oblong, above rounded, suboval or subhexagonal, incrassate, papillæ simple or bifurcate, prominent. Caps. emergent, leptodermous, pale yellow when empty, oblong or ovalcylindric, defluent at base into a longish neck, passing into a very short 
pedicel; when dry contracted, pale brown, deeply sulcate, wall with $S$ narrow bands the length of sporangium, of $2-4$ rows of quadrang. cells, with incrassate lateral walls, stomata superficial; teeth of per. pale yellowish ; 8 bigeminate, sometimes partially cleft in the divisural line or perforated at summit, papillose or with the papillæ forming anastomosing vermicular lines, when dry recurved on the outer wall of capsule, cilia 8, filiform, of two series of cells. Lid conic, apiculate, yellow with a red margin. Calyptra conic, not inflated, covering the caps., light olive-green with the apex black, slightly hairy, rarely almost naked; vaginula smooth. Male infl. lateral, bracts ovate, rather obtuse.

HAB.-Trees in damp shady places, sometimes on walls. Fr. 6-7.

Var. $\beta$. rivale. Wils.

Stems loosely tufted; leaves succulent, lurid green, broader, very ubtuse, lax when dry. Calyptra narrow, lurid green : caps. exserted oblongpyriform, less tapering into the pedicel, not so contracted when dry, with broader ribs of $4-5$ rows of cells, cilia 8 shorter.

Syn.-Carringt. in Trans. Bot. soc. Edin. 1858 , p. 54, Phytol. I858, p. 573.

$\mathrm{H}_{\mathrm{AB}}$ - - On trees by streams.

Congleton Cloud (Wilson I854). Laskill, Yorks. (Baker I854). By the Wye, Cheedale (Whitehcad 1878)!! By the Ribble at Horton (Ashton and Whitehcad I878)!! Millersdale (Holt I884)!! Dailly, with O. Sprucei (Shaw I86I)!

Var. $\gamma$. fastigiatum $($ Bruch) Hueben.

Tufts smaller, denser and turgid, deep green; leaves oblong-lanceolate, shorter, with very small papillæe and laxer cells; caps. stouter, darker brown, less tapering, urceolate when dry, the ribs broader, teeth and cilia shorter, the latter wider, papillose; calyptra wider, straw-coloured, ferruginous.

Sy'.-Orthotrichun affine SchwaEG. Suppl. I, P. II, Ig, t. 49.

Orthotrichum fastigiatum BRUCH, BRID. Bry. univ, i, 785. WALlR. Fl. cr. germ. i, 209. Br. Sch. Bry. eur. fasc. 2-3, p. I8, t. 8. C. Muedz. Synops. i, 6g8. Wils. Bry. br. I8o, t. 45. Schimp. Synops. 266, 2 ed. 322. De Not. Epil. 308. Juratz. Laubm. oest.-ung. 203. Hoвк. Syn. 9I. BERK. Handb. 223. Venturi in Musc. gall. I7 I, t. 47.

Orth. affine Var. fastigiatum Hueben. Musc. germ. 365. Husn. Mouss, nord-ouest Ios. Hammar Mon. Orthot. suec. 5 .

Orth. ncglectum Schimp. Synops. 2 ed. 330.

Hab.-On trees in open fields, especially in limestone districts.

Greta bridge, Yorks. and Scale hill, Sussex (Borrcr). Newcastle (Winch). Bolton Abbey and Malham (Nowcll). Dailly, Wemys Bay, Dunoon, Inverkip and Callander (Dr. Wood)! Nant-y-Belan (Wilson 1833). Conway (Palgrave). Frodsham, Cheshire (Wilson 1845$) !$ Thirsk and Laskill, Yorks. (Bakcr).

This variable species may be known by the thin pale capsule, cylindric and fusiform when enpty, and always with narrow ribs. The var. vivale by its obtuse leaves approaches $O$. vivulave, but the stomata and larger leaf-cells at once distinguish it. 


\section{ORTHOTRICHUM SPECIOSUM Nees.}

Autoicous; in large loose tufts. Leaves oblongo-lanceolate, acute, revolute at margin. Caps. emersed, cylindraceous with a long neck, pale, with 8 faint bands in the upper half; teeth 8 bigeminate, pale, reflexed, cilia 8, papillose, calyptra hairy. (T. LVI, A.)

SrN - Orthotrichum striatum HEDw. Stirp. ii, t. 36, f. I-3 (I788).

Orthotrichum speciosum NEES AB E, in STURM Deutsch, fl. II, fasc. I7 (I8Ig). Funck Moost. 34, t. 23 (I82I). Hook. Grev. in Edin. J. Sc. i, I24 (I824). Grev. Scot. cr. fl. iii, 137 (I825), Brid. Bry.un. i, 280 (I826). Hсok. Tayl. Musc.br. 2 ed. I30, Suppl. t. 4 (r827). Hueben. Musc. germ. 367 (I833). Br. Sch. Bry. eur. Fasc. 2-3, p. Ig t. 9 (1836). Rabenh. Deutsch. kr. fl. ii, S. 3, I82 (1848). C. Muell. Synops. 705 (1849). Hammar Mon. Orthot. suec. 6 (I852). Wils. Bry. br. I82, t. 34 (1855). Schimp. Synops. 270 (1860), 2 ed. 322. Berk. Handb. br. m. 223 (1863). Milde Biy. siles. 175 (1867). De Not. Epil. bri. ital. 308 (I869). Boulay F1. cr. de l'Est 608 (1872). Hobk. Sjn. br. m. 92 (I873). Juratz. Laubm. oest.-ung. 202 (r882). Leso. James Moss. N. Amer. I6g (I884). VENTURI in Musc. gall. I68, t. 46. (I887).

Dorcadion speciosum Linds. Musc. scand. 28 (1879).

Autoicous; tufts loose, more or less dense, yellow-green, fuscous at base, the stems branched, $\mathrm{I}-\mathrm{I} \frac{1}{2} \mathrm{in}$. high. Leaves laxly imbricated when dry, patulous or slightly recurved when moist, oblong-lanceolate, more or less longly acuminate, acute, all margin revolute, nerve nearly reaching apex; cells at base elongato-rectang., with unequally incrassate walls, gradually passing upward into rounded strongly incrassate cells with one or more simple or bifid papilla. Caps. emersed or emergent, leptodermous, faintly narrorved below the mouth, passing gradually in to the pedicel by a longish neck, cylindric or rarely oval-oblong when dry, smooth, greenish, afterwards pale yellow, more or less furrowed; stomata superficial; bands 8 , faint or at most marked by a short row of large quadrangular longitudinal cells; teeth 8 bigeminate, rarely cleft in median line, pale, densely papillose, opake, revolute, with the upper part applied to capsule wall, cilia 8 white, large papillose, sinuose at margin. Lid conic with red border. Cal. conic-campanulate, blackish at apex, covering all caps., and with yellow hairs. Male infl. axillar, gemmiform, the bracts ovate, acuminate.

$\mathrm{H}_{\mathrm{AB}}$ - Trees in alpine districts, not common. Fr. 7-8.

Montrose (Reid). Forfar (Drummond). Corrie Moolzie, Braemar (Wilson I836)!! Kinnordey (Sir F. Hooker). Henfield, Sussex (Spruce). Hurst \& Tilgate (Mitten). Settle, Yorks. Aviemore (Whitehcad I876)!! Ballater (G. Davies 1867)! Stockton forest, Yorks. (Spruce r843)!

Larger than $O$. affine, with less dense leaves, the capsule longer and cylindraceous, pale yellow, the bands indistinct; the branches also are longer, and the seta is variable in length, but the capsule is always more exserted than in $O$. affine, the bands being most evident after sporing; the leaves are frequently of a reddish-brown colour with areolation varying in density. 
Endostome of 16 broad papillose cilia, erose at margin, of two rows of cells.

\section{ORTHOTRICHUM STRIATUM (L.) Hedw.}

Autoicous; in irregular tufts. Leaves lanceolate, acuminate witl a revolute margin. Caps. immersed, oval, without striæ, per. of I6 geminate teeth, circularly revolute when dry, bat not touching wall of caps., cilia 16 , broad, erose at margin; calyptra conic, deeply striate. (T. LVI, C.)

Syn.-Polytrichun calyptra striata sursum pilosa L. F1. suec. 869.

Bryum striatum L. Sp. pl. I I 5 (I753), Syst. nat. ii, 70 I. Wiтh. Bot. alr. br. veg. ii, 67 I (г776). Hoffm. Deutsch. fl. ii, 25 (I796). Аввот F1. Bedf. 236 (I798).

Polytrichum striatum Huds. Fl. angl. 40I (I 762 ). Neck. Meth. musc. I2I (I77I). LiGHTF. F1. scot. ii, 704 (I777). HuLl Br. A. P. 2, 248 (I799).

Polytrichum bryoides $\alpha$. striatum WeIss Crypt. Goett. I I5 (I770). WER. Fl. goett. 39 (1778).

Bryum striatum var. ithyphyllum $\mathrm{E}_{\mathrm{HRH}}$. in Hann. mag. $\mathrm{r}_{780}$ p. 236.

Wiissia polytrichoides Wigg. Prim. f. hols. n. 82 I ( 1780$)$.

Grimmia striata HeDw. Fund. II, 89 (I782). RоTн Fl. germ. i, 455 (I788),

Weissia ithyphylla a. major EHRH. Beitr. i, Igr ( $\left.7_{7} 87\right)$.

Orthotrichum striatum Hedw. Musc. frond. ii, 99, t. 36, f. 9 (I788), Sp. musc. ites (ISor). Swartz Musc. suec. 42 (1798). Dicks. Fasc. Cr. IV, 5 (I8OI). Brid. Musc. rec. II, P. II, 20 (I8or), Sp. musc. II, 3 (I8I 2), Mant. III (I8Ig), Bry. univ. i, 290 (I826). Smith Fl. brit. I 262 (I8ot), Eng. Bot. t. 2187. Turn. Musc. hib. 95 (ISO4). P. Beaur. Prodr. Si (i805). Schultz Fl, starg. 308 (i806). Web. Mohr Bot. Tasch. 234 (I807). VorT Musc. herb. 62 (I8I2). Wahlenb. Fl. lapp. 365 (I8I2), Fl. carp. 354 (I8I4). Roerhl. Deutsch. fl. iii, 8I (I8I3). Schwaeg. Suppl. I, P. II, 29, t. 54 (I8I6). MarT. Fl. cr. erl. 77 (I8I7). STURm Deutsch. Fl. II, I3. Hook. TAYL. Musc. br. 75, t. 2 I (I8I8). Funck Moost. 25, t. 23 (IS2I). Gray Nat. arr. br. pl. i, 747 (IS2I). Hook. Grev, in Edin. J. Sc. I824, p. I23. WallR. Fl. cr. germ. i, 2 I 2 (I83I). HUEBen. Musc. germ. 37 I (I833). Hook. Fl. scot. P. II, I37 (I82I), Brit. fl. ii, 55 (I833). MACk. F1. hib. P. 2, 30 (1836). C. Muell. Synops. i, 708 (I849).

Grimmia oblonga Schrank Baiers. fl. ii, 443 (1789).

Weissia striata SiBth. Fl. oxon. 287 (1794). Roth Fl. germ. iii, P. I, I20 (r8oo).

Orthotrichum leiocarpum Br. Sch. Bry. eur. Fasc. 2-3, p. 28, t. I5 (I837). DE Not. Syllab. I56 (I838), Epil. bri. ital. 3I7 (I869). RABENH. Deutsch. kr. f. ii, S. 3, I $8_{5}$ (i848.) Hammar Mon. Orth. suec. I4 (1852). Wils. Bry. br. i86, t. 2 I (I855). Schimp. Synops. 278 (i860), 2 ed. 337. Berk. Handb. br. m. 227, t. 20, f. 8 (I863). Milde Bry. siles. I79 (1869). Boulay Fl. cr. de l'Est 6or (1872). Hobk. Syn. br. m. 94 (I873). Husn. Mouss. nord-ouest I Io (I873). Juratz. Laubm. oester.-lung. Ig9 (I882). LesQ. James Moss. N. Amer. I74 (I884). Venturi in Musc. gall. I65, t. 45 (I887).

Dorcadion striatum LINDB. Musc. scand. 28 (I879).

Autoicous; tufts irregular or more or less dense, with fastigiate branches, ramulose, erect or decumbent, $\mathrm{I}-3 \mathrm{in}$. long, radiculose at base, deep or yellowish green. Leaves loosely imbricated when dry, spreading when moist, when wetted strongly recurved and then quickly erect, lanceolate or longly attenuate, the margin recurved or revolute to the point; cells unistratose, basal smootl, quadrangular, flexuose, passing gradually up into roundish, strongly incrassate with simple papillæ. Caps. immersed, smooth, without any strix, pale yellow, oval or oblong, rounded at base and suddenly narowed into a very short 
pedicel, contracted slightly below the moutl, stomata superficial; peristome of 16 teeth with a strongly marked divisural line and short articulations, transversely striolate, densely papillose, pale yellow, opake, when dry circularly revolute but not touching the caps. wall except with the points, endostome of I6 cilia, erect, broad, erose at margins, yellowish, papillose, of two rows of cells; lid conic elongate, red at margin; calyptra conic, straw-coloured with a dark tip and many yellow hairs; annulus double persistent. Male infl. gemmifornı, lateral axillar.

НАв.-On trees, not uncommon. Fr. 4-5.

Linnæus assigns the following character to his Bryum striatum, "antheris sessilibus sparsis, calyptris striatis sursum pilosis," and it is evident his name referred to the calyptra and not to the capsule, as was assumed by Schimper and his followers, and therefore in our opinion the name striatum must be retained. The species may be known from $O$. affine by its smaller size, dense leaves, smooth capsule and 16 cilia.

\section{ORTHOTRICHUM LYELLII. Hook. Tayl.}

Dioicous; in tall lax tufts.' Leaves patent and recurved, longly lanc., acute, bearing rufous, clavate gemmæ. Caps. oval-oblong, striate, decurrent in a longish neck; teeth $I 6$, pale, revolute, cilia 16 , broad, appendiculate. (T. LVI, B.)

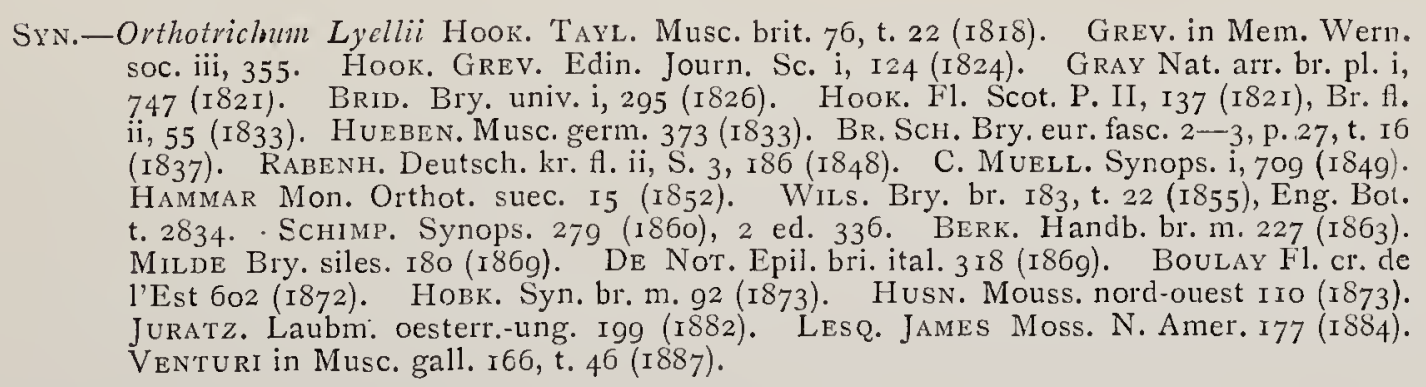

Dioicous; in large lax tufts $\mathrm{I}-4$ in. high, dull yellowish-grecn above, fuscous and naked at base, the stems with subarcuate branches, soft, erect or ascending. Leaves incumbent and spreading when dry, strongly patent and recurved when moist, undulate at margin, from an oblong base very longly lanc., narrow, acute, the margin recurved above the base, plane in all the rest of the leaf, the surface bearing many rufous septate, clavate or branched protonemal processes; nerve vanishing in the point, which is sometimes slightly toothed; cells at base smooth, elongated, subflexuose, above small rounded or suboval, 
strongly incrassate, with prominent conical papillæ. Caps. immersed, yellowish-brown, oval-oblong, 8-striate, decurrent at base in a longish neck, slightly narrowed below mouth, when dry and empty elongate, deeply sulcate; stomata few, superficial; teeth I6, geminate, pale, revolute when dry, cilia $I 6$, rather broad, appendiculate, papillose, rufous; lid pale, nearly conical ; calyptra conic, elongate, with yellow hairs. Male infl. lateral, axillar.

Hab.-Trunks of old trees, not unfrequent. Fr. 7.

This fine moss may be readily known by its large size and long subsquarrose leaves, and is scattered throughout the whole kingdom, for I have found it in fine fruit at Virginia Water, and at Finlarig, Killin, as well as in Yorkshire and intermediate districts. Dr. Spruce found a marked form by the Ouse near York in I843, with rigid, closely appressed leaves.

Sect. 2. CALYPTOPORUS Lindb. Stomata immersed in the wall of capsule and more or less covered by some of its epidermal cells.

* Upper leaves hair-pointed, cilia 16.

\section{ORTHOTRICHUM DIAPHANUM Schrad.}

Autoicous ; in small loose cushions, hoary at top. Leaves oblonglanc., with acuminate hyaline points. Caps. emerging, oblong, suddenly contracted at base, teeth $I 6$, cilia $I 6$, cal. campanulate, nearly naked. (T. LVI, D.)

Syn.-Orthotrichum diaphanum Schrad. Spic. F1. germ. 69 (I794). HofFM. Deutsch. fl. ii, 26 (I796). Brid. Musc. rec, II, P. II, 29 (I80I), Sp. musc. II, I (I8I2). Mant. II I (ISIg), Bry. univ. i, 293 (1826). SM. Fl. brit. I235 (1807), Eng. Bot. t. I324. Turn. Musc. hib. 99, t. 9, f. I (I804). Schultz Fl. starg. 3 I0 (I806). Wei. Mohr Bot. Tasch. 234 (I807). VoIT Musc. herb. 62 (I8I2). S'Turm Deutsch. fl. II, I4 (I8I3). RoeHL. Deutsch. H. iii, 8I (I8I3). SchwaEg. Suppl. I, P. Il, 3 I, t. 55 (ISI6). MART. F1. cr. erl. 78 (I8I7). Hook. TAYL. Musc. br. 74, t. 2I (I8I8). GRAY Nat. arr. br. pl. i, 746 (I82I). Hook. Fl. scot. P. II, 137 (I82I), Br. fl. ii, 54 (I833). Funck Moost. 35, t. 23 (I821). Hook. Grev. in Edin. J. Sc. I824, p. I23. Hueben. Musc. germ. 377 (I833). Mack. Fl. hib. P. 2, 30 (I836). BR. Sch. Bry. eur. fasc. 2-3, p. 25, t. I4 (I83S). DE Not. Syllab. I57 (1838), Epil. 3 I6 (1869). RABEnh. Deutsch. kr. fi. ii, S. 3 , I8 5 (I848). C. Muell. Synops. i, $69+$ (I849). Hammar Mon. Orthot. suec. I3 (I852). Wils. Bry. br. I85, t. 2 I (1855). Schimp. Synops. 277 (I860), 2 ed. 333. BERK. Handb. br. m. 226, t. 20 (I863). MILDE Bry. siles. I78 (I869). Boulay F1. cr. de l'Est 604 (I872). HoBK. Syn. br. m. 93 (1873). Husn. Mouss. nord-ouest Iog (1873). JuRAtz. Laubm. oesterung. 204 (I882). Lese. James Moss. N. Amer. 176 (I884). Venturi in Musc. gall. I 93 , t. 52(I888).

Bryum diafhanun GMEL. (L.) Syst. nat. ii, I335 (I79I).

Weissia diaphana Rотн Fl. germ. ii, P. I, 223 (I800).

O. aristatum TURN. Musc. hib. Ioo, t. 9, f. 2. SM. Fl. brit. I26 5 .

O. heterophyllum and $O$, pilosum P. BEauv. Prodr. 80 (I805).

Autoicous; in small irregular dark green tufts, hoary at top. Leaves imbricated when dry, erecto-patent when moist ; soft, oblong-lanc., termi- 
nated by a lanceolate membranous point, colourless, denticulate at margin, and composed of narrow elongate cells, margin revolute, nerve vanishing in the apiculus; cells at base quadrangular, elongate, above rounded and hexagonal, rather large, with very small obtuse papillæ. Caps. emergent, pale yellow, oblong, not contracted below mouth, leptodermous, when dry oblong-obovate, when moist suddenly contracted at base into a short pedicel, ridges 8 , of two rows of indistinct quadrangular cells; stomata numerous, immersed, with elevated border-cells. Calyptra naked or nearly so, campanulate, thin, greenish-yellow, brown at point: 8-plicate; lid short, conical. Peristome pale yellow, of I6 geminate teeth more or less cleft at point, papillose, long, recurved when dry, cilia $\mathbf{x} 6$, filiform, hyaline, papillose. Male infl. terminal on a short branch.

HAв.-Trunks of trees, walls, and old pales. Fr. 4 .

This little moss is easily overlooked, as it only grows in small tufts, and somewhat sporadically; it may be recognized at once by the hyaline points to the leaves.

** Peristome teeth striolate, with erect vertical lamellæ at base ; cilia none or rudimentary.

\section{ORTHOTRICHUM CUPULATUM Hoffm.}

Autoicous; in coarse dull green tufts. Leaves oblong lanceolate. Caps. immersed, oval-oblong with 16 ridges, calyptra campanulate, hairy; teeth $\mathrm{x} 6$, each with four basal lamellæ. (T. LVI, E.)

Sys.-Orthotrichum cupulatum HoFfm. Deutsch. fl. ii, 26 (I796). BRID. Musc. rec. II, P. II, 25 (I801), Sp. musc. II, Io (I8I2), Mant. Iog (I8I9), Bry. univ. i, 272 (I826). P. BEaUV. Prodr. 80 (ISO5). Schultz Fl. starg. 309 (I806). WEe. Mohr Bot. Tasch. 230 (I807). Schwaeg. Suppl. I, P. 11, 35, t. 55 (I8I6). Ноok. TaYl. Musc. br. 72, t. 2 I (I8I8). Hook. Fl. scot. P. II, I37 (I82I), Brit. Fl. ii, 53 (1833). Gray Nat. arr. br. pl. i, 745 Hook. Fl. Scot. Hook. Grev. in Edin. J. Sci. i, II2 (1824). Hueben. Musc. germ. 38 I (I833). Mack. Fl. hib. P. 2, 29 (I836). DE Not. Syllab. I50 (1838), Epil. bri. ital. 299 (1869). BR. Sсн. Bry. eur. fasc. $2-3$, p. 8 , t. 2 (1837). RaBEnh. Deutsch. kr. fl. ii. S. 3,176 (1848). C. Muell. Synops. i, 700 (1849). Hamiar Mon. Orthot. suec. I7 (1852). Wils. Bry. C. Muell. Synops. i, 700 (I 849 ). Hamar t. 20 (1863). MiLDE bry. siles. I70 (I869). Boulay Fl. cr. de l'Est 6I7 (1872). HobK. Syn. br. m. 89 (I873). Husn. Mouss. N. ouest 105 (1873). Juratz. Laubm. oester.ung. 2i i (I882). Lese. James Moss. N. Amer. I65 (1884). Vent. in Husn. Musc. gall. 160, t. 44 (1887).

Weissia cupulata RoTh Fl. germ. iii, P. I, 2 I7 (I80o).

O. urceolatum Schleich. Cat. pl. helv. 42 (I800).

Orthotrichum anonalum SM. F1. brit. I267 (I804), Eng. bot. t. 1423.

O. strangulatum P. Beauv. Prodr. 8I. Schwaeg. Suppl. I, P. II, 53, t. 34. Brid. Sp. musc. II, I3, Bry. univ. i, 273.

Brachytrichume cupulatum RoEHL. Deutsch. A. iii, 47 (I8I3). Ann. Wett. ges. iii, I95.

Dorcadion cupulatum LiND. Musc. scand, 28 (1879). 
Autoicous; in loose dull green or olivaceous tufts, $\frac{1}{2}-\mathrm{I}$ in. high. Leaves imbricated when dry, recurved when moist, oblong-lanc., rather obtuse, recurved at margin; cells above very small, subhexagonal òr rounded, incrassate, with $\mathrm{I}-2$ simple or rarely bifurcate papillæ, basal rectangular, smooth; nerve vanishing below the apex, channelled above. Caps. immersed, rarely exserted, pale olivaceous brown, ovaloblong, rounded at base and suddenly narrowed into a very short pedicel, urceolate when dry, with 16 ridges, the alternate ones shorter, or rarely with 8 only, each composed of $2-3$ rows of quadrate yellow incrassate cells; stomata immersed, the border cells elevated, not covering all the stomatic cells. Annulus of $2-3$ rows of compressed cells; lid shortly apiculate, pale yellow, orange at margin. Peristome simple, pale yellow, rarely with traces of cilia, teeth when dry spreading horizontally, never recurved, I6 geminate, with 4 basal lamellæ to each, reaching to second or third joint, or sometimes much higher, surface traversed by faint sinuose longitudinal lines. Calyptra swollen, campanulate, plicate, naked or with some hairs, brownish or ochraceous, rusty at apex. Male infl. pseudolateral, bracts ovate, obtuse.

HAB.-Rocks and walls in limestone districts. Fr $4-5$.

Var $\beta$. nudum (Dicks.)

Tufts more laxly pulvinate, deep green. Caps. partly or entirely exserted, attenuated at base into a longer narrower neck, teeth more distinctly striolate, with the external appendages more developed. Calyptra more conical, naked or with a few hairs.

SYN.-Orthotrichum nudum Dicks. Crypt. fasc. IV, 7, t. Io, f. I3 (I801). SM. Fl. brit. I 268. Eng. Bot. t. 1325. Turn. musc, hib. 97, Briv. Sp. musc. II, I2; Mant. III. VeN'1. in Husn. musc. gall. I6I, t. 45 .

O. commlitatum BRUCH in Brid. Bry. un. i, 784 .

O. Rudolphianum LEHM, in Flora 1827, p. 656 .

O. Flocrkci Hornsch. Brid. Bry. un. i, 783 .

O. cupulatum $\gamma$. rifarium Hueben, musc, germ. $38 \mathrm{I}$. Schimpen, אc.

O. cupulatum Var. nudum BraIthw.

НАв.-On stones by the side of streams.

Tanfield, Clapdale and Bolton Abbey, Yorks. (Bakcr 1856). Lewes ( 7 cuncr). Balcombe (Mitten). By the Hodder, Clitheroe (Wood I860)!! Litton, Yorks. (Whitchead and Ashton 1878$)$ !! Miller's dale and Monsal dale (Holt I884)!! Brigsteer, Westmoreland (Barncs)!

Thin species most resembles $O$. mpestre, but is easily separated by the shorter pale capsule with immersed stomata, I 6 strix, and different peristome; the var. mudum is usually of a lurid or blackisl green tint, reminding us of O. rivulave. 


\section{IO. ORTHOTRICHUM ANOMALUM. Hedw.}

Autiocous; in dense dark olive-green tufts. Leaves spreading, lanceolate, acute. Caps. exserted, oval-cylindric, with I6 ridges, the alternate ones fainter, teeth I6, equi-distant; calyptra conic-companulate, hairy. (T. LVII, A.)

Syn.-Orthotrichum anomalum Hedw. Musc. fr, ii, Io2, t. 37 (I788), Sp. musc. I62. Wer. Mohr Bot. Tasch. 229 (1807). Voit Musc. herb. 66 (I8I2). Sturm Deutsch. fl. II, I3. Wahlenb. F1. lapp. 366, $\beta$., Fl. calp. 354. Schwaeg. Suppl. I, P. II, 37 (I8I6). Hartm. Skand. f. Hueren. Musc. germ. 379 (I833). Br. Sch. Bry. eur. fasc. 2-3, n. ro, t. 3 (I837). De Not. Syllab. 449 (I838), Epil. bri. ital. 298 (r869). Rapenh. Deutsch. kr. fi. ii, S. 3, I77 (I848). C. Muell. Synops. i, 694 (I849). Hammar Mon. Orth. suec. 2 I (1852). Schimp. Synops. 262 (I860), 2 ed. 308. Wood in Phytologist I860, p. 353. Milde Bry. siles. I7 (I869). Boulay Fl. cr. de l'Est 6ig (I872). Hobk. Syn. br. m. 05 ( I 873 ). Husn. Mouss. nord-ouest I05 (1873). JuRatz. Laubm. oester.. ung. 2 I2 (I882). Lese. James Moss. N. Amer. I64 (I884). Vent, in Husn. Musc. gall. 158, t. 44 (1887).

Weissia anomala RoTH Tent. fl. germ. iii, P. I, 2 I 5 (I80o).

Orthotrichum saxatilc Brid. Musc. rec. II, P. II, 27 (I80I), Sp. musc. II, 9 (I8I2), Mant. I Io (18 19), Bry. univ. i, 275 (I826). Schultz Fl. starg. 27 (I806).

Brachytrichum saxatilc RoEHL. Deutsch. fl. iii, 47 (I8I3), Ann. Wett. ges. iii, I94.

Orthotrichum aureum MART. F1. cr. erl. 77, t. 2, f. 2 (I8I7).

Dorcadion anomalum Lindb. Musc. scand. 28 (I879).

Autoicous; tufts rather dense, olivaceous green or almost black. Stems $\frac{1}{2}-$ I in. high, erect, dichotomous and fastigiate. Leaves imbricated when dry, recurved when moist and then becoming patent, lanceolate, upper elongated, more or less suddenly acuminate, acute; nerve stout, vanishing below apex, cells in a single layer, basal rectang. smooth, the walls unequally thickened, gradually passing upward into hexagonal and rounded, with slightly incrassate walls and simple papillæ; margin recurved below. Caps. generally exserted above the perichætium, sub-cylindric or oval-cylindric, slightly contracted below the mouth, attenuated at base into a conical neck, passing more or less suddenly into the pedicel; stomata immersed, bands 8 or 16 , long as sporangium, orange-brown, the 8 principal of $2-3$ rows of quadrate cells with strongly thickened lateral walls, tle alternate bands fainter, sometimes almost imperceptible, annulus persistent, double: peristome simple, pale yellow, teeth erect when dry, 8 bigeminate, or I 6 geminate, longitudinally striolate, each tooth at base with four little striolate lamellæ, reaching the second joint or extending upvards in fragments; cilia none or rudimentary. Calyptra conic-campanulate, covering the caps, the hairs rusty-yellow. Lid conic-apiculate.

HAB.--Stones and trap rocks; rare. Fr. 5.

Trap rocks at Aberdour, Fife (Luckman I860)! Arthur's Seat (Dr. B. White I862)!! Largo Law, Fife (Howic 1865)!! Abbey Crag, Stirling (Lyle). Conway Castle (Hilson). Armagh (Adm. Fones). By the Dodder at Sallygap $(\mathrm{Om})$. 
Var. $\beta$. cylindricum Schimp.

Plants larger. Caps. longer, more exactly cylindric, more exserted, with 8 longer bands of larger more coloured cells, 8 cilia more or less well developed, teeth 8, imperfectly divided. Leaves longer, narrower, with a stronger nerve.

Syn.-Orthotrichum anomalum SM. Fl. brit. I265, Eng. Bot. t. 2696 . Turn. Musc. hib. 94.

Hook. Tay. Musc. br. 72, t. 2 I. Hook. Fl. scot. 137. Gray Arr. Br. pl. i, 745. Wils. Bry, brit. I77, t. 2 I.

Orthotriehum saxatile Schimp. Bry. eur. Suppl. fasc. I-2, p II. t. Io (I864). Новк. Syn. br. m. 94. Boulay Fl. cr. de l'Est 620. Husn. Mouss. N. ouest 106.

Orth. anomalum $\beta$. saxatile Milde Bry. siles. I7I. VeNturi in Husn. musc. gall. I79.

Orth. anomalum $\beta$. cylindricum. Schimp. Synops. 2 ed. 308.

Orth. anomalum $\beta$. ciliatum Juratz. Laubm. oesterr.-ung. $2 \mathrm{I} 3$.

HAB.-Limestone rocks and walls, not uncommon.

Frequent in the Buxton and Craven districts. Ormeshead (Wilson). Lake district (Whalley I 865). Castle Howard (Spruce I84I). Litton (Whitchead I879)!! Sussex. Devon (Holmes). Cheshire (Whitchead). Tulloch, Blair-Athol (Braithwaite I887)!! Bruton and Wilmcote, Warwick (Bagnail). Ireland (Dr. Moore). Chapel-en-le-Frith and Castleton, Derby (Holt I882)!!

There is no doubt that these two mosses only constitute a single species, for the presence or amount of development of the intermediate bands is very variable and affords no reliable character. Bridel tells us that he changed the name anomalum to saxatile, because there are other anomalous species! So much for Nature daring to offend the laws of humanity. I find no mention of saxatile in Dr. Wood's paper cited by Schimper, and as that name has been applied to both forms, it is also better to drop it altogether. See also Dr. Wood's Supplemental notes in Phytologist V, 26 (I86I).

*** Peristome teeth papillose, without lamellæ; cilia smooth, 8 or 16.

\section{ORTHOTRICHUM RIVULARE Tum.}

Autoicous; blackish green, growing in water. Leaves obionglinguiform, obtuse, apiculate. Capsule immersed, pyriform with $S$ broad bands; teeth reflexed when dry, cilia 8 , filiform, often with 8 shorter intermediate ones; calyptra naked (T. LVII, B.)

Syn.-Orthotrichtm rivulare TuRn. Musc. hib. 96, t. 8 (I804). SM. Fl. brit. I266 (I8ot). Eng.

Bot. t. 2 I 88. BRID. Sp. musc. II, 3 (I8I2), Mant. II I (ISIg), Bry. univ. i, 292 (IS26).

Schwalg. Suppl. I, P. II, 3 I (I8I6). Hook. Tayl. Musc. br. 75, t. 2 I (I8IS). GraI Nat. arr. br. pl. i, 747 (I82I). Hook. Fl. scot. P. 2, I37 (I82I), Br. Fl. ii, 55 (I833).

Hook. Grev. Edin. J. Sci. i, I23 (I824). Hueben. Musc. germ. 375 (I833). Mack. Fl. hib. P. 2, 30 (I836). Br. Sch. Bry. eur. fasc. 2-3, p. 25, t. I4 (I837). RABENH. Deutsch. kr. fl. ii, s. 3, I84 (I848). C. Muell. Synops. i, 699 (I849). Wils. Bry. br. I83, t. 2 I (I855). Schimp. Synops. 274 (I860), 2 ed. 338. BERK. Handb. br. m. 225 (I863). Milde Bry. siles. I77 (I869). Boulay Fl. cr. de l'Est 605 (I872). HoBK. Syn. br. m. 93 (I873). Husn. Mouss. N. ouest iog (IS73). Lesq. James Moss. N. Amer. I76 (1884). Venturi in Husn. Musc. gall. I 76, t. 48 (I887).

Autoicous; in loose blackish-green tufts, floating or submersed. Stems naked below, dichotomous and fasciculate branched, $\frac{3}{4}-I \frac{1}{2}$ in. 
high. Leaves laxly imbricated when dry, quickly recurved from the base when wet and again becoming spreading, oval at base, oblonglinguiform, rounded at apex and obtuse or very shortly apiculate, sometimes slightly toothed, revolute at margin in the lower half, recurved in upper half to apex; nerve very prominent at back, faintly channelled in front, ending suddenly below the summit; cells at base hyaline quadrate with thin walls, passing gradually into roundish, with very small papillæ. Caps. semi-immersed, yellow, contracted below the mouth when dry, 8-costate for all its length, when moist oval or ovaloblong, suddenly contracted into a very short pedicel; annulus persistent, of 4-5 rows of small angular cells, the bands reddish-yellow of $4-7$ series of quadrate cells, with strongly incrassate lateral walls, stomata immersed, with the border cells very prominent. Teeth 8 , orange, bigeminate, when dry recurved against the capsule, more or less perforated in the median line, very densely and finely papillose ; cilia 8 , filiform, long as teeth, yellow, faintly papillose, often 8 intermediate cilia more or less developed. Vaginula with colourless paraphyses. Lid conic, apiculate. Calyptra conic-campanulate, naked, lurid greenish with a blackish apex, plicate to base. Male infl. at base of fruiting branch.

HaB.-On rocks and stumps in water; not common. Fr. 4-5.

On the Cart and Calderwood burn (Don). Congleton, Cheshire and Nant-y-Belan, N. Wales (Wilson)!! Eskdale below Ainsthorpe and Ripon (Baker 1858). Corwen (Borstpierpoint (Mitten)! Cheviots (Hardy). Glenprosen (Fer. (Boswell 1859). Hurstpierpoint (Mitten)! CKinlay 1864). R. Teign at Fingle gusson). Keswick (Howell 1862)!! Ribble at Horton (Whitehead bridge (Brent). R. Dee, Llangollen (Nowell I862)!! Ribble at Horton (Lylc r842). and Ashton 1878$)$ !! The Wye, Cheedale (Whitehead I878)! Lowood, Windermere (Hint 1867 ) !

This fine but dingy moss is more frequent with us than in any other part of Europe, and by the obtuse leaves is most allied to the next species. From $O$. affine Var. vivale it is readily separated by the stomata.

\section{I2. ORTHOTRICHUM SPRUCEI Mont.}

Autoicous; short, sparingly branched. Leaves erecto-patent, oblong-spathulate, obtuse, apiculate, margin nearly plane. Caps. pyriform with 8 broad striæ, calyptra campanulate, naked, teeth 8 , bigeminate, cilia 8 or I6. (T. LVII, C.)

Syn.-Orthotrichum Rogeri Var. ARNOTT in litt.

Orthotrichum Sprucei Montagne MS. Spruce in Lond. J. Bot. 1845, p. I86. C. Muell. Synops. i, 699 (I849). BR. Sch. Bry. eur. fasc. 42, t. 2 (1849). Wils. Bry. br. I84, t. 45 (I855). Schimp. Synops. 273 (I860), 2 ed. 338. BERk. Handb. br. m. 225 (I862). Hobk. Syn. br. m. 93 (1873). VENTURI in HusN. Musc. gall. 177, t. 48 (1887). 
Autoicous; in dark lurid green, sparingly branched tufts. Leaves soft and succulent, rather distant, erect and loosely imbricated when dry, erecto-patent when moist, obovate-spathulate, rounded at point and muticous, the upper with a very small apiculus, revolute at margin at the base, and then recurved to some distance below the summit ; cells at base quadrangular, elongated next the nerve, passing gradually up into large rounded or angular, smootl or faintly papillose ones, nerve slender, lost below point. Perich. bracts longer, narrower, sulcate, with a shorter nerve, sometimes with a long piliform point. Caps. immersed, soft, pale, fuscous when old, oval pyriform, with a long sulcate neck, broadly 8-striate, stomata immersed; annulus of two rows of compressed cells, teeth 8, bigeminate, yellowish, reflexed when dry, densely and finely papillose, cilia 8, shorter than the teeth, yellow and finely papillose, sometimes $\mathrm{I} 6$; lid conic, rostellate. Calyptra companulate, greyish green, naked smooth, apex and edges of the plaits reddish. Male infl. gemmiform, bracts cucullato-incurved at apex.

HAB.-Trunks and roots of trees on river banks. Fr. 5-6.

Banks of the Ouse, near York, and of the Wharfe, and by the Cock, Tadcaster (Spruce 1842)!! Scotland by the Clyde (Drummond I 824). By the Thames, Wandsworth (Sowerby). Stapleton, near Bristol (Thwaites 1843)!! Henfield, Sussex (Mitton I844)! Near Temple Mill, Twycross (Bloxam 1844)!! By the Girvan, Dailly (Dr. Wood). Ilkley (Carrington). Kilvington and Mickley, Yorks. (Baker IS52)! Thirsk (Davics). Dalam Tower park (Bcrkelcy 1869). Castle Howard (Slater)!! Drumbridge, Down (7. H. Davies 1878). Birnam (Carrington 1857). Ross Bay (Carrington I 86I).

A very distinct species and scarcely found out of the kingdom. It may be readily known by its distant soft leaves with large cells and dingy lurid colour; unfortunately it is commonly impregnated with mud, and does not make elegant herbarium specimens. Few of the North Yorkshire streams are without this and the preceding species.

\section{I3. ORTHOTRICHUM STRAMINEUM Hornsch.}

Autoicous; in small loose tufts. Leaves lanceolate, carinate, acuminate. Caps. oblong-pyriform, emergent, with $S$ broad striæ, vaginula hairy; cilia 8 or I6; calyptra campanulate yellow, slightly hairy. (T. LVII, D.)

Syn.-Polytrichum Bryi ruralis facic, capsulis scssilibus minus Dillen. Hist. musc, 43x, t. 55, fig. 9 (I 74I), et Herb.

Orthotrichum stramineam. HoRNSch. in BRID. Bry. univ. i, 789 (I827). WaLLR. Fl. cr. germ. i, 2 Io (I83I). Hueben. Musc. germ. 363 (I833). BR. Sch. Bry. eur, fasc. 2-3, p. 24, t. I3 (I837). Rabenh. Deutsch. Kr. fl. ii, S. 3, I84 (I848). C. Muell. Synops. i, 697 (1849). Hartm. Skand. A. 5 ed. 367 (I849). Hammar Mon. Orth. suec. I2 (1852). Wils. Bry. br. I8o, t. 45 (1855). Schimp. Synops. 272 (I860), 2 ed. 325 . Berk. Handb. br. m. 224 (1863). Mrlde, Bry. siles, i76 (I869). DE Not. Epil. bri. 
ital. 3 I5 (1869). Boulay Fl. cr. de l'Est, 6I4 (1872). Hoвk. Syn. br. m. 9 I (1873). Husn. Mouss. N.-ouest Iog (I873). JURATZ. Laubm. oester.-ung. 206 (I882). VENTURI in HUSN. musc. gall. I82, t. 50 (1887).

Orthotrichum ambonatum BRID. Bry. univ. i, 787 .

Dorcadion stramineum LindB. Musc. scand. 28 ( $\mathrm{I} 879$ ).

Autoicous; in small loose yellowish-green tufts, $\frac{1}{2}-\frac{3}{4}$ in. high. Leaves imbricated when dry, or slightly flexuose, spreading when moist, long, lanceolate, acuminate, acute, or rounded obtuse and concave at point, or shortly apiculate, margin revolute, nerve disappearing at point in the upper leaves. Cells at base smooth, rectang., elongate next the nerve, passing gradually into rounded or subhexagonal, with thickened walls and prominent papillæ. Caps. more or less emergent, pachydermous, orange-brown, elliptic or oblong, suddenly narrowed towards base, with a short neck not defluent into pedicel, bands 8 , more or less distinct, orange-brown, of $2-5$ rows of quadrate cells with yellow thickened lateral walls, when dry the wrinkled capsule is more or less contracted below the mouth; stomata immersed, the border cells very prominent and nearly covering the stoma; annulus double, persistent. Teeth 8 , bigeminate, yellow, reflexed when dry, sometimes perforated towards point or gaping in the median line, very finely papillose; cilia 8 , subulate, of $\mathrm{I}-2$ rows of cells, wider at base, sometimes 8 intermediate cilia also present. Lid conic apiculate, yellow, pale red at margin. Calyptra covering most of caps., campanulate, apiculate, pale yellow with a brown point, slightly hairy. Vaginula very hairy. Male infl. at base of fertile branch.

HAB.-On trees and rocks; not rare. Fr. 6-7.

Castle Howard, Welburn, Teesdale and Deepdale (Spruce I836)! Thirsk, Beckdale and Guisbro (Baker I851)! Gresford, Wrexham (Wilson I843)!! Matlock Bridge (Spruce 1844). Fountains Abbey, Cartmel and Bolton (Carrington (1856). Sussex (Mitten). I844). Fountains Abey and Keswick (Nowcll I857)!! Killin (Moore I859). Fairhead, Antrim Ilkley, Malham and Keswick (Nowell I857)! Dent, Yorks. (Barnes I86I). Dailly and Balquidder (Hunt I 865)! Monsal dale and I. of Man (Holt I884)!! Muckross and Rossbeigh (Carrington). Fairhead, Seven churches and Wicklow (Moore). Lochearn head and Glen Ogle (Horn I887)!! Levens, Westmoreland (Barnes I868)!! Kilton, Saltburn and Skelton, Yorks. (R. Barnes 1887 )!! Tyn-y-groes (Holt 1888)!! Tollymore Park, Down (Rev. H. Waddell i 885$)$ !!

Var. $\beta$. patens (Bruch) Venturi.

Bands of capsule much fainter, composed of 2 series of quadrate cells with less thickened walls.

Syn.-Orthotrichum patens Bruch in BrID. Bry. univ, i, 787 . Br. Sch. Bry, eur. fasc. 2-3, p. I7, t. 7. DE Not. Syllab. I5I; Epil. 314. C. Muell. Synops. i, 703. Hueben. Musc. germ. 362. Hammar Mon. Io. Schimp. Synops. 267; 2 ed. 324. Milde Bry. siles. I75. Juratz. Laubm. 204. Hobk. Syn. 2 ed. 137.

Orth. stramineum $\beta$. patens VENTURI in HUSN. musc. gall. I83.

HAB. - Trees by streams. 
Congleton Cloud (Wilson I832)! Leicestershire (Rylands 1842)! Dailly, Ayrshire (Hunt $\mathrm{I} 865) !$ !

The typical form resembles $O$. affune in habit, but is smaller with more acuminate leaves, and the hairy vaginula, yellow calyptra, and orange caps. with immersed stomata at once distinguish it. $O$. patens is only a slight variety having narrower ribs, and the capsule shorter and less tapering at the base.

\section{I4. ORTHOTRICHUM SCHIMPERI Hamm.}

Autoicous; in small irregular tufts. Leaves broadly oblonglanceolate. Capsule immersed, ovate, ventricose, with a short shrivelled neck, and 8 broad orange striæ; teeth 8 , bigeminate, recurved when dry, cilia 8 , short, calyptra hemispheric, companulate, naked. (T. LVII, E.)

Syn.-Orthotrichum pumilum (non Swartz) Dicks. Pl. crypt. fasc. IV, 5 (I8or). SM. Fl. brit. I 264 (I804). Eng. Bot. t. 2i68. Turn. Musc. hib. 98 (I804). Web. Mohr. Bot. Tasch. 232 (I807). Schwaeg. Suppl. I, P. II, p. 22, t. 50, p.p. (I8I6). Hueben. Musc. germ. $35^{8}$ (1833). HARTM. Skand f. Br. Sch. Bry. eur. fasc. 2-3, p. I4, t. 5, f. I (I837). Rabenh. Deutsch. kr. f.. ii, S. 3, I79 (I848). C. Muell. Synops. i, 696 (I849). Wils. Bry. br. I78, t. 45 (I855).

Orthot. affine $\beta$. pumilum p.p. Ноoк. TAYL. Musc. br. 74 (1818). Hook. Grev. in Edin. J. Sc. I824, p. I2I. GRAY Nat. arr. br. pl. i, 746 (I82I). Hook. FI. scot. P.2, I37 (I82I).

Orthotrichum Schimperi Hammar Mon. Orthot. suec. 9 ( 1852 ). Boulay Fl. cr. de l'Est, 6i i (I872). JuRAtz. Laubm. oester.-ung. 208 (I882). Venturi in Husn. Musc. gall. I78, t. 48 (I887).

Orthotrichum fallax Schimp. Synops. 264 (I860), 2 ed. 327. Berk. Handb. br. m. 22 I (1863). Milde Bry. siles. I73 (I862). DE Not. Epil. 3 I2 (I869). Hobk. Syn. br. m. 9I (I873).

Dorcadion Schimperi Lindb. Musc. scand. 28 (1879).

Autoicous; in small dense dark green cushions, stems very short, fastigiate. Leaves imbricated when dry, recurved from the base when wet, then patent, oblong-lanceolate, obtuse or acuminate at point, entire or erose and sometimes decoloured, nerve vanishing below point; cells at base quadrate at margin, elongate next the nerve, passing gradually upward to rounded or hexagonal, with thin walls and very small papillæ, margin revolute in lower half and then recurved to some distance below summit. Caps. small, immersed, rarely emergent, ovaloblong with a swollen neck, suddenly narrowed into a very short pedicel, bands 8 , orange, of $4-5$ series of quadrangular cells with thick lateral walls, descending to middle of capsule, when dry and empty, contracted and furrowed; stomata immersed, the border cells covering a large part of the stomatic cells; vaginula naked. Annulus persistent, of $2-3$ rows of compressed cells. Teeth 8 , bigeminate, small orange yellow, finely papillose, rarely perforated to the middle, when dry recurved to 
the wall of capsule; cilia 8, shorter than the teeth, and of the same colour; lid conic, shortly apiculate. Calyptra naked or with a few short hairs, companulate-hemispheric, plicate from base to apex, yellowish brown. Male infl. at base of female branch.

Hab.-On trees, rare. Fr. 4 .

Kilcock, Meath (R. Bronun). Copgrove, Yorks. (Rev. F. Dalton). Ripon (Brunton). On ash, Clifton Ings, York (Spruce 1843)!! Addingham, Bolton-br. (Carrington 1858). Malahide (Moore I87I). Rowardennan, Loch Lomond (Dr. Wood 1875).

I have not seen any British specimen of $O$. pumilum SwartZ, and must therefore exclude it from our list; it differs from $O$ Schimperi by the more cylindric capsule, with a distinct neck tapering gradually into the pedicel, and paler yellow ribs.

O. Schimperi is one of our smallest species, with the capsule immersed entirely or to the middle.

\section{I5. ORTHOTRICHUM PALLENS Bruch.}

Autoicous; in very small lax green tufts. Leaves lanceolate, concave and rounded at point. Caps. emergent, oval-oblong, tapering gradually downwards, with 8 broad striæ; teeth 8 bigeminate, cilia I6, the alternate ones very small. Calyptra conic-campanulate, naked. (T. LVIII, A.)

Syn.-Orthotriehum pallens Bruch in BRID. Bry. univ. i, 788 (I827). BR. Sch. Bry. eur. fasc. $2-3$, p. 24 , t. I3 (I837). Rabenh. Deutsch. kr. fl. ii, S. 3, I84 (I848). C. Muell. Synops. i, 7or (I849). Hartm. skand. fl. Hammar Mon. Orthot. suec. I I (1852). Wylls. Bry. br. I79, t. 45 (1855). CARRINGt. Trans. Bot. soc. Edin. vi, 5 I (I858); et Phytologist I 858 , p. 57 I. Schimp. Synops. 27 I (1860), 2 ed. 33 I. BERK. Handb. Br. m. 224 (1863). Milde Bry. siles. I76 (I869). Hobk. Syn. Br.m.9I (I873). JuRATz. Laubm. oester.-ung. 207 (I882). Lesq. James Moss. N. Amer. I75 (I884). Venturi in HusN. Muscol. gall. I88, t. 5 I (1887).

Dorcadion pallens Lindi. Musc. scand. 28 (1879).

Autoicous; in very small, lax, irregular, pale green or yellow-green tufts, $\frac{1}{3}$ in. high, but little branched. Leaves imbricated when dry or loosely incumbent and slightly flexuose, when moist erecto-patent, from an oval-oblong base, lanceolate, the point concave and rounded, entire or crenulate at margin by projecting cells, or acuminate, or suddenly apiculate, margin revolute below the point; cells at base rectang. nearly diaphanous, gradually passing into rounded, angular or hexagonal, with slightly thickened yellowish walls; papillæ prominent simple or forked; nerve vanishing below point. Perich. bracts longer, narrowly ligulate, carinate, strongly nerved to apex. Caps. emergent, oval-oblong, pale yellow, defluent insensibly into a neck long as sporangium, on a very short pedicel, vaginula naked or witl some paraphyses, bands 8 , orange, 
of $2-4$ rows of cells with thickened yellow lateral walls; stomata immersed, the border cells not turgid. Teeth 8, bigeminate, pale yellow, perforated at top, rarely cleft in the median line, finely papillose, cilia 8 , smooth or papillose, filiform, with intermediate cilia very small or rudimentary. Lid conic, apiculate. Calyptra pale yellow, plicate, conico-campanulate, naked. Male infl. gemmiform, numerous, on a special branch, bracts ovate.

HAB.-On trees in hedges, rare. Fr. 5-6.

Clifton Ings, York, on willow with O. Sprucei (Spruce 1842)! Mickley, Yorks. (Baker). Addingham, between Bolton and Ilkley (Carrington 1855)! Miney and Trungle, Cornwall (Curnow). Westaston, Wicklow. Near Galway and Cork (Carroll).

This little moss has probably been overlooked, and has an elegant symmetric capsule and lingulate upper leaves with rounded points, the cells large for the size of the plant and resembling those of O. tenellum; the intermediate cilia are sometimes abortive. It may be known from $O$. Schimperi by its narrower and longer capsule with defluent neck, and more conical calyptra.

\section{I6. ORTHOTRICHUM TENELLUM Bnuch.}

Autoicous; in small loose deep green tufts. Leaves erecto-patent, oblong-lanceolate. Capsule emersed, narrow cylindric, with 8 broad bands : teeth 8 bigeminate, cilia 8 ; calyptra conic-campanulate, slightly hairy. (T. LVIII, B.)

SYN.-Orthotrichum tenellum BRUCH in BRID. Bry. univ. i, 786 (1827). WALLR. Fl. cr. germ. i, 209 (I83I). HuebeN. Musc. germ. 360 (I833). BR. Sch. Bry. eur. fasc. $2-3$, p. I5, t. 6 (I837). De Not. Syllab. I53 (1838), Epilogo 3 I I (I869). Rabenh. Deutsch. kr. fi. ii, S. 3, I79 (1848). C. Muell. Synops. i, 704 (1849). Hammar Mon. Orthot. suec. 5 (I852). Wils. Bry. br. I78, t. 45 (I855). Schimp. Synops. 265 (is6o), 2 ed. 329 . Berk. Handb. Br.m. 222 (I863). Milde Bry. siles. I73 (I869). Boulay Fl. cr. de l'Est 6 ro (1872). Hobr. Syn. Br. m. 9I (1873). Hus n. Mouss. N.-ouest IoS (I873). JuRATZ. Laubm. oester.-ung. 209 (I882). LeSQ. James Moss. N. Amer. I72 (IS84).

VENTURI in Husn. Musc. gall. $185, \mathrm{t} 50$ (I887).

Dorcadion tenellum LindB. Musc. scand. 28 (I 879 ).

Autoicous; in small loose deep green cushions $\frac{1}{3}-\frac{1}{2}$ in. high. Leaves imbricated when dry, erecto-patent when moist, from an oblong base, lanceolate, the apex muticous, apiculate or acuminate, margin revolute nearly to point, nerve vanishing at apex; cells at base diaphanous, quadrate, elongate next the nerve, passing gradually into angular or rounded, with thickened walls and very faint papillæ. Caps. emersed for all the length of the sporangium, pachydermous, golden-brown, narrow cylindric, not contracted below the mouth, furrowed for all the length, when moist oval-cylindric, passing gradually into a short neck; bands 8 , orange, broad and prominent, of 3-4 rows of quadrangular cells with strongly thickened lateral walls; stomata immersed, with strongly 
projecting border cells. Annulus of $3-4$ rows of compressed cells; teeth 8, bigeminate, pale brown, reflexed when dry, finely papillose, cilia 8 , shorter than the teeth; vaginula smooth. Lid conic, apiculate, pale red at margin. Calyptra narrow, conic, greenish jellow, glossy, slightly hairy. Male infl. axillar.

Hab.-On Willows, Poplar, and Elder. Fr. 5-6.

Near Bantry (Miss Hutchins). Near York and at Matlock bridge (Spruce 1844)! Sussex (Mitten). Gresford and Nant-y-Belan, N. Wales (Wilson I833)!! Thirsk and Ayton (Baker 1852). Bolton Abbey and Ilkley (Gibson 1834). Cartmel (Carrington I859). By the Cherwell and near Heyford, Oxon. (Boswell r859)! Derwentwater and Keswick (Hunt r863)!! Mucross (Carringto!). Rostellan, Cork, and Tervoe, Limerick (Carroll). Budleigh Salterton (Dickie). Stratford-on-Avon (Bagnall). Wemyss Bay and Inverkip (Hunt 1865)!! Sulby glen, Braddon, \&c., I. of Man (Holt r881)!! Great Houghton and Wittering, Northants (Dixon).

This pretty little moss has the habit of dwarf $O$. affine, but is soon distinguished by its long slender pale brown capsules, narrow leaves and narrow yellow calyptra.

\section{I7. ORTHOTRICHUM PULCHELLUM Bninton.}

Autoicous; in soft olivaceous tufts. Leaves somewhat crisped when dry, linear-lanceolate, acute. Caps. exserted, oval-oblong, 8-striate; calyptra campanulate, naked; teeth I6, geminate, reflexed against the capsule, cilia I6 or 8 . (T. LVIII, C.)

Syn.-Orthotrichum pulchellum Brunton in Eng. Bot. t. 1787 (1807). Hook. Tayl. Musc. br. 75 , t. 2 r (r8r8). Gray Nat. arr. Br. pl. i, 746 (I82r). Hook. Fl. scot. P. 2, I37 (r82I), Brit. f. ii, 56 (r833). Hook Grev. in Edin. J. Sc. i, I27 (I824). Mack. Fl. hibern. P. 2, 3r (r836). Br. Sch. Bry. eur. fasc. 2-3, p. 29, t. I8 (1837). Rabenh. Deutsch. kr. fl. ii, S. 3, r86 (r848). C. Muell. Synops. i, 7 I I (1849). Hartm. Skand. fl. Hammar Mon. Orthot. suec. 22 (1852). Wils. Bry. br. 186, t. 21 (1855). Schimp. Synops, 277 (I860), 2 ed. 334. Berk. Handb. Br. m. 226, t. 20 (r863). Milde Bry. siles. I78 (r869). Boulay Fl. cr. de 1'Est 599 (1872). Hobk. Syn. Br. m. 94 (1873). Husn. Mouss. N. ouest rro (1873). Leso. James Moss. N. Amer. 175 (1882). Venturi in Husn. Musc. gall. rgr, t. $5^{2}$ (1887).

Orthotrichum stenocarpum BRID. Bry. univ. i, 27 r (r826).

Dorcadion pulchellum LiNDB. Musc. scand. 28 (1879).

Autoicous; in low loose soft olivaceous tufts. Leaves flexuose when dry, recurving slightly when moist, and then becoming erectopatent, from an oval or oblong base, linear, acuminate, acute, the perich. bracts smaller and concealed by the upper leaves; margin loosely revolute in lower half, recurved above; nerve feeble, reaching to the point in the upper leaves; cells at base quadrang. elongated, gradually passing up into very minute rounded or subhexagonal, with thickened walls. Capsule small, yellowish, wholly exserted, oval-oblong, defluent on the pedicel, which passes but little the upper leaves, furrowed when dry and narrowed in the middle; bands 8 , of $3-4$ rows of quadrate cells 
with slightly thickened lateral walls; stomata immersed, the border cells projecting or in some cases not. Annulus persistent, double, very narrow: Teeth 8 , bigeminate, cleft nearly to basc into $\mathrm{I} 6$, reflexed against wall of capsule, orange-red, very finely papillose, cilia 8 , orange, usually with 8 intermediate ones. Lid conic, rostrate, yellow, red at margin. Calyptra conic, campanulate, naked, plicate, lacerate at base, yellowish with a fuscous point. Male infl. gemmiform, at base of a female branch.

HaB.-Trunks of trees, sometimes on walls. Fr. 5-6.

Frequent in subalpine districts. Hell-cleft and High Force, Teesdale (Spruce I843)!! Paper Mill wood, Over (Wilson I827)! Llanffinan (Wilson I855)! Blair Athole (Miss McInroy I859)! Dailly (Hunt I865)!! Colin Glen, Belfast (Stewart I868). Antrim and Derry (Moore). Pomeroy, Tyrone (Stewart 1878)!! Muckross (Holt I885)!! Rushen abbey, I. of Man (Holt I884)!! Glenalla, Donegal (Holt). Burgh Castle, Suffolk (Dixon). Lydford and Kitt's steps (Holmcs). On elder, Culag bridge, Lochinver (Braithwaite I887)!!

Var. $\beta$. Winteri (Schimp.)

Tufts irregular, deep green above, fuscous at base, capsule more exserted, oblongo-cylindraceous, with paler peristome.

Syn.-Orthotrichum Winteri Schimp. Bry. eur. Suppl. III-IV, t. II. Synops. 2 ed. 335. Milde Bry. siles. I79. Vent. in Husn. Musc. gall. I92, t. 52 .

HaB.-Penzance, Cornwall (Cumow $\mathrm{x} 868$ )!! distributed in Rabenhorst's

Bryotheca No. I079, under the name of O. pulchellum.

This lovely little moss has the leaves slightly crisped when dry, and thus leads us towards the next genus, to which it also approximates by the lengthened fruit stalks; the red peristome, I6 cilia and smooth calyptra readily distinguish it. In the moorland districts of $\mathrm{N}$. Yorlsshire and the Lowlands of Scotland it is quite common.

\section{WEISSIA EHRH.}

Hannov. mag. I779, p. I003.

Growing in small cushions on trees or very seldom on rocks, the stems branched, erect or decumbent. Leaves long, lanceolate flexuose, curled and twisted when dry, the base dilated and concave, with linear chlorophyllose cells in the middle and dilated hyaline ones at the sides. Calyptra yellow, plicate, cleft at base, covered with long flexuose yellow hairs. Capsule oval 8-striate, exserted on a tall pedicel, with a very long neck, the peristome as in Orthotrichum, ochrea indistinct or none.Der. after F. G. Weiss of Göttingen.

A very natural genus in habit and facies, and depending more on these for separation from Orthotrichum, than on any structural peculiarities, 
although the calyptra and texture of the leaf-base are more or less distinctive. About 36 species are referable to it, some of which have creeping stems as in the genus Macromitrium. In all our species the stomata are superficial.

The acute botanist Ehrhart was certainly the first to found a genus in honour of Weiss, the subsequent one of Hedwig applied to Bryum viridulum (Fund. II, 90), dating from I 782 ; Orthotrichum is posterior to both, and if the two are to be united in one genus, it must stand as Weissia. The name Weis on the title of the "Pl. crypt. Gotting." is no doubt a printer's error, as the correct spelling must be Weiss.

\section{Citavis to the, Species.}

Leaves rigid, not crisped.

- crisped when dry.

Upper leaves tipped with a cluster of gemma.

not tipped with gemmæ.

Caps. striate only at the contracted orifice.

Stem creeping, leaves slightly curled, per. simple.
not creeping, 1 . strongly curled, per. double.

Orifice of capsule contracted. not contracted.

Calyptra hairy ; caps. contracted below orifice.

Calyptra nearly smooth, caps. not contracted below orifice.

Americana.

phyllantha.

coarctata.

Drummondii,

Bruchii.

ulophylla.

vittata,

I. WEISSIA AMERICANA (P. Beauv.) Lindb.

Autoicous; in rigid, fragile, brown tufts. Leaves erect, nearly straight when dry, lanceolate. Capsule clavato-pyriform, 8-striate; calyptra campanulate, hairy. (T. LVIII, D.)

Syn.-Orthotrichum americanum P. Beauv. Prodr. 80 (I805): SchwaEgr. Suppl. I, P. II, 37, et Suppl. II, P. I, I 44, t. I38 (1823). BRID. Bry. univ. 278 (I826).

Orthotrichum anomalum $\beta$. americanum BRID. Sp. musc. II, IO (I8I2).

Orthotrichum Hutchinsia Sm. Eng. Bot. t. 2523 (I8I3). Hook. TaYL. Musc. br. 73, t. 2 I (I8I8). Funck Moost. 34, t. 23 (I82I). Schwaeg. Suppl. II, P. I, I45, t. I38 (1823), Flora vi, 55 (1824). Brid. Bry. univ. i, 277 (1826). GRAY Nat. arr. Br.pl.i, 746 (1821). Hook. Fl. scot. P. 2, I37 (I82I), Brit. fl. ii, 56 (I833). Hook. Grev. Edin. J. Sc. i, I 25 (1824). Hueblen. Musc. germ. 353 (I833). Mack. Fl. hibern. P. 2, 30 (I836). Br. Sch. Bry. eur. Fasc. $2-3$, p. 20 , t. Io (I837). De Not. Syllab. I54 (I838). Rabenh. Deutsch. kr. fl. ii, S. 3 , I 82 (I848). C. MUell. Synops. i, 692 (I849). Hartm. Skand. fl. 5 ed. 369 (I849). Wils. Bry. br. I90, t. 2 I (1855). Husn. Mouss. N. ouest 103 (I873). Hoвk. Syn. br. m. 96 (1873).

Orthotrichum strictum BRID. Bry. univ. i, 289.

Orth. nigricans BRID. Bry. univ. i, 792.

Orth. nigritum Br. Sch. Bry. eur. Fasc. 2-3, P. I I, t. 4. C. Muelı. Synops. i, 692.

Ulotrichum Hutchinsia Schimp. Bry. eur. Consp.

Ulota Hutchinsia Hammar Mon. Orth. suec. 27 (1852). Schimp. Coroll. Br. eur. $4 \mathbf{I}$ (1855), Synops. 255 (I860), 2 ed. 306. Berk. Handb. Br. m. 229 (I863). Milne Bry. siles. I66 (I869). DE Not. Epil. bri. ital. 290 (I869). JuRatz. Laubm. oestr.-ung. I94 (1882). Leso. James Moss. N. Amer. I63 (1884). Huss. Musc. gall. I53, t. 43 (1887).

Weissia americana LindB. Musc. scand. 28 (1879). 
Autoicous; in dark brown rigid fragile tufts, blackish and defoliate at base; stems dense-leaved, sparingly branched. Leaves not crisped, erecto-appressed when dry, erecto-patent when moist, oblongo-lanceolate, concave-carinate, revolute at margin, the nerve very thick, reaching nearly to point; cells at base rectangular, very narrow, fulvous, the marginal quadrate, hyaline, upper small round incrassate. Capsule yellowish, pyriform, attenuated at base, slightly narrowed at orifice, 8-striate, when old and empty deeply furrowed, brown; lid rostrate; teeth bigeminate, reflexed when dry, pale, rugulose, cilia 8 , rather short, of two rows of cells. Calyptra conico-campanulate, very rough with golden yellow ramenta. Male infl. axillary or terminal, reddish.

HAB. - On rocks and stones in subalpine districts. Fr. 7.

Bantry (Miss Hutchins). Wicklow, Galway, and Connemara. By the Plym, Devon (Tozer). Yarmouth (Turner). Llanberis (Ralfs 1840)! Snowdon, Ben Ledi (Dr. Wood). Connant-mawr, N. Wales (Dixon I855). Pass of Leny (McKinlay I861). Glen Callater (Dickie 186I)! Beddgelert (Hunt I865)!! Falls of Lochay and Glen Torridon (Hunt I865)!! Tyn-y-groes and Rhaiader Dhu (Holt 1882)!! Kintail and Loch Coruisk (Dixon I883). Cader Idris (Whitehead I879)!! Ben Cruban, Perth (Whiteliead $\times 874) !$ !

Intermediate between Orthotrichum and Weissia, resembling the former in the straight leaves, and the latter in the capsule.

\section{WEISSIA COARCTATA (P. Beanv.) Lindb.}

Autoicous; in loose tufts, decumbent at base. Leaves crisped when dry, linear-lanceolate. Capsule on a longish pedicel, obovate, much contracted and plicate at mouth, with 8 very short bands. Calyptra conic-campanulate, hairy. (T. LVIII, E.)

Syn.-Orthotrichum coarctatum P. Beauv. Prodr. 80 (I805). Brid. Sp. musc. II, I3 (I8I2), Mant. I I (I8I9). Bry. univ. i, 288 (I826). Schwaeg. Suppl. I, P. II, 26, t. 52 (I8I6).

Orthotrichum plicatum LuDw, in litt.

Splaclnum Wulfenianum SchwaEg. Suppl. I, P. I, 46, t. I4 (I8I I).

Orthotrichum Ludwigii Brid. Sp. musc. II, 6 (ISI2). Schwaeg. Suppl. I, P. II, 24, t. 5 I. Funck Moost. 34, t. 23 (I82I). Hook. Grev. Edin. J. Sc. i, I25 (IS24). Grev. Scott. cr. fl. t. I33 (I825). Hook. l'ayl. Musc. br. 2 ed. I32, Suppl. t. 4 (IS27). Huebran. Musc. germ. 346 (I833). Hook. Br. A. ii, 56 (I833). Br. Sch. Bry. eur. fasc. $2-3$, p. I2, t. 4 (I837). DE Not. Syllab. 154 (I838). RABENh. Deutsch. kr. A. ii, S. 3, I 78 (I848). Harta. Skand. A. 5 ed. 369 (1849). C. Muell. Synops. i, 7 It (I849). Wils. Bry. brit. 187, t. 34 (I855). HoBk. Syn. br. m. 95 (1873). HUSN. Mouss. N. ouest IO3 (I873).

Ulota Ludwigii Brid. Mant. I I2 (I8rg), Bry. univ. i, 302. Hammar Mon. Orthot. suec. 28 (I852). Schimp. Coroll. Bry. eur. 4 I (1855). Synops. 254 (IS60), 2 ed. 30 I. Berk. Handb. Br. m. 228 (I863). Milde Bry. siles. 166 (I869). DE Not. Epil. bri. ital. 29 I (I869). JURA'Tz. Laubm. oest.-ung. 193 (I882). Leso. James Moss. N. Amer. i6r (I884). Husn. Musc. gall. I5 I, t. 43 ( 1887 ).

Ulotrichum Ludwigii Schimp. Consp. Bry. eur.

Weissia coarctata LrNDB. Musc. scand. 28 (I879). 
Autoicous; in small yellow-brown tufts, stems erect, decumbent at base, sparingly branched, fastigiate. Leaves densely imbricated, appressed and slightly crisped when dry, erect when moist, lanceolate acuminate, or from a narrowly ovate ventricose base, elongato-lanc., plane or recurved at margin, carinate, nerve vanishing below apex; cells at basal margin quadrate, hyaline, the rest very narrow, upper rounded and oval, incrassate. Capsule oboval, afterivards clavatopyriform, pale fuscous, leptodermous, much contracted at mouth and witl 8 short plaits below it, the rest scarcely sulcate, bands 8 , short, of quadrate cells strongly incrassate laterally, those of the sulci rectangular; stomata numerous on the neck. Lid hemispherical, rostellate. Calyptra straw-coloured, densely hairy. Teeth 8, bigeminate, whitish, erect when dry, cilia 8 , very short, or altogether obsolete.

Hab.-Young trees in subalpine woods. Fr. 8-9.

Hill of Finhaven (Drummond). Trossachs (Wilson 1832). Glen Falloch and Killin (Hunt I865) !! Rowardennan (Dr. Wood $\mathrm{I} 875$ ). Torc wood and Glena, Killarney (Carrington I86r). Danny, Sussex (Mitten). Clova (Fergusson).

Readily known by the very contracted mouth of the capsule, which gives it a very peculiar appearance, also by the short bands and plaits below it.

\section{WEISSIA DRUMMONDII (Hook. Grev.) Lindb.}

Autoicous; stem creeping, with erect branches. Leaves spreading, linear-lanc., appressed, and scarcely crisped when dry, nearly plane at margin. Caps, oblongo-pyriform, on a long pedicel; calyptra conicocampanulate, hairy, teeth I6, geminate, pale. (T. LIX, A.)

Syn.-Orthotrichum Drummondii Hook. Grev. Edin. Journ. Sc. i, I20 (1824). Grev. Scott. cr. fl. t. II5 (I824). Hook. Tayl. Musc. brit. 2 ed. I26, Suppl. t. 4 (I827). Hueben. Musc. germ. 345 (1833). Hook. Br. fl. ii, 54 (IS33). Br. Sch. Bry. eur. fasc. $2-3$, p. I2, t. 3 (I837). Rabenh. Deutsch. kr. fl. ii, s. 3, I78 (1848). C. Muell. Synops. i, 712 (1849). Wils. Bry. br. 189, t. 34 (1855). Hobk. Syn. br. m. 96 (I873).

Ulota Drummondii Brid. Bry. univ. i, 299 (1826). Hammar Mon. Orth. suec. 29 (1852). Schimp. Coroll. 4 I (I855). Synops. 253 (I860), 2 ed. 300. Berk. Handb. br. m. 228 (I863). Milde Bry. siles. I65 (1869). Juratz. Laubm. oest.-ung. I93 (1884). LesQ. James Moss. N. Amer. I6I (I884). Husn. Musc. gall. I 50, t. 43 (I887).

Orthotrichum subrepens SOMMeRF. Suppl. Fl. lapp. I9I, t. i (I826).

Macromitrium Drummondii HAMPE in Flora 1837, p. 280.

Weissia Drummondii LindB. Musc. scand. 28 (1879).

Autoicous; in depressed pale yellowish-green tufts, stems longly trailing, witl erect branches and fasciculate shoots. Leaves erecto. patent when moist, erect straight and scarcely crisped when dry, lineallanceolate, obtuse, ovate and concave at base, plane or slightly recurved at margin, nerve vanishing below apex; basal cells linear in the middle, 
quadrato-rectang. at margin, upper quadrato-rotundate, papillose. Capsule obovate-clavate, contracted at mouth, pale brown, obliquely 8-striate to base, fusiform when old, cells of striæ rectangular, leptodermous; lid pale with a subulate beak; teeth 16 , geminate, whitish, recurving when dry; rudimentary cilia sometimes present. Calyptra very sparingly hairy.

HaB.-Trunks of alder, birch and mountain ash in subalpine districts. Fr. 7 -8.

Frequent in Forfar and Perthshire, Braemar, Loch Maree (Hunt 1866)!! High Force, Teesdale (Spruce I842). Cronkley Fell (Stubler I866)!! Powerscourt, Killarney and Luggielaw (Moore). Alford, Aberdeen (Mrs. Farquharson (I88I)!!

This pretty species, by its creeping stems, resembles in habit the great exotic genus Macromitrinm; the leaves are very slightly curled, and the endostome is wanting.

\section{WEISSIA BRUCHII (Hornsch.) Lindb.}

Autoicous; pulvinate, branched. Leaves linear-lanceolate, crisped when dry. Capsule on a long pedicel, oblong-pyriform, witl 8 broad strix, contracted at mouth when dry; calyptra very hairy. (T. LIX, B.)

Syn.-Ulota Bruchii Hornsch. Mas. Brid. Bry. un. i, 794 (1827). Schimp. Synops. 256 (IS60), 2 ed. 303. Berk. Handb. br. m. 229 (1863). Milde Bry. siles. 167 (I869). JURATz. Laubm. oest.-ung. I95 (I882). Lesq. James Moss. N. Amer. I62 (I884). Hobk. Syn. br. m. 2 ed. I3I (1884). Husn. Musc. gall. I5I, t. 43 (I887).

Orthotrichum coarctatum (non P.B.) Hueben. Musc. germ. p.p. 349 (I883). BR. Sch. Bry. eur. fasc. $2-3$, p. 2 I, t. I I, excl. syn. (I837). RabenH. Deutsch. kr. fl, ii, s. 3 , 183 (1848). C. Muell. Synops, i, 7 13 (1849).

Orthotrichum dilatatum BR. Scr. Bry. eur. fasc, $2-3$, p. 22, t. I I (I837).

Ulota coarctata Hammar Mon. Orth. suec. 25 , p.p. (1852).

Orthotrichum Bruchii Wils. Bry. br. I88, t. 45 (1855). Huss. Mouss. N. ouest I04 (I873). Hosk. syn. Br. m. 96 (1873).

Ulotrichum coarctatum Schimp. Consp. Bry. eur.

Weissia Bruchii Lindb. Musc, scand. 28 (1879).

Autoicous; in soft pulvinate tufts, bright yellow-green above, ferruginous at base, the stems erect or ascending from a decumbent naked base, repeatedly dichotomous. Leaves from an ovate concave base, long, linear-lanceolate, subflexuose, twisted and contorted when dry, more gradually pointed than in $W$. ulophylla and with a paler nerve, margin plane above, recurved below; cells at basal wings quadrate, hyaline, with incrassate transverse walls, those next the nerve larger, rectangular, in straight rows, the upper with smaller papillæ; perich. bracts longer, erect, sulcate at base. Calyptra densely hairy. Capsule 
on a longr pedicel, oval-pyriform, yellow-brown, pachydermous, gradually attenuated into a long neck, 8-costate, when dry and empty elongated, fusiform, contracted at mouth, fuscous; cells of the bands in 5 rows, quadrate, thickened in the longitudinal walls; lid pale, convex, rostellate; teeth bigeminate, finally $\mathrm{I} 6$ and geminate, reflexed when dry, pale papillose, cilia 8 , long as teeth, or 16 alternately long and short, narrow. Spores green, larger than in $W$. ulophylla.

НАв.-On trees; not uncommon. Fr. 7-8.

This is more robust than $W$. ulophylla, the leaves less crisped, with larger cells, those next the nerve at base longer and laxer; the capsule is more exserted, darker brown, when empty attenuated, fusiform, contracted and twisted at mouth. The two species sometimes grow together.

\section{WEISSIA ULOPHYLLA Ekrh.}

Autoicous; soft and pulvinate, branched. Leaves strongly crisped when dry, from a concave ovate base, linear-lanceolate. Caps. clavate, attenuated in a long neck, strongly striate, contracted below the wide mouth; calyptra very hairy. (T. LIX, D.)

Syn.-Muscus capitulis longis acutis pilosissimis D. Sherardi RAY Synops. 2 ed. p. 32 (I6g6).

Polytrichum minus foliis capillaceis D1Ll. Cat. Giss. 222 (17Ig).

Polytrichun capsulis oblongo-rotundis, calyptris pilosissimis Dill. in Ray Synops. 3 ed. 9I (I 724$)$.

Polytrichum capillaceum crispun calyptris acutis pilosissimis DiLl. Hist. musc. 433, t. 55, f. II (I74I) et Herbar.

Polytrichum striatum $\delta$. L. Sp. plant. IIIj (I753). Huds. Fl. angl. 40I (I762). Wiтh. Bot. arr. Br. veg. ii, 67r (I776).

Polytrichum bryoides, capillaceum. Weiss Crypt. Gott. I77 (I770).

Polytrichum striatım NEck. Meth. musc. I2 I (177I).

Bryum striatum Var. ulophyllum EHRH. Hann. mag. I78o, p. 236.

Weissia ulophylla Енвн. Beitrag. i, IgI (I787). LiNDb. Act. soc. sc. fenn. X, I 2 (I871).

Bryum crispum GmeL. (L.) Syst. nat. ii, I335 (I79I). LAICH. Pl. eur. 483 (I794). Horrm. Deutsch. A. ii, 25 (I796). Wiтн. Bot. arr. br. vez. 3 ed. iii, 827 (1796). Aввот Fl. bedf. 236 ( 1798 ).

Orthotrichum crispum Hedw. Musc. fr. ii, 96, t. 35 ( 7788 ), Sp. musc. I52 (I801). 'Тмm Fl. megap. (1788). Brid. Musc. rec. II, P. II, Ig (I80I), Sp. Musc. II, 5 (I8I2). Swartz Musc. suec. 42 (1798). SMith Eng. Bot. t. 996 (1801), Fl. brit. 1266 (I804). Turn. Musc. hib. G3 (I804). P. Beauv. Prodr. 80 (I805). Schultz Fl, starg. 308 (I806). Voit Musc. herb. 65 (I8I2). Wahlenb. Fl. lapp. 364 (I8I2), Fl. carpat. 354 (I8I4). Schwaeg. Suppl. I, P. II, I3 (I8I6). Roehl. Deutsch. fl. iii, 8I (I8I3). Mart. Fl. cr. erl. n. 86 (18I7). Hook. TaYl. 73, t. 2i (I8I8). Hartm. Skand.fl. Houk. Fl. scot. P. 2, r37 (I821), Br. fl. ii, 56 (1833). GRAY Nat. arr. br. pl, i, 745 (I82I). FuncK Moost. 34, t. 23 (I82I). Hook. Grev. Edin. J. Sc. i, 126 (1824). HUEBEN. Musc. germ. $35^{\circ}$ (I833). Mack. Fl. hib. P. 2, 36 (1836). BR. Sch. Bry. eur. fasc. $2-3,23$, t. I2 (1837). DE Not. Syllab. I55 (I838). RABENH. Deutsch. kr. fl. ii, S. $3,183(1848)$. C. Muell. Synops. i, 7 I2 (I849). Wils. Bry. br. 188, t. 2 I (r855). Husn. Mouss. N. ouest $\mathrm{IO}_{4}$ (1873). Hовk. Syn, br. m. 95 (1873).

Weissia crispa Siвтн. Fl, oxon. 287 (1794). Roth Fl. germ. iii, P. I, 222 (ISoo). 
Neckera ulophylla Web. MoHr Bot. Tasch. 236 (I8c7)

Ulota crispa Brid. Mant. il2 (I8Ig), Bry. univ. i, 299 (I826). Hammar Mon. Orth. suec. 24 (1852). Schimp. Coroll. 4I (1855), Synops. 257 (I860), 2 ed. 304. BERK. Handb. br. m. 229 (I863). Milde Bry. siles. I68 (I869). DE Not. Epil. bri. ital. 288 (I869). Juratz. Laubm. oester.-ung. I96 (I882). Lesq. James Moss. N. Amer. i62 (I884). Husn. Musc. gall. I52, t. 43 (I887).

Autoicous; in dense rounded cushions, or rather lax and irregular in outline, yellow green above, ferruginous at base, bearing old and young capsules at the same time. Stems erect or decumbent at base, branched; leaves densely crowded, strongly curled and twisted when dry, patulous when moist, from a concave ovate base, linear-lanceolate, the margin recurved in the lower half, nerve yellow, reaching nearly to apex; cells at base rectangular, brown, the alar hyaline with thickened transverse walls, those towards the nerve elongated, in oblique rows, upper rounded, incrassate. Capsule exserted, leptodermous, oval, gradually attenuated, in a long neck and strong scarcely twisting pedicel, 8-striate, contracted below the wide orifice, younger ferruginous the old brown or strawcoloured, after maturity and when dry, elongate fusiform, deeply sulcate; cells of the vittæ in four rovs, rufous; lid hemispherical, longpointed ; teeth 8 , bigeminate, pale, cilia 8 , or rarely 16 , narrowly lanceolate, of two rows of cells up to middle. Calyptra pale yellow, very rough, campanulate. Male infl. lateral.

HaB.-On trees; common in subalpine districts. Fr. 5-6.

\section{Var. $\beta$. intermedia Schimp.}

Leaves longer, with more numerous quadrate lyyaline cells at basal margin; caps. more cylindric, not contracted below the mouth, less tapering at base.

Srn.-Ulotu crispula $\beta$. ambigua Schimp. Synops. 258.

Ulota intermedic Schimp. Synops. 2 ed. 305. Juratz. Laubm. oest.-ung, ig6. Husn. Musc. gall. 152, t. 43 .

HAB.-Here and there with the typical form.

Near Loch Lomond (Schimper I868)! Castle Howard (Spruce I847)! Dunoon (Share I860)!! Wychwood forest, Stokenchurch and Bagley wood (Boswell). Rosslin and Skye (Boswell). Strome ferry (Dixon I883).

Var. $\gamma$. crispula (Bruch) Hammar.

In smaller tufts. Leaves narrow and shorter, more laxly areolate. Caps. pale, leptodermous, oval-pyriform, with a long neck, when dry and empty, short truncate urceolate, scarcely contracted below the mouth, the neck suddenly contracted and plicate.

Syn.-Orthotrichum crispum. $\beta$. minus Schwaeg. Suppl. I, P. II, 25.

Ulota cristula Bruch Mss. Brid. Bry. Univ. i, 792 (1827). Schimp. Synops، 258. DE Not. Epil. 28g. Berk. Handb. 230. Milde i68, Lesq. James i63. Husn. Musc, gall. 152, t. 43 . 
Orthotrichum crispulum Br. ScH. Bry. eur. fasc. $2--3$, p. 23, t. I2. RaBenH. Deutsch. kr.

fl. r83. C. Muell Synops. 713. Wils. Bry. brit. 187, t. 45. HoBk. Synops. 85.

Ulota crispa $\beta$. crispula HAMmar Mon. 24.

Weissia crispula Linde. Act. soc. sc. fenn. x., I2.

HaB.--Subalpine districts.

Not unfrequent in the Lake country, N. Yorkshire and S. Scotland.

Weissia ulophylla in its typical form is best known by the old capsule having a wide trumpet-shaped mouth, and being contracted below it, the var. intermedia however has the capsule scarcely showing any constriction, and yet we occasionally meet with some where this is decidedly evident, so that we cannot look upon it as other than a mere form. We must also agree with Dr. Carrington in regarding $W$. crispula as nothing more than a variety, for although at first sight the small thin pale abbreviated capsule, suddenly contracted at base into a tapering neck, appears to be characteristic, numerous transition forms occur so linked with the typical, that it is not possible to maintain them as distinct. I have to thank Mr. Holt for a long series of specimens from various localities which have confirmed me in this view of the species.

6. WEISSIA VITTATA (Mitt.) Braithw.

Autoicous; cirrato-crispate when dry. Leaves lineal-lanceolate. Calyptra glossy straw-colour, almost naked. Caps. oval-oblong, with a long neck, not contracted below mouth. (T. LIX, C.)

Syn.-Ulota vitlata Mi'TT. Journ. Linn. soc. viii, 3 (I864).

Orthotrichum calvescens Wirs. MSS. CaRRington Trans. Bot. soc. Edin. viii, 386 (r866). Hoвk. Syn. Br. m. 95 (1873).

Ulota calvescens Schimp. Bry. eur. Suppl. fasc. 3-4 (1866), Synops. 2 ed. 303 (1876).

Weissia vittata Brarthw. in Journ. Bot. 1873 , p. 202.

Orthotrichum Paivanum Schimp. MSS.

Autoicous; in small yellow green cushions. Leaves densely crowded, patent, cirrato-crispate when dry, from an oval base, which has a deep furrow on each side, lineal-lanceolate, basal cells subvermicular, quadrate at margin, and with 5-8 rows of very narrow rectangular cells next the margin, forming a band as high as the middle of leaf, apical irregularly rounded-hexagonal, very small, narrower than in W. Bruchii. Perich. bracts rather shorter than comal leaves; vaginula naked. Calyptra glossy strav-colour, with very few hairs. Caps. on a longer more slender subflexuose pedicel, oval-oblong, with a very long neck gradually attenuated into pedicel, but little altered when dry and empty, less deeply sulcate, not contracted at or below mouth; teeth larger, bigeminate, partly separated at apex, or perforated between. when 
dry, spreading and reflexed against wall of capsule, very densely papillose externally, cilia 8, filiform, long as teeth, pale yellowish. Male inf. terminal.

HAB.-Branches of small trees; not common. Fr. 6.

On hawthorn and Mountain Ash at Torc waterfall, Killarney (Moore I858)!! Loch Finnehy, Kerry (Spruce I842)! Muckross and O'Sullivan's Cascade. Glens'esk, Antrim (Stewart I882)!! Glerariffe, Antrim (Stewart I889)!! Rowardennan, Loch Lomond (F. Bury I859). Westmoreland (Barnes and Stabler).

With the habit of $W$. Bruchii, this fine species is quite distinct, the calyptra being nearly bare, and the marginal band of long narrow cells a marked feature, these cells vary in number and extent in different leaves, but are always more or less evident; Mr. Stewart's specimen hears scattered oblong gemmæ on the leaves. The species was first discovered by Mr. Johnson in Madeira.

\section{WEISSIA PHYLLANTHA (Brid.) Lindb.}

Dioicous; densely pulvinate. Leaves long, lineal-lanceolate, not dilated at base, strongly crisped when dry, the upper with the nerve thickened at apex and bearing a cluster of septate gemmæ. Caps. oval-oblong, not contracted at mouth. (T. LIX, E.)

Syn.-Ulota phyllantha Brid. Mant. ir3 (i8Ig). Hammar Mon. Orth. suec. 30 (I8j2). Schimp. Coroll. Bry. eur. 4I (I855), Synops. 259 (I860), 2 ed. 306. Berk. Handb. Br. m. 230 (I863). Mrlde Bry. siles. i68 (1869). Lese. James Moss. N. Amer. i63 (I884). Husn. Musc. gall. I53, t. 43 (I887). RENauld and Cardot in Rev. bryol. I $888, \mathrm{p} .3^{6 .}$

Orthotrichum phyllanthum Steud. Nom. crypt. $30+$ (I82I). Br. Sch. Bry. eur. fasc. 2-3, p. 30, t. I8 (I837). Wils. Bry. brit. I9o, t. 46 (1855). HARTM. Skand fl. HusN. Mouss. N. ouest 104 (1873). Новк. Syn. br. m. 96 (1873).

Orthotriehnum Futlandicum Brid. Bry. univ. i. 296 (I326). C. Muell. Synops. i, 7 I 7 (I849).

Orthotrichum faseiculare BRID. Bry. univ. i, 790.

Gy'mnostomum viridissimum Davies Welsh Botan. 103 (1813).

Ulotrichum phyllanthum ScHimp. Bry. eur. Conspec.

Weissia pliyllantha Lind. Musc. scand. 28 (1879).

Dioicous; densely pulvinate, bright yellow-green above, ferruginous belorv; stems $\frac{1}{2}-\mathrm{I}$ in. high, erect, but little branched. Leaves circinatocrispate and twisting when dry, long, lineal-lanceolate, not dilated at base, obtuse, very slightly concave, revolute at margin below, nerre stout, vanishing at apex, in the upper leaves expanded into a thick point bearing a cluster of fuscous elliptic septate propagula; cells abore minute, quadrate, papillose, at the plicate base pale, rectangular, the lowest rufescent, with only a single series of hyaline ones at margin. Perich. bracts much elongated, sinuoso-crenulate at margin; vaginula naked, caps. on a longish yellow seta, oval-oblong, not contracted at mouth, plicate when dry, with a longly attenuated neck, pale green 
when young, fuscous when old, and with $\&$ strong twisted ridges; teeth 8, bigeminate, pale, truncate and slightly lacerate at point, not reflexed when dry, cilia 8, broad and short, of two rows of cells. Calyptra slightly hairy. Lid conic-acuminate, pale yellow, with a reddisl margin. Spores green, very finely punctulate. Male infi. gemmiform, among the comal leaves; bracts oblong, acuminate, mucronate with the excurrent nerve.

HAB.-Trees and rocks near the sea ; not uncommon ; also found inland. Fr. 5.

High rocks, Tunbridge wells, with I caps. (Spruce I $\left.\delta_{+} 6\right)$ ! Mucross, Killarney, 5 caps. (Schimpor i 868)!

In appearance this somewhat resembles $W$. crispa but has longer leaves, not dilated at base, the quadrate hyaline cells only forming a single row at margin, and the upper leaves generally tipped with a cluster of brownish gemmæ. The fruit was first described by MM. Renauld and Cardot, from specimens collected in Oregon, by Mr. 'T. Howell, and a sharp-eyed American lady (Mrs. Britton, of Columbia College), when working at Kew last autumn, found 5 capsules on the specimen collected by Schimper himself at Killarney, but which had not been noticed. This led our veteran bryologist, Spruce, to look over his early gatherings, and among some IV. crispa, collected by him at Tunbridge WVells, the same lady detected a single damaged capsule of $W$. phyllantha.

The inland specinens from Yorkshire, Sussex, \&c., are shorter and paler than those from the coast, and I have noticed it particularly fine and abundant at Lochinver, Sutherlandshire.

TAB. XLVI. A. Grimmia confcrta (Arthur's Seat, Greville). B. var. pruinosa (Largo, Howie). C. G. apocarpa (Eskdale, Braithwaite). $\beta$. var. alpicola (Clova, Gardiner), $\gamma$. var. rivnlaris (Ben Lawers, Braithwaite), $\delta$. var. gracilis (Campsie, Hmit). D. G.maritima (Penzance, Curnoz'). E. G. anodon (Arthur's Seat, Bcll).

TAв. XLVII. A. Grimmia crinita (Hatton, Bagnall). B. G. incurva (Braemar, Sim). C. G. clongata (Clova, Fcrgusson). D. G. funalis (Craigailleach, Hunt). E. G. torquata (Ben Lawers, Braithwaite). F. G. Stirtoni (Glasgow, Stirton).

TAв. XLVIII. A. Grimmia Muehlcnbeckii (Kynance, Holmes). B. G. microcarpa (Ben Lawers). C. G. pulvinata (Dorking). D. G. orbicularis (Ormeshead, Wilson). E. G. trichophylla (Arthur's Seat, Hunt). F. G. Hartmani (Killin, Hunt).

TAB. XLIX. A. Grimmia subsquarrosa (Perth, Dr. White). B. G. dccipicns (Convay, Wilson). C. G. clatior (Norway, Lindberg). D. G. Donii (Clova, Braithwaite). E. G. alpestris (Ballater, Forgusson). F. G. montana.

Tав. L. A. Grimmia ovata (Clova, Fergusson). B. G. ovalis (Snowdon, Wilson). C. G. campestris (Arthur's Seat, Hunt). D. G. atrata (Clova, Fcryzusson). E. G. mincolor (Clova, Fergusson). F. G. clliptica (Snowdon, Wilson).

Tas. LI. A. Grimmia patcns (Ben Lawers, Braithraitc). B. G. aquatica (Bowness, Barnes). C. G. acicularis (Ben Lawers). D. G. affinis (Snowdon). E. G. obtusa (Lough Bray, Lindberg). F. G. ramulosa (Herb. I'ilson).

TAв. LII.' A. Grimmia heterosticha (Ben Lawers, Brathwaitc.) B. G. fascicularis (Killin, Braithwaite). C. G. hypnoides (Rosedale, Braithwaitc). D. G. cancscens (by Loch Tay, Braithwaite).

Tar. LIII. A. Coscinodon cribrosus (Coniston, Binstead). B. Glyphomitrinm Davicsii (Mull,

Hunt). C. G. polyphyllum (Aber, Braithwaite). D. G.
E. Ancet. Lapponicum (Ben Lawers). F. A. Mongcotii. 
TAB. LIV. A. Pleurozygodon acstivus (Ben Lawers), $\beta$. var. pellucida. B. Zygodon Stirtoni (Elie, Howic). C. Z. viridissimus (Lodore, Binstead). D. Z. conoideus (Killarney, Hunt). E. Z. Forstevi (Epping Forest, Holmes). F. Z. gracilis (Heselton gill, Nowell).

TAB. LV. A. Orthotrichum obtusifolium (York, Wilson). B. O. rupestre (Tummel bridge, Braithwaitc). $\quad \gamma$. Var. Sturmii. C. O. Shawii (Kilkerran Castle, Shaw). D. O. affine (Eskdale, Braithwaite), $\gamma$. Var.fastigiatum.

TAв. LVI. A. Orth. speciosum (Braemar, Hunt). B. O. Lyellii (Windsor). C. O. striatum (Teesdale, Noz'ell). D. O. diaphamum (Virginia water, Braithwaitc). E. O. cupulatum (Eskdale, Braithwaitc).

TAB. LVII. A. Orth. anomalum (Aberdour, Howie), $\beta$. var. cylindricum. B. O. rivulare (Malton, Slater). C. O. Sprucci (York, Spruce). D. O. straminemm (Killin, Moore), $\beta$. var. patens. E. O. Schimperi (Bolton bridge).

TAB. LVIII, A. Orth. pallens (York, Spruce). B. O. tenellum (Keswick, Hunt). C. O. pulchellum (Lochinver, Braitlwate), $\beta$. var. Winteri (Penzance, Curnow). D. Weissia americana (Tyn-y-groes, Holt). E. W. coarctata (Braemar, Hunt).

Tав. LIX. A. Weissia Drummondii (Teesdale, Spruce). B. W. Bruchii (Killin, Braitluwaite). C. W. vittata (Killarney, Holt). D. W. ulopliylla and Var. crispula (Eskdale, Braithwaite). E. W. plyyllantha (Killarney, Schimper).

a. Fertile plant. a*. Ditto mag. b. Male. c. Sterile plant. I. Leaf mag. Ix. Trans. section of leaf. ra. Apex. raa. lab. areolation of apex or base of leaf. 2. Perich. bract. 3. Male inf. 4. Bract, antheridia and paraphyses. 5. Capsule. 6. Calyptra. 7. Operculum. 8. Tooth of peristome. 9. Spores. Io. Gemmæ. s. Stoma. 



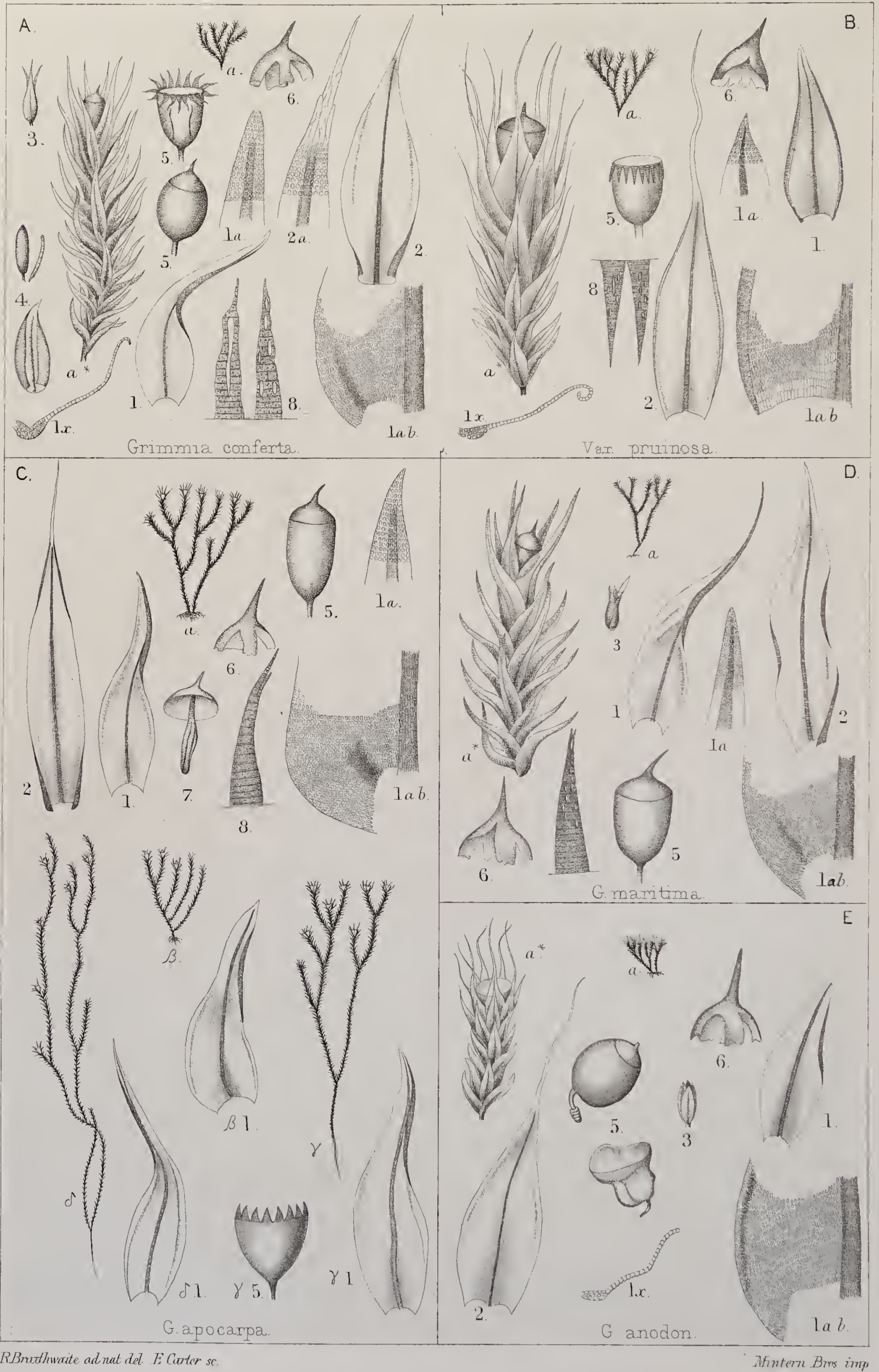




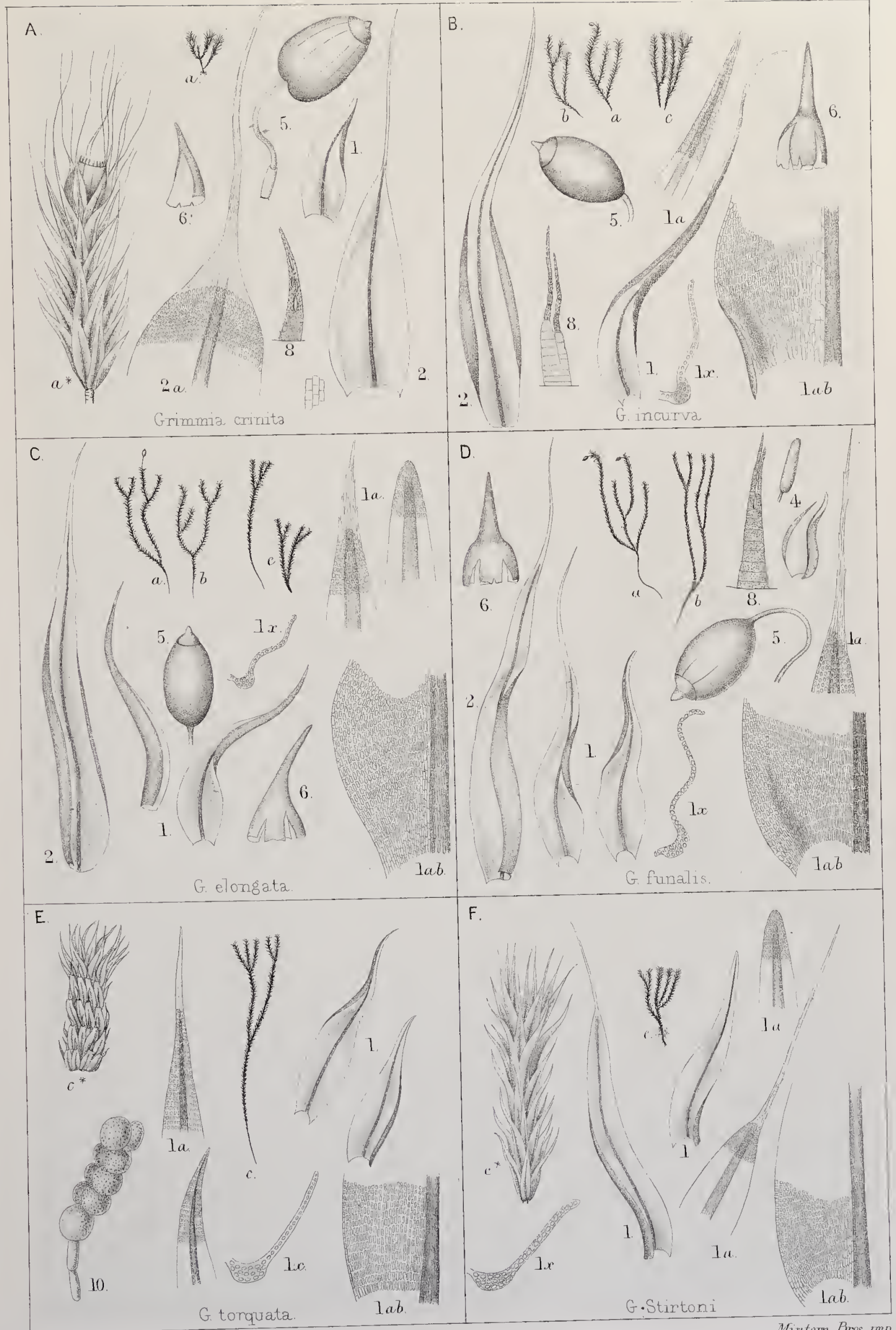

R Broulhwate ud nat dol. ECrrtersc 




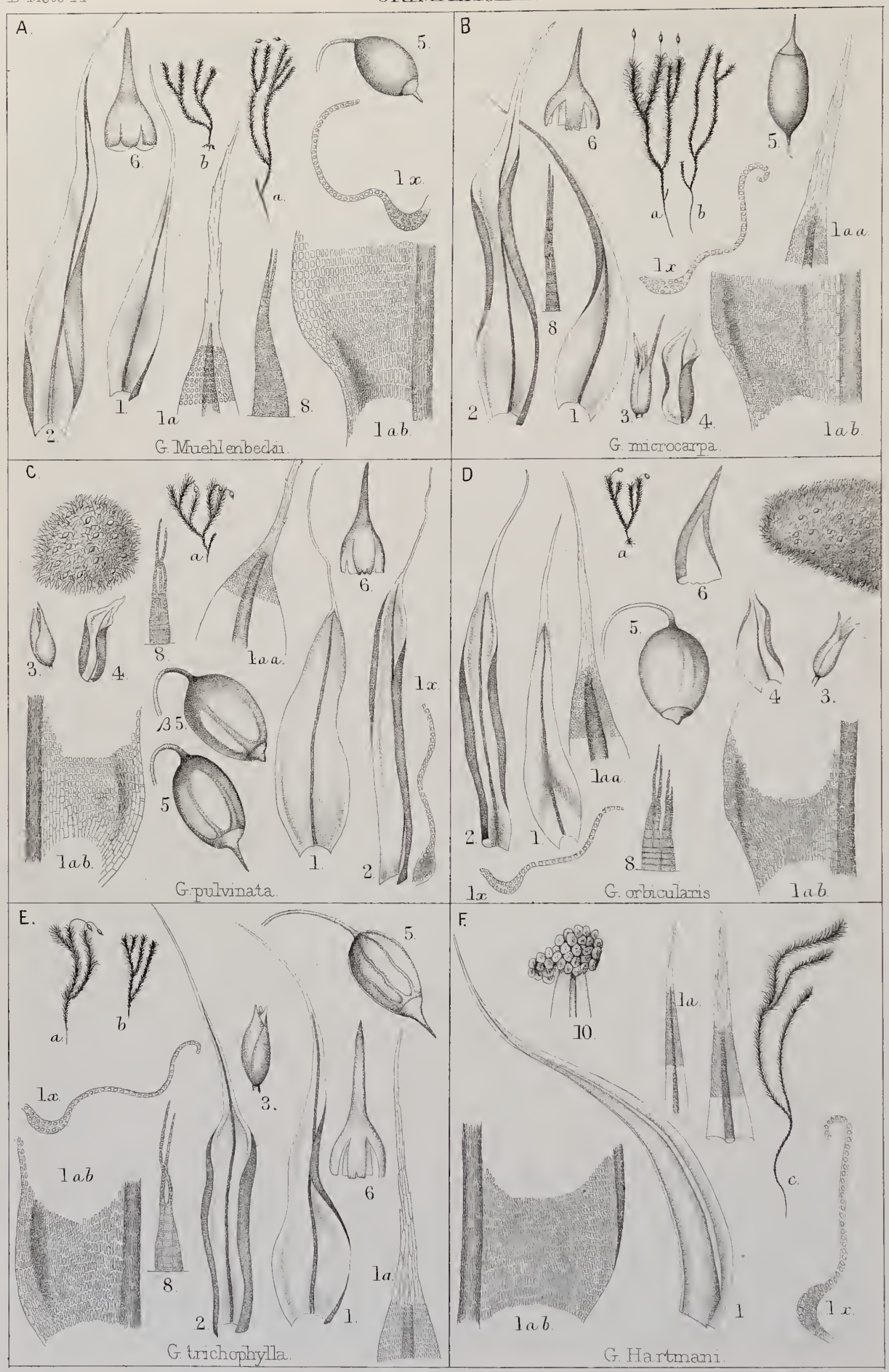

R Brazthwalte ad nat, delt F.Carter se

Whatem Bros тmp 


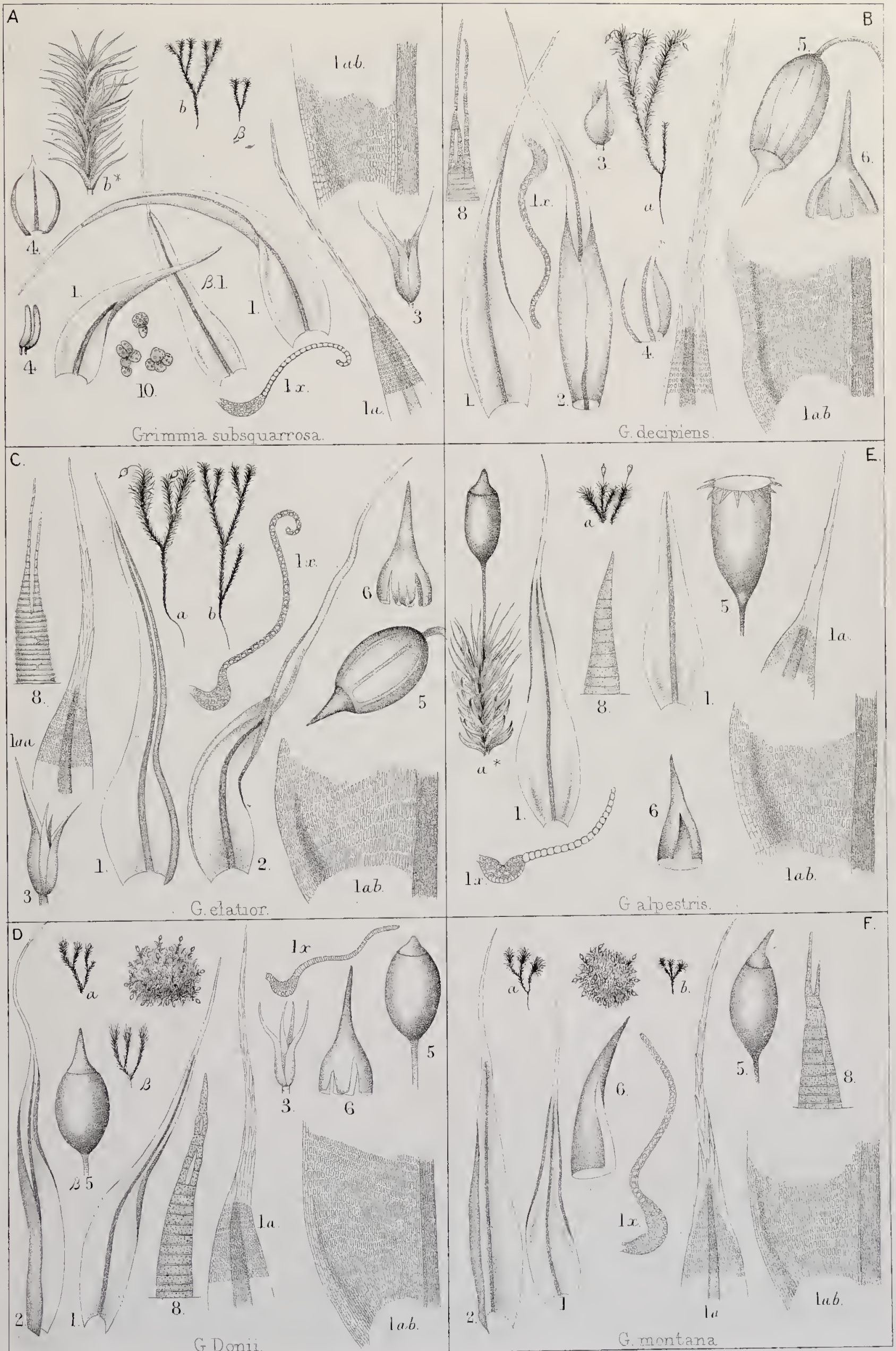

RBuithwaite wh met de ECarterse 




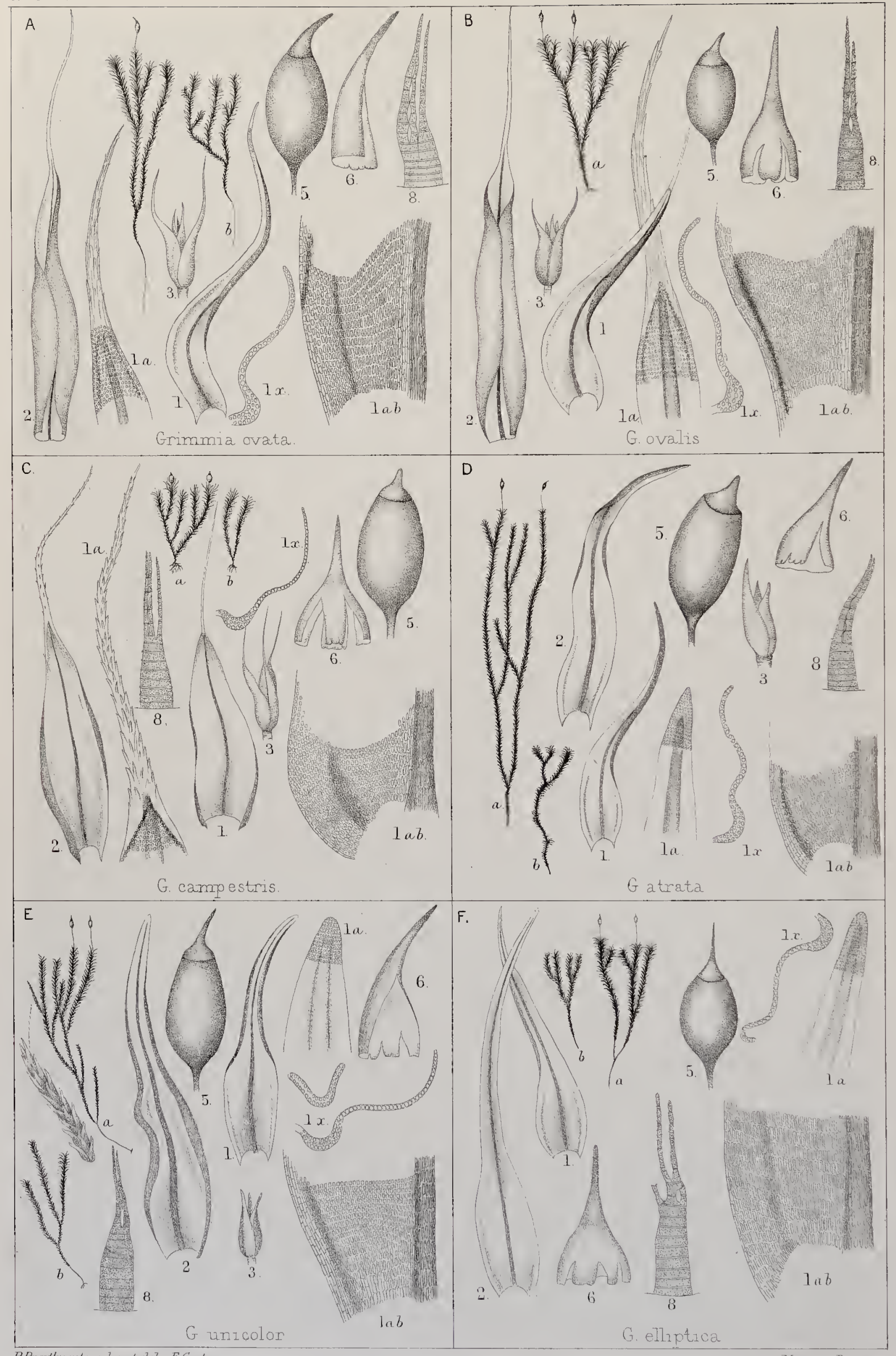



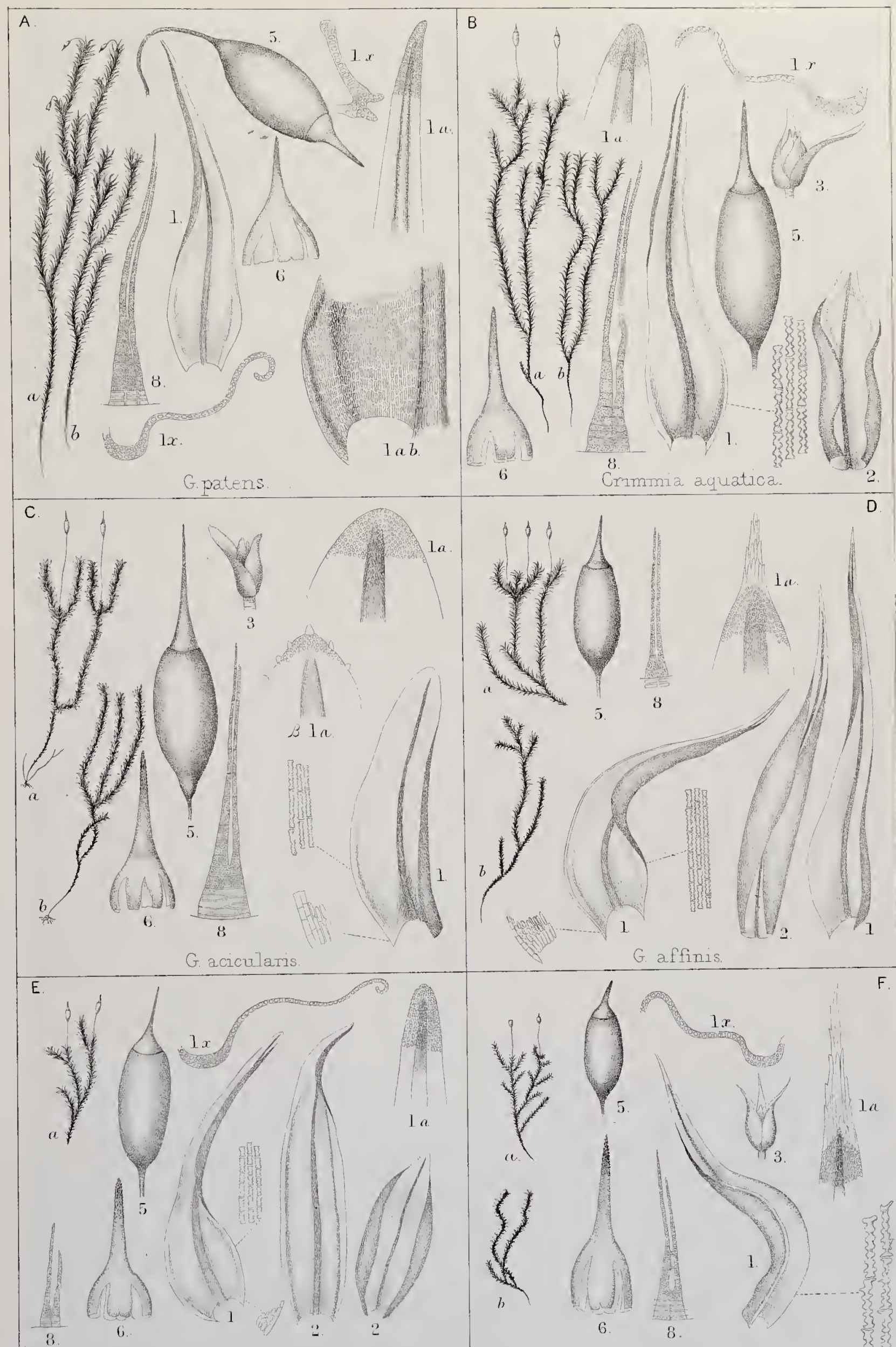

G. obtusa

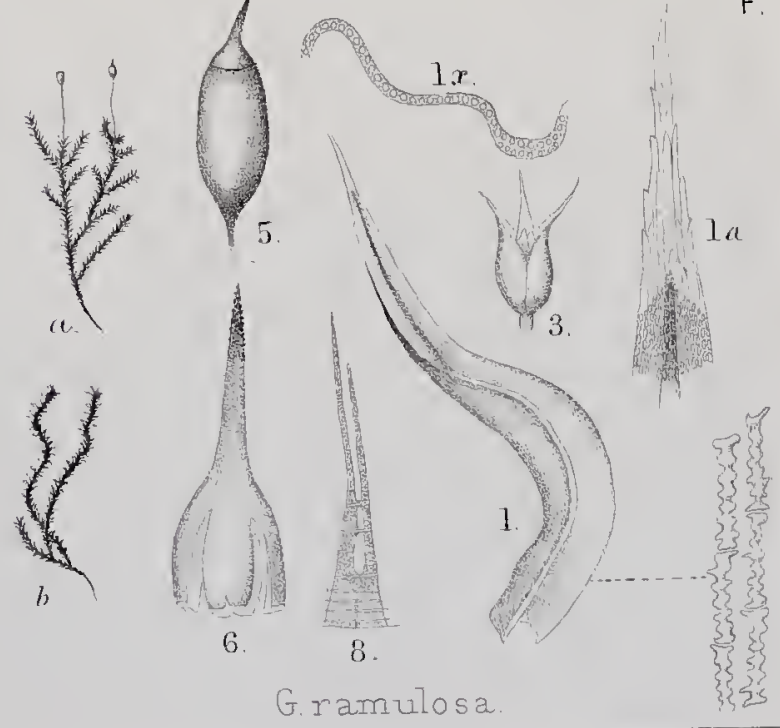






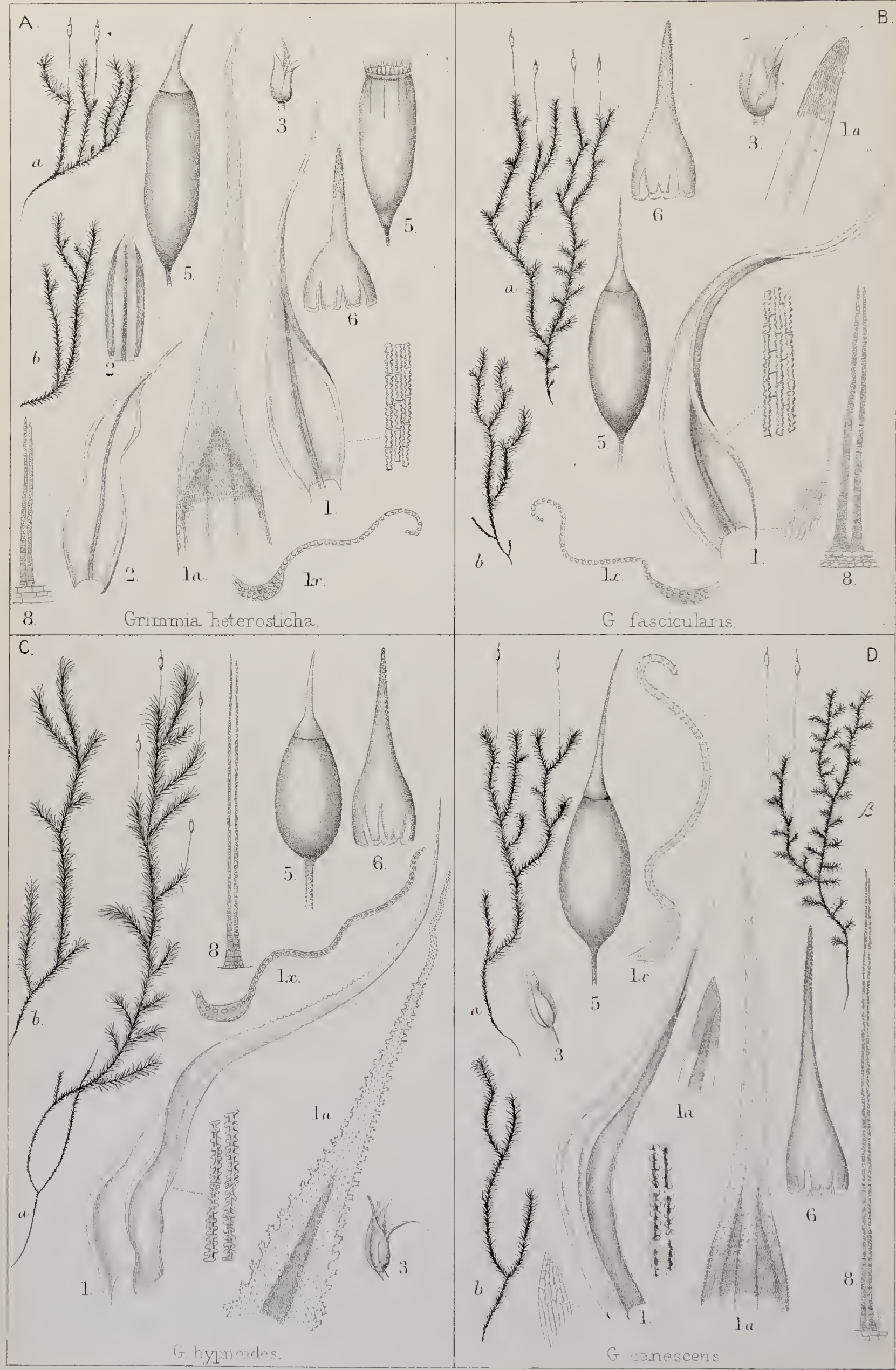

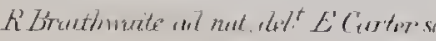




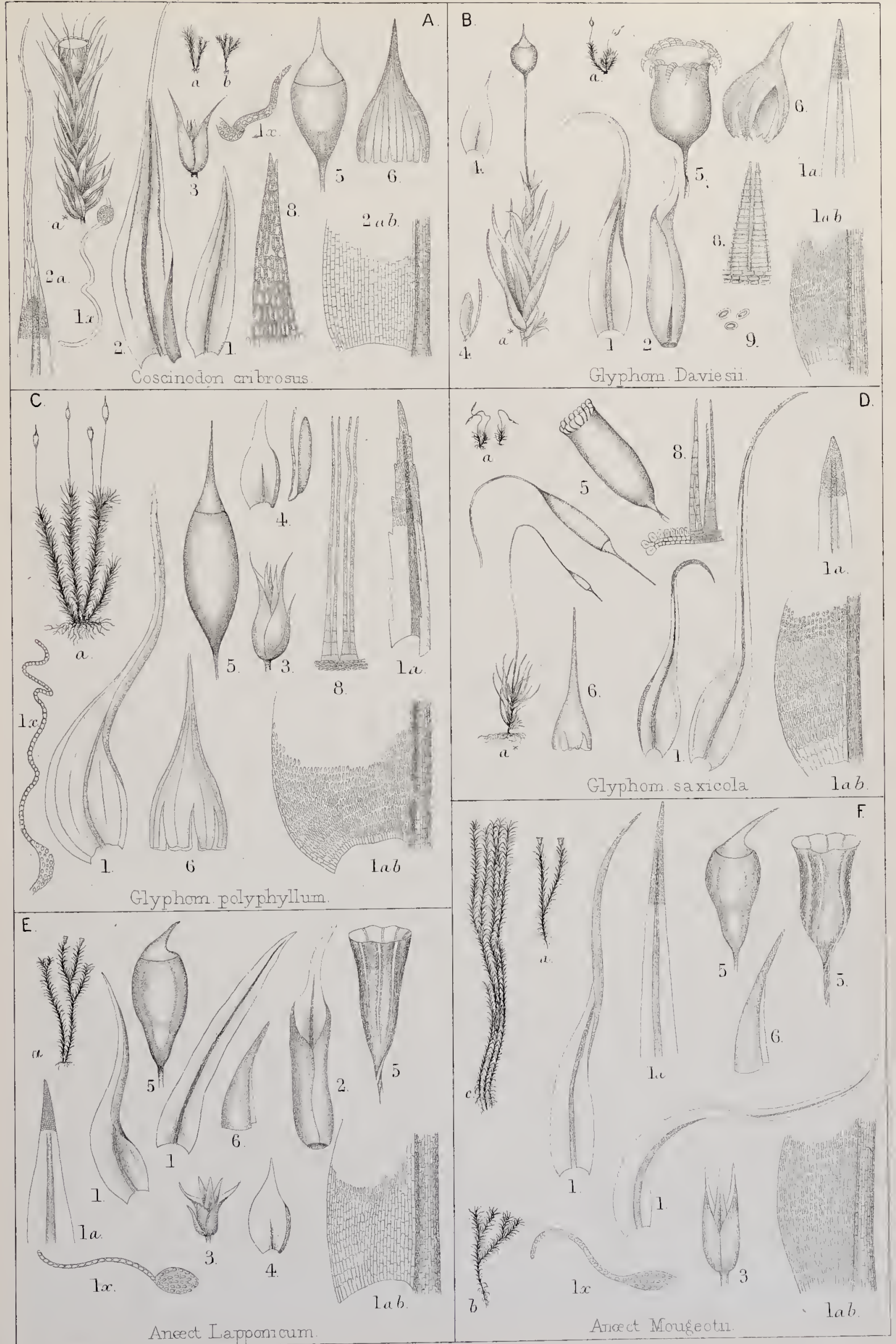

PiBrastravale ad nat det E rarter sc 




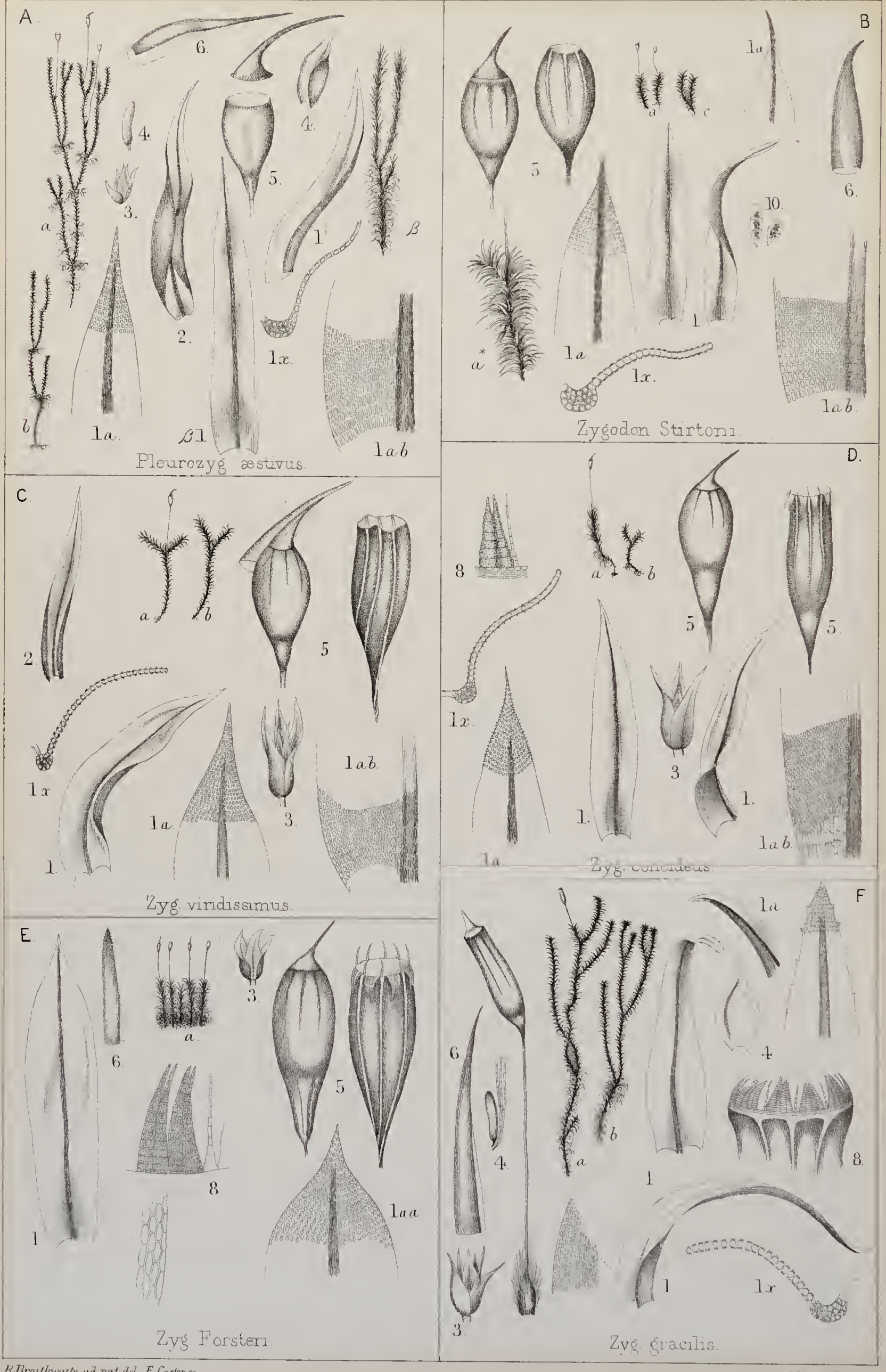

Ifonfern Bren imp 


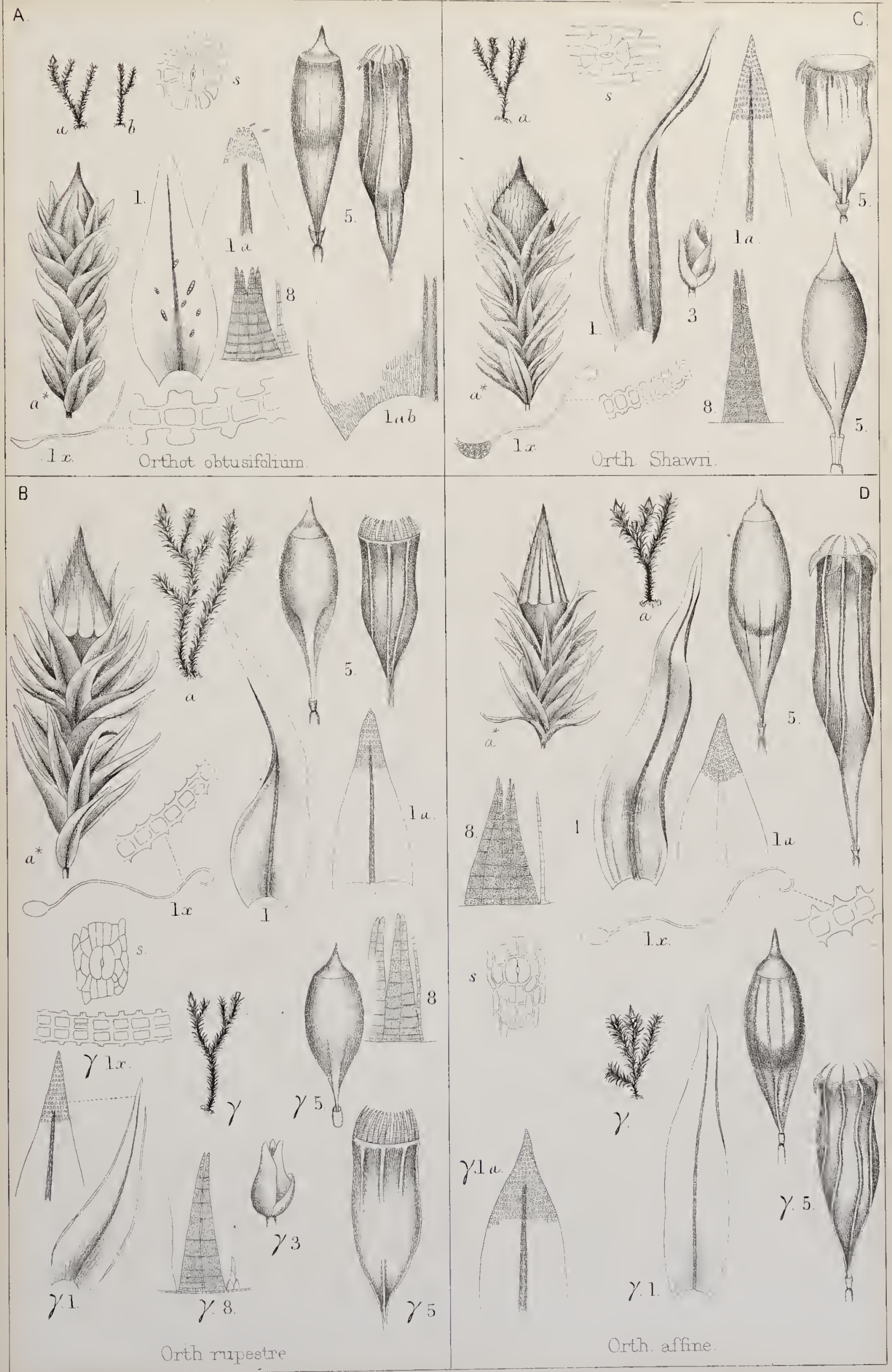






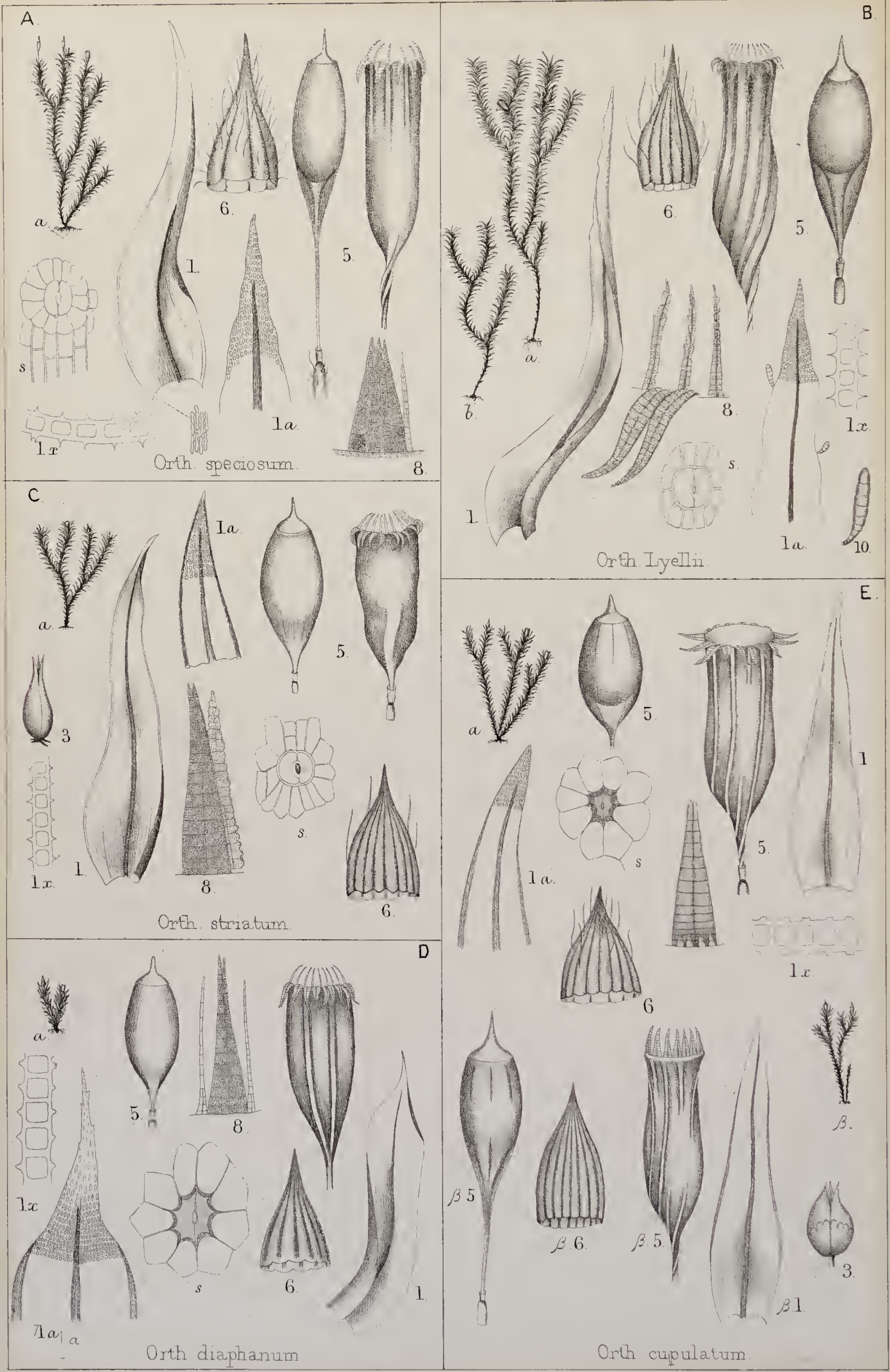




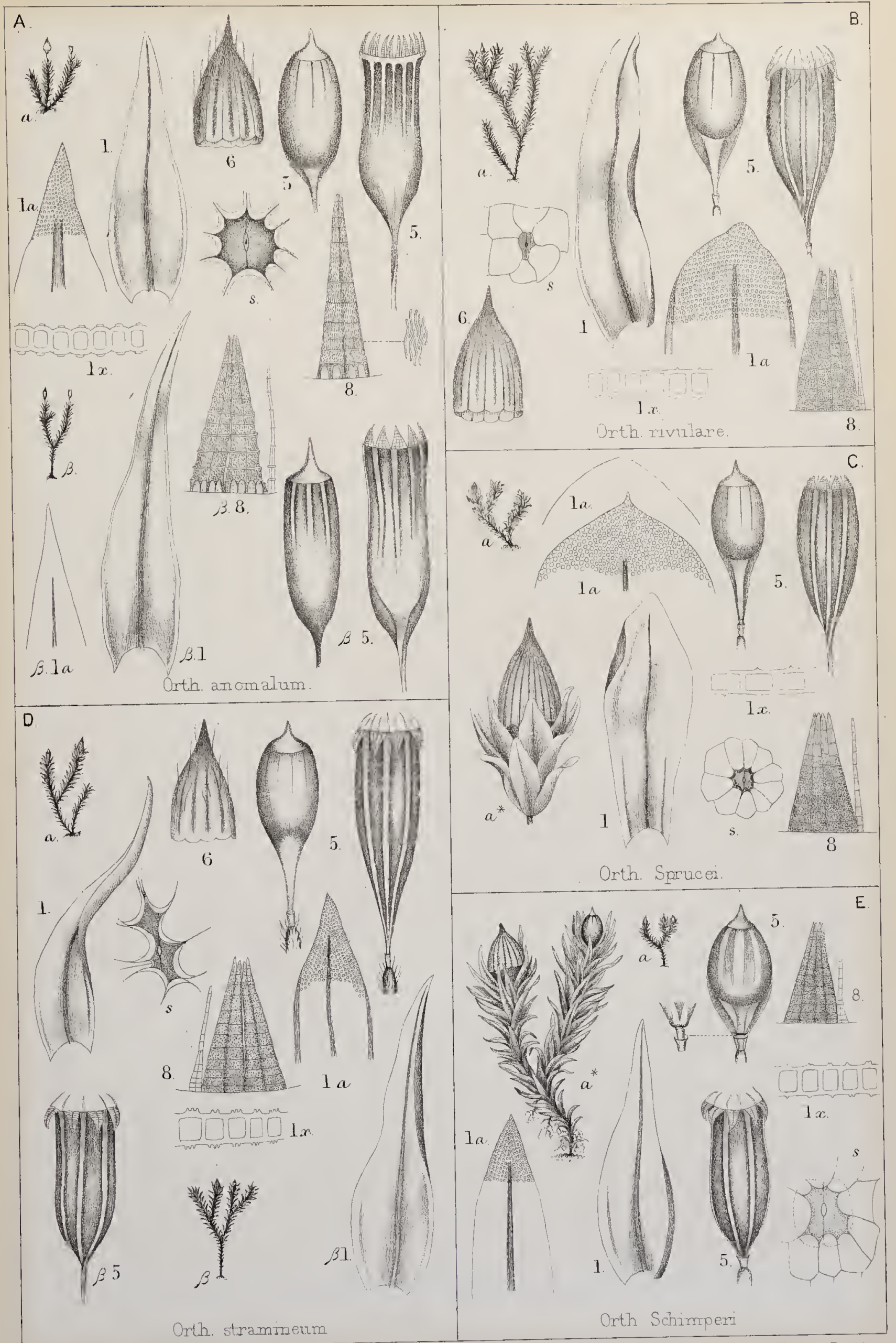

Orth. straminetm 




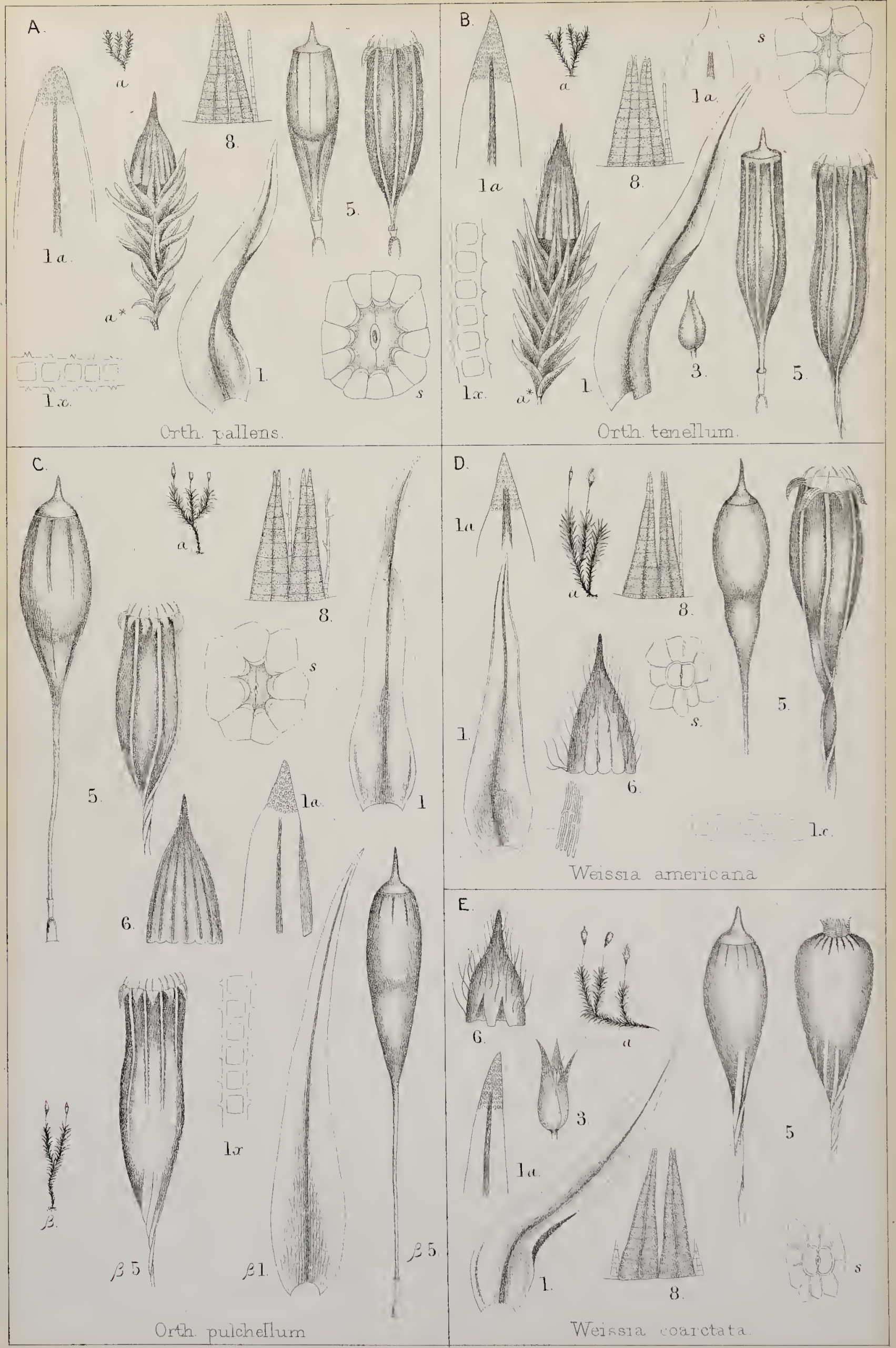

R Brauthwaits ad nat det ECorter so 


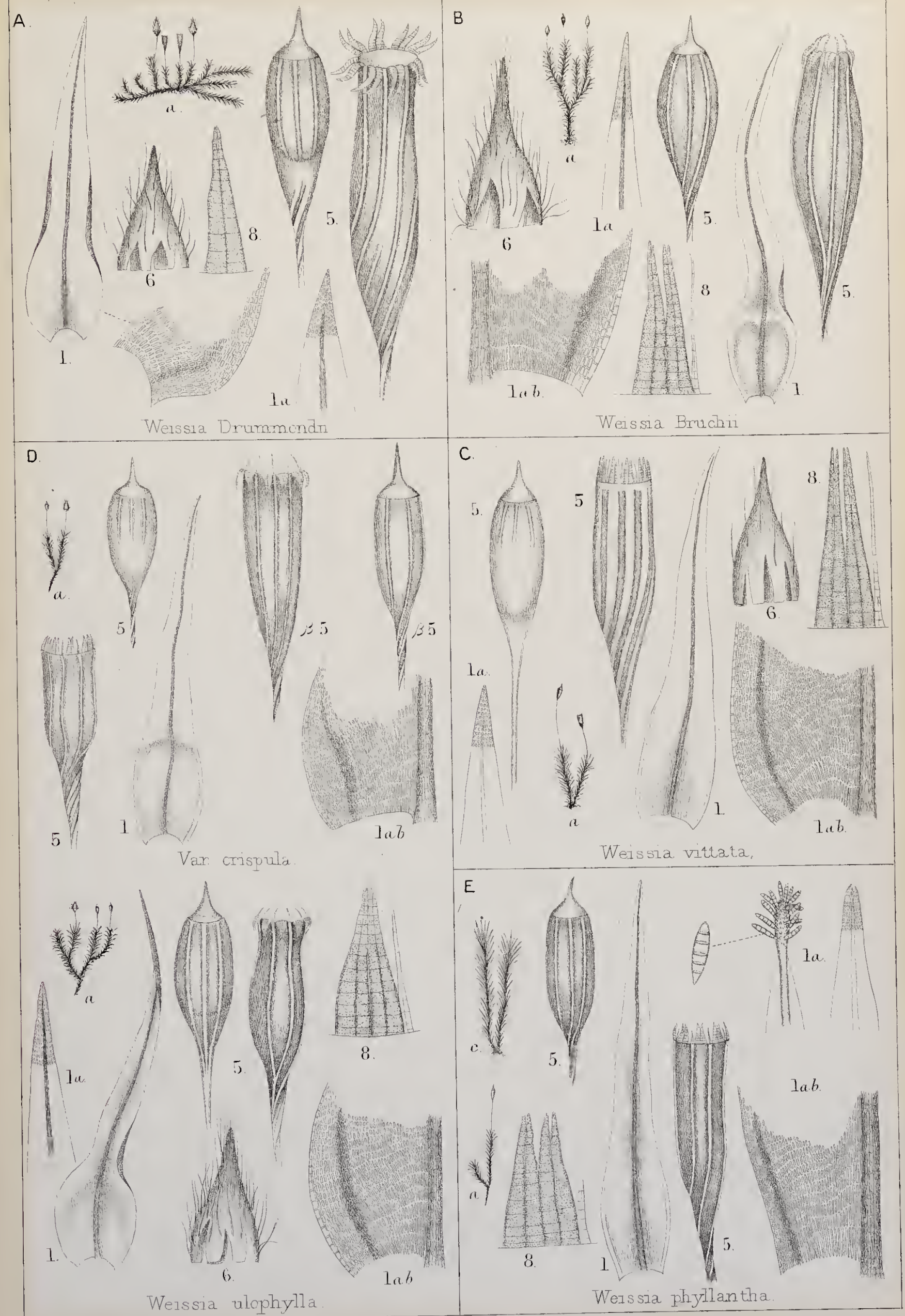

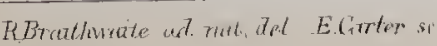





\section{SCH ISTOSTE GACE}


SCHISTOSTEGA MoHr.

Schistostega osmundacea (Dicks.) Mohr. 


\section{Fan. I . SCHISTOSTEGACE}

Plants very small and slender, of two forms, with persistent branching confervoid protonema, simple, rooting only at base; fertile stems naked below, frondiform, with the leaves bifarious, inserted vertically and confluent at base, or only with a terminal rosette of smaller leaves, inserted horizontally and quinquefarious, sterile stems larger, frondiform. Leaves all nerveless, plane, oval-rhomboid, with lax prosenchymatous rhomboidal cells. Capsule minute, globose-oval, exannulate, gymnostomous. Calyptra cylindrico-conical, minute, fugacious. Lid convex. Inhabits dark holes and caverns.

\section{SCHISTOSTEGA Mohr.}

Obs. botan. 26 (1803).

Plants small, slender, naked below. Leaves dimorphous, bifarious and inserted vertically or smaller and comant, inserted horizontally, lanceolate, nerveless, laxly areolate. Capsule minute, globose, gymnostomous; calyptra minute, conical, dimidiate. Der. $\sigma \chi \iota \sigma \tau o s$ cleft, $\sigma \tau \epsilon \gamma \eta$ a lid, applied in error.

\section{SCHISTOSTEGA OSMUNDACEA (Dicks.) Molv.}

The only species of the genus. (T. LX.)

Syn.-Mnium osmundaceum Dicks. Cr. Fasc. I, 3, t. I, fig. 4 (1785).

Dicksonia pusilla Ен Rн. Pl. crypt. n. 65 (1786).

Gymnostomum pennatum Hedw. Musc. fr. i, $7^{8}$, t. 29 ( $7_{787}$ ), Sp. musc. 3 I (I80r). Brid. Musc. rec. II, P. I, 43 (1798), Sp. musc. I, 34 (I806), Mant. musc. I6 (I8I0). Roth Fl. germ. iii, P. I, I28 (1800). RoenL. Moosg. deutsch. 84 (1800), Ann. Wett. ges. II, 133. Spreng. Enleit. 269 (1804). P. Beauv. 59 (1805). Schkuhr Deutsch. kr. gew. P. II, 3I, t. I2 (I8Io). Schwaegr. Suppl. I, P. I, I9 (I8II). MarT. Fl. cr. Erl. I24 ( 1817$)$.

Bryum pennatum GMel. (L.) Syst. nat. ii, I35 (I79I). LaICh. Pl. eur. 482 (I794). Wirh. Bot. arr. br. veg. 3 ed. iii, 82 I (1796). Hull Br. fl. P. 2, 239 (1799).

Gymnostomum osmundaceum Hofrm. Deutsch. fl. ii, 28 (1796). SM. Fl. brit. iii, rr6r (1804), Eng. Bot. t. 2213.

Schistostega osmundacea Moнr Obs. bot. 26 (I803). Weв. Mонг Bot. Tasch. 92, t. 6, f. 9, 1807). RовнL. Deutsch. fl. iii, 4I (1813). Sturm Deutsch. fl. cr. 2, n. I2 (I8I2). Funck Moost. 8 , t. 6 (I821). NEes Horssch. Bry. germ. i, Io8, t. 9, f. I (1823). Brid. Bry. univ., i, Iro (1826). Hueben. Musc. germ. 65 (1833). Br. Sch. Bry. eur. fasc. I7 (1843). Rabenh. Deutsch. kr. fl. ii, S. 3, 306 (1848). C. Muell. Synops. i, 38 (1849). Wils. Bry. brit. 300, t. 8 (1855). Schimp. Synops. 293 (Ir60), 2 ed. 352. Berk. Handb. Br. m. I6r, t. I4 (1863). DE Not. Epil. bri. ital. 726 (1869). MrLdE 
Bry. siles. I 84 (I869). HoBk. Syn, br, m, I35 (I873). HUSN. Mouss. nord-ouest II 2 (I873), Musc. gall. 200, t. 54 (I888). JuRATZ. Laubm, oesterr.-ung. 223 (I882). LesQ. James Moss. N. Amer. I88 (I884).

Schistostega pennata Hook. TAYL. Musc. br. I4, t. 8 (I8I8). GRev. in Mem. Wern. Soc. iii, 363 (I82I). Gray Nat, arr. br. pl. i, 7I3 (I82I). Hook. Br. fl, ii, I2 (I833).

Dioicous; springing annually from a persistent, branched confervoid protonema, composed of globose cells, roid of chlorophyl. Tufts loose, soft, pale bluish-green, rufescent at base. Stems very slender, naked at base, the vertical leaves rhomboidal, acuminate, decurrent and confluent at base, the horizontal smaller lanceolate, all entire, nerveless, with lax, rlombic sparingly chlorophyllose cells. Caps. on a long seta, minute, globose-oval, brownish-green ; lid yellow with a red margin. Male infl. terminal, gemmiform, antheridia and archegonia without paraphyses.

HAB.-Caverns in sandstone recks, and dark holes. Fr. 3-4.

Between Zele and S. Tawton, Devon (Newberry). Tildersley and Worsley, Ianc. (Evans).
Gallows hill, Nottingham forest (Fowitt). Rowter rock, Winster, Derby (Bomeman)
Helsby crag, Warrington (Wilson)! Green's clough and Thieveley scouts (Nowell)!!
Alderley edge (Hunt). Frodsham, Cheshire (IVilson). Upton's sand caves, Overton
hills, Cheshire (Robinson I866)! Trengwainton quarry, Cornwall (Curnoz'). In old
rabbit holes, Bickleigh down, Yanaton down, Leatherton-tor and Mount Edgcumbe
(Holmes)!! Bolney, Sussex (Mitten). Charlesworth and New Mills, Derby
(IVhitchead). Near Guisbro, Yorks. (R. Barnes I888)!!

This lovely little moss is quite peculiar for the manner in which the distichous leaves run into each other at the base, as well as for the remarkable effect produced by the confervoid protonema (Catoptridium smaragdinum Brid. Bry. univ. ii, t. Suppl. I.), the globose cells of which act as lenses, and refract the light rays, producing a golden green or iridescent effulgence.

\section{TAB. LX.}

Schistostega osmundacea (Guisbro', R, Barnes).

a. Fertile plant. a*. a**. The same magnified. b**. Male plant mag. I. Tertical leaves. 2. Protonema. 3. Antheridia and bràct. 4. Calyptra. 5. Capsule. 


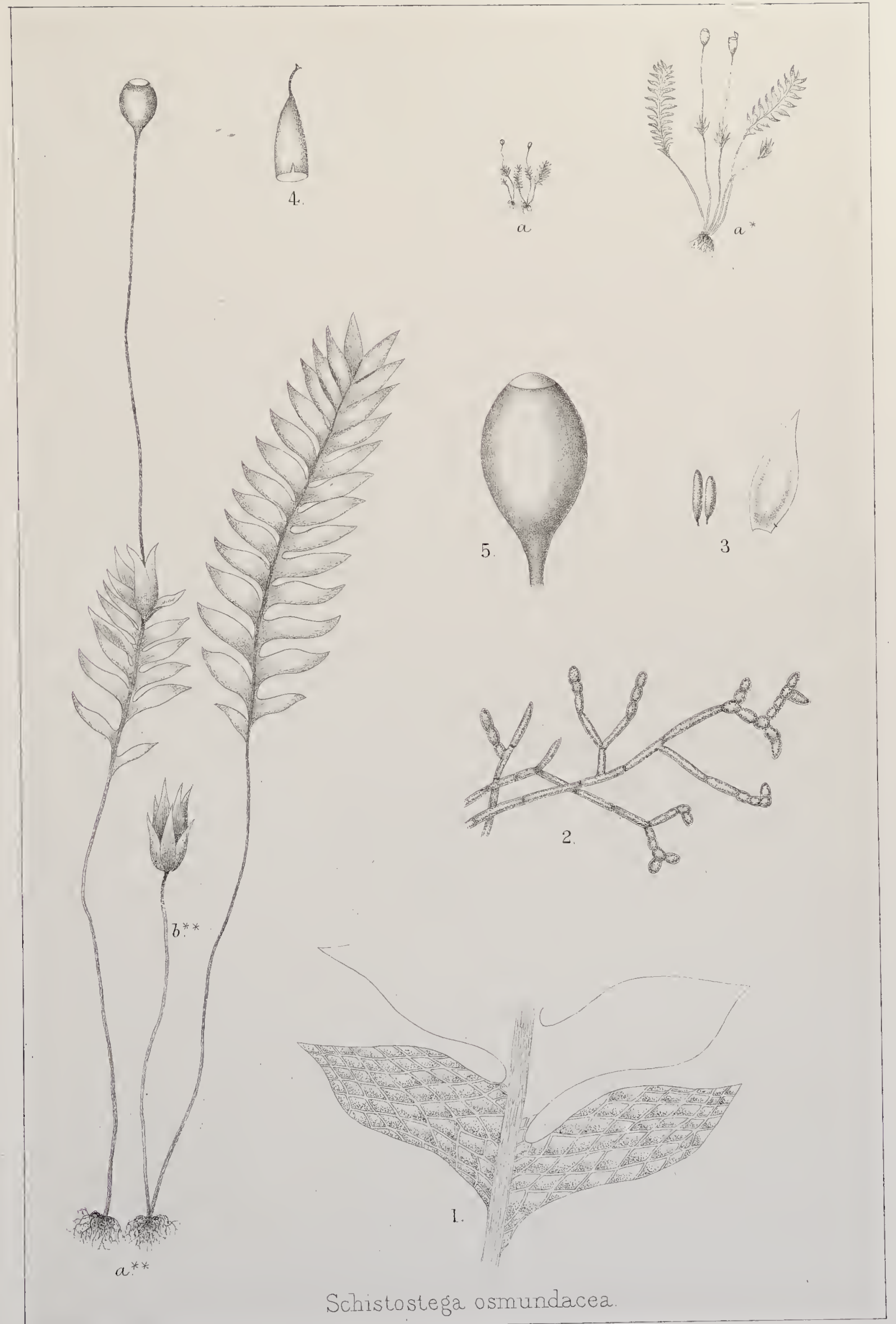



S P LACH N A E Æ. 
SPLACHNUM L.

1. Splachnum ampullaceum $L$.

2. - vasculosum $L$.

3. —— pedunculatum (Hidds.) Lindb.

TETRAPLODON BR. SCH.

1. Tetraplodon bryoides $(Z \circ c g a)$ Lindt.

2. - angustatus (Sw.) Br. Sch.

TAYLORIA Hook.

1. Tayloria tenuis (Dicks.) Schimp.

2. __ lingulata (Dicks.) Lindb. 


\section{Fan. I2. SPLACHNACEA.}

Plants gregarious or cæspitant, dichotomous with few branches. Leaves slender-nerved, broad, membranous and flaccid, the cells large lax pellucid, rhombic or pentagonal, smooth. Infl. terminal, the male subdiscoid or capituliform. Capsule on a tall seta, subcylindric, erect, with a distinct hypophysis which is obconic, pyriform, globose or umbrella-shaped, collapsing when old; calyptra cucullate and cleft on one side or conic and entire; peristome of 16 geminate or 8 bigeminate lineal-lanc. teeth, strongly lygroscopic; spores smooth. Inhabiting the earth, but especially on rotten dung and other animal matters.

This distinct family comprises about 40 species, some of them ranking amongst the most elegant of known mosses, and especially remarkable for the great spongy and often gaily coloured hypophysis, which forms the major portion of the fruit.

The cleistocarpous genus Voitia HoRNscH. finds its most natural place in this family.

\section{SPLACHNUM $L$.}

Sp. plant. I Io8 (I753).

Plants laxly tufted, with slender dichotomous stems. Leaves remote, patulous, the upper rosulate, broadly obovate-lanc. narrow at base, cells very lax, hexagonal. Caps. on a long seta, oval and shortly cylindric, on a very much larger hypophysis of a different colour, and pyriform, globose or umbraculiform; teeth of peristome $\mathrm{I} 6$, lineal, geminate, reflexed when dry. Inhabiting rotten peat and dung.-Der. $\Sigma \pi \lambda a \gamma \chi^{v o v}$ used by Dioscorides for the lichen Sticta pulmonaria.

This genus comprises 7 species which fall naturally into two sections according to the form of the hypophysis; in the first of these, Ampullaria C. Muelz.-to which all our British species belong,-- this organ has the form of an inverted flask, but in Umbracularia it is immensely dilated like an expanded umbrella. The species referable to the latter are S. vubrum, luteun and melanocaulon, and it is quite possible that $S$. lutenn may turn up in some of the deer forests of Sutherland or Caithness, although all three are most at home in Lapland.

\section{Clavis to the Species.}

Hypophysis vesicular, tapering downward. globose. 


\section{SPLACHNUM AMPULLACEUM $L$.}

Autoicous and dioicous; leaves obovato-lanc. acutely acuminate, serrate in upper part; caps. oblong with a large inversely flask-shaped hypophysis tapering down into the seta. (T. LXI, A.)

Syn.-Adiantum anreum minus palustrc, capitulis erectis coronatis W. Sherard. Ray Synops. 237 ( I6go).

Bryum ercctis gigartinis capitulis, foliis scrpylli pcllucidis acutis DILL. in RAY Syn. 3 ed. 93 , n. 6 ( 1724 ).

Brym ampullacenm, foliis thymi pellucidis, collo strictiori Dill. Hist. musc. $343, \mathrm{t} .44$, f. 3 ( $174 \mathrm{r}$ ), et Herb.

Splachnum ampullaceum L. Sp. pl. iाo8 (I753). Syst. nat. ii, 699. Amœen. acad. ii, 280. Huds. Fl. angl. 399 (I762). Neck. meth. musc. I25 (I77I). Wiтh. Bot. arr. br. veg. ii, 66i (I776). Lightf. Fl. scot. ii, 696 (I777). Fl. dan. t. 822 (I780). Ehrн. Hann. Mag. I780, p. 235. Hedw. Fund. II, 88, t. 7, f. 33, 34 (I782); Musc. fr. ii, 4I, t. I4 (I788); Sp. musc. 53 (I8OI). ReLH. Fl. cant. 4I4 (I785). Roth Fl. germ. i, 454 (1788). Sm. Eng. Bot. t. I44 (ז793), Fl. brit. iii, II75 (I804). Sibth. Fl. oxon. 275 (I794). Hoffm. Deutsch. fl. ii. 23 (I795). Brid. Musc. rec. II, P. I, Iog (I798), Sp. musc. I, 82 (1806), Mant. I08 (r8Ig), Bry. univ. i, 259 (I826). Swartz Musc. suec. 23 (I798). Аввот Fl. bedf. 23 I (I798). Hull Br. A. P. II, 246 (I799). Roehl. Monsg. deutsch. 225 (I800); Deutsch. f. iii. 43 (I8I3). Turn. Musc. hib. I6 (I807). P. Beauv. Prodr. 88 (I80j). Web. Mohr Bot. Tasch. 99 (i807). Schivaeg. Suppl. I P. I, 52 (I8II). MART. Fl. cr. erl. II6 (I8I7). Hook. TAYL. Musc. brit. 20, t. 9 (r8I8). Hook. F1. scot. P. 2, I25 (I82I); Br.fl. ii, I5 (I833). Funck Moost. II, t. 7 (I82I). Gray Nat. arr. br. pl. i, 7 I8 (I82I). Hueben. Musc. germ. 77 (I833). Mack. Fl. hib. P. 2, I3 (I836). De Not. Syllab. 27 I (I838), Epil. bri. ital. 46r (I869). Br. Sch. Bry. eur. fasc. 23-24, p. ro, t. 6 (I814). Rabenh. Deutsch. kr. fl. ii, S. 3, 95 (I848). C. Muell. Synops. i, I46 (I849). Wils. Bry. brit. $28 \mathrm{~g}$, t. 9 (1855). Schimp. Synops. 309 (I860), 2 ed. 369. Berk. Handb. br. m. I66, t. I5 (I863). Milde Bry. siles. I 87 (I869). Hobis. Syn. br. m. I33 (I873). Husn. Mouss. nord-ouest I I3 (I873), Musc. gall. 206, t. $5^{6}$ (I888). JuRAtz. Laubm. oester.-ung. 235 (I882). Lesq. James Moss. N. Amer. I94 (1884).

Sflachnum Tumerianum Dicks. Cr. fasć. 2, p. 3, t. Io, f. I I (I79o). BRID. Sp. musc. I, I53; Mant. I08. Sm. Eng. Bot. t. III6; Fl. brit. II76.

Autoicous and dioicous, in small lax tufts. Lower leaves lanceolate, upper obovato-and elongato-lanc. with a long acute point, coarsely serrate at point, very soft, pale green, the nerve vanishing below apex. Caps. ovali-cylindric pale yellow, the hypophysis large, pyriform, succulent, pink when young, purple when old, defluent on a long purple seta ; lid convex, yellow, teeth pale yellow, rather obtuse, 8 bigeminate and erect, finally 6 geminate and reflexed against caps. wall. Male infl. terminal, the bracts broadly oval at base, longly lineal-subulate.

HAB.-On dung on wet heaths. Fr. 5-6.

Near Itchin Ferry (Shcrard). Near Addington, Surrey (Dillcuilus). Snowdon (Griffith). Exeter (Turner). Ashdown Forest (Borrcr). Terrington Carr, Yorks. (Tcesdalc)!! Ross, Hereford (Watkins)!! Windermere (Nowell I859). Kildale, Yolks. (Mndd 1855). Oxford (Boswell I857). Levens (Barncs I868). Bowness (Hunt 1867). Devon (Holmcs). Stayley Brushes (Whitchcad), and many other places in England and Ireland.

Our most beautiful species, varying considerably in the size and colour of the hypophysis, which when fully developed is of a clear lilac tint, but often it is quite narrow and pale greenish, and then represents the form S. Turnerianum. 


\section{SPLACHNUM VASCULOSUM $L$.}

Dioicous, deep green. Leaves ovate, obtuse, entire. Caps. cylindric, with a large globose dark purple hypophysis. (T. LXI. B.)

Syn.-Splachumm vasculosum L. Sp. pl. 2 ed. I 572 ( $7_{76}$ ), Syst. nat. ii, 699. Ehrir. Hann. Mag. I784, r. 142. HeDw. Musc. frond. ii, 44, t. I5 (I788), Sp. musc. 53 (I80I). Hoffm. Deutsch. f. ii, 23 (r795). Brid. Musc. rec. II, P. I, Iro (1798); Sp. musc. P. I, I52 (I806); Mant. I07 (I8I9); Bry. univ. i, 257 (I826). SwarTz Musc. suec. 23 (r798). P. Beauv. Prodr. 89 (1805). Web. Mohr Bot. Tasch. roo (1807). Schkuhr Deutsch. kr. gew. P. II, 4r, t. I7 (I8ro). Fl. dan. t. I4I3 (I8ro). ScrwaEg. Suppl. I, P. I, 57 (r8Ir). Wahlenb. Fl. lapp. 308 (I8I2). Hook. Tayl. Musc. br. 2I, t. $3^{\mathrm{I}}$ (I818). Hook. Fl. scot. P. 2, I25 (1821); Br. Fl. ii, i6 (1833). Funck Moost. ii, t. 7 (r821). Gray Nat. arr. br. pl. i, 7 rg (I82I). Grev. Scott. cr. f. t. I79 (I826). Hueben. Musc. germ. $78(1833)$. BR. Sch. Bry. eur. fasc. $23-24$. p. II, t. 7 ( 8444$)$. Rabenh. Deutsch. kr. fl. ii, s. 3,94 (I848). C. Muell. Synops. i. 145 (1849). Wils. Bry. br. 288, t. 3 I (1855). Schimp. Syn. 308 (I860), 2 ed. 368 . Berk. Handb. br. m. r66, t. 15, f. 5 (1863). Milde Bry. Siles. 187 (1869). Hobk. Syn. br. m. I33 (1873). Leso. James. Moss. N. Amer. r94 (r884). Husn. Musc. gall. 206, t. 56 (I888).

Splachnum rugosum Dicks. Crypt. Fasc. iv, t. Io, f. 7 (r8or). Sm. Fl. brit. Ir73; Eng. Bot. t. 2094. Brid.-Web. Mohr.-SchkuHr.

S. zasculosum Var. acutifolia Grev. Scott. cr. fl. t. 3 rI.

Dioicous; in soft swelling deep green tufts, black at base. Stems nearly simple or innovating, radiculose, $\mathrm{I}-3$ in. high. Leaves large, distant, narrow at base, lower suborbiculate, upper broadly ovate, somewhat acuminate, obtuse, entire, nerve thin vanishing below apex; cells oblong-hexagonal. Caps. shortly cylindric, rufous, seta pale red, long as stem, hypophysis large spherical, minutely tubercular, dark purplebrown, wrinkled when dry and becoming black by age; lid convex, yellow; teeth conjoined in pairs, shorter, orange. Male plants more slender, often in separate tufts, the leaves smaller and more remote, infl. terminal, the bracts from a broadly oval sheathing base, longly acuminate, obtuse.

Нав.-Wet peaty places in the Highlands. Fr. 7 .

Ben Lawers (Mackay I803)!! Clova (Don). Ben More of Dochart. Fewla burn and Loch Brandy (Gardiner)!! Glass Mhiel (7. B. Syme $185 \mathrm{r}$ ). Glen Prosen (Fergusson 1868)!!

A fine moss only found at considerable elevations and in boggy places, the old capsule becoming singularly wrinkled and pitted.

\section{SPLAChNUM PEDUNCULATUM (Huds.)}

Dioicous; laxly tufted. Leaves spreading, obovate-acuminate, entire or serrated, nerved to apex. Capsule subcylindric, hypophysis ovate or subspherical, teeth large, lineal, reflexed. (T. LXI, C.) 
Syn. - Muscus trichoides palustris cestivus, capitulis nigris erectis, collo luteo finbriato D. Richardson. Dill. in Ray Syn. 3 ed. 93 (I 724 ).

Bryum erectis gigartinis capitulis, foliis serpylli pellucidis obtusis DıLL. 1. c. T. 3, fig. 2.

Bryum ampullacenm, foliis thymi pellucidis, collo crassiorc DILL. Hist. musc. 344, T. 44, f. 4 (I $74 \mathrm{I})$ et Herb.

Phascum pedunculatum Huds. Fl. angl. 397 (г762). Wıтн. Bot. arr. Br. veg. ii, 660 ( 1776$)$.

Splachnum longisctum Schrank Baiers. fl. ii, 44 r (I789).

Splachnum ovatum Dicks. Pl. cr. fasc. II, 2 (I790). W1тн. Bot. arr. 3 ed. iii, 793 (r796). Brid. Musc. rec. II, P. I, 103 ( $\left.179^{4}\right)$, Sp. musc. I, I 49 (I 306$)$, Mant. Io6 (I819), Bry. univ. i, 253 (1826). Hull Br. A. P. 2, 246 (1799). Hedw. Sp. musc. 54, t. 8, f. 4-6 (180i). Turn. Musc. hib. I5 (I804). SM. Fl. brit. II73 (1804); Eng. Bot. t. I59o. Schwaeg. Suppl. I, P. I, 50 (I8II).

Splachnum spharicum plur. auct.

Dioicous; laxly cæspitose, deep green. Stem short, with long radicles. Lower leaves remote, minute, acuminate-ovate, upper much larger, crowded in a patulous coma, from a narrow base broadly obovate, acuminate, entire or coarsely serrate, nerved to apex, cells oblonghexagonal. Seta elongated setaceous, orange. Caps. subcylindric, greenish-fuscous, hypophysis thicker, glossy, ovate, blackish-red; lid mamillate, teeth large, lineal, approximate in pairs, orange, finally reflexed against the caps., columella much exserted, capitate; calyp. small fugacious. Male plant more slender, bracts from a broad concave sheathing base, longly apiculate.

Hab.-Dung of sheep and cattle on wet moorlands; common in alpine districts. Fr. 5-6.

\section{Var. $\beta$ sphæricum (Swartz).}

Stem simple, leaves spathulate-acuminate, serrated at apex; hypophysis globose, red-brown, long as capsule.

Srn.-Splachnum spharicum Swartz Meth. musc. 373, t. I, f. I (I787), Musc. suec. 22. Hedw. Musc. fr. ii, 46, t. I6. Sp. musc. 55. With. Bot. arr. 3 ed. iii, 79I. Hoffar. Deutsch. fl. ii, 22. BrId. Musc. rec. II, P. I, I I I ; Sp. musc. I, I50; Mant. Io7 ; Bry. univ. i, 256 . Roenl. Moosg. deutsch. 23 I Deutsch. f. iii, 44. Turn. Musc. hib. I5. SM. Fl. brit. I 174; Eng. Bot. t. 785. RoTh Fl. germ. iii, P. I, I36. Web. MoнR Bot. Tasch. Ioo. Schkuhr Deutsch. kr. gew. P. II, 40, t. I6. SchWaeg. Suppl. I, P. I, 54. Wahlenb. Fl. lapp. 308. Hook. TAYl. Musc. br. 18, t. 9. Hook. Fl. scot. P. 2, I24. Gray Nat. arr. i, 717. Hueben. Musc. germ. 8o. De Not. Syll. 272, Epil. 462. Br. Sch. Bry. eur. fasc. 23-24. C. Mulld. Synops. i, I44. Wils. Biy. br. 290, t. 9. Schimp. Synops. 307. BERK. Handb. br. m. I65. Milde Bry. siles. I87. Hokk. Synops. I33. Husn. Musc. gall. 206, t. 56 . Juratz.

Splachnum gracilc Dicks. Crypt. Fasc. IV, 3, t. Io, f. 5. Bridel. Sm. Fl. brit. Eng. Bot. t. Ig2I. Schwaeg. Suppl. I, P. I, t. I5.

Splachnum vasculosum Lightf. Fl. scot. ii, 697 (1777). Huds. F1 angl. 2 ed. 469 (I778). Hull Br. A. 245.

S. refractum BR1D . Sp. musc. I, I45 (I 806).

S. pusillum P. Beauv. Prodr. 89 .

HAB.-In similar localities, but more common. 
This moss varies very much in size, and in the width and serration of the leaves, and sometimes the filiform seta attains a length of 7 inches. The difference between the typical form and the variety lies in the hypophysis, which is more elongated in the former. Dickson's $S$, ovatum is represented on fig. $2 \mathrm{~A}$.

\title{
2. TETRAPLODON Br. Sch.
}

\author{
Bry. eur. fasc. $23-24$ (1 844$)$.
}

Densely crespitoso-pulvinate, interwoven below with radicular tomentum. Leaves elongate-lanc. or ovate-oblong, running out into a subulate point. Calyptra conico-cucullate, then cleft to middle; caps. oval-cylindric, solid, with a thicker obconic solid hypophysis of same colour; teeth shorter, conjoined in fours, solid, finally geminate, reflexed when dry, columella not exserted. Der. $\tau \epsilon \tau \rho a \pi \lambda$ ovs fourfold, odovs a tooth.

This small genus of 4 species differs from Splachmm principally in the fruit, the capsule and hypophysis being of the same colour and consistence, and the latter not inflated.

\section{Clavis to the Species.}

Seta elongated; leaves entire.

bryoides.

very short; leaves serrated. angustatus.

\section{TETRAPLODON BRYOIDES (Zoga) Lindb.}

Autoicous; leaves obvate, suddenly attenuated into a long point, entire. Caps. on a long. seta, oval, blackish, with an obovate hypophysis; lid conic, obtuse. (T. LXII, A.)

Syn.-Splachnum bryoides Zoega in OlaFs. et Pov. Reis. Island ii, I2 (I $77^{2}$ ).

Splachnum mnioides Swartz Meth. musc. 26 (I78I), Nova act. Upsal. iv, 24I (I784), Musc. suec. 23. Dicks. Fasc. pl. cr. I, 2 (I785). Hedw. Musc. fr. ii, 36, t. I I (I788),

Sp. musc. 5I. Schrank Baiers. Al. ii, 440 ( 1789$)$. With. Bot. arr. 3 ed. iii, 793 (1796). Brid. Musc. rec. II, P. I, IO3 (I798), Sp. musc. I, I42 (I806), Mant. IO4 (I8Ig), Bry. univ. i, 240 (I826). Hull Br. f. P. 2, 246 (I 799). SM. Fl. brit. II69 (I804), Eng. Bot. univ. i, 240 (I826). Prodr. 89 (I805). Web. Mohr Bot. Tasch. I03 (1807). Schkuhr Deutsch. kr. gew. P. II, 42, t. I8 (I8Io). Schwaeg. Suppl. I, P. I, 48 (I8II). Hook. TAYL. Musc. br. 20, t. 9 (I8I8). Hook. Fl. scot. P. 2, I24 (I82I), Br. fl. ii, I5 (I833). Gayl. Musc. br. 20, t. 9 i, 7 I8 (I82I). Hueb. Musc. germ. 83 (I833). Mack. fl. hib. P. 2, $13(1836)$.

Splachnum urceolatum (non BR. Scr.) Hedw. St.cr. ii, 39, t. I3 (I788). Dicks. Pl.crspt. Fasc. II, 2 (I790). SM. Fl. brit. II70; Eng. Bot. t. 2417 . Brid. With. Hull. Wahlenb. Fl. lapp. 309 (I8I2), Fl. carp. 335 (I8I4).

Splachnum purpureum Wiтн. Bot. arr. 3 ed. iii, 794 .

S. arcticum, propinquum, exsertum and paradoxum R. BR. in App. to Parry's Ist. voy. p. 301 (1824).

S. Adansianum Schwaeg. Suppl. II, P. II, t. I 78 (I826). 
Tetraplodon mnioides BR. Sch. Bry. eur. fasc. $23-24$, p. 5, t. 2 (I 844$)$. RABEnh. Deutsch. kr. fl. ii, S. 3, gi (I848). C. Muell. Syn. i, I30 (I849). Wils. Bry. br. 29 I, t. 9 (i855). Schimp. Synops. 304 (1860), 2 ed. 364. BERK. Handb. br. m. I65, t. I5, f. 2 (I863). Milde Bry. siles. I87 (I869). HobK. Syn. br. m. i34 (I873). Juratz. Laubm. oester.-ung. 232 (I882). Lesq. James Moss. N. Amer. Ig2 (I884). HusN. Musc. gall. 205, t. 55 (I888).

Tetraplodon bryoides Linde. Musc. scand. I9 (1879).

Autoicous; $\frac{1}{2}-3$ in. high, branched, robust, covered below with rufous tomentum. Leaves crowded, laxly imbricated, obovate-oblong, acuminate and narrowed suddenly into a flexuose yellowish subula, deeply concave, with a yellow border and entire margin, the nerve prolonged into the subula. Capsule on a long solid orange-red glossy pedicel, oval with an obovate-obconic greenish hypophysis, annulate, pale fuscous, becoming deep rufous when old, when dry and empty contracted below the mouth, with a narrower rugose rufous hypophysis; lid obtusely conic, teeth lineal-lanc, at first quaternate, finally geminate, orange red.

Hab.-On decayed bones and dung in mountain districts. Fr. 5. Scotland, Wales, N. of England and Ireland.

\section{Var. $\beta$. Breweri (Hedw.)}

Branches slender; leaves lax, narrower, broadly lanc., patent; caps. less elevated, with smaller hypophysis.

SyN.-Bryum ampullaceum, foliis et ampullis angustioribus Dill. Hist. musc. 345 , t. 44, fig. 5 , et Herb.

Splachnum Brewerianum Hedw. St. cr. ii, I05, t. 38 (I788), Sp. musc. 49. With. Bot. arr. 3 ed. iii, 792. Brid. Musc. rec. II, P. I, II4; Sp. musc. I, I47; Mant. Io6; Bry. univ. i, 25I. Schwaeg. Suppl. I, P. I, 49.

Splachnum fastigiatum Dicks. Pl. cr. III, 2. Swartz Musc. suec. 24. Sm. Fl. brit. II72. Eng. Bot. t. 786 .

Splachnum mnioides $\beta$. majus. Hook. TAYL. Musc. br. 20.

Tetraplodon mnioides $\beta$. Breweriants BR. ScH. Bry. eur. et Synops.

Tetraplodon Brewcrianus DE Not. Epil. 466 (I869).

Haв.--In similar localities to the type.

This fine moss generally bears a profusion of capsules, and its tufts are conspicuous in the peat bogs in which it is generally found. Decayed bones of sheep form the substratum to which it generally attaches itself, and it is probable that when we find it on the peat that sheep's or rabbits' bones have previously laid there and afterwards disappeared by decay.

\section{TETRAPLODON ANGUSTATUS (Swartz) Br. Sch.}

Autoicous; tufted, pale green. Leaves lax, ovato-lanc., with long tapering points, serrated above. Caps. on a short seta, narrow, with a long tapering hypophysis, teeth of per. bigeminate. (T. LXII, B.) 
Syn.-Splachnum angustatum SwarTz Meth. musc. 33 ( 1787 ), Musc. suec. 23 (I798). Hedw. Musc. fr. ii, 37, t. I 2 ( I788), Sp. musc. 5r (r8or). Dicks. Pl. cr. fasc. II, 3 (r790). With. Bot, arr. 3 ed. iii, 792 (1796). Brid. Musc. rec. II, P. I, Io8 (r798), Sp. musc. I, r48 (r806), Mant. Io6 (I8I9), Bry. univ. i, 248 (I826). Hull Br. fl. P. 2, 246 (I799), Sm. Eng. Bot. t. rr 32 (I803), Fl. brit. iii, II69 (r80 t). P. Beauv. Prodr., 88 (1805). Web. Mohr Bot. Tasch. 97 (I807). Schkuhr Deutsch. kr. gew. P. II, 38, t. I4 (I8Io). Schwaeis. Suppl. I, P. I, 48 (r8II). Roehl. Deutsch. fi, iii, 42 (I8I3). Wahlen. F1. lapp. 309 (I8I2). HoOK. TAYL. Musc. br. 20, t. 9 (18r8). HoOK. Fl. scot. P. 2, I24 (r82 r), Br. fl. ii, r5 (r833). Gray Nat. arr. br. pl. i, 7r8 (r82r). Funck Moost.t.7, f. 3 (r82r). Hueben. Musc. germ. 82 (1833). DE Not. Syllab. 275 (1838).

Tetraplodon angustatus BR. Sch. Bry. eur. fasc. 23-24, Mon. 4, t. I (I844). Rabenh. Deutsch. kr. fl. ii, S. 3, go (1848). C. Muell. Synops. i, I30 (1849). Wils. Bry. br. 292, t. 9 (I 855 ). Schimp. Synops. 303 (r860), 2 ed. 363. Berk. Handb. br. m. 164 t. 15, f. I (I863). Mrlde Bry. siles. I86 (r869). De Not. Epil. bri. ital. 467 (I869). HoBk. Syn. br.m. r34 (I873). JuRATz. Laubm. oester.-ung.23r (I882). LesQ. JaMes Moss. N. Amer. Ig2 (I884). HusN. Musc, gall. 204, t. 55 (r888).

Autoicous; in small dense pale green tufts, with ferruginous radicular tomentum. Stem slender $\frac{1}{2}-2$ in. high, repeatedly divided, fastigiate. Leaves distant, erecto-patent, soft, elongato-lanceolate, running out into a very long yellow flexuose subula, with the nerve prolonged into it, margin serrate above; those of the sterile branches broader with shorter points. Caps. on a short pale seta, scarce overtopping the leaves, pale brownish, constricted below the mouth when dry, small oval with a pyriform hypophysis; lid convex or obtusely conical ; teeth bigeminate or approximate in pairs, lanc. obtuse, reddish brown. Male infl. at base of innovation or terminal on a branch, bracts from a broad base, narrowly acuminate, obsoletely nerved.

HAB.-Dung and decayed arimal matter, rare. Fr. 7-8.

Near Loch Awen (Dickson). Cairngorm. Glen Dole (Wilson)!! Ben Wyvis (McKinlay). Glen Dee, Aberdeen (F.B. Syme r85I)!

\section{3. 'TAYLORIA Hook.}

Journ. Sc. \& Arts No. 3, p. I44 (I8I6).

In lax tufts, tomentose; leaves spathulate laxly areolate. Calyptra mitræform, inflexed and narrorved at base, cleft on one side, lacerate and erose at margin, capsule cylindraceous with a narrow subpyriform hypophysis, expanded at mouth when dry; teeth of per. I6, entire or cleft, lanceolate or long and lash-shaped. Male infl. capituliform.

Der.-After Dr. T. Taylor.

The two sections of this genus comprise about 25 species, most of them fine mosses with tall setæ, the capsules wide-mouthed and much broader than the hypophysis. In Tayloria splachnoides the teeth of per. are very long and twisted. 
Clavis to the Species.

Leaves acute and serrated at point.

tenuis. - obtuse and entire.

lingulata.

Sect. I. EUTAYLORIA Lindb. Columella exserted; teeth of per. reflexed when dry. Leaves acuminate, serrate; male infl. capituliform.

\section{TAYLORIA TENUIS (Dicks.) Schimp.}

Autoicous; laxly tufted. Leaves spathulate acuminate, serrated above. Caps. oval, with a long narrow hypophysis, pale brown; teeth long, dark purple, reflexed when dry. (T. LXII, C.)

Syn.-Splachmum tenue Dicks. Pl. cr. Fasc. II, 2, t. 4, f. 2 (I790). With. Bot. arr. 3 ed. iii, 793 (I796). Hull Br. fl. P. 2, 246 (I799). Sm. Fl. brit. I I7 I (I804), Eng. Bot. t. I I33. Web. Mohr Bot. Tasch, 98, t. 7, f. 2-3 (1807). Schkuhr Deutsch. kr. gew. P. II, 35, t. I4 (I8Io). Roenl. Deutsch. fl. iii, 42 (I8I3). Hook. TAYL, Musc. br. I9, t. 9 (I8I8). Gray Nat. arr. br. pl. i, 718 (I82I). Hook. Fl. scot. P. 2, I24 (I82I), Br. Fl. ii, I5 (1833). Brid. Bry. univ. i, 247 (I826). Hueb. Musc. germ. 88 (I833). DE Not. Syllab. 273 (1838), Epil. 463 p. p. (1869).

Splachnum lingulatum (non Dicks.) Hoffm. Deutsch. f. ii, 23 (I795). Roth Fl. germ. iii, P. I, I37 (I800).

Grimmia splachnoides SM. Fl. br. I 197 (non Eng. Bot.).

Splachnum attenuatum Brid. Musc. rec. II, P. I, IO7 (I798), Sp. musc. I, I46 (I8a6), Mant. I06 (I8Ig).

Splachnum serratum ScirwaEg. Suppl. I, P. I, 49.

Tayloria serrata Var. $\gamma$. tenuis BR. Sch. Bry. eur. fasc. $23-24$, p. 6, t. 2 (I 844 ). C. Muell. Synops. i, I33 (1849). Wils. Bry. brit. 294, t. 9 (1855). Schimp. Synops. 300 (I860). BERK. Handb. br. m. I64, t. I4, f. 7 (I863). MILDE Bry. siles. I86 (I869). Hobk. Syn. I34 (1873). Husn. Musc. gall. 203 (1888).

Tayloria tenuis Scinmp. Synops. 2 ed. 360 (I 876 ). Juratz. Laubm. oester..ung. 228 (I882). Hoвk. Syn. 2 ē̃. I 4 I (I884).

Autoicous; in irregular lax tufts, soft, slender, with rufous tomentum. Leaves broadly spathulate, shortly acuminate, very thin and flaccid, pale with lax irregular hexagonal cells, margin serrated above, nerve reaching nearly to apex. Caps. on a slender seta, small oval, with a long narrow tapering hypophysis, pale brownish becoming black by age, when dry and empty strongly contracted below, with a wide mouth; columella much exserted; teeth long, dark purple, glossy, reflexed when dry and closely appressed to the capsule: spores larger. Male infl. terminal on special branclies or at the base of innovations, capituliform.

$\mathrm{HAB}_{\mathrm{A}}$ - Rotten turfy soil on mountains; rare. Fr. 7-8.

Leney (Dr. Buchanan I782). Ben Lawers (Dickson). Head of Glen Callater (G. Don)! Killin (Binstead I885)!! Benbradagh Mtn., Co. Derry, Ireland (Stewart I868)!!

Very distinct in the ripe stage, by its narrow contracted hypophysis and wide mouthed capsule with long exserted columella. It evidently differs 
from $T$. serrata, and had been confounded with it from the circumstance of growing intermixed.

Sect. 2. CYRTODON (Brown). Peristome not reflexed when dry; columella slightly or not exserted. Leaves obtuse, entire. Male infl. gemmiform.

\section{TAYLORIA LINGULATA (Dicks.) Lindb.}

Synoicous; tall, densely tufted. Leaves erecto-patent, lingulate, obtuse, entire, nerve ceasing below apex. Caps. obovate, with a short neck tapering into seta; teeth of peristome I6, equidistant, yellow. (T. LXII, D).

Syn.-Splaclinum lingulatum Dicks. Crypt. Fasc. IV, 4, t. Io, f. 6 (I80I). Sm. F1. brit. I I77 (1804), Eng. Bot. t. 2095. Brid. Sp. musc. I, I43 (1806), Mant. I05. SPreng. (L.) Syst. Veg. I6 ed. iv, I52 (1827).

Bryum reticulatum Dicks. Crypt. Fasc. II, 4, t. 4, f. 6 (?).

Weissia splachnoides Swartz in litt. in SM. Fl. brit. 1197 ut synon. (1804). BrID. Sp. musc. I, I I7 (I806), Mant. 45 (I8Ig). SchwaEg. Suppl. I, P. I, 63, t. I7 (I8II). Wahlenb. Fl. lapp. 326 (I8I2). Hook. Tayl. Musc. br. 42, t. I4 (I8I8). GRAY Nat. arr. br. pl. i, 729 (I82I). Hook. Fl. scot. P. 2, I30 (I82I). Funck Moostasch. I2, t. 9 (I82I). Grev. Scott. cr. fl. t. I45 (1825). Hook. in F1. Lond. t. I92.

Cyrtodon splachnoides R. Br. in App. to Parry's I Voy. p. 299 (I 824). Hook. Br. fl. ii, I 7 (I833).

Dissodon splachnoides Grev. Arn. in Mem. Wern. soc. v, 468, t. I3 (1825). Br. Sch. Bry. eur. 23-24, p. Io, t. 3 (I844). Rabenh. Deutsch. kr. fl. ii, S. 3, 94 (I848). C. Muell. Synops. i, I39 (I849). WiLs. Bry. br. 297, t. I4 (I855). SchImp. Synops. 298 (I860), 2 ed. 358 . Berk. Handb. br. m. I63, t. I4, f. 6 (1863). Hobk. Synops. 135 (1873). Juratz. Laubm. oester.-ung. 227 (I882). Lesq. James Moss. N. Amer. Igo (1884). HusN. Musc. gall, 202, t. 54 (I888).

Weissia turbinata Drumm. Musc. bor. amer. n. 64 .

Eremodon splachnoides Brid. Bry. univ. i, 234 (1826). Nees Hornsch. Bry. germ. ii, P. II, I73, t. 39 (I83I). HuEBEN. Musc. germ. 9 I (I833).

Tayloria lingulata LindB. Musc. Scand. Ig (1879).

Synoicous and autoicous; in wide dense tufts $\mathrm{I}-5$ in. high, dark green above, blackish at base; the stems repeatedly dichotomous and fastigiate. Leaves gradually accrescent upward, suberect, crowded, very soft, obovate-oblong and lingulate, dark green, black when old, concave, entire, obtuse; cells lax hexagono-rectangular, longer at base; nerve vanishing below apex. Seta $\mathrm{I}-2$ in. long, reddish yellow. Caps. orange-brown, erect, rarely oblique, oval with a swollen neck tapering downwards into the seta, when dry and empty globose-turbinate with the columella a little exserted; calyptra submitræform, whitish; lid convex-conic, apiculate; teeth yellowish, equidistant, acuminate, erect. HAB.-Turf bogs on the higher Scotch mountains. Fr. 8.

Ben Lawers (Don)!! Craig Chailleach (Hooker). Ben Lomond (G. Don). Clova (Fergusson I868) 
A beautiful moss, varying considerably in size according to the moisture of its locality. Its near ally Tayloria Froelichii (HEDw.) MiTT. formerly regarded as British, is now expunged from our list, poor specimens of $T$. lingulata having been erroneously referred to it.

TAd. LXI. A. Splachnum ampullaceum (Levens, Barnes). B. Spl. vasculosum (Clova, Gardiner). C. Spl.pedunculatum (Witherslack Moss, Barnes). A 2, The form ovatum, ß. Var. spharicum (Little Wyvis, Braithwaite).

TAB. LXII. A. Tctraplodon bryoides (Ben Lawers, Braithwaite). B. Var. Brezeri. B. Tetr. angustatus (Glen Dole, Wilson). C. Tayloria tennis (Killin, Binstead). D. Taylori a lingulata (Clova, Fergusson).

a. Fertile plant. b. Male. I. Leaf mag. Ia. Apex of leaf. 3. Male inf. 4. Bract. antheridia and paraphyses. 5. Capsule. 6. Calyptra. 8. Peristome. 

A

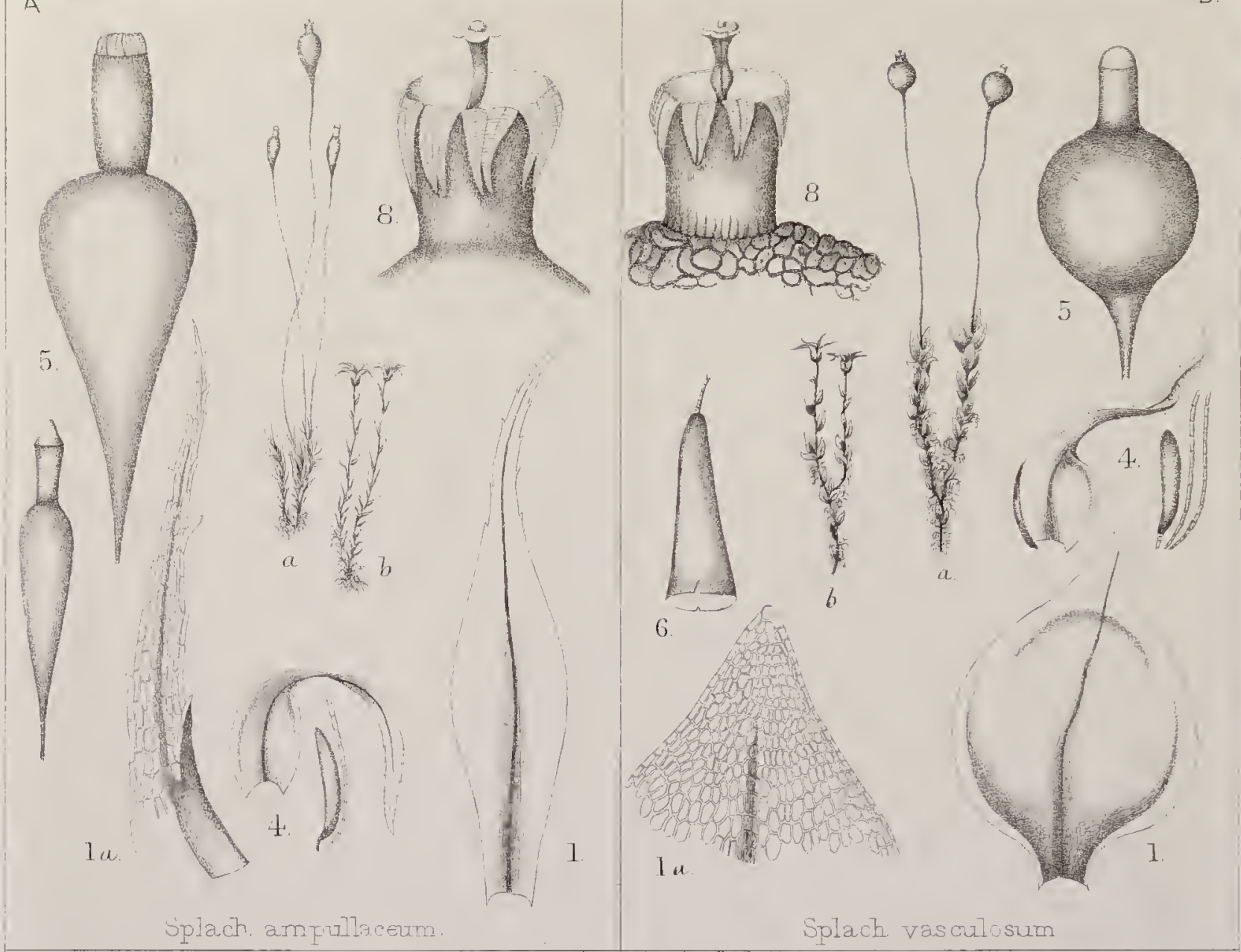

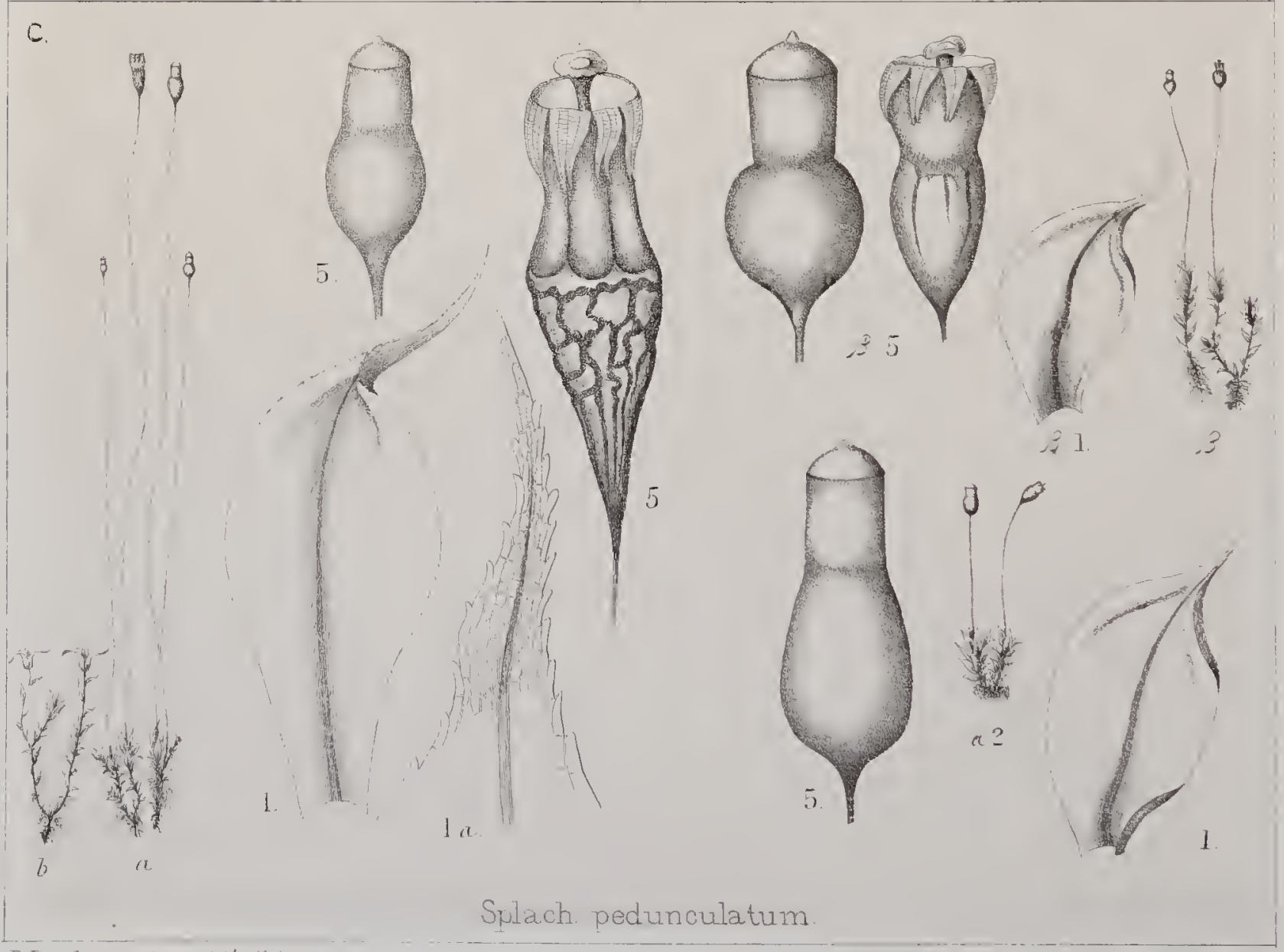




$$
\begin{aligned}
& P^{4} y^{9} \\
& \frac{1}{a}+y^{2} y^{2} \\
& \text { g. }
\end{aligned}
$$



O E D I P O D I C E 
OEDIPODIUM Schwaeg.

Oedipodium Griffithii (Dicks.) Schwaeg. 


\section{Fan. I3. OEDIPODIACEAE.}

Plants succulent, in small dark green tufts. Leaves broad, opake, the cells very smooth, chlorophyllose, the median multangular-oval with trigonous spaces, the uppermost smaller, angular-rounded; nerve very broad and flat, prominent beneath. Calyptra conico-cylindric, thin, cleft up one side ; caps. gymnostomous, subglobose, tapering downward into a long tubular hypophysis which takes the place of a seta; columella dilated at apex; spores papillose. Inhabiting crevices of alpine rocks.

\section{OEDIPODIUM Schraeg.}

Suppl. II, P. I, t. I05 (I823).

Capsule clavato-pyriform, the hypophysis tapering downward to the vaginula, gymnostomous. Calyptra narrow, fugacious, cleft at side. Spores papillose. Leaves quinquefarious, rounded obovate, the cells large rounded-hexagonal, opake and chlorophyllose. Der. oios a swelling, movs a foot.

\section{OEDIPODIUM GRIFFITHII (Dicks.) Schwaeg.}

The only species of the genus. (T. LXIII.)

Syn.-Splachnum Froelichianum (non Hedw.) WrTh. Bot. arr. br. veg. 3 ed. iii, 794 excl. syn. (1796). Hull Br. A. P.II, 246 (I799). Swartz in Web. Mohr Bot. Tasch. Io5 in obs. (I807). Schwaeg. Suppl. I, P. I, 5I, p. p. (I8II). Brid. Mant. Io5, p. p. (I8Ig). Bryum Griffithianum Dicks. Crypt. Fasc. IV, 8, t. Io, f. Io (ISoI).

Splachnum? succulentum Brid. Musc, rec. II, P. III, 64 in obs. (I803). P. BEAUv. Prodr. 89 (I 805$)$.

Gymnostomum Griffithianum SM. Fl. brit. II62 (I804), Eng. Bot. t. I938. BRID. Sp. musc. I, 37 (I806). Hook. TAY. Musc. br. I I, t. 7 (I8I8). GRaY nat. arr. br. pl. i, 7I4 (I821). HARTM. Skand. f. 2 ed. 300 (1832).

Oedipodium Griffithianum Schwaeg. Suppl. II, P. I, I5, t. I05 (I823). BRID. Bry. univ. ii, 83 (1827). Hook. Br. Fl. ii, 6 (1833). Mack. Fl. hib. P. 2, 9 (1836). Valent. in Tr. Linn. Soc. xviii, 499, t. 35 (1840). BR. Sch. Bry. eur. Fasc. 23-24, Mon. 4, t. I (I844). Aongst. in Fries Sum. veg. scand. i, 9o (1846). C. Muell. Synops. i, I28 (I848). HaRtm. Sk. fl. 5 ed. (I849). Wils. Bry. br. 298, t. 7 (I855). Schimp. Synops. 295 (I 860), 2 ed. 354. BERK. Handb. br. m. 162, t. I 4, f. 5 (I863). LiNDB. in Not. ur Sallsk. Fn. Fl. fenn. 1870, p. 46. Hoвk. Syn. br. m. I35 (1873). Husn. Musc. gall. 201, t. 54 (I888).

Physcomitrium Griffithianum Aongst. Disp. musc. Sc. Io (1842). HARTm. Sk. Al. 4 ed. 365 (I 843$)$.

Synoicous and autoicous; plants succulent, in soft dark green tufts $\frac{1}{2}-$ I in. high. Stems innovating below apex, thick, covered with long 
hyaline articulated threads. Leaves from a very narrow base, obovatespathulate, very obtuse, entire, lower minute, remote, accrescent upward, rosulate at apex, patent when moist, corrugated and flexuose when dry, the upper often bearing axillary, obovate gemmæ, margin entire, longly ciliate at base, nerve broad flattened, prominent only beneath, vanishing below apex; cells smooth, chlorophyllose, basal rectangular, slightly incrassate, median multangular-oval with trigonous spaces, upper smaller, multangular-rounded. Seta scarcely any, its place being taken by a very long. spongy tubular hypophysis, twisted to the left when dry, and having large scattered stomata; calyptra fugacious, thin membranous, hyaline at lower part, fuscescent above. Caps. solid, subspherical, orangebrown, defluent into the long pale greenish white hypophysis; lid convex or obtusely conic; annulus and peristome wanting.

$\mathrm{H}_{\mathrm{AB}}$.-Clefts of rocks and wet peaty soil, on mountains, rare. Fr. 7-8.

Snowdon (Griffith)!! Carnedd Llewellyn and Glyder Vawr (Wilson) !! Ingleboro' (Dalton and Hooker). Clova mountains (Don and Drummond)!! Ben Nevis and Ben Cruachan (Rev. C. Smith). Ben Ledi (Hooker). Ben Arthur (McKinlay)!! Ben Challum (Stirton)! Head of Kentmere (Stabler I 867)! Helvellyn and sporadically throughout the Lake district (Binstead). The Bizzle and Henhole, Cheviots (Hardy). Forfar (Don). Ben Laoigh (Eving).

This curious moss differs so much in leaf structure from the Splachnaceæ, that I have followed Linberg in regarding it as the type of a distinct family. The pale succulent peduncle resembles much more that of a fungermania than that of a moss. Out of Great Britain it has only been found in a few places in Norway and Lapland.

\section{TAB. LXIII.}

Oedipodium Griffthii (Glyder Vawr, George).

a. Fertile plant. a*, The same magnified. I. Leaf. Ia. Apex, ra. b. Areolation of base. 4. Antheridium and paraphysis. 5. Capsule. 5x. Section of same. 6. Calyptra. Iо. Gemmæ. 


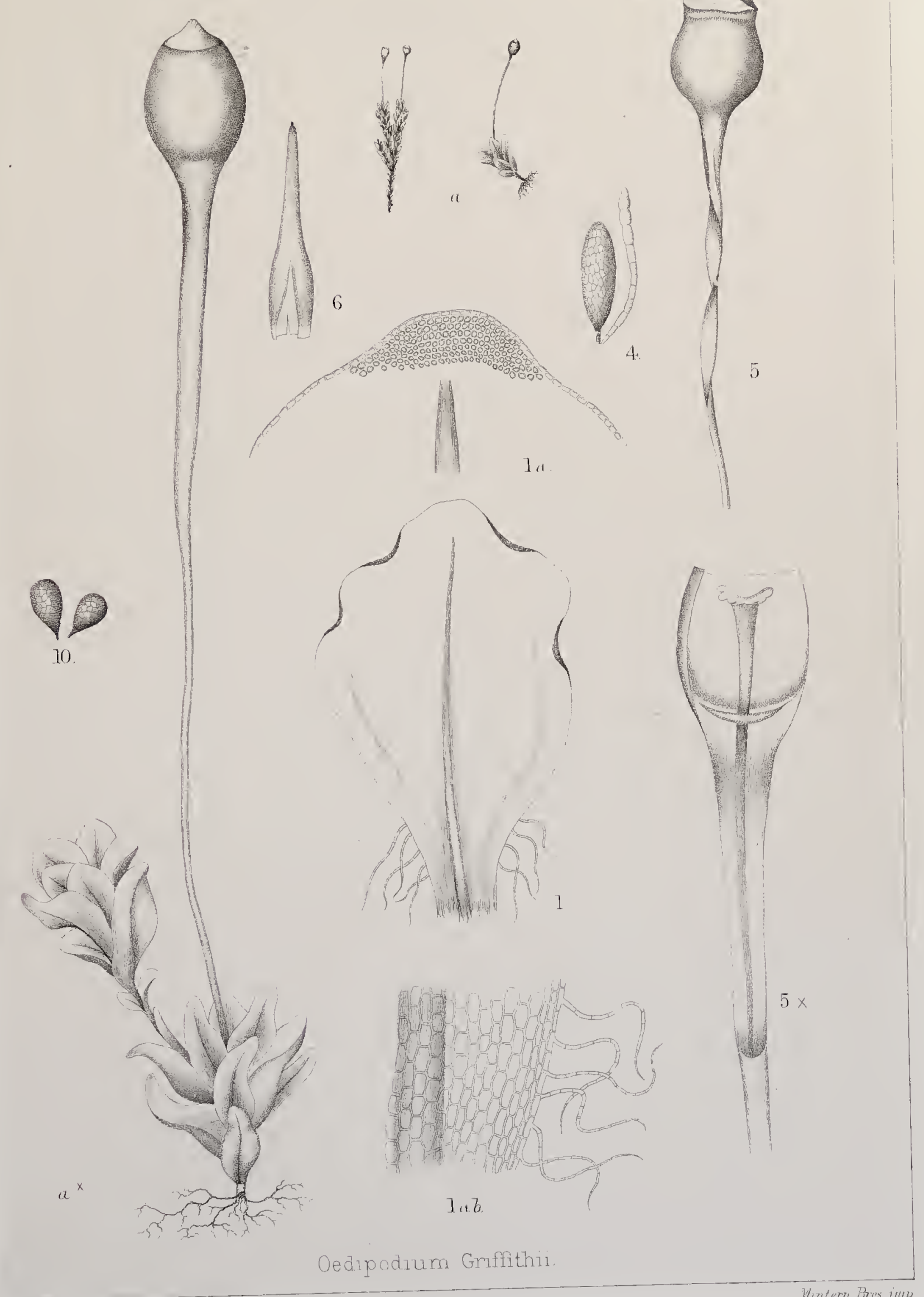

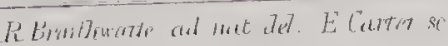



F U N A R I A E $Æ$. 
Subf. I. DISCELIEAE.

DISCELIUM BRID.

Discelium nudum (Dicks.) Brid.

Subf. 2. AMBLYODONTERE.

AMBLYODON P. BEAUV.

Amblyodon dealbatus (Dicks.) P. Beauv.

Subf. 3. FUNARIERE.

NANOMITRIUM LINDE.

Nanomitrium tenerum (Bruch) Lindb.

PHYSCOMITRELLA BR. Sch.

Physcomitrella patens (Hedw.) B.S.

PHYSCOMITRIUM BRID.

1. Physcomitrium sphæricum (Ludw.) Brid.

2. pyriforme (L.) Brid.

FUNARIA SCHREE.

1. Funaria obtusa (Dicks.) Lindb.

2. - fascicularis (Dicks.) Schimp.

3. - attenuata (Dicks.) Lindb.

4. - calcarea Wahlenb.

5. —_ microstoma Br. Sch.

6. - hygrometrica (L.) Sibth. 


\section{Fam. I4. FUNARIACEÆ.}

Plants terrestrial, soft, gregarious or laxly tufted. Leaves ovatolanceolate, with a thin nerve, cells large, lax hyaline smooth, hexagonal or oblongo-rhomboid. Caps. spherical, oval or pyriform, with a distinct neck, erect or cernuous, regular or gibbous, peristome none, single or double, teeth $\mathbf{} 6$, acuminate and twisted to the right, or small and straight, calyptra inflated, with a long beak, cleft on one side or many-lobed.

This family, numbering about $\mathrm{I} 35$ species, is principally characterised by its large lax parenchymatous cells, and pyriform capsules, inflated calyptra and oblique cartilaginous teeth. The majority are found in the temperate regions of the northern hemisphere, but many occur in S. America and Australia.

Subf. I. Discelieæ. Plants nearly stemless, gemmiform, attached to persistent protonema; leaves sheathing nerveless, with lax hexagonal cells, without chlorophyl. Caps. on a long seta, subglobose, inclined; peristome of 16 lanceolate teeth, cleft and gaping in the lower half.

\section{DISCELIUM. Brid.}

Bry, univ. i, 365 (1826).

Calyptra very narrow, cleft on one side with the margins involute at base. Caps. subglobose with a short neck, teeth $\mathbf{I} 6$, cartilaginous, lanceolate, cleft in the middle, trabeculate.-Der. ois two, $\sigma \kappa \epsilon \lambda o s$ a leg.

\section{DISCELIUM NUDUM (Dicks.) Brid.}

The only species. (T. LXIV, A.)

Syn.-Bryım nudum Dicks. Crypt. Fasc. IV, 7, t. IO, f. I5 (I80I). Brid. Musc. rec. II, P. III, 6i (1803). P. Beauv. Prodr. 48 (1805).

Grimmia nuda Sm. F1. brit. II97 (I804), Eng. Bot. t. I42I. Turn. Musc. hib. 25 (1804). BRID. Sp. musc. I, IOI (1806).

Weissia incarnata SchwaEg. Suppl. I, P. I, 66, t. I8 (I81 I).

Wcissia rosea Wahlenb. F1. lapp. 325 , t. I9 (1812).

Weissia muda Hook. Tay. Musc. br. 43, t. I4 (1818). Gray Nat. arr. br. pl. i, 729 (I821). Hook. Fl. scot. P. II, 130 (I82 I), Br.fl. ii, 19 (1833).

Coscinodon nudus Brid. Mant. 48 (1819). 
Discelium nudum Brid. Bry. univ. i, 366 (I826). Br. Sch. Bry. eur. Fasc. 29-30, p. 4, t. I (I846). C. Muell. in Bot. Zeit. 1843, p. 5, Synops. i, I49 (1849). Wils. Bry. br. 286, t. I4 (I855). Schimp. Synops. 3 I 2 (I860), 2 ed. 372 . BERK. Handb. br. m. I67, t. I5, f. 6 (I863). HoBk. Syn. br. m. I33 (I873). Husn. Mouss. nord-ouest I 4 (I873), Musc. gall. 2 I I, t. 57 (I888). Milde Bry. siles. I88 (I869). Lesq. James Moss. N. Amer. 188 (1884).

Dioicous; plants annual, nearly stemless, attached to green protonema. Leaves few, imbricated sheathing, ovato-lanceolate, entire, with only faint traces of a nerve, cells large lax hyaline, oblongohexagonal. Caps. very small, on a long flexuose red seta, pachydermous, reddish-brown, subglobose, cernuous on a suddenly bent neck; calyptra narrow, subulate, fugacious, split up on one side, contracted at base and often left behind adhering to the seta; annulus large, subpersistent, of tivo rows of cells, lid convex-conic; teeth I6, red lanceolate striate, cloven half way from the base upward. Male plants minute, gemmiform, nestling on the protonema, antheridia few, with subclavate paraphyses.

НАв.-Clay banks, rare. Fr. 2-3.

About Manchester (Caley)!! By the Tay near Perth (Don). Shibden and Todmorden,
Yorks. (Nowell). Marple, Cheshire (Whitehead). Boggart hole Clough, and Haughton
Dale, Lancashire. Ram's Clough, Ashton-under-Lyne. Berrow bridge, Bolton
(F. Sims I888)!! Kirby Bank, Cleveland (Rev. F. Dalton, Fun.)

This curious moss is clearly most allied to Funaria by the cell structure of the leaves, although the form of the capsule at once reminds us of Catoscopimm, yet the broad annulus is also Funarioid, while the teeth of peristome are rather sui generis, though resembling those of Trematodon. The green protonema covers the clay banks where it grows, in autumn, and this turns red and withers away after the fruit is formed, and in spring the whole surface generally crumbles away and disappears until the following autumn.

Subf. 2. Amblyodonteæ. Stem elongated, branched. Capsule asymmetric, pyriform; peristome double, outer of 16 short erect obtuse teeth, inner much longer of I6 lanceolate fissile teeth on a short membrane. Calyptra narrow, cucullate.

\section{AMBLYODON P. Beaw.}

Prodr. 4I (I805).

Calyptra very fugacious, cucullate, narrow. Caps. pyriform, asymmetrice; peristome of I6 short lanceolate obtuse erect teeth, endostome a short sulcate membrane with $\mathrm{I} 6$ lanceolate subulate teeth much longer and splitting in the middle. Leaves Funarioid in

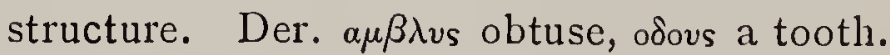




\title{
AMBLYODON DEALBATUS (Dicks.) P. Beau.
}

\author{
The only species. (T. LXIV, B.)
}

Syn.-Bryum dealbatum Dicks. Crypt. Fasc. II, 8, t. 5, f. 3 (I790). With. Bot. arr. 3 ed. iii, 8I6 (I796). Hull Br. fl. P. 2, 258 (I799). SM. Fl. brit. 1550 (I804), Eng. Bot. t. I 57 I. Turn. Musc. hib. II5 (I804). Gray Nat. arr. br. pl. i, 768 (I82 I). Hook. Tay. Musc. brit. II 7, t. 28 (18I8). Hook. Fl. scot. P. 2, I 49 (I821), Br. fl. ii, 58 (I833). Mack. Fl, hibern. P. 2, 3I (I836).

Mcesia dealbata Swartz Musc. suec. 44 et 94, t. 5, f. Io (I 798). Hedw. Sp. musc. I74, t. 4 I (I80I). BRID. Musc. rec. II, P. III, I6g (I 603 ), Sp. musc. III, Io4 (I8I7), Mant. I22 (I8Ig), Bry. univ. ii, 63 (I827). WEB. Mohr Bot. Tasch. 375 (I807). STURM Deutsch. fl. 2, io (I809). Wahlenb. Fl. lapp. 357 (I8I2). Roenl. Deutsch. fl. iii, I2 I (I8I3). Schwaeg. Suppl. I, P. II, 83 (I8I6). Funck Moost. 44, t. 28 (I82 I). P. Beauv. Mem. Soc. Linn. Par. t. 8, (I822). Hueben. Musc. germ. 490 (1833). De Not. Syll. I 07 (1838).

Amblyodon dcalbatus P. Beauv. Prodr. $4 \mathrm{I}$ (I805). BR. Sch. Bry. eur. Fasc. ro, p. 5, t. i, (I84I). Rabenh. Deutsch. kr. Fl. ii, S. 3, Ig6 (I848). C. Muell. Synops. i, I 27 (I849). Wils. Bry. br. 267 , t. 28 (I855). Schimp. Synops. 404 (I860), 2 ed. 496 . Berk. Handb. br.m. I79, t. I7, f. 7 (I863). Milde Bry. siles. I98 (I869). DE Not. Epil. bri. ital. 440 (I869). Hoвk. Syn. br. m. I25 (I873). Juratz. Laubm. oester.-ung. 3 I 5 (I88). Leso. James Moss. N. Amer. 2 I I (I884).

Autoicous and polyoicous; short, nearly simple, laxly cæspitose. Leaves ovato-lanc., pale green becoming whitish by age, the lower pale red, twisted when dry, the comal minutely serrate at apex, nerve yellowish, vanishing below apex; cells in the lower half, long lax and rectangular, above polygonal. Caps. on a long reddish seta, leptodermous, pale yellowish brown, erecto-cernuous, from an erect neck, suboblique pyriform, arcuate when dry; calyptra small conicomitræform, contracted at base, then split on one side; annulus simple, lid small convex-conic; teeth of peristome reddish short ligulate obtuse, only half the length of the processes of endostome which are I6 and carinate. Male infl. discoid, terminal.

Hab.-Wet places in subalpine districts; not common. Fr. 6-7.

Scotch mountains (Dickson). Suffolk (Eagle). Malham Tarn (Wilson)!! Stansfield moor, Todmorden (Nowell)!! Sandy shore at Southport and Crosby. Gordale. Sutton Park, Birmingham (Bagnall). Ben Laoigh (Ewing).

This moss in its fruit resembles Meesea, but the reticulation of the leaf so closely corresponds to that of Funaria, that it must certainly be referred to the same family, with which it also agrees in its clavate paraphyses.

Subf. 3. Funarieœ. Annual terrestrial mosses, with usually simple stems. Calyptra when young quadrangular-inflated, when ripe longer than capsule, rostrate slit up on one side and dimidiate or lobed. Peristome simple, double or sometimes none. Leaves with lax cells. 


\section{NANOMITRIUM Lindb.}

Not. ur Sällsk. Fn. et Fl. Fenn. förh. I874, p. 409 .

Plants very minute, nidulant in persistent protonema. Caps. globose, immersed, cleistocarpous, apiculate or muticous; calyptra minute, subdisciform, stylidiiferous, closely adherent. Leaves nerveless, with lax, smooth cells.--Der. vavos dwarf, $\mu$ itpoov a calyptra.

\section{NANOMITRIUM TENERUM (Bruch) Lindb.}

Synoicous; protonema less conspicuous. Leaves patulous, broadly ovato-lanceolate, obsoletely denticulate at apex, pale and flaccid. Caps. soft, pale ochraceous, subspherical; spores less distinctly verrucose. (T. LXIV, C.)

Syn.-Phascum tenerum Bruch MS. Br. Sch. Bry. eur. Fasc. I, p. 6, n. 2 (1837) Schwaeg. Suppl. IV, t. 302 a. (1842). HoBk. Synors. 27 (1873).

Ephemerum serratum $\gamma \cdot$ tenerum HAMPE Flora xx, P. I, 285 (1837).

Ephencrum tenerum C. Muell. Bot. Zeit. I847, p. Ioi ; Synops. i, 3 I (I848). Rabenh. Deutsch. kr. fl. ii, S. $3,84(\mathrm{I} 848)$. Bry. eur. fasc. 42, p. 4 (I 849$)$. Schimp. Synops. 4 (I860); 2 ed. 4. Milde Bry. siles. Igo (I869). JAEG. Ber. St. Gall. gesells. I869, p. 99 . Philib. in Rev. bry. 1878, p. 26. Husn. Mouss. nord.ouest 2 ed. 99 (I882), Musc. gall. 208, t. 56 (I 888 ).

Micromitrinm megalosporum Austin Musc. appalach. II, n. 47 (I87o). Sulliv. Icones suppl. 20, t. II (I874).

Nanomitrium tenerum LiNDB, in Not. ur Sällsk. 1. c.

Synoicous; plants very minute, nidulant in persistent protonema. Leaves broadly ovato-lanceolate, nerveless, obtusely serrate in the upper half, cells lax rhomboid-rectangular. Caps. nearly sessile, leptodermous, globose, immersed, apiculate or muticous, soft and pale; calyptra very short and small, closely adhering to apex of capsule; vaginula large, truncate, obovate; spores slightly verrucose, not large.

HAB.-On mud removed from a fish-pond at Pond Leigh, Hurstpierpoint (Mitten I 854)!! Fr. I I.

This remarkable little moss was first found by Breutel, at Niesky, and once only, and Mr. Mitten informs me that he also found it in abundance in the locality mentioned, but he has never met with it since. As a genus it differs from Ephemenum by the flattish cap-lilie calyptra, and the lax smooth non-incrassate leaf-cells. The name Micromitrinm being already adopted by Spruce for a group of Orthotrichex, Lindberg changed Austin's generic name to the equally appropriate one of Nanomitrium. Three more species are found in America. 


\title{
4. PHYSCOMITRELLA $\mathrm{Br}$. S $\mathrm{ch}$.
}

Bry. eur. Fasc, 42 (1849).

Plants minute, without protonema. Leaves rosulate, thin nerved, with lax 5-6 angled cells. Caps. on a short pedicel, cleistocarpous, immersed or exserted, globose, minutely apiculate; calyptra conicocampanulate. Der.--diminutive of Physcomitrium.

\section{PHYSCOMITRELLA PATENS (Hedw.) Br.Sch.}

\author{
The only species. (T. LXIV, D.)
}

Syn.-Phascum patens Hedw. Musc. fr. i, 28, t. to (I787), Sp. musc. 2o. Hoffm. Deutsch. fl. ii, I9 (I796). Brid. Musc. rec. II, P. I, I4, t. I, f. 2 (I798), Sp. musc. I, 5 (I806), Mant. 7 (I8I9). Bry. univ. i, 33 (I826). RoEhl. Moosg. deutsch. 22 (I80o), Deutsch. fl. iii, 34 (I8I3), Ann. Wett. ges. i, igo. Roth Fl. germ. iii, P. I, II2 (I800). Dicrs. Crypt. Fasc. iv, 2 (I80I). SM. F1. br. I I 50 (I804), Eng. Bot. t. I 279. TuRN. Musc. hib. 2 (I804). P. Beauv. Prodr. 82 (I805). Schultz Fl. starg. 272 (I806). Web. Mohr Bot. Tasch. 70 (I807). SchkuHR Deutsch. kr. gew. P. II, II, t. 4 (I8Io). Schwaeg Suppl. I, P. I, 7 (I8II). Sturm Deutsch. fl. 2, I2 (I8II). LA PYl. Journ. Bot. 1813, p. 287 , t. I9. Hook. TAYl. Musc. br. 7 , t. 5 (1818). Funck Moost. 3 t. I (I 82 I). GRAY Nat. arr. br. pl. i, 7 II (I82I). NEES HoRnsch. Bry. germ. I, 49, t. 5 (1823). Hook. br. fl. ii, 3 (1833). Hueben. Musc. germ. 9 (I833). Br. Sch. Bry. eur. Fasc. I, t. 3 (1836). DE NoT. Syllab. 307 (1838). Wils. Bry. brit. 34, t. 5 (1855). Hobk. Syn. 29 (1873). Husn. Mouss. nord-ouest 33 (1873).

Ephemerum patens HaMPe in Linnæa 1832. C. Muell. in Bot. Zeit. 1847 , p. roI; Synops. i, 53 (I 848 ). Rabenh. Deutsch. kr. fl. ii, S. 3, 85 (I848).

Physcomitrella patcns Schimp. Bry. eur. Fasc. 42, t. 2 (1849), Synops. 3 (I860), 2 ed. 8. Berk. Handb. br. m. 303, t. 24, f. 9 (IS63). Milde Bry. siles. igi (I869). De Not. Epil. 739 (I869). Jafger Ber. St. Gall. gesells. I03 (I869). Juratz. Laubm. oester.ung. 236 (I882). Hoвk. Syn. 2 ed. I 44 (I884). Leso. James Moss. N. Amer. 39 (I884). Husn. Musc. gall. 2 10, t. 57 (I888).

Aphanorrhegma patens Lindb. Oefver. K. vet. akad. Foerh. I864, p 592.

Paroicous and synoicous; very small, gregarious, pale green. Lower leaves scattered lanceolate recurved, upper larger, crowded, rosulate, spreading or recurved, obovate-oblong and spatliulate, somewhat acuminate, serrulate in the upper half, nerve thin vanishing below apex; cells lax, rectangular and elongato-liexagonal. Calyptra conico-campanulate. Caps. usually immersed, cleistocarpous, fuscescent, globose apiculate, leptodermous; spores large, roughish. Male infl. 6-8 antheridia enclosed by a minute nerveless bract, or sometimes mixed with the archegonia.

Hab.-Damp clay fields and mud of dried-up pools. Fr. 9 .

Stockton forest, York (Spruce)! Sussex (Mitten). Crewe (Wilson I863)!! Ashley mill and Mere Mere (Hunt 1869)!! Belfast. Devon.

Var. B. Lucasii (Nees. Hsch.) Schimp.

Stem very short. Leaves more crowded, shorter, broader, more erect. 
Syn.-Phascum Lucasianum Nees Hsch. Bry. germ. i, 44, t. 5, f. 5. BRId. Bry. univ. i, 32. Hueben. Musc. germ. 7 .

Plyscomitrella patens Var. $\beta$. Lucasiana Schimp.

Hab.-Chapel-en-le-Frith, Derby. (Prof. Barker, I887)!

\section{PHYSCOMITRIUM. Brid.}

Bry. univ. i, 97 (1826).

Plants resembling Funaria. Calyptra small fugacious, mitræform, cleft, rostrate, covering only the upper half of capsule. Caps. symmetric, pyriform, lid from a slightly convex base, abruptly rostrate or apiculate; peristome none. Der. $\phi v \sigma \kappa \eta$ a bladder, and $\mu \iota \tau$ เ calyptra.

For this genus of some 30 species, Lindberg retains the old title Gymnostomnm HeDw., but as that genus was simply a receptacle for all the mosses which had no peristome, I have preferred the later but more definite title, as its most distinctive character depends on the inflated lobulate calyptra.

\section{PHYSCOMITRIUM SPHERICUM (Ludw.) Brid.}

Autoicous; leaves obovate, concave spreading, obtuse entire, nerve ceasing below apex. Caps. on a short seta, semiglobose with a distinct neck ; lid obtusely conical. (T. LXIV, E.)

Syn.-Gymnostomum sphaericum Ludw. MSS. Schkukr Deutsch. kr. gew. P. 2, 26, t. II b. (I8Io). Schwaeg. in Schrad. Neu J. Eot. iv, I5, t. 2, f. B. (I8Io), et Suppl. I, P. I, p. 2I, t. 8 (I8II). La PYl. in PoIr. Encycl, bot. Suppl. II, 868 (I8II). Kaulf. in Sturm Deutsch. fl. II, I5 (18I5). Brid. Mant. I4 (I8Ig). NEes Hscir. Bry. germ. i, I24, t. 9, f. 3 (I823). Hueben. Musc. germ. 43 (1833). Lindb. Musc. Scand. I8 (I879). Gymnostomum Physcomitrium spharicum BRID. Bry. univ. i, 97 (1826).

Anoctangium spharicum SPRENG. in L. Syst. veg. I6 ed. iv, P. I, I46 (I827).

Physcomitrium spharicum Brid. Bry. univ. ii, 8I5 (I827). Fuerne, in Flora xii, P. II, Erganz. 9 (I829). HAMPE in ditto xx, P. I, 285 (I837). DE Not. Syll. 280 (I838). Br. Scr. Bry. eur. Fasc. II, Io, t. I, p. p. (I 84 I). C. Muell. Synops. i, i I5 (IS49). RABENH. Deutech. kr. fl. ii, S. 3, 87 (I848). Wils. Bry. br. 275, t. 52 (I855), Eng. Bot. t. 2830. Schimp. Syn. 3I4, p. p. (I860), 2 ed. 375. BERk. Handb. I74 (I863). Milde Bry. siles, Ig2 (I\&6g). LINDB. in Not. ur Saell. Fn. F1. fenn. I8;0, p. 54. Hobk. Syn. I28 (1873). Husn. Mouss. nord-ouest II4 (1873), Musc. gall. 2I2, t. 57 (I888). JURATZ. Laubm. oester.-ung. 237 (1882).

Autoicous; minute, densely gregarious. Leaves rather dense, suberect, subcymbiform-concave, obovate, obtuse, quite entire, nerve vanishing below apex, the upper cells smail subquadrate. Seta short reddish, twisting to the right when dry, caps. semiglobose, smooth of small roundish cells, with $2-3$ rows at orifice rectangular, not constricted 
below the wide mouth, annulus simple, fragmentary; lid nearly flat, shortly and obtusely rostellate.

HAв.-Dried mud at Mere Mere, Cheshire (Wilson, I834)!! Fr.9-Io.

This rare little moss resembles some of the Phasca in the unpleasant habit of disappearing for years, and then suddenly reappearing, as it did in I868, when Mr. Hunt collected splendid specimens. A closely allied species Physc. eurystomum (N.-Esen.) SENDtn. has been found growing with this in Germany, Holland, and France, and differs in the apiculate obtusely serrate leaves, with larger polygonal upper cells and a taller and larger capsule.

\section{PHYSCOMITRIUM PYRIFORME (L.) Brid.}

Autoicous; leaves distant erecto-patent, obovato-lanceolate, coarsely serrate above, nerve vanishing below apex. Caps. on a long seta, shortly pyriform, lid convex-conic, shortly rostellate. (T. LXIV, F.)

Syn.-Muscus trichodes humilior, capitulis piriformibus crectis Doody. Ray Synops. app. 243 (I6go).

Muscus capillaris parvus, capitulis magnis piriformibus ercctis in pediculis brovibus RAY Synops. 2 ed. 29, n. 7 (I6g6).

Bryum parvum, erectis piriformibus majusculis capitulis, foliolis serpylli pcllucidis DiLL. Cat. Giss. 223 (I 7 I 9 ), et in RAy Syn. 3 ed. 93, n. 7 (I 724 ).

Bryum serpillifolium pellucidun, capsulis pyriformibus Dill. Hist. musc. 345 , t. 44, f. 6 , A-L (I74I), et Herb.

Bryum pyriforme L. Sp. pl. III6 (I 753$)$. Huds. Fl. angl. 404 (I762). Weiss Cr. Goett. I87 (I770). Neck. Meth. musc. I97 (I771). With. Bot. arr. ii, 672 (I776). Lightf. Fl. scot. ii, 7 I8 (I777). RelH. Fl. cant. Suppl. I8 (I786). AвBot Fl. Bedf. 24I (I798). Hull Br. fl. P. 2, 257 (I 799 ).

Phascum pyriforme SwarTz Meth. musc. 25 (I78I).

Gynnostomum pyriforme HEDw. Fund. II, 87 (I782), Sp. musc. 38 (I8oI). Roth Tent. f. germ. i, 453 (I788). Sibth. Fl. oxon. 274 (I794). Hoffm. Deutsch. fl. ii, 27 (I795). Brid. Musc. rec. II, P. I, 36 (I798), Sp. musc. I, 27 (I806), Mant. I4. I8Ig. SwarTz Musc. suec. 20 (I798). RoEHL. Moosg. deutsch. 73 (I8oo), Deutsch. fl. iii, 39 (I8I3). Sm. Fl. brit. II6o (I804). Turn. Musc. hib. i I (I804). P. Beauv. Prodr. 59 (I805). Sturm Deutsch. f. II, 8 (I805). Schultz F1. starg. 279 (1806). Web. Mohr Bot. Tasch. 8 (I8o7). Schkuhr Deutsch. cr. gew. P. II, 30, t. I2 (I8Io). Schwaeg. Supp. I, P. I, 24 (I8II). VoIt musc. herb. I6 (I8I2). MART. Fl. cr. erl. I20 (I8I7). HoOK. Tayl. Musc. br. I3, t. 7 (I8I8). Hartm. Skand. fl. 382 (I820). Wahlenb. Fl. unsal. 389 (I820). Hook. Fl. scot. P. 2, I23 (I82I), Br. fl. ii, 9 (I833). Funck. Moost. 6, t. 4 (I82I). Gray Nat. arr. br. pl. i, 7 I6 (I82I). NeEs Hsch. Bry. germ. i, I44, t. IO, f. II (I823). Hueben. Musc. germ. 45 (1833).

Pottia pyriformis EHRH. Beitr. i, I88 (1787).

Gymnostomum longifolium Schleich. Cat. pl. Helv. 4 ed. 40 (I82I). Steud. Nomencl. I 92 (I 824).

Gym. Physcomitrium pyriforme BrID. Bry. univ. i, 98 (I826).

Physcomitrium pyriforme BrID. Bry. univ. ii, 8I5 (I827). FUERNR. in Flora xii, P. II, Erganz. 9 (I829). Hampe in Flora xx, P. I, 285 (I837). De Not. Syllab. 282 (I838), Epilogo 456 (I869). Br. Sch. Bry. eur. Fasc. I I (I84I). C. Muell. Synops. i, I I6 (I848). Rabenh. Deutsch. kr. fl. ii, S. 3,87 (I848). Wils. Bry. br. 275, t. 7 (I855). Schimp. Synops. 3 I 5 (I860), 2 ed. 376 . Berk. Handb. br. m. I74 (I863). MiLDE Bry. siles. 239 (I869). Linds. in Not. ur Saells. Fn. et Fl. fenn. xi, 49 (1870). Новк. Synops. I28 (I873). Husn. Mouss. nord-ouest I I 5 (I873), Musc. gall. 213, t. 58 (I888). Juratz. Laubm. oester.-ung. I94 (I882). Leso. James Moss. N. Amer. I97 (I884). 
Autoicous ; densely gregarious or matted, pale green, stem 3-6 lines, often divided ; leaves distant, erecto-patent, flaccid, obovate-oblong, abruptly acuminate, obtusely serrate in upper half, nerve vanishing in the point, cells large oblong-hexagonal. Calyptra erect, $4-5$ lobed at base. Caps. on a long seta, erect, roundish-pyriform, contracted below the mouth when dry, rufo-fuscous, smooth, the marginal cells rectangular in I2-I6 rows, the neck short and well-defined, annulus of two rows of cells, lid convex-conic, shortly rostellate, spores spinulose.

HAB.-Moist banks and borders of ditches; not uncommon. Fr. 4.

Readily known by the lobed calyptra from the similar Funaria fascicularis, which has also a plano-convex lid.

\section{FUNARIA Schreb.}

In L. Gen. plant. 8 ed. ii, 760 ( $179 \mathrm{I})$.

Plants short and simple, inhabiting the ground, with laxly areolate ovato-lanc. leaves. Calyptra long-persistent, covering the greater part of the fruit, large inflato-cucullate, entire at base, long-beaked. Caps. pyriform, oblique and cernuous, or symmetric and erect; lid planoconvex, sometimes mamillate; peristome double, simple or none, teeth I6 often twisted obliquely to the right, with their points attached to a central disc; endostome of 16 lanc. processes opposite to the teeth and adhering to them at base. Male infl. discoid, on a short branch.-Der. from funis a rope, referring to the twisted seta.

The genus Funaria comprises nearly roo species, the larger half belonging to the section Entosthodon, which is connected to Funaria by such a gradually ascending series of closely allied species, that they can only form one extremely natural genus, the distinctive characters of which reside in the form of the calyptra and operculum. The peristome attains its highest development in $F$. hygrometrica, in which the teeth are spirally twisted and at about $\frac{2}{3}$ their length dip straight downwards and then inwards to be attached to a little central sieve-like disc, affording a beautiful object for the microscope.

\section{Clavis to the Species.}

Capsule symmetric.

Peristome none.

Leaves bordered, caps, short-necked. Peristome single.

L. not bordered, caps. long-necked.

Capsule asymmetric, gibbous.

Caps. smooth, annulus none.

- striate, ann. large, coloured.

Lid very small, subconic, endostome rudimentary.

-- broader, convex, endos. well developed.

\author{
obtusa. \\ fascicularis. \\ attenuata. \\ calearea.
}

microstoma. hy'grometrica.

Sect. r. ENTOSTHODON. Capsule nearly regular, erect, peristome none, simple or sometimes double. 


\section{FUNARIA OBTUSA (Dicks.) Lindb.}

Autoicous; laxly gregarious. Leaves oval-lanc., with a thickened border, obsoletely toothed. Caps. erect, sub-globose, short-necked, lid convex, peristome none. (T. LXV, A.)

Syn.-Bryum obtusum Dicks. Crypt. Fasc. ii, 5, t. 4, f. 7 (I790). Gmel. in L. Syst. nat. I3 ed. ii, I 334 (I79I). With. Bot. arr. 3 ed. iii, 8I I (I796). Hull Br. fl. P. 2, 256 (I799).

Gymnostomum dubium BrID. Musc. rec. II, P. I, 42 (I798).

Gymn. obtusmm (non Turn.) Sw. in Schrad. Journ. Fot. ii, I7 I p. p. (I8oI). Hedw. Sp. musc. 34, t. 2, f. I-3 (I80I). P. Beauv. Prodr. 59 (I805). Brid. Sp. musc. I, 32, p. p. (I806), Mant. 15, p. p. (I819), Bry. univ. i, 73, p.p. (I826). La PyL. in Poir. Enc. Bot. Suppl. ii, 868, p. p. (I8II). Schwaeg. Suppl. I, P. I, 2I, p. p. (I8I I). Savi Bot. etr. iii, 32 (I8I8). STEUd. Nomenc. crypt. I92, p. p. (I824).

Gymn. fasciculare (non BRID.) Sm. Eng. Bot. t. I245 (I803), Fl. brit. II65, p. p. (I804). Turn. Musc. hib. Io, p. p. (I804). Hook. TAy. Musc. br. I2, t. 7 (I8I8).

Bry, univ. i, I03. var. $\beta$. Schultzii NeEs Hsch. Bry. Germ. i, I43 (I823). BRID.

Gymn. Ahnfelti Fries St. agr. femsj. 28 (I825). Ahnf. in Fries Novit. 299 (I828). Hartm. Skand. fl. 2 ed. 300 (I832). LindGr. in. Bot. Not. I842, p. 73.

Hymenostomum Ahnfelti Grev. MSS. Fries St. agr. femsj. Ioo (I827).

Gymn. affine Hueben. Musc. germ. 42, p. p. (1833).

Gymn. Bonplandi (non Brid.) Buching. in Flora xix, P. I, I I (1836).

Physcomitrium Bonplandi (non Brid.) BRuch MSS. HAMpe in Flora xx, P. I, 285 (IS37). De Not. Syllab. 283 (I 838 ). AnNGST. Disp. musc. scand. Io (I 842 ).

Gymn. ericetorum Bals. De Not, in Mem. Acc. Torin. XL, 348 (I838).

Physcom. ericetorm BR. SCH. Bry. eur. fasc. II, p. I3, t. 3 (I84I). C. MUELL. in Linnæa xviii, 695 (I 844 ). Spruce in Tr. Bot. soc. Edin. iii, I65 (I849). Wils. Bry. br. 273, t. 7 (I855). HobK. Syn. I 27 (I873). Husn. Mouss, nord-ouest I I 5 (I873).

Physcom. Ahnfelti Hartm. Skand. fl. 4 ed. 365 (I843). Aongstr. in Nova act. soc. Upsal. xii, 359 (I844), et in Fries Summ. veg. Scand. i, 89 (I846).

Entosthodon ericetornm C. Muell. Synops. i, I22 (I848), Deutsch. Moos. I 35 (I853). Rabenh. Deutsch. kr. fl. ii, S. 3, 88 (I848). Schimp. Coroll. 6i (I855), Synops. 3 I6 (I860), 2 ed. 378 . LANie in Fl. dan. fasc. 45, t. 2687 (r86r). BERK. Handb. br. m. I75 (I863). Milde Bry. siles. I95 (I869). De Not. Epilogo 454 (I869). Juratz. Laubm. oester.-ung. 240 (I88i). Husw. Musc. gall. 214, t. $5^{8}$ (I888).

Entost. obtusus Lindb. in Oefv. V. ak. Foerh. xxi, 22I, in obs. (1864).

Entost. Notarisii Schimp. MSS. PIcc. in Comm. critt. ital. fasc. 4, 30 (I863). De Not. in eod. diar. ii, 23 (I866), Ep1l. bri. ital. 455 (1869).

Entost. fascicularis forma M. LANGE in Bot. Tidssk. ii, 240 (1868).

Entost. Curnowii Davies MSS. a robust form.

Funaria obtusa LindB. in Not. ur Saells. Fn. et Fl. fenn. foerh. xi, 65 (1870).

Autoicous; loosely gregarious, simple or branched, fulvescent, slightly glossy. Lower leaves remote, lanc., upper crowded in a coma, broadly obovato-lanc., acuminate, with a yellowish border of $\mathrm{I}-3$ rows of long very narrow cells, the margin obtusely dentate or nearly entire ; nerve vanishing below or at the apex, yellow, fuscous when old; cells lax and pellucid. Caps, rather small, erect on a straight seta, subglobose with a short neck, solid, rufescent, when dry and deoperculate slightly contracted below the mouth, gymnostomous; calyptra inflated, cucullate; lid convex, mamillate. 
HAB.-Wet heaths and banks of sandy clay; common in subalpine districts. Fr. 3-4.

A very variable plant as to size and also in the length and width of the leaves; it much resembles $F$. fascicularis from which it is immediately distirguished by the narrowly limbate leaves.

2. FUNARIA FASCICULARIS (Dicks.) Schimp.

Autoicous; densely gregarious. Leaves oblongo-lanc., acuminate, serrate, not limbate. Caps. erect, shortly pyriform, peristome fugacious; lid convex. (T. LXV, B.)

Syn.-Bryum serpyll. pollucidum, capsulis pyriformibus Dill. Hist. musc. t. 44, f. 6, M.

Bryum fasciculare Dicks. Crypt. Fasc. III, 3, t. 7, f. 5 (I793). With. Bot. arr. 3 ed. iii, SI 5 ( I796). Hull Br. fl. P. 2, 257 (I799).

Gymmostomum fascicularc Brid. Musc. rec. II, P. I, 44 (I798), Sp. musc. I, 28 (I806), Mant. I5 (I8Ig). Henw. Sp. musc. 38, t. 4, f. 5-8 (I80 I). SM. Fl. brit. II65 (I804). Turn. Masc. hib. Io (1804). Schultz Fl. Starg. 279 (I806). Web. Mohr Bot. Tasch, 89 (I807). Sturm Deutsch. Fl. II, Io (I80g). Schkuhr Deutsch. kr. gew. P. II, 30, t. I 2 (I8I0). Schwaeg. Suppl. I, P. I, 24, (I8II). VoIt Musc. herb. I6 (I8I2). Roenl. Deutsch: f. jii, 40 (I8I3), Ann. Wett. ges, ii, I28. Hook. TAy. Musc. br. I2, t. 7 (I8I8). Funck Moost. 6, t. 4 (I8II). Gray Nat. arr. br. pl. i, 7 I5 (I8II). Hook. Fl. scot. P. II, I23 (I82I), Br. Fl. ii, 9 (I833). NeEs Hsch. Bry. germ. i, I4I, t. Io, f. Io (I823). IIUeben. Musc. germ. 45 (I833). Mack. Fl. hib. P. 2, I I (I836).

Gy'mn. (Phy'scomitrium) fascicularc BRID. Bry. univ. i, IOI (IS26).

Physcomitrium fasciculare FUERnR. in Flora xii, P. II, Erganz. 9 (I82g). HAMPE in eod. diar. xx, P. I, 285 (I837). De Not. Syllab. 282 (I838). BR. Sch. Bry. eur. fasc. II, p. I3, t. 4 (I84I). Wils. Bry. br. 274, t. 52 (I855). Hoвk. Syn. br. m. I27 (IS73). HusN. M. nord-ouest I I5 (I873).

Entosthodon fascicularis C. Muell. Synops. i, I20 (I848). Rabenh. Deutsch. kr. f. ii, S. 3, 88 (I848). Schimp. Synops. 3 I 7 (I860). BERK. Handb. br. m. I75 (I863). Di Not. Epil. 453 (I869). Husn. Musc. gall, $21_{5}$, t. $5^{8}$ (I888).

Funaria fascicularis Schimp. Synops. 700 (I860), 2 ed. $38 \mathrm{I}$. Lindb. in Oefv. v. Akad. foerh. IS6 +, p. 597. Milde Biry. siles. Ig6 (I869). JuRAtz. Laubm. oester.-ung. 24 I (I882). HOBK. Syn. 2 ed. I45 (1884).

Autoicous; densely gregarious and subcæspitant, deep yellowgreen. Lower leaves very small, the comal patulous, oblongo and spathulato-lanc., acuminate, sharply serrate in the upper part, not limbate, twisting somewhat when dry, nerve vanishing below apex. Caps. on a straight reddish seta, a little asymmetric, spherical, or with the sliort neck, shortly pyriform, reddish-brown, contracted and more elongated when old, not annulate; calyptra inflated yellowish, lid small, convex, the cells spirally oblique, peristome rudimentary and fugacious, consisting of short papillose fragments, spores strongly verruculose.

HAB.-In fields and on banks, generally distributed in subalpine districts, but not common. Fr. 4-5.

Most resembling Ployscomitrium pyriforme, but readily distinguished by the different calyptra and lid. 


\section{FUNARIA ATtenUATA (Dicks.) Lindb.}

Autoicous; densely gregarious. Leaves in a spreading rosette, broadly obovate-oblong, acuminate, the margin slightly crenate, nerve vanishing. Caps. erect, pyriform with a long defluent neck, teeth of peristome $I 6$, small lanceolate-subulate, lid flattish convex. (T. LXIV, C.)

Syn.-Bryum attenuatum Dicks. Crypt. Fasc. IV, p. 8, t. Io, f. 8 (180r). BRID. Musc. rec. II, P. III, 63 (I803), Sp. musc. IIII, 6 (I8I7), Mant. Ir7 (I8Ig), Bry. univ. i, 638, p.p. (I826). Sm. Fl. brit. I360 (I804), Eng. Bot. t. 2433. Schwaeg. Suppl. I, P. II, I20 (I8I6). Steud. Nomencl. crypt. 86 (I824).

Orthopyxis? attonuata P. BEAuv. Prodr. 79 (1805).

Gymnostomum pyriforme BRID. Sp. musc. I, 27, p. p. (r806).

Splachmum furcssi Schwaeg. Suppl. I, P. I, 55 (I8II). Brid. Mant. Iog; Bry. univ. i, 263. C. Muell. Synops. i, $\mathrm{I}_{4} 8(\mathrm{I} 848)$.

Funaria Templctoni Sm. Eng. Bot. t. 2524 (1813).

Weissia Templetoni Hook. in Curt. Fil. Lond. i (I8I7), et F1. Scot. II, I30 (r82I). Hook. Tay. Musc. brit. 42, t. I4 (I8IS). Gray Nat. arr. Br. pl. i, 729 (I82I).

Wcissia longicullis LINK. MSS. BRID. Mant. 45.

Entosthodon Templetoni Schwaeg. Suppl. II, P. I, 44, t. II3 (1823), et in L. Sp. pl. 4 ed.v, P. II, 47 (r830). Brid. Bry. univ. i, 379. Hook. Br. fl. ii, 5r (I833). Bals. De Not. in Mem. Accad. Torin. xl, 337 (I838). DE Not. Syll. 227 (I838). BR. Sch. Bry. eur. fasc. Ir, p. 3, t. I (184I). C. Mueld. Synops. i, I24 (I848). Wils. Bry. br. 272, t. I4 (I855). Schimp. Coroll. 6r (1855), Synops. 3 I9 (I860), 2 ed. 379. Berr. Handb. br. m. I76, t. I6, f. 5 (I863). Hовк. Syn. br.m. I I27 (1873). Husn. Mouss. nord-ouest I 5 (1873). Musc. gall. 2I 5, t. 58 (I888). LesQ. James Moss. N. Amer. 200 (1884).

Ercmodon longicollis BrID. Bry. univ. i, 234.

Entosthodon rupestris BriD. ditto p. 379 ut syn.

Gymnos. Pliyscomitrium latifolium BrID. op. c. $7^{60}$.

Physc. latifolizm Brid. Bry. univ. ii, $8 \mathrm{I}_{5}$ (I827). Bry. eur, fasc. Ir, p. 15.

Funaria Fontancsii (non Schwaeg.) Bals. De Not. Prodr. bry. mediol. 32 (I 834 ).

Plyss. Entosthodon Tcmpletoni C. Muell. in Linnza xviii, 696 (I844).

Physc. Solcirolii Mont. in Ann. sc. nat. 4 ser, vii, I52 (I857).

Funaria attenuata Lindb. Not. ur Saells. Fn. et Fl. fenn. foeth. xi, 64 (1870).

Autoicous; laxly or densely gregarious, simple. Cauline leaves very small, few and distant, comal in a patent rosette or laxly imbricated, broadly obovate or spatliulate-oblong, acuminate, the margin slightly crenate by projecting cells, with a very narrow yellow border, nerve vanishing below apex. Caps. on an orange seta, erect pyriform with a long neck attenuated downward, leptodermous, yellowish-brown, finally truncate obconic and rufo-fuscous; annulus none, lid flattish convex; teeth of per. I6, from a confluent base, lanceolate-subulate, remotely articulate, pale and papillose, when dry depressed and connivent.

$\mathrm{HAB}$. - Shady banks and wet sandstone rocks. Fr. 6-7.

Not uncommon in Ireland, West of Scotland and Wales. Lake district. Plymouth (Holmes)!! By Clifton Viaduct, Manchester (Horsefield).

Varies much in the length and width of the leaves and generally found on dripping banks of streams, intermixed with other mosses.

Sect. 2. EUFUNARIA. Capsule oblique, gibbous, cernuous, peristome present. 


\section{FUNARIA CALCAREA Wahlent.}

Autoicous; leaves obovate-oblong, suddenly apiculate, margin obtusely serrate, nerve vanishing. Caps. shortly pyriform, not annulate, smooth. (T. LXV, D.)

Syn.-Funaria calcarea WAHLENB. in Vet. ak. handl. xxvii, I37, t. 4, f. 2 (I806). WeB. MohR Bot. Tasch. 380 (I807). Hartm. Skand. f. (I820). Schimp. Synops. 320 (1860), 2 ed. 382. LiNDB. in Oefvers. vet. akad. foerh. xx, 398 (1863). Husn. Mouss. nord-onest Ii6 (I873), Musc. gall. 2I6, t. 58 (I888). JuRAtz. Laubm. oester.-ung. 242 (I882). Boulay Musc. de Fr. 298 (I884). Hoвk. Synops. 2 ed. I 46 (I884).

Funaria Muehlcnbergii (non Hedw. f.) Turn. in Konig Sims Ann. Bot. ii, I98 (I8o6). Schwaeg. Suppl. I, P. II, 78, p. p. (I8I6). Brid. Sp. musc. III, 68, p. p. (I8I7), Bry. univ. ii, 55, p. p. (I827). Hook. TAYL. Musc. brit. 69, p. p., t. 20 (I8I8). Hook. Fl. scot. II, I36 (I821), Br. fl. 52 (I833). Hueben. Musc. germ. 498 (1833). De Not. Syllab. I44 (1838). Br. Sch. Bry. eur. fasc. II, p. 6, p. p., t. I (184I). C. Muell. Synops. i, IO9 p. p. (1848). Rabenh. Deutsch. kr. fl. ii, S. 3, 89, p. p. (1848). Spruce in Ann. Mag. n. h. 2 ser., iii, 37 I (I849). Wils. Bry. brit. 27 I, p. p., t. 20 (1855). BERToL. Fl. ital. crypt. 305 (I859). BERK. Handb. Br. m. I77, (I863). Hobk. Synops. I 26 (1873).

Funaria hibcrnica Hook. in Curt. Fl. Lond. 2 ed. ( $8 \mathrm{I} 77$ ). Hook. TAyl. Musc. br. 69, p. p., t. 20. Brid. Bry. univ. ii, 56 (1827). Br. Sch. Bry. eur. 1. c. t. 2. C. Muell. Syn. i, IIo. Wils. Bry. br. 270 , t. 20. Bertol. Fl. ital. cr. 306. Schimp. Synops. 322. DE Nот. Epilogo 450. Husn. Mouss, nord.ouest i 6.

Funaria meditcranea LindB. in Oefv. v. akad. foerh. xx, 399 (I863). MiLde Bry. siles. I97 (I869). De Not. Epilogo 449 (I869). LesQ. James Moss. N. Amer. 201 (I884).

Autoicous; laxly cæspitose with short stems. Lower leaves remote, oblongo-lanc., deflexed, upper erecto-patent, obovate-oblong, more or less suddenly acuminate, with a slender apiculus or flexuose subula; margin in the upper half obtusely serrate, or nearly entire, nerve yellowish, vanishing below apex. Seta erect, reddish, twisting to the left or sometimes also to the right at the top; caps. turgid, sliortly pyriform, suberect, gibbous, leptodermous, brownish-yellow, finally reddish-brown, and contracted below the mouth; annulus none, lid convex-conic, reddish at margin; teeth lanc.-subulate, bright red, processes of endostome lanceolate, $\frac{2}{3}$ the length of teeth, spores large, verrucose.

HAB.-Rocks and walls in limestone districts. Fr. 4-5.

Sussex Downs (Borrer). Malham, Yorks. (Nowell 1856). Matlock and Millers dale (Wilson)!! Levens (Barnes)!! About Cork and Blarney (Taylor).

Var. $\beta$. patula $B r$. Sch.

Stem more slender, leaves patent, with short points, entire at margin.

Syn.-Funaria Fontanesii Schwaeg. Suppl. I, P. II, 8o, p. p., t. 66 (I8I6). Brid. Bry. univ. ii, 56 .

Funaria neglecta DE Not. MSS.

HaB.-Same localities as the type.

St. Vincent's rocks (Thwaitcs I843). Worthing and Torquay (Mrs. Robcrtson I859)! Plymouth (Holmes 1868).

The two species here brought together have both been referred to a third-F. Muehlenbergii-an American moss which appears to be distinct. 
This has led to inextricable confusion in the synonymy, which Lindberg attempted to end by renaming them; his $F$. Americana=the genuine F. Muehlenbergii Hedw. f., his $F$. Mediterranea $=F$. Mushlenbergii Turn., and his $F$. calcarea $=F$. hibernica Hook. ; that the last is perfectly correct is clear from Wahlenberg's beautiful figure, and also that it must stand as the type of the species, being a larger plant with larger and more sharply serrate leaves, but that these trivial differences are sufficient to maintain the other even as a variety must be answered in the negative, for every stage of projection of the marginal cells constituting the teeth, may be noticed down to an almost entire edge to the leaf.

\section{FUNARIA MICROSTOMA Br. Sch.}

Autoicous; resembling $F$. hygrometrica. Leaves oval, acuminate, entire, nerve lost in the point. Caps. decurved, annulate; lid small, subconic, endostome rudimentary. (T. LXV, E.)

Syn.-Funaria microstoma Br. Sch. Bry. eur. fasc. II, p. 9, t. 4 (184I). C. Muell. Synops. i, Io6 (I848). Rabenh. Deutsch. kr. fi. ii, S. 3, 90 (I848). Schimp. Synops. 324 (I860), 2 ed. 385 . De Not. Epilogo 447 (1869). HoBk. Synops. I26 (I873). HusN. Mouss. nord.ouest II 7 (1873), Musc. gall. 2 Ig, t. 59 (I888). JURATz. Laubm. oester.-ung. 243 (I882). Boulay Musc. de Fr. 298 (I884). Lesq. James Moss. N. Amer. 203 (I884).

Autoicous; resembling F. lyggrometrica. Comal leaves connivent in a gemma, oval, longly acuminate, very concave, entire, the nerve vanishing in the point. Caps. turned downward on a stouter seta arcuate above, turgidly pyriform, more solid, deep bay, subnitid, less deeply sulcate when dry; annulus broad, lid much smaller, subconic, mamillar; peristome smaller, endostome very imperfect, agglutinated to the base of the teeth, yellowish; spores twice the size smooth, punctulate. Male infl. on a radical branch.

HaB.-Open commons or heaths, rare. Fr. 7-8.

Maresfield, Sussex (Mitten). Ashdown Forest (Davies I865)!! New Forest (Davies).

Very closely resembling $F$. hygromatrica and probably passed by for that species; it differs however in the small mouth and rudimentary endostome.

\section{EUNARIA HYGROMETRICA (L.) Sibth.}

Autoicous; cæspitose. Leaves ovato-lanc., concave entire, nerved nearly to point. Caps. pyriform-ventricose, furrowed, mouth oblique, corrugated, annulate, seta curved, flexuose. (T. LXV, F.)

Syn.-Muscus trichoides minor, foliis ad canlen convolutis, capitulis subrotundis reflexis. Doody. Ray Synops. App. 244 (16go).

Adiantum aureum minus, foliis bulbi in modum dispositis. Vernon. Ray Synops. 2 ed. $33(1696)$.

Muscus capillaris pediculis bulbosis uncialibus pallidis, capitula oblonga reflexa sustinen. tibus RAY op. c. 34 . 
Brynm aurenm cap. reflcxis piriformibus, calyptra quadrangulari, foliis in bulbi formam congcstis Drll. Cat. giss. 227 (I7I9), et in RAY Synops. 3 ed. IOI, n. 49 (I 24 ).

Bryum bulbiformc aurcum, calyptra quadrangnlari, capsulis piriformibus mutantibus DrLl. Hist. musc. 407 t. 52 , f. 75 (I74I) et Herbar.

Mnimm hygronctricum L. Sp. pl. IIIo (I753), Syst. nat. ii, 700. WeISs Cr. Goett. I47 (1770). Fl. Dan. t. 648, f. 2. Wrth. Bot. arr. ii, 664 (i776). Pollich Pl. Palat. iii, n. 983 (I777). LightF. Fl. scot. ii, 709 (I777). Reli. Fl. cant. 399 (I785). Hoffm. Deutsch. fl. ii, 50 (I795). Аввот Fl. bedf. 233 (I798). Sturm Deutsch.fl. II, 2 (I798). Hull Br. fl. P. 2, 249 (I 799).

Bryum hygronctramm Huns. Fl. angl. 4I6 (I762)... Neck. Meth. musc. 22I (I77I). Web. Spic. Fl. gott. I8I (I778). Vill. Pl. Dauph. iii, 89o (I786). Eng. Bot. t. 342.

Foclreutera hygrometrica HeDw. Fund. II, 95 (I 782 ). TImm F1. megap. n. 853 (I788). Roth Tent. fl. germ. i, 477 (i788). Schrank Baiers. fl. ii, 48 I (I789), Pr. fl. salisb. n. $85^{\mathrm{I}}$ (1792).

Funaria hygrometrica Sibth. Fl. Oxon. 288 (I794). Schrad. Samml. kr. gew. i, n. 63 (I796), et in Usteri Ann. Bot. xix, I ro (I796). Roth Tent. fl. germ. iii, P. I, 225 (I800). Thunb. Prodr. pl. cap. II, I74 (I800). Hedw. Sp. musc. I72 (I8oi). Brid. Musc. rec. II, p. III, II8 (I8o3), sp. musc. III, 65 (I8I7), Mant. I23 (I8Ig), Bry. univ. ii, 5I (I827). Sm. Fl. brit. I338 (I804). TURn. Musc. hib. IO6 (I804). Schultz Fl. starg. 350 (I806). Web. MoHR Bot. Tasch. 378 (I807). Vort Musc. herb. I 26 (I8I2). Wahlenb. Fl. lapp. 350 (I8I2). Roenl. Deutsch. fl. iii, irz (I8I3). Hook. F1. Lond. 2 ed. c. ic., Fl. scot. P. II, I36 (I82I), Br. fl. ii, 52 (I833). Schwaeg. Suppl. I, P. II, 75 (I8I6). Mart. Fl. cr. erl. 74 (I8I7). Hook. TAYL. Musc. br. 69, t. Io (I8I8). HARTm. Skand. fl. Gray Nat. arr. br. pl. i, 744 (I82I). Funck Moost. 42, t. 33 (I82I). Hueben. Musc. germ. 497 (I833). Mack. Fl. hibern. P. 2, 29 (I836). De Not. Syll. I43 (1838), Epilogo 446 (1869). Br. Sch. Bry. eur. fasc. I I, 8, t. 3 (I84t). Rabenh. Deutsch. kr. fl. ii, S. 3,89 (I848). C. Muell. Synops. i, Io7 (I849). WILs. Bry. br. 269, t. 20 (I 855 ). ScHimp. Synops. 323 (IS60), 2 ed. 384. Berk. Handb. br. m. I77, t. I6, f. 6 (I863). Milde Bry. siles. I97 (I869). HoвK. Synops. I 26 (I873). Husn. Mouss. nord-ouest II7 (I873), Musc. gall. 218, t. 59 (I888). JURATz. Laubm. oester..ung. 242 (I882). Boulay Musc. de Fr. 297 (I884). Lesq. James Mosses N. Amer. 202 (I884).

Strephedium hygronctricum P. Beauv. Prodr. 89 (I805).

Funaria campylopus Brid. Bry. univ. ii, 739 (I827).

Autoicous; short, cæspitose, yellowish green; stems simple or divided at base. Comal leaves at first connivent, crowded in a rosette, rarely patulous, thin and concave, ovate-oblong, acuminate, quite entire, nerve reaching apex. Caps. on a long flexuose seta, twisting to right above, to left below, arcuate at top, turgidly pyriform, depressed or turned downward, coriaceous, orange or rufous, when dry deeply sulcate, the mouth oblique, surrounded by a corrugated border; lid broadly convex, grooved to receive the annulus which is crimson, broad and revoluble; teeth of peristome lanceolate-subulate, falcate, pale red, depressed at points when dry and connivent on a central sieve-like disc; processes of endostome lanceolate-subulate, $\frac{2}{3}$ length of teeth. Spores ferruginous, small, smooth. Male infl. terminal on a short basal branch, bracts subspathulate, serrated at apex.

HaB.-On the ground, heaths, and banks, common. Fr. 5-8.

Var $\beta$. patula $B r$. Sch.

Stem slender, divided, comal leaves patulous, longer and narrower, flexuose at margin, twisted when dry. Syn,-Br, Sch. Bry. eur. fasc. i i, p. 8, t. 3. C. Muell. Wilson, \&c. 
Hab.-In moister places.

Var. $\gamma \cdot$ calvescens (Schwaeg.) Schimp.

Laxly cæspitose; leaves patulous, longly sheathing, flexuose at margin. Caps. on a long straight seta, erect or inclined, with a narrow neck.

Syn.-Funaria calvesccns Schwaeg. Suppl. I, P. II, 77, t. 65 (r8r6). Brid. Sp. musc. III, 66, Bry. univ. ii, 53. C. Muell. Syn. i, ro7.

Funaria androgyna Brid. Bry. univ. ii, 58.

F. hygrometrica $\gamma$, calvescens $\mathrm{BR}$. ScH. Bry. eur. 1. c.

HAB.-In warm moist places.

Woolston moss (Wilson)!! Arniston woods, Edinburgh (F. B. Syme I 860)!

This universally distributed moss presents great variety, not only according to its locality, but at various stages in the growth of the same plants, as is admirably pointed out by Dillenius. The highly developed peristome is quite peculiar among mosses, the points of the teeth being attached to a central cribrose disc resembling the top of a thimble, which being at a lower level than the teeth, they reach by bending downward and then inward, thus forming a funnel-shaped cavity in the middle.

Tab. LXIV. A. Discelium nudum (Ashton, Whitehead). B. Amblyodon dealbatus (Southport, Hunt). C. Nanomitrinm tcucrum (Hurstpierpoint, Mitten). D. Physcomitrella patens (Mere, Hunt). E. Physcomitrium spharicum (Mere, Hunt). F. Physc. pyriforme (Tottenham, Braitlwaitc).

TAB. LXV. A. Funaria obtusa (Goathland, Braithzaite). B. Fun. fascicularis (Dolgelly, Mrs. Braithwaite). C. Fun. attenuata (Teesdale, Slater). D. Fun. calcarea (Millersdale, Holmes). E. Fun. microstona (Ashdown forest, Davies). F. Fum. hy grometrica (Chislehurst, Braithwaite). $\gamma$. Var. calvcscens (Woolston moss, Wilson).

a. Fertile plant. a*. Ditto mag. b. Male. r. Leaf mag. ra. Apex. rab. Areolation of base. 3. Male infl. 4. Antheridia and paraphyses. 5. Capsule. 6. Calyptra. 8. Teeth of peristome. 9. Spores. 




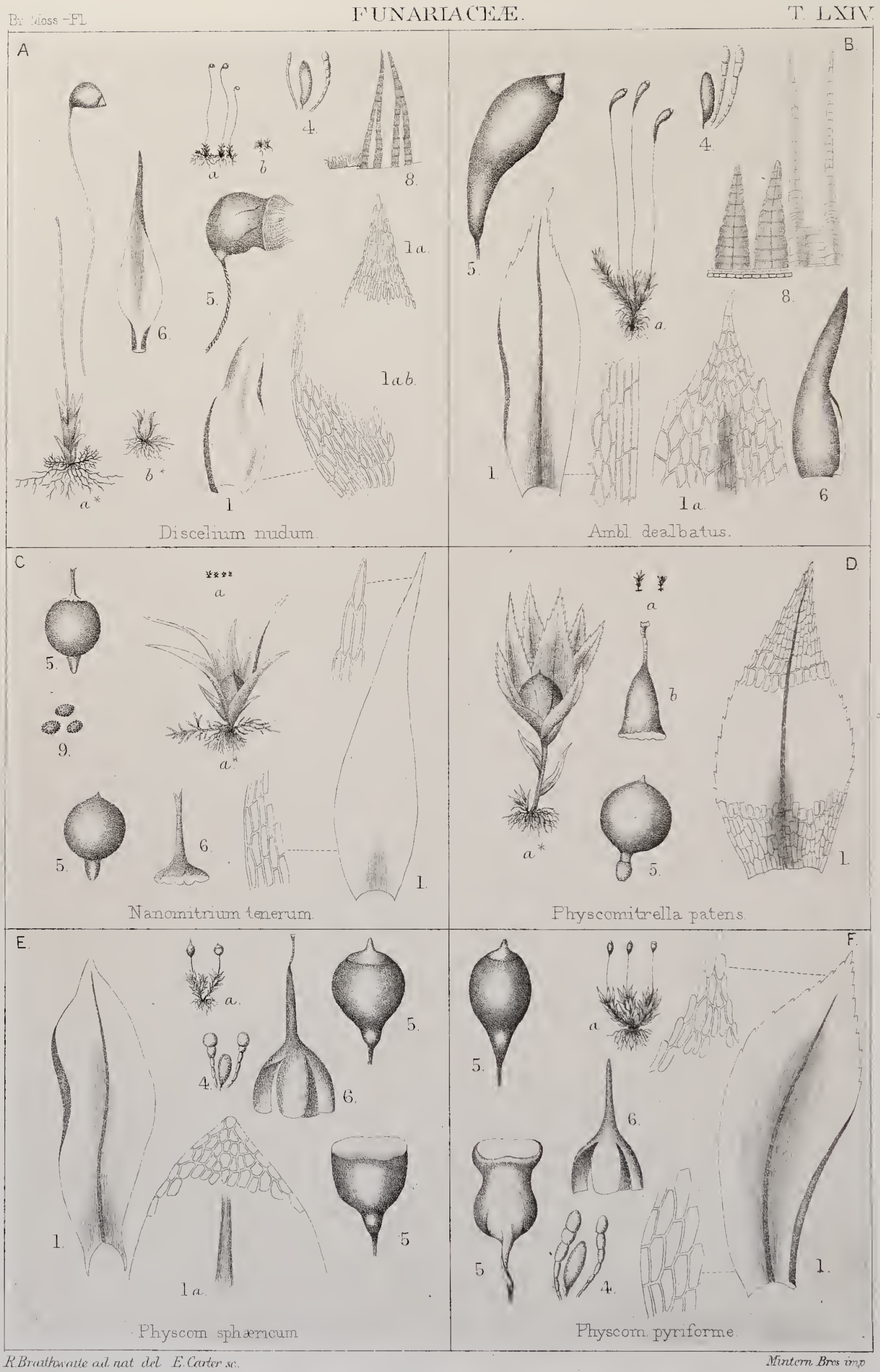




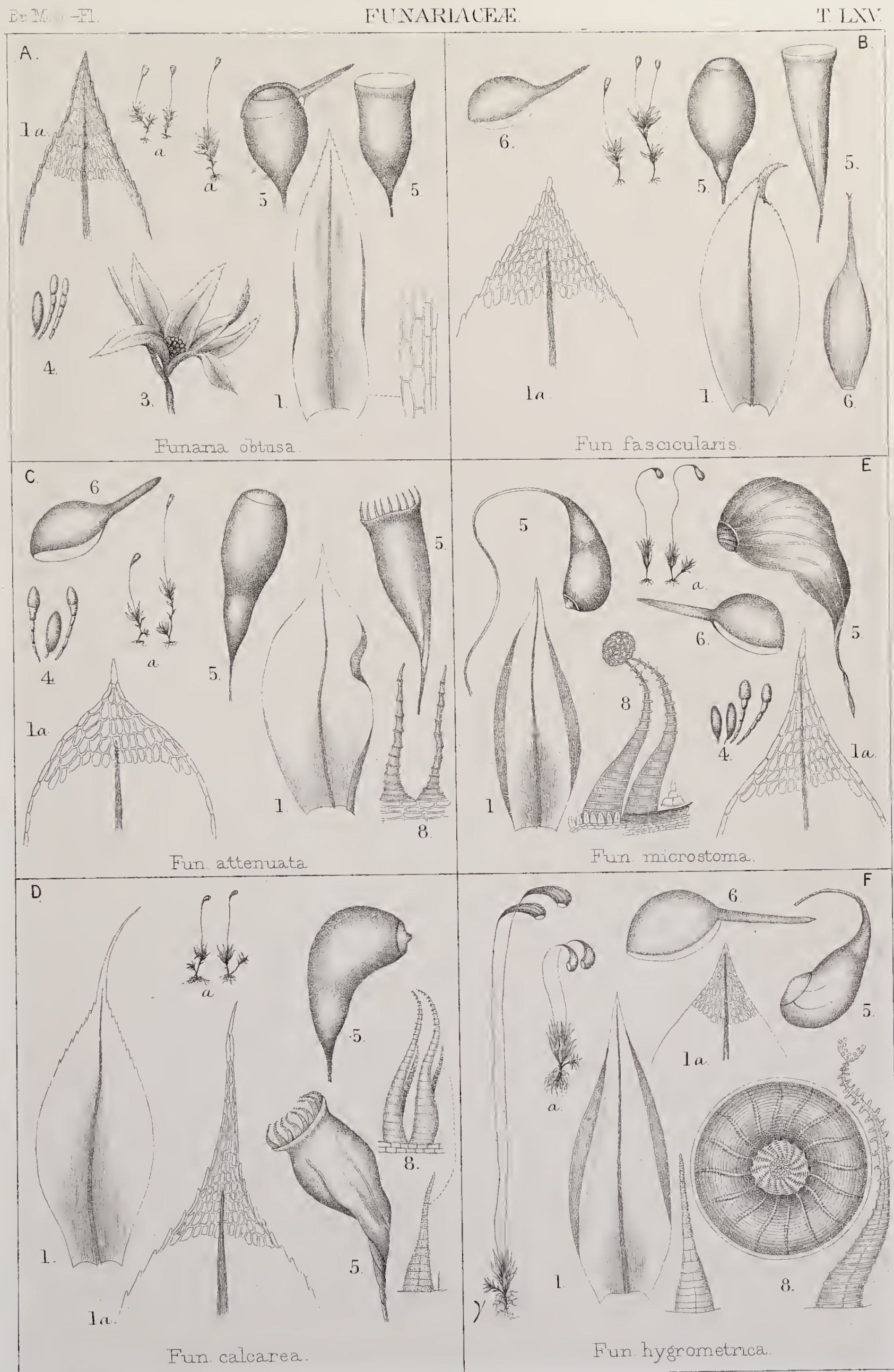

RBrrathwerite ad nat de. ECartor sc 

B R Y A C E $Æ$. 
OREAS BRID.

Oreas Mielichhoferi (Funck) Brid.

STABLERIA LINDB. Stableria gracilis (Wils.) Lindb.

LEPTOBRYUM WILS.

Leptobryum pyriforme (L.) Wils.

\section{POHLIA HEDw.}

1. Pohlia acuminata Hornsch.

2. polymorpha Hornsch.

3. elongata Hedu.

4. - cruda (L.) Lindb.

5. cucullata (Schwa,g.) Bruch.

6. - nutans (Schreb.) Lindb.

\%. Larnea (L.) Lindb.

8. - annotina (L.) Lindb.

9. —— Ludwigii (Spreng.) Lindb.

10. - commutata (Schimp.) Lindb.

11. - gracilis (Schleich.) Lindb.

12. albicans (Wahlenb.) Lindb.

\section{EPIPTERYGIUM LINDB.}

Epipterygium Tozeri (Grev.) Lindb.

\section{PLAGIOBRYUM LINDB.}

1. Plagiobryum Zierii (Dicks.) Lindb. 2. demissum (Hornsch.) Lindb.

\section{BRYUM DILL.}

1. Bryum filiforme Dicks.

2. - juliforme (Solms) Schimp.
3. Bryum concinnatum Spruce.

4. lacustre (Bland.) Brid.

5. inclinatum (Sw.) Bland.

6. pendulum (Hornsch.) Schimp.

7. purpurascens (R. Br.) Br. Scl.

8. Warneum Blandow.

9. Cernuum (Sw.) Lindb.

10. Marratii Wils.

11. calophyllum $R . B r$.

12. fallax Milde.

13. intermedium Brid.

14. - bimum Schrcb.

15. - affine (Bruch) Lindb.

16. - torquescens $B r . S c h$.

17. - pallescens Schleich.

18. - cæspiticium $L$.

19. argenteum $L$.

20. bicolor Dicks.

21. erythrocarpon Schw.

22. - murale Wils.

23. rubens Mitt.

24. Mildei Furatz.

25. Muehlenbeckii $\mathrm{Br}$. Sch.

26. - gemmiparum De Not.

27. alpinum $H u d s$.

28. pallens Sw.

29. - Duvalii Voit.

30. turbinatum (Hed.) Schw.

31. ventricosum Dicks.

32. - neodamense Itzigs.

33. - cyclophyllum (Schw.) Br. Sch.

34. capillare $L$.

35. Donii Grev.

36. - provinciale Philib.

37. barbatum Wiis.

38. - proliferum (L.) Sibth. 


\section{FAM. I5. BRYACEA.}

Plants innovating below the inflorescence or from the base. Stem erect simple or with binate innovations below the apex, repeatedly dichotomous and fastigiate, with copious radicles. Leaves plurifarious, ovate, lanceolate or subulate, nerved and often dentate and limbate at margin; cells parenchymatous, subequal, or prosenchymatous and rhomboid towards apex, all smooth. Calyptra cucullate, smooth, narrow, fugacious. Caps. on an elongate seta, globose, ovate, or with the neck pyriform, usually cernuous or pendulous; lid mamillar, rarely rostrate; peristome double, very rarely none, rarely simple. Male infl. gemmiform or discoid. Inhabiting the ground, rocks and walls.

This large family including some 500 species, is readily recognizable so far as the great genus Bryum is concerned, but the species present much nniformity among themselves, and are thus difficult of determination, especially in the sterile condition. The position of the male inflorescence should be carefully looked for, as it affords much assistance in the discrimination of closely allied species.

Subf. I. Oreadeæ. Infl. on short lateral branches near the base of the stem. Leaves small, pellucid. Caps. gibbous or symmetric; peristome simple, teeth confluent at base, becoming narrow and linear.

\section{OREAS Brid.}

Bry. univ. i, 380 (1826).

Calyptra narrow, cucullate. Caps. clavate-oval or pyriform, smooth, pendulous on a short arcuate seta, or taller and erect; teeth of peristome 16 , narrow, remotely trabeculate, entire or foraminate. Plants densely compacted, fastigiate, with slender innovations arising below the infl.; growing on alpine rocks. Der. opos a mountain.

The genus Oreas was founded by Bridel on three species-O. Mielichhoferi, elongata and Martii, - of these the last is a species of Oncophonus of the section Rhabdoweissia, the other two only constitute a single species and must of course retain the original generic name. Mr. Mitten unites with Mielichhoferia, Leptochlana MonT. and Haplomitrium HaMpe, numbering together some 34 species, with a double or single peristome or none.

\section{OREAS MIELICHHOFERI (Funck) Brid.}

Dioicous; in compact glossy deep green tufts. Leaves small imbricated, lanceolate, serrate at apex, nerve vanishing. Caps. pyriform smooth, teeth broad at base. (T. LXVI, A.) 
Syn.-Wcissia Miclichhofcri Funck Crypt. gew. Fasc. 24, n. 490 (I8I9). Moost. 13, t. 9 (I82I). Hook. Musc, exot. ii, 7, t. IOI (1820). Hornsch, in Flora I8Ig, p. 86. Schwaeg. Suppl. II, P. I, 47, t. I I4 (1823). Duby Bot. gall. 372 (1830).

Orcas Miclichhofcri BrID. Bry. univ. i, 38 I (I826).

Miclichloferia nitida Hornsch. Bry. germ. ii, P. II, I83, t. 4I (I83I). Br. Sch. Bry. eur. fasc. $23-24$, t. I (I844). Rabenh. Deutsch. kr. fl. ii, S. 3, I97 (I848). C. Muell. Synops. i, 234 (1849). Wils. Bry. br. 262, t. 6I (I855). Schimp. Synops. 325 (I860), 2 ed. 386. Berk. Handb. Br. m. I6I (I863). DE Not. Epilogo 44I (I869). JuRAtz. Laubm, oester.-ung. 244 (I882). Lesq. James Moss. N. Amer. 2 I 4 (I884). Husn. Musc. gall. 2 I9, t. 59 (1888).

Apiocarpa Mielichhoferi Hueben. Musc. germ. I55 (1833). De Not. Syllab. 225 (1838).

Dioicous; in short very dense, deep green silky tufts, fuscousblack at base. Stems $2-4$ in. higl, slender, fastigiate. Leaves small, rather rigid, erecto-patent, imbricated when dry, lanceolate, accrescent upward, sharply serrate at apex, nerve vanishing below point, cells above narrowly linear-rhomboid, laxer below. Caps. from a longish neck, oval symmetric, erect, or oblique, leptodermous, rufous-yellow, on a slender flexuose purple seta; lid shortly conic obtuse; annulus compound, revoluble; teeth narrow, linear, pale yellow, nodoso-articulate, dilated and confluent at base. Male plant more slender, the infl. on short branches, gemmiform.

HAB.-Dripping rocks; rare. Fr. 8-9.

Var. $\beta$. compacta (Hornsch.).

Shorter, very densely compacted; stems slender, the leaves shorter, densely imbricated; capsule erect.

Syn.-Weissia compacta Hornsch. Hoppe Pl, alp. exsic. Dec. 2.

Wcissia clongata Hoor. Musc. exot. ii, t. I02, Br. f. ii, I9.

Mielichhoferia nitida $\beta$. gracilis Bry. eur., Wilson, De Not. Новк. Synop. \&.c.

$\mathrm{H}_{\mathrm{AB}}$.-In the same localities as the type.

Micaceous rocks at Head of Glen Callater (Grevillc I830) !! Liassic rocks above Ingleby Greenhow, Cleveland (Mudd I862) !! Corry of Loch Ceander (Roy IS68)!

The variety only has been found in this country, and is remarlsable for the very dense velvet-green patches. The Rev. Mr. Fergusson has found it bears a few capsules on rare occasions.

Sulbf. 2. Bryeæ. Inflorescence terminal. Leaves ovate or lanceolate, the cells rhomboid, rarely vermicular. Caps. pyriform or clavate; peristome double, teeth strongly barred, lanceolate.

\section{STABLERIA Lindb.}

Utkast till en nat. grupp. Eur. bladm. 20 (1878).

Plants slender, cæspitose, the leaves narrow, flexuose, with hexagonorlomboid areolation, calyptra cucullate. Caps. erect or inclined, from a longislı neck, oblong, leptodermous, on a slender seta; lid conicorostellate; peristome of I6 slender subremote teeth, inserted below the mouth, incurved when dry, remotely trabeculate, endostome a narrow 
basal membrane with I6 filiform processes. Growing on sandstone rocks. Der.-after Mr. G. Stabler, an ardent bryologist, of Levens in Westmoreland".

The genus Orthodontium was founded by Schwaegrichen in 1827 on two mosses O. julaceum which is a Brynm, and O. lineave, an African moss, which thus forms the type of the genus, and to which he afterwards agreed that $O$. gracile should be added, and several other exotic species very similar in habit raised the number to $\mathrm{r}$. Mitten however recognized two different types among them and in I869 (Musci austro-amer.) founded the genus A palodinm, very near to $Z$ ygodon, unfortunately embracing the original O. lineare, while gracile and others were retained under Orthodontium. The punctilious Lindberg restored Orthodontimm to lineare, and re-named the Bryaceous genus Stablevia.

\section{STABLERIA GRACILIS (Wils.) Lindb.}

Autoicous; slender, sparingly branched. Leaves comant, lanceolatesubulate, flexuose, nerved, entire. Caps. nearly erect, narrowly pyriform, long-necked; lid conic, rostellate, teeth slender, endostome half their length. (T. LXVI, B.)

Sys.-Bryum gracile WiLs. Engl. bot. Suppl, t. 2835 (1839).

Orthodontium gracile SchwaEg. in lit. ad Wilson. Br. ScH. Bry. eur. fasc. 23-24, p. 4, t. I (I844). C. Muell. Synops. i, 238 (1849). Wils. Bry brit. 2 I8, t. 47 (I855). Schimp. Synops. 328 (I 860 ), 2 ed. 389 . BERK. Handb. br. m. 205, t. I8, f. 4 (I863). Hobk. Syn.br. m. Io6 (I873). Boulay Musc. de Fr. 295 (1884). Husn. Musc. gall. 220 , t. 59 (I888).

Stableria gracilis LiNDB. Utk. till en nat. grupp. Eur. bladm. med topps. frukt 20 (I878).

Paroicous and autoicous; in small subpulvinate tufts, bright or yellowish-green, fragile, sparingly branched from base. Lower leaves minute, lanceolate, upper crowded in a coma, soft, flexuose, elongate lanc.-subulate, cells narrow sublinear above, at base lax, hexagonorectangular hyaline, margin plane, nearly entire, often undulate, nerve vanishing at apex. Antheridia in axils of comal leaves, paraphysate, or gemmiform. Caps. on a slender pale red seta, erect or obliquate, slender oval with a long neck, leptodermous, pale yellowish, cernuous when diy and empty, sulcate, obconic, wide-mouthed; lid conic, rostellate; teetl subirregular, pale, inflexed when dry, perforated here and there in the middle line, processes of endostome much shorter.

\section{HAB.-Sandstone rocks and black earth; rare. Fr. 3.}

Helsby, Frodsham and Alderley edge, Cheshire (IVilson I833)!! Harrison's rocks, Tunbridge wells (Borrer 1 844)!! High rocks (Rceves). The Strid, Wharfedale (Sprucc). West Kilbride, Ayrshire (Boyd I887)!!

Besides the British stations, it has only been found at two localities in Finistère, France. The Abyssinian plant referred to it, has been named by Mueller O. athiopicum. 


\section{LEPTOBRYUM Wils.}

Bry, brit. 2 I9 (1855).

Plants annual, innovating only at base, slender simple. Leaves narrow, flexuoso-subulate with a broad nerve, cells lax rectangulohexagonal at base, above linear-rhomboid. Calyptra narrow, cucullate. Capsule pendulous, leptodermous, long-necked, vernicose, peristome bryoid. Der. $\lambda \epsilon \pi \tau$ os slender, $\beta$ pvov a moss.

A small genus of 3 species, another-L. teminerve SPRUCE-coming from the Andes, and the third L. vobustum from Australia. Its mode of growth and general habit alone separate it from Pohlia.

\section{LEPTOBRYUM PYRIFORME (L.) Wils.}

Synoicous; in dense silky patches. Upper leaves comant, elongated, linear-setaceous, nerve half width of base, reaching nearly to apex. Caps. pendulous, pyriform, glossy. (T. LXVI, C.)

Syn. - Bryum trichodes aureum, capsulis piriformibus nutantibus Dill. Hist. musc. 39I, t. 50, f. 60 (I74I), et Herb.

Mnium pyriforme L. Sp. pl. III2 (I753). WeIss Crypt. Goett. I52 (I770). With. Bot. arr. br. pl. 667 (I 776 ). Ehrh. Hann. Mag. I780, p. 236 . P. BEAuv. Prodr. 76 (I805).

Bryum aureum Huds. Fl. angl. 4I2 (I762). Schreb. Spic. Fl. Lips. 8 I (I77I). Web. Spic. fl. goett. II4 (I 778 ). LAm. Cand. Fl. franc. i, 500 (I778). Sm. Eng. Bot. t. 389 (1797), F1. brit. I348 (1804). Hull Br. fl. P. II, 265 (I799). TuRN. Musc. hib. II 8 (I804).

Bryun mupeun Neck. Meth. musc. 220 (I77 I).

Bryum pyriforme Wigg. Prim. Fl. Hols. 29 (I 780 ). Hedw. Fund. musc. II, 94 (I782). Vill. Pl. Dauph. iii, 887 (i 786 ). Swartz Musc. suec. 45 (I798). Roth Fl. germ. iii, P. I, 25I (1800). Voit Musc. herb.92 (I8I2). Mart. Fl. cr. erl. 6o (I8I7). Hook. Tail. Musc. br. II 8 , t. $2 S$ (I8I8). BRID. Mant. I20 (I8I9). GraY Nat. arr. br. pl. i, 768 (I82I). Hook. Fl. Scot. P. II, I49 (I82I). Br. fl. ii, 6o (I833). Hueben. Musc. germ. $45^{2}$ (1833). De Not. Syllab. I35 (1838). Br. Sch. Bry. eur. fasc. 6-9, 45, t. I8 (I839). Rabenh. Deutsch. kr. fl. 212 (I848). C. Muell. Synops. i, 330 (I849). Husn. Mouss. nord-ouest 122 (I873). Bovlay Musc. de Fr. 292 (I884).

Webera pyriformis HeDw. Musc. fr. i. 5, t. 3 (I787), Sp. musc. 69 (I80I). Roth Fl. germ. i, 477 (I788). Timm Prod. fl. meg. n. 855 (I788). BRid. Musc. rec. II, P. III, I 24 (1803), Sp. musc. III, 35 (I8I7). Schultz Fl. starg. n. 35 I (1806). Roehl. Deutsch. fl. iii, 97 (I8I3). Schwaeg. Suppl. I, P. II, 56 (I8I6). Funck Moost. 3 S. t. 25 (I82I).

Bryum mnioides Gmel. (L.) Syst, nat. ii, I330 (I79r).

Hypunm pyriforme Weв. MoHr Bot. Tasch. 274 (1807).

Bryum Webera pyriformis BRID. Bry. univ. i, 63 I (1826).

Leptobryum pyriforme Wils. Bry. br. 219, t, 28 (i855). Schimp. Synops. 329 (I860), 2 ed. 390 . BERK. Handb. br. m. 204, t. I8, f. 3 (I863). Milde Bry. siles. I99 (I869). De Not. Epilogo 434 (I869). HobK. Syn. Io6 (I873). Juratz. Laubm. oester.-ung. 246 (I882). Lesq. James Moss. N. Amer. 215 (I884). Husn. Musc. gall. 22I, t. 60 (I 888$)$.

Synoicous; laxly cæspitose, soft, silky bright green. Stem $\frac{1}{2}-\mathrm{I}$ in. ligh, very slender, with slender innovations from the base; lower leaves distant, narrowly lanc., upper crowded in a coma, much longer, from a lanc. base, subulate, flexuose, margin serrated at point, cells above very narrow, long, linear, broader below; nerve dilated at base, excurrent. Infl. subcapituliform, synoicous, paraphyses numerous, acute, bracts 
subvaginant and broader at base, suddenly narrowed and patent; caps. on a very slender flexuose reddish seta, inclined or pendulous, leptodermous, from a longish neck, oval-globose or pyriform, glossy, golden-yellow and castaneous; annulus broad, revoluble, lid convex, apiculate; teeth pale yellow, lanceolate, processes of endostome keeled, gaping and perforated in the middle, with long appendiculate cilia.

HAB.-Shady rocks and walls, and sandy or turfy soil. Fr. 5-6.

This elegant moss has leaves closely resembling those of Dicranella heteromalla, and what appear to be male plants may be seen in the tufts, which on dissection, however, will be found to contain abortive archegonia as well as fertile antheridia.

\section{POHLIA Hedw. \\ Musc. frond. i, $g 6\left({ }^{7} 787\right)$.}

Stem slender, innovating from the base. Leaves lanc., generally glossy, the uppermost narrower and suddenly elongated, nerve terete, cells at base rhomboidal, above narrow, linear or rhomboido-hexagonal. Calyptra very narrow and fugacious. Caps. with a long neck and clavate or with a shorter neck and pyriform; peristome bryoid.-Der. after Dr. Pohl of Dresden.

This genus is by C. Mueller and MitTEn retained as a section of Brynm, from which it differs only in the slender habit of the species, and their narrow elongated comal leaves with narrow or linear cells in the upper part. The name Webera is generally used for the genus, and was applied by HEDwiG to Brymn mitans and pyriforme in the same volume of his work, as, however, it was preoccupied by Ehrhart in I770 (see Moss-Flora i, 29I), Pohlia must be adopted in its place. About 50 species have been referred to this genus.

\section{Ceavis to the Species.}

Sect. I. Eupohlia. Upper leaves suddenly elongated, dull green. Capsule narrow, with a long neck. Cilia none or rudimentary.

Autoicous.

Paroicous.

Neck of capsule shorter than sporangium.

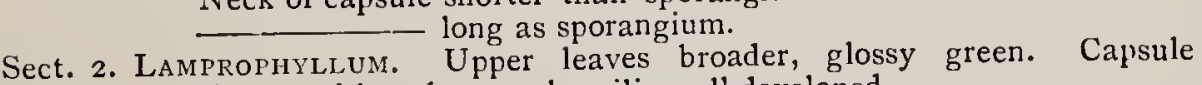
pyriform, with a short neck; cilia well developed.

Polyoicous.

Paroicous.

Leaves ovato-lanceolate, nearly entire.

L lanceolate, serrulate at apex.

acuminata.

Dioicous.

Capsule exannulate, turbinate when old.

Small, pale yellowish green.

Robust, glaucous green.

- annulate, oblong when old.

Leaves oval, obtuse.

- lanceolate, pointed.

Upper leaves nerved to apex.

polymorpha. clongata.

not nerved to apex.

Stem strong; leaves soft, erecto-patent.

- filiform, leaves rigid, appressed.

cruda.

cucullata.

nutans.

carnea.

albicans.

Ludroigii.

annotina.

commutata. gracilis. 
Sect. I. EUPOHLIA. Plants slender, lower leaves very small remote, upper long narrow comant, dull green or slightly glossy, with linear-rhomboid cells. Caps. with a long neck, oblong, membrane of endostome narrow, processes nearly entire, without cilia, or rarely with short ones.

\section{POHLIA ACUMINATA Honnsch.}

Autoicous; densely tufted, rigid. Comal leaves long straight lineal-lanc., serrate at apex, nerved to point, margin reflexed below. Caps. horizontal on a long seta, from a long neck, cylindric-pyriform; lid acutely conic. (T. LXVI, D.)

Syn.-Pohlia acuminata Hornsch. Flora ii, P. II, 94 (I8I9). Funck Moost. 40, t. 26 (I82I). Ficin. Fl. Dresd. ii, 66 (I823). Brid. Bry. univ. i, 6ro (1826). Wallr. Fl. cr. germ. i, 220 (1831).

Webcra elongata $\beta$, aeuminata Schwaeg. Sp. musc. 49 (1830).

Pohlia elongata $\gamma$. acuminata Hueben. Musc. germ. 473 (I 833 ).

Bryum acuminatum Br. Sch. Bry. eur. fasc. 6-9, p. 2 I, t. 6 (1839). Rabenh. Deutsch. kr. fl. ii, S. 3, 204 (1848). C. Muell. Synops. i, 326 (I849). WILs. Bry. brit. 22 I, t. 47 (1855). Hовк. Syn. br. m. Iog (I873). Boulay Musc. de Fr. i, 289 (I884).

Webera acuminata Schimp. Coroll. 64 (1856), Synops. 330 (1860), 2 ed. $39 \mathrm{I}$. Berk. Handb. br. m. 200 (1863). MiLde Bry. siles. 20I (1869). DE Not. Epilogo 428 (I869). Juratz. Laubm. oester.-ung. 247 (I882). Leso. James Moss. N. Amer. 2 I6 (I884). Hobk. Synops. 2 ed. I53 (I884). Husn. Musc. gall. 226, t. 60 (I889). Limpr. in Rabenh. Deutsch. kr. fl. Laubm. ii, 234 (1892).

Autoicous; densely cæspitose, rigid, rather glossy green, fuscous at base. Lowest leaves ovate acute, accrescent upward, comal erect, long ovato-lanc., very acute, serrate at apex, the margin reflexed below, nerve rather strong vanishing in the apex, or excurrent, upper cells narrow linear, slightly flexuose. Caps. horizontal, on a long reddish seta arcuate at top, with a long neck, clavato-pyriform, pale fuscous; lid acutely conic or subrostellate, red at base; annulus compound ; peristome large, ferruginous; processes of endostome very narrow, long as teeth, without cilia. Male infl. gemmiform below the female, bracts ovate.

HAB.-Banks and stony places in the higher mountains. Fr. 8.

Ben Nevis and Ben Cruachan (Hooker)! Craig Challeach and Ben Lawers (Hooker)!! Teesdale (Sprucc). Twll du (Wilson I821)! Brandon Mtn., Kerry (Wilson I82S)!

Toole's rocks, Wicklow (Moore). Glen Prosen (Fergtusson). Ben Laoigh (Eving).

This and the two following species are very closely allied, and they depend for their stability as species principally on the position of the male reproductive organs. Whether this may be invariable or not may be open to doubt, as we find in some other mosses it is not always reliable.

\section{POHLIA POLYMORPHA Hornsch.}

Paroicous; laxly tufted. Comal leaves oblong-lanc., sharply serrate at apex, nerve vanishing at point. Caps. from a shorter neck, oval-oblong, horizontal, lid conic, muticous. Antheridia axillar. (T. LXVI, E.) 
Syn.-Polllia polymorpha Hornsch. Flora ii, P. II, 94 (I8I9). FuncK Moost. 42, t. 27 (I82I). BRID. Bry. univ. i, 6 I9 (1826).

Bryum polymorphum BR. Sch. Bry. eur. fasc. 6-9, p. 25, t. 8 (I839). RabenH. Deutsch. kr. A. ii, S. 3, 205 (I848). C. Muell. Synops. i, 329 (I849). WILS. Bry. brit. 222, t. 47 (I855). Hовк. Synops. Iog (I873). Bovlay Musc. de Fr. i, 288 (I884).

Webera polymorpla Schimp. Coroll. 65 (I856), Synops. 33i (I860), 2 ed. 392. Berk. Handb. br. n. 200 (1863). Milde Bry. siles. 200 (I869). DE Not. Epilogo 428 (I869). JuRATz. Laubm. oester.-ung. 248 (I882). HoBk. Synops. 2 ed. I53 (I884). Husn. Musc. gall. 226, t. 6r (I889). Limpr. in RabenH. D. kr. f. Laubm. ii, 239 (I892).

Paroicous; in lax irregular tufts closely resembling $P$. acuminata. Leaves ovato-lanc., softer, shorter, upper cells shorter, less incrassate, margin more distinctly serrate. Caps. from a shorter neck, oval-oblong, brown, with a shorter orange muticous lid. Antheridia in pairs in the axils of the upper bracts.

$\mathrm{H}_{\mathrm{AB}}$.-On rocks and turf in mountains; not common. Fr. 7-8.

Cwm Idwel (Wilson I830)!! Loch Earn head (Wilson 1836) ! Ben Lawers (Hunt 1868)!! Cheviots $($ Hardy). Knock-nel-down, Tipperary (Moore). Clova (Fergusson).

Var. $\beta$. brachycarpa (Homsch.)

Stems shorter, dense-leaved; capsules shorter, thicker, pale, constricted below the mouth, seta straight or curved.

Syn.-Pohlia brachycarpa Hornsch. Flora ii, 96. Funck Moost. 4I, t. 26. Brid. Bry. univ. i, 6I6.

Meesia curviseta Schwaeg. Suppl. III, P. I, t. 234.

Bryum polymorphum var. brachycarpum Schime. Bry. eur. et Synops.

HAB.-Summit of Lochnagar (Wilson)!!

Var. $\gamma$. gracilis (Hornsch).

Stems slender, elongated, naked or radiculose below, branches from base of stem, elongated; capsule small, slender.

Syn.-Pohlia gracilis Hornsch. Flora ii, Ioo. Funck Moost., 42, t. 27. Brid. Bry. univ. i, 6 I8.

Bryum polymorphum var. gracile. Schimp. Bry. eur. et Synops.

НАв.-Carnedd Llewellyn (Wilson r 854 )!

This moss appears to be intermediate between P. acuminata and elongata, and agrees with the latter in the male infl., but the capsule is shorter than that of either. Many varieties have been established, but I can only recognise the two described as indigenous.

\section{POHLIA ELONGATA Hedw.}

Paroicous; gregarious. Lower leaves ovato-lanc., upper elongatolanc, erecto-patent, serrate at apex, nerve vanishing. Caps. elongate elliptic, with a long neck, drooping, cilia of endostome none or rudimentary. (T. LXVI, F.) 
SyN.-Bryum foliis gramineis pellucidis, cauliculo rubente. Dill. Hist. musc. 359, t. 46, f. 17 (I74I).

Bryum trichodes late-virens, capitulis cernnis oblongis p.p. Dill. in Ray Synops. 3 ed. Ioo (I 721 ) ; Hist. 39I, t. 50, f. 6I, C-E., et Herb.

Pohlia elongata Hedw. Stirp. i, 96, t. 36 (1787), Sp. musc. I7I (I80I). Swartz Musc. suec. 44 (I798). Rотн Fl. germ. iii, P. I, 224 (I800). BRID. Musc. rect. II, P, III, I42 (1803), Sp. musc. III, 74 (I8I7), Mant. II5 (I8I9), Bry. univ. i, 608 (I826). VoIT Musc. herb. 70 (I8I2). Roehl. Deutsch. fl. iii, 88 (I8I3). HoRnsch. in Flora ii, 94 (I8Ig). Funck Moost. 40, t. 26 (I82I). Hueben. Musc. germ. 473 (I833). De Not. Syllab. II 4 (1838).

Bryum clongatum Dicks. Crypt. Fasc. II, 8 (I790). Wither. Bot. arr. 3 ed. iii, 832 (I796). Hull Br. fl. P. II, 263 (I799). Sm. Fl. brit. I349 (I804)? Hook. TAYl. Musc. br. I20, t. 30 p.p. (I8I8). Hook. Fi. Scot. P. II, I5I (I82I), Br. H. ii, 62 (I833). GRay Nat. arr. br. pl. i, 77 I (I82I). Br. Sch. Bry. eur. fasc. 6-9, p. 32, t. IO, II (I839). Rabenh. Deutsch. kr. fl. ii, S. 3, 207 (I848). C. Muell. Synops. i, 336 (I849). Wils. Bry. br. 223 , t. 30 (I855). Hовк. Synops. Iog (1873). HuSN. Mouss. nord-ouest I20 (I873). Boul. Musc. de Fr. i, 287 (1884).

Bryum cylindricum Dicks. Crypt. Fasc. IV, t. I I, f. 4 (I80 I).

Mnium elongatum P. BEAUv. Prodz. 75 (1805).

Leskea elongata WEB. MoHR. Bot. Tasch. 243 (1807).

Pohlia cylindrica HoRnsch. Flora I8I9, p. 93.

Webera elongata Schwaeg. (L.) Sp. musc. 48 (1830). Schimp. Coroll, 65 (I856), Synops. 332 (I860), 2 ed. 394. BERK. Handb. br. m. 20I (I863). Milde Bry. siles. 200 (1869). DE Not. Epilogo 426 (1869). JuRATz. Laubm. oester.-ung. 249 (I882). HoBk. Synops. 2 ed. I53 (I884). Lese. James Moss. N. Amer. 2 I6 (I884). Husn. Musc. gall. 227, t. 6r (I889). Limpr. in RABENH. D. kr. fl. Laubm. ii, 24I (I892).

Lamprophyllum elongatum LindB. Revis. crit. ic. fl. dan. 27 (1871).

Paroicous; in small tufts or gregarious, stems $\frac{1}{2}-\mathrm{I}$ in. high, simple, pale silky green. Comal leaves elongato-lanc., erecto-patent, acute, more or less sharply serrate at apex, margin recurved below middle, nerve stout, vanishing at or below apex, cells above linear-rhomboid or subvermiform, basal narrow hexagono-rectangular. Caps. on a long purple seta, suberect or inclined, very narrow, elongato-elliptic, with the neck longer than the sporangium, pale cinnamon-brown; when dry and deoperculated, ascending, slightly constricted below the mouth; lid orange, acute or slightly rostellate, teeth lanceolate-subulate, yellowish, processes of endostome punctate, entire, cilia two, short or rudimentary.

HAB.-Rocks and gravelly banks in subalpine places; not uncommon. Fr. 8.

An elegant species, readily known by its clavate capsule and the most distinct of these three closely allied plants, although some forms occur with a shorter capsule which approach the other two more nearly. Pollia longicollis (SwARTZ) is also allied, and may be found in the north, as it occurs in Norway and Lapland; it is a more robust plant with larger and broader leaves, the capsule with a shorter, thicker neck, and endostome well-developed.

Sect. 2. LAMPROPHYLLUM. Leaves broader, more laxly areolate, the comal less suddenly elongate. Caps. thicker, with a short neck, membrane of endostome broader, with cilia. 


\section{POHLIA CRUDA (L.) Lindb.}

Polyoicous; cæspitose. Lower leaves ovato-lanc., upper linearlanc., patent, serrate at apex. Caps. cernuous, oblong-pyriform with a short neck, cilia perfect. (T. LXVII, A.)

SYN.-Bryum pendulum hornum molle, foliis ct lanccolatis et granincis Dili, Hist. musc. 40I, t. 5 I, f. 7 o (I74I), et Herb.

Mnium crudum L. Sp. plant. III2 (I753), Syst. nat, ii, 7oo, Syst. veg. 947. With. Bot. arr. ii, 667 (I 776 ). LightF. Fl. scot. ii, 7 I2 (I 777 ). Hedw. Fund. musc. II, 94 (I782), Musc. fr. i, s9, t. 37 ( 1787 ), Sp. musc. I89 (I8or). Roth Tent. Fl. germ. i, 475 (I788). Hoffm. Deutsch. fl. ii, 48 (I 795). Brid. Musc. rec. II, P. III, 85 (I803), Sp. musc. III, 47 (I8I7). P. Beauv. Prodr. 73 (I805). Schultz Fl. starg. 345 (1806). Roehl. Deutsch. fl. iii, 93 (I8I3). Schwaeg. Suppl. I, P. II, I27 (I8I6). Mart. Fl. cr. erl. 65 (I8I7). Funck Moost. 50, t. 32 (I82I).

Bryum crudum Huds. Fl. angl. 4I5 (I762). Schreb. Spic. fl. lips. 83 (I77I). Neck. Meth. musc. 223 (I77I). Vill. Pl. Dauph. 888 (1786). Swartz Musc. suec. 49 (I798). Hull Br. fl. P. 2, 266 (I799). Rотн Fl. germ. iii, P. I, 242 (I800). Sm. Fl. brit. I36I (1804). Eng. bot. t. I604. Turn. Musc. hib. I30 (1804). Hook. Tayl. Musc. bi. IIg, t. 28 (I8I8). BRID. Mant. IIg (I8Ig). Hook. Fl. scot. P. 2, I50 (I82I), Br. fl. ii, 58 (I833). Hartm. Scand. fl. Gray Nat. arr. i, 768 (I821). Mack. Fl. hib. P. 2, 3 I (I836). DE Not. Syllab. I33 (I838). BR. Sch. Bry. eur. fasc. 6-9, p. 37, t. I3 (i839). Rabenh. Deutsch. kr. fl. ii, Sect. 3, 209 (1848). C. Muell. Synops. i, 333 (I849). WILs. Bry. br. 224, t. 28 (1855). Husn. Mouss. nord-ouest 120 (1873). Hobk. Synops. I Io (I873). Boul. Musc. de Fr. i, 283 (I884).

Hypu

Webera intermedia Schleich. Cat. pl. helv. Cent. IV, n. 18 (1807).

Bryam Polla cruda Brid. Biy. univ. i, 693 (1826).

Webera cruda Schwaeg. Sp. musc. 50 (I830). Hueben. Musc. germ. 425 (1833). Schimp. Coroll. 65 (I856), Synops. 337 (I860), 2 ed. 398. BERk. Handb. br. In. 202 (I863). Milde Bry. siles, 202 (I869). DE Not. Epilogo 424 (I869). JuRAtz. Laubm. oester.ung. 253 (I882). Leso. James Moss. N. Amer. 2 I8 (I884). HobK. Synops. 2 ed. I54 (I884). Husn. Musc. gall. 228, t. 6r (1889). Limpr. in Rabenh. D. kr. fl. Laubm. ii, 247 (1892).

Lamprophyllum crudum Linds. Revis. crit. ic. fl. dan. 87 (1871).

Pohlia cruda Linds. Musc. Scand. I8 (I879).

Autoicous, sometimes dioicous, paroicous or synoicous; cæspitose, erect $\mathrm{I}-3$ in. high, with simple reddish stems. Lower leaves broadly ovato-lanc., entire with plane margins, gradually accrescent upward, comal patent, long linear-lanc., remotely serrate at apex, all golden glossy or glaucous green, with the nerve red at base, vanishing below apex; cells firm, narrow and elongated. Caps. cernuous or horizontal, on a flexuose reddish seta, leptodermous, oblong-pyriform, often ventricose, with a short neck, before sporing fuscous-yellow, when empty pale brown, narrowed at mouth; lid convex, apiculate, peristome pale yellow, cilia $2-3$ perfect, half the length of processes.

HAB.-Clefts of rocks and sandy banks in mountains. Fr. 7-8.

An elegant moss frequent in Scotland and growing especially fine and abundant in Teesdale, where it adorns the scarrs with its golden glistening tufts. 


\section{POHLIA CUCULLATA (Schwaeg.) Brich.}

Paroicous; densely cæspitose, bright green. Lower leaves broad ovato-lanc. rather obtuse, comal narrow, lanc., serrate at apex. Caps. on a short seta, pendulous, oval, thickish with a short neck, lid small, conic, obtuse. (LXVII, B.)

Syn.-Bryztm cucullatum SchwaEg. Suppl. I, P. II, 94, t. 68 (I8I6). BRID. Sp. musc. III, I4 (I8I7), Mant. rI7 (I8Ig), Bry, univ. i, 649 (I826). Wallr. Fl, cr. germ. i, 239 (I83 I). BR. Sch. Bry. eur. fasc. 6-9, p. 27, t. 7 (1839). C. Muell. Synops. i, 328 (1849). Boul. Musc. de Fr. i, 286 (1884).

Pohlia cucullata Bruch in Flora 1826, p. 276. Schwaeg. Sp. musc.i, 73 (1830). Hueben. Musc. germ. 48i (1833). DE Not. Syllab. I Io (1838).

Pohlia latevircns De NoT. Mant. musc. n. 7 (1836), Syllab. II I (I838).

Webera cucullata Schimp. Coroll. 66 (1856), Synops. 236 (1860), 2 ed. 397. Milde Bry. siles. 202 (1869). De Nót. Epilogo 430 (I869). JURATz. Laubm. oester.-ung. 252 (1882). Leso. James Moss. N. Amer. 218 (I884). Husn. Musc. gall, 229, t. 62 (I889). Limpr. in RABENH. D. kr. fl. Laubm. ii, 253 (I892).

Lamprophyllum cucullatum LindB. Rev. crit. icon. fl. dan. 87 (1871).

Paroicous; densely cæspitose, fastigiate, bright green. Stems generally decumbent at base, erect, simple or sparingly branched, radiculose. Lower leaves subimbricated, ovate, concave, muticous, entire, upper longer, narrow lanc., with the margin scarcely revolute, faintly serrate at apex, and not unfrequently cucullato-incurved, all very soft, subopake, with thickish vanishing nerve, cells rhombic, narrow, elongated. Caps. pendulous, on a shortish flexuose red seta hooked at top, thickish, with the neck shortly pyriform, when dry and empty not contracted below the mouth, but with the orifice narrowed, soft, badious, when old black-brown; lid small orange, conic, obtuse; teeth narrow, shorter, yellowish, inner very slender pale, cilia fugacious.

HAB.-Damp ground on mountains, rare. Fr. 8.

Mountains in Artan (Borrer)! Ben Attow, Ross-shire (Dixon 1883)!!

This moss is very near $P$. nutans, but is scarcely glossy, the leaves often cucullate at apex, their cells looser and thin-walled.

\section{POHLIA NUTANS (Schreb.) Lindb.}

Paroicous; densely cæspitant, shining green. Lower leaves ovatolanc., entire, upper gradually longer, lineal-lanc., serrate at apex. Caps. pendulous, oval-pyriform with a wide mouth, lid mammillate. (T. LXVII, C.)

Syn.-Bryum trichodes late-virens, capitulis cermuis oblongis DiLL. Hist. musc. 391, t. 50, f. 6 I A-B, et Herb.

Mnium pyriforme $\beta$. WeIss Crypt. Goett. I53 (I770).

Bryum nutans Schreb. Spic. fl. Lips. 8I (I77I). Swartz Musc. suec. 46 (I798). Roth Fl. germ iii, P. I, 252 (I800). SM. Fl. brit. I347 (I804), Eng. Bot.t. I240. TURN. Musc. hib. II7 (I804). Voit Musc. herb. 9o (I8I2). MART.Fl. cr. erl.6o (I8I7). Ноок TAYL. Musc. br. I23, t. 29 (I8I8). Hook. Fl. scot. P. II, I5I (IS2I), Br. fl. ii, 6I (I833). Gray Nat. arr. br. pl. i, 77 I (I821). Mack. Fl. hib. P. 2, 32 (I836). DE Not. Syllab. I34 (1838). Br. Sch. Bry. eur. fasc, 6-9, p. 34, t. I2 (1839). Rabenh. 
Deutsch. kr. fl. ii, S. 3, 208 (I848). C. Muell. Synops. i, 335 (I849). Wils. Bry. br. 225, t. 29 (I 855$)$. Husx. Mouss. nord-ouest $120(1873)$. HoBk. Syn. br. m. IIo (1873). Boul. Musc. de Fr. i, 284 (I884).

Bryum aureuí $\beta$. majus WeB. Spic. fl. Goett. II5 (I778).

Bryum sericeum Huds. Fl. angl. 2 ed. 487 ( 1778 ). SiBth. Fl. oxon. 292 (I 794$)$. Wither. Bot. arr. 3 ed. iii, 839 (1796). Hull Br. Fl. P. 2, 265 (1799).

Webera nutans Hedw. Musc. frond. i, ro, t. 4 (1787), Sp. musc. r68 (r8or). Roth Tent. Fl. germ. i, 477 (1788). Trmm Prodr. Fl. megap. n. 856 (I788). Schrank Bayers. fl. ii, 483 (I789). BRID. Musc. rec. II, P. III, I25 (I803). Sp. musc. III, 36 (I8I7). Schultz Fl. starg. 354 (I8o6). SchWaeg. Suppl. I, P. I, 67 (I8II). Funck Moost. 39, t. 25 (I821). Hueben. Musc. germ. 429 (I833). Schimp. Coroll. 66 (I856), Synops. 332 (I 860), 2 ed. 396. Berk. Handb. Br. m. 201 (1863). Milde Bry. siles, 201 (I869). DE Not. Epilogo 427 (I869). Juratz. Laubm. oester.-ung. 25 I (I882). LesQ. James Moss. N. Amer. 217 (I884). Hobk. Synops. 2 ed. I54 (I884). Husn. Musc. gall. 228, t. 6I (1889). LIMPR. in RABENH. D. kr. fl. Laubm. ii, 249 (1892).

Mnium mutans Hofrm. Deutsch. fl. ii, 49 (I796). P. Beauv. Prodr. 75 (1805).

Bryum interruptum Dicks. Crypt. fasc. IV, I3, t. I I, f. 6 (I8or). SM. F1. brit. I363 (1804).

Bryum compactum (non Dicks.) Turn. Musc. hib, I24 (1804).

Hypnum nutans WEB. MoHR Bot. Tasch, 287 (I807).

Bryum Webera rutans Brid. Bry. univ. i, 634 (1826).

Lamprophyllum mutans LiNDB. Rev. crit. ic. Fl. dan. 25 (I87r).

Pohlia nutans Lindb. Musc. scand. I 8 (1879).

Paroicous; densely cæspitant $\frac{1}{2}-2$ in. high. Leaves imbricated, erect, shining pale green, with the margin reflexed above the middle, lower ovato-lanc., entire, upper gradually longer, lineal-lanc., serrate at apex, sericeo-nitent, nerve reddish, rather thick, ending at or below apex, cells narrow, elongated. Seta reddish-yellow, variable in length, hooked at apex; caps. leptodermous, subpendulous, oblong or obovate with a short-neck, wide-mouthed, from yellow becoming fuscescent, when old rufescent, when dry and empty, contracted below mouth; lid broadly convex, mammillate, annulus broad, revoluble; teeth orange, pale at the filiform points; membrane of endostome pale yellow, the processes widely gaping, and with two cilia as long as teeth. Antheridia axillary in pairs.

Hab.-Sandy or turfy heaths, common. Fr. 5-6.

Var. $\beta$. longiseta (Brid.)

Stems short, simple; comal leaves narrower, longer, acuminate, patent; caps. on a very long seta, pendulous, large, thick.

Syn.-Bryum Webera longiseta Brid. Bry. univ. i, 636 .

Bryum mutans Var. longisetum Bry. eur.

HaB.-On damp heaths and open drains.

Putney Heath (Braithwaite I865)!! Woolston moss (Wilson 1838)!! Great Mis-tor, Devon (Holnes). Co. Down, Ireland (Stewart r882)!!

Var. $\gamma$. bicolor (Hoppe \& Hornsch.)

More compact, comal leaves shorter, erect, leaves of the sterile shoots ovate, acute with an excurrent nerve; caps. cernuous, thick, darker coloured on the upper surface. 
Syn.-Wcbcra bicolor H. Hsch. in Flora 1819 , p. Io2.

Bryum nutans $\gamma$. bicolor Bry. eur. \&c.

HaB.-Alpine moorlands.

This neat moss varies greatly in size and habit, according to season and locality, so that the numerous varieties are scarcely tenable; longiseta is a very elegant plant, with a pedicel often 3 in. long.

\section{POHLIA CARNEA (L.) Lindb.}

Dioicous; laxly cæspitose, pale green with a red stem. Comal leaves long, narrowly lanc., obtusely serrate at apex, laxly areolate, nerve vanishing. Seta thick, bent at neck of caps., which is pendulous, ovate-oblong, wide-mouthed when dry; lid convex, teeth red. (T. LXVII, D.)

Syn.-Bryum nitidnm, foliis scrpylli pellucidis, angustioribus refcxis, capitulis snbrotundis carnei coloris in pediculis brevioribus DILL, in RAY Synops. 3 ed. Io2, n. 53 (I724).

Bryum lanceolatum pcllucidum, capsulis rotundis pendulis carneis DILL. Hist. musc. 400 , t. 5o, f. 69 (I 74I), et Herb.

Brynm carneum L. Sp. plant. I I22 (1753), Syst. nat. ii, 702, Syst. veg. 949. HuDs. F1. angl. 4 I 4 (I762). Neck. Meth. musc. 202 (I77I). With. Bot. arr. i1,679 (I776). RelH. Fl. cant. 406 (I785). VILl. Pl. Dauph. iii, 886 (I786). RоTH Fl. germ. i, 474 (I788). Schrad. Spic. fl. germ. 70 (I794). Hull Br. fl. P. 2, 265 (I 799). Swartz Musc. suec. 47 (I798). BRID. Musc. rec. II, P. III, 24 (I803), Sp. musc. III, I 7 (I8I7), Mant. II 8 (I819). Bry. univ. i, 652 (I826). Sm. Eng. Bot. t. 360; Fl. brit. I352 (1804). TurN. musc. hib. II9 (I804). Schultz Fl. starg. 359 (1806). Roenl. Deutsch. fl. iii, 9 I (I8I3). SchwaEg. Suppl. I, P. II, gi (I8I6). MarT. Fl. cr. erl. 53 (I8I7). Hook. TAYl. musc. br. IIg, t. 29 (I8I8). GRAY nat. arr. i, 789 (I82I). Funck Moost, 47, t. 29 (I82I). Hook. Fl. scot. P. II, I50 (I82I), Brit. Fl. ii, 59 (I833). HuEBeN, musc. germ. $45^{8}$ (I833). Mack. Fl. hib. P. 2, 3i (I836). De Not. Syllab. I20 (I838). BR. Sch. Bry. eur. fasc. 6-9, p. 42, t. I6 (I839). RABENH. Deutsch. kr. fl. ii, S. 3, 210 (I848). C. Muell. Synops. i, 294 (I849). Wils. Bry. br. 227, t. 29 (I855). Новk. Synops. I Io (1873). Husn. Mouss. nord-ouest I2I (I873). Boul. Musc. de Fr. i, 282 (I884).

Bryum dclicatultun HeDw. Musc. fr. i, 52, t. 20 (1787), Sp. musc. 73. Timm Fl. meg. n. 839 (1788).

Mnium canneum Swartz Meth. musc. 366 (I787). Hoffm. Deutsch. fl. ii, 5I (I795). P. Beauv. Prodr. 74 (1805).

Hypnum carneum WeB. MoнR Bot. Tasch. 278 (I807).

Webcra carnea Schimp. Coroll. 67 (I856), Synops. 34I (I860), 2 ed. 405. Berk. Handb. Br. m. 202 (I863). Milde Bry, siles. 204 (I869). De Not. Epil. 422 (I869). Juratz. Laubm. oester.-ung. 258 (I882). Lese. James Moss. N. Amer. 22 I (I884). Hobr. Synops. 2 ed. I55 (I884). Husn. musc. gall. 23 I, t. 62 (I889).

Pohlia camea Lindi. Musc. Scand. I7 (1879).

Mniobryum carncum Limpr. in RaBenH. D. kr. f. Laubm. ii, 275 (I892).

Dioicous; gregarious or laxly cæspitose, pale green, nearly simple. Stem red, 3-6 lines long. Leaves distant, accrescent upward, lanc., straiglit, the comal longisl, erect, lineal-lanc., obtusely serrate at apex, pale green, subnitid, nerve red, vanishing; cells laxer, rlomboidhexagonal. Caps. on a thickish red succulent seta arcuate at summit, inclined and pendulous, from a short solid neck, ovate-oblong, pachydermous, fleshy, pale red, when dry retracted, subhemispherical, 
wide-mouthed, rufous; annulus none, lid large convex, mammillate; per. large, teeth solid, orange, dark red when dry, endostome yellow, the processes serrate, with cilia in pairs.

HAB.--Clay fields and sides of ditches and water-courses. Fr. 4.

Very variable in size, and sometimes slender, more than an inch high and of a dull green colour.

Pohlia pulchella (HEDW.) is very closely allied, but is a smaller more slender plant, with the capsule distinctly annulate, smaller and thin.walled and with smaller leaf-cells. It has been recorded from Dunottar $1 \mathcal{F}$. Sim I870), but the specimens I have seen are $P$. cannea .

\section{POHLIA ANNOTINA (L.) Lindb.}

Dioicous; in loose pale green tufts. Leaves lax, lanceolate, subserrulate above, comal elongated; nerve vanishing below apex. Caps, oblong-pyriform, pendulous. (T. LXVII, E.)

SYN.-Mnium annotinum L. Sp. pl. I II I (I753); Syst. veg. 946. WeIss Crypt. goett. I5I (I770). Ehrh. Hann. mag. I780, p. 236 . Hoffm. Deutsch. fl. ii, 49 (I795). P. Beauv. Prodr. 73 (I8c5).

Bryam annotinnm Huds. Fl. angl. 414 (I762). NEck. Meth. musc. 222 (I77I). Hedw. Fund. musc. II, 94 (I782), Sp. musc. I83, t. 43 (1801). Roth Fl. germ. i, 475 (I788). SWARTz musc. suec. 50 (I798), et in SCHRAD. Journ. bot. ii, i82, t. 3 (1800). Hull Br. fl. II, 255 (I799). BrID. Musc. rec. II, P. III, 32 (I803), Sp. musc. III, 22 (I8I7), Mant. 108 (1819), Bry. univ. i, 662 (I826). Sm. Fl. brit. 1358 p.p. (1804), Eng. Bot. t. I862, p.p. TURN. Musc. hib. I28 (I804). Schultz Fl. starg. 340 (I806). Wahlenb. Fl. lapp. 3.59 (I8I2). Schwaeg. Suppl. I, P. II, 93 (I8I6). Mart. Fl. cr. er1. 6I (I8I7). HuEBen. Musc. germ. 43I (I833). BR. Sch. Bry. eur. fasc. 6-9, p 40, t. I 5 (I839). Rabenh. Deutsch. kr. fl. ii, S. 3, 2 I0 (I848). C. Muell. Synops. i, 33I (I849). Wils. in Eng. Bot. Suppl. t. 2856 (I84I), Bry. br. 226, t. 47 (1855). HoBk. Synops. Iro (I873). Husn. Mouss. nord-ouest I20 (I873). Boul. Musc. de Fr. i, 28I (1884).

Trentepohlia evecta Roth in Usteri Ann. Bot. Io Stuck, 52 (I794). Hoffm. Deutsch. fl. ii, I 7 , t. I 4 ( I 796).

Hy'pnm annotinum Schrank Baiers. fl. ii, 474 (I789). Web. Mohr Bot. Tasch. 280 (I807).

Webcra annotina Schwaeg. (L.) Sp. musc. 52 (1830). Schimp. Coroll. 67 (1856), Synops. 339 (1860), 2 ed. 400. BERK. Handb. br. m. 202 (1863). MILDE Bry. siles. 203 (I869). De Not. Epilogo 42 I (1869). JURATz. Laubm. oester.-ung. 254 (I882). HoBk. Synops. 2 ed. 154 (I884). LesQ. James Moss. N. Amer. 219 (1884). Hus N. Musc. gall. 230, t. 62 (1889). Limpr. in Rabenh. D. kr. fl. Laubm. ii, 266 (1892).

Lamprophyllum annotinum LiNDB. Rev. crit. icon. fl. dan. 75 (187 I).

Pohlia annotina Lindb. Musc. scand. 18 (1879).

Dioicous ; loosely tufted, pale or yellowish-green. Stem red, erect, branched at base. Leaves lanceolate, small and distant below, accrescent upward, comal elongated, erecto-patent, serrulate at point, the margin reflexed in lower half, nerve reaching nearly to apex; cells narrow, linear-rhomboid, basal purple, wider, hexagono-rectangular. Caps. on a pale red seta, pendulous, narrowly pyriform with a long neck, pruinose, pale yellowish-red, finally reddish-brown and contracted 
below the mouth; annulus compound, lid conical, pointed, orange; peristome yellowish, membrane of endostome half as high as the teeth, processes gaping, cilia 2, rough.

Male infl. terminal, gemmiform, bracts spreading, lanceolate, pointed. Sterile branches with numerous red axillar gemmæ, by which the plant is commonly propagated.

HAB.-Sandstone cuttings and sandy banks. Fr. 5-6.

Var. $\beta$. tenuifolia Schimp. Synops. 2 ed. 401 .

Slender, the sterile branches longish and generally free from gemmæ; upper leaves oblongo-lanc., sharply serrate at apex, lower subpatent, ovatolanc., the cells laxer ; caps. pale with narrower teeth.

НAB.-Wet sandy places with the type.

Var. $\gamma$. angustifolia Schimp. Synops. 2 ed. 40 I.

Sterile branches numerous slender flexuose; comal leaves longer, narrower, lanc.-subulate, obsoletely serrate at apex, the nerve subexcurrent, the lower narrowly lanc., cells thin and narrow.

HAB.-Sandy bogs near Warrington (Wilson).

The fruit is rare, but the gemmiparous state is frequent, and the gemmæ in wet places often pass into small leafy bulbils, which are readily detached from the plants.

\section{POHLIA LUDWIGII (Spreng.) Lindb.}

Dioicous ; tufted, from a decumbent base, erect, red below, deep green above. Leaves decurrent, broadly obovate, obtuse, comal oblongolanc., serrulate at apex, recurved at margin; nerve vanishing. Caps. inclined, oval-oblong; lid mammillar. (T. LXVIII, B.)

Syn.-Bryum Ludwigii Spreng. MSS. Schwaeg. Suppl. I, P. II, 95, t. 68 (I8I6). Brid. Bry. univ. i, 647 p.p. (1826). Hook. Br. fl. 59 (1833). Wils. Eng. Bot. Suppl. t. $28_{55}$ (184I), Bry. br. 228, t. 47 (1855). Boul. Musc. de Fr. i, 279 (I884).

Bryum Weigelii Brid. Bry. univ. i, 647 (r826).

Webera Breidleri Juratz. Verh. k.k. zool.-bot. Ges. Wien I870, p. I6S c. ic. Laubm. oest.-ung. 255 (1882).

Webera Ludwigii Schimp. Synops. 2 ed. 402 (I876). LIMPr. in Rabenh. D. kr. A. Laubm. ii, 256 (I892).

Bryum laxifolium WARNST. in Hedwigia $1887, \mathrm{p} .53$.

Pohlia Ludwigii LINDB.

Dioicous; soft laxly caspitant, $\mathbf{I}-2$ in. higlı, red or blackish at base, dark green above, scarcely glossy when dry. Stem and branches purple erect, slender, sparingly radiculose ; lower leaves remote, broadly ovate, obtuse, entire, more crowded upward, erecto-patent, longly 
decurrent, not carinate; comal densely crowded, oblongo-lanc., serrulate at apex, margin narrowly recurved, nerve purple, vanishing below apex, thick at base; cells rather lax, thin, rhombo-hexagonal above, more rectangular at base. Caps. on a flexuose reddish seta suddenly bent below the capsule, subpendulous, oval-pyriform, brownish, annulate, slightly constricted below the mouth; lid conical, obtuse or apiculate; peristome pale yellow, teeth lineal-lanc., basal membrane of endostome reaching middle of teeth, processes gaping at the keel, with 2-3 cilia. Male plant more slender, the infl. terminal, dense, gemmiform, bracts broadly ovate, pointed, orange at base.

$\mathrm{HAB}_{1}$ - Black peaty soil on alpine rocks, rare. Fr. 8-9.

Ben Nevis (Hooker 1837)! Ben Lawers (Hooker). Clova Mountains (Fergusson 1867)!! Carnedd Llewellyn, N. Wales (Wilson I843). Glen Callater and Ben Mac Dhui (Wilson 1836)!! Ben-na-Bourd and Lochnagar (Inntt 1868)!!

Var. $\beta$. latifolia (Schimp.) Synops. 2 ed. 402.

Plants $3-4$ in. high, in lax soft tufts. Leaves large, broadly ovate, gradually pointed, concave, the margin slightly reflexed; obsoletely serrate at apex, cells more lax.

HAB.--Alpine bogs.

Mickledon, Scawfell (Boswell r872)!! Ben Lawers (Boswell 1873). Ben Challum (Binstead 1885)!! Esk House, Scawfell (Dixon r891)!!

There appears to be some confusion with respect to Schimper's varieties latifolia and elata, as I cannot find specimens of either in his herbarium, or that of Mr. Hunt, our specimens agree best with his description of latifolia (Pyrenees, Goulard).

\section{Io. POHLIA COMMUTATA (Schimp.) Lindb.}

Dioicous; in erect yellow-green tufts, blackish at base. Leaves not or slightly decurrent, smaller, ovato-lanc., nerve vanishing. Caps. drooping, oval-oblong, lid convex, apiculate. (T. LXVIII, C.)

Syn.-Bryum Ludwigii plur. auct. Br. Scн. Bry. eur. fasc. 6-9, p. 38 , t. I4 excl. Var. $\beta$ (1839). Boul. Musc. de Fr. i, 279 (1884).

Webera Lndwigii Schimp. Coroll. 67 (1856), Synops. 340 (1860). DE Not. Epil. 4 I9 (I869). Juratz. Laubm. oester..ung. 256 (1882).

Webera commutata Schimp. Synops. 2 ed. 403 (1876). Lesq. James Moss. N. Amer. 220 (I884). Husn. Musc. gall. 230, t. 62 (1889). Limpr. in Rabenh. D. kr. fl. Laubm. ii, $258(1892)$.

Bryum Schimperi WiLs. MSS.

Bryum catenulatum ScHimp. Synops. 2 ed. 47 I.

Pohlia commntata Lindb. Musc. Scand. I7 (1879). CARdot in Rev. bryol. I886, p. 28.

Dioicous; resembling $P$. Ludwigii but smaller, tufts dense, yellowgreen above, fuscous or blackish at base, the stem red, sparingly 
radiculose. Leaves smaller, softer, erecto-patent when moist, imbricated and somewhat incurved when dry, glossy, scarcely decurrent, carinate at back, lower ovato-lanc., upper larger oblongo- or lineallanc., more or less serrate at the pointed apex; nerve strong, vanishing, margin plane or reflexed at base; cells narrower, hexagono-rhomboid. Caps. on a shorter red seta, smaller oval-oblong or pyriform, pale brown, lid conic, apiculate. Male plants more slender, simple; bracts ovato-lanc.

НАв.-Wet peaty soil on the higher mountains, rare. Fr. 8.

Ben Lawers (Wilson I836)!! Ben Lomond (Stirton 1865)! Snowdon (Hunt I865)! Crow Road, Campsie (Hunt r866)!! Lochnagar (Hunt 1868)!

Long confounded with $P$. Ludwigii, but differing in the leaves which are scarcely decurrent, narrower, more pointed, more distinctly serrated and carinate at back. Schimper's Brynm catemulatum appears to be only a stouter more rigid form, with the leaves incurved when dry, and his Brymm filum an extremely attenuated variety.

\section{I . POHLIA GRACILIS (Schleich.) Lindb.}

Dioicous; stems filiform, loosely tufted. Leaves small, erect, ovate, pointed, faintly serrate at apex, upper longer and more acute, nerve vanishing below point. Caps. pendulous, small, ovate, lid apiculate. (T. LXVIII, D.)

Syn.-Bryum gracile Schleich. Catal. pl. helv. 4 ed. (I82I).

Bryum Ludwigii $\beta$. gracile Br. Scr. Bry. eur. fasc. $6-9$, p. 39, t. I4 $\beta$. (I839). C. Muell. Synops. i, 333 (1849).

Webera Ludwigii $\beta$. gracilis Schimp. Coroll. 67 (1856). Synops. 340 (1860).

Webera gracilis DE Not. Epilogo 4 I8 (I869). JURATz. Lautm. oester.-ung. 263 (ISS2). Limpr. in RABEnh. D. kr. f. Laubm. ii. 263 (I892).

Webera commutata $\beta$. gracilis Schimp. Synops. 2 ed. 404 (1876).

Pohlia gracilis LindB. Musc. scand. I7 (I879).

Bryum commutatum $\beta$. gracile Boulay Musc. Fr. i, 279 (I884).

Dioicous; much more slender than $P$. commutata, in loose yellowgreen, glossy tufts, blackish at base, with many rigid filiform shoots, short in the fertile plants, elongated and often with red axillar gemmr in the sterile. Leaves erect, appressed when dry, rigid, ovate and ovato-lanc., short-pointed, without chlorophyl, margin plane, faintly serrate at apex; nerve thinner lost at or below the point. Caps. turgidly ovate, cernuous, small, reddish-brown, lid orange, hemispherical, apiculate. 
Hab.-Mountain rocks, very rare. Fr. 8.

Ben Lomond, sterile (Dr. Stirton $\mathbf{1 8 6}$ )!

This is certainly distinct from $P$. commutata and fruits freely when at home, as by the glacier streams in Lapland and the Swiss Alps.

\section{I2. POHLIA ALBICANS (Wahlenb.) Lindb.}

Dioicous; in pale glaucous green tufts with red stems. Leaves subdecurrent, lanceolate, lower ovato-lanc., upper lanc. acuminate, serrate at apex. Caps. pendulous, pyriform, exannulate, lid conic. (T. LXVIII, A.)

Syn.-Bry'm albicans Wahlend, in Web. Mohr Ind. Musei. pl. cr. (1803). Roehl. Deutsch. fl. iii, 92 (I8I3). BrId. Sp. Musc. III, I9 (I8I7), Mant. II8 (I8I9), Bry. univ. i, 656 (I826). Hook. Br. fl. ii, 59 (1833). C. Muell. Synops. i, 295 (1848). Wils. in Eng. Bot. Suppl. t. 2836 (1840). Husn. Mouss. nord-ouest 122 (1873). Новк. Syn. br. m. ir I (I873). Boul. Musc. de Fr. i, 277 (I884).

Bryum nigricaus et $B$. compactum Dicks. Crypt. Fasc. IV, I5, t. I I (I8o I).

Hypnum Wahlenbergii WEB. MOHR Bot. Tasch. 280 (1807).

Mnium albicans WAHLENB. Fl. lapp. 353 (1812).

Bryum Wahlenbergii Schwaeg. Suppl. I, P. II, 92, t. 70 (18I6). Hueben. Musc. germ. 456 (1833). De, Not. Syllab. i I 5 (1838). Br. Sch. Bry. eur. fasc. 6-9, p. 44, t. 7 (1839). WiLs. Bry. brit. 228, t. 47 (I 855 ).

Webera albicans Schimp. Coroll. 67 (1856). Synops, 343 (1860), 2 ed. 407. Berk. Handb. br. m. 203 (1863). MILDE Bry. siles. 204 (1869). DE Not. Epilogo 420 (1869). Jurat $z$. Laubm. oester.-ung. 259 (I882). HobK. Synops. 2 ed. I56 (I884). Leso. James Moss. N. Amer. 222 (1884). HusN. Musc. gall. 232, t. 62 (I889).

Lamprophyllum albicans LiNDB. Oefver. vet. ak. foerh. 1867 .

Pohlia albicans Lindb. Musc. scand. I7 (1879).

Mniobryum albicans LiMPR. in RABENH. D. kr. fl. Laubm. ii, 277 (1892).

Dioicous; in soft pale glaucous green tufts $\mathrm{I}-3$ in. high. Stem red, often decumbent at base. Lower leaves ovate and ovate-oblong, acuminate, upper elongato-lanc., subdecurrent, plane, acute, serrate at apex, cells narrowly rhomboid-hexagonal, nerve vanishing below apex. Caps. on a long red seta, geniculate at base, inclined or pendulous, shortly pyriform, with a swollen neck, glaucous green and pruinose, becoming orange-brown, when old subglobose truncate and blackish; annulus none, lid small, hemispheric-conic ; teeth of per orange, cilia of end. I-2, elongated. Male plants slender, infl. discoid, terminal, bracts broadly lanc.

HAB.-On clay banks and by streams in subalpine districts. Fr. 5-6.

Var. $\beta$. glacialis (Schleich.)

Plants tall with broader leaves, more laxly imbricated, the colour of a dingy or brownish hue. 
Syn.-Mnitm glaciale Schleich. PI, cr. helv. Cent. III, No. 4 I.

Bryun glaciale Brid. Br. univ. i, 852 .

Bryum Wahlenbergii $\beta$. glaciale Hueben. Musc. germ. 456.

Bryun albicans $\beta$. glaciale C. Muell. Synops. i, 295.

Webera albicans $\beta$. glacialis Sснімг. Coroll. 67 , et Synops.

HAB.-In more mountainous places.

Loch Brandy, Clova (Braithwaite 1864)!! Ben Lawers (Hunt 1865). Canlochan, Braemar (Hunt)!! Mael Girdy (Whitchcad I875).

Much more robust than the type, resembling $B$. turbinatum Var. latifolium, and rarely producing fruit.

\section{EPIPTERYGIUM Lindb.}

Oefv. vet. ak. foerhandl. xix, 603 (1862).

Small mosses inhabiting wet clay banks and resembling in liabit some species of Mnimm. Leaves-especially in the sterile plants--of two forms, unequal, two lateral rows large distichous and somewhat complanate, two or three anterior rows minute stipuliform. Infl. and fruit as in Pohlia.-Der. $\epsilon \pi \iota$ upon, $\pi \tau \epsilon \rho v \iota$ - a little wing.

Elegant mosses of peculiar habit which fairly entitles them to generic distinction. A second and larger species-E. Famaicense LINDB.-is found in the West Indies.

\section{EPIPTERYGIUM TOZERI (Gvev.) Lindb.}

Larger leaves decurrent, oboval, acutely acuminate, with a narrow reddish border; smaller suberect, minute distant lanceolate, in two rows. (T. LXVIII, E.)

Syn.-Bryum Tozeri Grev. Scott. cr. f. v. t. 285 (1827). Hook. Br. fl, ii, 65 (1833). Br. Sch. Bry, eur. fasc. 6-9, p. 4 I, t. I6 (I839). C. MUlel. Synops. i, 298 (IS49). Wils. Bry. br. 249 , t. 50 (1855). Boul. Musc. de Fr. i, 283 (I884). Lesq. James Moss. N. Amer. 222 (I884).

Bryum marginatum Bruch in F. Muell. musc. Sard. (1827).

Webcra Tozeri Schimp. Coroll. 67 (1856), Synops. 342 (I869), 2 ed. 406. Berk. Handb. $\mathrm{Br}$. m. 204 (1863). DE Not. Epilogo 423 (I869). HoBk. Synops. 2 ed. I55 (I884). Lesq. James Moss. N. Amer. 222 (1884). Boul. Musc. de Fr. i, 283 (1884). HusN. Musc. gall. 232, t. 62 (1889).

Epipterygium Tozeri LindB. l.c.

Anisostichium Tozeri Mitт. Journ. Linn. soc. vii, Bot. II9 (I863).

Dioicous; plants gregarious, small soft pale green, reddish at base, with a few slender branches and purple radicles. Lower leaves distant obovate, acutely acuminate, longly decurrent, upper more crowded, 
broader, narrowed at base, quite entire, nerve reddish, reaching middle, often forked, all with a reddish limb of several rows of very narrow cells, the other cells lax rhomboido-hexagonal, or 5-8 angled; those of the anterior rows remote minute lanceolate. Perich. bracts small, lanc., caps. pendulous on a red seta geniculate at base, obovate with a short neck, soft pale brown, rufescent, wide-mouthed when old; lid conic rufous, annulus of many series of cells; teeth small, reddish-yellow, endostome thin, hyaline, with $\mathrm{I}-2$ short cilia. Male plant more slender, upper leaves acuminate-ligulate, perig. bracts oval-oblong, nerve obsolete.

HAB.-Wet clay banks and by streams, rare. Fr. 3-4.

By the Dart, Devon (Tozer)! Penzance (Ralfs)!! Torquay (Miss Griffiths). Henfield (Borrer). Near Hurstpierpoint (Mitten)! Swanscombe Wood, Kent (Folnns)! Plymouth and Buckfastleigh (Holmes I867)!! By the Lee, Cork (Alexander I840). On the Wye at Breinton (Ley).

\section{PLAGIOBRYUM Lindb.}

Oefv. vet. akał. foerh. xix, 606 (1862).

Plants short in small tufts, the leaves resembling those of Bryum, laxly areolate, closely imbricated. Caps. horizontal or decurved, gibbous, with a very long narrow neck, the mouth oblique; calyptra cucullate, peristome as in Pohlia.-Der. $\pi \lambda a \gamma$ cos ollique, $\beta$ pvov Bryum.

The name Zievia of Schimper cannot possibly be used for this moss, as it was adopted by Smith for a genus of Australian Rutaceæ in I798 (Trans. Linn. Soc. iv, 216). A third species P. leptocladon (Sulliv.) is found in Cuba. The gibbous capsule and oblique mouth give them somewhat the aspect of Funaria, and the teeth of the peristome are shorter than the processes of the endostome.

\section{Clavis to the Species.}

Leaves oval plane, nerve vanishing.

Zierii.

- lanceolate, revolute, nerve excurrent.

demissum.

\section{PLAGIOBRYUM ZIERII (Dicks.) Lindb.}

Dioicous; in short silvery pale reddish tufts with julaceous branches. Leaves ovate-acuminate, imbricated, entire, nerve vanishing below apex. Caps. clavate, subpyriform, cernuous, gibbous, mouth oblique; endostome longer than peristome, cilia imperfect. (T. LXIX, A.) 
Srn.-Bryum Zierii Dicks. Cr. Fasc. I, t. 4, f. Io (I785). Wither. Bot. arr. br. veg. 3 ed. iii, 839 (1796). Hull Br. fl. P. 2, 256 (1799). Hedw. Sp. musc. t. 44, f. I-4 (1801). Turn. Musc. hib. I23 (I804). SM. Fl. brit. I356 (I804), Eng. bot. t. IO2I. BRID. Musc. rec. II, P. III, 2 I (I803), Sp. musc. III, 9 (I8I7), Mant. II7 (I8Ig), Bry. univ, i, 64I (I826). Wahlenb. Fl. lapp. 36 i (ISI2). Roehl. Deutsch, fl. iii, go (I8I3). Schwaeg. Suppl. I, P. II, 89 (I8I6). Hook TAYl. Musc. br. I20, t. 29 (I818). FuncK Moost. 46, t. 29 (r82 I). Hook. Fl. Scot. P. II, I50 (I82I), Br. fl. ii, 6o (I833). Gray Nat. arr. br. pl. i, 769 (IS2I). MAck. Fl. hibern. P. 2, 30 (I836). BR. Sch. Bry. eur. fasc. 6-9, Mon. 30 , t. 9 (I839). Rabeni. Deutsch. kr. fl. ii, S. 3, 206 (I848). Hartm. Skand. fl, C. Muell. Synops. i, 288 (1849). Wils. Bry. br. 247, t. 29 (1855). HobK. Syn. I 20 (1873). Juratz. Laubm. oester.-ung. 297 (I882). Boul. Musc. de Fr. i, 290 (I884).

Mnium Zierii P. Beauv. Prodr. 77 (I805).

Hypnum Zierii Weв. MoнR Bot. Tasch. 275 (I807).

Pohlia Zierii Schwaeg. Sp. musc, i, 76 (1830). Hueben. Musc. germ. 465 (1833). De Not. Syllab. II 2 (1838).

Zieria julacea Schimp. Coroll. 68 ( 1856 ), Synops. 384 (1860), 2 ed. 473. Berk. Handb. br.m. I 87 , t. I8 (I863). MiLdE Bry. siles. 222 (I869). DE Not. Epilogo 432 (I869). Hoвk. Syn. 2 ed. I56 (1884). Lesq. James Moss. N. Amer. 240 (I 884 ).

Plagiobryum Zierii Lindb. l.c. (I862). Husn. Musc. gall, i, 22 t, t. 60 (I888). Limpr. in RABENH. D. kr. fl. Laubm. ii, 226 (I892).

Cladodium Zierii HAMPE Fl. hercyn. (1873).

Dioicous; in lax soft tufts, pale silvery green above, pale claret at base, stems short, with fragile julaceous branches. Lower leaves distant, mixed with radicles, upper densely imbricated, oblong-lanc., broadly ovate-acuminate, cochleariform-concave, plane at margin, with the points recurved, nerve vanishing, cells very lax and soft, hyaline; perich. bracts larger lanc., acuminate. Caps. on a reddish seta arcuate at top, horizontal or inclined, the neck twice the length of sporangium, reddish-brown, clavato-pyriform, gibbous, lid conic acute; annulus separating spirally, teeth orange at base, pale and subulate at apex, rather shorter than the processes and incurved between them when dry, cilia rudimentary. Male infl. gemmaceous.

HAB.-Crevices of mountain rocks. Not common. Fr. Io-II.

Ben Lawers and Craig Chailleach, Glen Lochay, Glen Dole, Cader Idris (Wilson 1840 )!! Teesdale (Spruce)!! Arncliff, Yorks. (Whitehead r868). Largs, Ayr (Boyd I886)!! Farragon and Gargunnock hill, Stirling (Stirling r889)!!

\section{PLAGIOBRYUM DEMISSUM (Hornsch.) Lindb.}

Dioicous; in short dense tufts. I,eaves ovate, cuspidate with the excurrent nerve. Caps. cernuous, incurved, unsymmetric, subgibbosopyriform, pale brown, teeth short, processes connate at apex, cilia abortive. (T. LXIX, B.)

Syn.-Meesia demissa Hornsch. Flora r819, p. Ic6. Brıd. Bry. univ. ii, 64 (I827). Funck Moost. t. 28, f. 4 (I82I). Schwaeg. Suppl. III, P. I, t. 233 (I827).

Bryum demissum Hoок. Musc. exot. ii, t. 99 (I820), Musc. br. 2 ed. 206, Suppl. t. 6 (I 827 ), Br. fl. ii, 62 (I833). Grev. Scott. Cr. fl. ii, t. 92 (I825). Br. Sch. Bry. eur. fasc. 6-9, Mon. 30, t. 9 (I839). Rabenh. Deutsch, kr. fl. ii, S. 3, 207 (IS48). C. Muell. 
Synops. i, 289 (1849). WrLs. Bry. br. 248 , t. 36 (1855). Новк. Syn. I20 (1873). Juratz. Laubm. oester.-ung. 297 (I882). Boul. Musc. de Fr. i, 29 I (I884).

Pohlia demissa Hueb. Musc. germ. 466 (1833). De Not. Syllab. 113 (1838).

Zieria demissa Schimp. Coroll. 69 (г856), Synops. 385 (1860), 2 ed. 473 . Berк. Handb. br. m. I88 (I863). DE Not. Epilogo 433 (I869). Hosk. Syn. 2 ed. $5^{6}$ (1884). Lesq. James Moss. N. Amer. 24 I (1884).

Plagiobryum demissum Lindb. Oefv. vet. ak. foerh. I862, p. 6о6. Husn. Musc. gall. i, 224, t. 60 (1888). Limpr. in Rabenh. D. kr. fl. Laubm. ii, 228, Fig. 268 (I892).

Dioicous; in dense rufescent tufts, stems very short, radiculose, with many very short innovations. Lower leaves ovate-acuminate, the nerve vanishing below apex, upper oblong-lanc., longly cuspidate with the excurrent nerve, the margin recurved, all erecto-patent, rufescent by age, cells rhombic-hexagonal above, rectangular at base. Caps. bent down on an arcuate orange seta, irregular, gibboso-pyriform, pale brown, lid small, mammillar, teeth lanceolate, ferruginous below, half the length of the processes which cohere above by transverse trabeculæ, cilia I-2, very short. Male infl. gemmaceous.

HaB.-Rocks on the summit of the Breadalbane range. Rare. Fr. 8.

Ben Lawers and Craig Chailleach.

This fine moss only grows at the summits of the mountains in crevices of rocks filled with black humus in which the roots are deeply fixed. 'The position of the capsule varies with age, being at first horizontal, then bent down by the curvature of the seta until it almost touches the leaves, and when empty more or less erect.

\section{BRYUM Dill.}

Catal. pl. circa Gissam 222 (1719).

Plants generally with a pair of innovations below the floriferous apex, thus becoming repeatedly dichotomous, the stems interwoven with radicles. Leaves in 5 or 8 rows, semiamplexicaul, more or less decurrent, smooth, ovate or lanceolate, rarely obtuse; nerve terete, usually excurrent, cells rather lax, hexagono-rhombic, and quadrate or rectangular at base. Calyptra small cucullate. Caps. on a long wiry seta, inclined or pendulous, pyriform to subglobose with a solid neck, regular or slightly incurved, coriaceous, lid convex apiculate, annulate; peristome of 16 long lanc. teeth, densely articulated in the lower half, lamellate internally, endostome a I6-carinate membrane half the length of the teeth, with I6 lanceolate keeled processes, gaping or perforated 
in the keel and $\mathrm{I}-3$ intermediate filiform cilia, generally transversely appendiculate, rarely abortive. Growing on the ground, rocks and walls, rarely on tree trunks.-Der. $\beta$ pvov a moss.

The genus Bryn comprises some 400 species, varying in size, but in most cases closely allied in habit and by the form of their beautiful pearshaped capsules. The leaves in many approximate so closely in form and structure, that in a sterile condition it is hardly possible to determine the species with certainty, as the nature of the endostome and relation of the reproductive organs must be clearly made out. The former is best attained by soaking the capsule, cutting off the peristome and laying it flat in water between two slides.

The formation of the endostome has been used to characterise some other sections of the genus, thus in Brachymenium, it is reduced to a simple erose membrane about half as high as the teeth, and in Acidodontium the processes are cleft into two divergent segments; but after all these groups are purely artificial, and though most useful in hunting up species, they often separate far apart some which are closely allied, e.g., $B$. fallax and B. pallens. Again, we may notice a close relationship among certain species and yet be quite unable to define it in words, as in B. argenteum, bicolor, erythrocarpum, murale, marginatum, Mildei, \&c., or in B. lacustre, Marratii, turbinatum, calophylluw and Warneum, and there is a capillare group, and most distinct of all that marked by $B$. proliferum; continued observation of the living plants in the field of Nature may eventually clear away some of the difficulties which at present beset our path.

\section{Clavis to the Species.}

Sect. I. SCLERODONTIUM. Shoots filiform, julaceous with appressed coriaceous leaves, the upper cells linear.

Leaves obtuse, the nerve vanishing.

filiforme. pointed, nerved to apex. concinnatum.

Sect. 2. CLADODIUM. Leaves erecto-patent. Endostome adhering to peristome, cilia abortive.

Nerve vanishing.

Capsule subglobose, leaves obtuse.

oblong, leaves pointed.

Marratii.

Leaves short-pointed, nerve reaching apex.

Not limbate.

Limbate.

Synoicous, caps. pale on a short seta.

Dioicous, caps. brown on a long seta.

calophyllum.

gradually acuminate with long points.

Not limbate.

Limbate.

Caps. prominent on the back, mouth oblique.

lacustre.

purpurascons. fallax.

- regular, nerve longly excurrent.

Caps. narrowly pyriform, long-necked.

ventricose in middle, short-necked.

Warneum.

cernuนum.

inclinatum.

pendulum. 
Sect. 3. EUBRYUM. Leaves erecto-patent. Endostome free, with $2-4$ appendiculate cilia.

With stolons, leaves large clustered at summit.

proliferum.

Without stolons, leaves scattered.

Nerve vanishing below apex.

Leaves obtuse and rounded at point.

- acute.

Leaves distant.

Nerve reaching apex or exclirrent.

cyclophyllum.

Leaves limbate.

Leaves muticous, cucullate at apex.

- acuminate at apex, with a longly excurrent nerve.

Autoicous.

Sylloicous.

Leaves spirally twisted when dry.

Dioicous.

Leaves spirally twisted when dry.

Leaves acute, mucronate.

$$
\text { not spirally twisted. }
$$

Duvalii.

argenteum.

Neodamense.

pallescens.

torquescens.

affine.

capillare.

rubens.

Leaves decurrent.

Synoicous.

Dioicous.

bimum.

pallens.

not decurrent.

Leaves twisted when dry.

not twisted.

Caps. shortly pyriform, constricted below lid.

Leaves not limbate.

- long, obconic, not constricted.

Donii.

turbinatum.

ventricosum.

Leaves in rosettes, interrupting the stem.

provinciale.

Synoicous.

Dioicous.

Capsule abruptly ending at base.

intermedium.

bicolor.

murale.

Lid hemispheric, obtuse.

- conic, apiculate.

Nerve longly excurrent.

- reaching a pex or nearly.

Leaf point acuminate, serrulate.

rather obtuse.

Glossy, nerved to apex.

Not glossy, nerve vanishing.

cespiticium.

erythrocarpon.

Mildei.

alpinum.

Muehlenbeckii.

Sect. I. SCLERODICTYON. Innovations filiform, julaceous; leaves appressed, concave, with the upper cells linear or vermicular.

\section{BRYUM FILIFORME Dicks.}

Dioicous ; densely cæspitose, glossy yellow-green, with long slender innovations. Leaves densely imbricated appressed, broadly ovate, obtuse cymbiform, entire, nerve vanishing below apex. Caps. pendulous, oblong, pale brown, lid mammillate. (T. LXIX, C.)

SyN.-Bryum pendulum, surculis teretibus vividibus Dill. Hist. musc. 394 , t. 50, f. 63 D. ( 74 I), et Herb. p.p.

Bryum fliforme Dicks. F1.crypt. fasc. IV, I6, excl. syn. (I8or). LindB. Not. ur Säll. Fn. et Fl. fenn. xi, 43 (1870). Schimp. Synops. 2 ed. 465 (1876). Juratz. Laubm. oest. ung. 295 (1882). Boul. Musc. de Fr. i, 293 (1884). 
Bryum julaceum (non Schrad.) Sm. Fl. brit. iii, 1357, p.p. (1804), Eng. Bot. t. 2270 (I8I I). Hook. Tayl. Musc. br. II 8 (excl. syn.), t. 28 (I8I8). GRay Nat. arr. br. pl. i, 768 (I82I). Ноок. Fl. scot. P. II, I49 (1821), Br. Fl. 58 (1833). BRID. Bry. univ. i, 659, p.p. (1826). Schwaeg. Suppl. II, P. II, I57, p.p. t. I95, excl. fig. II (I827), et in L. Sp. pl. 4 ed. V, P. II, 68, p.p. (I830). HuEben. Musc. germ. 459, excl. syn. (I 833). HARTM. Skand. fl. 2-9 ed. MACK. Fl. hib. P. 2, 3I (1836). DE Not. in Mem. acc. Torin. xl, 33I, p.p. (I838), Syllab. musc. II7, p.p. (I838). BR. Scн. Bry. eur. fasc. 6-9, Mon. 79, t. 40 (I839). C. Muelt, Synops. i, 3 I5 (I849). Rabenh. Deutsch. kr. fl. ii, S. 3, 22I (1848). Wils. Bry. br. 246, excl. syn. et var. $\beta$. t. 28 (1855). Новк. Synops. I 19 ( 1873 ).

Anomobryum julaceum Schimp. Synops. 382, p.p. (1860). Berk. Handb. br. m. I88 (I863). ZETT. Musc. pyren. 34 (I866).

Webera julacca De Not. Epil. bri. ital. $4^{\mathrm{I}} 6$ (1869).

Bryum (Anomobryum) filiforme Schimp. Syn. 2 ed. 465 (1876).

Anomobryum filiforme Husn. Musc. gall. i, 222, t. 60 (I888). Limpr. in Rabenh. D. kr. fl. Laubm. ii, 2 I 8 (1892).

Dioicous; in tallish glossy pale green tufts, the branches long and filiform, with densely imbricated leaves. Leaves not altered by moisture, ovate or oval-oblong, obtuse, very concave, margin erect, entire or minutely serrulate at apex, nerve yellow, vanishing at summit, cells variable, upper flexuoso-linear or narrowly rhomboid, incrassate, lower laxer and thinner, hexagono-rectangular. Perich. bracts longer, ovatolanc., muticous and acute. Caps. on a reddish seta arcuate at top, inclined or subpendulous, oval or narrowly oblong with an attenuated neck, usually a very little incurved, pale reddish or castaneous, scarcely contracted below the mouth when dry; lid high, convex with a short papilla, rufous, very glossy, annulus compound, separating spirally; teeth light ferrug. below, subulate and hyaline above, endostome yellowish, the processes lacunose, with I-3 longly appendiculate cilia. Male plant very slender, the infl. gemmiform, bracts roundish, nerveless. HAB.-Wet places among rocks in alpine districts. Fr. 8-9.

Frequent on the mountains of Scotland, Wales, and N. of England, and about Killarney, Ireland, the leaves quite of different texture from those of $B$. argenteum, for which it has several times been mistaken.

\section{BRYUM CONCINNATUM Spruce.}

Dioicous; smaller than $B$. filiforme. Leaves ovate acute, nerved to apex, the cells narrow linear-hexagonal. (T. L.XIX, D.)

Syn.-Bryum concinnatum Spruce in Trans. bot. soc. Edin. iii, I55 (1849). C. Muell. Synops. ii, 575 (I85I). Hartm. Sk. fl. 9 ed. ii, 34 (I864). Schimp. Synops. 2 ed. 468 (I876). Juratz. Laubm. oester.-ung. 296 (I882). Lindb. Not. ur Sällsk. Fn. et fl. Fenn. 1870 , p. 44. Hobx. Synops. 2 ed. 168 (1884).

Bryum julaceum Var. $\beta$. concinnatum Wis.s. Bry. br. 246 (1855). Hoßk. Synops. I I9 (I 873 ). Bryum nimbigenum TAYL. MSS. HaRTM. Skand. fl. 8 ed. 367 (I861).

Anomobryum concinnatum Lindb. in Oefv. Vet. ak. foerh. xviii, 277 (186I). Husn. Musc. gall. 223, t. 6o (I888). LIMPR. in RABENH. D. kr. fl. Laubm. ii, 22 I (1892).

An. julaceum Var. $\beta$. concinuatum Zет'T. Musc. pyr. 34 (1866).

Bryum filiforme Var. concinnatum Boul. Musc. de Fr. i, 294 (1884). 
Dioicous; filiform, in dull silky green tufts often obscured by muddy deposit. Leaves densely crowded, imbricated, sometimes with axillar bulbils, ovate or elliptic, less concave, more or less acuminate with a short recurved acute apiculus, entire or obsoletely denticulate at apex; nerve yellowish, lost in the point, cells laxer, narrowly hexagonorhomboidal, indistinctly curved.

HAB.-Dripping subalpine rocks, rare. Fr. unknown.

Caldron Snout, Teesdale (Spruce I 843)!! Knockavohila, Kenmare (Taylor). Ochil hills o (Lyle r 849)! Black Force, Yorks. (Binstead I 886)!! Kisdon Force, East Gill and West Stonesdale beck in Upper Swaledale (R. Barnes I889)!! Stanner rocks, Radnor (Binstead $\mathbf{1 8 9 2 ) ! !}$

A softer plant than $B$. filiforme, readily known by the acutely pointed leaves which are not closely appressed but divergent at point.

Sect. 2. CLADODIUM. Leaf-cells hexagono-rhombic; endostome adherent to teeth of peristome or free and without cilia, or with short exappendiculate cilia.

\section{BRYUM LACUSTRE (Bland.) Brid.}

Synoicous; stem short, branched. Leaves ovate, acute, concave, with recurved margins, nerved to apex. Caps. pendulous, pyriform, lid small apiculate. (T. LXIX, E.)

Syn.-Mnium lacustre Bland. Musc. exsic. n. I32 (I804). Roenl. Deutsch. fl. iii, 96 (I8I3). Schwaeg. Suppl. I, P. II, I24, t. 79 (1816). Schultz Suppl. F1. Starg. 86 (I819).

Hypuum lacustre WeB. MoHr Bot. Tasch. 285 (1807).

Bryum lacustre Brid. Mant. I20 (I8Ig). BR. Sch. Bry. eur. fasc. 6-9, Mon. I6, t. 2 (1839). C. Muell. Synops. i, 268 (1849). RaB̉enh. Deutsch. kr. fl. ii, S. 3, 202 (I848). Wils. Bry. br. 229, t. 48 (I855). Schimp. Synops. 352 (I860), 2 ed. 422 . Berk. Handb. br. m. Igi (I863). MiLde Bry. siles. 207 (I869). HoBk. Syn. br. m. II2 (I873). HusN. Musc. gall. 237, t. 64 (I889). Juratz. Laubm. oester.-ung. 264 (I882). Boul. Musc. de Fr. i, 274 (I884). Limpr. in Rabenh. D. kr. A. Laubm. ii, 3 I 5 (I892).

Bryum caspiticium Var. Hook. TAY. Musc. br. I2 I (I8I8).

Bryum cermum Brid. Bry. univ. i, 85 (1827).

Bryum W'ebera lacustris Brid. Bry. univ. i, 636 .

Pohlia lacustris HueB. Musc. germ. 483 (1833).

Synoicous; widely tufted, the stems short, radiculose, branclies longer. Leaves rather solid, chlorophyllose, lower small distant, broadly ovate, acuminate, upper suddenly larger, forming a patent coma, broadly oblong, acutely acuminate, carinate-concave, margin entire not thickened, broadly reflexed; nerve strong, rufous, vanishing below the apex or excurrent in an apiculus, cells scarcely thickened. Vaginula thick, covered with paraphyses; fruit varying in size and length of seta in the same tuft, caps. small, on a long slender seta, inclined or rarely pendulous, oblong-pyriform, slightly incurved, soft, pale brown with a 
darker neck; annulus broad, lid conical; per. small yellow, membrane of endostome not reaching middle of teetl, processes widely gaping, with 2 rudimentary cilia.

HaB.-Wet sandy places, not common. Fr. 6-7.

Yarmouth (Tumer). Wangford, Sulfolk (Eagle ISO4)! Freshfield and Ainsdale, Southport (Hunt I860)!! Taunton, Ashton-under-Lyne (Schimper I865)!! Coatham marshes, Yorks. (R. Barnes I89I)!!

This moss is generally found along with B. calophyllum, Wavnenm and Marratii, and appears to indicate that ail have sprung from some common ancestor.

\section{BRYUM INCLINATUM (Sw.) Bland.}

Synoicous; cæspitose, stem short, sparingly branched. Leaves spreading, ovato-lanceolate, entire, nerve excurrent. Caps. pendulous, ventricose-pyriform with a small mouth. (T. LXIX, F.)

Syn.-Pohlia inclinata Swartz Musc. suec. 45 et 96, t. 5, f. II (I798). Brid. Musc. rec. II, P. III, I44 (I803), Sp. musc. III, 76 (I8I7), Mant. I15 (I8I9). Schultz Fl. starg. 354 (I806). Schwaeg. Suppl. I, P. II, 73, t. 63 (I8I6). Hornsch. in Flora ii, IOI (I8Ig). Funck Moost. 42, t. 27 (I82I). Hueben. Musc. germ. 475 (I833). De Not. Syllab. 109 ( 1838$)$.

Leskea inclinata Wев. Mонг Bot. Tasch. 244 et 482 (I807).

Bryum inclinatum Blandow in Sturm Deutsch. fl. 2, fasc. I I (I8Io). Br. Sch. Bry. eur. Fasc. 6-9, p. I7, t. 3 (I839). C. Muell. Synops. i, 269 (I849). Rabenh. Deutsch. kr. fl. ii, S. 3, 202 (I848). Wils. Bry. br. 236, t. 49 (I855). Schimp. Synops. 350 (I86o), 2 ed. 4 Ig. BERK. Handb. br. m. Igo (I863). MILDE Bry. siles. 206 (I869). De Not. Epilogo 4n3 (I869). Hoвk. Synops. I 6 (I873). Huss. Mouss. nord-ouest II9 (I873), Musc. gall. 235, t. 63 (I889). JuRAtz. Laubm. oest.-ung. 262 (I882). LesQ. James Moss. N. Amer. 225 (I884). Boul. Musc. de Fr. i, 276 (I884). Limpr. in Rabenh. D. kr. fl. Laubm. ii, 3 I 9 (I892).

Mnium intermedium Var. RoenL. Deutsch. fl. iii, 93 ( 18 r 3 ).

Bryum turbinatum Var. HooK. TAYL. Musc. br. I22 (I8I8).

Cladodium inclinatum BRID. Bry. univ. i, 62I (1826).

Synoicous; very like $B$. pendulum. Leaves softer, subrevolute, rather more widely limbate, acutely carinate toward apex, nerve rufous, excurrent in a toothed hair. Caps. on a long purple seta, inclined or pendulous, from a longer neck, ovate or oblong, often a little incurved, somewhat contracted below the moutl when dry, rufo-fuscous or badious, annulus broad, lid from a convex base broader with a shorter point; endostome free above, the membrane half the length of the teeth, processes long free, perforated in the keel, cilia none.

HaB.-On walls and banks, not uncommon. Fr. 5 .

Differs from $B$. pendulnm by the more lanceolate leaves with broader limb, caps. more slender and symmetric with a wider lid. From B.caspiticium by the endostome and inflor. as well as small mouth of capsule, and less silky leaves. $B$. longisetum BLAND. appears to be only a variety. 


\section{BRYUM PENDULUM (Hornsch.) Schim .}

Synoicous; compactly tufted. Leaves ovate acuminate, concave, recurved at margin, nerve excurrent. Caps. ventricose pyriform with a small mouth, endostome adherent. (T. LXX, A.)

Syn.-Cynontodium cernum Hedw. Sp. musc. 58, t. 9 (r8or). P. Beauv. Prodr. $5^{2}$ (1805).

Cynodontium cermum Schwaeg. Suppl. I, P. I, iro (r8rr).

Cynodon cermu

Ptychostomum cornumu Hornsch. Flora V, Syll. I, p. 64 (I822). Brid. Bry. univ, i, 600 (i826). Wahlen. Fl. Suec. 728 (i826). Hueben. musc. germ. 493 (1833).

Ptychostomum pendulum Hornsch. Flora l.c. Brid. Bry, univ, i, 599 (I826).

Bryum cernumu Br. Sch. Bry. eur. Fasc. 6-9, p. I4, t. I (I839). C. Mueld. Synops. i, 266 (I849). Rabenh. Deutsch. kr. f. ii, s. 3, 20 r (r848). Wils. Bry. br. 235, t. 48 (1855). Hartm. Skand. fl. Hobk. Synops. Tr5 (1873).

Bryum pendulum Schimp. Coroll. 7o ( 1856 ), Synops. 349 (1860), 2 ed. 4I4. Berk. Handb. br. m. I89 (1863). MILde Bry. siles. 205 (I869). DE Not. Epil. 387 (I869). HusN. Mouss. nord-ouest r r 9 (1873). Musc. gall. 235, t. 63 (r889). Juratz. Laubm. oest.-ung. 26r (1882). Hork. Syn. 2 ed. I57 (1884). LesQ. James Moss. N. Amer. 225 (1884). Boul. Musc. de Fr. i, 275 (t884). Limpro in Rabenh. D. kr. fl. Laubni. ii, $293(1892)$.

Synoicous; sometimes also with gemmiform male infl. intermixed; densely cæspitant and tomentose, dull green with short branches. Comal leaves densely crowded, erecto-patent, ovato-lanc., carinate concave, the nerve stout, far excurrent, margin more or less reflexed, narrowly limbate, serrulate or entire at extreme apex, all rather rigid; cells dense, rhombic above, rectangular and red at base. Caps. rich brown, pendulous, from a neck swollen at base shorter than the sporangium, oval or ovato-globose, slightly contracted below the mouth, shorter or longer, lid rather small, broadly conic, acutely apiculate; annulus broad; teeth of peristome reddish-yellow at base, and according to Husnot traversed on the back by many fine sinuous lines, endostome adherent, the processes only partly free, cilia rudimentary.

HAB.-On walls, rocks and waste ground; not uncommon. Fr. 5.

Very variable in size and form of capsule and differing from B. inclinatum by the broader leaves and more ventricose capsule with adherent endostome, and from $B$. caspiticium by the small mouth of capsule, the infl. and endostome.

\section{BRYUM PURPURASCENS (R. Br.) Br. Sch.}

Synoicous; plants slender dull green, purplish at apex. Leaves ovato-lanc., mucronate with the excurrent nerve, narrowly limbate, slightly recurved at margin. Caps. pendulous, oblongo-pyriform, lid hemispherical, cilia imperfect. (T. LXXII, A.) 
Sy'n.-Pohlia purpurascens R. Br. Suppl. App. to Parry's Voy. I97 (I824).

Hemisynapsium arcticum $\beta$. purpurascens BrID. Bry. univ. i, 606 (1826).

Pohlia arctica Var. purpurascens Schwaeg. Sp. musc. 74 (1830).

Bry'un purpurascens Br. Sch. Bry. eur. Fasc. 32, t. 3 (1846). C. Muell. Synops. i, 270 (1849). Schimp. Synops. 345 (1860), 2 ed. 4Io. Hartm. Skand, fi. LesQ. James Moss. N. Amer. 224 (1884).

Bryum fuscum Ferg. in Naturalist N.S. V, 82 (1880). Новк. Synops. 2 ed. 157 (1884).

Synoicous or heteroicous, in loose tufts, dull green below, purplish at apex. Stems slender with innovations from below the perichætium which are sometimes flagelliform, with a few small leaves. Lower leaves ovate, acute, upper oblongo-lanc., patent, twisted when dry, mucronate with the excurrent yellow nerve, concave, narrowly limbate, margin slightly recurved, entire or with $\mathrm{I}-2$ irregular teeth at apex; cells at base rectangular, above rhombo-hexagonal. Perich. bracts lanc., more acuminate; seta red, bent suddenly at top. Caps. pendulous, oblong-pyriform with the neck shorter than sporangium, regular, pale fuscous, rufescent at neck; annulus large, lid small hemispherical, mammillar, of the same colour as caps., peristome yellow, processes of endostome free, lanc.-subulate, cleft, cilia imperfect.

$\mathrm{H}_{\mathrm{AB}}$.-Crevices of limestone rocks, very rare. Fr. 7. Near Litton, Yorks. (Whitehead I 879)!

The single plant sent by Mr. Whitehead quite agrees with Norwegian specimens of this scarce moss, except that it is more stunted and consequently the stem, leaves and capsule are shorter. Another closely allied species ( $B r$. arcticum $\mathrm{R}$. BR.) is more frequent in Scandinavia than the present one and is not unlikely to occur here; it has more acuminate leaves, with longer points, and a ferruginous border.

\section{BRYUM WARNEUM Blandow.}

Autoicous; in small tufts with few branches. Leaves oblong, acuminate, with a narrow border, plane above. Caps. pendulous, ventricose-pyriform with a small mouth. (T. LXX, B.)

Syn.-Bryum Warneum Bland. Musc. exs. fasc. IV, n. I84 (I805). Brid. Bry. univ, i, 675 (I826). Br. Sch. Bry. eur. fasc. 6-9, p. 20, t. 5 (I839). C. Muell. Synops. i, 272 (1849). Rabenh. Deutsch. kr. fi. ii, S. 3, 204 (I848). Hartm. Skand. fl. Wils. Bry. br. p. xii, t. 12 (1855). Schimp. Synops. 35I (1860), 2 ed. 421 . BERk. Handb.br.m. Igo (1863). Milde Bry. siles. 207 (1869). Hobk. Syn. II 2 (1873). Juratz. Laubm. oest.-ung. 263 (1882). Lesq. James Moss. N. Amer. 226 (1884). Boul. Musc. de Fr. i, 273 (1884). Husn. Musc. gall. i, 237, t. 63 (I889). Limpr. in Rabenh. D. kr. f. Laubın. ii, 290 (1892).

Bryum caspiticium $\beta$. Warneum Bland. Schwaeg. Suppl. I, P. II, t. Iog (1816).

Bryum flagellare BriD. Sp. Musc. III, 30 (I8I7), Mant. IIS (I8I9). Funck Moost. 48, t. 30 (1821).

Pohlia Warenensis Scimaeg. Suppl. III, P. I, t. 236 (1827). Hueben. Musc. germ. 477 (1833).

Bryum strictum and B. oclandicum PhILIs, in Rev. bryol. x886-7. 
Autoicous or rarely synoicous, in small irregular tufts. Stem short, simple or sparingly branched, the branches short, usually with several long flagelliform innovations. Leaves rather distant, patent, curved and flexuose when dry, ovato-acuminate, margin plane above, a little reflexed below, narrowly limbate, remotely serrate at apex; nerve excurrent in a short point, cells rather lax. Caps. on a long straight seta, suddenly pendulous, obovate or subgloboso-pyriform, brown; lid small convex apiculate, long persistent; endostome membrane adhering; processes free narrow scarce perforate, cilia rudimentary. Male infl. terminal, in the comal leaves, minute subglobose, bracts 3 , broadly obovate, suddenly apiculate, outer one nerved.

HAB.-Sandy or muddy ground by the sea or streams, rare. Fr. 8-9.

Tent's moor, Fife (Ogilvie I853)! Shore at Southport (Marrat and Wilson)!! Taunton, Ashton-under-Lyne (Whitchcad and Schofield I865)!! N. Bull, Dublin (Orr i860). Portmarnock and Malahide. Coatham marshes, Yorks. (R. Barnes I89I)!!

\section{BRYUM CERNUUM (Sw.) Lindb.}

Autoicous; cæspitose, green. Leaves oval-lanc., plane above, the nerve excurrent. Caps, pendulous, irregular clavate, mouth small and oblique. (T. LXX, C.)

Syn.-Didymodon cernulus Swartz. Musc. suec. 28, t. I, f. 2 (1798).

Pohlia uliginosa BRUch MSS.

Cladodium uliginosum BrID. Bry. univ. i, 84I (1827).

Bryam uliginosum BR. Sch. Bry. eur. fasc. 6-9, p. I8, t. 4 (1839). C. Muelt. Synops. i, 27 I (I849). RABenh. Deutsch. kr. fl. ii, S. 3, 203 (I848). Wils. Bry. br. 234, t. 48 (I855). . Schimp. Synops, 347 (1860), 2 ed. 425 . Berk. Handb. br. m. I89 (I863). MiLdE Bry. siles. 208 (I869). Hobk. Synops. II5 (I873). JuRATz. Laubm. oest.-ung. 264 (I882). Husn. Musc. gall. i, 236, t. 63 (I889). Lesq. James Moss. N. Amer. 227 (1884).

Bryum cernumm LindB. Musc. scand. 16 (1879).

Autoicous; in loose olivaceous green tufts, the stems branclied with short innovations, densely radiculose. Lower leaves ovate acuminate, comal ovate-oblong and elongate lanceolate, with a narrow brownishyellow border of $2-3$ rows of narrow cells, margin reflexed in the lower half, distantly serrate at apex, shortly cuspidate with the brownish excurrent nerve, cells rather large, soft. Caps. on a long reddish seta arcuate above, horizontal or inclined, elongato-pyriform, somewhat incurved and prominent on the back, pale fuscous or yellowish brown when old, the mouth small and rather oblique, not contracted below it when dry; lid very small, orange, annulus broad; processes of endostome cleft along the keel, cilia imperfect. Male infl. near the female, gemmiform. 
$\mathrm{H}_{\mathrm{AB}}$.-Boggy ground, sandy banks and by streams. Fr. 8.

Manchester and Southport (Wood $\left.\mathrm{I}_{443}\right) !$ Ashton, Prestwich and Bowdon (Hunt 1863$)$ : Grange (Hunt I868)! Inverarnan (Hunt I866)! Oxford (Boswell)!! Hattersley, Cheshire (Whitehead). Dublin. Sea coast at Whitby and Saltburn, Yorks.

A fine moss readily known by its long seta and pale gibbous capsule with oblique mouth, by which it differs from $B$. pallens, a species having capsules of the same ashy colour, but with cilia on the endostome. Lindberg has identified it with original specimens of D. cermuns from Swartz.

\section{BRYUM MARRATII Wils.}

Autoicous ; in small lax tufts. Leaves spreading, elliptic, concave, muticous, entire, nerve vanishing below apex. Caps. small pendulous, subglobose, endostome adherent. (T. LXX, D.)

Syn.-Bryum Marratii Wils. Bry. brit. p. xi, t. 32 (1855). BR. Sch. Bry. eur. fasc. 62-64, Suppl. (1855). Schimp. Synops. 354 (I860), 2 ed. 423. BERK. Handb. br. m. IgI (I863). Milde Bry. siles. 209 (I869). LindB. Bot. notis. i868 p. 260. Hobk. Syn. br. m. ili (I873). Husn. Musc. gall. i, 238, t. 64 (I889). LiMPR. in Rabenh. D. kr. f. Laubm. ii, 287 (I892).

Autoicous; in small lax irregular tufts, short and slender with numerous innovations. Leaves erecto-patent, oblongo and elongatoelliptic, obtuse, entire, very concave, incurved at apex when dry so as to be somewhat boat-shaped, nerve slender, vanishing below apex, cells above hexagono-rhombic, at base rectangular, narrowed at margin. Caps. on a slender subflexuose red seta arcuate at apex, pendulous or inclined, pachydermous, rufous, minute subglobose with a slort neck defluent into the seta, when old, globose with a small mouth; lid small conic, acutely apiculate, reddish, annulus broad; teeth of peristome deep red, connivent, endostome adherent, the cilia abortive. Male inf. terminal on a short branch, gemmiform, bracts small, ovato-acuminate.

$\mathrm{H}_{\mathrm{AB}}$. - Wet sandy places by the sea, rare. Fr. 9 .

Sands at Southport (Marrat 1854)! Tents Muir, Fife (Howic)!! Drigg, Cumberland (Rev. A. Ley I88I). Coatham marshes, Yorks. (R. Barnes I8gi !!

Grows in company with $B$. calophyllum and resembling that species, but differing in the small round caps., red peristome and narrower obtuse leaves.

\section{IO. BRYUM CALOPHYLLUM $R . B r$.}

Autoicous; loosely tufted. Leaves erecto-patent, concave, roundish-ovate, nerved almost to apex. Caps. elliptic-oblong, pendulous, lid short, apiculate. (T. LXX, E.) 
Syn.-Bryum calophyllum R. Br. App. to Parry's Voy. Ig6 (I824). C. Muell. Synops. i, 287 (I849). Wils. Bry. brit. p. xi, t. 33 (I 855). Schimp. Synops. 353 (I86o), 2 ed. 424. BERK. Handb. br. m. IgI (I863). MILDE Bry. siles. 208 (1869). HoBK. Synops. br. m. III (I873). Leso. James Moss. N. Amer, 227 (I884). BuUl. Musc. de Fr. i, 273 (I884). Husn. Musc. gall. 238, t. 64 (1889). Limpr. in Rabenh. D. kr. fl. Laubm. ii, 305 ( 1892$)$.

Cladodium calophyllum Brid. Bry. univ, i, 622 (1826).

Bryum intricatum Brid. op. c. 680.

Pollia calophylla SchwaEg. Spec. musc. 75 (1830).

Polllia latifolia BRUCH MSS.

Bryum latifolium Br. Sch. Bry. eur. Fasc. 6-9, p. I9, t. 4 (I839). C. Muell. Synops. i, 286 (I849). Rabenh. Deutsch. kr. fl. ii, S. 3, 204 (1848).

Autoicous; in loose incoherent soft pale green tufts; stem short, simple or branched, with few radicles. Stem-leaves remote, orbicularovate, obtuse, comal crowded, laxly imbricated in an obtuse gemmule, broadly ovate and oval-oblong, narrowed into a short obtuse acumen; all rather succulent, very concave, margin entire, plane or slightly recurved, not limbate, nerve vanishing at or below apex, cells narrowly rectangular and rhombic-hexagonal; perich. bracts narrower, innermost lanceolate, lax-celled. Caps. on a long straight rigid red seta, geniculate at base, suddenly pendulous, shortly pyriform with a short neck, sliglitly contracted below the mouth when dry, ferruginous brown; peristome yellow, endostome with narrow slightly perforated processes, cilia rudimentary. Male infl. gemmiform, $\mathrm{I}-2$ at base of female.

HАв.-Wet sandy ground, rare. Fr. 9-10.

Sands at Southport (Marrat)!! Ashton-under-Lyne (Gordon I865)!! Tent's Muir, Fife (Howie). Coatham marshes, Yorks. (R. Barnles r8gr)!! Braunton Burrows, Devon (Mitten). Sands of Barry, Dundee (Holmes I8go)!!

\section{Ir. BRYUM FALLAX Milde.}

Dioicous; in dingy green tufts. Stem leaves obovate, carinate, short pointed, limbate, nerved to apex. Caps. pyriform, with a long neck and small mouth, cilia of endostome rudimentary. (T. LXXII, B.) Syn.-Bryum fallax Milde Bry. Siles. 209 (1869). Schimp. Synops. 2 ed. +26 (1876). Boul. Musc. de Fr. i, 272 (1884). Husn. Musc. gall. i, 238, t. 64 (1889).

Bryum pallens $\beta$. fallax Juratz. Laubm. oester.-ung. 287 (I882).

Dioicous; in lax soft tufts, rufous green above, short. Stem-leaves obovate-spatulate, short-pointed, carinate, narrowly limbate, broadly recurved, nerved to the apex; comal oblong, gradually acuminate, reddish at base, twisting when dry, inner perichætial smaller lanceolate, ramuline leaves distant, oblong-lanc.; cells rather lax, hexagonorhombic, basal hexagono-rectangular. Caps. on a long rufous seta, 
hamato-arcuate above, inclined or pendulous, pyriform, castaneous, the neck long as sporangium and sulcate when dry; annulus broad, lid small, mammillate, peristome pale yellow, teeth lineal-subulate, endostome united to peristome for half its length, processes long as teeth, gaping widely, cilia short and rudimentary. Male plants small, simple, the infl. terminal, gemmiform, enclosed in the comal leaves, inner bracts laxly areolate, without nerve or limb.

HAB.-Wet sandy heaths, rare. Fr. 7-8.

Tilgate forest, Sussex (Mitten 1846)!! Snowdon (Mitten).

This moss is closely allied to $B$. pallens and has probably been confounded with that species; it may be known by the abortive cilia of the endostome and broad short-pointed leaves.

Sect. 3. EUBRYUM. Leaf-cells hexagono-rhombic; endostome quite free, the basal membrane elongated, with long processes and $2-4$ equally long cilia, appendiculate at joints.

\section{I2. BRYUM INTERMEDIUM Brid.}

Synoicous; cæspitose. Leaves erecto-patent, ovato-lanceolate, the margin reflexed, nerve excurrent. Caps. pendulous, narrow pyriform, long-necked, lid apiculate. (T. LXX, F.)

Syn.-Pohlia internedia Brid. Musc. rec. II, P. III, I44, t. 2, f. I2 (I803). Schultz Fl. starg. 254 (1806).

Hypunm intermedium WEE. MOHR Bot. Tasch. 283 (1807).

Webera intermedia Schwaeg. Suppl. I, P. II, 67, t. 75 (18I6). BRID. Sp. musc. III, 37 (I8I7). Hornsch. Flora ii, IO2 (I8Ig). Funck Moost. 39, t. 25 (I821).

Bryum turbinatum var. Hook. TAYL. Musc. br. I22 (1818).

Bryum intermedium BRID. Mant. I20 (I8I9). BR. Sch. Bry. eur. Fasc. 6-9, p. 47, t. I9 (I839). Rabenh. Deutsch. kr. fl. ii, S. 3, 2 г2 (r848). C. Muell. Synops, i, 278 (I849). Wils. Bry. br. 236, t. 49 (1855). Schimp. Synops. 356 (1860), 2 ed. 428 . BERK. Handb. br. m. Ig2 (I863). MiLde Bry. siles. 2 Io (I869). Hobk. Synops. i i6 (1873). Juratz. Laubm. oester.-ung. 265 (I882). Lesq. James Moss. N. Amer. 228 (I884). Boul. M Lsc. de Fr. i, 269 (r884). Husn. Musc. gall. 247, t. 67 (I889).

Bryum Webera intermedia BrID. Bry. univ. i, 632 (1826).

Bryum pallescens $\beta$. intermedium Schwaeg. Sp. musc. i, 6I (1830). Hueben. Musc. germ. 446 (1833).

Synoicous; in wide deep green tufts, densely radiculose at base, stems short, branched with short innovations. Lower leaves ovatoupper oblongo- and elongato-lanc., nerve red at base, excurrent in a long remotely denticulate point, margin entire, subrevolute, with a very narrow border. Caps. horizontal and inclined, from a neck as long as sporangium, oblongo- and elongato-pyriform, slightly incurved, rufousbrown or fuscous, lid convex-conic, acute shining. Annulus separating 
in fragments; processes of endostome when dry, projected between the incurved teeth, cilia shortly appendiculate.

HAB.-Walls and shady ground. Fr. 6-9.

This may be distinguished from $B$. pallescens and caspiticium by the synoicous infl., and the narrower caps. with a longer neck and narrower mouth.

\section{I3. BRYUM BIMUM Schreb.}

Synoicous; in tall dense tufts. Leaves spreading ovato-lanc., decurrent, cuspidate with the excurrent nerve, the margin recurved. Caps. pendulous, oblong-pyriform, lid large, manmilar. (T. LXXI, A.)

SYN،-Brymm lanc. bimum, setis et caps. longis pendulis p.p. Dill. Hist. musc. 405, t. 5 I, f. 73 F. et Herb.

Bryum bimum Schreb. Spic. Fl. Lips. 83 (I77r). Roth Fl. germ. iii, P. I, 243 (I80o). Turn. Musc. hibern. I 37 (I804). Funck Moost. 49, t. 3 I (I821). Brid. Bry. univ. i, 678, p.p. (1826). BR. Sch. Bry. eur. fasc. 6-9, p, 50, t. 2 I (1839). C. Muell. Synups. i, 257 (I849). Rabenh. Deutsch. kr. f. ii, S. 3, 213 (I848). Wils. Bry. br. 238 , t. 49 (I855). Schimp. Synops. 357 (I860), 2 ed. 430. Berk. Handb. br. m. I92 (I863). Milde Bry. siles. 2 Io (186y). De Not. Fpilogo 386 (I869). Hobk. Synops. I 6 (I873). Husn. Mouss, nord-ouest I22 (I873), Musc. gall. 249, t. 68 (I889). Juratz. Laubm. oest.-ung. 267 (1882). Boul. Musc. de Fr. i, 267 (1884). Lesq. James Moss. N. Amer. 229 (I884).

Mnium bimum Brid. Musc. rec. II, P. III, 93 (I803), Sp. musc. II, 53 (I8r2), p.p.

Bryum psendotriquetrum $\beta$. SchwaEg. Suppl. I, P. II, 2 I I (I8I6).

Bryzum ventricosum p p. Hook. TAYL. Musc. br. 124 (1818).

Synoicous; in dense shorter or taller tufts, green or olivaceous above, brown or blackish at base; stems with rufous tomentum, fastigiate-branched. Leaves semiamplexicaul, decurrent, patulous, when dry laxly imbricated and a little twisted, outer comal elliptic shortly acuminate, median oblong-lanc., shortly cuspidate with the reddish-brown excurrent nerve, lower ovate or elliptic, slortly pointed, margin revolute with a limb of $2-4$ rows of narrow cells, bluntly serrate at apex. Caps. pendulous on a long seta, obovate- or oblong-pyriform, slightly constricted below the mouth when dry, ferruginous-brown, lid mammilar, large; membrane of endostome prolonged.

НАB.-Bogs and marshy ground. Fr. 6-7.

This moss was long confounded with B. ventricosum Dicks, but differs in the synoicous infl., the leaves also are more divergent and laxer, distinctly cuspidate, and the capsule shorter and more regular. 


\section{I4. BRYUM AFFINE (Bnuch) Lindb.}

Synoicous; shorter and denser. Leaves ovato-lanc., longly cuspidate with the excurrent nerve, comal long and lanc. Caps. with a long neck. (T. LXXI, B.)

Syn.-Webera affinis BRUCH in BrID. Bry. univ. i, 848 (1827).

Bryum capillare $\gamma$. affine BRID. 1.c.

Pohlia paradoxa Hueben. Musc. germ. 479 (I833).

Bryum bimum Var. cuspidatum Br. Sch. Bry. eur. fasc. 6-9, p. 50 (1839). Schimp. Synops. 357. Wils. Bry. brit. 238 (1855).

Bryum cuspidatum Schimp. Synops. 2 ed. 430 (1876). Boul. Musc. de Fr. i, 267 (1884).

Bryum paradoxum JuRatz. Laubm. oest.-ung. 266 (I882).

Bryum cirratum Var. cuspidatum Huss. Musc. gall. 248 (I 889 ).

Synoicous; densely cæspitose and tomentose. Lower leaves minute ovate acuminate, median larger ovato-lanc. longly cuspidate with the excurrent nerve, uppermost forming a loose patent coma, twice as large, oblong-lanc., with a border of $2-3$ rows of narrow yellowish cells. Caps. inclined or subpendulous, with a long obconic neck, more or less oblongo-obconic, contracted below the mouth when dry, fuscescent; lid conic apiculate. Teeth long, yellow, membrane of endostome prolonged, processes widely gaping, cilia with long appendages.

НAB.-Walls and damp rocks. Fr. 6-7.

Kirkham and Egglestone, Yorks. (Spruce I843)! Orford, Warrington (Wilson). Eccles and Bowdon (Hunt 186I)!! Old gravel pit at Ashton and clayfields at Old Trafford (Hunt 1863). Buxton (Hunt I871)! Mucross, Killarney (Hunt I872). Rocks by Falls of Lochay (Hunt 1865)!! Todmorden (Nowell r 860 ). Romiley, Cheshire (Whitehcad). Swinner gill, Upper Swaledale (R. Barncs I $89 \mathrm{I})$ !!

Var. $\beta$. cirratum (Hornsch.)

More branched, glossy yellowish green, often with long slender innovations; leaves ovate, longer, gradually acuminate, revolute at margin, border broader of $3-5$ rows of cells, nerve excurrent in a long remotely denticulate point, piliform in the uppermost leaves. Caps. shorter.

Syn.-Bryum cirratum Hornsch. in Flora ii, 90 (1819). Funck Moost. 48, t. 30. Brid. Bry. univ. i, 672. C. Muell. Synops. i, 278 . Schimp. Bry. eur. fasc. 32, t. I I, Synops. 356, 2 ed. 429. De Not. Epilogo 386. Milde Bry. siles. 2 I I. Husn. Musc. gall. 248 , t. 67. Boul. Musc. de Fr. i, 268.

Bryum paradoxum Var. $\beta$. cirratum Juratz, Laubm. oest.-ung. 266.

HaB.-Mountain rocks. (Ben Lawers Stivton I868)!

Although very near to $B$. bimum, this species appears to be distinct in the form of the leaf and longly excurrent nerve. 'The Var. $\beta$. is clearly the alpine form of the plant. 


\section{I5. BRYUM TORQUESCENS Br. Sch.}

Synoicous; densely matted, radiculose; lower leaves ovato-lanc., cuspidate, upper ovate, cuspidate, divergent, twisted when dry, the margin reflexed. Caps. large pendulous, obconical, a little incurved. (T. LXXI, C.)

Sy',-Bry'um torquescens Br. Sch. Bry. eur. fasc. 6-9, p. 49, t. 20 (1839). Rabenh. Deutsch. kr. A. ii, S. 3, 2I 3 (1848). C. Muell. Synops. i, 277 (1849). Wils. Bry. br. 239, t. 49 (1855). Schimp. Synops. 358 (I860), 2 ed. 431. BERK. Handb. br. m. I93 (I863). Milde Bry. siles. 2II (I869). DE Not. Epil. 396 (I869). Hobk. Syn. br. m. in6 (1873). Husn. Mouss. nord-ouest I23 (1873). JuRatz. Laubm. oest.-ung. 268 (I882). Lesq. James Moss. N. Amer. 230 (I884). Boul. Musc. de Fr, i, 269 (1884).

Bryum capillare Var. torquescens HusN. Musc. gall. i, 240 ( 1889 ).

Synoicous; short cæspitant, with many black-purple radicles. Leaves distant, spirally twisted when dry, lax flaccid, elongato-lanc., complicato-carinate, subflexuose with recurved margins, comal densely crowded, ovate and oblong-lanc., concave, all entire with a very narrow border, nerve reddish excurrent in a long smooth point. Caps. inclined and pendulous, somewhat incurved, elongate-obconic, red or rufousbrown, lid convex, acutely apiculate, glossy rufous red.

$\mathrm{HAB}_{\mathrm{A}}-\mathrm{On}$ walls and rocks; not common. Fr. 6-7.

Gormire (Borrer 1844). Hurstpierpoint (Mitten). Tunbridge Wells (Fenner), Cleve hill. Levens (Barnes 1869). Mucruss (Hunt 1872)!! Near Dublin (Moore). Mallow, Cork (Holt I885)!! Hayle sands, Penzance (Curnow 1872). Great Doward hill (Rev. A. Lcy)! Longbridge, Devon (Holmes).

Closely resembling $B$. capillare, and possibly to be regarded as only a variety of that species.

\section{BRYUM PALLESCENS Schleich.}

Autoicous; cæspitose, stems taller, branched; leaves ovato-lanc., entire, margin reflexed, nerve excurrent. Caps. oblong-pyriform, horizontal or cernuous; iid conic acuminate. (T. LXXI, D.)

Syn.-Bryum pallescens Schleich. Crypt. helv. exs. No. 28 (i8o7). Schwaeg. Suppl. I, P. JI, I07, t. 75 (1816). Funck Moost. 48, t. 30 (1821). Brid. Bry. univ. i, 645 (1826). Hueben. Musc. germ. 446 (I833). Br. Schimp. Bry. eur. fasc. 6-9, p. 5 I, t. 22 (I839). Rabenh. Deutsch. kr. fl. ii, S. 3, 213 (1848). C. Muell. Synops. i, 279 (I849). Wils. Bry. brit. 234, t. 48 (I855). Schimp. Synops. 360 (I860), 2 ed. 433. BERK. Handb. br. m. 193 (I863). DE Not. Epilogo 384 (I869). Milde Bry. siles. 212 (I869). Hork. Synops. II5 (1873). JuRATz. Laubm. oest.-ung. 269 (1882). Boul. Musc. de Fr. i, 266 (1884). Lesq. James Moss. N. Amer. 23 I (1884). Husn. Musc. gall. i, 248 , t. 67 (i 889 ).

Autoicous; in cushioned tufts, green above, fuscescent below, interwoven with rufous tomentum. Stems branched, purple. Lower leaves distant, ovate, acutely acuminate, nerve lost below apex, comal oblong-acuminate, apiculate or cuspidate with the excurrent nerve, 
broadly bordered and subrevolute at margin, reddish at base, slightly twisted when dry. Caps. on a reddish seta arcuate above, horizontal or inclined, long-necked, clavato-pyriform, regular, contracted below mouth when dry, at first yellowish, finally reddish fuscous; lid convex apiculate shining; teeth reddish below, pale yellow above. Male infl. secund on a proper branch.

HAB.- Rocks and walls in subalpine districts, not common. Fr. 7-8.

Teesdale (Spruce, I 843$)$. Ochil hills $(L y l e)$. Clonmel, Ireland (Sidebotham). Swaledale and Yoredale (Baker I 853). Strath Tummel (Greville i 855$)$. Appleton, Warrington (Wilson 1859). Arncliff and Malham (Nowell 1862)!! Ben Lawers (Hunt 1868)!! Monsall dale (Holt i 879$) !$ !

\section{Var. $\beta$. contextum (IIonisch.)}

Stems taller, more compact, much branched; capsule on a shorter seta, shorter ventricose more or less cernuous.

Syn.-Bryum contextum Hoppe Hornsch. in Flora 1819, p. 9I. Brid. Bry. univ. i, 646.

Bry'um palleseens Var. contextum Br. ScH. Bry. eur.

\section{HAB.-Ettersgill beck, Teesdale (Spruce I843)!}

This fine species varies considerably in size and in the size and direction of the capsule, and comes nearest to $B$. intermedium. Its close ally B. subrotundum BR1D, is found in Norway, but I have seen no British specimens.

\section{BRYUM CÆSPITICIUM $L$.}

Dioicous; in small pale green dense tufts. Leaves erecto-patent, ovato-lanceolate, nerve excurrent, margin reflexed. Caps. pendulous, oblong-obovate, wide-mouthed; lid large mammillate. (T. LXXI, E.)

Syn.--Bryum pendulum, ovatum, caspiticium et pilosum, seta bicolori DrLL. Hist. musc. 396, t. 50, f. $66 \mathrm{D}-\mathrm{D}(\mathrm{I} 74 \mathrm{I})$ et Herbar.

Bryum easpitieium L. Sp. pl. I I I I (I753), Fl. suec. Ioro. Huds. Fl. angl. 4 I3 (I $76 z$ ). Weiss Cr. Goett. 203 (I770). Neck. Meth. musc. 228 (I77I). Wither. Bot. arr. Br. veg. ii, 679 (I 776 ). LightF. Fl. scot. ii, 736 (I777). SibTh. Fl. oxon. 290 (I 794 ). Swartz Musc. suec. 5o (1798). Hull Br. f.. P. 2, 256 (1799). Roth Fl. germ. iii, P. I, 239 (I800). Hedw. Sp. musc. I80 (I801). Turn. Musc. hib. I 20 (I804). SM. Fl. brit. I354 (I804), Eng. Bot. t. I904. CuRT. Fl. Lond. t. I64. VolT Musc. herb. 9 I (I8I2). Wahlenb. fl. lapp. 36o (I8I2). Schwaeg. Suppl. I, P. II, iog (I8I6). Brid. Sp. Musc. III, I6 (I8I7), Mant. I I8 (I8Ig), Bry. univ. i, 669 (I826). Hook. Tay'l. Musc. brit. 127, t. 29 (1818): GRAY Nat. arr. Br. pl. i, 770 (1821). Hook. Fl. Scot. P. 2, I50 (I82I), Br. fl. ii, 6I (I833). Hueben. Musc. germ. 443 (I833). Funck Moost. 48, t. 30 (182I). MAck. Fl. hib. P. 2, 32 (1836). BR. Sch. Bry. eur. fasc. 6-9, p. 7o, t. 34 (I839). DE NoT. Syll. I 22 (I838), Epilogo 397 (I869). Rabenh. Deutsch. kr. fl. ii, S. 3, 2I 7 (I848). C. Muell. Synops. i, 284 (I849). Wils. Bry. br. 243, t. 29 (I 855). Schimp. Synops. 367 (I860), 2 ed. 443. BERK. Handb. br. m. I95 (I863). Milde Bry. siles. 216 (I869). Hobk. Syn. br, m. II 8 (I873). Husn. Mouss. rordouest I24 (I873), Musc. gall. i, 24 I, t. 65 (I889). JuRATz. Laubm. oest.-ung. 279 (I882). Leso. James Moss. N. Amer. 235 (I884). Boul. Musc. de Fr. i, 255 (I884).

Hypmm erespiticium Schranck Baiers. f. ii, 473 (i789). Web. Mohr. Bot. Tasch. $283(1807)$. 
Mnium caspiticium Hedw. Fund. II, 94 (1782). ReLh. Fl. cant. yoo (I785). Roth Fl. germ. i, 475 (1788). HofFM. Deutsch. fl. ii, 5o (1795). Аввот Fl. bedf. 235 (I798). Brid. Musc. rec. II, P. III, 96 (I803). P. BeaUv. Prodr. 94 (1805). Schultz Fl. starg. 345 (1806). ROEHL. Deutsch. fl. iii, 95 (I8I3).

Dioicous; in small pale green subsericeous tufts, interwoven with ferruginous tomentum at base. Lower leaves remote, minute lanc., upper forming a laxly imbricated coma, suddenly larger ovato- and oblongo-lanc., longly cuspidate with the excurrent nerve, branch leaves crowded, ovato-lanc., all concave with the margin entire and reflexed; the marginal cells long and narrow. Caps. oblongo- and elongatopyriform, sometimes unequal and ventricose, inclined or pendulous, fuscous, wide-mouthed when dry, lid large mammillar, rufous, glossy; teeth yellow, processes gaping, short and broad, cilia $2-3$ with long appendages. Male plants slender, with annual shoots.

$\mathrm{H}_{\mathrm{AB}}$. -Walls, rocks and dry banks, common. Fr. 5-6.

Var. $\beta$. Kunzei (Hornsch.).

Densely cæspitose, branches julaceous, leaves imbricated, broadly ovate, suddenly cuspidate with the longly excurrent nerve; caps. fuscescent.

Syn.-Bryum Kunzei Hornsch. in Flora ii, 90 (18I9). Brid. Bry. univ, i, 66r.

B. caspiticium Var. $\beta$. inlbricatum Schmp. Bry, eur. 7o, Synops. 368.

HAB. - Dry turf and walls.

Little Doward hill, Hereford (Rev. A. Ley I873)!

A common species, but variable in the form of the capsule, though exhibiting great uniformity in the silky green leaves.

\section{BRYUM ARGENTEUM $L$.}

Dioicous; in whitish-green silvery tufts, with slender julaceous branches. Leaves imbricated obovate, very concave, apiculate, nerve ceasing below apex. Caps. pendulous, oval-oblong, lid mammillats. (T. LXXII, C.)

Syn.-Muscus argentells capitulis reffcxis Ray Synops. 2 ed. 34, n. 5 (I6g6).

Bryum capitulis subrotundis reflcxis, cauliculis teretibus argenteis Dinc. Cat. Giss. 226 (17 I8), et in RAY Synops. 3 ed. 100 (1724).

Bryum pendulum julaceun argenteum et sericeum DicL. Hist. musc. 392, t. 50, fig. 62 (I74I), et Herbar.

Bryum argenteum L. Sp. Pl. II 20 (1753), Syst. Nat. ii, 700. HuDS. Fl. angl. 4I3 (1762). Weiss Cr. goett. I99 (1770). NECK. Meth. musc. 201 (1771). Wiтh. Bot. arr. br. veg. ii, 678 (I776). LightF. Fl. scot. ii, 735 (I777). WeB. Fl. goett. II2 (I778). HeDw. Fund. II, 94 (I782), Sp. Musc. I8I (I80r). Relh. Fl. cant. 406 (1785). RoTH. Fl. germ. i, 473 (1788). Sibrh. Fl, oxon. 293 (I794). CurT. Fl. Lond. fasc. 3 , t. 67. 
Swartz Musc. suec. 47 (I798). Abbot Fl. bedf. 243 (I798). Hull Br. fl. P. 2, 256 (I799). Fl. dan. t. 880. Smith F1. brit. I355 (1804), Eng. Bot. t. I602. Turn. Musc. hib. I22 (I804). BRID. Musc. rec. II, P. III, 26 (I803), Sp. musc. III, 20 (I8I7), Mant. ir8 (r819), Bry. univ. i, 657 (1826). Schultz Fl. Starg. 340 (1806). Voit Musc. herb. 85 (I8I2). Wahl. F1. lapp. 36I (I8I2). Schwaeg. Suppl. I, P. II, 88 (I8I6). Mart. F1. cr. erl. 57 (I8I7). Hook. Tayl. Musc. br. 126, t. 29 (18I8). Hartm. Skand. fl. Funck Moost. 46, t. 29 (I82I). Gray Nat. arr. br. pl. i, 769 (I82I)- Hook. Fl. Scot. P. 2, I50 (I82r), Br. Fl. ii, 60 (I833). Hueben. Musc. germ. 462 (I833). Mack. Fl. hib. P. 2, 3 I (I836). DE Not. Syll. II8 (I833), Epilogo 4Io (I859). Br. Sch. Bry. eur. fasc. 6-9, p. 78, t. 4 I (I839). Rabenh. Deutsch. kr. fl. ii, S. 3, 22 I (I848). C. Muell. Synops. i, 3 I 4 (1849). Wils. Bry. brit. 247 , t. 29 (I855). Schimp. Synops. 369 (I860), 2 ed. 448. Berk. Handb. br. m. 195 (1863). Milde Bry. siles. 2 I8 (1869). Hobk. Syn. I I9 (I873). Husn. Mouss. nord-ouest I 25 (I873), Musc. gall. 243 , t. 66 (I889). Juratz. Laubm. oest.-ung. 28 I (I882). LesQ. James Moss. N. Amer. 234 (1884). Boul. Musc. de Fr. i, 248 (1884).

Hypnum argenteum Schrank Baiers. fl. ii, 469 (I789). WeB. MoHr Bot. Tasch. 276 ( 1807$)$.

Mnium argenteum Hoffm. Deutsch. fl. ii, 5 I (I795). P. BeAuv. Prodr. 74 (I805).

Bryum Barnesii Schimp. Synops. 2 ed. 47 I (1876).

Dioicous; in irregular laxly cohering tufts, whitish-green, silvery and glossy when dry. Plants short, slender radiculose, with slender julaceous branches; leaves obovate, very concave, suddenly apiculate, laxly reticulate, comal oblong, gradually apiculate, the nerve vanishing above the middle, margin plane, quite entire. Caps. pendulous, on a seta arcuate at top, oblong, contracted below mouth when dry, rufous red, blackish when old, lid convex, scarcely apiculate, orange; teeth orange at base, yellowish above, incurved between the processes when dry. Male plant slender, perig. bracts broadly oval, apiculate.

HAB.-Waste ground, walls and rocks; common. Fr. Io-II.

Var. $\beta$. majus BR. Sch.

Taller, more densely matted, glaucous green; leaves submuticous, caps. scarce elevated above the branches.

SYn.--Bryum julaceum Schrad. Spic. fl. germ. 7o (I794). Brid. Bry. univ. i, 859, p.p.

Bryum argentenm Var. majus Br. Sch. Bry. eur. 79. C. Mueld. Synops, i, 3 I4. Wils. Bry. brit. 247 .

HaB.-In damp shady places.

Var. $\gamma$. lanatum (P. Beauv.).

Compactly tufted, branches shorter, snowy-white; leaves longly apiculate or prolonged into a flexuose hair void of chlorophyl, scariose and silvery white when dry.

Syn.-Mnium lanatum P. BEAuv. Prodr. 75 (1805).

Bryum lanatum BrID. Sp. Musc. III, 20; Mant. Ir8; Bry. univ. i, 659 .

Bryum argenteum Var. lanatum Br. ScH. Bry. eur. C. MUELl. Wilson.

НАв. - In warm stony places; rare. 
Hedge bank, Southport (Wild 1882)!! Mortar of a bridge near Kendal (Binstead I886)!!

This common moss varies very much according to locality, and when growing in wet shady places quite loses its silvery appearance. Brymm Barmesii Schimp. appears to be only a form starved by growth among sand.

\section{I9. BRYUM BICOLOR Dicks.}

Dioicous; stems short, branched, dull green. Leaves erectopatent or appressed, ovato-lanc. or ovate, concave, margin reflexed, nerve reaching point or slightly excurrent. Caps. oval, short, constricted below the lid. (T. LXXII, D.)

Syn.-Bryum pendulum, surculis teretibus viridibus Dill. Hist. musc. 394, t. 50, fig. 63, A, B, E, et fig. 66, A, F, G (I74I), et Herbar.

Bryum bicolor Dicks. Pl. crypt. fasc. 4, I6 (I80I). SM. Fl. brit. I355 (I804). TURN. Musc. hit. I2I, t. II, f. 2 (1804).

Bryum dichotomum HeDw. Sp. musc. I83, t. 42 (I $80 \mathrm{I}$ ). BRID. Musc. rec. II, P. III, 22 (I805), Mant. I I7 (I819), Bry. univ. i, 646 (I826). Mitr. Journ. Linn. Soc. Bot. xii, 3OI (I 869).

Mnium bicolor et $M$. dichotomum P. BEAuv. Prodr. 74 (1805).

Bryum atropurpureum WeB. MOHR Ind. mus. in WaHLend. Fl. lapp. 360 (I8I2). Hueben. Musc. germ. 449 (I833). De Not. Syllab. I20 (I838), Epilogo 399 (1869). Br. Sch. Bry. eur. fasc. 6-9, p. 73 , t. 37 (I839). Rabenh. Deutsch. kr. fl. ii, S. 3, 2 I 8 (I848). C. Muell. Synops. i, 306 (I849). Wils. Bry. br. 244, t. 50 (I855). Schimp. Synops. 364 (I860), 2 ed. 438 . BERK. Handb. br. m. I94 (1863). MilDE Bry. siles. 2 I 4 (I869). Husn. Mouss. nord-ouest I24 (I873), Musc. gall. 244, t. 66 (I889). JuRAtz. Laubm. oest.-ung. 272 (I882). LesQ. JAMES Moss. N. Amer. 232 (I884). Hoвk. Synops. 2 ed. I62 (I 884 ). Boul. Musc. de Fr. i, 249 (I884).

Bryum pulchellum $\beta$. atropurpureum Wahlenb. Fl. lapp. 360 (I8I2). Schwaeg. Suppl. I, P. II, 9 I (I8I6).

Bryum erythrocarpon (non Schwaeg.) BRID. Sp. Musc. III, I8 (I8I7), Mant. II8 (I8I9), Bry. univ. i, 654 (I 826 ). Wallr. Fl. cr. germ. i, 270 (I83I). HoBK. Syl!. Br. m. II8 (1873).

Bryum caspiticium Hook. TAYL. Musc. br. I2I, p.p. (1818).

Bryum carneum $\beta$. pusillum Schul tz Suppl. F1. starg. 84 (I8I9).

Bryum bulbillosum Mont. Ann. des sc. nat. 2 Ser. xvi, 268 (I84I). C. Mueli. Synops. i, 3OI (I849).

Dioicous; in dense light green patches, the stems branched, radiculose. Lower leaves small, distant, lanc., the upper crowded in a laxly imbricated coma, much larger, ovate-acuminate, concave, shortly apiculate with the excurrent nerve, margin entire, reflexed towards base, cells lax, rhombo-hexagonal, at base rectangular. Caps. on a short hexuose red seta, arcuate above, pendulous, from a swollen neck rugulose when dry, broadly oval, from reddish yellow, blood red, and finally black-purple, very slightly contracted below mouth when dry; lid large, wider than mouth of caps., convex, apiculate, blood red, shining, teeth 
reddish at base. Male plant more slender, infl. gemmaceous, bracts broadly ovate, acuminate.

HAB.-On banks, roadsides and walls, often with B. argenteum. Fr. 5 .

Globose axillary compound gemmæ are frequently seen on this plant. which is easily known by the abruptly ending base of capsule, though this is still more pronounced in the closely allied $B$. versicolor Braun. It varies considerably in size, and the leaves occasionally have the nerve vanishing below the point.

Var. $\beta$. gracilentum. Tayl. MSS.

Gemmiparous, taller and more slender. Leaves broader and more obtuse, the nerve vanishing below the apex.

HAB.-With the typical form. Not uncommon.

\section{BRYUM ERYTHROCARPON Schwaeg.}

Dioicous ; stems short, leaves ovato-lanc., erecto-patent, cuspidate with the shortly excurrent nerve, serrulate at apex. Caps. pendulous, oblong-pyriform, lid sharply pointed. (T. LXXII, E.)

Sys.-Bryum pendulum ovatum, caspiticium et pilosum, seta bicolori p.p. Dill. Hist. musc. 397 , t. 50 , fig. $66 \mathrm{E}$.

Bryum erythrocarpon Schwaeg. Suppl. I, P. II, Ioo, t, 70 (I8I6), excl. syn. Brid. Mart. Fl. cr. Erl. 58 (I8I7). Schultz Suppl. Fl. starg. 84 (I8Ig). Funck Moost. t. 29 (IS2I). Hueben. Musc. germ. 447 (I833). De Not. Syllab. I22 (I838), Epilogo 399 (I869). Br. Sch. Bry. eur. fasc. 6-9, p. 72, t. 36 (I839). Rabenh. Deutsch. cr. A. ii, S. 3, 2 IS (I 848 ). C. Muell. Synops. i, 297 (I 849 ). Schimp. Synops. 363 (1860), 2 ed. 436 Berk. Handb. br. m. I93 (I863). Milde Bry. siles. 2 I3 (I869). Husn. Mouss. nordouest I23 (I873), Musc. gall. 245, t. 66 (I889). JURATz. Laubm. oest.-ung. 27 I (IS82). Lesq. James Moss. N. Amer. 232 (I884). Hobk. Synops. 2 ed. I62 (IS84). Boul. Musc. de Fr. i, 250 (1884).

Bryum sanguineum BRID. Sp. musc. III, 28 (I $8 \mathrm{I} 7$ ), Mant. II 8 (I $8 \mathrm{I} 9$ ), Bry. univ, i, 67 I (r826). Wallr. Fl. cr. germ. i, 270 (1831). Wils. Bry. br. 243, t. 50 (I855). HobK. Syn. br. m. II8 (1873).

Dioicous; in short loose tufts, green with a reddish or brownish tinge. Stem slender, branched, radiculose at base, sometimes with red globose axillar gemmæ. Leaves crowded, erecto-patent, or remote and patent, straight or slightly recurved, somewhat rigid, lanc. or elongatelanc., shortly mucronate with the excurrent nerve, margin reflexed below, serrulate at apex, without any border; nerve red, vanishing below or at the point or excurrent, cells rather large, hexagonal. Caps. pendulous on a long red seta arched at top, oblongo- and obconicpyriform, brown or deep red; annulus broad, lid large, convex-conic, 
sharp-pointed purple, shining; teeth pale ferruginous, endostome pale, with $2-3$ cilia. Male plant more slender, infl. terminal, thick and gemmiform, internal bracts broadly obovate, cuspidate.

HAB.-Gravelly and sandy heaths and on walls. Fr. 6-7.

This species is closely allied to $B$. bicolor Dicks., but the fruit is larger and more tapering into the seta, and the leaves more attenuated at points. The seta varies considerably in length, and the capsule in colour from a light rusty brown to the deepest purple red.

\section{I. BRYUM MURALE Wils.}

Dioicous; densely tufted, leaves shorter lanceolate, with small narrow cells, entire, nerve excurrent in a long point. Caps. pendulous, pyriform with a tapering neck, and large obtuse lid. (T. LXXII, F.)

Syn.-Bryum erythrocarpum Var. $\beta$. murorum Schimp. Synops. 363 (1860).

Bryum murale Wils. Mss. Milde Bry. siles. 2 I3 (I869). HobK. Synops. II8 (1873). Schimp. Synops. 2 ed. 437 (I 876 ). JuRATz. Laubm. oest.-ung. 27 I (1882). Boul. Musc. de Fr. i, 25 I (I884). Husn. Musc. gall. 244, t. 66 (I889).

Dioicous; in dense pulvinate cæspitose tufts, green above, brownish green when old, interwoven with dense tomentum ; stem short, fastigiatebranched. Leaves erecto-patent, when dry imbricated, rather rigid, the upper crowded into a gemmiform coma, lower comal longish lanc., inner from a broad base, lanceolate, lower crowded, shorter, not limbate, a little reflexed at margin, entire at apex, all longly cuspidate with the excurrent rufous nerve; cells smaller and more linear than in $B$. erythrocarpon, rhomboid-hexagonal, at base rectangular. Caps. on a dark purple seta arched at top, pendulous, with the neck clavatopyriform, regular or slightly arched, blood-red, blackish by age; lid large, almost hemisplierical, obtuse or with a very small apiculus, purple, shining, annulus broad; teeth large, endostome yellowish, the processes perforated, cilia with long appendages. Male infl. comant, the bracts like the leaves.

HAB.-On mortar of walls and stony ground, not uncommon. Fr. 5-6.

Tyfry, N. Wales (Wilson 1856) !! Oxford, Bangor and Aber (Boszell 1863)!! Moffat (Howie I863)! Beddgelert (Holmes I876)!! Tremode, I. of Man (Holt I884)!! Warminster, Somerset (Binstead I887)!! Castlethorpe, Bucks. (H. N. Dixon I89o)!!

Intermediate between $B$. erythrocarpon and $B$. bicolor, resembling the former in the shape of the capsule, and the latter in the leaves, the cells of which are denser than in either, the obtuse lid is also a marked feature. 


\section{BRYUM RUBENS Mitten.}

Dioicous; leaves ovate acuminate, narrowly limbate, faintly serrate at apex, nerve excurrent. Caps. as in B. crythrocarpon. (T. LXXIII, A.)

Sys.-Bryum radiculosum BrID. Sp. musc. III, I8 (I8I7), Mant. II8 (I8I9), Bry. univ. i, 655 (I826) ?

Bryum vubens Mitr. in Lond. Journ. of Bot. 1856, p. 232. Journ. Linn. Soc. i, Suppl. 69 (1859).

Bryun erythrocarpon $\beta$. sylvaticum HAMPE Exsicc. n. 20 r.

Bryum erythrocarpon Var. limbatum Berthoumieu Rev. bryol. 1883, p. 67.

Dioicous; stems short, in rather loose tufts, rufous at base. Leaves dull yellowish green, ovato-elliptic, acuminate, faintly serrate at apex or entire, margin plane with a narrow yellowish limb of $3-5$ rows of extremely narrow linear cells, the rest being firm, hexagonal with thin walls, the basal hexagono-rectangular; nerve reddish, excurrent in an apiculus; perich. bracts smaller than the leaves, narrower, with a more distinct border. Seta red, variable in length; caps. cernuous, clavateoblong, rusty red, lid large, brighter red, shining, shortly conical with an acute apiculus; teeth of peristome small, attenuated in the upper half. Male plants short, the infl. terminal.

HAB.-On the ground, not common.

Hurstpierpoint and Maresfield, Sussex (Mitten I849)!!

This moss appears to be specifically distinct by its bordered leaves, though coming near to $B$. evythrocarpon, in fact $B$. bicolor, orythrocarpon, vubens, muvale and marginatum form a very closely allied group, which may be connected by intermediate forms. The present species may belong to $B$. vadiculosum of Bridel, but it must remain doubtful as he does not describe the border to the leaf. The leaf-cells are wider than in B. erythrocarpon, and according to Mr. Mitten it is found in central Europe, N. Asia and N. America.

\section{BRYUM MILDEI furatz.}

Dioicous; in dense pulvinate tufts. Leaves imbricated, erectopatent, ovato-lanc. acute, entire, revolute at margin, nerve excurrent in an apiculus. Caps. pendulous, obovate. (T. LXXIII, B.)

Syn. Brymm aficulatum (non Schwaeg.) Wils. Bry. br. 245, t. 50 (I855).

Bryum Mildcammm Juratz. Verh. z.-b. Gesells. Wien I862, 1. 967, et in Bot. Zeit. I864, III, n. 5. Laubm, oester.-ung. 275 (I882). MILDE Bry. siles. 216 (IS69). DE Not. Epilogo 402 (1869). Sciimp. Synops. 2 ed. 446 (I876). Boul. Musc. de Irs. $i_{\text {, }}$ 254 (1884). HUSN. Musc. gall. 246, t. 66 (I889,. 
Dioicous; densely pulvinato-cæspitose, yellorv-green above with a silky gloss, dark brown at base with some rufous radicles. Stems $\frac{1}{2}$ - I in. high, dense leaved, with slender branches. Leaves erect and imbricated when dry, erecto-patent when moist, sometimes red at base, elliptic or ovato-lanc., gradually pointed, carinate-concave, margin revolute to apex, entire, or with a few irregular teeth at point, nerve rufescent at base, strong, excurrent in a short point, areolation dense, narrowly hexagonal is bove, narrower at margin, quadrato-hexagonal at base. Caps. on a rufous-purple seta, inclined or pendulous, obovateoblong narrowed into a slightly incurved neck, rufescent, finally castaneous, scarce contracted below the mouth when dry; lid convexconic, mammillar, shortly apiculate, rufous, shining. Teeth of per. lanceolate yellow, processes of endostome perforated, with $2-3$ cilia.

$\mathrm{H}_{\mathrm{AB}}$. - Wet rocks and by waterfalls. Fr. 7-8.

Holwick Scarr and Maizebeck, Teesdale (Spruce 1843)!! Slemish mountain, Antrim, Ireland (Moore)! Kilrock Quarry, Howth $(O r r)$. Baie de Gouffe, Guernsey (Cardot I885)! ! all sterile.

This moss in habit and colour closely resemble $B$. caspiticium, and it also comes near $B$. Funckii Scrwaeg. The Teesdale specimens are densely tufted and have shorter leaves than the type, while Moore's specimens are laxer with a laxer areolation, probably due to a greater amount of moisture at its place of growtli.

\section{BRYUM MUEHLENBECKII Br. Sch.}

Dioicous ; in loose olivaceous-green tufts, dichotomously branched. Leaves erecto-patent, imbricated, elliptic-oblong rather obtuse, incurved at point, revolute at margin, nerve vanishing. Caps. pendulous; oblong, ferruginous. (T. LXXIII, C.)

Syn.-Bryum alpinum Var. brevifolium Myrin Cor. Fl. ups. 68 (1833).

Bryum Muohlenbeckii Br. Sch. Bry. eur. fasc. 32, Suppl. t. I3 (1846). Rabenh. Deutsch. kr. fl. ii, S. 3, 220 (1848). C. Muell. Synops. i, 286 (1849). Wils. Bry. br. 231, t. 48 (I855). Schimp. Synops. 366 (I860), 2 ed. 44I. BERK. Handb. br. m. I94 (I863). MILDE Bry. siles. 216 (I869). DE Not. Epilogo 405 (1869). HoBk. Syn. br. m. II3 (I873). JuRatz. Laubm. oest.-ung. 277 (I882). Lesq. James Moss. N. Amer. 233 (1884). Boul. Musc. de Fr. i, 253 (I884). Husn. Musc. gall. 247, t. 67 (1889).

Bryum Raui Austin in Coult. Bot. Gaz. ii, Iro.

Dioicous; in laxly cohering olivaceous-green opake tufts. Stems repeatedly dichotomous, fastigiate, radiculose at base, flaccid. Leaves densely crowded, imbricated, erect, lower ovate, upper elliptic-oblong, parabolicly pointed, with the apex obtuse incurved and somewhat cucullate, all carinate-concave, entire, margin revolute, nerve rufous, vanishing at apex, cells much laxer than in B. alpimum. Seta red, erect, 
hooked at apex; caps. from a slender neck, elongato-pyriform, rufescent or fuscous, not constricted at mouth; lid hemispherical, mucronate, glossy, teeth of per. yellowish, lanceolate, processes of end, lanceolate, attenuate, gaping at the keel, cilia in pairs, appendiculate.

HAB.-Wet mountain rocks; rare. Fr. 7-8.

Devonshire (Herb. Hooker). Ben Nevis (Stirton I866)! Sleddale Forest, Westmoreland, on a wet rock (Binstead I886)!!

Closely resembling B. alpimum, but differing in the dull olivaceous colour, and broader, more concave and more obtuse leaves incurved at point. All the British specimens are sterile.

\section{BRYUM ALPINUM Huds.}

Dioicous; in dense glossy purple tufts, the stems but little branched. Leaves imbricated, straight, lanceolate, recurved at margin, nerve reaching point or excurrent. Caps. pendulous, oblong-pyriform, dark red, constricted below mouth. (T. LXXIII, D.)

Syn.-Bryum hypnoides pendulum sericeum, coma insigni atro-rubente Dill. Hist. Musc. 394, t. 50, f. $64, \mathrm{~A}-\mathrm{C}$ (I74I), et Herbar.

Bryum alpinum Huds. Fl. angl. 4I5 (I762). L. Mant. ii, 309 (I767), Syst. Veg. 949. WrTh. Bot. arr. br. Veg. ii, 679 (I776). Lightf. F1. scot. ii, 738 (1777). SivarTz Musc. suec. 47 (I798). Hull Br. fl. P. 2, 254 (I799). BRID. Musc. rec. II, P. III, 30 (I803), Sp. musc. III, 23 (I8I7), Mant. I 8 (I8I9), Bry. univ. i, 663 (I826). Sm. F1. brit. I353 (1804), Eng. Bot. t. I623. TuRn. Musc. hib. I25 (I804). Wahlen. F1. lapp. 360 (I8I2). Roenl. Deutsch. fl. iii, 9 I (I8I3). Schwaeg. Suppl. I, P. II. 98, t. 73 (I8I6). Hook. Tayl. Musc. br. I24, t. 28 (I8I8). Hartm. Skand. f. Hook. Fl. Scot. P. 2, I5 I (I82I), Br. fl. ii, 62 (I833). FUNCK Moost. 47, t. 30 (I82I). GRAY Nat. arr. br. pl. i, 77 I (I82I). HuEBEN. Musc. germ. 450 (I833). DE Not. Syllab. I 28 (I838), Epilogo 404 (1869). BR. Sch. Bry. eur. fasc. 6-9, p. 76, t. 39 (I839). Ramenh. Deutsch. kr. fl. ii, S. 3, 220 (I848). C. Muell. Synops. i, 285 (I849). Wils. Bry. br. 23 I, t. 28 (1855). ScHimp. Synops. 366 (1860), 2 ed. 440. Berk. Handb. br. m. I94 (1863). Milde Bry. siles. 2 I $_{5}$ (I869). HoBk. Syn. br. m. II3 (I873). Husn. Mouss. nord-ouest I24 (I873), Musc. gall. 246, t. 67 (I889). Juratz. Laubm. oest.-ung. 276 (1882). Leso. James Moss. N. Amer. 233 (I884). Boul. Musc. de Fr. i, 252 (I884).

Mnium alpinum Swartz Meth. musc. 366 (I787). P. Beauv. Prodr. 73 (I805).

Dioicous; in dense tufts or expanded patches, purple, chocolate coloured or brownish green, shining with a golden-green gloss. Stems erect or decumbent at base, slightly radiculose below, rigid, simple or branched, uniformly dense-leaved. Leaves erecto-patent, straight, imbricated when dry, lanc. and oblong-lanc., more or less acute, carinate, entire or obsoletely serrate at apex, margin reflexed, nerve strong, purple, ending at point or excurrent in a short mucro, cells more elongated linear and incrassate. Seta arcuate above, caps. pendulous, coriaceous, obovate-oblong and obconic-pyriform, with a longish neck, crimson, blackish purple when old, slightly contracted below the mouth when dry; lid inammillar, shining; teeth of per. pale ferruginous, endostome yellow, cilia $3-4$, appendiculate.

HAB.-Moist alpine rocks; not uncommon. Fr. 6-7. 
Var. $\beta$. meridionale (Schimp.)

Leaves very rigid, narrower, more densely areolate; upper cells linearhexagonal, lower longish hexagono-rectangular.

Syn.-Schimp. Synops. 2 ed. 44 I.

HAB.--On rocks by the sea. Penzance (Cumow I862)!! Near Robin Hood's Bay, Yorks. (Slater I 888)!!

Few mosses surpass Bryum alpimum in beauty when growing in a congenial locality, the blood-red capsules and claret coloured foliage with a golden metallic-like lustre cannot be surpassed.

\section{BRYUM GEMMIPARUM De Not.}

Dioicous; in densely matted dingy green tufts. Leaves densely imbricated, very concave, ovate, obtuse at point, marginal cells long and narrow. Caps. as in B. alpimum. (T. LXXIII, D. .)

Syn.-Bryum alpinum $\beta$. mediterraneum DE Nor. Syllab. I29 (I838).

Bryum gemmiparum DE Not. Cronaca briol, ital. in Comm. II, 25 (I866), Epilogo 406 (I869). Schimp. Syllops. 2 ed. 442 (I876). Juratz. Laubm, oester.-ung. 277 (I882).

Hobk. Synops. 2 ed. I63 (1884). Limpr, in Rabenh. D. kr. n. Laubm. ii, 397 (1893).

Bryın muticum Lange Tosk. mossor, in Bot. Tidsk. Kjöbenh. (ז868).

Bryum alpinum forma ovata gemmpara Boul. Musc. de Fr. i, 253 (I884).

Bryum alpinum Var. gemmiparum HusN. Musc. gall. 247 (I889).

Dioicous ; in dense light brownish-green tufts, matted at base with rufous tomentum and coated with earth. Young shoots green, I-3 given off below the apex of stem, often with bulbiform gemmæ in axils of upper leaves. Leaves dense, imbricated when dry, erecto-patent when moist, lower ovate, acuminate, upper ovato-elliptic, very concave, entire, narrowed into a bluntish point, margin recurved in the lower half, nerve yellowish, ending in the apex or just below it; cells chlorophyllose, rhomboid-hexagonal, rather laxer at base, quadrate at angles, gradually longer and narrower at margin so as almost to form a limb. Caps. ovato- or oblongo-pyriform, reddish brown, inclined or pendulous, lid convex shortly apiculate, teeth yellowish, processes pale, gaping. Male plants intermixed, innermost bracts nerveless.

НАв.-Wet rocks in limestone districts of South Europe. Fr. 4-5.

Rocks by R. Usk near Senny bridge, Monmouth (Boswell and Ley I883)!! and in R. Grwyne, Brecon (Rev. A. Ley I89o)!!

I find this is nearer $B$. Muehlenbeckii than $B$. alpimum to which I had referred it. It differs in the young shoots being green, the leaves thinner, soft, 
not decurrent, with blunt points, thinner nerve and long narrow marginal cells. The fruit is very rare and our plants are quite sterile; it is essentially a plant of the Mediterranean region.

\section{BRYUM PALLENS Swavtz.}

Dioicous ; in brownish green or reddish tufts. Leaves lax, ovateacuminate decurrent, narrowly limbate, nerve slightly excurrent. Caps. long-necked pyriform, slightly incurved, pale brown. (T. LXXIII, E.)

SYN.-Bryum nitidum, foliis serpilli angustioribus, minus DrLl. Cat. Giss. 228 (1718).

Bryum annotinum lanceolatum pellucidum, capsulis oblongis pendulis. DILL. Hist. musc. 399, t. 5o, f. 68 (I74I) et Herb.

Bryum pallens Swartz Musc. suec. 47 et 98 , t. 4, f. I2 (I 799). RoeHL. Deutsch. fl. iii, 96 (I8I3). Schwaeg. Suppl. I, P. II, i I I, t. 72 (I8I6). Brid. Sp. musc. III, 9 (I8I7), Mant. II7 (I8I9), Bryol. univ. i, 642 (I826). Funck Moostasch. 49, t. 3 I (I82I). Hueben. Musc. germ. 440 (I833). Br. Sch. Bry. eur. Fasc. 6-9, p. 68, t. 33 (1839). Rabenh. D. kr. fl. ii, S. 3 , 215 (I848). C. Muell. Synops. i, 256 (I849). Wils. Bry. br. 233, t. 29 (I 855 ). Schimp. Synops. 376 (I860), 2 ed. 456. BERK. Handb. br. m. Ig8 (1863). De Not. Epilogo 382 (1869). Milde Bry. siles. 220 (I869). Hobk. Syn. br. m. I 4 (I873). Husn. Mouss. nord-ouest i26 (I873), Musc. gall. 25 I, t. 68. Juratz. Laubm. oest.-ung. 286 (I882). Boul. Musc. de Fr. i, 260 (I884). Lesq. James Moss. N. Amer. 237 (I884). Limpr. in Raben. D. kr. fl. Laubm. ii, 433 (1893).

Pohlia pallens Brid. Musc. rec. II, P. III, I45 (I803).

Hypun pallens WEB. MоHR Bot. Tasch. 286 (1807).

Bryum turbinatum Нook. TAYL. Musc. br. I22, t. 29 (1818).

Bryum attenuatum BRID. Bry. univ. i, 638 (1826).

Ptychostomum cernum HuEBen. Musc. germ. 493 (1833).

Bryum origanum Bosw. in Naturalist I879 p. 33. Hовк. Synops. 2 ed. I66 (I884).

Dioicous; in soft lax or dense tufts, dingy olive-green, winecoloured or rosy purple, dark brown at base. Stems short, with a ferv innovations at summit. Leaves erecto-patent, lower remote ovatolanc., decurrent, upper crowded, oblong and elongate, acuminate, all with a narrow brownish limb, of $2-3$ rows of incrassate cells; margin entire, plane above, revolute in lower half; cells lax, rhombohexagonal, at base hexagono-rectangular, nerve strong, reddish, ending at apex or shortly excurrent. Caps. on a long brownish-red seta, horizontal or inclined, cinereous or yellowish, castaneous when old, pyriform with a long somewhat incurved neck, scarcely contracted below the mouth; lid rather large, apiculate, yellow shining. Peristome yellow, densely articulated, endostome paler, when dry projecting between the teeth. Male plant more slender, infl. gemmiform, the bracts lanceolate, divergent.

HaB.-Rocks and stones by streams and wet ground. Fr. 6.

Var. $\beta$. speciosum (Voit) Schimp. 
Taller; caps. larger, inclined, on a longer seta; lid smaller.

Syn.-Bryum speciosum VoIt in StURm Deutsch. Fl. II, Pt. I4 (1813).

Bryum pallens' $\beta$. nicrostomum Bry. eur. fasc. 6-9, p. 69 (1839).

Bryum pallens $\beta$. speciosum Schimp. Synops. 377 .

HAB.-Wet hollows in mountains. Midhill near Killin (Holt 1880)!! Ben

More, Loch Lomond (Hunt I 865)!

A very variable species, readily known by its red tint, pale long-necked caps., not contracted below the narrow mouth, blackish brown when old. It differs from $B$. cernum by the red colour and larger lid as well as the endostome.

\section{BRYUM DUVALII Voit.}

Dioicous; in lax soft tufts. Leaves distant, ovato-lanc., longly decurrent, patulous, entire, nerve vanishing below apex. Caps. pendulous, obovate with a long neck, strongly contracted below mouth. (T. LXXIII, F.)

Syn.-Bryum Duvalii VoIt in Sturm Deutschl. Fl. II, I2 (I8I I). BRID. Mant. II8 (I8I9), Bry. univ. i, 679 (I 826). Hueben. Musc. germ. 436 (I833). BR. ScH. Bry. eur. fasc. 6-9, p. 64, t. 3I (1839). Rabeni. D. kr. A. ii, S. 3, 2 I6 (1848). C. Muell. Synops. i, 260 (I848). Schimp. Synops. 379 (I860), 2 ed. 458 . DE Not. Epil. $37^{8}$ (I869). MILde Bry. siles. 220 (I869). HoBK. Synops. I I4 (I873). JURATz. Laubm. oest.-ung. 288 (1882). Boulay Musc. Fr. i, 257 (1884). LesQ. James Moss. N. Amer. 238 (I884). Husn. Musc. gall. 250, t. 68 '(1889). Limpr. in Raben. D. kr. fl. Laubm. ii, 429 (r893).

Mnium Duvalii Schwaeg. Suppl. I, P. II, I26, t. 79 (I8I6). BRID. Sp. musc. III, 59 (I817). Funck Moost. 50, t. 32 (I821).

Bryum ventricosum Var. SchwaEG. Sp. musc. 54 (1830).

Dioicous; in large, soft lax tufts, pale green or tinged with purple. Stems elongated, with long slender innovations. Leaves distant, patulous, broadly ovato-lanc., strongly decurrent, nearly plane, quite entire, the nerve vanishing below the short point; when dry strongly contracted and incurved, dingy green, cells lax rhombo-hexagonal above, elongato-rectangular at base, the two marginal rows very narrow and somewhat incrassate so as to form a faint border. Caps. on a long slender red seta, pendulous, obovate-oblong with a long neck, ferruginous or fuscous, strongly contracted below the mouth; lid mamillar, of the same colour; peristome pale yellow. Male infl. subdiscoid.

HAB.-Wet moorlands and by streams on mountains. Fr. 8.

Ben Lawers (W. Bell 1860$)$ !! Clova (Forgusson). Braemar (Whitehead I875)!! Ben More (Stirton). Glas Meal (Hunt). Hartfell and Helvellyn. Howgill Fells, Yorks. (Binstead I886)!! Dollywaggon Pike, Westmoreland (Binstead 1885) Stromness (Stirton).

A very striking moss by its dingy curling leaves, strongly decurrent and distant from each other; it very seldom bears fruit, and has not been found fertile here. 
29. BRYUM TURBINATUM (Hedw.) Schwaeg.

Dioicous; in dingy green tufts. Leaves erecto-patent, ovate, acuminate, faintly limbate, nerve excurrent, rufous. Caps. pendulous, stoutly pyriform, ferruginous, constricted below the dilated mouth. (T. LXXIV, A.)

Syn.-Bryum palustre complieatum rubens, capsulis turbinatis pendulis DiLl. Hist. musc. 406, t. 52, fig. 75 (I 74I) et Herbar.

Mnium turbinatum HEDW. Musc. frond. iii, 22, t. 8 ( $\mathrm{I} 792$ ), Sp. musc. I9o (I80I). HofFM. Deutsch. fl. ii, 49 (I796). BRID. Musc. rec. II, P. III, 95 (I803), Sp. musc. III, 6 I (1817). RoenL. Deutsch. fl. iii, 94 (1813).

Hypuum turbinatum WeB. MOHR Bot. Tasch. 282 (1807).

Brym turbinatum Schwaeg. Suppl. I, p. II, IOg (18I6). BRID. Bryol. univ. i, 68I (I826), excl. syn. HuEBen. Musc. germ. 439 (1833). BR. Sch. Bry. eur. fasc. 6-9, p. 65, t. 32 (1839). C. Muell. Synops. i, 259 (I849). Wils. Bry. br. 232, t. 48 (18 85 ). Schimp. Synops. 380 (I860), 2 ed. 46I. BERK. Handb. br. m. I98 (1863). MildE Bry. siles. 22 I (1 869). De Not. Epilogo 379 (1869). HoBk. Syn. br. m. II3 (1873). JuRATz. Laubm. oest.-ung. 29I (1882). Boul. Musc. Fr. 258 (1884). LesQ. James Moss. N. Amer. 238 (I884). Husn. Musc. gall. 25I, t. 69 (I889). Limpr. in RABEN. D. kr. fl. Laubm. ii, $436(1893)$.

Dioicous; in low dense tufts, dull green or with a rufescent tint, fuscous and tomentose at base, the sterile shoots often elongated. Leaves erecto-patent, the lower small, ovate shortly acuminate, upper comant, gradually larger, not decurrent at base, oblong-lanceolate, carinate, acute, narrowly limbate with $2-3$ rows of very narrow cells, margin reflexed nearly to base, obsoletely serrate at apex; nerve strong rufescent, excurrent in a mucro ; cells lax rhombic-hexagonal, rectangular at base. Caps. pendulous with an obconic neck long as sporangium, regular, stoutly pyriform, ferruginous, strongly contracted below the wide mouth when dry, turbinate; lid convex, apiculate, same colour as caps.; teeth long and yellow, cilia of endostome with long appendages, papillose. Male plants in separate tufts or intermixed, slender, simple, infl. subdiscoid, bracts broadly lanc., innermost rounded, nerveless.

HAB.-Wet sandy and gravelly places, rare. Fr. 6-7.

Scarwheel by the Irwell, Broughton, near Manchester. Fakenham, Norfolk (G. Fitt I 849$)$ ! Gravel pit at Ashton-under-Lyne (Whitehead and Seholefield i 865$) ! !$ Marple, Cheshire (Whitehead). Clifton, Manchester (Wild $\mathrm{I} 877) ! !$ Albourne, Sussex (Mitten). Shotover, Oxon. (Boswell r885)!! Rocks in the Grwyne, Hereford and Brecon (A "lg. Ley r8go)!!

\section{Var. $\beta$. latifolium (Schleich.)}

Plants $2-5$ in. high, nearly simple, in loose turgid yellowish-green tufts. Leaves large, broadly ovate, rounded-obtuse, very concave, somewhat cucullate; nerve lost in the apex, or excurrent. 
Syn.-Mnium latifolinm Schleich. Catal. (1807). SchwaEg. Suppl. I, P. II, I38 (1816).

Bryum latifolinm BRID. Mant. I20 (1819). HoBk. Syn. br. m. II3 (1873).

Bryum turbinatiom $\gamma$. latifolium BR. Sch. Bry. eur. 1. c. t. $32 \gamma$. Schimp. Synops. 380.

Bryum Schleicheri Var. $\gamma$. latifolinm Schimp. Syn. 2 ed. 463 (1876). Hoвk. Synops. 2 ed. I67 (1884). Limpr. in Raben. D. kr. fl. Laubm. ii, 439.

HAB.-About alpine springs and streams.

Touch moor, Stirling (Croall I877)!! Ben More. Ben Lawers (Boswell). Shetland (McKinlay). Ben Laoigh (Ering).

This moss is very variable, and resembles the equally variable $B$. pallens, but differs in the shorter regular capsule strongly contracted below the mouth. The Var. $\beta$. by its large size has quite a different appearance, but it agrees entirely with the type in structure, and presents numerous forms intermediate between the two; it corresponds closely to Var. glacialis of Pohlia albicans.

\section{BRYUM VENTRICOSUM Dicks.}

Dioicous; in loosely matted tufts. Stems tall, robust, sparingly branched. Leaves erecto-patent, subdecurrent, longish-lanc., pointed, narrowly limbate, margin recurved, entire or subserrulate at apex, nerve reaching apex or excurrent. Caps. subcylindric, regular or somewhat ventricose on the under side; lid mammillate. (T. LXXIV, B.)

Syn.-Bryum nitidum, foliis serpylli angustioribus, majus Dill. Cat. Giss. 228 (1718).

Hypnum palustre crectum breve, foliis brcvibus, tcnuibus angustis, minus confertis DiLL. op. c. 220.

Brynm annotinum palustre, capsulis ventricosis pendulis DILL. Hist. musc. 404, t. $5 \mathrm{I}$, fig. 72 (I74I) et Herbar.

Bryum lanceolatum binum, setis et capsulis longis pondulis DILL. Hist. musc. 405, t. $5^{\text {I }}$, fig. 73, A-B, et Herbar.

Bryum triquetrum HuDs. Fl. angl. 416 (I762).

Bryum ventricosum Dicks. Fasc, crypt. I, 4 (I785). Swartz Musc. suec. 49 (I798). Hook. Tayl. Musc. brit. I24, t. 3o, p.p. (I8I8). Gray Nat. arr. br.pl. i, 77 I (I82I). HоoK. Fl. scot. I5 I (I82I), Br. Al. ii, 62 (I833). MAск. Fl. hibern. P. 2, 33 (I836). DE Not. Syllab. I27, p.p. (1838).

Brrum cubitale Dicks. Fasc. crypt. II, 9, t. 5, f. 2 (I790). Sm. F1. brit. 1368 (1804). Eng. Bot. t. 1518.

Mnium pseudotriquetrum HEDw. Musc. frond. iii, 19, t. 7, p.p. (1792), Sp. musc. rgo (I80 I). With. Bot. arr. 3 ed. iii, 809 (I796). Brid. Musc. rec. II, P. III, gi (I803); Sp. musc. III, 57 (I8I7). SchulTz Fl. starg. 344 (I806).

Hypum pseudotriquetrum WeB. MoHR Bot. Tasch. 288 (I 807 ).

Bryum pseudotriquctrum Schwaeg. Suppl. I, P. II, I Io, excl. B. bimm (โ816). Brid. Mant. II8 (I8I9); Bry. univ. i, 676 (I826). Hueben. Musc. germ. 433 (I833). Br. Sch. Bry. eur. fasc. 6-9, p. 54, t. 24 (I839). Rabenh. Deutsch. kr. fi. ii, s. 3, 2 I 4 (I848). C. Muell. Synops. i, 258 (1849). Wils. Bryol. brit. 230, t. 30 (1855). Schimp. Synops. 375 (I860), 2 ed. 459. Berk. Handb. Br. m. I97 (I863). Milde Bry. siles. 219 (1869). DE Not. Epilogo 390 (I869). HoBk. Syn. br. m. II2 (1873). HuSN. Mouss. nord-oulest I 25 (I873) ; Musc. gall. 249, t. 68 (I889). Juratz. Laubm. oester.-ung. 289 (1882). Boul. Musc. de France 260 (1884). LEsq. James Moss. N. Amer. 238 (1884). Limpr. in Rabenh. Kr. fl. Laubm. ii, 440 (1893).

Bryum subobliquum LINDGR. Bot. Not. I842, p. I8. 
Dioicous; in dense olivaceous green tufts, interwoven with brown tomentum. Stems erect, 2-6 in. high, red, rigid, slightly branched. Leaves accrescent upward, comant, erecto-patent, decurrent at base, oblong-lanc., gradually apiculate, slightly serrulate at point, nerve strong, rufous, prolonged into the point ; margin reflexed, with a yellow limb of $3-5$ rows of narrow cells, upper cells incrassate, rhombo. hexagonal, basal red, rectangular. Capsule on a long purple seta, pendulous, ferruginous, elongate-obconic, often slightly curved upward and subventricose beneath, constricted below the mouth when dry; lid of the same colour, mamillar, glossy; peristome pale red. Male infl. subdiscoid-gemmiform, the bracts broadly ovato-cordate, acuminate, nerved.

HAB.-Moorland bogs and wet rocks by streams, not uncommon. Fr. 6-7.

Var. $\beta$. compactum Br. Sch. Bry. eur. 1. c.

Stems short, compactly tufted. Capsule shorter, obovate, with a more pointed lid.

НАв.—On the higher mountains. Southport (Whitehead I863)!

This moss often grows in large patches, and when loaded with fruit has a very beautiful appearance. On moorland banks where water is always trickling down, it may generally be found in perfection, and is a more robust plant than $B$. bimum, from which it is best distinguished by the dioicous inflorescence and more or less ventricose capsule.

\section{BRYUM NEODAMENSE Itzigs.}

Dioicous; in lax brownish green tufts. Leaves lax, remote, upper obovate-oblong, somewhat cucullate, limbate, nerved to apex. Caps. pendulous, obovate, constricted below mouth. (T. LXXIV, C.)

Syn.-Bryun ncodanense ITZ1GSoHn in Flora 184 I, I, p. 360 . C. Muell. Synops. i, 258 (I848). Hoвk. Synops. iा 2 (1873). Schimp. Synops. 2 ed. 460 (I876). JuRATz. Laubm. oest.-ung. 290 (I 882 ). Boul. Musc. Fr. i, 260 (1884). HusN. Musc. gall. 250, t. 68 (I889). Limpr. in Rabenh. D. kr. fl. Laubm. ii, 427 (1893).

Bryum pscudotriquctrum $\delta$ cavifolium Schimp. Coroll. $7^{6}$ (1856), Synops. $37^{6}$ ( 1860 ). Milde Bry. siles. 219 (1869).

Bryum cavifolium WILS. MSS.

Dioicous; in tall lax brownish green tufts, interwoven with brown radicles. Stems slender, lax-leaved, red, dense leaved at apex. Lower leaves small, distant, ovate, obtuse, the nerve ending below apex, upper comant, larger, patent, decurrent, obovate and elliptic-oblong, very 
concave, twisted when dry, nerved nearly to apex, or in the uppermost excurrent in a point; margin erect entire, limbate with $3-6$ rows of narrow yellowish cells, upper leaf cells rhombo-hexagonal, basal rectangular. Caps. on a long seta, pendulous, brown, obovato-obconic, the neck shorter than sporangium, constricted below the mouth when dry, lid shortly apiculate. Male plant as in B. ventricosum.

HАв.-Wet heaths near the sea; rare. Fr. 7.

South sands at Southport (Dr. Wood 1859$) ! !$ Sands of Barrie, Dundee (Rev. F.Fergusson I87 I) !

This moss, if not a very elegant one, has quite a distinct habit not much like that of $B$. ventricosim, and may easily be recognised by its broad obtuse entire leaves. The fruit is very rare and has only once been found in England.

\section{BRYOM CYCLOPHYLLUM (Schwagg.) Br. Sch.}

Dioicous; in soft bright green tufts. Leaves distant, broadly obovate, entire, concave, obtuse, nerve vanishing below apex. Caps. pendulous shortly pyriform, lid large, yellow. (T. LXXV, D.)

Syn.-Mnium cyclophyllım Schwaeg. Suppl. II, P. II, I6o, t. I94 (I827). Hueben. Musc. germ. 422 (1833).

Bryum tortifolium Brid. Bry. univ. i, Suppl. 844 (1827).

Bryum cyclophyllum Br. Sch. Bry. eur. fasc. 6-9, 63, t. 30 (1839). RABENH. Deutsch. kr. fl. ii, S. 3, 216 (1848). C. Muell. Synops. i, 287 (I848). Schimp. Synops. 377 (I860), 2 ed. 455. Milde Bry. siles. 220 (1869). Boulay Musc. Fr. 247 (I884). (I860), 2 ed. 455. Milde in RABENh. D. kr. fl. Laubm. ii, 425 (1893).

Dioicous; in soft lax.bright green tufts, blackish at base. Stems short and slender with few branches. Cauline leaves remote, narrowed at base, broadly obovate, comal larger, few, broadly oblong, all concave, obtuse, quite entire, curled when dry, nerve vanishing below apex, cells lax, soft, rhombic-hexagonal, indistinctly limbate by $\mathrm{I}-2$ rows of long narrow ones. Caps. pendulous, shortly pyriform, leptodermous, pale ferruginous, wide-mouthed, strongly contracted below it when dry; lid large, mamillar, yellow, glossy; teeth ferruginous at base, incurved when dry. Male plant in distinct tufts, the infl. 3-4 gemmiform, among the comal leaves.

HAB.-Mud of dried up pools on peat-moors; rare. Fr. 6. Gathered in the Grampians by Mr. Grant, of Lossiemouth. (Scottish Natuvalist, iv, p. 6I.)

The only record I have of this as a British moss is that by Mr. Fergusson in the journal mentioned, and with so distinct a plant it is not likely there 
could be any mistake. The figures are from Swedish specimans and will enable our young collectors to identify it, if they should be fortunate enough to meet with it.

\section{BRYUM CAPILLARE $L$.}

Dioicous; in dense tufts reddish at base. Leaves spirally twisted when dry, obovate or spatulate, with long hair-points, limbate with $\mathrm{I}-4$ rows of yellow cells, entire; nerve vanishing at point. Caps. clavate or cylindric. (T. LXXIV, D.)

Syn.-Muscus trichodes, capitulis oblongis reflexis Doody. RAY Syn. 243 (I6go).

Bryum nitidum, foliis serpylli pellucidis, capitulis reflexis e surculis annotinis et marcidis egredientibus Dill. Cat. Giss. 227 (I7 18 ).

Bryum foliis latiusculis congestis, capsulis longis nutantibus DiLl. Hist. musc. $398, \mathrm{t} .5$, f. 67 ( $174 \mathrm{I})$, et Herbar.

Bryum stellare roseum pendulum minus, capsulis et setis longioribns DilL. op. c. $4 \mathrm{I} 2$, t. 52 , f. 78 ; et Herbar.

Bryum capillare L. Sp. pl. II 2 I (I 753); Syst. Nat. ii, 700. Huds. Fl. angl. 4I 4 (I762). Wither. Bot. arr. ii, 667 (I776). LightF. Fl. scot. ii, 737 (I777). SibTh. Fl. oxon. 290 (I794). Swartz Musc. suec. 50 (I798). Hull Br. fl. P. 2, 255 (I799). Hedw. Sp. musc. I82 (I80I). Sm. Fl. brit. iii, I357 (I804), Eng. Bot. t. 2007. Turn. Musc. hib. I20 (I804). VoIT Musc. herb. 9I (I8I2). Wahlen. Fl. lapp. 359 (I8I 2). Roenl. Deutsch. Fl. iii, 93 (I8I3). Schwaeg. Suppl. I, P. II, II8, t. 74 (18I6.) Mart. Fl. cr. erl. 63 (I8I7). Brid. Sp. musc. III, 24 (I8I7), Mant. II8 (I8Ig), Bry. univ. i, 665 (I826). Hook. Tayl. Musc. br. I2I, t. 29 (I8I8). Hook. Hi.' scot. P. 2, I 50 (I82I), Br. Fl. ii, 6o (I833). Funck Moostasch. 49, t. 3I (I82I). Gray Nat. arr. br. pl. i, 770 (I82I). Hueben. Musc. germ. 442 (I833). Mack. Fl. hib. P. 2, 32 (1836). DE Not. Syllab. I3 I (I 838), Epilogo 394 (I869). Br. Sch. Bry. eur. fasc. 6-9, p. 6o, t. 28, 29 (I839). RABENH. Deutsch. kr. fl. ii, S. 3, 2 I6 (I 848). C. Muell. Synops. i, 28I (I849). Wils. Bry. brit. 240, t. 29 (1855). Schimp. Synops. 370 (I860), 2 ed. 449. Berk. Handb. br. m. I95 (I863). Milde Bry. siles. 2 I 8 (I869). Hobk. Synops. II7 (I873). Husn. Mouss. nord-ouest I 25 (I873), Musc. gall. 240 , t. 65 (I889). JuRatz. Laubm. oester.-ung. 282 (I882). Boulay Musc. de Fr. I, 24I (I884). LesQ. James Moss. N. Amer. 235 (I884). Limpr. in Rabenh. kr. fl. Laubm. ii, 375 (I893).

Muium capillare Hedw. Fund. II, 94 (I782). L. Syst. Veg. I4 ed. 947 (I 784$)$. RelHaN Fl. cantab. 399 (I785). Roth F1. germ. i, 475 (I788). HoffM. Deutsch. f. ii, 50 (I795). Aввот Fl. Bedf. 234 (I798). Brid. Musc. rec. II, P. III, 99 (I803). Schultz Fl. starg. 347 (1806).

Hypnum capillare WeIss Crypt. Gottin. 205 (I770).

Bryum squalidum VILL. P1. Dauph. iii, 889, t. 54 (I 786 ).

Dioicous; densely or laxly tufted, bright or dull green above, fuscescent at base with rufous-brown tomentum. Leaves spirally twisted when dry, or loosely incumbent, soft, broadly oblong and spathulate, acuminate and ending in a longish piliform entire or remotely denticulate point, plano-concave, margin reflexed, nerve reddish, vanishing or excurrent. The comal leaves large and rosettelike; cells lax, the marginal $\mathrm{I}-4$ rows very narrow, forming a yellowish limb, the upper rhombo-hexagonal, basal rectangular. Caps. on a tall red seta, cernuous, slightly incurved, horizontal, inclined or 
subpendulous, oblongo or elongate-obconic, rufo-fuscous, when dry and empty obconic, slightly contracted below mouth; lid large mamillar, apiculate, rufo-fuscous, shining; teeth rufous at base, pale at apex. Male plants like the female.

HAB.-On the ground, walls, trunks of trees and thatch; common. Fr. 4-6.

\section{Var. $\beta$. macrocarpum Hueben.}

Densely cæspitose, leaves broader with a broader limb, nerve excurrent in a solid brownish point. Caps. thicker, darker red.

Syn.-B. capillare Var. B. macrocarpum HUEBEN. Musc. germ. 442.

B. capillare Var. $\beta$. majus Bry, eur. 1. c. p. 6r.

B. capillare Var. $\beta$. cuspidatum Schimp. Cor. 74 .

HAB.—Old walls and roofs. Killarney (Moove)!

Var. $\gamma$. rosulatum Mitt.

Plants very short, cæspitulose, tomentose at base. Leaves crowded in rosulate heads, oval or spathulate, shortly acuminate, quite entire, the apex often twisted and recurved, nerve vanishing about half way up the leaf, limb of $\mathrm{I}-3$ rows of very narrow cells.

Sys.-B. capillare Var. vosulatum MIrT. MS. Ann. mag. nat. hist. 2 ser. viii, 367 (1851).

HAB.-Woolsonbury hill, Sussex; ster. (Mitten I849)!

Var. $\delta$. flaccidum Schimp.

Stem slender, with many slender branches, often with axillary chlorophyllose brood-filaments. Leaves laxer, soft, patulous, more distant, not spirally twisted, narrowly limbate, undulate, serrate at point.

Syn.-Bry. eur. fasc. 6-9, p. 6I, t. 29.

B. capillare Var. angustatum Boulay Musc. de 1'Est p. 396 (I 872 ).

HAB.-Crow road, Campsie (Hunt I 866)! Wall at Malham, Yorks. (Binstead 1885)!! Newtimber, Sussex (Davies).

Var. $\epsilon$. Ferchelii $(F u n c k) B v$. Sch.

Compactly tufted, dull green or brownish. Leaves appressed, small, concave, obovate-acuminate, suddenly narrowed into a twisted point.

Syn. -Bryun Ferchelii Funck m.s. BRID. Bry. univ. i, 847.

B. capillare Var. Ferchelii Bry. eur.

HAB.-Old wall at Killin (Hunt $\mathrm{r} 866)$ !!

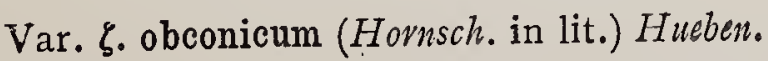

Densely tufted; leaves appressed or but little twisted when dry, ovate, acuminate, the comal erect and incurved. Capsule with a longer neck.

Sys.-Bryum obconicum HoRnsch. in lit. Bry. eur. WiLs. Bry, brit.

B. capillare Var. obconicum HuebEN. Musc. germ. 442. HusN. Musc. gall. 24 I.

$\mathrm{H}_{\mathrm{AB}}$ - - Walls and sandstone rocks. 
Barnard Castle (Spruce I843). Hill cliff quarry (Wilson I860)!! Thirsk (Nowell I854)! Slate rocks at Bangor (Hunt 1854 )!! Rossit and Gresford (Hunt 1860)! Greta bridge (Borrer). Mucruss, Killarney (Hunt 1867)!! Dailly, Ayr (Shaw 1865). Shaughbridge, Devon (Holmes)!! Levens (Barnes)!! Luxulyan, Cornwall (Holmes I 884).

Like all mosses of wide distribution $B$. capillave varies much both in the fruit and leaves, and after examining a large number of specimens of $B$. obconicum, I feel constrained to rank it among the varieties, as none of its characters appear to me weighty enough to be of specific value. Nontwisted leaves occur in several forms of $B$. capillave, and the capsular neck varies considerably in length, as does also the acumination of the leaf point, but the cell-structure of the leaves is identical. Of course if we are to adopt the modern idea of subspecies, as well as varieties, then obconicum must rank among the former.

\section{BRYUM DONII Grev.}

Dioicous; resembling $B$. capillare. Leaves spreading, slightly crisped when dry, ovate-oblong, subserrate at apex, with a narrow thickened border, nerve scarcely excurrent. Caps. conico-clavate. (T.LXXV,A.)

\section{SYN.-Bryum corsicum WALK. ARN. MSS.}

Bryum capillare $\delta$. corsicum BrID. Bry. univ. i, 849 (1827).

Bryum Donianum Grev. in Trans. Linn. Soc. xv, 345, t. 3, f. 6 (1828). Wrls. Bry. br. 24r, t. 49 (1855). Schimp. Synop. 373 (1860), 2 ed. 454 . BERK. Handb. br. m. Ig6 (1863). DE Not. Epil. 39 I (1869). Hobk. Syn. br. m. il7 (1873). Juratz. Laubm. oester.-ung. 285 (1882). Boul. Musc. de Fr. I, 265 (I884). HusN. Musc. gall. 239, t. 64 (I889). Limpr. in RABEn. kr. fl. Laubm. ii, 378 (1893).

Bryum insulare De Not. Spicil. 7 (r837), et Syllab. 228 ( 1838 ).

Bryum platyloma (non Schwaeg.) BR. Sch. Bry eur. fasc. 6-9, p. 58, t. 26 (I839). C. Muell. Synops. i, 282 (1849).

Bryum Muelleri Spruce Musc. Pyr. I38, et Ann. mag. nat. hist. I849.

Dioicous; resembling $B$. capillare, but shorter and in smaller tufts. Upper leaves crowded in a coma, erecto-patent, somewhat twisted when dry, subpathulate-oblong and elongate, limb yellowish, narrow and incrassate of $2-3$ strata of narrow pachydermous cells confluent with the apical mucro, distantly serrate at point; nerve strong, excurrent in a solid fuscous point; cells denser, more solid. Caps. inclined, rather large, oblongo-obconic, rufous-brown, lid mamillar, castaneous, very glossy. Male infl. gemmiform, in the coma.

HaB.-Gravelly banks and rocks; not common. Fr. 5-6.

Near Winchelsea, Sussex (Fenner 1844$)$ ! Winwick stone quarry near Warrington and Conway (Wilson). Damp sand-bank near Hurstpierpoint (Mitten). Penzance (Curnow 1869)!! Lancing and Betchworth (Davies 1857)!! Dadnor, near Ross (Rcv. A. Ley I8yo)! Torquay and Anglesey. 
This fine moss bears much resemblance to $B$. capillave, but the leaves have only short points with the nerve just excurrent, and a much thicker limb. It is most frequént in the Mediterranean region and Canary Islands.

\section{BRYUM PROVINCIALE Philit.}

Polyoicous; stem branched, the innovations with the comal leaves suddenly larger and crowded, ovate-oblong concave, serrulate in upper part, the nerve excurrent. Capsule pendulous, obconic-pyriform. (T. LXXV, B.)

Syn.-Bryum Billardieri (non Schwaegr.) Br. Sch. Bry. eur. fasc. 6-9, p. 58, t. 26 (r839). Wils. Bry. brit. 242, t. 50 (I855). HoBk. Syn. br. m. II8 (I873).

Bryum Canariense (non Brid.) Schimp. Synops. 374 (I860). BERK. Handb. br. m. I97 (1863). DE Not. Epilogo 393 (1869).

Bryım provinciale Philib. MSS. Schimp. Synops. 2 ed. 432 (1876). JuRatz. Laubm. oester.-ung. 285 (1882). HoBk. Synops. 2 ed. I6I (I884). Lesq. James Moss. N. Amer. 230 (I884). Boulay Musc. Fr. 27 I (I884). Limpr. in Rabenh. D. kr. fl. Laubm. ii, 364 ( 1893 ).

B. Canariense Var. provinciale Huss. Musc. gall. 239 (1889).

Polyoicous; the same plant often bearing male, female and synoicous infl. Laxly cæspitose, bright green above, fuscous at base with ferruginous tomentum, the innovations single or in pairs. Lower leaves remote, small, ovato-lanc., shortly cuspidate, upper suddenly larger, crowded in a many leaved rosette, not limbate, the outer concave obovate, shortly acuminate, nerve strong rufous excurrent in a short point, margin narrowly recurved in lower half, plane and minutely serrate above; the median lineal-oblong acuminate, rather more cuspidate; the inner narrower, the margin to apex more broadly reflexed; cells rhombic-hexagonal above, rectangular and red at base. Perich. bracts smaller lanc., longly cuspidate, margin subrevolute. Capsule on a rufous seta, pendulous, longly obconic, rufous-orange, not contracted below the mouth; lid convex-conic, pointed, reddish-brown, annulus broad; peristome large, the teeth yellow below, hyaline above, processes widely gaping.

HAB.-Calcareous hills in S. of England ; rare. Fr. 5.

Old ant hills on Woolsonbury hill, Sussex (Mitten)!! Ightham, Kent c. fr. (Holmes). Worthing. Wookey, near Wells, Somerset c. fr. (Binstead I887)!! Lord's wood, Great Doward hill, Hereford c. fr. (Rev. A. Ley I 874$)$ !

Another moss allied to $B$. capillave but with non-limbate leaves, and with a different habit, the stem being interrupted by the leaves clustering into rosettes. B. Canariense BRID. has a similar habit but is dioicous, the leaves with a denser areolation and more minutely serrulate. B. Billardievi SchwaEg. is Australian. 


\section{BRYUM BARBATUM Wils.}

Dioicous; densely cæspitose, soft, fastigiate branched. Leaves ovate, pointed, running out into a recurved apiculus, nerve reaching point or excurrent, margin erect entire, not limbate, cells hexagonorhombic. (T. LXXV, E.)

SYN.-Bryum barbatum WiLs. MSS. HUnt in Mem. Lit. Phil. Soc. Manch. 3 ser. iii, 238 (1866). Новк. Syn. br. m. I14 (1873).

Bryum Stirtoni Schimp. Synops. 2 ed. 470 (1876). Limpr. in RABENH. Deutsch. kr. flora, Laubm. ii, 43I (I893).

Dioicous; densely cæspitose, soft, light green above, pale brown below with rufous tomentum. Stems $I_{2} \frac{1}{2}$ in. high, red, slender, fastigiate branched. Lower leaves smaller remote patent, ovate, shortly pointed, submuticous, nerve vanishing below or in the apex, upper rather larger with a recurved apiculus, nerve yellowish-green, ending at the point or excurrent as a short hair; both concave the margin erect, entire not limbate, cells chlorophyllose, shortly hexagono-rhombic, larger and longer at base, in the perich. bracts longer, narrower, and red at base, enclosing a few archegonia and paraphyses.

HAB.-On the ground near summit of Ben Ledi. (Stivton \& McKinlay I864)!!

This moss has unfortunately never been found with fruit, but in habit it resembles some forms of $B$. pallens, though perhaps coming nearest to B. capillave in form and structure of leaf. It does not appear to have been found again since its first discovery, nor to have been met with in any other locality.

\section{BRYUM PROLIFERUM (L.) Sibth.}

Dioicous; laxly cæspitose. Cauline leaves minute, squamiform, comal large, crowded in a rosette, spathulate, apiculate, serrated, nerved to apex. Capsules aggregated, oblong pendulous slightly incurved. (T. LXXV, C.)

Syn.-Bryum roseum majus foliis oblongis Dillen. in RAy Synops. 3 ed. 92 (1724).

Bryum stellare roseum majus, capsulis ovatis pendulis. Dillen. Hist. musc. 4II, t. 52, f. 77 (174r), et Herbar.

Mnium serpyllifolium $\gamma$. proliferum L. Sp. pl. III3 (1753). Syst. nat. ii, ror. LightF. Fl. scot. ii, 715 (r777)

Mnium roseum WeIss Crypt. Gotting. I57 (I 770). Hedw. Sp. musc. I94 (I80r). BRID. Musc. rec. II, P. III, ro4 (1803), Sp. Musc. III, 49 (1817). SchulTz Fl. Starg. 348 (I806). Wahlenb. F1. lapp. 354 (I8I2). Roenl. Deutsch. fl, iii, 96 (1813). Schivaeg. Suppl. I, P. II, I35 (I8I6). HUEBen. Musc. germ. 404 (1833). DE No'T. Syllab. I36 $\left(183^{8}\right)$. 
Bryum roseum Schreb. Spic. fl. Lips. 84 (I77I). Neck. Meth. musc. 2 I9 (I 77 I). Web. Spic. fl. goett. I Ig ( I778). Swartz Musc. suec. 5 r (I798). Roth Fl. germ. iii, P. 2, 247 (I800). SM. Fl. brit. I 370 (I 804 ), Eng. Bot. t. 2395. Turn. Musc. hib. I32 (I80t). BRID. Mant. IIg (18I8). Hook. TAYL. Musc. brit. I20, t. 29 (I8I8). Hook. Fl. scot. P, 2, I50 (I82I), Brit. fl. ii, 63 (I833). Gray Nat. arr. Br. pl. i, 769 (I82I). Mack. Fl. hib. P. 2, 33 (I 836 ). Br. Sch. Bry. eur. fasc. $6-9$, p. 56, t. 25 (I 839 ). RABEnH. Deutsch. kr. f. ii, S. 3, 222 (I848). C. Muell. Synops. i, 247 (1848). Wris. Bry. br. 356, t. 29 (1855). Schrmp. Synops. 38 r (1860), 2 ed. 466. Berk. Handb. br. m. I98 (I863). De Not. Epilogo 389 (1869). Mridde Bry. siles. 222 (I869). Hobk. Synops. I20 (1873). Husn. Mouss. nord-ouest I26 (I873), Musc. gall.252, t.69 (I889). JuRATz. Laubm. oester.-ung. 296 (I882). Boulay Musc. de Fr. i, 246 (I884). Lesq. James Moss. N. Amer. 239 (1884).

Mnium proliferum Leyss. Fl. halens. 272 (I783). GmeL. (L.) Syst. nat. ii, I330 (I79I). Wither. Bot. arr. Br. veg. 3 ed. iii, 806 (r796).

Hypum roseum Schrank Bayer. F1. ii, 47 I (I789). Web. Mohr Bot. Tasch. 297 (1807). Bryum troliferum SiBTH. F1. oxon. 292 (1794).

Bryum Polla rosea Brid. Bry. univ. i, 696 (I826).

Rhodobryum roseum LimpR. in RABENH. D. kr. fl. Laubm. ii, 445 (1893).

Dioicous; in tall gregarious or lax deep green tufts, the stem producing subterranean radiculose stolons. Cauline leaves small and thin, distant, lanceolate, squamiform and appressed; comal leaves very large, crowded in a rosette, elongate-spathulate, acute, rather curled when dry, margin strongly serrate in upper half, reflexed below; nerve broad at base, vanishing below apex; cells thin, rather lax, longish rhombo-hexagonal. Perich. bracts smaller, lanceolate acuminate; setæ $\mathrm{I}-3$ in a perichætium, stout, rufous-purple, arcuate at top; caps. pendulous, solid, rufous-brown, elongate-obconic, slightly incurved, sometimes obovate-oblong and equal, not contracted below mouth when dry; teeth long, ferruginous, endostome yellow with a broad membrane, processes lacunose. Male plants in separate tufts, smaller, the leaves shorter, broader, and expanded like a star.

HAB.-Shady places in woods and by streams. Fr. ro, rare.

Lydford, Devon c. fr. (Rev. C. A. Fohns I845)!! Near Over, Cheshire c. fr. (Hunt)! Hustyn woods, Cornwall c. fr. (Tellam).

This fine moss has all the appearance of a Mnium, and represents a small group of which B. giganterm, umbraculum, Commersoni and Beyrichii are examples. Linnæus had evidently some misgiving about his four varieties of Mnium serpyllifolium a. punctatum, $\beta$. cuspidatum, $\gamma$. proliferum, $\delta$. undulatum, as he says, "varietates has pro distinctis speciebus sumunt varii, ego ob suas caussas ita conjuxi, ut qui distinguendas velit, facile distinctas tradat."

\section{A D D E N D .}

\section{BRYUM JULIFORME (Solms) Schimp.}

Dioicous; glossy yellowish green, with very slender julaceous branches. Leaves imbricated, appressed, ovate-elliptic with a recurved 
apiculus, the cells of upper half very narrow and serpentine. Capsule. pale, subclavate-oblong, lid large, mamillate. ( $T$. LXXV, F.) Syn.-Bryum julaceum SchwaEg. in L. Sp. pl. 4 ed. v., P. 2, p. 68 p.p. (I83o). Bals. DE
Not. in Mem. Acc. Torin. xl, 331, p.p. (I838). DE Not. Syllab. I77, p.p. (I838). Mont. P1. cell. canar. 34 (1840).

Anonobryum julaceum Schimp. Synops. 382, p.p. (1860). DE Not. in Comm. Soc. critt. ital. ii, fasc. 2, p. 23 (1866), forma.

Anomobryum juliforme C. DE Solms-LaubaCH Tentam. bryo-geogr. 38 (I868). LIMPR. in RABEN. D. kr. A. Laubm. ii, 222 (1892).

Webera Neapolitana De Not. Epil. 4 I 7 (1869).

Bryum campestre Lindb. Not. Saells. Fauna et A. fenn. xi, 4 I (1870).

Bryum juliforme Schrmp. Synops. 2 ed. 466 ( 1876$)$. Juratz. Laubm. oester.-ung. 296 (I882).

Bryum filiforme Var. $\beta$. Neapolitanum Boulay Musc. de Fr. i, 293 (I884).

Anomobryum filiforme Var. juliforme Husn. Musc. gall. 222 (I888).

Dioicous; in loose yellow-green glossy tufts, the stems short slender julaceous, with I-3 short branches above. Leaves imbricated, appressed, cymbiform-concave, ovate with a very short recurved apiculus, margin minutely serrulate at apex, nerve vanishing below apex; cells in the upper half incrassate, very long and narrow, more or less flexuouse, below lax and thin-walled, hexagono-rectangular. Perich. bracts longer, ovato-lanc., seta red slender; caps. small, pale brown, subclavate-oblong, lid large hemispherical, mamillate, orange. Male plants more slender, infl. gemmiform, bracts broadly ovate, pointed, indistinctly nerved.

HAB.-Moist turfy soil or rocks, very rare. Fr. 4. Near Penzance, sterile (Mitten E Curnow)!!

This slender little moss is intermediate between $B$. filiforme and concinnatum, and may readily be distinguished by the structure of the leaf, the cells in the upper half being more flexuose and much longer and narrower than in B. filiforme.

\section{BRYUM CASPITICIUM.}

Var. $\gamma$. badium (Bruch) Brid.

Plants more slender, in loose tufts, often tinged with red; leaves firmer with an excurrent reddish yellow nerve; capsule dark brown.

Syn.-Bryum badium BRUcH MSS. RUThE in Verh. bot. ver. prov. Brandenb. I867, p. 6I. Milde Bry. siles. 217. Schimp. Synops. 2 ed. 444. Juratz. Laubm. 279. Limpr. D. kr. f. Laubm. ii, 383 .

Bryum caspiticium Var. $\gamma$. badium BrId. Bry. univ. i, 850 (1827).

Bryum caspiticium Var. $\beta$. gracilescens Bry. eur. 
$\mathrm{HAB}_{\mathrm{A}}$ - Sandy ground and damp walls; rare. Sands at Milnthorpe, Westmoreland (Barnes I 868)!

Although this moss is usually regarded as a species, it differs so little from $B$. caspiticium that I prefer retaining it as a variety. Our plant is only slightly tinged with red, but has the stiff narrower leaves of $B$. badinm.

Corrig.-p. 160, for Sclerodontium read Sclerodictyon; p. 166, for Bryum fuscum read Bryum rufum.

TAB. LXVI. A. Oreas Mielichhoferi (Norway, Binstcad). B. Stableria gracilis (Alderley edge, Hunt). C. Leptobryum pyriforme (Box hill). D. Pohlia acuminata (Ben Nevis, Wilson). E. P. polymorpha (Cwm Idwel, Wilson). F. P. clongata (Ben Lawers, Braithroaite).

TAв. LXVII. A. Pohlia cruda (Teesdale, Braithwaite). B. P. cricullata (c. Ben Attow, Dixon). C. P. nutans (Malham, Braithwaite). D. P. carnea (Malham, Braithwaite). E. P. annotina (Alderley, Hunt).

TAB. LXVIII. A. Pohlia albicans (Ben Wyvis, Braithwaite). B. P. Ludwigii (Clova, Fergusson). C. P. commutata (Ben Lawers, Wilson). D. P. gracilis (Tromsoe, Norway, Braithroaite). E. Epipterygium Tozeri (Penzance, Curnow).

TAB. LXIX. A. Plagiobryum Zicrii (Teesdale, Dr.Fraser). B. P. demissum (Craig Chailleach, Braithwaite). C. Bryum fllforme (Ben Lawers, Braithwaite). D. B. concinnatum (Swaledale, Barncs). $\quad$ E. B. lacustre (Coatham, Barnes). F. B. inclinatum (Teesdale).

TAB. LXX. A. Bryum pondulum (Southport, Hunt). B. B. Warneum (Southport, Wilson). C. B. cernum (Saltburn, Barnes). D. B. Marratii (Coatham,Barncs). E. B. calophyllum (Coatham, Barnes). F. B. intermcdiun (Whitby, Braithwaite).

TAB. LXXI. A. Bryum bimun (Warrington, Wilson). B. B. affule (Bowdon, Hunt). C. B. torquescens (Mucruss, Hunt). D. B.pallescens (Monsal dale, Holt). E. B.caspiticium (Esk dale, Braithwaite).

TAB. LXXII. A.Bryumpurpurascens (Norway). B. B. fallax (Sussex, Mitten). C. B.argcnteum (Wimbledon, Braithwaite). D. B. bicolor (Shoreham, Davies). E. B. erythrocarpon (Tilgate, Davies). F. B. muirale (Oxford, Boswell).

Tав. LXXIII. A. Bryum rubcns (Hurstpierpoint, Mitten). B. B. Mildci. C. B. Muehlenbeckii (Switzerland). D. B. alpinum (Killin, Braithwaite). E. B. pallcns (Ben Lawers, Holt). F. B. Duvalii (Vosges, Schimper).

TAB. LXXIV. A. Bryum turbinatum (Ashton, Whitehead). B. B. ventricosum (Goathland, Braithreaite). C. B. neodamense (Southport, Wood). D. B. capillare.

Taв. LXXV. A. Bryum Donii (Penzance, Curnoz). B. B. provincialc (Wells, Binstead). C. B. proliferum (Lydford, Holmes). D. B. cyclophyllum (Sweden, Lindberg). E. B. barbatum (Ben Ledi). F. B. juliforme (Penzance, Dixon).

a. Fertile plant. b. Male. c. Sterile plant. I. Leaf mag. 1x. Transv. section. Ia. Apex. rb. Base of leat. 2. Perich. bract. 3. Male infl. 4. Antheridia and bract. 5. Capsule. 6. Calyptra. 7. Operculum. 8. Peristome. 8e. Endostome. Io. Gemma. 



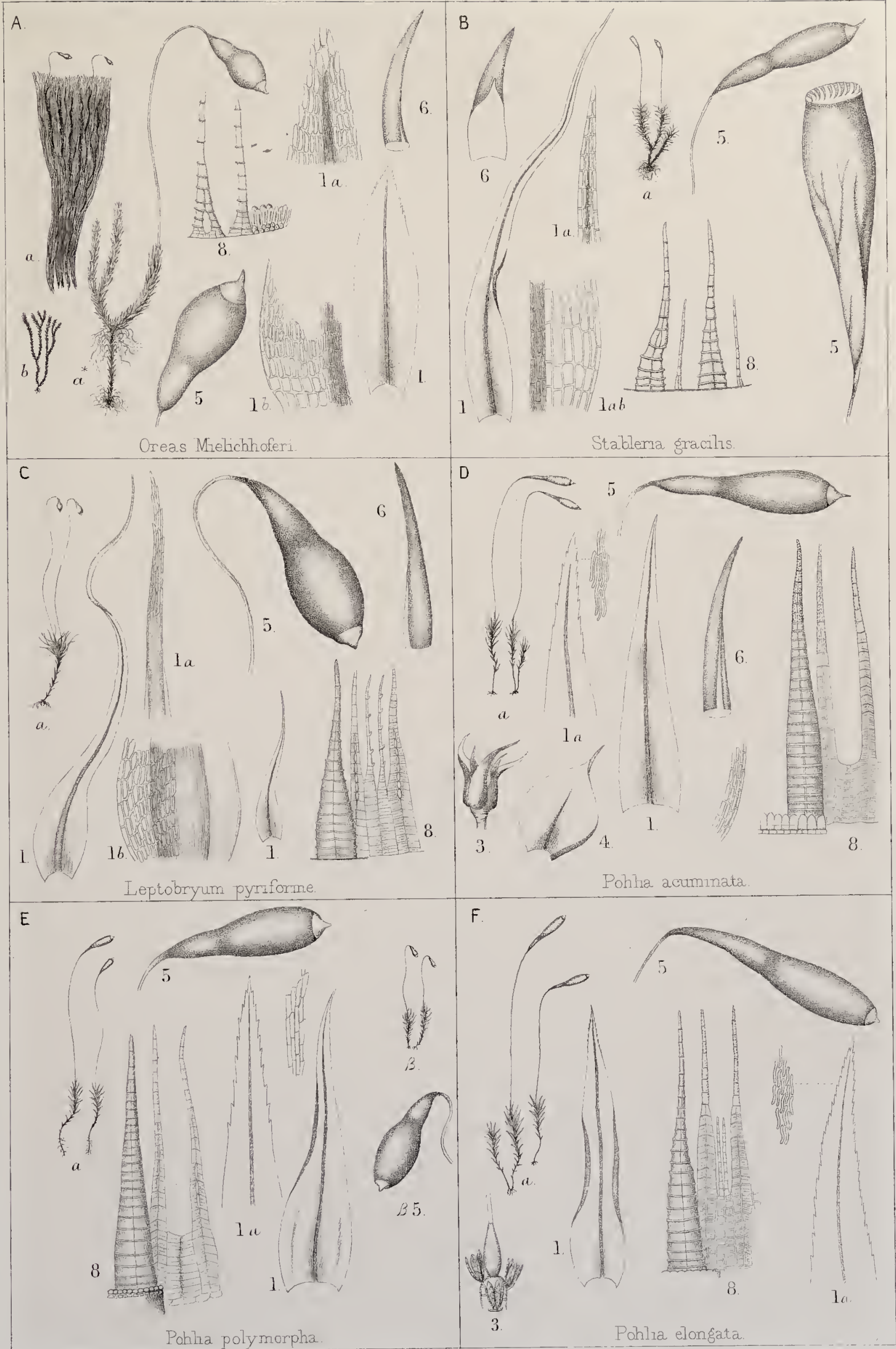

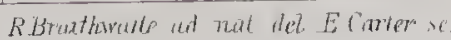






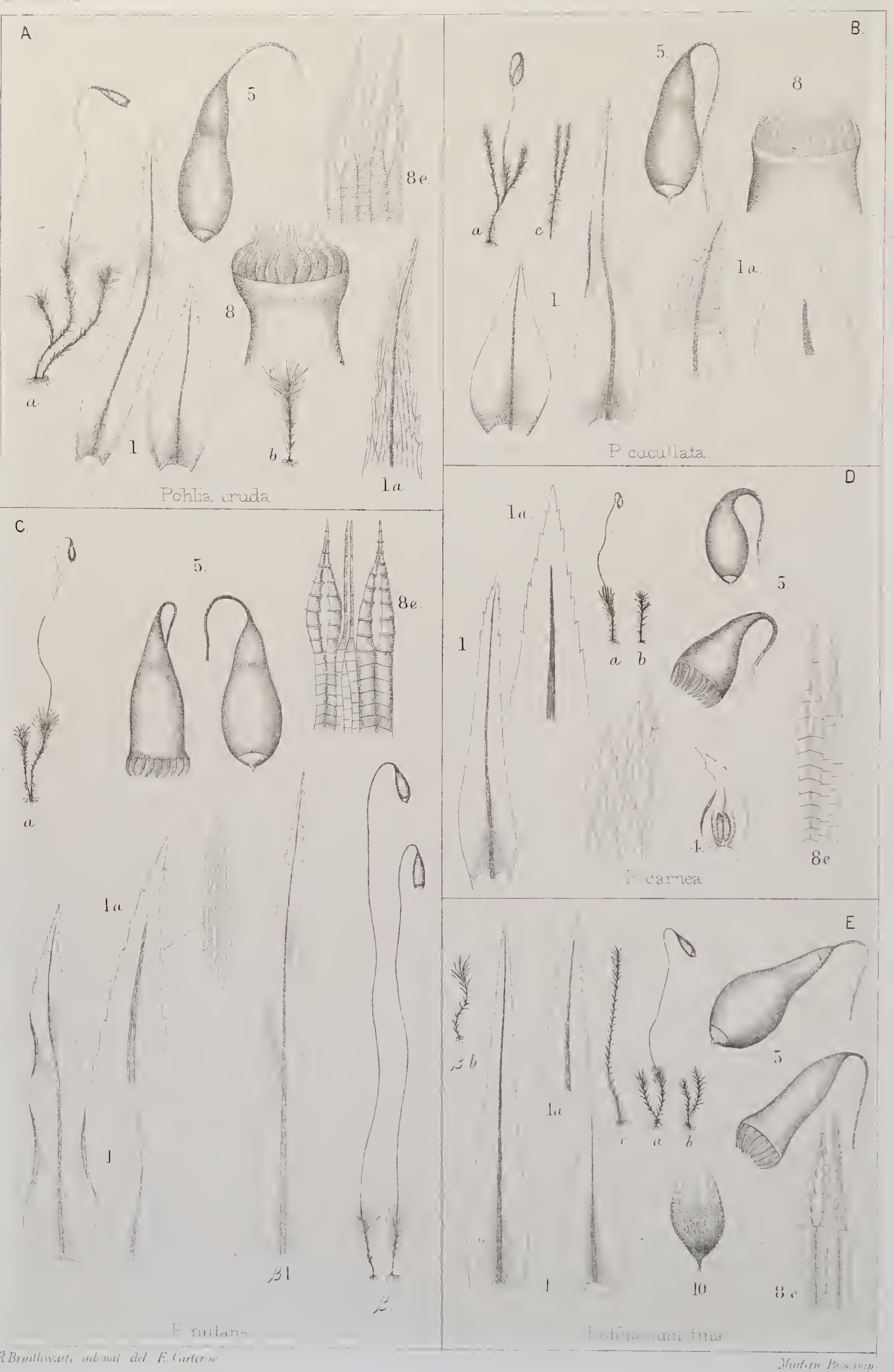




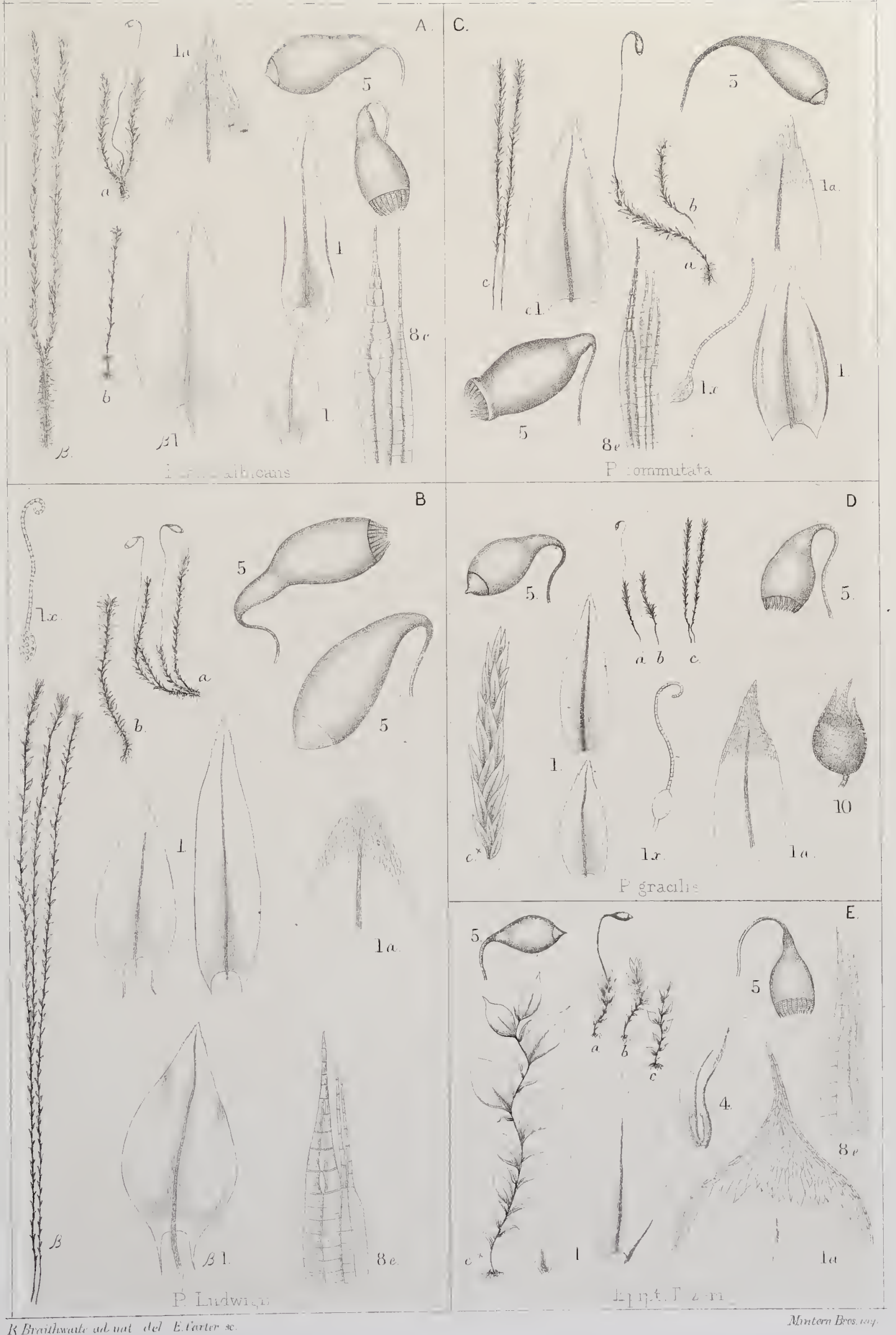




BHEYATHE

T. LXXX

A.
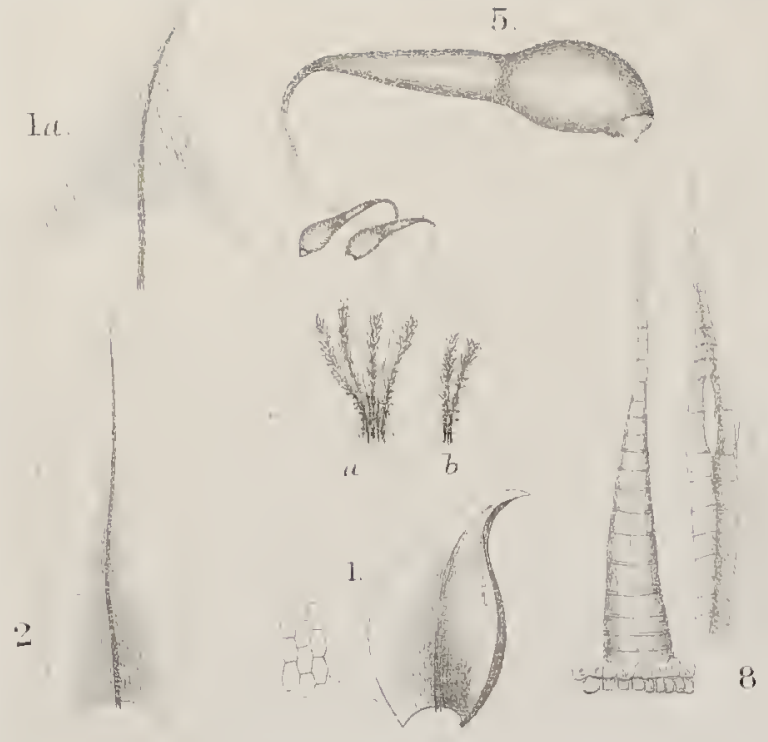

Pla giobryum Zieric

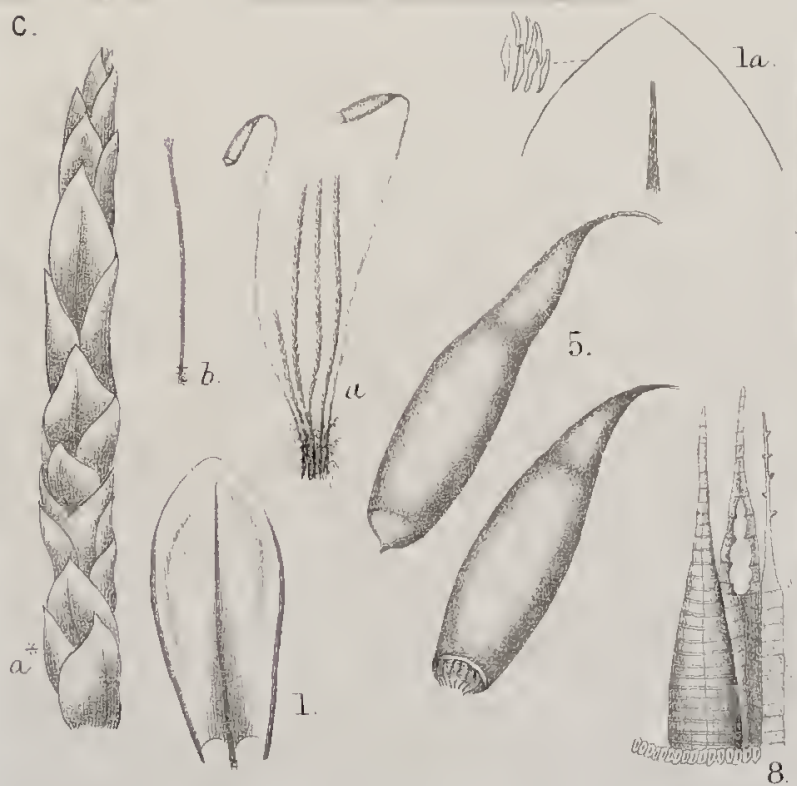

Eryum filiforme
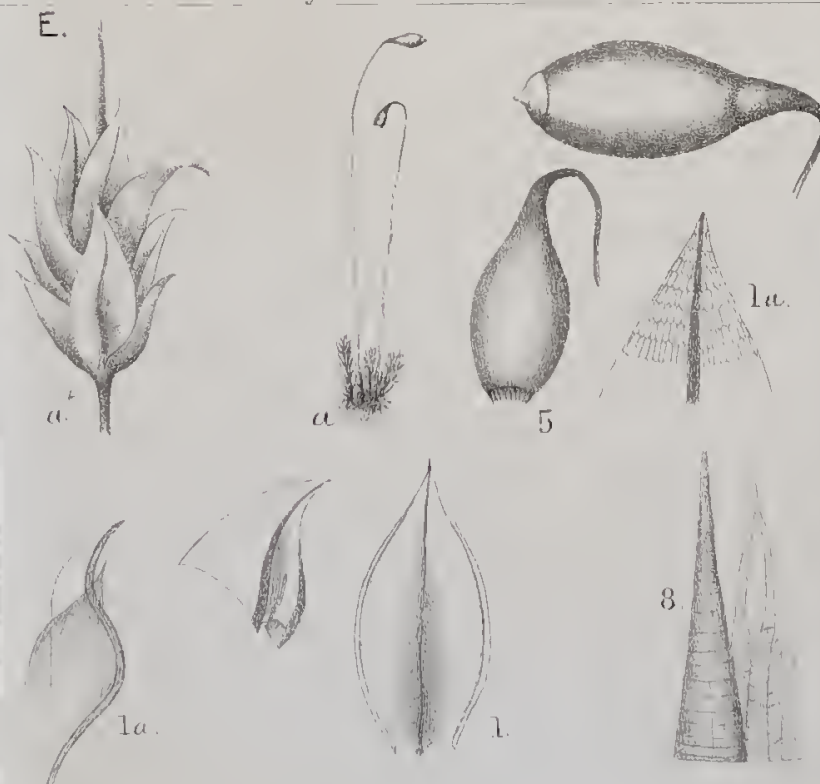

Br lacustre

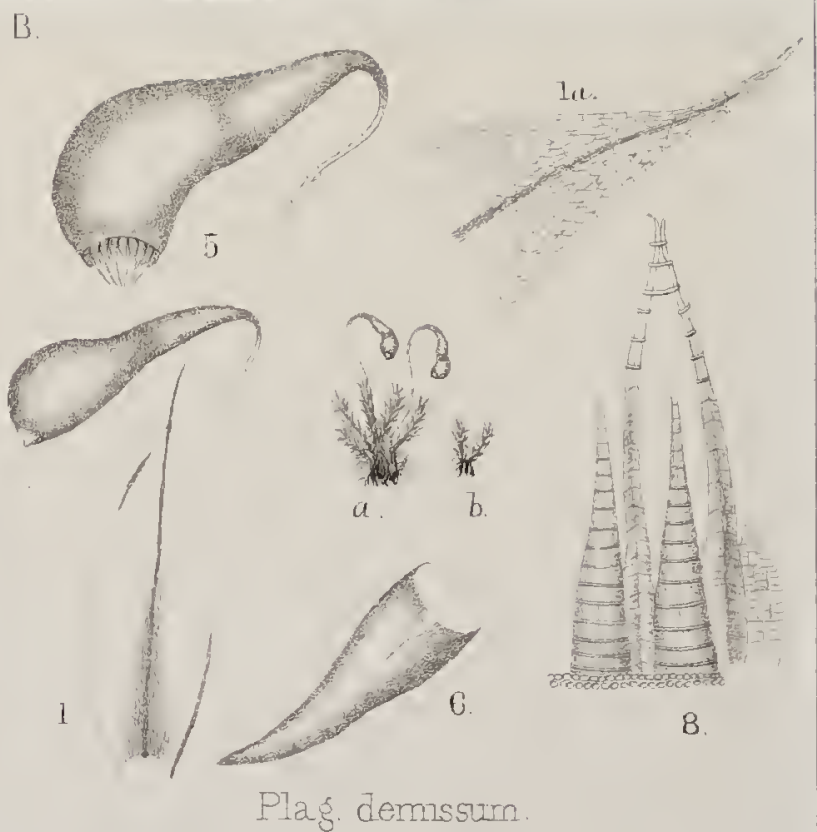

D

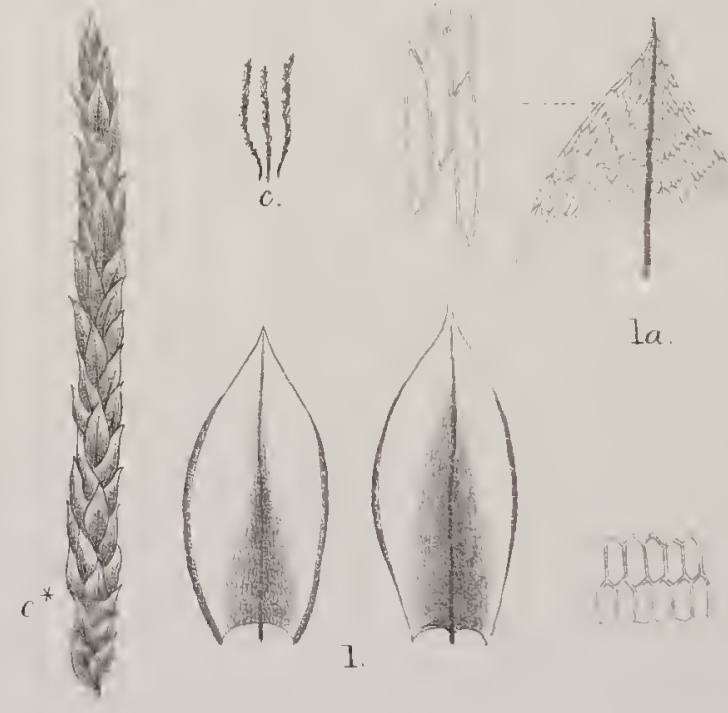

Br. concinnaturn

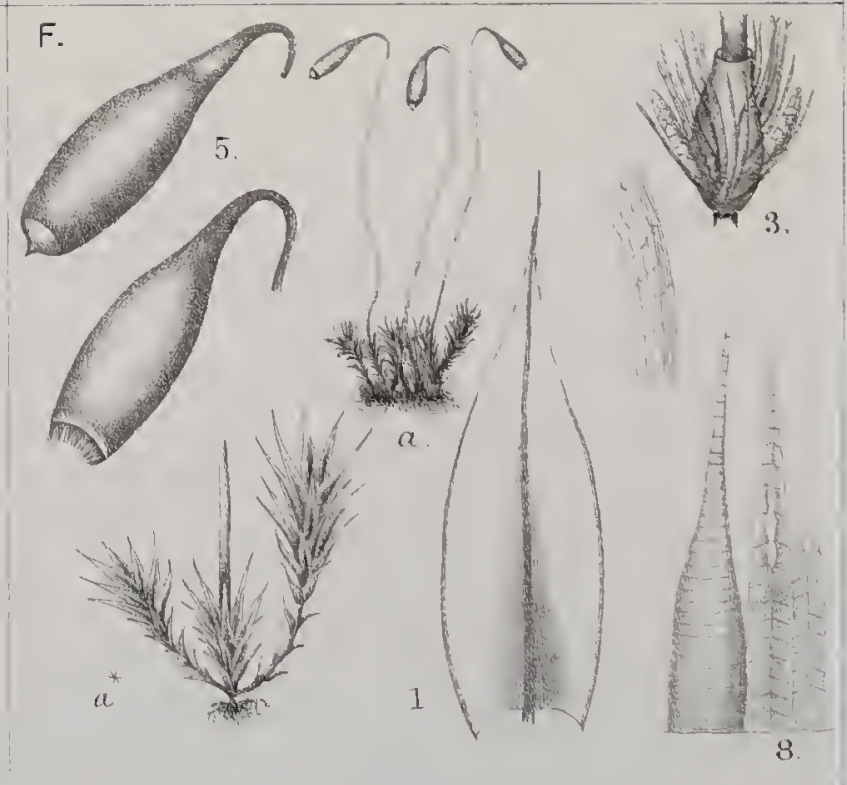

Br. inchinatum. 
A
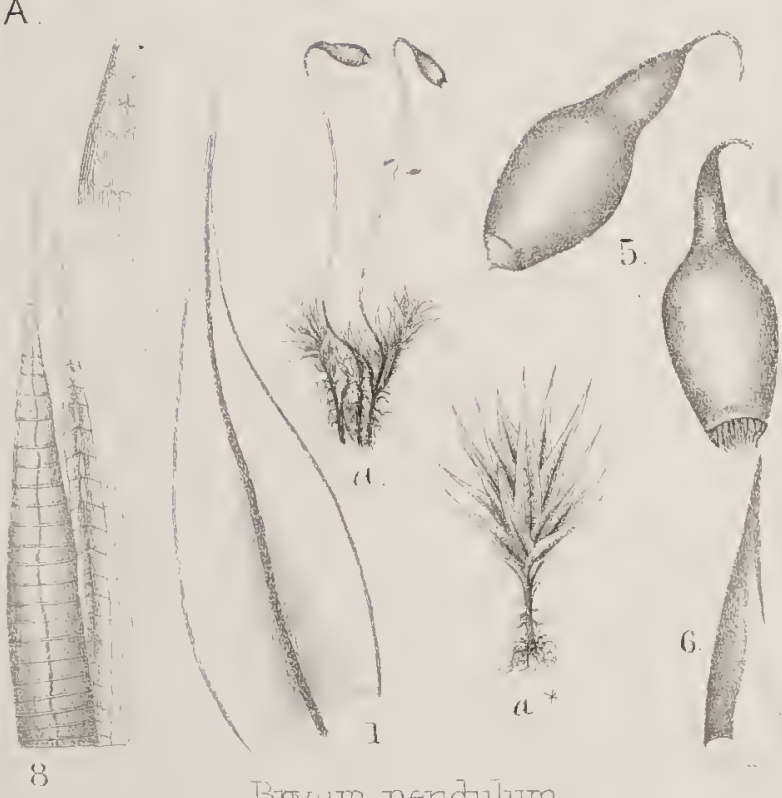

8

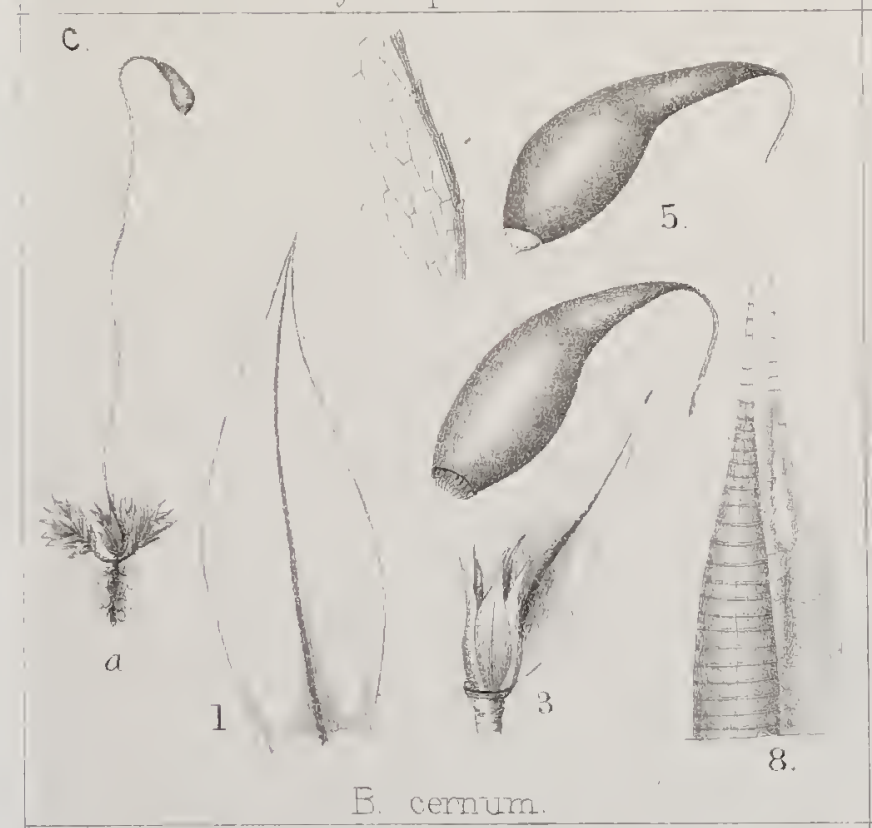

Bryum pendulum.

E.

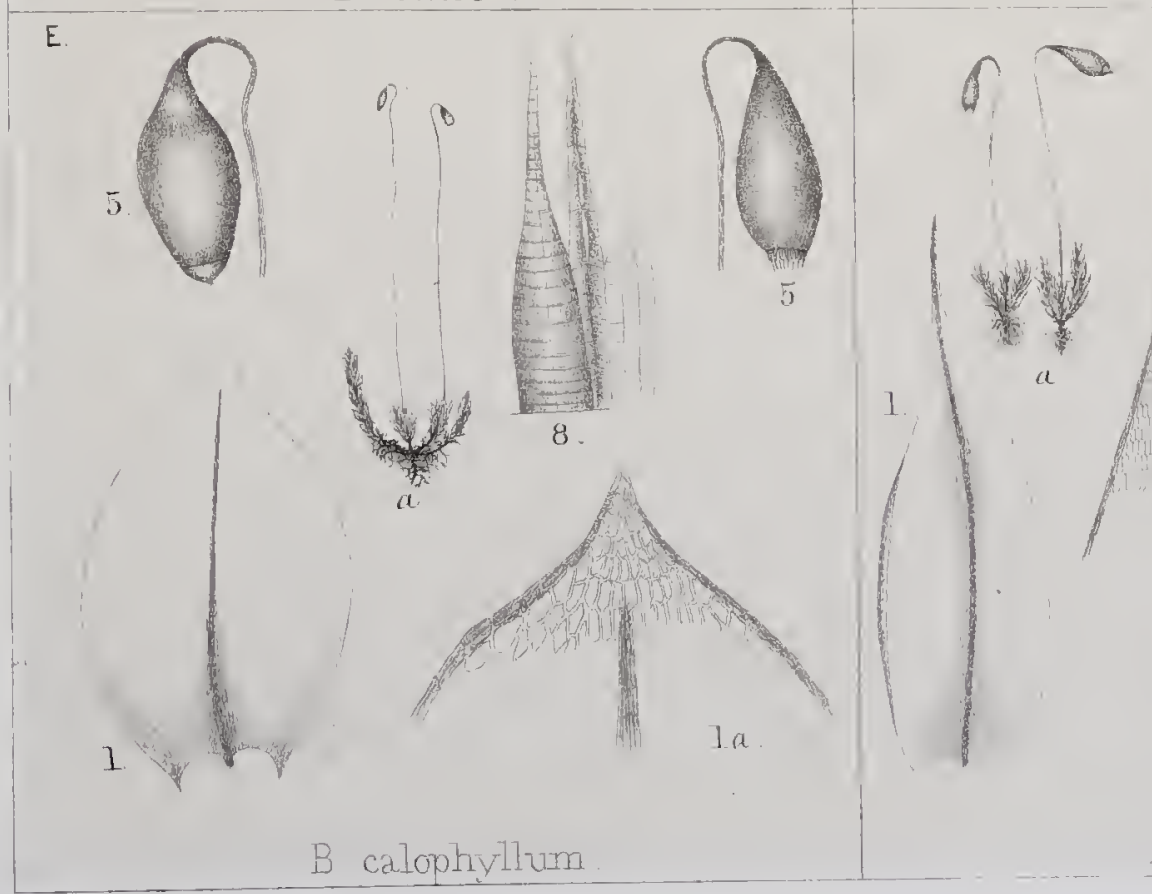

B. cernum

W*

la.

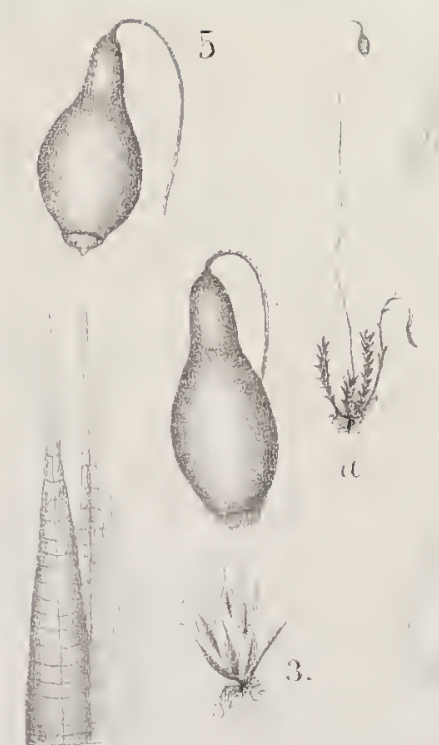

8

B. Warnerm
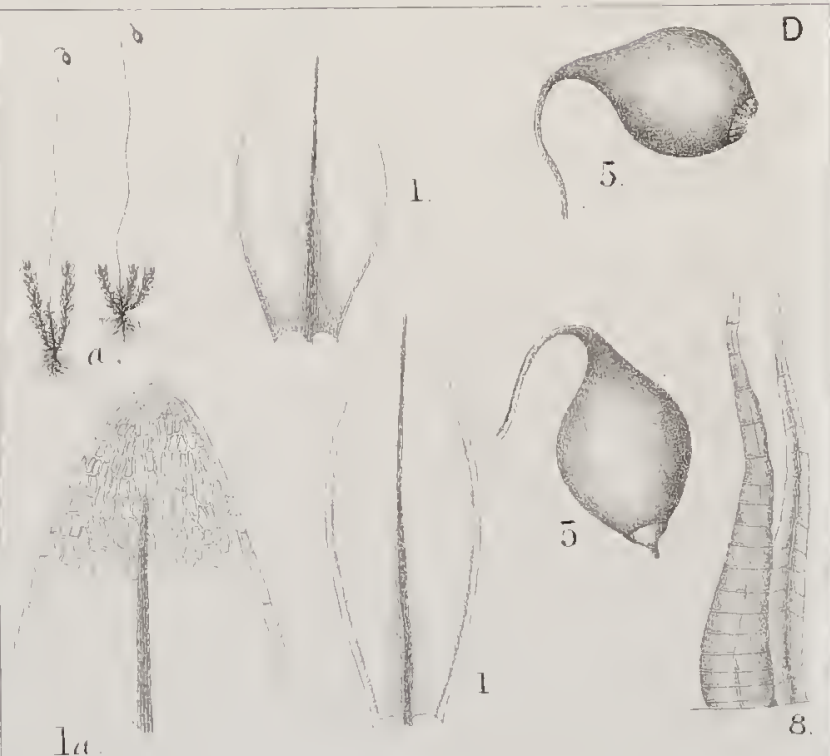



\section{-}



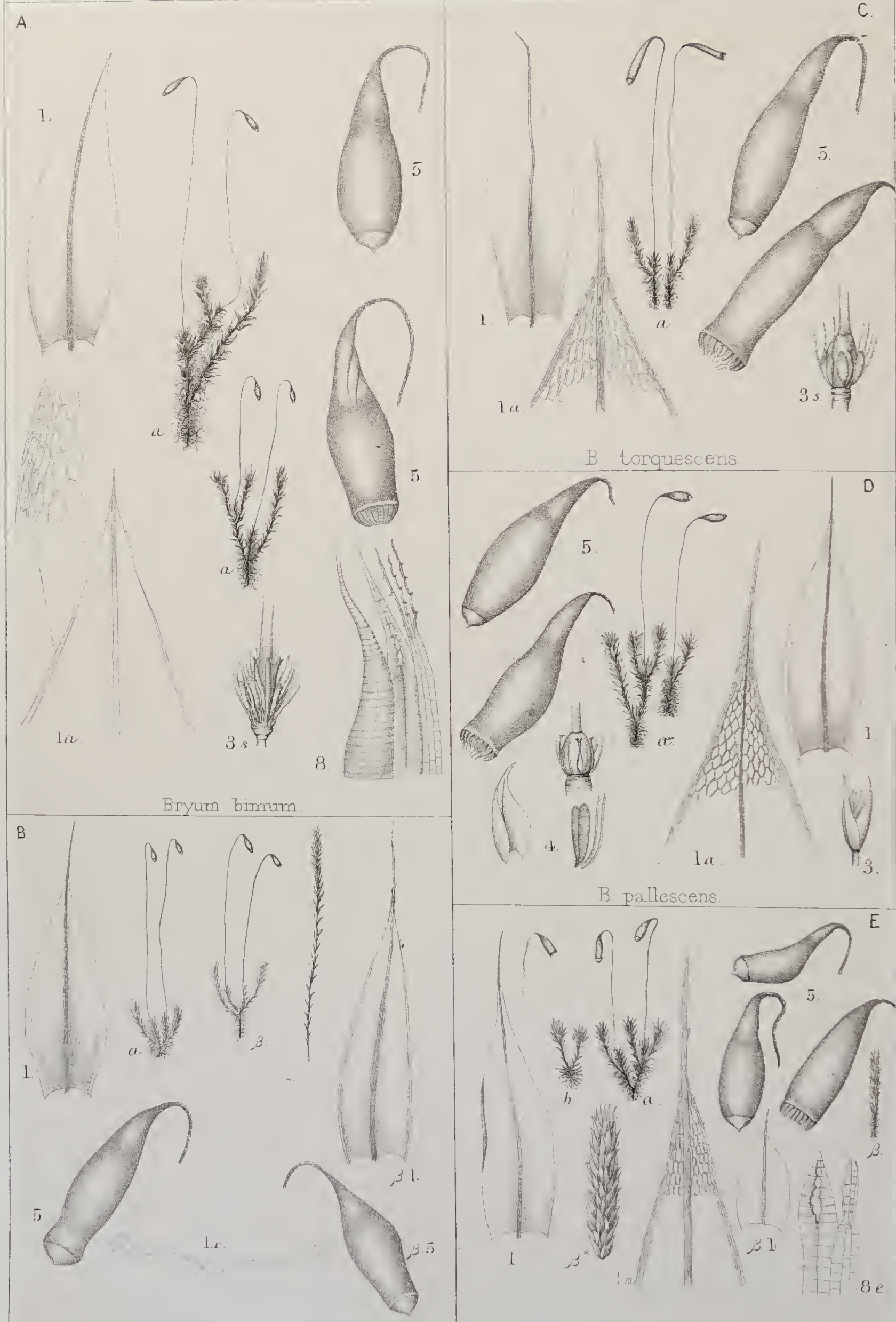

b afline

B. castitulum 


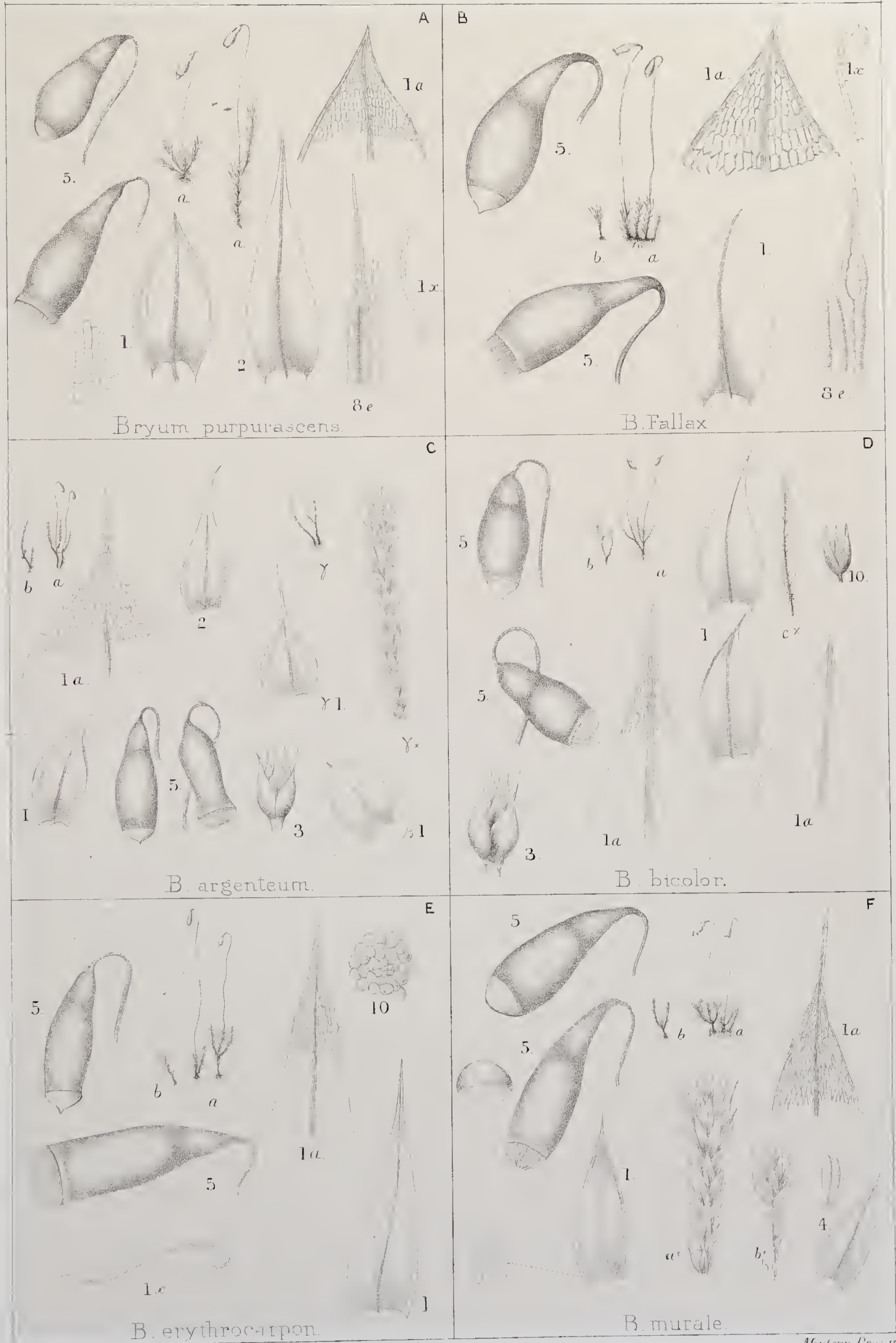

B. erythroratipoth 



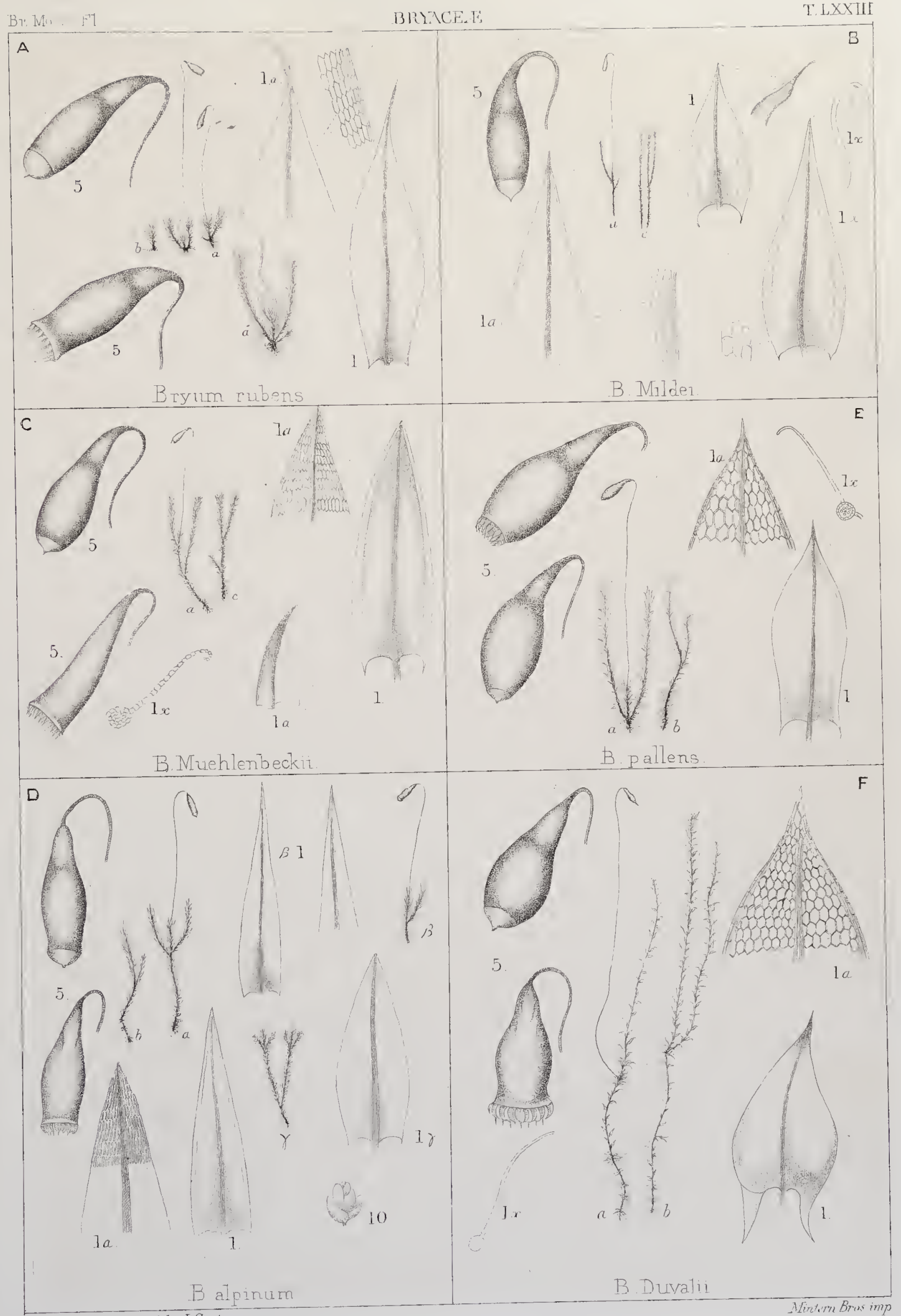





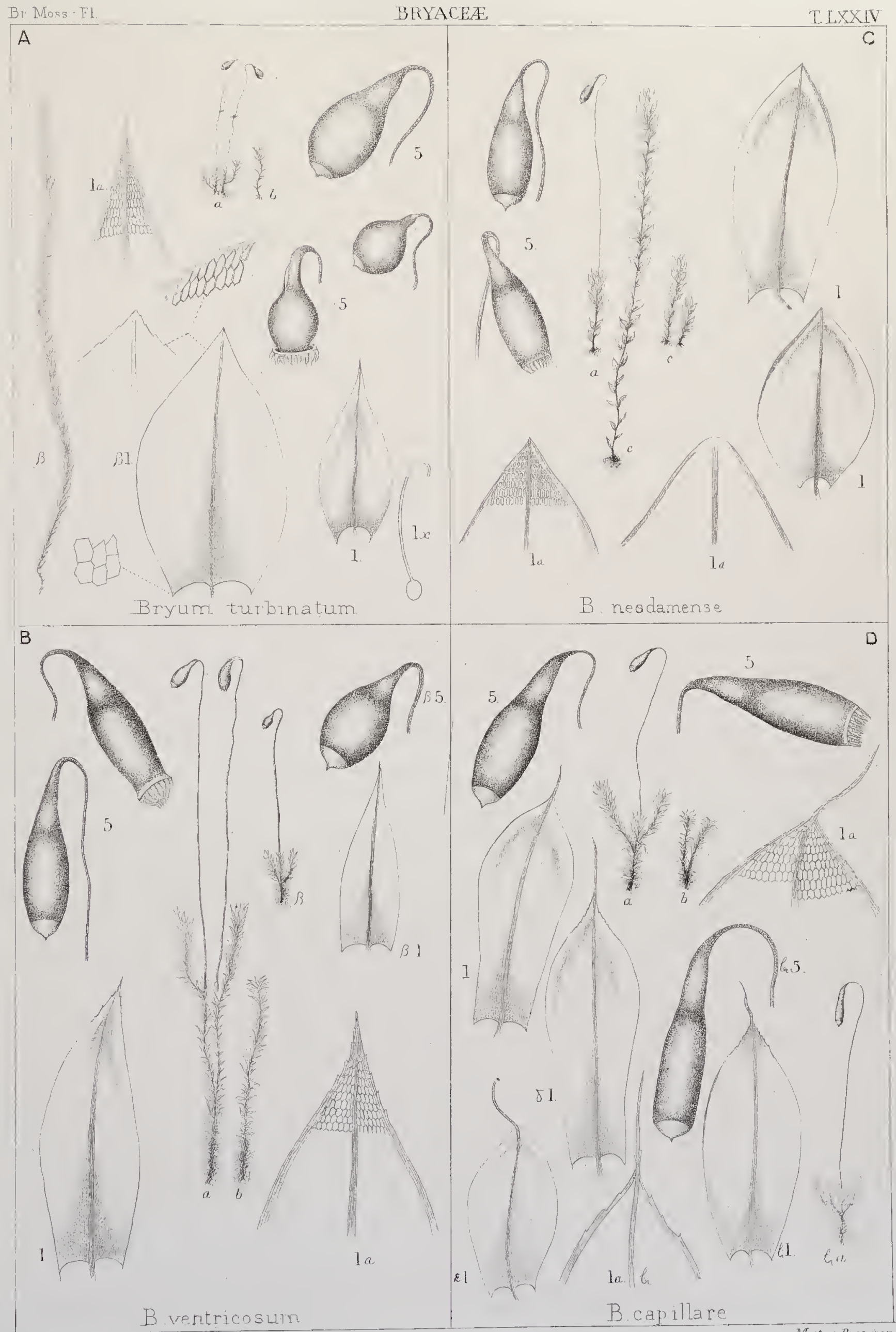





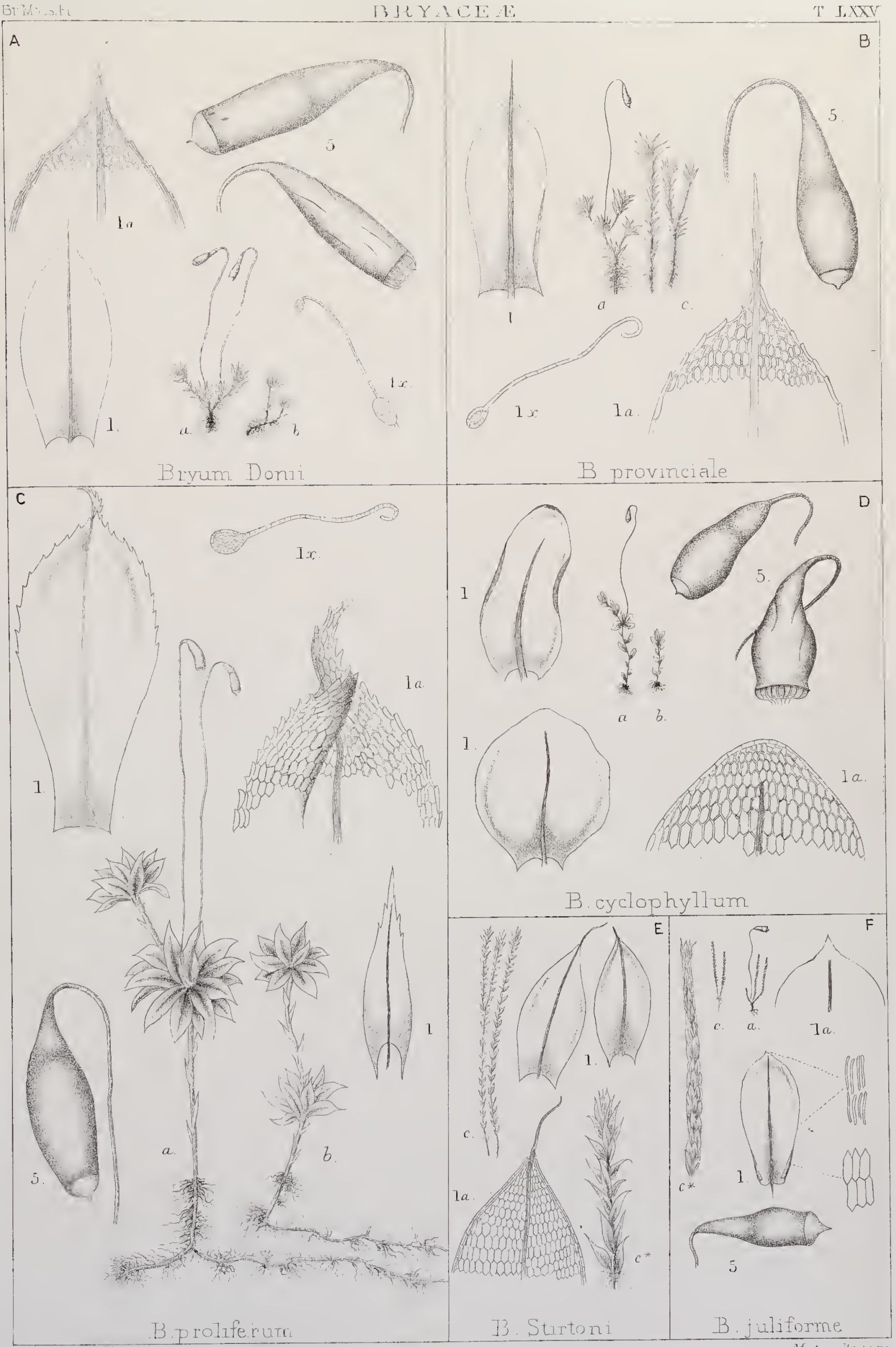



B A R T R A I A C E $\mathbb{E}$. 
CONOSTOMUM SWARTZ.

Conostomum boreale Sw.

BARTRAMIA HEDW.

1. Bartramia Oederi (Gunn.) Sw.

2. - stricta Brid.

3. - pomiformis (L.) Hedw.

4. - Norvegica (Gunn.) Lindb.

5. _._ ithyphylla Brid.

PHILONOTIS BRID.

1. Philonotis Wilsoni (Br.Sch.).

2. $\longrightarrow$ rigida Brid.

3. - cæaspitosa Wils.

4. - fontana (L.) Brid.

5. —_- seriata Mitt.

6. - calcarea Br. Sch.

7. - adpressa Fergus.

BREUTELIA SCHIMP.

Breutelia chrysocoma (Dicks.) Lindb.

CATOSCOPIUM BRID.

Catoscopium nigritum (Hedw.) Brid. 


\section{Fan. I6. BAR'TRAMIACE无.}

Perennial mosses growing in tomentose cushioned tufts, innovating below the inflorescence and finally becoming dichotomous. Leaves in 5-8 rows, ovato-lanceolate or subulate, serrated at margin and often at back of nerve, mamilloso-papillose on both sides, very rarely smooth, the papilla being near the transverse wall at end of cell, the upper cells small rectangular or quadrate, the basal smooth, hexagonorectangular. Calyptra small, cucullate, very fugacious. Capsule more or less spherical, without a neck, cernuous or rarely erect, with an oblique mouth, when dry pressed in at base, striated and furrowed, rarely smooth. Annulus none. Lid minute, muticous. Peristome rarely none or simple, teeth $\mathrm{I} 6$, inserted below the mouth of capsule, often between the lamellæ in the upper half, having on the inner side, central thickened deposits; endostome shorter, carinate-plicate, the processes cleft into two diverging legs, cilia none or ill-developed. Male infl. terminal discoid, rarely gemmaceous.-Inhabiting the earth, rocks or bogs.

This family of over 200 species is one of the most beautiful among mosses, especially in the larger forms, and is marked by the globose fruits which before ripening are often covered with a glaucous bloom. It is widely distributed, but about half the species are natives of S. America, and we have 22 in Europe.

Sect. I. BARTRAMIEÆ. Capsule large, striato-sulcate, teeth lanceolate; leaf-cells papillose.

\section{CONOSTOMUM Swartz.}

Schrad. neu Journ. Bot. I, P. III, 26 (1806).

Plants erect, straight, densely crowded in small fastigiate tufts, tomentoso-radiculose. Leaves in 5 rows, imbricated, lanceolate carinate, with the areolation of Bartramia. Calyptra cucullate, long persistent. Capsule elevated on a tall seta, cernuous, turgidly obovate, striate; lid minute with a short beak. Peristome simple of 16 teeth, long lineal-lanceolate, connivent into a cone and bound together at apex.

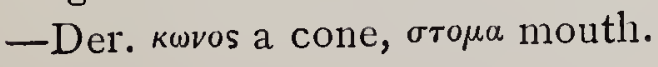


A genus closely allied to Bartramia and depending chiefly on the elegant dome-like arrangement of the teeth of peristome. Four more species are recorded, natives of S. America and Australia.

\section{CONOSTOMUM BOREALE Swartz.}

Dioicous; compactly tufted, slender, fragile. Leaves in 5 rows, narrow lanc., cuspidate, serrate at apex. Caps. obovate, striate, deeply furrowed. (T. LXXVI, A.)

Syn.-Bryum tetragonum Dicks. PI. crypt. Fasc. II, 8, t. 4, f. 9 (I79o). Wither. Bot. arr. 3 ed. iii, 835 (I7y6). BRID. Musc. rec. II, P. III, 59 (I803).

- Grimmia conostoma Sm. F1. brit. II69 (I804) ; Eng. Bot. t. II35.

Conostomum boreale Swartz in Schrad. neu Journ. Bot. i, P. III, 26, t. 5 (I806). Schwaeg. Suppl. I, P. I, 79, t. 20 (I8II). WAHLEN. F1. 1app. 3I7, t. 2 I (I8I2), F1. carpat. 233 (I8I4). Hook. TAYL. Musc. br. 20, t. IO (I8I8). BRID. Bry. univ. i, I50 (I826). Hook. Fl. scot. P. 2, I25 (I82I), Br. F]. ii, I7. Hueben. Musc. germ. I57 (1833). Gray. Nat. arr. Br. pl. i, 7 I9 (I82I). DE Not. Syllab. 223 (I838), Epilogo 267 (I869). NeEs HoRnsch. Bry. germ. ii, P. I, p. 22, t. I3 (I827). C. Muell. Synops. i, 469 (I849). Wils. Bry. brit. 284 , t. Io (I855). Schimp. Synops. 42 I (I860), 2 ed. 514. BERK. Handb. br. m. I69 (1863). HobK. Syn. br. m. I32 (1873). JURATz. Laubm. oester.-ung. 330 (I882). Lesq. James Moss. N. Amer. 207 (I884). Husn. Musc. gall. 264, t. 73 (I890). Limpr. in Rabenh. D. kr. fl. Laubm. ii, 55 I (1893).

Conostomum arcticum SWARTz in BRID. Sp. musc. I, I27 (I806).

Bartramia conostona BR. Sch. Bry. eur. fasc. I2, p. I6, t. 7 (1842). RABEN. D. kr. fl. ii, S. 3, I9I (1848).

Conostomum tetragonum Lindi. Oefv. K. Vet.-Ak. Foerh. I863, p. 8.

Dioicous; compactly tufted, glaucous green above, brown at base; plants slender, fragile, fastigiate. Leaves densely crowded in 5 rows, erect, rigid, the lower lanc., gradually becoming longer upwards, narrowly lanc., serrate at apex, acute, carinate; nerve reaching apex, in the upper leaves excurrent in a long point and slightly serrate at back, leaf-cells rectangular; perich. bracts larger, thinner with a thin nerve. Seta pale red, caps. turgidly obovate, pale brown, deeply sulcate; peristome inserted far below the mouth, teeth I6, purple, linear-lanc., distant from each other at base, connate at apex. Male infl. round, bracts from a broad base, concave, lanceolate, innermost shorter, laxly areolate.

НАв.-Damp peaty places on the higher Scotch mountains. Ben Lomond, Ben Lawers, Craig Chailleach, \&c. Fr. 7-8.

Characterized by the peristome, the teeth of which arch gracefully inward and are united together by their points. As the original name tetvagonum expresses an error, I have maintained the later one of Swartz. 


\section{BARTRAMIA Hedw.}

Descr. Musc. frond. ii, I I I (I789).

Stem erect dichotomous branched, the cuticle of small cells. Leaves in 8 rows, opake, lanceolate or lineal-subulate, papillose; cells small rectangular. Capsule globose, striate, sulcate; peristome rarely none or simple, teeth $\mathbf{I} 6$, endostome a narrow basal membrane with I 6 carinate processes shorter than the teeth, finally separating into two divergent legs, cilia rarely present. Inhabiting the ground or rocks.Der. after John Bartram, of Pennsylvania, who sent mosses to Dillenius.

\section{Clavis to the Species.}

Leaves smooth on both sides.

Oederi.

papillose.

Leaves not sheathing at base.

Leaves rigid, capsule regular, erect. crisped, capsule irregular, inclined. sheathing at base.

Seta straight. Leaves plane at margin.

short and arched. Leaves revolute at margin.

stricta. pomiformis.

itlyphylla. norvegica.

Sect. I. OREADELLA C. Muell. Stems fastigiate branched. Leaves complicate-carinate, revolute at margin, smooth.

\section{BARTRAMIA OEDERI (Gunn.) Sw.}

Synoicous; in large dull green tufts. Leaves lanceolate, smooth, patenti-recurved, revolute at margin, carinate, serrate at apex. Capsule small globose. (T. LXXVI, B.)

SYN.-Bryum foliis striatis acuminatis reflexis, capsulis spharicis subnutantibus, maturitate striatis OEDER Fl. dan. II, p. 9, t. $47^{8}$ (I769).

Bryum Oederi Gunn. Fl, norveg. n. 1005 (1772).

Bryum pomiforme $\beta$. Oederi VilL. Pl. Dauph. iii, 878 (1786).

Bryum lacerum ViLL. op. c. 879 .

Bartramia gracilis Floerke, Schrad. Journ. Bot. ii, I7 I (I799). Sm. Eng. Bot. t. I826. WAHLENB. Fl. lapp. 363 (1812), Fl. carpat. 354 (1814). Hook. TAYL. Musc. brit. 86, t. 23 (I818). Hook. Fl. scot. P. 2, I4O (I821), Br. Fl. ii, 67 (1833). GraY Nat. arr. br. pl. i, $75^{\circ}$ (1821). C. Muell. Synops. i, 508 (I849). Новк. Synops. 132 (I873).

Mnium gracile Funck Fasc. crypt. IV, p. 93.

Bartrania Oederi Swartz in Schrad. Journ. Bot. ii, I8I, t. 3 B, f. 5 (I800). Brid.'Musc. rec. II, P. III, I36, t. 2, f. 9 (I803), Sp. musc. III, 86 (I817), Mant. I16 (1819), Bry. univ. ii, 46 (1827). WeB. MOHR Bot. Tasch. I 76 (1807). ROEHL. Deutsch. Fl, iii, 89 (I813). SchWaEg. Suppl. I, P. II, 49, t. 59 (I816). MART. Fl. cr. Erl. 58 (I817). 89 (I8I3). Sch WAEG. Suppl. Huost. 36, t. 24 (I82I). Hueben. Musc. germ. 5 ro (I833). DE Not. Syllab. 99 (1838), Epilogo 264 (I869). BR. Sch. Bry. eur. fasc. 12, p. 12, t. 3 (1842). Rabenh. D. kr. fl. ii, S. 3 , I90 (I848). WILs. Bry. brit. 282, t. 23 (I855). Schimp. Synops. 420 (I860), 2 ed. 542. BERK. Handb. br. m. I7 I t. I6 (1863). MILDE Bry. siles. 239 (I869). 
HoвK. Synops. 2 ed. I49 (I884). JuRATZ. Laubm. oester.-ung. 329 (1882). Lesq. James Moss. N. Amer. 205 (1884). Boul. Musc. de Fr. i, 219 (1884). HusN. Musc, gall. 266, t. 73 ( 1890$)$.

Bartramia longiseta BRID. Musc. rec. II, P. III, 136, t. 2, f. Io (1803).

Bartramia alpina Schleich. Cent. IV, n. I7.

Bartramia subintegrifolia P. Beauv. Prodr. 44 (1805).

Bartramia grandiflora SchwaEg. Suppl. I, P. II, 48, t. 58 (I816).

Plagiopils Oederi Limpr. in Rabenh. D. kr. fl. Laubm. ii, 548 (1893).

Synoicous; tall and slender, densely crowded in large dull green tufts variegated with fuscous, interwoven below with ferruginous tomentum. Leaves patulous and recurved, rather distant, twisted when dry, soft, narrowly lanceolate, complicate-carinate and serrate towards apex, margin subrevolute, cells quadrate and rectangular, smooth; nerve ending in the point. Caps. on a slender purple seta, slightly cernuous, small globose, when dry and empty ovate-oblong, deeply sulcate; lid small conical; peristome reddish, smooth.

HAB.-Wet calcareous rocks in mountains. Fr. 6-7.

White Force, Teesdale (Nowell)!! Stroneuch rocks, Glen Lyon (Hunt I872)!! Longsleddale, Westmoreland (Binstead I886)!!

This is readily distinguished by the leaf cells being smooth on both sides, and the plants are sometimes loaded with capsules.

Sect. 2. EUBARTRAMIA. C. Muell. Stems dichotomously branched. Leaves straight, erect, minutely areolated.

\section{BARTRAMIA STRICTA Brid.}

Synoicous; in short dense glaucous-green tufts. Leaves straight, erect lanceolate-subulate, revolute at basal margin, serrate above. Caps. regular, erect, peristome simple. (T. LXXVII, A.)

SYN.-Bartramia stricta BRID. Musc. rec. II, P. III, I32, t. I, f. 5 (I803), Sp. musc. III, 85 (I8I7), Mant. II6 (I8I9), Bry. univ. ii, 45 (I827). Schwaeg. Suppl. I, P. II, 53, t. 60

(I8I6). Hueben. Musc. germ. 509 (I833). DE Not. Syllab. 100 (1838), Epilogo 266 (1869). Br. Sch. Bry. eur. fasc. I2, p. Io, t. I (1842). Rabenh. D. kr. fl. ii, S. 3, Igo (1848). C. Muell. Synops. i, 500 (I849). Schimp. Synops. 417 (I860), 2 ed. 509 , Husn. Mouss, nord-ouest 133 (I873), Musc. gall. 265, t. 73 (189o). Hoвk. Synops. I 28 (1873). Juratz. Laubm. oester.-ung, 326 (I882). Boulay Musc. de Fr. 22I (I884). Lesq. James Moss. N. Amer. 20.5 (I884). Limpr. in Rabenh. D. kr. fi. Laubm. ii, 545 (1893).

Bartramia strictifolia TAYL. in Lond. Journ. Bot. I846, p. 54.

Synoicous; in broad cushioned tufts, glaucous-green above, brownish below with rufous tomentum and earth at base; stem short rigid. Leaves erecto-patent, from a narrow ovate base, rigid, fragile, 
the comal larger, lanceolate-subulate, minutely serrate above; nerve yellow, excurrent in the subula, cells rectangular papillose on both sides, $3-5$ rows at basal angles laxer and more quadrate. Seta straight, quadrangular at summit; caps. erect or slightly cernuous, ovato-globose, regular, castaneous, finely striate, contracted and sulcate when dry; lid convex or mamillar; peristome orange, sometimes perforated in the dorsal line, endostome wanting.

$\mathrm{H}_{\mathrm{AB}}$.-On earth and rocks in hollow ways, very rare. Fr. 5.

Near Maresfield, Sussex (Davies 1864)!!

A very distinct moss, inhabiting principally the Mediterranean region; in habit it resembles $B$. ithyphylla, but differs in the non-sheathing base of leaf.

\section{BARTRAMIA POMIFORMIS (L.) Hedw.}

Autoicous; dichotomous fastigiate-branched. Leaves crisped when dry, linear lanceolate, scabrous, serrated. Capsule cernuous, spherical. (T. LXXVI, C.)

Syn.-Muscus trichodes medius, capitulis spharicis Doody RAY Synops. App. 243 (I69o).

Bryum trichoides virescens, erectis majusculis capitulis maliformibus DiLl. Cat. Giss. 224 (I 7 I 8).

Bryum capillaceum, capsulis spharicis Dill. Hist. musc. 339, t. 44, f. I A-B (I74I) et Herb.

Brytm pomiforme L. Sp. pl. I I 5 (I753), Syst. Nat. ii. 7o. Huds. Fl. angl. 404 (I762). Weiss Crypt. goett. I8I (I770): Neck. Meth. musc. 208 (I77 I). Wither. Bot. arr. ii, 67I (I776). LiGHTF. Fl. scot. ii, 7I7 (1777). WEBER. Spic.fl. gott. xI9 (I778). REI.HAN Fl. cant. Suppl. 3, то (I793). VILL. Pl. Dauph. iii. 878 (I786). Аввот Fl. bedf. 240 (I798). Hull Br. fl. P. 2, 259 (I799).

Webera pomiformis HEDw. Fund. ii, 95 (I782). RoTH Tent. fl. germ. i, 477 (I788).

Mnium poniforme L. Jun. Meth. musc. $36_{4}\left(\mathrm{I}_{7} 87\right)$.

Bartramia foniformis HEDw. Sp. musc. I64 (I8or). BRID. Musc. rec. II, P. III, I3I, t. I, f. 3 (1803), Sp. musc. III, 83 (18I7), Mant. II6 (I8Ig), Bry. univ. ii, 39 (1827). SM. Fl. brit. I 540 (1804), Eng. Bot. t. 998 . TurN. Musc. hib. I08 (1804). SchwaEg. Suppl. I, P. II, 45, t. 68 (I8I6). Hook. TAYL. Musc. brit. 85, t. 23 (18I8). Hook. Fl. scot. P. 2, p. I39 (182I), Br. fl. ii, 66 (1833). GraY Nat. arr. Br. pl. i, 750(182I). HuebeN. Musc. germ. 506 (I833). DE Notr. Syllab. 99 (I838), Epilogo 263 (I869), BR. Sch. Bry. eur. Fasc. I2, p. 13 , t. 4 (I842). Rabenh. D. kr. fl. ii, S. 3, I9I (1848). C. Muell. Synops. i, 499 (1849). Wils. Bry. brit. 28I, t. 23 (1855). Schimp. Synops. 4I8 (I860), 2 ed. 5I I. IBERK. Handb. br. m. I70, t. I6, f. 2 (I863). Milde Bry. siles. 238 (I869). Hobk. Synops. I3 I (I873). Husn. Mouss, nord-ouest I32 (1873), Musc. gall. 266, t. 73 (I89c). Juratz. Laubm. oester.-ung. 327 (I882). Boul. Musc. de Fir.219(1884). Lesq. James Moss. N. Amer. 206 (1884). Limpr. in Rabenh. D. kr. fl. Laubm. ii, 543 (1893).

Bartramia vulgaris LAMK DE CAND. Fl, franc. i, 509 (1865).

Bartramia crispa $\beta$ minor Sw. MSS. WeB. Mohr. Bot. Tasch. 272 (I807). WAHLEnb. Fl. lapp. 362 (1812).

Bartramia crispa $\beta$. pomiformis Lind. Musc. scand. I5 (1879).

Autoicous; in small cushioned tufts, soft, glaucous or yellow-green above, fuscous below with rusty tomentum. Leaves erecto-patent and 
patulous, when dry flexuose or curled, gradually lanc.-subulate, carinate, sharply serrate, the margin revolute towards base, nerve excurrent in a spinulose arista, serrated at back. Caps. on a red seta, cernuous, globose, pale brown, deeply furrowed; lid conical, teeth of peristome rufescent, densely articulated, connivent when moist. Male infl. terminal, near the female.

HAB.-Stony banks and clefts of rocks, not uncommon. Fr. 5 .

Var. $\beta$. crispa (Sw.)

Plants taller, more slender in laxer tufts; leaves less crowded, longer, twisted and curled when dry, branches often longer than the seta.

Syn.-Bartramia crispa Sw. Musc. suec. 73 (1799). Bridel, Schwaegrjchen, Lindberg, \&c.

Bartramia hercynica Floerke in Schrad. Journ. ii, I7 I (1799).

Bartramia incurva Hoppe in StURM D. f. II, 6.

Bartramia erispa a major WEB. MонR Tasch. I73.

Bartramia poniformis a major HooK. TAYL. Musc. brit.

НАв.-Wet stony places on mountains.

Corrymulzie, Aberdeen (Syme 185I)! Teesdale, Blea beck (Baker 1856)! Ben Voirlich (Hunt $\mathrm{r} 865)$ !! Helvellyn (Hunt 1862)!!

Sect. 3. VAGINELLA C. Mull. Stems dichotomous. Leaves from a sheathing laxly areolate base, erect, suddenly reflexed, minutely areolate.

4. BARTRAMIA NORVEGICA (Gumn.) Lindb.

Autoicous; stem elongated with irregular branches; leaves spreading from an erect dilated pale sheathing base, linear-subulate, serrated, nerve excurrent; seta short curved. (T. LXXVI, D.)

SYN.-Bryum foliis nollibus subulatis, sctis brevissimis ularibus, capsulis ovatis HALLER Hist. st. helv. n. 1802 , t. 45 , f. 8 ( 1768$)$.

Bryum foliis subulatis capsulis spharicis stratis in pednnculis brevibus OEDER Fl. dan. iii, t. 538 , f. 3 (I 770$)$.

Bryum norvegicum GuNN. Fl. norveg. ii, $\mathrm{r}_{3} 8$ (I 772 ).

Bryun laterale LightF. Fl. scot. ii, 727 (I777).

Bryum pendulum OEDER Fl. dan. v, t. 823 (I780).

Webera Halleriana HeDw. Fund. II, 95 (I782).

Webera clandestina Henw. op. c. I04, t. 6, f. 30 (I782).

Bryum recurvum WULF. in JAcQ. Collect. ii, 224 ( $\mathrm{I} 788$ ).

Bryum alpinum WuLF, in Berlin Schrift. iii, I, 156 .

Bartramia Halleriana Hedw. Descr. ii, III, t. 40 ( 1789 ). Swartz Musc. suec. 74 (I799), et in Schrad. Journ. Bot. I80o, t. 3 B, f. 6. BRID. Musc. rec. II, P. III, I37, t. 2 , f. II (1803), Sp. musc. III, 78 (I817), Mant. Ir 5 (I8r9), Bry. univ. ii, 33 (I827). SM. FI. brit. I339 (1804), Eng. Bot. t. 997. Turn. Musc. hib. Iog (r804). P. Beauv. Prodr. 43 (I805). Web. Mohr Bot. Tasch. 275 (I807). Wahlenb. Fl. lapp. 362 (I8I2), FI. carpat. 352 (I8I4). Roenl. D. fi. iii, 89 (I8I3). Schwaeg. Suppl. I, P. II, 64 (I8I6) 
Hook. TAyl. Musc. brit. 87, t. 23 (I8r8). Hook. Fl. scot. I 40 (I82I), Br. fl. ii, 67. Gray Nat. arr. br. pl. i, 75I (1821). Hueben. Musc. germ. 504 (1833). DE Not. Syllab. 98 (1838), Epilago 262 (I869). BR. Sch. Bry. eur. fasc. I2, p. 14, t. 5 (r842). C. Muell. Synops. i, 495 (r847). Rabenh. D. kr. fl. ii, S. 3, Igr (r848). Wils. Bry. br. 28 r, t. 23 (I855). Schimp. Synops. 4 I 9 (1860), 2 ed. 512. BERK. Handb. br. m. I7o (1863). MrLDE Bry. siles. 239 (1869). Hobk. Syn. br. m. I3 (1873). Juratz. Laubm. oester.-ung. 328 (r882). Boul. Musc. de Fr. 2 I8 (r884). LesQ. James Moss. N. Amer. 206 (1884). Husn. Musc. gall. 266, t. 74 (1890). Limpr. in RABEnH. D. kr. fl. Laubm. ii, 54: (1893).

Bryum Bartramia GMEL. Syst. nat. ii, I335 (I79I).

Mnium laterale HoFfM. Deutsch. fl. ii, 54 (1796).

Bryum pomiforme $\beta$. Halleri Vill. P1. Dauph. iii, 878 ( ${ }_{7}{ }^{86)}$ ).

Bartramia lateralis ClaIRv.

Bartramia Norvegica LrNDB. in Oef. Vet.-Ak. Foerh. xx, 389 (I863).

Autoicous; in large swollen soft bright green tufts, with dense ferruginous tomentum. Leaves from a whitish subvaginant base patent or subsecund, subflexuose when dry, long and setaceous, the margin revolute above the sheathing base, sharply serrate at upper part, cells rectangular, nerve excurrent. Caps. on a short arcuate seta, often in pairs, spherical, pale brown, not striate, furrowed; lid minute convexconic; teeth dark brown, lanc.-subulate. Male infl. terminal, near the female.

HAB.-Damp rocks on mountains, as about Snowdon and Lake district. Fr. 7 .

\section{BARTRAMIA ITHYPHYLLA Brid.}

Synoicous; in small dense fastigiate tufts. Leaves from a white sheathing erect base; lanc.-subulate, straight, finely serrulate, nerve broad, continuous. Caps. oblique. (T. LXXVI, E.)

Syn. Bartramia pomiformis (non L.) Swartz Musc. suec. 75 (1799), et in Schrad. Journ. I800, II, t. 3, B. f. 4. WahlenB. Fl. lapp. 362 (r8r2), Fl. carpat. 353 (I8I4).

Bartramia ithyphylla Brid. Musc. rec. II, P. III, I32, t. I. f. 6 ( 1803 ), Sp. Musc. III, 85 (I8r7), Mant. Ir6 (r8I9), Bry. univ. ii, 43 (r827). P. Beauv. Prodr. 43 (r805). Schultz IFl. stargard. 355 (I806), Eng. Bot. t. I7 ro. Roehl. Deutsch. f. iii, 88 (1818). Schwaeg. Suppl. I, P. II, 3 I, t. 60 (1816). Hi, 1833 ). Funck Moost. 36, t. 24 (I82I) Hook. Fl. Scot. P. 2, r 40 (r82r), Br. fl. ii, 66 (r833). Fusc. germ. 508 (I833). De Not. Gray Nat. arr. br. pl. i, 750 (I82r). Br. ScH. Bry. eur. fasc. r2, p. Ir, t. 2 (I842). Syllab. roo (1838), Epilogo 265 (r869). BR. Sch. Br. Synops. i, 493 (1849). Wils. Bry. RABEnh. D. kr. fl. ii, S. 3 , r9o (rops. 418 (r860), 2 ed. 5 ro. BERK. Handb. br. m. r6g (r863). MiLDe Bry. siles. 238 (r869). Hobk. Synops. 132 (1873). Juratz. Laubm. (I882). Boulay Musc. Fr. 220 (r884). Leso. James Moss. N. Amer. 205 (r884). Husn. Musc. gall. 265, t. 73 (r89o). Limpr. in Rabenh. D. kr. fl. Laubm. ii, 539 (1893).

Synoicous; in dense bluish-green or yellowish-green tufts with ferruginous tomentum, the branches fastigiate. Leaves erecto-patent rigid, straight when dry, from a white dilated sheathing base suddenly lineal-subulate, the margin flat and sharply serrulate, nerve broad, 
occupying almost the whole subula, cells at base, linear, above rectangular. Caps. inclined, spherical, striate, pale brown, when dry oblong incurved, deeply sulcate, lid conical, muticous; teeth rufo-fuscous, endostome orange, half length of teeth.

$\mathrm{H}_{\mathrm{AB}}$.-On the ground and clefts of rocks in the mountains. Common. Fr. 6. Resembling a small state of $B$. pomiformis, but readily distinguished by the straight subulate leaves with sheathing white bases.

\title{
3. PHILONOTIS Brid.
}

Bry. univ, ii, $\mathrm{I}_{5}(\mathrm{I} 827)$.

Plants short and decumbent or tall and erect, the fertile apex with verticillate or fascicled innovations, the rest dichotomous with binate innovations, and shoots placed spirally below the male infl., densely tomentose, the cuticular cells of stem large and vesicular. Leaves uniform or biform, one or both cell-angles with a papilla. Caps. cernuous globose, striate; cilia of endostome distinct binate. Growing in bogs or wet places.-Der, $\phi \iota \lambda \epsilon \omega$ to love, vorıa moisture.

A genus of some 80 species, in the larger forms possessing a very natural habit, and some so closely allied that considerable difficulty is experienced in drawing up their distinctive characters. Most of them require a permanent supply of moisture, and hence they thrive best in moorland bogs or where trickling springs permeate the surface.

\section{Clav1s to the Species.}

Autoicous. Dioicous.

Very small, gymnostomous.

Short, fasciculate-branched, peristomate.

Leaves densely imbricated.

Bracts of male infl. acute, nerved to point.

Leaves falcato-secund, laxly areolate.

- secund, densely areolate.

- obtuse, nerve vanishing.

Upper leaves imbricated, erecto-patent.

— distant, erecto-appressed, decurrent.

\author{
Wilsoni. \\ rigida. \\ calcarea. \\ caspitosa. \\ fontana. \\ seriata. \\ adpressa.
}

Sect. I. PHILONOTULA C. Muell. Plants dwarf, procumbent, fasciculate, and irregularly branched, with erect or secund leaves. Synoicous or autoicous, $\precsim$ gemmaceous.

\section{PHILONOTIS WILSONI (Br. Sch.)}

Synoicous; minute, fasciculate branched. Leaves ovate-acuminate, nerved to apex. Caps. subpyriform, smooth, gymnostomous. (T. LXXVII, B.) 
Syn.-Glyphocarpa? cernua WILs. in Hook. Journ. Bot. iii, $38_{3}$ (I84 I). Name only.

Bartramidula Wilsoni BR. Sch. Bry. eur. fasc. 29-30, p. 3, t. I (1846). Wils. Eng. Bot. Suppl. t. 2919 (1847), Bry. brit. 276, t. 52 (I855). Schimp. Synops. 423 (I860), 2 ed. 516. BERK. Handb. br. m. I73 (1863). Hовк. Synops. I28 (1873). HuSN. Musc. gall. 267, t. 74 (189o). Limpr. in Rabes. D. kr. fl. Laubm. ii, 555 (1893).

Bartramia Wilsoni C. Muell. Synops. i, 479 (1849).

Bartramidula cermua LindB. Oefv. Vet.-Ak. Foerh. $186_{3}$, No. 7.

Synoicous; small slender procumbent at base, in little pale green lax tufts. Leaves erecto-patent or subsecund, lanceolate, acute smooth, margin flat, denticulate above; cells lax, elongate rectangular above, wider at base; nerve ending below the point. Caps. $2-5$ in one perichætium, very soft, globoso-pyriform with a short neck, on an arcuate seta, cernuous, pale brown, not striate, wrinkled when dry; lid very small plano-convex; peristome none.

HAв.-Heathy ground on mountains, rare. Fr. Io.

Connor hill, Dingle (Wilson I829)! Knockavohila, Kenmare (Taylor). Cwm Bychan, Harlech (Rev. T. Salwey i 84I)! Glen Dole, Clova (Croall).

Except in the stations quoted, this pretty little moss has only been recorded from the island of Fernando Po (Mamn); its delicate capsule is usually tinged with pink when growing, but this is lost in drying. About 30 species of this group are known.

\section{PHILONOTIS RIGIDA Brid.}

Autoicous; densely, cæspitose, glossy. Leaves erect, straight, lanceolate, serrulate with excurrent nerve. Caps. obliquely cernuous, striate. (T. LXXVII, C.)

Syn.-Philonotis rigida Brid. Bry. univ. ii, I7 (1827). Schrmp. Synops. 424 (1860), 2 ed. 5I7. DE Not. Epilogo 259 (I869). JuRatz. Laubm. oester.-ung. 33 I (I882). Boul. Musc. de Fr. 2 I7 (I884). Hobk. Synops. 2 ed. I49 (I884). HusN. Musc. gall. 268, t. 74 (I89o). Limpr. in Rabenh. D. kr. A. Luabm. ii, 558 (I893).

Bartramia rigida Bals. DE Not. Pugill. musc. I (1833). DE Not. Syllab. 102 (I838). Br. Sch. Bry. eur. Fasc. I2, p. 20, t. i I (I842). C. Muell. Synops. i, 47 I (I849). Wils. Bry. brit. 278 , t. 52 (I855). BERK. Handb. br. m. I7I (1863). HoBk. Synops. I 29 (I873).

Autoicous; in small tufts, glossy brownish green above and dense reddish tomentum at base. Stem short, vaguely and fasciculate branched below the inflorescence, fragile. Leaves crowded erectopatent, appressed when dry, rigid, lanceolate, shortly aristate with the stout excurrent nerve, margin sharply serrated, slightly reflexed ; cells papillose at upper end, narrowly rectangular above, laxer and wider at base. Perich. bracts few, shorter than vaginula, from a 
broadly ovate base, lanceolate-subula te. Caps. on a long red seta, large globose with a narrow mouth, striate, pale brown, lid convex apiculate; teeth of peristome shorter dark purple, incurved when dry, with interlamellar thickenings in the upper half, endostome orange, papillose. Male infl. near the female, gemmiform, bracts ovato-lanc.

HAB.-Wet rocks and sandy banks; rare. Fr. 6

Bantry (Miss Hutchins). Maghanabo Glen, Dingle (Wilson r829). Dunkerron and Killarney (Taylor)!! Mousehole cave, Penzance (Curnow). Beddgelert (Hunt)!! Friog, Monmouth (Percival i877). Arklow (Moore! Sulby Glen, Kirkmichael, Laxey and near Douglas, Isle of Man (Holt I886)!! Porthmear cove, W. Cornwall (Marquand $\mathbf{r} 880$ ).

This species is allied to $P$. marchica (W1LLD.) BRID. A moss which has been reported more than once as British, and ought to be found here, as it is met with throughout Europe, but hitherto it has not been identified among native specimens. P. marchica is dioicous, the leaves with plane margins, and acute pointed perigonial bracts; otherwise it resembles a slender state of $P$. fontana which has generally been mistaken for it.

Sect. 2. EUPHILONTIS. Plants more robust, erect; cuticle of stem formed of large leptodermous hyaline cells. Dioicous, $\delta$ discoid.

\section{PHILONOTIS CESPITOSA Wils.}

Dioicous; densely tufted, short and slender. Leaves biform, the appressed ovate with plane margins, the secund subfalcate, lanceolate, all non-plicate. Capsule horizontal. (T. LXXVII, E.)

Syn.-Philonotis caspitosa Wils. MSS. MILdE Bry. siles. 24 I (I869). HoBk Synops. I30 (1873). Husn. Musc. gall. 269, t. 75 (1890). Limpr. in RABenH. D, kr. fl. Laubm. ii, 570 (1893).

Philonotis fontana $\beta$. caspitosa Limpr. Krypt. fl. v. Schl. Ir6 (1875). HoBk. Synops. 2 ed. r50 (1884). Boul. Musc. de Fr. 2 I6 (1884).

Dioicous; in soft dense dull-green tufts, stems slender, $\mathrm{I}-2$ in. high, united by blackish-brown tomentum, the branches falcate at point. Leaves biform, the appressed leaves ovate, concave, pointed, with plane margins, the secund leaves subfalcate, lanceolate, with long points, all without plaits and the margins with distant small teeth; nerve thin, shortly excurrent; upper cells thick-walled, narrow, with a papilla at the lower angle, the basal oval and rectangular, smooth. Capsule resembling that of $P$. fontana. Male plants shorter, the bracts erectopatent, very broadly ovate, acutely pointed, nerved to the apex.

HAB.-Swamps and boggy heaths, rare and sterile. Fr. 6.

Walton Swamps, Cheshire (Wilson r860)!! Harts hill, Henfield, Grendon, Curdworth, footways near Hockley and Studley all in Warwickshire (Bagnall).

Resembling $P$. marchica in aspect and not found with fruit in this country. A section of the stem is not unlike that of Sphagnum subsecundum. 


\section{PHILONOTIS FONTANA (L.) Brid.}

Dioicous; in dense glaucescent or yellowish green tufts. Leaves biform, those of male shoot appressed, ovate acute, the rest erectopatent or subsecund, ovato-lanc., acute, $2-3$ plicate at base, nerve excurrent, denticulate with pairs of mamillæ. Bracts of male infl. broad obtuse, the nerve vanishing. (T. LXXVIII, B.)

Syn.-Muscus palustris, Adianto aureo affinis, scapis tenuibus, foliolis brevibus Ray Hist. i, I24, n. 6 (1686); Synops. 19, n. 4 (169o).

Muscus palustris cinereo-viridis, scapis longis tenuibus, foliolis brevissimis Ray Synops. 2 ed. 32 , n. Ig (1696).

Muscus stellaris ramosus palustris, pediculo aureo crecto, capitulo magno spharico RAY Op. c. 33, n. 28.

Hypnum palustre evectum trichodes, ramulis tcretibus clegantibus nujus DiLl. Cat. Giss. 220 (17 78 ).

Bryum palustre, scapis teretibus stellatis, capsulis maguis subrotundis Dill. Hist. musc. 340, t. 44, f. 2 (I 74 I) et Herbar.

Muium fontanum L. Sp. plant. I I Io (I753). WEISS Crypt. goett. I45 (I770). WiTHER. Bot. arr. ii, 664 (I776). LIGHTF. F1. scot. ii, 708 (I777). WEB. Spic. fl. goett. I2I (I778). HeDw. Fund. II, 94 (I782), Sp. musc. I95 (I80I). RELH. Fl, cant. 398 (I785). Roth Fl. germ. i, 474 (I788). HofFM. Deutsch. f.. ii, 54 (I795). Аввот Fl, bedf. 232 (I798). Hull Br. f. P. 2, 249 (I799). Brid. Musc. rec. II, P. III, 78 (1803). Wahlenb. Fl. lapp. 352 (I8I2), Fl. carp. 350 (I8I4).

Bryum fontanum Huds. Fl. angl. 404 ( 1762 ). Schreb. Sp. fl. lips. 75 (177I). Neck. Meth. musc. 209 (I77 I). Vill. Pl. Dauph. iii, 89o (i786). SibTh. Fl. oxon. 289 (I794), Eng. Bot. t. 39o. Swartz Musc. suec. 48 (I799).

Hyputm fontanum Schrank Baiers. fl. ii, 472 (1789).

Bartramia fontana Swartz in Schrad. Bot. Journ. ii, 183, t. 3 B.A. (180o). SMith Fl. brit. 1342 (1804). Turn. Musc. hib. 82 (1804). P. Beauv. Prodr. 43 (1805). Web. Mohr Bot. Tasch. 278 (I807). Voit Musc. herb. 82 (I8I2). Roenl. Deutsch. fl. iii, 69 (I8I3). Schwaeg. Suppl. I, P. II, 6r (I8I6). Hook. Tayl. Musc. brit. 87, t. 23 (I8I8). Brid. Sp. musc. III, 89 (I8I7), Mant. II6 (I8Ig). Gray Nat. arr. br. pl. i, 75 I (I82I). Hook. Fl. scot. P. 2, I40 (I82I). MAck. Fl. hib. P. 2, 34 (I833). DE Not. Syllab. IOI (I838). BR. SCH. Bry. eur. Fasc. I2, I8, t. $9(\mathbf{1} 842)$. RABEnh. D. kr. fl. ii, s. 3, I92 (1848). C. Muell. Synops. i, 474 (1849). Wils. Bryol. brit. 279, t. 23 (1855). Berk. Handb. br. m. I72 (1863). HовK. Synops. I 29 (1873).

Philonotis fontana: Brid. Bry. univ. ii, I8 (1827). Hueben. Musc. germ. 500 (1833). Schimp. Coroll. 86 (1856), Synops. 426 (1860), 2 ed. 519. Milde Bry. siles. 240 (1869). DE Not. Epilogo 256 (1869). Hobk. Synops. 2 ed. I50 (1884). Juratz. Laubm. oester.-ling. 332 (1882). Boulay Musc. de Fr. I, 215 (1884). Lesq. James Moss. N. Amer. 209 (1884). Husn. Musc. gall. 269, t. 74 (189o). Limpr, in Rabenh. D. kr. fl. Laubm. ii, 566 (1893).

Didymodon mollis Schimp. Syn. 2 ed. 167 (1876).

Dioicous; in wide dense yellowish or glaucous-green tufts, interwoven with ferruginous tomentum. Stem tall nearly simple or giving off several long branches below the infl. Leaves biform, the upper of the male shoot small ovate, appressed, bluntly acuminate, nerved to apex; those of the main branches erecto-patent or somewhat secund, ovato-lanc., acute or aristate with the excurrent nerve, the base with $I-2$ plaits on each side, the margin revolute in the lower half, bluntly toothed by pairs of mamillæ; cells elongated, with a papilla at the 
lower angle. Seta slender purple. Caps. inclined, ovato-globose, pachydermous, when dry curved and sulcate; lid small conic, teeth of peristome purple, finely papillose, the upper third with hemispherical thickenings between the lamellæ. Male infl. broadly discoid, inner bracts from an erect yellow base, shortly ovato-lanceolate, obtuse serrate, the nerve broad thin, vanishing.

НАв.-About springs and gravelly moorland bogs. Fr. 6-7.

Var. $\beta$. falcata Brid.

Branches hooked at apex. Leaves falcato-secund lanceolate-subulate, nerve stronger, rufescent, perigonial bracts acute with excurrent nerve.

Syn.-P. fontana var. falcata Brid. Bry. univ. ii, 21. Schimper, Wilson, C. Muell., \&c.

HaB.-Twll du (Hunt I865)!! near Killin (Binstead 1885)!!

Var. $\gamma$. capillaris Lindb.

Tufts small, lax., the stems extremely slender $\frac{1}{2}$ in. high. Leaves distant, uniform, lanceolate-subulate, not plicate, the margin plane.

SYN.-Philonotis capillaris LindB. in Hedwigia $\mathbf{1 8 6 7 , ~ p . ~} 40$ et in HARTM. Skand. fl. Io ed. ii, 46 (I87 I).

$\mathrm{H}_{\mathrm{AB}}$.-About springs and in the clefts of rocks.

Ben Arthur by Loch Long (Stirton I866)! Alderley. Cheshire (Hunt I863)!! Shanklin, Isle of Wight (Davies I865)!! Carnedd Dafyd, Caernarvon (Rev. A. Ley I887)!!

Var. $\delta$. compacta Schimp.

In compact swollen tufts, densely tomentose; stems slender. Leaves uniform, imbricated, shortly ovato-lanc., nerve reaching apex or excurrent, margin obsoletely serrulate.

Syn.-Phil. fontana var. compacta Schimp. Synops. 2 ed. 520. Hoвk. Syn. 2 ed. I 5 I.

Philonotis firma FERGUS. MS.

HAB.-Clova (Fergusson). Ben-mac-Dhui (Whitehead 1876)!!

This most Protean moss is the centre of a small group of closely allied species which are difficult to discriminate and as an aid in this direction an additional character of some importance has been found in the form of the bracts in the male inflorescence. $P$. pumila has been established as a species by several authors, but apparently only for dwarf forms of $P$. fontana.

\section{PHILONOTIS SERIATA Mitt.}

Dioicous; resembling $P$. fontana, in rather lax tufts. Leaves of male innov. ovate, rather obtuse, the rest longer, acute, arranged in 
spiral rows, appressed and with two deep plaits on each side at base. (T. LXXVIII, A.)

Syn.-Bryum lycopodiforme Schleich. Cat. pl. Helv. 2 ed. p. 28 ( 1807 ), name only.

Bartramia fontana var. falcata Hook. in Trans. Linn. Soc. ix, 317, t. 27, f. 4 (1808).

Philonotis seriata Mrtr. Journ. Linn. Soc. i, Suppl. 63 (185y). Hunr in Mem. Lit. Phil Soc. Manch. v, то3 (I872). Hobk. Synops. I30 (I873). Limpr. in Rabenh. D. kr. fl. Laubm. ii, 57 I (1893).

Dioicous; in stiffish yellow-green tufts with rufous tomentum, readily falling asunder, and with the habit of $P$. fontana. Leaves in spiral rows, imbricated when dry, erect or subfalcate, biform, those of the male innov. ovate, bluntish, the nerve vanishing, the rest deltoidovate, acutely pointed, the nerve thick, reaching apex or vanishing, all somewhat decurrent, concave, with two deep plaits at base on each side, margin revolute in lower third, bluntly toothed by single or double mamillæ; nerve very strong, rough at back, reaching to apex; cells above small and rectangular, with a mamilla at the lower and often also at the upper end, below laxer oval and longish with a central mamilla on both sides. Perich. bracts with the nerve excurrent. Caps. on a long strajght seta, cernuous, striate and furrowed, lid conic obtuse, peristome rufous, endostome orange, finely papillose. Male infl. thick, bracts erecto-patent, from a very concave broad base, ovate, obtuse, finely serrate, the nerve vanishing below point.

НАв.-Bogs in alpine moorlands, rare. Fr. 7 .

Ben-na-Bourd (Gardincr 1844). Glen Prosen hill and about springs at head of Clova (Fergusson I868)!!

A very beautiful moss, the spirally imbricated arrangement of the leaves giving the branches an amentiform appearance. It is found in the Alps, Tyrol, Styria, Norway and Lapland, and lias probably been overlooked as a form of $P$. fontana.

\section{PHILONOTIS CALCAREA Schimp.}

Dioicous ; tall glaucous-green. Leaves crowded secund, ovato-lanc., gradually tapering upivard, cancave, margins plane. Perigonial bracts acuminate, acute, nerved to apex. (T. LXXVIII, C.)

Syn.-Bartrania calcarea Br. Sch. Bry. eur. Fasc. I2, p. I9, t. Io (1842). C. Muell. Synops. i, 475 (I849). Rabenh. D. kr. fl. ii, S. 3, I93 (I848). Wils. Bry. brit. 280, t. 52 (1855). BERk. Handb. br. m. I72, t. I6 (1863). Hosk. Syn. I3 I (1873).

Philonotis calcarea Schimp. Coroll. 86 (1856), Synops. 427 (I860), 2 ed. 520. Milde Bry. siles. 24I (I869). DE NoT. Epilogo 256 (I869). JURATz. Laubm. oester.-ung. 333 (I882), Boul. Musc. de Fr. I, 2I4 (I884). Husn. Musc. gall. 270, t. 75 (I89o). Limpr. in Rabenh. D. kr. fl. Laubm. ii, 564 (1893). 
Dioicous; more robust, in large bright green tufts, with dense darkbrown tomentum. Leaves uniform, large, crowded, secund or subfalcate, ovato-lanc., acuminate, acute, those of male shoot often incumbent, smaller with shorter points; sharply serrate at margin, revolute at base and with a faint plait near the margin, the falcate leaves revolute on one side to point; nerve thicker and more solid; cells laxer, with weaker papillæ. Perich. bracts elongated, capsule horizontal, ovato-globose, with many striæ, lid conical obtuse; teeth of peristome from a broad base, reddish-yellow, endostome orange. Perigonial bracts from an erect yellow base, spreading horizontally, longly lanc., acutely pointed, nerved to the apex, finely serrate.

HaB.-Deep moorland bogs in limestone districts. Plentiful in Teesdale where it was first found by Dr. Spruce in 1843. Fr. 7 .

Very near to $P$. fontana, but the colour is so different that it has quite a distinct aspect. The laxer areolation, and acutely acuminate perigonial bracts are distinctive.

\section{PHILONOTIS ADPRESSA Fergus.}

Infl. unknown ; plants long, slender in loose tufts, without tomentum. Leaves uniform distant, appressed, broadly ovate nerved to apex, the point bluntish and incurved. (T. LXXVIII, D.)

Syn.-Philonotis adpressa (non Hook. Wils.) FERGUsson in lit. Hunt in Men. Lit. Phil. Soc. Manch. v. IO2 (I872). Hobk. Synops. I30 (I873). Limpr. in RABENH. D. kr. fl. Laubm. ii, 574 (1893).

P. fontana var. adpressa Ferg. Limpr. Krypt. fl. Schles. i, II6 (I875).

Plants slender elongated, dull or glaucous green, in loose tufts readily falling asunder and with scarcely any tomentum, and only a few short axillar shoots, the stems thin and brittle. Leaves uniform, loose and distant, appressed, broadly ovate, decurrent, very concave, the apex incurved bluntish or acute, margin revolute at base, serrate with mostly double mamillæ, nerve very strong ending just before the apex, very rough at back, with a single plait on each side at base; cells small ovoid above, oval and longish at base; in the greater part of the leaf the middle of the cell-lumen is strongly mamillose, in the upper cells the mamilla is near the lower end.

НАB.-About mountain springs, rare.

Glen Prosen and Glen Dole, Clova (Firgusson 1868). Glas Mheal, Perthshire (Hunt 1868)! Moy Laggan, Perthshire (Mrs. Farquharson I879)! Spring under Scaur-naGillean, Skye (Binstcad I885)!! Ben Lawers (Dixon I893). 
A peculiar plant coming nearest to $P$. seriata in the form and direction of the leaves. Bartramia (Philonotis) appressa Hook. fil. WiLs. a New Zealand moss, had been previously named by them Hypunn scabrifolium, which may be retained for it as Philonotis scabrifolia.

\section{BREUTELIA Schimp.}

Coroll. 85 (1856).

Plants robust, coated with rufous tomentum, irregularly branched. Leaves squarrosely patent in 8 rows, with $3-4$ deep plaits on each side, cells incrassate, linear. Capsule drooping, peristome as in Bartramia. Inhabiting the ground and wet rocks.-Der. after C. Breutel, bishop of Brueder-gemeinde.

A fine genus of about 80 species, most of them being natives of S. America. Our only species, so frequent with us, is quite rare on the Continent.

\section{BREUTELIA CHRYSOCOMA (Dicks.) Lindb.}

Dioicous; robust, in yellow-green tomentose tufts. Leaves dense squarrosely divergent, lanceolate, acuminate acute, nerve lost in the point. Caps. on a cygneous pedicel, ovato-globose. (T. LXXVIII, E.)

Syn.-Hypnum palustre erectum, coma lutea basi nigricante DiLl. in R.AY Synops. 3 ed. 83 (I 724 ), Hist. musc. 302 , t. 39, f. 36 (I74I) et Herbar.

Hypnum chrysocomum Dicks. Pl. crypt. brit. Fasc. II, I2 (I7go). P. Beauv. 62 (I805).

Mninm arcuatum Dicks. Op. c. Fasc. III, 2, t. 7, f. 3 (I793). Wiтн. Bot. arr. 3 ed. iii, $803(1796)$.

Bryum arcuatum Hull Br. Fl. P. 2, 255 (I799).

Mnium chrysocomum HeDw: Sp. musc. 74 (I80I).

Bartramia arcuata Swartz in Schrad. Journ. Bot. ii, I82 (r8or). Brid. Musc. rec. II, P. III, I40 (I803), Sp. musc. III, 79 (I8I7), Mant. II6 (I819), Bry. univ. ii, 35 (I827). Sm. Fl. bi it. I343 (I804), Eng. Bot. t. I237. Turn. Musc. hib. Iog (1804). Schwaeg. Suppl. I, P. II, 6I, t. 62 (I8I6). Hook. Tayl. Musc. br. 88, t. 23 (I8I8). Hook. Fl. scot. P. 2, I40 (I82I). GRay Nat. arr. Br.pl. i,75I (I82I). BR. Sch. Bry. eur. Fasc. I2, p. 15, t. 6 (I842). C. Muelz. Synops. i, 487 (I849). Wils. Bry. brit. 283, t. 23 (I855). BERK. Handb. br. m. I73 (1863). HоBK. Synops. I 29 (1873).

Breutelia arcuata Schimp. Coroll. 85 (I856), Synops. 427 (1860), 2 ed. 522. Milde Bry. siles. 240 (I869). DE Not. Epilogo 260 (I 869). Hoвk. Synops. 2 ed. I5 I (I 884). Boul. Musc. de Fr. I, 213 (IS84). HUSn. Musc. gall. 270, t. 75 (I89o). Limpr. in Rabeni. D. kr. fl. Lautu. ii, 553 (1893).

Breutelia chrysocoma LiNDB. Oefv. Vet.-Akad. foerh. I863. n. 7 .

Dioicous; plants robust in large irregular tufts, coated with ferruginous tomentum, yellow-green and glossy above, stems flexuosoerect or procumbent, irregularly branched, shorter branches patulous in whorls below the inflor., longer scattered throughout the stem. Leaves subvaginant at base, lanceolate, longly acuminate, with a thin 
nerve, squarrosely divergent, with $3-+$ deep plaits on each side at base, serrate at margin, nerve vanishing in the point; cells incrassate linear, at basal angles quadrato-hexagonal. Perich. bracts erect, not papillose, oblong-lanceolate. Caps. bent down on a short geniculate seta, ovato-spheric, leptodermous dingy-orange, striated and furrowed when dry; lid very small, deep red, conical, obtuse; teeth of peristome orange with hyaline points, endostome as in Bartramia. Male infl. thick and discoid, bracts from an erect base, divergent.

HAB.-Wet heaths and rocks in alpine moorlands and by waterfalls. Fr. 6, rare.

In fr. Lydford Falls (Greville)! Cromaglown (Wilson). Llyn Ogwen and Beddgelert. Trosachs (Mrs. Robertson).

This fine species is very seldom met with in fruit, but in a sterile form is frequent on subalpine moorlands where moisture is present, and in habit bears considerable resemblance to Hylocominm triquetrum.

Sect. 2. CATOSCOPIEÆ. Capsule very small, smooth and polished; teeth short and obtuse; leaf-cells smooth.

\section{CATOSCOPIUM Brid.}

Bryol. univ. i, 368 (I826).

Plants slender, compactly tufted, radiculose at base. Leaves erecto-patent, the cells incrassate, smooth, roundish-hexagonal. Capsule very small witl a short neck, horizontal, oval-spherical, hard, black and glossy. Calyptra narrowly cucullate. Peristome of 16 lanceolate short obtuse teeth, irregular at margin. Endostome abortive. Spores large smootl. Inhabiting mountain bogs and wet rocks.-Der. $\kappa \alpha \tau \omega$ downward, $\sigma \kappa \circ \pi \epsilon \omega$ to look. (T. LXXVII, D.)

The only species of the genus has some resemblance to Discelium in the capsule, but in its leaf-structure finds its most fitting place in Bartramiacer.

\section{CATOSCOPIUM NIGRITUM (Hed.) Brid.}

SYn.-Weissia nigrita Hedv. St. crypt. iii, 97, t. 39 (I792), Sp. musc. 72 (ISoI). Brid. Musc. rec. II. P. I, 80 (I798), Sp. musc. I, II9 (1806), Mant. 47 (1819). Roehl. Moosg. deutsch. I6 4 (1800), Deutsch. f. iii, 52 (1813), Ann. Wett. gesells. iii, IIo. Schwaeg. Suppl. I, P. I, 74 (I8II). Wahlen. Fl. lapp. 323 (I8I2). Hook. TAyl. Musc. brit. 43 t. I4 (I8I8). GRAY Nat. arr. br. pl. i, 729 (I82I). Hook. Fl. scot. P. 2, I30 (I82I).

Brvnm nigritum Dicks. Fasc. pl. crypt. III, 9 (I793). Wither. Bot. arrang. 3 ed. iii, 840 (1796). Hofk'M. Deutsch. A. ii, 33 (I796). Hull Br. f. P. 2, 266 (I796). P. Beauv. Prodr. 48 (1805).

Grimmia nigrita Sмrтн Fl. brit. iii, II95 (I804), Eng. Bot.t. I895. Roth. Fl. germ. iii, I 46 (1800). Web. Mohr Bot. Tasch. 147 (1807). Schkuhr Deutsch. Moos. 50, t. 26
(1810). 
Catoscopium nigritum Brid. Bry. univ. i, 368 (I826). NeEs Hornsch. Bry. germ. ii, P. 2, I92, t. 42 (I83I). Hueben. Musc. germ. I52 (I833). De Not. Syllab. 226 (I838), Epilogo 443 (I869). BR. Sch. Bry. eur. Fasc. I2 (I842). RabenH. D. kr. f. ii, S. 3, I88 (I848). C. Muell. Synops. i, 5 IO (I849). Wils. Bry. brit. 285, t. I4 (I855). Schimp. Synops. 405 (I860), 2 ed. 498. Berk. Hamb. br. m. I68, t. I5 (I863). Milde Bry. siles. 236 (I869). Hobk. Synops. I32 (I873). JuRAtz. Laubm. oester.-ung. 316 (I882). Boul. Musc. de Fr. I, 533 (I884). Lesq. James Moss. N. Amer. 2ir (I884). Husn. Musc. gall. 283, t. 79 (I890). Limpr. in Raben. D. kr. f. Laubm. ii, 5 I8 (I893).

Dioicous ; densely cæspitose, bright or olive green above, ferruginous and radiculose below; stem filiform, sparingly branched, uniformly leafy. Leaves erecto-patent, lanceolate acuminate, not decurrent, margin entire slightly recurved, nerve vanishing in the point; cells small, rectangular, quadrate at basal angles. Perich. bracts larger, semivaginant at base, lanc.-subulate, flat at margin. Caps. on a purple seta, horizontal or nutant, globose, very small, pachydermous, with a short curved neck, reddish-brown, finally black, shining, hard and brittle. Calyptra narrow, cucullate. Lid depresso-conic. Peristome of 16 incurved pale bluntly lanc. teeth, irregular at margin, endostome none or sometimes presenting a short membrane. Male infl. gemmiform, bracts, ovato-subulate.

HAB. - Wet mountain rocks and marshy heaths, not common. Fr. 7-8.

Ben-y-Gloe and Craig Ower, Blair Athol. Breadalbane range. Sands of Barry, Dundee (Don). Widdy bank, Teesdale (Borrer and Nowell). Southport Sands.

TAB. LXXVI. A. Conostomum boreale (Craigailleach, Braithwaite). B. Bartrania Oederi (Teesdale, Nowell). C. B. pomiformis (Abbey wood, Braithwaite). D. B. Norvegica (Cwm Idwell, Braithwaite). E. B. ithyphylla (Ben Lawers, Braithwaite).

Tав. LXXVII. A. Bartramia stricta (Maresfield, Davies). B. Philonotis Wilsoni (Clova Croall). C. P. rigida (Arklow, Moore). D. Catoscopium nigritum (Ben-y-Gloe, Horm). E. Phil. caspitosa (Walton Swamp, Wilson, and Breslau, Milde).

TAB. LXXVIII. A. Philonotis seriata (Clova, Fergusson). B. P. fontana (Tummel bridge, Braithwaite). C. P. calcarea (Teesdale, Braithroaite). D. P.adpressa (Skye, Binstead). E. Breutelia arcuata (Lydford, Holmes). 



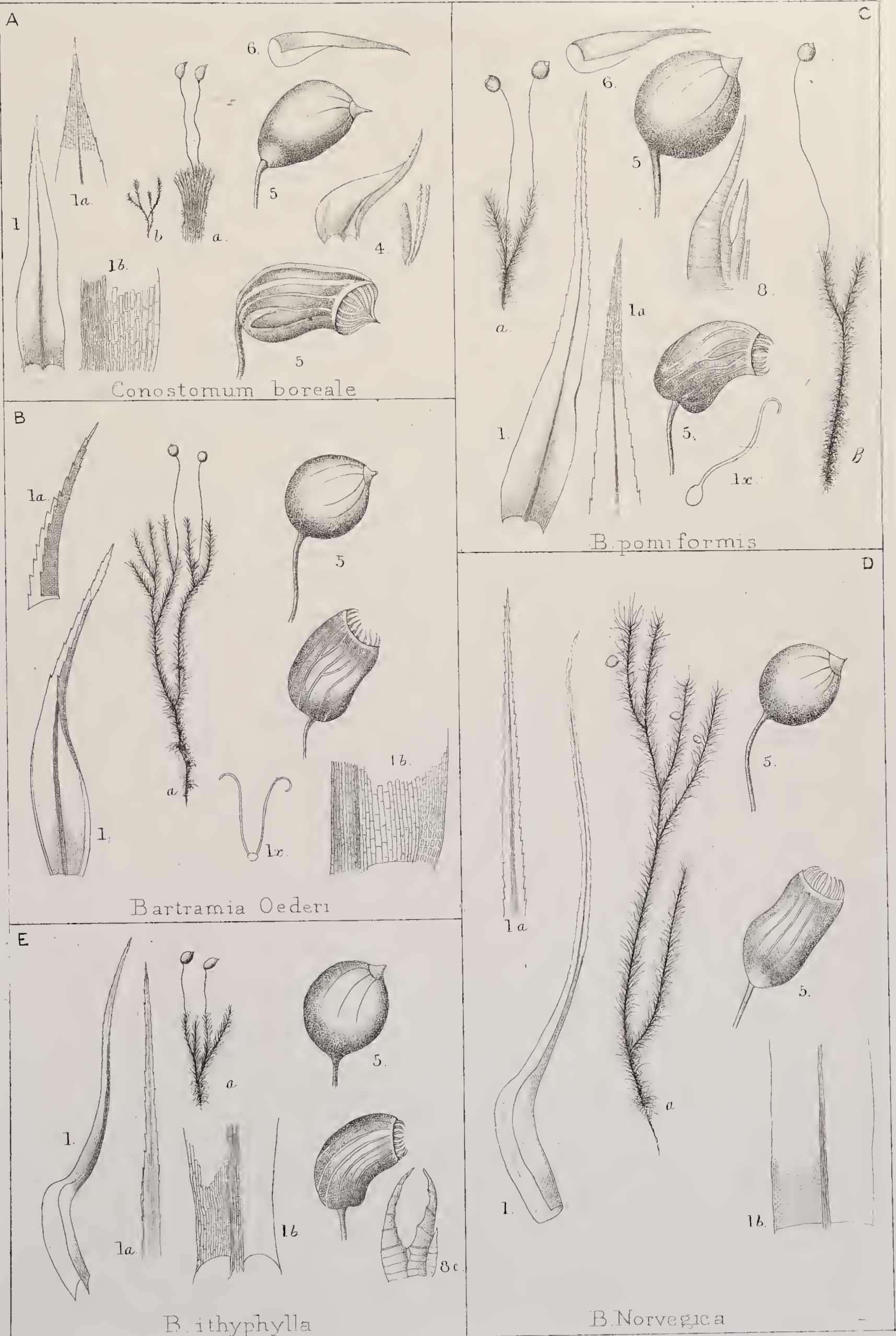





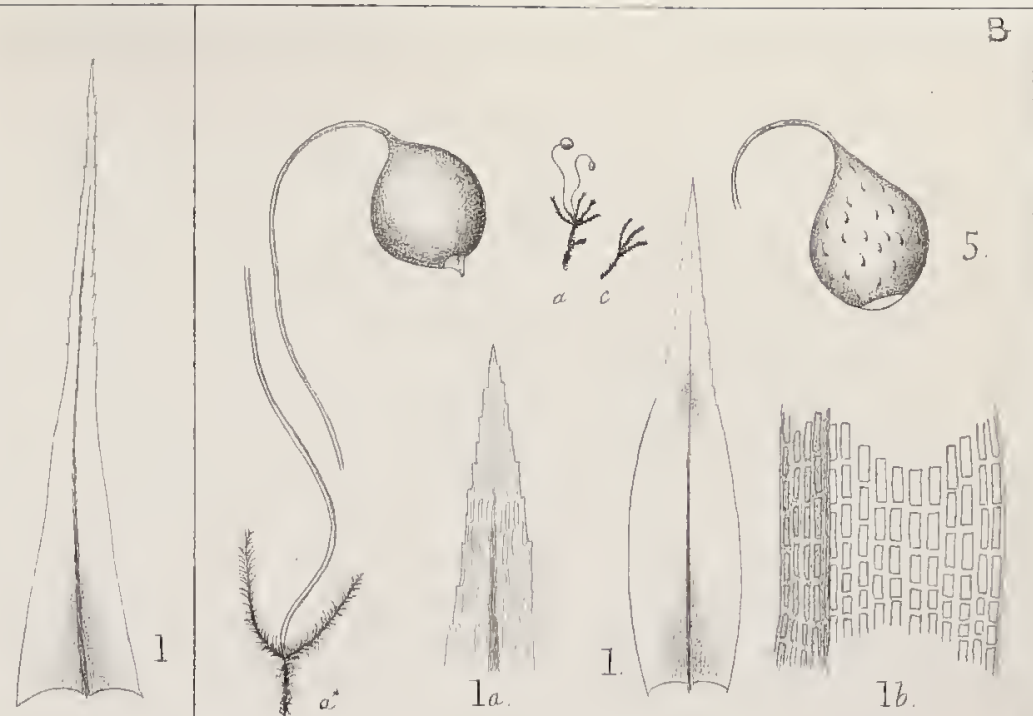

5.

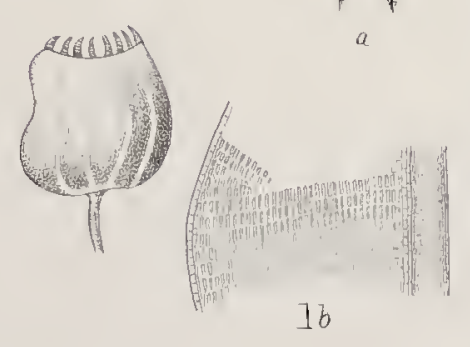

Bartramia stricta

C

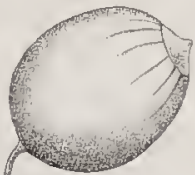

5
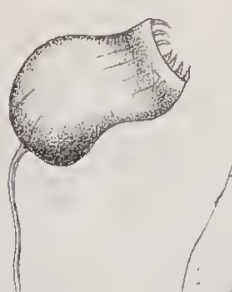

2

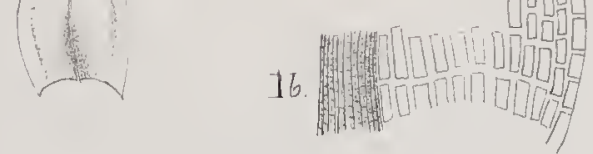

P. rigida.

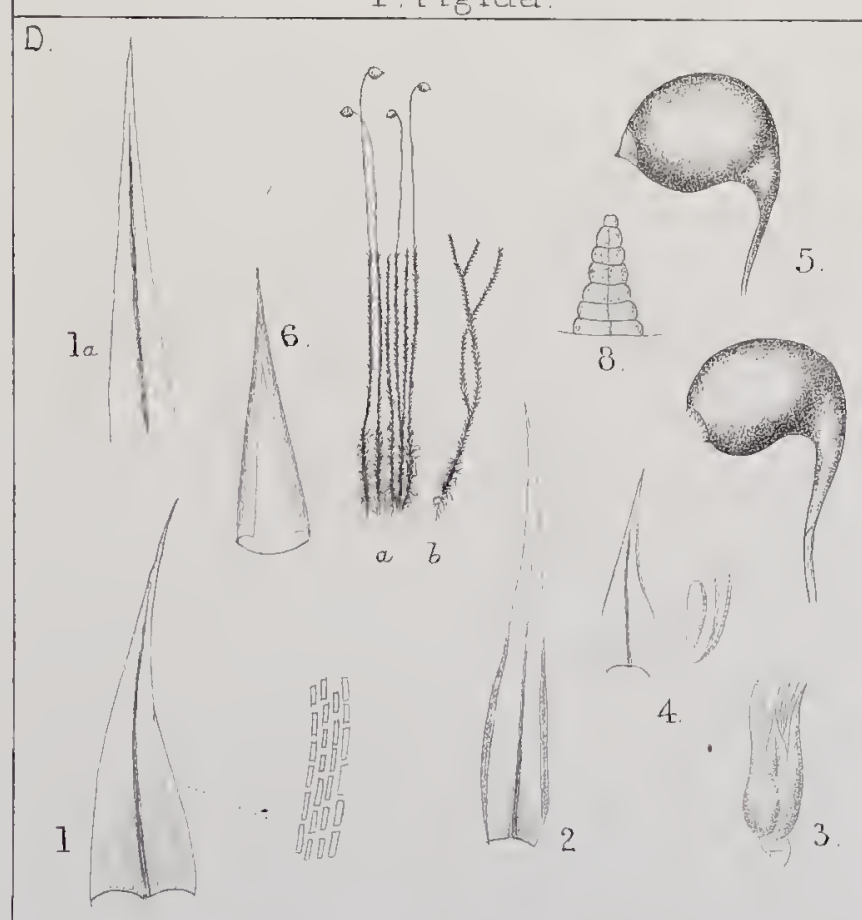

Catoscopizm nigritum
Philonotis Wilsoni

E
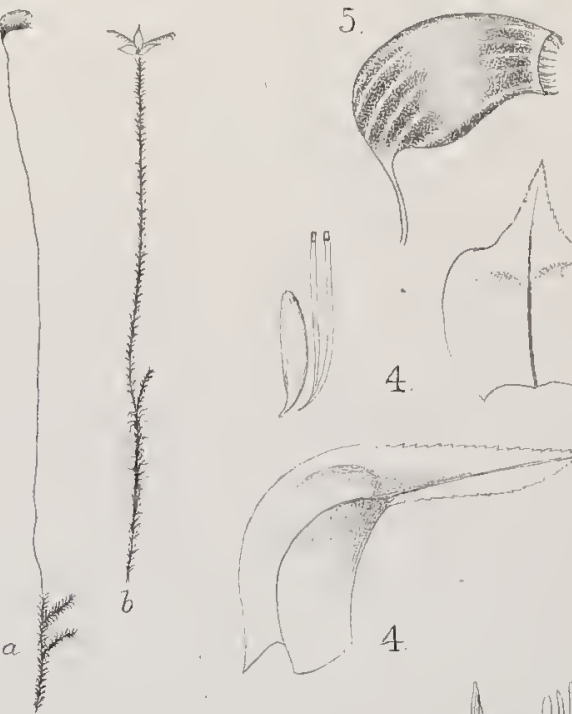

4.
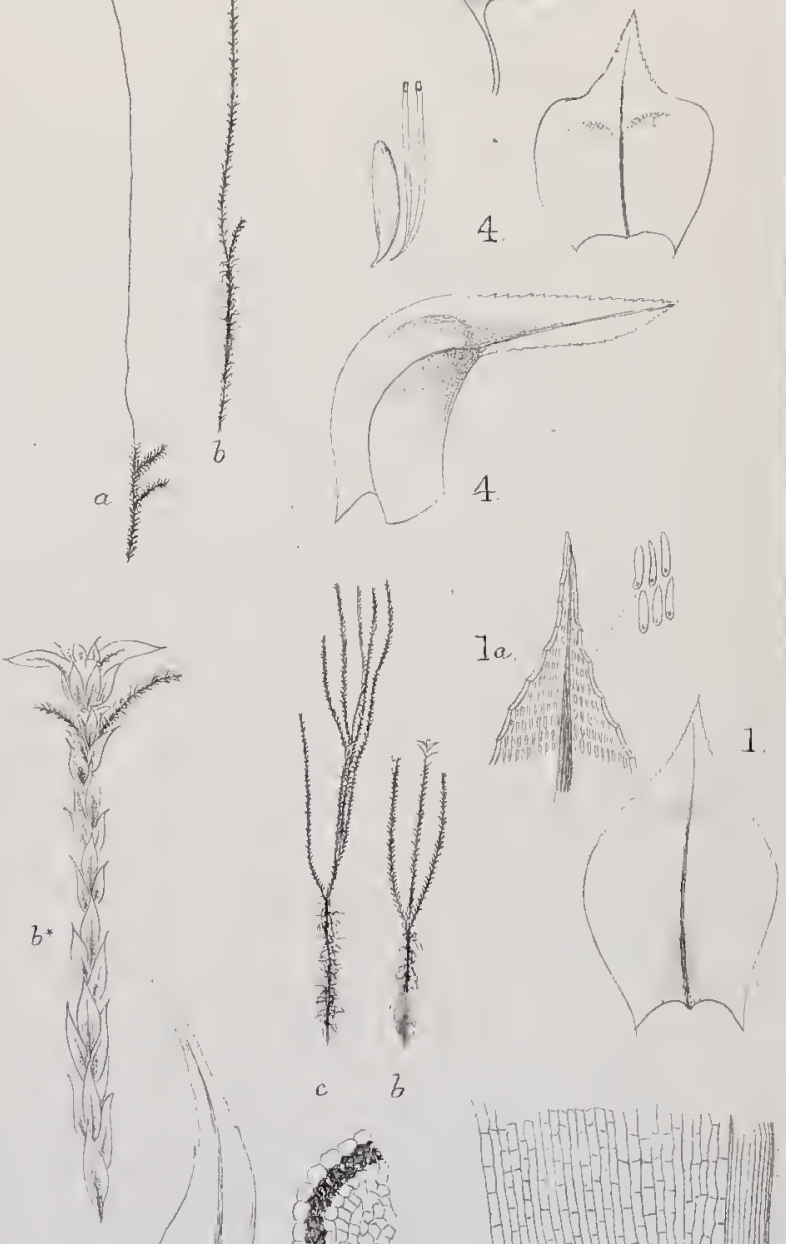

1

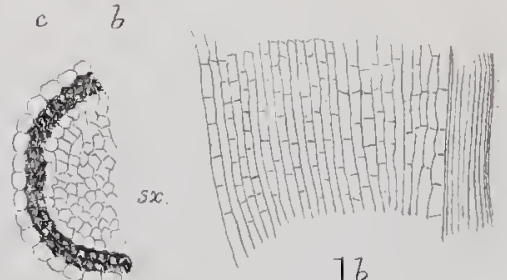

16. 



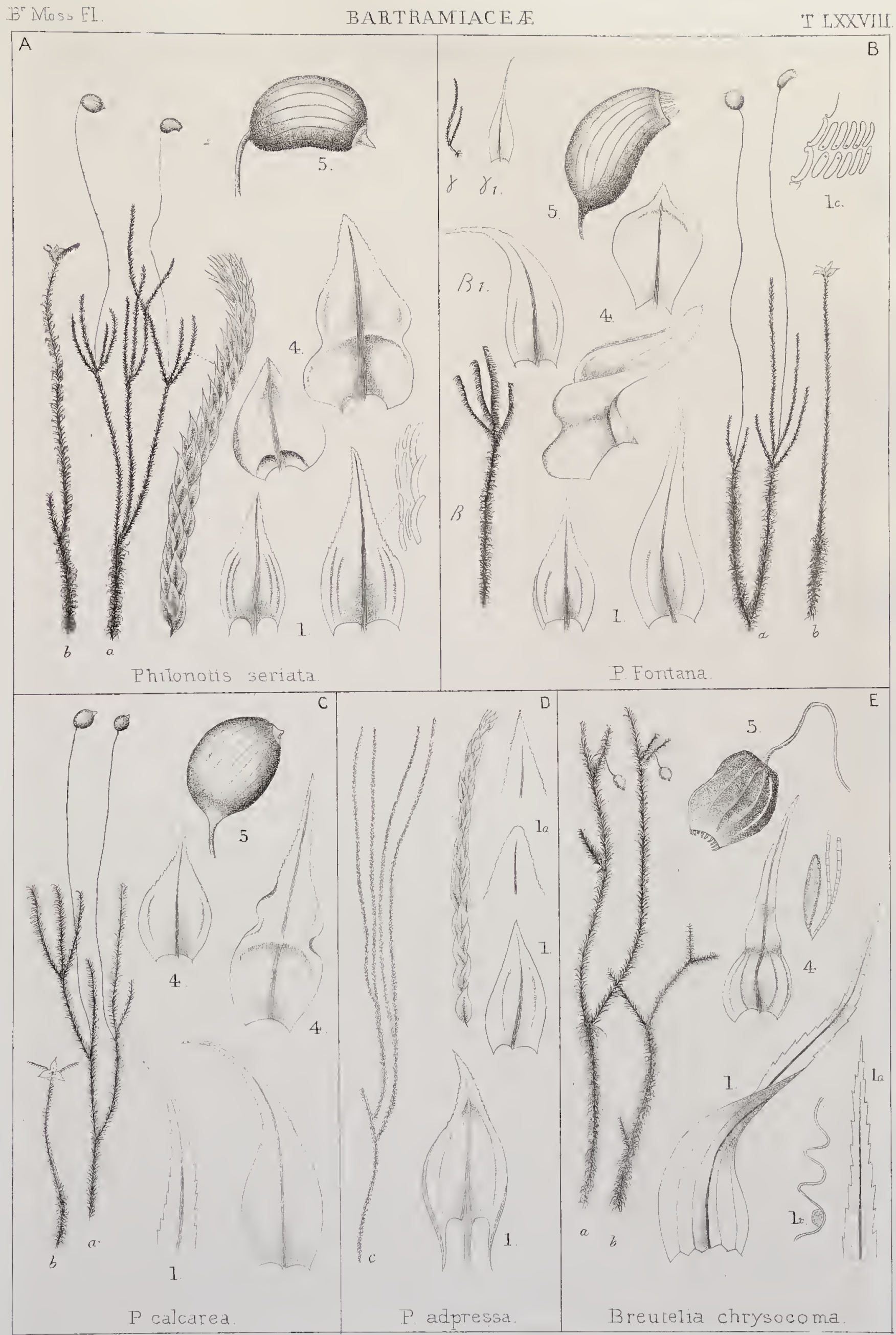

R Brauthwale ad ant dell J.Cartri on 

M E E S E A E 
MEESEA HEDW.

Meesea trichodes (L.) Spruce.

PALUDELLA EHRH.

Paludella squarrosa (L.) Brid. 


\section{Fam. 17. MEESEACEÆ.}

Stems elongated, densely tomentose. Leaves in $3-8$ rows, somewhat dense, of equal size, divergent or squarrose, entire or serrated, the cells parenchymatous above, with thick walls, lax and rectangular at base, smooth or mamillose. Capsule on a long seta, from an erect longish neck, curved clavato-pyriform, not striate, with a small oblique mouth. Peristome much shorter than endostome or of equal length, the teeth mnioid, processes of endostome 16 , cilia short or rudimentary. Inhabiting wet moorlands or deep bogs.

\section{MEESEA Hedw. \\ Fund. musc. II, 97 (1782).}

Stems tomentose, densely or laxly cæspitant. Leaves in 3,5 or 8 rows, with a solid nerve, the cells smooth, chlorophyllose, hexagonorectangular. Caps. on a long seta, with a long narrow neck, curved pyriform, small-mouthed; calyptra narrow and cucullate, lid convexconic; peristome of 16 short obtuse remotely articulated teeth, endostome a very short membrane with I 6 processes two or three times the length of the teeth, lineal and often united at point by lateral appendages, cilia short or rudimentary. Male infl. discoid with clavate paraphyses.-Der. after David Meese, a Dutch gardener.

A small genus of 8 or 9 species, or which four are European. M. triquetra (L.) Aongst. should be looked for here as it is widely diffused on the continent, it is a much larger plant, having leaves in three rows and with plane margins. Amblyodon resembles this genus in the fruit, but the leaves are funarioid in structure.

\section{MEESEA TRICHODES (L.) Spruce.}

Autoicous and synoicous; densely tufted. Leaves in 8 rows, linear-lanceolate, obtuse, entire and revolute at margin, the cells nearly uniform. (T. LXXIX, A.)

Syn.-Bryum trichodes aureum, capsulis incurvis obtusis, in setis longis Dill. Hist. musc. $3^{89}$, t. 49 , f. $5^{8}$ (I 74 I), et Herbar. 
Bryum trichodes L. Sp. plant. II20 (1753) ; Syst. nat. ii, 702. NECK. Meth. musc. I98 (1771). EHRH. Hann. mag. I780, p. 236 . Dicks. Pl. crypt. fasc. II, 7 (I790). HuLL Br. fl. P. 2, 263 (1799). SM. F1. brit. 1350 (1804), Eng. Bot. t. 15I7. Hoox. TAYL. Musc. brit. II6, t. 28 (1818). Hook. Fl. scot. P. 2, I 49 (182I). GRAy Nat. arr. Br.pl. i, 767 (1821). DuBY Bot. gall. ii, 549 (1830).

Hypnum trichodes WEB. Spic. fl. Goett. 87 (1778).

Mnium trichodes L. FIL. Meth. musc. 365 (1787). Hoffm. Deutsch. fl. ii, 47 (1795).

Meesia uliginosa HeDw. Descr. i, T, t. I et 2 (I 787 ), Sp. musc. I73 (I801). SwARTz Musc. Suec. 44 (1798). BRID. Musc. rec. II, P. III, I66 (1803), Sp. musc. III, IO2 (1817), Mant. I22 (I819), Bry. univ. ii, 6o (1827). Schultz Fl. starg. 357 (1806). Web. Mohr Bot. Tasch. 374 (1807). Schwaeg. Suppl. I, P. 2, 82 (I8II). Wahlenb. Fl. lapp. 357 (I812), Fil. carp. 35 I (1814). Roehl. Deutsch. fl. iii, I2I (1813). MarT. Fl. cr. erl. 74 (I8I7). Funck Moost. 43, t. 28 (1821). Hueben. Musc. germ. 487 (1833). DE Not. Syllab. Io7 (1838), Epilogo 438 (1869). BR. Scr. Bry. eur. Fasc. Io (I84I). Rabenh. D. kr. fl. ii, S. 3, I95 (I848). C. Muell. Synops. i, 465 (1 849 ). WiLs. Bry. brit. 266, t. 28 (1855). SchImP. Synops. 407 (1860). 2 ed. 490. Berk. Handb. Br. m. I79, t. I6 (1863). Milde Bry. siles. 234 (I869). HobK. Synops. Fr. m. I25 (1873). HUSN. Mouss. nord-ouest 2 ed. II5 (1882), Musc. gall. 261, t. 72 (1890). LesQ. James Moss. N. Amer. 212 (1884).

Mnium uliginosum Gmed. Syst. nat. ii, 1329 (I79r). WITH. Bot. arr. 3 ed. iii, 800 (1796).

Amblyodon uliginosus P. Beauv. Prodr. $4 \mathrm{I}$ (1805).

Meesea trichodes Spruce Ann. Mag. nat. hist. 2 ser. iii, 369 (1849). JuRATz. Laubm. oester.-ung. $3^{1} 7$ (1882). Boul. Musc. Fr. 229 (1884). LIMPR. in Rab. D. kr. fl. Laubm. ii, 507 (1893).

Autoicous and synoicous; in small dense yellowish-green tufts, brown and tomentose at base. Stems dichotomous or fasciculatebranched. Leaves in 8 rows, accrescent upward, erecto-patent, lower lanceolate, upper lineal-lanc., obtuse, margin revolute, entire, nerve thick $\frac{2}{3}$ width of base, vanishing below apex; cells incrassate above, rectangular or quadrate, thinner and elongated at base. Seta more or less elongated, purple; caps. castaneous, dark brown when old, from an erect neck, curved-pyriform; lid small, conic, umbonate, annulus of I row of cells; teeth of peristome orange, lanc., obtuse, perforated above in the dorsal line; endostome yellow, the processes lineal much longer than teeth, cilia rudimentary.

Haв.-Boggy moorlands in mountain districts. Fr. 6-7.

Mountains of Scotland and N. of England. Sand hills at Southport, Lancashire.

Var. $\beta$. alpina $(F u n c k)$.

Leaves more rigid, straight, more acute ; caps. shorter.

Syn.-Meesea alpina FuncK in Flora $I_{25}$, p. 274.

Meesea stricta et angustifolia Brid. Bry. univ. ii, 61-62.

Meesea uliginosa varr. alpina et angustifolia RABEN, D. kr. fl. II, S. 3, 195.

HAB.-On the higher mountains. Ben Lawers and Craigailleach.

Var. $\gamma$. minor (Brid.). 
Plants dwarf with short erect obtuse leaves, capsule short and thick.

Syn.-Meesea minor Brid. Musc. rec. II, P. III, I68, \&. 2, f. I3.

M. uliginosa $\beta$. minor SchwaEg. Suppl. I, P. I, 82.

HAB.-Ben Lawers.

\section{PALUDELLA Ehrh.}

Phytophyl. No. 69 (1788).

Plants tall, densely tomentose, growing in deep bogs. Leaves in five rows, equal decurrent, squarroso-recurved, the cells roundishhexagonal, elongated at base. Calyptra long, very narrow, fugacious. Caps. on a very long seta, from a short erect neck, cernuous, smooth, oblong ; annulus double, lid convex apiculate ; peristome as in Pohlia.Der. palus a marsh.

\section{PalUdella squarrosa (L.) Brid.}

The only species. (T. LXXIX, B.)

Syn.-Bryum squarrosum L. Sp. plant. II20 (I753). Syst. nat. ii, 702, Syst. veg. 949. Timm F1. megap. n. 840 (I788). Swartz Musc. suec. 48 (I799). Hedw. Sp. musc. i66, t. 44, f. 6-II (I80I). BRID. Musc. rec. II, P. III, I9 (I803). Schultz F1. starg. 338 (I806). Roenl. Deutech. Fl. iii, 90 (I8I3). Schwaeg. Suppl. I, P. II, 20 (I8I6). WiLs. in Eng. Bot. Suppl. t. 2767 .

Minium squarrosum L. Jun. Meth. musc. 364 ( 1787 ). Hofrm. Deutsch. fi. ii, 47 (I 795). Wahlenb. Fl. lapp. 356 (1812).

Orthopyxis squarrosa P. Beauv. Prodr. 72 (1805).

Hypum Paludella Weв. Mон Bot. Tasch. 274 (I807).

Paludella squarrosa BRID. Sp. musc. III, 74 (I8I7), Mant. II5 (I8Ig), Bry. univ. ii, I (1827). Schwaeg. Suppl. II, P. II, 27, t. I6I (I826). HUeben. musc. germ. 398 (1833). DE Not. Syllab. I05 (I838), Epilogo 488 (I869). BR. Sch. Bry. eur. fasc. Io, t. I (I84I). Rabenh. D. kr. fl. II, S. 3, I94 (I848). C. Muell. Synops. i, 468 (I849). Wils. Bry. br. 264, t. 50 (I855). Schimp. Synops. 4Io (I860), 2 ed. 502. Berk. Handb. br. m. I80 (I863). MiLde Bry. siles. 235 (I869). HoBk. Synops. br. m. I25 (I873). Juratz. Laubm. oest.-ung. 320 (I882). Lesq. James Moss. N. Amer. 214 (I884). Boul. Musc. Fr. 227 (1884). HusN. Musc. gall. 263, t. 73 (189o). Limpr. in RAB. D. kr. fl. Laubm. ii, 499 (:893).

Dioicous; in tall dense tufts, bright yellow-green above, blackishbrown at base, coated with soft brown tomentum. Leaves crowded in 5 rows, ovato-lanc., from an erect decurrent base, squarrose, strongly recurved, acutely carinate, margin recurved below, plane above, serrate at apex; nerve thin vanishing below point, cells roundish-hexagonal above, oval in the middle, elongated at base, mamillose on both sides. Perich. bracts erect, lanc., revolute at margin. Seta long, red; caps. from a short erect neck, ovate, curved, yellow-brown, lid conic, apiculate; 
peristome bryoid, endostome equally high, processes linear, cleft or perforated in middle. Male plant smaller, the infl. discoid, terminal, bracts very broad, obovate-lanc., nerved.

$\mathrm{H}_{\mathrm{AB}}$.-Deep peat bogs, very rare and sterile. Fr. 6.

Knutsford moor, Cheshire (Wilson I832)! Terrington Carr, Yorkshire (Ibbotson I842)!!

This beautiful moss is now extinct in both localities. At Terrington it was plentiful and fully $6 \mathrm{in}$. high, but Mr. Slater informs me that in I86I a deep drain was cut through the bog, and in 1868 he could only find a few stems not attaining more than $2 \mathrm{in.} \mathrm{It} \mathrm{has} \mathrm{been} \mathrm{reported} \mathrm{as} \mathrm{found} \mathrm{on}$ Ingleboro, but I have not been able to obtain any certain evidence as to the correctness of this record.

TAB. LXXIX. A. Meesea trichodes (Southport, Hunt), $\beta$. Var. alpina (Ben Lawers, Hunt). B. Paludella squarrosa (a. b. Norway, Lindberg, c. Terrington Carr, Spruce).

a. Fertile plant. b. Male. c. Sterile plant. I. Leaf. Ią. Apex. Ix. Section of same. 2. Perich. bract. 4. Antheridium and bract. 5. Capsule. 8. Peristome. 


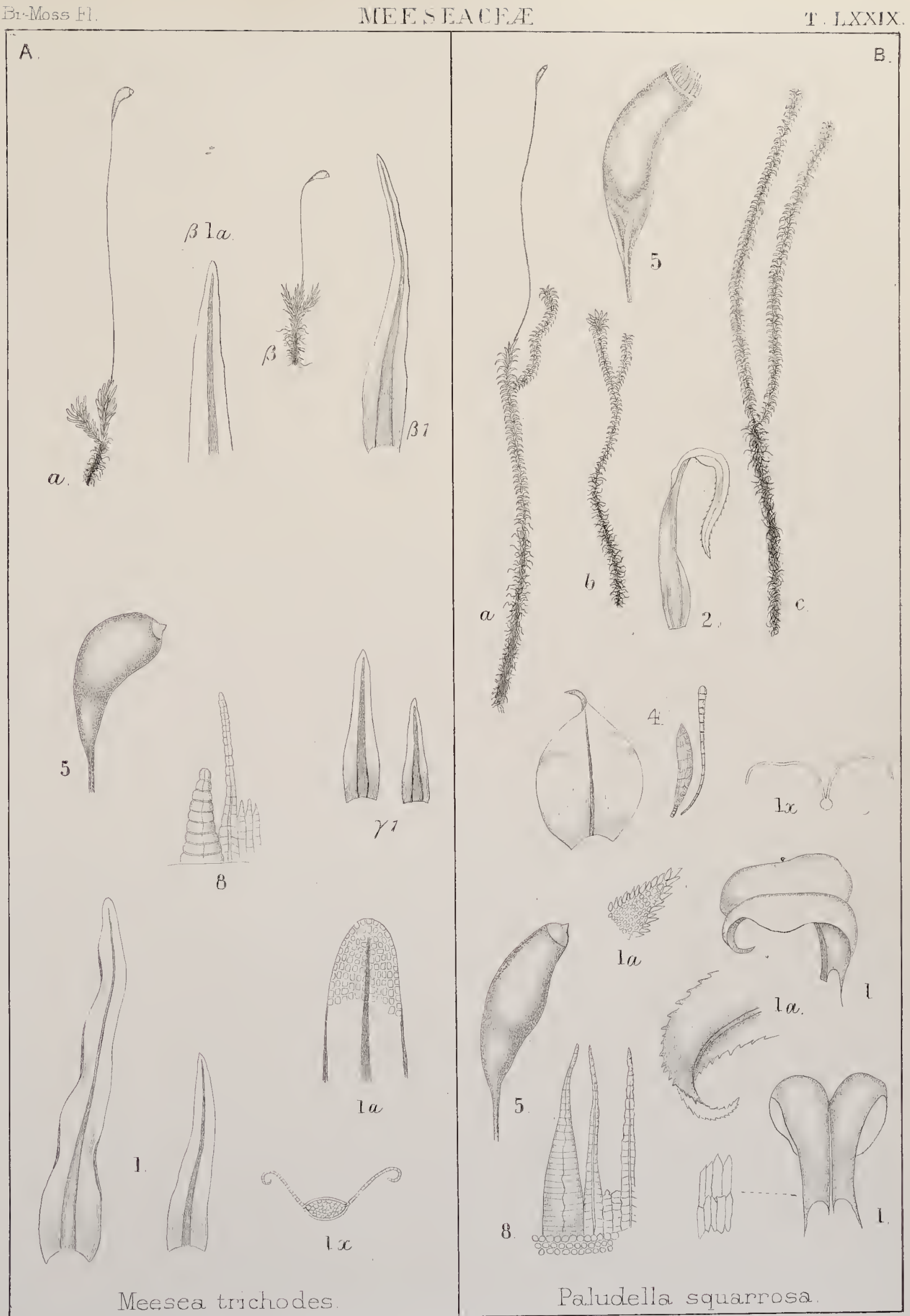



M N I A C E $Æ$. 
GYMNOCYBE FRIES.

1. Gymnocybe palustris (L.) Fries.

2. turgida (Wahlenb.) Lindb.

ORTHOPYXIS P. BEAUV.

Orthopyxis androgyna (L.) P. Beauv.

TIMMIA HEDW.

1. Timmia austriaca Hedw.

2. - norvegica $Z$ ett.

MNIUM DILL. L.

1. Mnium spinosum (Voit) Schwaeg.

2. —_ marginatum (Dicks.) P. Beauv.

3. —_ riparium Mitt.

4. orthorrhynchum Br. Sch.

5. - hornum $L$.

6. - silvaticum $L i n d b$.

7. - Seligeri furatz.

8. - cuspidatum L. Neck.

9. - undulatum $L$.

10. - rostratum Schrad.

11. - stellare Reich.

12. — cinclidioides (Blytt) Hucben.

13. - pseudopunctatum Br. Sch.

14. - punctatum $L$.

CINCLIDIUM SWARTZ.

Cinclidium stygium Swartz. 


\section{Fam. I8. MNIACE $Æ$.}

Robust mosses, the stems generally tall and densely tomentose, with numerous branches or creeping stolons and flagella. Leaves large and accrescent upward into a coma, firm, broadly ovate, elliptic or lingulate, often with a thickened and dentate limb. Cells smooth or very rarely papillose, long and rectangular at base, rounded-hexagonal above, chlorophyllose or strongly incrassate. Capsule on a long rigid seta, often several in one perichætium, longish-oval or subcylindric, cernuous; calyptra small, cucullate; peristome highly developed, bryoid. Male infl. terminal discoid. Inhabiting bogs, heathy ground and woodlands.

This fine family comprises about roo species, and its fruit closely resembles that of Brym but is more cylindric, and as in that genus the peristomes attain their highest development among the acrocarpous mosses. The genus Rhizogonium of some 30 species is almost entirely confined to the southern hemisphere and is remarkable for its basal fructification. Lindberg separates Rhiz. microphyllum as the genus Trachycystis, standing near Orthopyxis by its papillose leaves; $R$. acanthoneuron as Lencolepis, and $R$. subbasilare as Goniobryum, both having lax funarioid areolation as in Amblyodon.

Sect. I. GYMNOCYBEÆ. Stem branched, often with slender sterile shoots or pseudopodia, which are leafless or bearing a few small scattered leaves below, and at apex a cluster of gemmæ. Leaves in 8 rows, cells small, each with a long papilla on both sides. Caps. oval or subcylindric, 8-striate, costate when dry.

\section{GYMNOCYBE Fries.}

St. agr. femsj, 27 (1825).

Bog mosses with the habit of Dicramm Bergeri, often bearing pseudopodia, naked or with undeveloped leaves. Leaves oblongolanceolate, imbricated, the cells at base in $2-3$ strata, large empty and pellucid, quadrato-rectangular, those above minute rounded, strongly incrassate, with trigonous interspaces and a large central papilla on each side. Capsule irregular oblique, teeth of peristome subulate, processes of endostome cleft in the keel, cilia 2-3. Male infl. discoid with clavate paraphyses.-Der. $\gamma v \mu v o s$ naked, $\kappa v \beta \eta$ a head. 
A small genus of three species, usually combined with the next, but differing in habit, in the andrœcium and leaf-structure, so that it is more convenient to keep them separate.

\section{Clavis to the Species.}

Leaves erecto-patent, acute and serrate at point. imbricated, obtuse, entire.

palustris. turgida.

\section{GYMNOCYBE PALUSTRIS (L.) Fries.}

Dioicous; in tall branched tomentose tufts. Leaves narrow, elongato-lanceolate, acute, eroso-serrate towards apex, nerve vanishing. Capsule oval-cylindric, curved, lid conical. (T. LXXX, A.)

SYN.-Muscus capillaceus palustris flagellis longioribus bifurcatis MERR. Pinax 75 (1667). RAY Synops. 2 ed, 374 (16g6).

Muscus trichoides major palustris citrini coloris Doody, RAy Synops. 2 ed. $33^{8}$ (1696).

Hypnum palustre crectum brevius, ramis longioribus, foliis angustioribus DiLl. Cat. Giss. 2 I 9 (I 7 I 8$)$.

Mni:m majus, ramulis longioribus bifurcatis DILL. in RAY Synops. 3 ed. 78 (I724), Hist. musc. 233 , t. 3 I, f. 3 (I 74 I) et Herbar.

Mnium palustre L. Sp. pl. IIIo (1753). Huds. Fl. angl. 402 (I762). Weiss Crypt. goett. $165(1770)$. SCHREB. Spic. Fl. lips. I02 (I 77 I). Wirh. Bot. arr. br. veg. ii, $\mathrm{f \sigma}_{4}\left(\mathrm{I}_{77} 6\right)$. LightF. Fl. scot. ii, 708 (I777). Hedw. Fund. II, 94 (I 782 ), Sp. musc. I88 (ISoI). RELH. Fl. cant. 398 (I785). RoTh Fl, germ. I, 474 (I788). BRID. Musc. rec. II, P. III, 73 (1803), Sp. musc. III, 42 (I817), Bry. univ. ii, 7 (1827). SMITH Fl. brit. I346 (1804). Schultz Fl. starg. 34I (I806). Wahlens. Fl. lapp. 352 (I8I2). Roehl. Deutsch. f. iii, 92 (I8I3). Schwaeg. Suppl. I, P. II, I22 (I8I6). MarT. Fl. cr. erl. 65 (I8I7). C. Muell. Synops. i, I69 (1849).

Brynm palustre Neck. Meth. musc. 210 (I77I). WeBer Spic. f. goett. I23 (1778). Eng. Rot. t. 39I. Swartz Musc. suec. 46 (I798). Turn. Musc. hib. II3 (ISo4). Hook. TAYL. Musc. brit. II5, t. 28 (I8I8). Hook. Fl. scot. II, I49 (I82I). GRAY Nat. arr. br. pl. i, $76_{7}$ (I82r).

Bryum ventricosum (non Dicks.) SiвTh. Fl. oxon. 289 (I794).

Hypnum palustre (non HuDs.) WeB. MoHR Ind. mus. pl. cr. (I803).

Orthopyxis palustris P. Beauv. Prodr. 32 et 79 (1805).

Hypnum clodes (non SPRUce) WeB. MoHr Bot. Tasch. 272 (ISO7).

Gymnocybe palustris Fries St. agr. femsj. 27 (1825). LindB. Not. ur saells. Faun. et Fl. fenn. foerh. ix, 86 (1867). MILDE Bry. siles. 237 (1869).

Aulacomnitum palustre Schwaeg. Suppl. 1II, P. I, 4, t. 216 (1827). Hueben. Musc. germ. 392 (1833). De Not. Syllab. IO4 (1838), Epil. 270 (I869). BR. Sch. Bry. eur. fasc. Io, p. 9 , t. 3 (184I). RABEN. D. kr. fl. ii, S. 3, 229 (I848). WILs. Bry. brit. 216, t. $28\left({ }^{2} 8_{55}\right)$. Schimp. Synops. 4 I 2 (I860), 2 ed. 505. BERK. Handb. br. m. 206, t. I 8 (I863). HoвK. Syn. br. m. IO5 (1873). HuSN. Mouss. nord-ouest I30 (1873), Musc. gall. 260, t. 72 (I89o). Juratz. Laubm. oester.-ung. 322 (I882). Boulay Musc. Fr. 223 (I884). Lesq. James Moss. N. Amer. 252 (I884). Limpr. in Rabenh. D. kr. A. Laubm. ii, 525 ( 1893 ).

Limnobryum palustrc RABEN. Krypt. fl. Sachs. i, 502 (I863).

Spharocephalus palustris LindB. Musc. Scand. I4 (I879). 
Dioicous; growing in bogs in large yellowish-green tufts, stems 2-4 in. high, densely coated with ferruginous tomentum. Leaves erecto-patent, broadly lanc. or lineal, slightly decurrent, acute at point, the margin revolute, eroso-serrate towards apex; nerve vanishing at apex, cells irregular, roundish or angular, strongly incrassate, with a conical hyaline papilla on each side, the basal brown, rectangular smooth. Perich. bracts longer, more pointed, with narrower cells, seta pale red. Caps. cernuous, long ovate, incurved, castaneous, 8 -striate, erect when dry, contracted below mouth; lid short yellowish, with a short apiculus; peristome yellow, the teeth lanc.-subulate, finely papillose, cilia of endostome $3-4$, long as processes. Male infl. discoid, the bracts broad at base, lineal-lanceolate, patent, antheridia clavate.

HaB.-Moorland bogs; common on mountains. Fr. 6.

Var. $\beta$. imbricata (Bv. Sch.) Lindb.

Leaves broader, imbricated, obtuse, entire, not twisted when dry. Pseudopodia absent.

Syn. -Mnium turgidum (non WaHLens.) Funck MSS.

Aulacomnium palustre Var. $\beta$. imbricatum Bry. eur. fasc. Io.

Gymnocybe palustris Var. $\gamma$. imbricata LiNDB. op. c. 87.

$\mathrm{H}_{\mathrm{AB}}$.-On the higher mountains in drier places.

East Butterwick, Lincoln (Rev. M. Peacock)!! Ayrshire (Shaw)!

Var. $\gamma$. fascicularis (Bvid.) Lindb.

Stems much branched with short innovations; leaves fasciculate, obtuse, entire; flagelliform shoots often from the axils of the floral leaves.

SYN.-Mnium fasciculare BRID. Bry, univ, ii, 733.

Aulacomnium palustre $\gamma \cdot$ fasciculare Bry. Eur.

Gymnocybe palustris Var. $\delta$. fascicularis LinDB. op. c. 88.

HAB.-Moorland bogs.

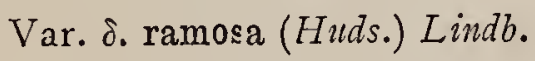

Stem decumbent, branched, bearing short pseudopodia in the axils of the comal leaves, naked in the upper part and bearing at the summit a cluster of leaf-like gemmæ. Leaves with acuminate points.

Syn.-Mnium majus, minus ramosum, capitulis pulvernlentis crebrioribus DilL. Hist. musc. 235, n. 4 et Flerb.

Mnium ramosum Huds. Fl. angl. 403.

Mnium prolixum NEck. Meth. musc. 235.

Bryum androgynum $\beta$. prolixum Roтn Tent. fl. germ. iii, P. I, 229.

Mnium polycephalum BRID. Musc. rec. II, P. III, 74. 
Bryum palustre $\beta$. ramosum 'TURN. Musc. hib. II3.

Orthopyxis ramosa P. Beauv. Podr. 32 et 79 .

Aulacomnium palustre $\beta$. polycephalum HUEBEN. Musc. germ. 393.

Gymnocybe palustris Var. $\epsilon$. ramosa LINDB. op. c. 88.

$\mathrm{H}_{\mathrm{AB}}$.-In similar localities with the type.

New Forest near Hythe, Hants (Binstead I887)!!

2. GYMNOCYBE TORGIDA (Wahlen.) Lindb.

Dioicous; in large loose tufts. Leaves imbricated, obovate, concave obtuse entire. Lid obtuse. (T. LXXX, B.)

Syn.-Hypnum illeeebrum L. Fl. suec. 2 ed. 399, excl. n. (1755).

Hypmum turgidum WaHLenb. MSS. Web. Mohr Ind. mus. pl. cr. name only (I8o3).

Mnium arrhenopterum SM. in Trans. L. Soc. vii, 263, p.p. (1804).

Arrhenopterim turgidum Wahlenb. MSS. Web. Mohr Bot. Tasch. 318 in obs. (1807).

Mnium turgidum Wahlenb. Fl. lapp. 35I, t. 23 (I8I2). Schwaeg. Suppl. I, P. II, I23, t. 77 (I8I6). Brid. Sp. musc. III, 4 I (18I7), Mant. I2 I (I89I), Bry. univ. ii, II (I827).

FunCK Moost. 51, t. 32 (I821). C. Mulll. Synops. i, I 7 I (I849).

Bryum turgidum SWartz Summa Veg. scand. 4I (I8I4). .

Bryum (Streptotheca) turgidum W. ARN. in Mem. Soc. hist. nat. Paris ii, 292 (r825).

Aulacomnium turgidum Schwaeg. Suppl. III, P. I, 7 (1827). Hueben. Musc. germ. 395 (I833). Br. Sch. Bry. eur. fasc. Io, p. 8, t. 2 (I8.11). Schimp. Synops. 4 I3 (I860), 2 ed. 506. Juratz. Laubm. oester.-ung. 323 (I882). Hobk. Synops. 2 ed. I74 (I884). LesQ. Jaines Moss. N. Amer. 253 (1884). Limpr. in Rabenh. D. kr. fl. Laubm. ii, 530 (I893).

Gymnoeybe turgida LindB, in Not. ur saells. Faun. et Fl. fenn. foerh. ix, 85 (I867).

Spharocephalus turgidus LINDB. Musc. scand. I4 (1879).

Dioicous; in large yellowish-green tufts, readily falling asunder, yellowish-brown at base, not interwoven with tomentum. Stem $3-5$ in. long, fragile, irregularly branched, thickened towards apex. Leaves imbricated, scarce decurrent, concave, longish obovate, broadly rounded, quite entire, reflexed at margin in lower half, incurved at apex; nerve thin, vanishing below apex, cells roundish, incrassate with a short papilla on each side, the basal in two strata, brownish, smootl, rectangular with some shorter rectangular green cells above them. Perich. bracts lanceolate. Caps. cernuous, ovate-oblong, symmetric curved, yellowish brown, 8-striate, lid conic, obtuse.

HaB.-Wet turfy places in mountains, rare. Fr. 7 .

Ben More of Dochart (Prof. Barker 1871). Whernside, Yorks. (West and Lees 1878)! Ben Challum, Perthshire (Eving and Binstead)!! Creag Mhor, Perthshire (Holnes I888)!! All sterile. 
This plant is rarely found with fruit, and when this does occur as in Norway and Lapland, it is only found in small quantity. It might be confounded with the Var. imbricata of last species, but may be known by the larger size, absence of tomentum, and broader very obtuse leaves.

\section{ORTHOPYXIS P.Beauv.}

Prodr. p. 3 I (1805).

Growing on sandy banks or rotten trunks of trees. With or without pseudopodia. Leaves entirely unistratose, with cells all of the same form, round, incrassate with a large central papilla on each side. Capsule regular, suberect. Male infl. gemmiform with filiform paraphyses.-Der. op $\theta_{0}$ straight $\pi v \xi$ ss a capsule.

Our species is the only one found in Eurcpe, a second O. heterosticha (Hedw.) P. Beauv. occurs in N. America. The old authors mistook the gemmæ for male organs and this gave rise to the incorrect specific name.

\section{ORTHOPYXIS ANDROGYNA (L.) P. Beawv.}

Dioicous; leaves patent, narrow lanceolate. Capsule regular. (T. LXXX, C.)

SYN,-Muscus capillaris omnium minimis foriis, pediculis, capitulis Vernonis Ray Synops. 2 ed. 30 , n. Io (1696).

Muscus trichoides parvus capitulo conglomerato seu botryoide Doodii RAY op. c. 33, n. 3 I.

Mnium perangustis et brevibus foliis DiLl. Cat. Giss. 214 et App. 84, t. I, f. A-C (I7Ig), in RAY Synops. 3 ed. 78 (I 724 ), Hist. musc. 230, t. 3I, f. I (I 74I) et Herbar:

Mnium androgynum i. Sp. F1. ii, IIIo (I753), Syst. nat. ii, 700. Huds. Fl. angl. 403 (I762). Weiss Cr. Goett. I63 (1770). With. Bot. arrang. ii, 664 (1776). LightF. Fl. scot. ii, 706 (I777). Hedw. Theor. gen. I40, t. I2, f. $48-50$ (I784). F1. dan. t. 299 . Hof FM. Deutsch. fl. ii, 46 (1796). Eng. Bot. t. 1238. BRid. Bry. univ. ii, 5 (1827). C. Muell. Synops. i, I70 (I849). Lindb. Musc. scand. I4 (I879).

Mnium angustifolium NECK. Meth. musc. 234 (I 77 I).

Bryum androgynum WeB. Spic. fl. Gott. 122 (I778). Hedw. Fund. musc. II, 94, t. 5 (I782), Sp. musc. I78 (1801). Roth Fl. germ. i, 472 (I788). Аввот Fl. bedf. 778 (I 798 ). Huli P. III, I6 (1803), Mant. II (I8Ig). TuRn. Musc. hib. II2 (1804). SMITH Fl. brit. P. III, I6 (I803), Mant. II7 (1819). Schultz Fl. starg. 338 (I806). Roenl. Deutsch. fl. iii, 9o (1813). Voit Musc. herb. 84 (1812). Hook. TayL. Musc. br. I15, t. 28 (I8I8). Hook. Fl. scot. P.2, I49 (I82I). GRAY Nat. arr. br. pl. i, 767 (I82I).

Hypnum androgynum Schrank Bayer. fl. ii, 469 (I789). WeB. Mohr Bot. Tasch. 280 (1807).

Orthopy xis androgyna P. Beauv. Prodr. 32 et $7^{8}$ (1805). LindB. Not. ur Saells. faun. fl. fenn. ix, 77 (1867).

Gymnocejhalus androgynus Rich. MS. Schwaeg. Suppl. I, P. II, 87 (I8I6). Brid. Sp. musc. III, 2 (I8I7). MART. Fl. cr. erl. $5^{6}$ (I8I7).

Fusiconia androgyna P. Beauv. Mem. soc. Linn. Par. i, t. 7, f. 5 (1822).

Gymnocybe androgyna Fries St. agr. femsj. 27 (1825). 
Aulacomnium androgynum Schwaeg. Suppl. III, P. I, 2, t. 2 I5 (1827). Hueben. Musc. germ. 39I (I832). Br. Sch. Bry. eur. fasc. Io, t. 4 (I84I). Rabenh. D. kr. fl. II, s. 3, 230 (I848). Wils. Bry. br. 217, t. 28 (1855). Schimp. Synops. 4 II (IS60), 2 ed. 503. Berk. Handb. br. m. 205 (I863). Milde Bry. siles. 236 (I869). HoBK. Synops. IO5 (I873). Juratz. Laubm. oest.-ung. 32I (I882). Boulay Musc. Fr. 225 (I884). Lesq. James Moss. N. Amer. 252 (1884). Husn. Musc. gall. 259, t. 72 (I890). Limpr. in Rabenh. D. kr. fl. Laubm. ii, 523 (1893).

Sphaerocephalus androgynus Lindi. Not. ur Saells. Fauna Fl. fenn. foerh. ix, p. 4I, Raett. och tillaeg. (1867).

Dioicous; densely pulvinato-cæspitose, deep green above, ferruginous and tomentose at base, $\frac{1}{2}-2$ in. high. Pseudopodia numerous, terminating in a globose head of elliptic gonidia, each of $2-4$ cells. Leaves erectopatent, linear-lanceolate, eroso-denticulate at apex, incurved when dry, margin reflexed in the lower half, nerve pale, vanishing and often flexuose towards apex; cells rounded, incrassate, with a papilla on each side. Perich. bracts lanceolate-subulate; caps. ferruginous, oblongocylindric, erect, then cernuous, when dry and deoperculate, horizontal, contracted, deeply sulcate; calyptra reaching middle of caps., longbeaked, lid large, convex at base, shortly conic; peristome very pale yellow. Male infl. terminal, gemmiform, bracts I2, linear-lanceolate.

HAB.-Woods and shaded gravelly banks. Fr. 6, very rare.

In fruit between Plumstead and Abbey Wood, Kent (Dillenius, Mitten r843, Braithwaite I854)! ! now destroyed. Dunmore Tower, near Airth, Falkirk (Lyle I849)! Valley of the Churnet, Stafford (Dr. Fraser I868)!!

The numerous pseudopodia on this moss with their clusters of gemmx, at once catch the eye, and no doubt afford a ready means for the increase of the species. It is extremely rare in Ireland; in Epping Forest it is frequent in hollows in the trunks of pollard hornbeams.

Sect. 2. TIMMIEÆ. Resembling Polytrichum in habit. Leaves from an appressed sheathing base, lanceolate, the cells small, hexagono-rotundate.

\section{TIMMIA Hedw.}

Stirp. cr. $i, 8_{3}(1787)$.

Stems simple, the leaves equal, sheathing at base, elongatolanceolate, serrate. Caps. ovate-oblong with a short neck, not striate; calyptra small, cucullate, peristome as in Mnimm.-Der. after J. C. Timm, of Malchin, in Mecklenburg.

A small genus of pretty mosses of which two other species are found in Europe, T. megapolitana and bavarica; all are very mucl alike in habit, which quite resembles that of Polytrichum.

\section{Clavis to the Species.}

Leal-base orange, widely sleathing, smooth at back. 


\section{TIMMIA AUSTRIACA Hedw.}

Dioicous; leaves long, lanceolate, from an orange sheathing base above which the margin is inciso-serrate. Caps. ovate-oblong; cilia of endostome not appendiculate. (T. LXXX, D.)

Syn.-Timmia anstriaca Hedw. Sp. musc. I76, t. 42, f. I-7 (I80). BRID. Musc. rec. II, P. III, I55 (I803), Sp. musc. IIT, 98 (I8I 7), Mant. I22 (I8I9), Bry. univ. ii, 7I (I827).

Wen. Mohr Bot. Tasch. 254 (I807). Roehl. Deutsch. fl. iii, 85 (1813). WaHLEN. Fl. lapp. $35 j$ (I8I 2). Schwaeg. Suppl. I, P. II, p. 84 (I8I6). Funck. Moost. 44, t. 36 (I82I). Hessl. Comm. de Timmia 2I, f. 4 (I822). Hueben. Musc. germ. 5I4 (I833). Br. Sch. Bry. eur. fasc. Io, p. 7, t. 2 (I84I). C. Muell. Synops. i, I89 (I849). RABENH. Deutsch. kr. fl. ii, s. 3,232 (I848). Wils. Bry. br. 214, t. 36 (I8 55 ). Schimp. Synops. 43I (I860), 2 ed. 525. BERK. Handb. br. m. 206 (I863). LindB. in Oefv. af K. Vet. Akad. Foerh. I864, p. 333. Milne Bry. siles. 243 (1869). DE Not. Epilogo 350 (I869). HoBK. Syn. br. m. I04 (I873). JuRATz. Laubm. oester.-ung. 334 (I882). Lesq. James Moss. N. Amer. 255 (1884). Husn. Musc. gall. 272, t. 75 (189o). LIMPR. in RABENH. D. kr. fl. Laubm. ii, 584 (I894).

Mnium austriacum P. BEAUV. Prodr. 74 (1805).

Timmia polytrichoides $\beta$. lntescens BRID. Sp. musc. III, 99 (I8I7).

Timmia lutescens BrIn. Bry. univ. II, 72 (1827).

Timmia megapolitana Var. $\beta$. Hook. Tayl. Musc. br. 2 ed. IgI, Supp1. t. 6 (I827). Grev. Scott. Cr. fl. vi, t. 326 (I828).

Dioicous; tall, robust, in rather dense tufts, yellowish green above, ferruginous at base. Leaves from a reddish brown sheathing base, suddenly lineal-lanceolate, rather glossy, erecto-patent, biplicate, when dry incumbent, subarcuate and convolute-concave above, the margin coarsely serrate, nerve serrate at back of the rather obtuse apex, cells linear at base, quadrate and incrassate above. Perich. bracts shorter; caps. horizontal, on a long seta, longish oval, reddish-brown, faintly striate, furrowed when dry; annulus broad, triple, lid orange-red, hemispherical with a small point; teeth yellowish-white, papillose, those of endostome not appendiculate. Male plant resembling the female, the leaves more divaricate, bracts patent.

\section{$\mathrm{H}_{\mathrm{AB}}$ - - Rocks and stony places on mountains, very rare, sterile.}

Rocks by the Isla, above Airly Castle, Forfarshire (Drummond 1824)! Ben Lawers (Wilson I858)! Craig Mhor, Glen Lochay (Grieve I888) !!

Timmia megapolitana HEDw. is smaller, autoicous, the leaf-base less sheathing and papillose at back, the processes of endostome with prickleshaped appendages; it has been recorded from Ben Lawers, but all the specimens I have seen so named belong to the next species.

\section{TIMMIA NORVEGICA $Z$ ett.}

Dioicous; leaves not sheathing, having a band of thin hyaline cells at their insertion, serrate in the upper half. (T. LXXX, E.) 
Syn.-Timmia norvcgica ZETT. in Oefv. Vet.-Ak. Foerh. xix, 364 (1862), et in Bull. soc. bot. Fr. I862, p. 288 . SChimp. Synups. 2 ed. 526 (I 876 ). JuRAtz. Laubn. oester-ung. 335 (I882). Hовк. Synops. 2 ed. I75 (1884). Boul. Musc. Fr. 2 II (I884). HusN. Musc. gall. 27 I, t. 75 (I89o). LIMPR. in RABEN. D. kr. fl. Laubm. ii, 580 (1894).

Timmia megapolitana $\beta$. norvegica LindB, in Oefv. Vet.-Ak. Foerh. I864, p. 337.

Dioicous; in loose dark green tufts, fuscescent at base, laxly interwoven with radicles and with hyaline paraphysiform hairs in the axils of the upper leaves. Leaves soft, scarcely sheathing cirratocrispate when dry, the upper long erect, yellowish-green, from an indistinctly sheathing yellow base, with a band of fragile hyaline cells at the insertion to the stem, gradually lineal-lanceolate, erecto-patent, short pointed, convolute-concave, shortly serrate in upper half of margin, indistinctly so below, cells in the lower half of leaf coarsely papillose at back, rectangular, upper hexagono-quadrate and papillose in front, nerve strong, reddish. Caps. horizontal, longish oval, lid reddish-yellow, with a very small point, inner peristome without appendages.

$\mathrm{H}_{\mathrm{AB}}$ - - On moist turfy ground and mountain rocks, rare.

Ben Lawers (McKinlay Iô66)!! Wood at south side of Powerscourt waterfall, Ireland (D. Orr).

The fruit has only been found in very small quantity, in three localities in the Tyrol.

Sect. 3. MNIEA. Plants tall, often with creeping stolons. Leaves large, with large smooth cells. Capsules oval or pyriform, pendulous, smooth.

\section{MNIUM Dill. L.}

Hist. musc. 229 (1741).

Fine showy mosses growing in damp shady ground, and under mountain rocks, usually innovating from the base of stem. Leaves large, especially in the coma, ovate, elliptic or spatulate; frequently with a thickened serrated limb, the cells parenchymatous, incrassate smooth. Capsule on a long rigid seta, pendulous or horizontal, oval, regular, calyptra small cucullate, peristome of I6 lanceolate cuspidate teeth, trabeculate externally, lamellose internally, endostome processes as long as peristome with $2-4$ nodose cilia. Male infl. discoid with clavate paraphyses.-Der. $\mu v$ vov a moss.

About 50 species of this fine genus have been described, the greater part of which are natives of the north temperate zone. The peristome and endostome are both highly developed, and resemble those of the section 
Eubryum. The distinction from Bryum depends on the habit of the plants and on the leaf-structure, the cells being very different from those of Brymm.

\section{Clavis to the Species.}

Leaves with a thickened limb.

Margin biserrate.

Nerve vanishing below apex.

reaching apex.

Synoicous.

Dioicous.

Leaf-cells in oblique rows.

not seriate.

Leaves lax rufescent, with large cells. dense green, with minute cells. serrate with solitary teeth.

Synoicous.

Lid convex.

rostrate.

hormum.

Dioicous.

Leaves broadly ovate.

Marginal teeth spinulose, of 3 cells.

entire.

ligulate.

Synoicous, nerve vanishing.

Dioicous, nerved to apex.

not limbate.

Leaves pointed, bluntly toothed by projecting cells.

obtuse, ertire.

marginatum.

spinosum.

riparium.

orthorrhynchum.

silvaticum.

rostratum.

cuspidatum.

Seligeri.

undulatum.

pseudopunctatum. functatum.

stellare.

cinclidioides.

*Limb doubly serrate.

\section{MNIUM SPINOSUM (Voit) Schwaeg.}

Dioicous; in loose blackish-green tufts. Lowest leaves minute, squamiform, upper large, obovate cuspidate, the cells in oblique rows. Caps. oval-oblong, lid conic rostellate. (T. LXXXI, A.)

Syn.-Bryum spinosum Vort in Sturm Deutsch. fl. II, II (I8Io). Brid. Mant. II9 (I8Ig).

Mnium rostratum $\beta$. spinosum RoEHL. Deutsch. fl. iii, $9^{6}$ ( $\left.18 \mathrm{r} 3\right)$.

Mnium spinosum SchWaEg. Suppl. I, p. II, I30, t. 78 (I8I6). BRID. Sp. musc. III, 48 (I8I7). Hartm. Skand. fl. Hueben. Musc. germ. 4Io (I833). Br. Sch. Bry. eur. fasc. 5 , p. 26 , t. 6 (1836). C. Muell. Synops. i, I62 (1849). Schimp. Synops. 394 (I860), 2 ed. 486. LiNDb. in Not. Sael. Fn. et Fl. fenn. ix, 45 (I867). DE Not. Épilogo 363 (I869). Milde Bry. siles. 228 (I869). Hobk. Synops. I22 (I873). Juratz. Laubm. oester.-ung. 305 (I882). Boulay Musc. fr. 233 (I884). Lesq. James Moss. N. Amer. 246 (1887). Husn. Musc. gall. 256, t. 70 (1889). Limpr. in Rabenh. D. kr. fl. Laubin. ii, 405 (I893).

Muium (Polla) spinosa Brid. Bry. univ. i, 7 I I p.p. (1826).

Mnium melanostomum BRID. MSS.

Astrophyllum spinosum Linds. Musc. scand. I4 (1879).

Dioicous; robust, in very loose dingy or black-green tufts. Stems radiculose at base, blackish, often with $2-3$ branches, dense-leaved subarcuate and flagelliform. Lowest leaves minute, squamiform, 
obtuse, entire, scariose; upper large, patent, crisped and undulate when dry, obovate-spathulate, shortly cuspidate with the excurrent nerve which is rufous and serrate at back of apex, cells in oblique rows roundish-angular. Perich. bracts narrower, lanc., often enclosing several capsules, seta red, caps. horizontal or slightly inclined, ovaloblong, rufous brown; lid conic, obtusely rostellate : peristome reddishbrown, endostome orange. Male infl. large rosaceous.

HAB.-Pine woods and shady mountain rocks, very rare. Fr. 7 .

Under rocks on Ben Lawers (McKinlay 1867)!! Glen Shee, Clova (Fergiusson 1876).

A fine moss of somewhat rigid texture, and by no means attractive appearance owing to the dark dingy green colour. Only a few capsules have been found here.

\section{MNIUM MARGINATUM (Dicks.) P. Beauv.}

Synoicous; in loose bright green tufts. Leaves distant, decurrent, lower obovate-lanc., upper spathulate, limb bispinoso-serrate. Caps. ovate, shortly rostrate. (T. LXXXI, B.)

Syn.-Bryum marginatum Dicks. Pl. crypt. br. fasc. II, 9, t. 5 (I79o). Wither. Bot. arr. br. pl. 3 ed. iii, 84 I (I796). Hull Br. fl. P. 2, 267 (I 799). SMith F1. brit. I362 (I8c4); Eng. Bot. t. I473, Trans. Linn. Soc. xi, 290 (I'I I ). TuRn. Musc. hib. I29 (I 804). Hook. TAYl. Musc. br. I26, t. 3 I (I8I8). Hook. Fl. Scot. P. 2, I52 (I82I), Br. fl, ii, 64 (1833). Gray Nat. arr. br. pl. i, $77^{2}$ (I82I). Mack. Fl. hib. P. 2, 33 (1836).

Mnizm scrratum Schrad, in L. (GMEL.) Syst. nat. I 3 ed. ii, I330 (x79I). Brid. Musc. rec. II, P. III, 84, t. I, f. 2 (I803), Sp. musc. III, 44 (I8I7). P. BeAUV. Podr. 77 (ISO5). Schultz Fl. Starg. 243 (I806). Schwaeg. Suppl. I, P. 2, I28, t. 78 (1816). Sturm Deutsch. fl. cr. II, Io. MART. Fl. cr. erl. 67 (I8I7). Funck. Moost. 5I, t. 32 (I82I). Hueben. Musc. germ. 418 (1833). BR. Sch. Bry. eur. fasc. 5, p. 24, t. 5 (I838). DE IJot. Syll. I39 (1838), Epilogo 365 (1869). RABEnh. Deutsch. cr. A. II, s. 3, 225 (1848). C. Muell. Synops. i, 163 (1848). Wils. Bry. brit. 255, t. 3 I (I855). Schimp. Synops. 392 (I860), 2 ed. 48 I. BERk. Handb. br. m. I $8_{4}$ (I863). Milde Bry. siles. 227 (I869). Hobk. Synops. I 22 (I873). JuRATz. Laubm. oester.-ung. 302 (I882). Lesq. James Moss. N. Amer. 245 (I884). Limpr. in Raben. D. kr. fl. Laubm. ii, 46 I (1893).

Bryum serratum Schrad. Spic. fl. germ. i, 7 I (I794), Syst. Samm1. cr. gew. P I, I5, n. 68 ( 1796$)$.

Hyp. serratum WEB. MoHR Ind. mus. pl. cr. (I803).

Mnium marginatum P. Beauv. Prodr. 75 (x805). Roenl. Deutsch. F1. iii, 93 (I $8 \mathrm{I} 3$ ). LindB. in Not. saell. Fn. fl. fenn. ix, 46 (1867). Bovl. Musc. Fr. 235 (I884). HusN. Musc. gall. 256, t. 70 (I89o).

Hyp. marginatum Weв. Monr Bot. Tasch. 292 (1807).

Bryum Polla serrata Brid. Bry. univ. i, 689 (1826).

Astrophyllum marginatum LindB. Musc. scand. $x_{4}(1879)$.

Synoicous; in lax soft bright green tufts, brownish red at base. Stems $\frac{1}{2}-I$ in. purplish, simple, erect. Leaves distant, erecto-patent, soft, twisted when dry, longly decurrent, the lower obovate-lanceolate, 
uppermost spathulate-lanceolate, perich. bracts narrowly lanc., all of them acutely acuminate, the margins confluent in the point, nerve vanishing in or below the apex, red, smooth at back, limb of $2-5$ rows of yellow or red cells, bispinoso-serrate in the upper half; cells irregular hexagonal-rotundate, not seriate, rectangular at base. Caps. I or 2 on a pale red seta, horizontal, oval-oblong, pale yellow with a reddish mouth, soft, lid pale with a short oblique beak; peristome ferruginous, punctate, endostome orange.

$\mathrm{H}_{\mathrm{AB}}$.- Rocks and stony ground in woods, not uncommon。 Fr. 4 .

Resembling $M$. hornm in habit, but smaller and brighter green with the infl. synoicous. Most frequent in limestone districts.

\section{MNIUM RIPARIUM Mitt.}

Dioicous; resembling $M$. marginatum. Leaves oval-lanceolate, with two rows of short obtuse teeth nearly to base, rufescent, laxly nreolate, nerve spinulose at back of apex. Peristome greenish yellow. (T. LXXXI, C.)

Syn.-Mnium riparium Mitт. Journ. Linn. Soc. viii, 30 , in Obs. (1864). LindB. Not. ur Saells. pro. Fn. et Fl. fenn. ix, 50 p.p. (I867). HobK. Synops. I22 (1873). Schimp. Synops. 2 ed. 484 (I876). JuRATz. Laubm. oester.-ung. 303 (I882). Limpr. in RABenh. D. kr. fl. Laubm. ii, 458 (I893)! !

Mnium orthorrhynchum WiLs. Bry. brit. 255, t. 5 I (1855).

Mnium anbiguum H. MuELL, in Verh. bot. Ver. Prov. Brandenb. viii, 67 (1866).

Astrophyllum riparium LindB. Musc. scand. I4 (1879).

Mnium marginatum Var. riparium Huss. Musc. gall. 256 (1889).

Dioicous; plants small, seldom above I in. high, lax-leaved, green, acquiring a rufescent or vinous tint, in loose tufts, the radical shoots more slender and elongated. Leaves slightly decurrent, distant, divergent, crumpled when dry, oval-lanceolate with a short point, limb red, of $2-3$ rows of very narrow cells, with two rows of short blunt teeth nearly to the base; nerve red, ending in the point and faintly toothed at back, cells large roundish-angular, incrassate, about - Or5- $020 \mathrm{~mm}$. in diameter, rectangular at base. Seta short, pale red, caps. cernuous, elliptic, pale brown; lid convex with a short beak, peristome greenish-yellow, endostome yellow.

$\mathrm{H}_{\mathrm{AB}}$. - On stumps by shady banks of rivers and in woods, rare. Fr. 5.

Pondleigh stream, Hurstpierpoint (Mitten I856)!! Mowthorpe Dale, Castle Howard (Spruce 1844)!! By a stream near Perth (R. Meldrum I 886)!!

This species has been confused with $M$. orthorrhynchum, by Wilson and others, even Lindberg ascribes minute areolation to M. viparium instead of to 
the latter, and also erroneously refers $M$. lycopodioides to it. Like several other mosses growing by streams, it is liable to be covered by floods and hence charged with sand and dirt. It differs from $M$. orthorrhynchum in the colour and laxer areolation of the more distant leaves, and is altogether a smaller plant. The male and sterile specimens have alone been found here.

\section{MNIUM ORTHORRHYNCHUM Br. Sch.}

Dioicous; more robust. Leaves longer and narrower, dense, dull green, ovato-lanceolate, with two rows of teeth in upper half, minutely areolate. Capsule oval. (T. LXXXI, D.)

Syn.-Mnium serratum Var. $\beta$. Schwaeg. Suppl. I, P. II, r29, t. 78 (18I6).

Mnium serratum $\beta$. Penninum De Nor. Syllab. I39 (1838).

Mninm orthorrhynchum (non BRID.) BR. ScH. Bry. eur. fasc. 5, p. 25, t. 5 ( $183 \delta$ ). Rabenh. D. kr. fl. ii, S. 3, 226 (1848). C. Muell. Synops. i, 163 (1849). Spruce in Tr. Bot. soc. Edin. iii, I5g (1849). Wils. Bry. brit. 255 , p.p. (I855). Schimp. Synops. 392 (1860), 2 ed. 482 . BERK. Handb. br. m. I85 (1863). LindB. Not. ur Saellsk. Fn. Fi. fenn. ix, 49 (I867). MiLde Bry. siles. 229 (1869). De Not. Epilogo 364 (1869). Hobk. Synops. I 22 (1873). JURATZ. Laubin. Oester.-ung. 3oI (1882). Boulay Musc. Fr. 234 (1884). Lesq. James Moss. N. Amer. 246 (1834). Husn. Musc. gall. 255, t. 70 (1889). Limpr. in Rabenh. D. kr. fl. Lauhm. ii, 455 (I893).

Mnium marginatum $\beta$. orthorrhynchum HARTM. Skand. A. 5 ed. 345 (1849).

Astrophyllum orthorrhynchum LindB. Musc. scand. I4 (I879).

Dioicous; more robust, densely matted, dull green above, reddish at base. Stem taller, densely leafy. Leaves erecto-patent, ovatolanceolate, the lower nearly entire, somewhat twisted when dry, limb narrow, doubly serrate in the upper half, nerve red, ending in the point, and serrate at back; cells not in rows, roundish-angular, - OI8-.025 mm. in diameter, strongly incrassate. Seta longer, red below, yellow above, caps. carnuous pale brown, oval, lid conic, shortly rostrate, peristome yellow-green. Male plants shorter with stout discoid many-bracted inflorescence.

$\mathrm{H}_{\mathrm{AB}}$.-Wet rocks and stony places in limestone districts. Fr. 7.

Arncliff Clouder, Yorks. c. fr. (Noteell r856)!! Ingleboro, on the Yoredale limestone at 2,000 ft. (Nozell I858)!! Hazelden Gill (Hunt I867)!! Litton Dale c. fr. (Whitehead and Ashton I879)!! On elder stumps in a marsh at Pont Esgob, Hereford (Aug. Ley I 8go)!! Lodore, Cumberland (Binstead I889)!! Stock Ghyll force, Ambleside and Naddle Forest (Binstead 1893 )!!

Taller, dense-leaved and more rigid than the last species, with much smaller areolation, and in habit resembling Mnium hormum.

\section{MNIUM HORNUM $L$.}

Dioicous; in dense dark green tufts. Leaves oblong-lanc., slightly decurrent, bispinoso-serrate, the nerve vanishing below apex. Caps. oblong-ovate, subpendulous, lid mamillate. (T. LXXXII, C.) 
Syn.-Mnium stellarc sylvarum capitulis magnis nutantibus Vernonis RAY Synops. 2 ed. 35 (I696).

Bryum nitidum capitulis majoribus reflexis calyptra imum vergente, pediculis oblongis $e$ cauliculis novis egredientibus DiLl. in RAY Synops. 3 ed. Io2 (172I).

Bryuu stellare hornum sylvarum capsulis magnis nutantibus DiLl. Hist. musc. 402, t. 5 I, f. 7 I (I 74I) et Herb.

Mnizm hornum L. Sp. pl. iाI2 (I753). With. Bot. arr. ii, 667 (I776). LightF. F1. scot. ii, 7 I I (I777). HEDW. Fund. I, t. II, et II, t. I (I782), Sp. musc. I88 (I8oI). Rotn Fl. germ. i, 475 (I788). Аввот Fl. bedf. 233 (I798). BRID. Musc. rec. II. P. III, >7 (I803), Sp. Musc. III, 47. Schultz Fl. starg. 342 (1806). P. Beauv. Prodr. 75 (1805). Roeml. Deutsch. fi. iii, 94 (I8I3). Schwaeg. Suppl. I, P. II, I28 (I8I6). Funck Moost. 5I, t. 32 (I82I). HUEBEN. Musc. germ. 4 I6 (I833). DE Not. Syilab. I3 (1838), Epilogo 364 (I869). BR. Sch. Bry. eur. fasc. 5, p. 22, t. 4 (I838). Rabenh. D. kr. Al. II, S. 3, 225 (I848). C. MUell. Synops. i, 165 (I848). WILs. Bry. brit. 256, t. 3 I (I855). Schimp. Synops. 39i (IS6o), 2 ed. $48 \mathrm{r}$. Berk. Handb. br. m. I84 (I863). Lindb. Not. ur Saells. Fn. Fl. fenn. ix, 54 (I867). Milde Bry. siles. 230 (i869). HobK. Synops. I23 (I873). Husn. Mouss. n.-ouest I29 (I873), Musc. gall. 255, t. 70 (1889). Juratz. Laubm. oester.-ung. 300 (1882). Boulay Musc. fr. 237 (1884). Lesq. James Moss. N. Amer. 245 (1884). Limpr. in Raben. D. kr. fl. Laubm. ii, $45^{2}$ (1893).

Bryum hornum Huds. Fl. angl. 4I5 (I762). SCHREB. Spic. fl. lips. 83 (I77 I). NECK. Meth. musc. 2I5 (I77 I). WEBER. Spic. fl. goett. II5 (I778). CURT. Fl. Lond. I, t. 7 I * Reli. Fl. cant. Supp. I7. Vill, Pl. Dauph.iii, 888 (I786). Sibth. F1. oxon. 290 (I791). Sivartz Musc. suec. 48 (I798). Hull Br. fl. P. 2, 266 (I799). Rotii. Fl. germ. iii, P. I. 237 (1800). Smith Fl. brit. I350 (1804), Eng. Bot. t. 227I. TurN. Musc. hib. I28 (I804). Hook. Tayl. Musc. br. I27, t. 3 I (I8I8). Brid. Mant. II9 (I8I9). Gray Bot. arr. br. pl. i, 773 (182I). Ноok. Fl. scot. P. 2, I52 (I82I).

Mnizm hornum a. serratifolinm Weiss Pl. c̀r. Gottin. I 49 (I77o).

Mnium stellatum LAM. F1. fr. i, 39 ( $\left.\mathrm{I}_{7} 8\right)$.

Hypnum hornum Weв. MOHR Ind. mus. pl. cr. (I803), Bot. Tasch. 293.

Bryun stellatum LAM. DE C. Fl. fr. 3 ed. ii, 507 ( $180 j)$.

Bryum Polla horna Brid. Br. univ. i, 695 (I826).

Astrophyllum hornum LinDB. Musc. scand. I 4 (I879).

Dioicous; densely cæspitose, $\mathrm{x}-3$ in. high, deep green above, reddish brown and tomentose at base. Stems simple, dense-leaved, erect. Leaves gradually accrescent upward, erecto-patent, slightly decurrent, somewhat twisted when dry, the lowest squamiform, entire at margin, median oval-oblong, upper oblongo-lanc., nerve ending below apex, serrate at back of apex, all acutely acuminate, limb and teeth rufous when old, the latter geminate; cells not seriate, rounded angular, pericl. bracts narrow, lingulate-spathulate. Capsule on a long subflexuose purple seta, arcuate above, drooping and horizontal, oblongovate, yellowish-brown with a red mouth, lid convex with a pointed papilla; teeth of peristome pale greenish-yellow, endostome pale orange. Male plant shorter, infl. discoid, inner bracts broadly oval, ventricose, laxly areolate, suddenly acuminate, simply toothed.

HAB.-Damp shady banks and in woods, common. Fr. 5-6.

The swan's-neck curvature of the seta is a striking feature in the present plant, and the elegant peristome adds still more to its beauty; it is singularly free from variation, and in habit closely resembles $M$. stellave. 
**Limb simply serrate.

\section{MNIUM SILVATICUM Lindb.}

Synoicous; fertile stem erect, simple. Leaves obovate, mucronate, comal ovato-lanceolate, simply serrate. Caps. ovate, subpendulous, lid convex. (T. LXXXI, E.)

Syn.-Bryum nitidum, foliis serpilli pellucidis oblongis, capitulis cernuis majusculis, e cauliculis novis et virentibus egredientibus Dill. Cat. Giss. 227 ( 17 I 8 ).

Bryum pendulum, foliis variis pellucidis, capsulis ovatis DiLL. Hist. musc. 4 I3, t. 53, f. 79 $A-C($ I 74 I) et Herb.

Mnium serpyllifolium Var. $\delta$. cuspidatum LAM. Fl. franc. i, 40 (I778). $\beta$. cuspidatum Auct. ant. p.p.

Mnium cuspidatum Hedw. Sp. musc. 192, t. 45, f. 5-6 (1801). Schwaeg. Suppl. I, P. II, I32 (I8I6). BRID. Sp. musc. III, 52 (1817). MART. Fl. cr.erl.67 (18I7). Hueben. Musc. germ. 409 (1833). Br. Sch. Bry. eur. fasc. 5, p. 29, t. 8 (1838). DE Not. Syllab. I39 (1838), Epilogo 36o (I869). RaBEnh. D. kr. fl. II, S. 3, 227 (I848). C. Muell. Synops. i, I6o (I848). Wils. Bry. br. 254, t. 3 I (I855). Schimp. Synops. 386 (I860), 2 ed. 475. BERK. Handb. br. m. I83, t. I7, f. 3 (1863). Milde Ery. siles. 225 (1869). HoBk. Synops. I2I (I873). HusN. Mouss. n.-oxest. I28 (I873), Musc. gall. 253 , t. 69 (1889). JuRATz. Laubm. oester.-ung. 306 (1882). Boulay Musc. Fr. 24 I (I884). Lesq. James Moss. N. Amer. 242 (I884). Limpr, Laubm. ii, 475 (I893).

Bryum cuspidatum (non Schreb.) TuRn. Musc. hib. I3 I (1804). SMith F1. brit. I368 (1804), Eng. Bot. t. I474. Hook. TAYL. Musc. br. 127, t. 3 I (1818). GRaY Nat. arr. i, 773 (182I). Hook. Fl. Scot. P. 2, I52 (I821).

Hypinum aciphyllum WeB. MoHr Bot. Tasch, 295 p.p. (I807).

Bryum aciphyllum Var. VoIT in STURM Deutsch. fl. II, I2 (18II).

Bryum Polla cuspidata Brid. Bry. univ. i, 702 (1826)

Mnium silvaticum LiNDB. in Not. ur Saells. Fn. et Fl. fenn. ix, 59 (1867).

Astrophyllum silvaticum LiNDB. Musc. scand. I4 (1879).

Synoicous; simple, bright green above, strongly radiculose at base, with trailing and suberect shoots and subterranean stolons. Leaves decurrent, accrescent upward, undulate and crisped when dry, lowest obovate, entire, cauline erecto-patent, obovate, comal longer obovateoblong, those of stolons rounded obovate, all ending in a mucronate point; nerve strong, smooth at back, ending before or in the point; limb of $3-5$ series of unistratose cells, with solitary small yellowish teeth in the upper half. Leaf-cells not in rows, incrassate, roundish-oval. Caps. on a reddish-yellow seta, solitary oval subpendulous, pale ferruginous-brown; lid convex; peristome yellow, endostome orange, the processes widely lacunose, appendiculate, the basal membrane cribrose.

HAB.-Wet shady places in woods, on rocks and tree-roots. Fr. $4-5$.

This species is not uncommon and is smaller than M.cuspidatum (L.) NECK. with which it was confused by the older authors, and from which it differs by the inflorescence and serrature of leaves. It is most frequent on limestone. 


\section{MNIUM SELIGERI furatz.}

Dioicous; erect, densely tomentose. Leaves lax, oval, longly decurrent, deflexed and convex above, teeth short, obtuse, of one cell. Caps. oval, pendulous, lid convex. (T. LXXXII, A.)

Syn.-Mniun marginatum SeLIGer in Herb.

Mniun affine $\beta$. clatum Br. Sch. Bry. eur. fasc. 5, p. 3I, t. IO, f. 2 (I838). HarTM. Skand. fl. 9 ed. ii, 29 (1864). C. MuELl. Synops. i, 159, p.p. (1848). Schimp. Synops. 388 (1860).

Mnium insigne LindB. in Not. ur saells. Fn. Fl. fenn. ix, 65 (I867). Milde Bry. siles. 227 (IS69). Juratz. Laubm. Oester.-ung. 308 (1882).

Mnium Seligeri Jur. MSS. Limpr. in Rabenh. D. kr. fl. Laubm. ii, 479 (I893).

Astrophyllum Seligeri LindB. Musc. scand. I4 (1879).

Dioicous; in tall bright green soft tufts 3-4in. high. Stem erect, densely coated with ferruginous tomentum, sterile shoots erect, laxleaved. Stem leaves longly decurrent, decurved towards point and at sides so as to be convex, longish-oval, comal from a narrow base, ovalspatulate, with a short recurved point; limb of four rows of narrow cells, teeth solitary, pointing forwards, short obtuse, of one or rarely two cells, nerve excurrent in the point; cells in oblique rows, irregular, angular-roundish, with thick walls. Caps. pendulous, longish oval, usually solitary, lid orange, convex with a point, peristome pale yellowgreen.

$\mathrm{H}_{\mathrm{AB}}$. - Watery heaths and about springs. Fr. 5-6, rare.

Hell Kettles, Croft, Yorks. (Baker I856)! Hale moss, Cheshire (Wilson I858)!! Flitwick marsh, Beds. (Samnders I 888)!! Shap, Westmoreland (Binstead I 893)!!

This fine species is very close to $M$. cuspidatum L., but differs in habit, and the leaves are remarlably convex on the upper surface, from the bending down of the wings, the cells also having a lining of collenchyma, whicl swells by moisture and materially diminishes the cell-lumen, in which the chlorophyl usually runs together into bands lying free in the cavity. The true $M$. insigne Mitr. is confined to North America, and it was by mistake he referred the Croft specimens to it in Hook. Journ. Bot. viii, 230.

\section{MNIUM CUSPIDATUM (L.) Neck.}

Dioicous; with long trailing shoots. Leaves roundish and obovate, slightly decurrent, with long sharp points; teeth long divergent, of three cells. Caps. oblong, pendulous, lid convex. (T. LXXXII, B.)

Syn.-Bryum nitidum, foliis serpylli pellucidis subrotundis, elatius DilL. Cat. Giss. 228 (1718).

Brynm pendulum, foliis variis pellucidis, capsulis ovatis DILL. Hist. musc. 413, t. 53 , f. 79 D-L (174I), et Herb. 
Mnium serpyllifolium $\beta$. M. cuspidatum L. Sp. pl. ii, III3 (I753). B. rotundifolium LAM. Fl. franc. $i, 40\left(177^{8}\right)$.

Mnium cuspidatum Neck. in Act. ac. Theod.-palat. ii, 444 (I770). ReICH. Fl. moenofranc. ii, I 25 ( $\left.\mathrm{I}_{77} 8\right)$, et in L. Syst. pl. iv ( $\mathrm{I}_{780}$ ). LEYss. Fl. hal. 2 ed., 272 ( $\left.\mathrm{I}_{7} 8_{3}\right)$. Hoffm. Deutsch. fl. ii, 52 (I795). LindB. in Not. saells. Fn. et Fl. fenn. ix, 63 (1867). Var. $\beta$. Hedw. Sp. musc. I93 (1801). Var. $\beta$. affine Somm. Suppl. Fl. lapp. $5^{6}$ (1826).

Bryum polymorphum Neck. Meth. musc. 218 (I77I).

Bryum cuspidatum Schreb. Spic. fl. lips. 84 (I77I). Swartz in W. akad. nya Handl. xvi, 254 (I795), et Musc. suec. 5I (I799). Voit Musc. herb. 88 (I8I2). Wallm. in Liljebl. Svensk fl. 3 ed. $55^{2}$ (I816). HARTM. Skand. fl. (1820).

Hypnum cuspidatum Schrank Bayer. f. ii, 47 I (I789). Web. Mohr Ind. mus. pl.cr. (1803).

Mnium affine Bland. Musc. fr. exs. III, n. I33 (I804). SchwaEg. Suppl. I, P. II, I34 (I8I6). Brid. Sp. musc. III, 54 (I8I7), MART. Fl. cr. erl. 68, t. 2, f. I (I8I7). HuEBEN. Musc. germ. 407 (1833). BR. Sch. Bry. eur. fasc. 5, p. 3n, t. 9 (excl. fig. 22 b) (I838). DE Not. Syllab. I40 (1838), Epilogo 359 (I869). RABENh. D. kr. fl. ii, S. 3,228 (1848). C. Muell. Synops. i, I 59 (I849). Wils. Bry. br. 253, t. 5 I (1855). Schimp. Synops. 387 (I860), 2 ed. 476 . BERK. Handb. br. m. I82, t. I7, f. 2 (I863). Milde Bry. siles. 226 (1869). Hoвk. Synops. I2 I (1873). HusN. Mouss. nord-ouest. I28 (1873), Musc. gall. 254. f. 69 (I889). JuRAtz. Laubm. oester.-ung. 307 (I882). Boulay Musc. Fr. 239 (I884). Leso. James Moss. N. Amer. 244 (I884). Lrmpr. in Rabenh. D. kr. fl. Laubm. ii, 477 (1893).

Hypnum aciphyllum WeB. MoHr Bot. Tasch. 295, p.p. (1807).

Bryum aciphyllum VoIT in STURM Deutsch. fl. II, I2 (excl. var.) (I8I2).

Bryum affine Brid. Mant. II9 (I8Ig). Hоok. Br. fl. ii, 65. Wils. in Eng. Bot. suppl. t. 2739 .

Bryum Polla spinosa Brid. Bry. univ. i, 70r, p.p. (1826).

Bryum Polla affinis BRID. op. c. 704 .

Mnium uliginosum BRID. MS.

Astrophyllum cuspidatum LindB. Musc. scand. I3 (1879).

Dioicous; widely cæspitant, stolons long arcuate and rooting. Leaves patulous, when dry recurved and crisped at margin, lowest obovate-circular, median obovate-oblong, comal in a rosette, obovatospathulate, all slightly decurrent; nerve ending in the prickle-like point, limb of 3-4 rows of narrow unistratose cells, yellowish, the whole margin with long acute divergent teeth, each of 3 cells; leaf-cells in divergent rows, scarcely thickened. Caps. generally $2-5$ in one periclıætium, pendulous, oblong, glaucous green, turning brownish yellow, lid orange, convex apiculate. Peristome pale yellow, inner orange.

HaB.-On the ground in wet bushy places. Fr. 5 .

Var. $\beta$. elatum (Br.Sch.).

Stems taller, more slender, densely tufted, the shoots erect and elongated; leaves large, the teeth shorter and more distant.

Syn.-Mnium affine Var. $\beta$. elatum Br. Sch. Bry. eur. fasc. 5, p.p. Schimp. Synops.

Hab.-Bogs near Oxford (Boswell). Hale moss, \&c. (Wilson)!

Var. $\gamma$. rugicum LAUR. 
Stem erect, the leaves dingy green, distant, blackish when old, the margin with a few obsolete teeth or entire. Capsules one or several in a perichætium.

Syn.-Mnium rugicum LaUrer in Flora 1827, I, p. 292. Hueben. Musc. germ. 408. Limpr. in Rabenh. D. kr. fl. Laubm. ii, $48 \mathrm{I}$.

Mnium insigne $\beta$. pumilum Lrnde. in Not. Saells. Fn. F1. fenn. ix, 66.

Mnium paludosum Warnst. Moosfl. Prov. Brandenb. 56.

Astrophyllum rugicum Kind b. Arten. Laubm. Schwed. Norw. 6 I.

HAB.-Moorland bogs.

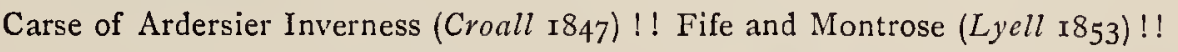

Another very closely allied species $M$. medium $\mathrm{BR}$. $\mathrm{ScH}_{\mathrm{c}}$. is general in Europe and ought to be found here; it is synoicous and is nearest to $M$. Seligeri, but I find the utmost difficulty in discriminating the various forms ; Limpricht retains $M$. nugicum as a fourth species, and certainly the leaf-margin differs widely from that of the type, the teeth when present corresponding to those of $M$. seligeri, while the leaf-base and cells are those of $M$. cuspidatum. The variety elatum is scarcely more than a large form, with which $M$. Seligeri had been confused, and through it the marginal teeth gradually disappear until it passes into rugicum.

\section{MNIUM UNDULATUM $L$.}

Dioicous; dendroid, stem simple with arcuate comal branches, leaves long lingulate, undulate, sharply serrate, nerved to apex. Caps. aggregated in one perichætium, oblong. (T, LXXXIII, A.)

Syn.-Muscus trichoides ramosus, foliis longis lucidis, et veluti crispis Ray Synops. app. 243 (169o).

$M$ uscus ad polytrichoidem accedens arbusculum referens, fol. longis et veluti crispis RAY Synops. 2 ed. 36 (1696).

Bryum nitidum foliis oblongis undatis, capitulis cernuis, arbusculum referens DiLL. Cat. Giss. 227 ( 17 I 9 ).

Bryum dendroides polycephalon, Phyllitidis folio undulato, pellucido, capsulis ovatis pendulis Dill. Hist. musc. 4Io, t. 52, f. 76 (I 74 I) et Herb.

Mnium serpyllifolium $\delta$. M. undulatum L. Sp. pl. II $\mathrm{I}_{3}$ (I 753 ).

Bryum serpyllifolium $\delta$. undulatum Huds. Fl. angl. 417 ( $\left.\mathrm{x}_{7} 62\right)$.

Mnium undulatum Neck. in Act. ac. Theod.-palat. ii, 444 (1770). WeIss P1. cr. gott. I 58 (r770). Hoffm. Deutsch. fl. ii, 53 (I795). Hedw. Sp. musc. I95 (r80r). P. BeAUv. Prodr. 77 (1805). Schwaeg. Suppl. I, P.II, I35 (I8I6). Mart. Fl. cr. erl. 70 (18I7). Hueben. Musc. germ. 405 (I833). DE Not. Syllab. I42 (I838), Epilogo 357 (I869). Br. Sch. Bry. eur. fasc. 5, p. 20, t. 3 (I838). Rabenh. D. kr. fl. II, S. 3,225 (I848). C. Muell. Synops. i, I6I (1849). Wils. Bry. br. 256, t. 30 (1855). Schimp. Synops. 389 (I860), 2 ed. 479. BERK. Handb. br. m. I83, t. I7, f. 4 (I863). LiNIB. Not. ur Saells. Fl. Faun. fenn. ix, 67 (I867). Milde Bry. siles. 227 (I869). Hobk. Synops. I 23 (I873). Husn. Mous. nord-ouest I28 (I873), Musc. gall. 255, t. 70 (I889). JuRatz. Laubm. oester-ung. 3 Io (I882). Boulay Musc. Fr. 238 (i884). Limpr. in Rabenh. D. kr. fl. Laubm. ii, 467 (I893).

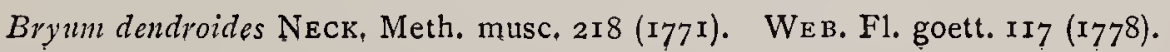


Bryum ligulatum Schreb. Spic. fl. lips. 84 (I77I). Wither. Bot. arr. ii, 673 (I 776 ). Swartz Musc. suec. 5I (I798). Sm. Fl. brit. I37I (I804), Eng. Bot. t. I449. Turn. Musc. hib. VoiT Musc. herb. 87 (I812). Hook. TAYL. Musc. br. I25, t. 30 (I8I8). Brid. Mant. iIg (ISIg). Hook. Fl, scot. P. 2, I5I (I82I). Gray Nat. arr. i, 772 (I8? I).

Mnium ligulatum WILld. F1. berol. 334 (I787). BRID. Musc. rec. I, P. III, II2 (I803), Sp. musc. III, 55 (I8I7). Schultz Fl. starg. 348 (I806). Roenl. Deutsch. fl. iii, 97 (I813).

Hypum undatum.Schraxk Bayers. fl. ii, 474 (I789).

Polytrichum undatum Schrank Prim. f. salisb. 223 (I792).

Bryım undulatum Siвтн. F1. oxon. 292 (1794). Roth. Fl. germ. ii, P. I, 249 (I8no).

Hypnum ligulatum WeB. MoHr Ind. mus. pl. cr. (1803), et Bot. Tasch. 298 (1807).

Bryum Polla ligulater BrJD. Bry. univ. i, 708 (I826).

Astrophyllum undulatum LindB. Musc. scand. I3 (1879).

Dioicous; tall, dendroid, widely cæspitant, deep green. Stem erect simple, with a number of branches arising from the rosette-like coma, which are flagelliform, dense-leaved and arcuate, and many strong horizontal stolons at base. Cauline leaves remote, oblong, comal elongate ligulate and decurrent, undulate, crisped when dry, limb of 3 rows of cells, confluent with the nerve at apex, simply serrate, leaf.cells irregular roundish. Capsules 2- Io in one perichætium, cernuous, oblong, yellowish, becoming castaneous, annulus large, lid convex apiculate, peristome greenish yellow.

$\mathrm{H}_{\mathrm{AB}}$ - - Damp shady woods and hedge banks. Fr. 5 .

This fine moss presents but little variation and is generally distributed, but the fruit is by no means frequent, when it does occur the number of capsules gives the plant a very handsome appearance.

\section{ro. MNIUM ROSTRATUM Schrad.}

Synoicous; in loose trailing dark-green patches. Leaves large oval-oblong, obtuse or apiculate, bluntly toothed. Caps. oval, horizontal, lid rostrate. (T. LXXXI, F.)

Syn.-Bryum pendulum, Serpylli folio longiore pellucido, capsulis oblongis cuspidatis DıLL. Hist. musc. 4 I6, t. 53 , f. 80 (174I) et Herb.

Bryum serpyllifolium Var. $\beta$. Huds. Fl. angl. 492 ( 1762 ).

Mnium rostratum Schrad. in L. (GMEL.) Syst. nat. I3 ed. ii, P. 2, I330 (179I). Hoffm. Deutsch. fl. ii, 52 (I795). Roenl. Deutsch. fl. iii, 96 (1813). Schwaeg. Suppl. I, P. II, I36, t. 79 (I8I6). MART. Fl. cr. erl. 70 (I8I7). Funck Moost. 52, t. 33 (I82I). HUEBen. Musc. germ. 4I2 (1833). BR. Sch. Bry. eur. fasc. 5, p. 27, t. 7 (1838). DE NoT. Syllab. I 4 I (I838), Epilogo 364 (I869). Rabenh. D. kr. fl. II, Seet. 3, 227 (I848). C. Muell. Synops. i, I 58 (I849). Wils. Bry. brit. 254, t. 30 (I855). Schimp. Synops. 390 (1860), 2 ed. 480 . BERK. Handb. br. m. I 84 (I863). LINDB. Not. ur Saellsk. Fl. Faun. fenn. ix, 58 (I 867). Milde Bry. siles. 224 (1869). HobK. Synops. I 2 I (I873). HUSN. Mouss. nord-ouest I28 (I873), Musc. gall: 254, t. 69 (I889). Juratz. Laubm. oest.-ung. 3Io (I882). Boulay Musc. fr. 24I (I884). Lesq. James Moss, N. Amer. 243 (I884). Limpr. in Raben,. D. kr, f, Laubm. ii, 470 (I893). 
Bryum rostratum Schrad. Spic. A. germ. i, 72 (1794). Roth Fl. germ. iii, P. I, 24 I (I80o). SM. Fl. brit. I369 (I804), Eng. Bot. t. I475. Hook. TAYL. Musc. brit. I26, t. 30 (1816). Hook. Fl. Scot. P. 2, I5I (1821). GRAY Nat. arr. i, $77^{2}$ (182I).

Mnium ellipticum Hof Fa. D. fl. ii, 52 (1795).

Mniun punctatum Var. 2. Wirr. Bot. arr. 4 ed. iii, 806 (180r).

Mnium longirostre BrID. Musc. rec. II, P. III, 106 (I8o3), Sp. musc. III, 5 I (1817).

Hypnum rostratum WeB. MoHr Bot. Tasch. 296 ( 1807 ).

Bryun longirostre BRID. Mant. IIg (1819).

Mnium serfyllifolium $\beta$. rostratum WahLend. F1. suec. ii, 723 (18 26$)$.

Bryum (Polla) rostrata Brid. Bry. uni\% i, 700 (1826).

Astrophyllum rostratum Lindr. Musc. scand. ${ }_{3}$ (i879).

Synoicous; in loose dark green trailing tufts, with slort erect fertile stems. Leaves shortly decurrent, broadly obovate, the comal spathulate, recurved and undulated when dry, obtuse or slightly mucronate, limbate, teeth solitary obtuse, or sometimes almost obsolete, nerve strong, confluent with the limb in the apiculus; cells incrassate, irregular rounded. Capsules several in one perichætium, inclined, oval, leptodermous, yellowish, the seta purple, arcuate at top; lid pale yellow, convex-conic, rostrate, calyptra persistent, reddisl ; peristome yellow, endostome orange.

HAB.-Shady banks and rocks by streams, not uncommon. Fr. 4 .

\section{MNIUM STELLARE Reich.}

Dioicous ; stem and shoots erect. Leaves oval oblong, acuminate not limbate, serrate in the upper half, nerve vanishing below apex. Caps. ovate, cernuous, lid hemispherical, obtuse. (T. LXXXII, D.)

Syn.-Mnizm Serpilli foliis tennibus pellncidis DiLl. Hist. musc. 232, t. 31, f. 2 A (1741), et Herbar.

Mnium stellare ReIch. Fl. mœno-franc. ii, I 25 (I778). Hedw. Sp. musc. I9I, t. 45, f. I-4 (I80I). Brid. Musc. rec. II, P. III, IO2 (1803), Sp. musc. III, 46 (I8I7). P. Beauv. (I805). Schultz Fl. starg. 346 (I806). Schwaeg. Suppl. I, P. II, I 28 (I8I6). MarT. Fl. cr. erl. 66 (I8I7), Hueben. Musc. germ. 420 (1833). BR. Sch. Bry. eur. fasc. 5. p. 33, t. I2 (1838). DE Not. Syllab. I37 (1838), Epilogo 367 (1869). RAabenH. D. kr. fl. ii, S. 3, 228 (I848). C. MuELL. Synops. i, I66 (I849). WILs. Bry. brit. 257 t. 5 I (I 855 ). Schimp. Synops. 396 (1860), 2 ed. 487 . BERK. Handb. br. m. I85 (I863). Linds. Not. ur Saellsk. Fl. Faun. fenn. foer. ix, 68 (1867). Milde Bry. siles. 230 (I86́g). HoBk. Synops. 123 (1873). HusN. Mouss. n.-ouest 129 (I873), Musc. gall. 256, t. 70 (I889). Juratz. Laubm. oest.-ung. 299 (I832). Boulay Musc. 1r. 244 (I884). Lese. James Moss. N. Amer. 247 (1884). Limpr. Laubm. ii, 482 (1893).

Bryum stellare Schrad. Syst. samml. lir: gew. i, 5 in obs. ( 1798$)$. Rотн Fl. germ. ini, P. I, 240 (1800). Vuit Musc. herb. 92 (I8́r2). Brid. Mant. irg (1819).

Hypnum stellare Weв. MонR Bot. Tasch. 294 (1807).

Bryum Polla stellaris BrID. Bry. univ. i, 6qI (1826).

Astrophy'llum stellare LrNDB. Musc. scand. I4 (I879). 
Dioicous; in soft dense tufts, $I-2$ in. high, brown at base, dark green above, changing to blue-green in water. Stems and basal shoots erect. Leaves accrescent upward, erecto-patent, shortly decurrent, undulate and twisted when dry, oblongo-elliptic, acutely acuminate, not limbate, lower nearly entire, upper with the margin from middle to apex with irregular somewhat obtuse teeth formed by the projecting ends of cells; nerve thin reddish, smootls at back, vanishing below apex; cells rounded and angular, irregular. Caps. on a reddish seta, cernuous, longish ovate, olivaceous-brown, lid convex obtuse, reddishyellow; peristome yellowish, endostome orange.

HAB.-Damp shady banks in woods and rotten stumps. Fr. 6, very rare.

Frequent in the N. of England and in limestone districts. With fruit at Winnats, Derby (Holt $\mathrm{I} 884) ! !$ and in a lane on Penyard hill, Ross (Miss E. Armitagc)!

Leaves entire.

\section{I2. MINIUM CINCLIDIOIDES (Blytt) Hueben.}

Dioicous; stems tall, erect. Leaves roundish-oval, entire, not limbate. Caps. pendulous, oval, lid convex, apiculate. (T. LXXXII, E.)

Syn.-Bryum cinclidioides Blyte MS. Lindgr. Musc. suec. exa. fasc. I, n. il (:835). Hartm. Skand. f. 3 ed. 293 (r838). C. Muell. Synops. i, 250 (1849).

Mninm cinclidioides Hueben. Musc. germ. $4 \mathrm{r} 6$ ( 1833 ). BR. Sch. Bry. eur. fasc. 5, p. 34, t. I3 $\left(\mathrm{r}_{3} 8\right.$ ). DE Not. Syllab. r40 (r838), Epilogo 358 (1869). Rabenh. D. kr. f. ii, S. 3,229 (1848). Wils. Bry. brit. 257, t. 5 I (1855). Schimp. Synops. 397 (r860) $2 \mathrm{ed}$. 488. BERK. Handb. br. m. I86 (I863). Linds. Notis. ur Saells. Faun. Fl. fenn. ix, 70 (1867). Milde Bry. siles. 23 I (r869). Hobk. Synops. I23 (r873). Juratz. Laubm. oester.-ung. 3 Ir (I882). Boul. Musc. Fr. 244 (1884). LesQ. James Moss N. Amer. 248 ( $\left.188_{4}\right)$. Husn. Musc. gall. 257, t. 7 I (I890). Limpr. in RABENH. D. kr. f. Laubm. ii, 485 (I 893 ).

Astrophyllum cinclidioidcs LiNDB. Musc. scand. I3 (I879).

Dioicous; tall in loose tufts, radiculose at base, sterile branches elongated erect. Leaves yellowish-green, large distant, lower roundedovate, upper broadly lingulate, rounded at apex with a short apiculus or slightly emarginate, broadly undulate, thin and soft, not limbate but with $\mathrm{I}-3$ rows of elongated marginal cells, those of the lamina in divergent rows, irregular rhombic. Caps. on a long slender reddish seta, suddenly pendulous, ovate, yellowish-brown ; lid convex apiculate ; peristome dark brown, the teeth perforated in the median line, endostome yellow.

$\mathrm{H}_{\mathrm{AB}}$ - -Grassy mountain heaths and marshes. Fr. 6 .

Glen Prosen, Menmuir and Findhaven hills, Clova (Forgusson I868)!! Ben Lawers. Loch-na-Gar (Ewing I886)! Margin of Tal-y-llyn lake, Merioneth. (Ley r 889 )! Grasmere, Westmoreland (Binstcad I 893 )!! 
13. MNIUM PSEUDOPUNCTATUM Br. Sch.

Synoicous; erect. Leaves roundish obovate obtuse entire, with a very narrow limb, nerve vanishing below apex, Caps. small roundishoval, lid rostellate. (T. LXXXIII, B.)

Syn.-Mnium psendopunctatum Br. Sch. in Hook. Lond. Journ. Bot. ii, 669 (1843). Lindb. Not. ur saells. Fn. et F1. fenn. foerh. ix, 68 (1867).

Bryum muioides WiLs. in Hook. Lond. Journ. Bot. iii, 427 (1844), Eng. Bot. Suppl. t. 2907.

Mnium subglobosum Br. Scri. Bry. eur. fasc. 3I, Suppl. $3, \mathrm{t} .3$ ( 1846$)$. RABEnh. D. kr. A. II, S. 3, $224(1848)$. C. MUell. Synops. i, 156 (1849). Wils. Bry. brit. 259, t. 5 I (I855). S' Schimp. Synops. 399 (1860), 2 ed. 490. BERK. Handb. tr. m. I87 (I863). MiLide Bry. siles. 224 (I869). Hobk. Syn. br. m. I24 (I873). JURATz. Laubm. oester.ung. 312 (I 882 ). Boulay Musc. Fr. 243 (I884). Lese. James Moss. N. Amer. 248 (1884). Husn. Musc. gall. 258, t. 71 (1890). Limpr. in RAbeni. D. kr. fl. Laubm. ii, 490 (1893).

Mnium punctatnm Var. subglobosum HAMPE MS.

Astrophyllum pscudopunctatum Lindi. Musc. scand. I3 (1879).

Synoicous; in wide irregular mats, densely coated with black or rufous tomentum, branches slender, erect. Leaves shortly decurrent, distant, green above, the lower becoming reddish, obovate, obtuse, entire, the limb of $\mathrm{I}-3$ rows of elongated narrow cells, nerve thin vanishing below the apex, leaf-cells lax, irregular angular-oval. Caps. small, cernuous, globose-oval, leptodermous, greenish-brown, lid conical, pointed or rostellate; peristome brownish-yellow, endostome orange.

HAB.-Marshy moorland heaths, not uncommon. Fr. 3 .

Longfield and Stansfield moors, Todmorden (Nozell 18 84$) ! !$ Malham Tarn (Nowell). Tintwisle and Stayley Brushes, Cheshire (Whitehead 186I)!! Bowness (Atkinson)! Sutton Park (Bagnall)!! Carmeadow, Derby (Holt 1882$) ! !$ Most of the Yorkshice moors and in Scotland:

Readily known when fertile by the synoicous inflorescence and small rounded capsules, and in the sterile state, although much like the next, the leaves will be seen to be softer, wider at base and with the nerve vanishing some distance below the summit, and also with a narrower limb.

\section{I4. MNIUM PUNCTATUM $L$.}

Dioicous; erect. Leaves roundisl, upper larger obovate, crowded into a rosette, entire, with a thick limb, nerve ending in the very small point. Caps. oval, lid conic rostellate. (T. LXXXIII, C.)

SYN.-Muscus polytrichoides foliis latis subrotundis RAY Synops. 2 ed. 35 (1696)

Bryum nitens, foliis serpylli pellucidis rotundis, capitulis cormuis majusculis, c cauliculis veteribus egredicutibus DILL. Cat. Giss. 227 (I 7 I 8 ). 
Bryum uitidum, Serpilli rotundis et latioribus foliis pellucidis DiLl. in RaY Synops. 3 ed. I03 (I72I).

Bryum pendulum, Serpilli folio votundiore pellucido, capsulis ovatis DiLL. Hist. musc. $4 \mathrm{I}$, t. 53 , f. 8 I (I74I) et Herb.

Mnium serpyllifolium a. M. functatum L. Sp. pl. III3 (1753).

Bryum serpyllifoliun a. punctatum Huds. Fl. angl. 4I7 ( $\left.{ }_{7} 62\right)$.

Muium serpyllifolium Neck. in Act. ac. Theod.-palat. ii, 444 (I770). LIGHTF. Fl. scot. ii, 713 (1777). Willd. Fl. berol, prodr. 332 (1787). Hof FM. Deutsch. Fl, ii, 52 (1795). WAHLENB. Fl, lapp. 353 (I8I2), Fl. upsal. 366 (1820), Fl. suec. ii, 723 (1826). LiNDB. Not. ur saells. Fn. et Fl. fenn. ix, 56 (1867).

Bryum serpyllifolizun Neck. Meth. musc. 216 (177I). SWARTz in W.-Ak. nya Handl. xvi, 253 (1795), et Musc. suec. 5 I (I799).

Bryum punctatun Schreb. Spic. fl. lips. 85 (177 I). Web. Spic. fl. goett. I16 (17/8) Sibth. Fl. oxon. 29I (1794). Roth Fl. germ. iii, P. I, 245 (I8uo). Smith Fl. brit. I368 (1804), Eng. Bot. t. I 183. TURN. Musc. hib. I32 (I 804). VoIT Musc. herb. 89 (I8I2). Hook. TAYy. Musc. br. I25, t. 30 (1818). Brid. Mant. II9 (I8Io). Hook. Fl. scot. P. II, I5I (I82I). Gray Nat. arr. Br. pl. i, 772 (I82I). MaCk. Fl. hib. P. 2, 33 (1836).

Mnium punctatum ReIch. Fl. moeno-franc. ii, I26 (1778), et in L. Syst. pl. iv (1780). Hedw. Fund. II, 94 (1782), Sp. musc. I93 (1801). Wither. Bot. arr. 3 ed. iii, 805 (I796). BRid. Musc. rec. II, P. III, ino (I803). P. Beauv. Prodr.76 (I805). Schultz Fl. starg. 349 (1806). RoEHL. Deutsch. fl. iii, 97 (IS13). Schwaeg. Suppl. I, P. II, I5 (:816). Hueben. Musc. germ. 413 (1833). DE Not. Syllab. I42 (1838), Epilogo 362 (1869). BR. Sch. Bry. eur. fasc. 5, p. I9, t. 2 ( 1838$)$. RABENH. D. kr. H. II, S. 3,224 (I848). C. Muelt. Synops. i, I55 (I849). Wils. Bry. brit. 258, t. 30 (1855). SCHimp. Synops. 399 (1860), 2 ed. 489 . BERK. Handb. br. m. 186, t. I7, f. 6 (1863). MILDE Bry. siles. 223 (1869). HoBK. Synops. I 24 (1873). Huss. Mouss. n.-ouest I29 (1873), Musc. gall. 257, t. 7 I (I 190 ). JURATZ. Laubm. oester.-ung. 3 I 2 (I 882). BoulaY Musc. Fr. 242 (I884). Lesq. James Moss. N. Amer. 248 (1884). Limpr. in Rabenh. Laubm. ii, 487 (1893).

Hypun punctatum Schranck Bayers. Fl. ii, 470 (1789). Web. Mohr Bot. Tasch. 296 (I807). Bryun Polla punctata Brid. Bry, univ. i, yo6 (1826).

Astrophyllum punctatum Linde. Musc. scand. 13 (1879).

Dioicous; in loose tufts, dark green above, reddish below, with reddish-brown tomentum. Stems rigid, I-3 in. high, with many erect shoots. Leaves distant, patulous and reflexed, upper $4-6$ in a rosette, broadly obovate-spatliulate, sliglitly emarginate and very minutely apiculate at apex, lower from a very narrow base, rounded obovate, limb rufescent, incrassate, cartilaginous, of $2-4$ rows of incrassate cells, nerve purplish, ending abruptly below or in the point; leaf-cclls angular-oval, highly chlorophyllose. Caps. horizontal or inclined, oval or ovate, yellowish-green becoming fuscescent; lid reddish-yellow, acutely rostrate; peristome yellow. Male plant more slender with fewer leaves.

HAB.-Wet rocks and sandy detritus of rivulets; common. Fr. $2-3$.

\section{Var. $\beta$. elatum Schimp.}

Taller, more densely tufted. Leaves larger, thinner, with a narrower thinner limb, and without an apiculus.

Syn.-Sciump. Synops. 398,2 ed. 489 . Limpr. op. c، 480 . 
HAB.-Bogs on the higher mountains.

\section{Glen Callater (Hunt)!}

Wilson had another variety which he named cochlearifolium, but the specimen I have seen differs in no way from the type, and the spoon-shape probably applies to the leaf in a growing state.

\section{CINCLIDIUM Swartz.}

Schrad, Journ. Bot. I80I, P. I, p. 25.

Plants tall resembling Mnium punctatum, interwoven with dense black tomentum. Leaves round, obovate, limbate, entire, cells liexagonal. Caps. pendulous, oblong; calyptra minute, cucullate, lid convex; peristome of I6 short obtuse incurved teeth, endostome a cupola-shaped membrane with I6 foramina opposite the teeth. Growing in spongy bogs.-Der. $\kappa \iota \gamma \lambda \iota s$ a lattice.

A fine genus agreeing closely with Mnium in its vegetative system, but differing widely in the peristome and endostome, the latter forming a beautiful membranous dome supported on 16 pillars, between which the teeth curve inward. Besides our British species, C. arcticum, subrotundum and hymenophyllum are Scandinavian, and C. latifolium Siberian.

\section{CINCLIDIUM STYGIUM Swartz.}

Synoicous; in loose tufts, deep green above, reddish-brown at base. Leaves rounded-obovate, apiculate, limb opake, nerve subexcurent. Caps. pendulous, oval-pyriform, lid convex obtuse. (T. LXXXIII, D.)

Syn.- Cinclidium stygium Swartz in SCHRAd. Journ. Bot. I8or, P. I, p. 27, t. 2. Web. Monr Bot. Tasch. 484 (1807). Wahlenb. Fi. lapp. 355 (I8I2). Roenl. Deutsch. fl. iii, izo (1813). Schwaeg. Suppl. I, P. II, 85, t, 67 (I8I6). BRID. Sp. musc. III, Io8 (18I7), Mant. I23 (18I9), Bry. univ. i, 7I 4 (I820). Funck. Moost. 45, t. 28 (I82I). HULblen. Musc. germ. 4OI (I833). Rabenh. D. kr. fl. II, S. 3, 223 (1848). C. Muell. Synops. i, I 53 (1849). WILs. Bry. brit. 260, t. 52 (1855), Eng. Bot. Suppl. t. 2840. Scrimp. Synops. $40 \mathrm{I}$ (1860), 2 ed. 492. BERK. Handb. br. m. I8I, t. I7 (1863). LiNdB. in Not. ur Saellsk. Faun. Fl. fenn. ix, 72 (I 867). MrLde Bry. siles. 230 (i869). DE Not. Epilogo 353 (1869). Hobk. Synops. I 24 (I873). JuRA?Z. Laubm. oester.-ung. 314 (I882). Boulay Musc. Fr. 232 (I884). LesQ. James Moss. N. Amer. 250 (I884). HusN. Musc. gall. 259, t. 7 I (I89o). Limrr. in RaBEN. D. kr. fl. Laubm. ii, 492 (I893).

Mcesca stygia Briv. Musc. rec. II, P. III, I 72 (1803).

Amblyodon stygius P. Beauv. Podr. 33 et 4 I ( 1805$)$.

Mnium (Cinclidium) stygium Br. ScH. Bry. eur. fasc. 5, 1\%, t. I (1838).

Synoicous; in loose tufts, the stems densely coated with blackishpurple tomentum nearly to apex. Lower leaves reddish-brown, 
scattered, rounded ovate, obtuse, upper dark green, in a rosette, from a narrow base, suddenly broadly ovate, apiculate, limb rufous, unistratose of 4-5 rows of narrow cells, nerve rufous, subexcurrent. Caps. on a pale red seta, pendulous, oval, greenish-yellow, leptodermous; lid convex, obtuse, outer peristome greenish-yellow, endostome orange, the apex perforated, basal membrane short, the 16 processes narrow, plicate-carinate.

HaB.-Spongy moorland bogs, not common. Fr. 6-7.

Near Malham Tarn, Yorkshire (Nowell 1836 )!! Suffolk (Skcpper). Ben Ledi (McKinlay and Stirton)!! Glenshee (Forgusson I876). Near High Force, Teesdale (West). Widdy bank, Teesdale (Bames)!! Howgill Fells, Westmoreland (Binstead 1806)!! Ben Lawers and Ben Ina (Stirton).

Taв. LXXX. A. Gjmnocybe palustris (Penzance, Curnow) $\beta$. Var. imbricata ò. Var. ramosa. B. G. turgida (Norway, Blytt). C. Orthopyxis androgyna (Abbey wood, Braithwaite). D. Timmia austriaca (Ben Lawers, Wilson). E. T. norvegica (Ben Lawers, Hunt).

TAB. LXXXI. A. Mnium spinosum (Ben Lawers McKinlay). B. M. marginatum (Matlock, Whitelicad). C. M. riparium (Pond Leigh, Mittch). D. M. orthorrlyunclum (Arncliff, Nowell). E. M. silvaticum (Cheedale, Holt). F. M. rostratum (Eskdale, Braitlwaitc). TAB. LXXXII. A. Mnium Scligcri (Shap, Binstead). B. M. cuspidatum (Wybunbury bog,
Wilson). C. M. hornum (Lingfield, Braitlwatc). D. M. stellarc (Winnats, Holt). E. M. cinclidioides (Clova, Firgusson).

TA5. LXXXIII. A. Muium undulatum (Stroud, Miss Gingcll). B. M. pscudopunctatum (Langford moor, Nowell). C. M. punctatum (Eskdale, Braithwaite) $\beta$. Var. clatum (Braemar, Hunt). D. Cinclidium stygium (Teesdale, Barnes).

a. Fertile plant. b. Male. c. Sterile plant. I. Leaf. ra. Apex. Ix. Transv. section. Im. Margin. 2. Perich. bract. 3. Male inf. 4. Bract and antheridia. 5. Capsule. 6. Calyptra. 8. Peristome. ro. Gemma. 

8.
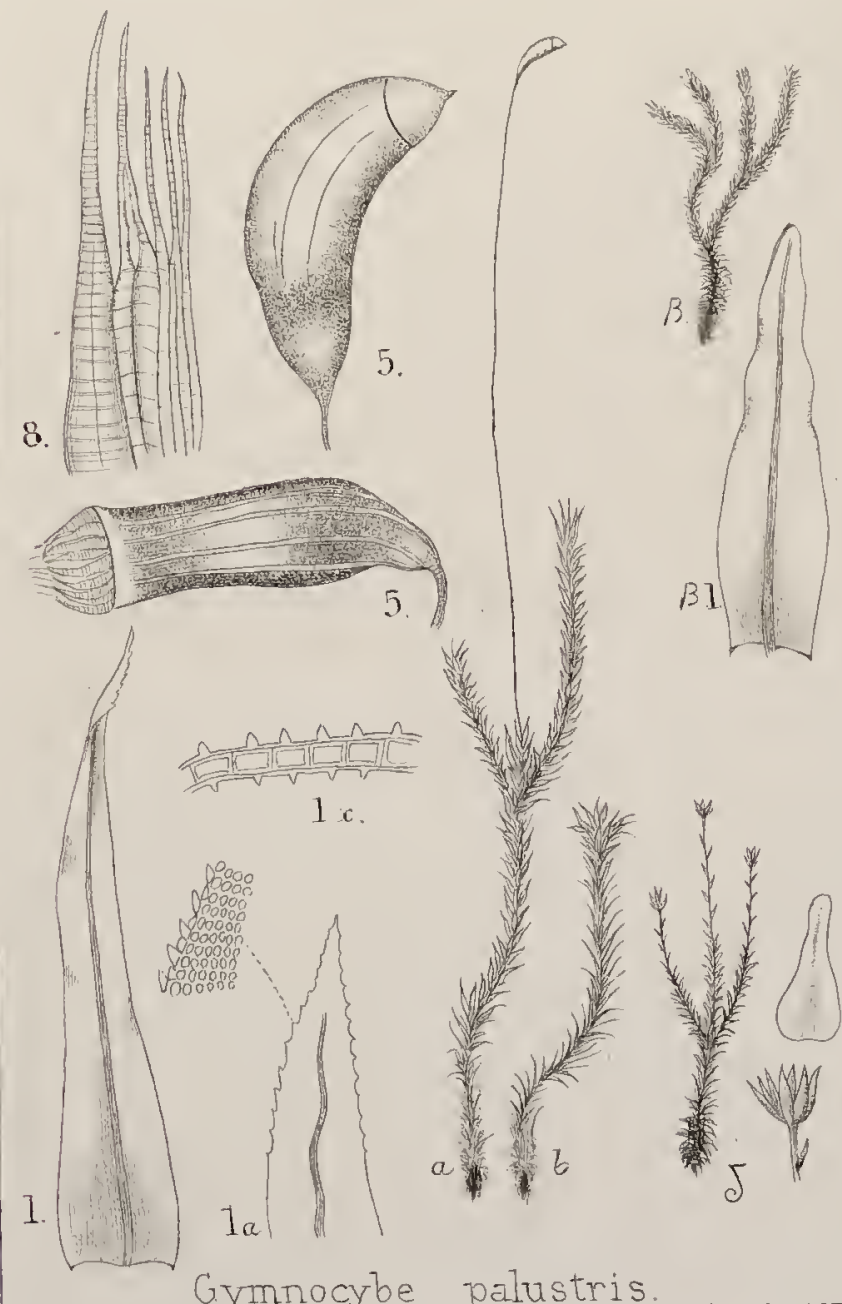

B

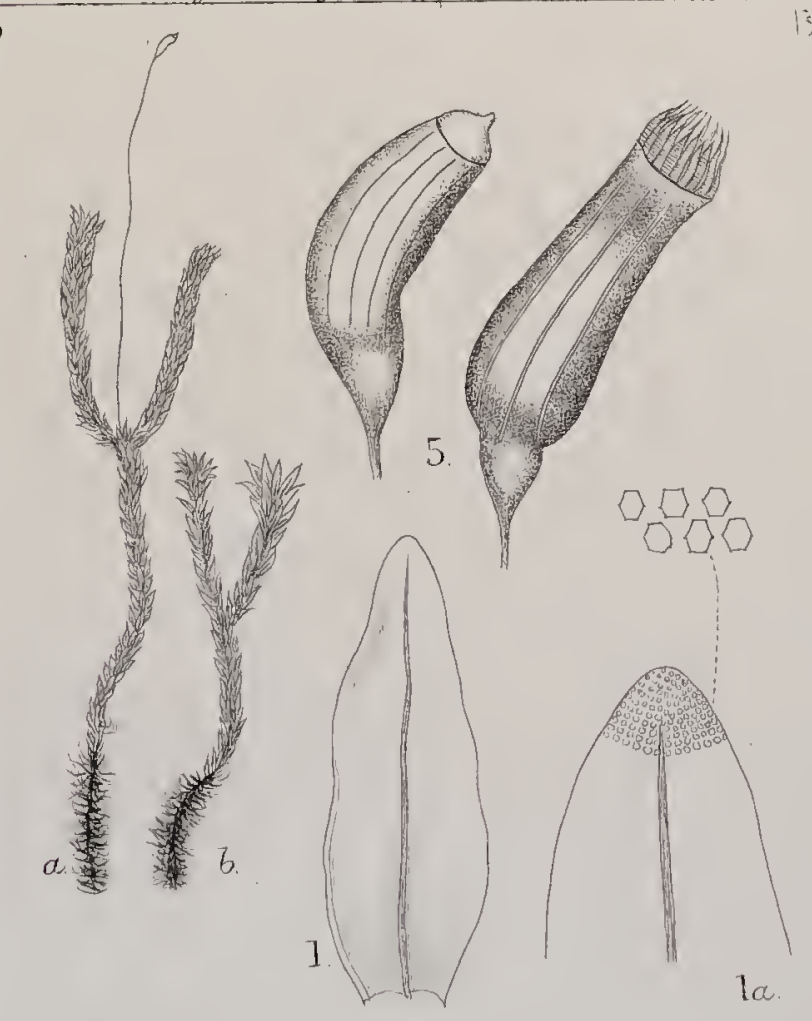

1.

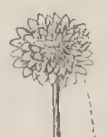
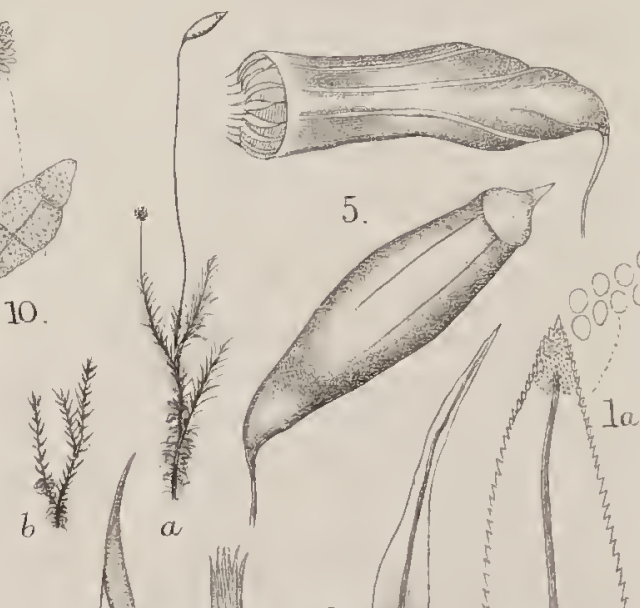

Orthopyxis androgyna
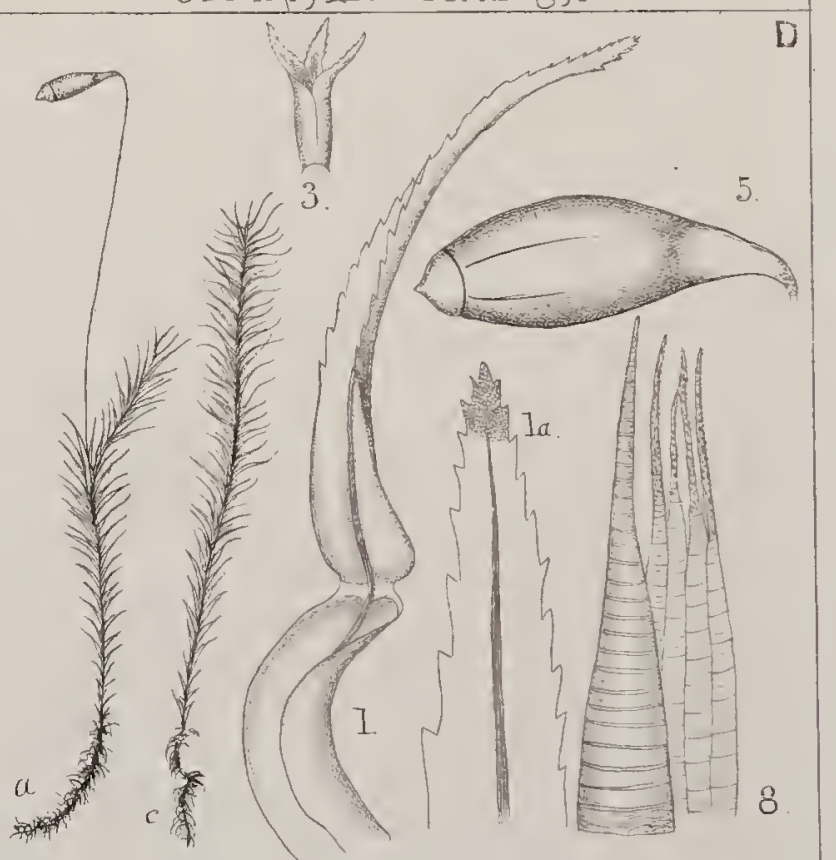

Timmia austraca.

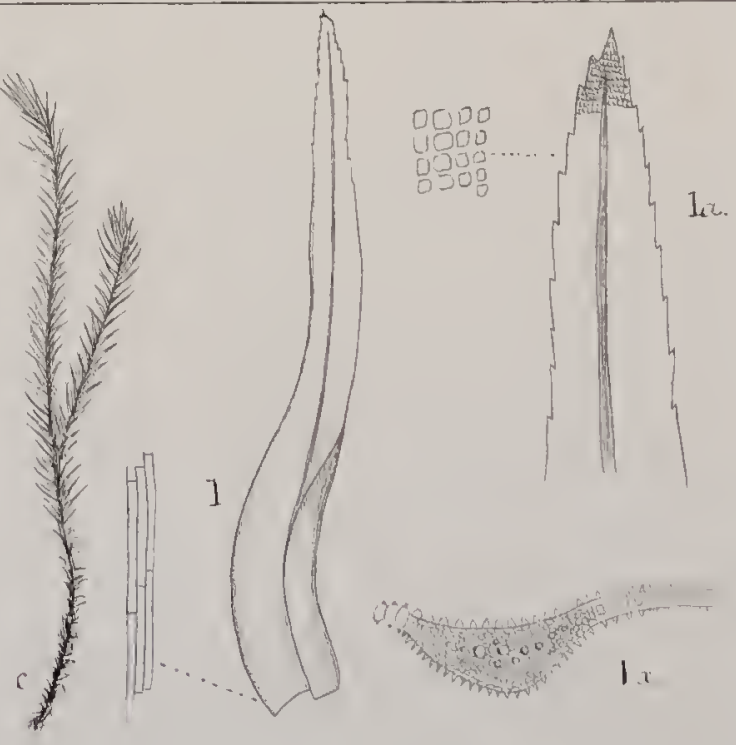

I. norvesica 


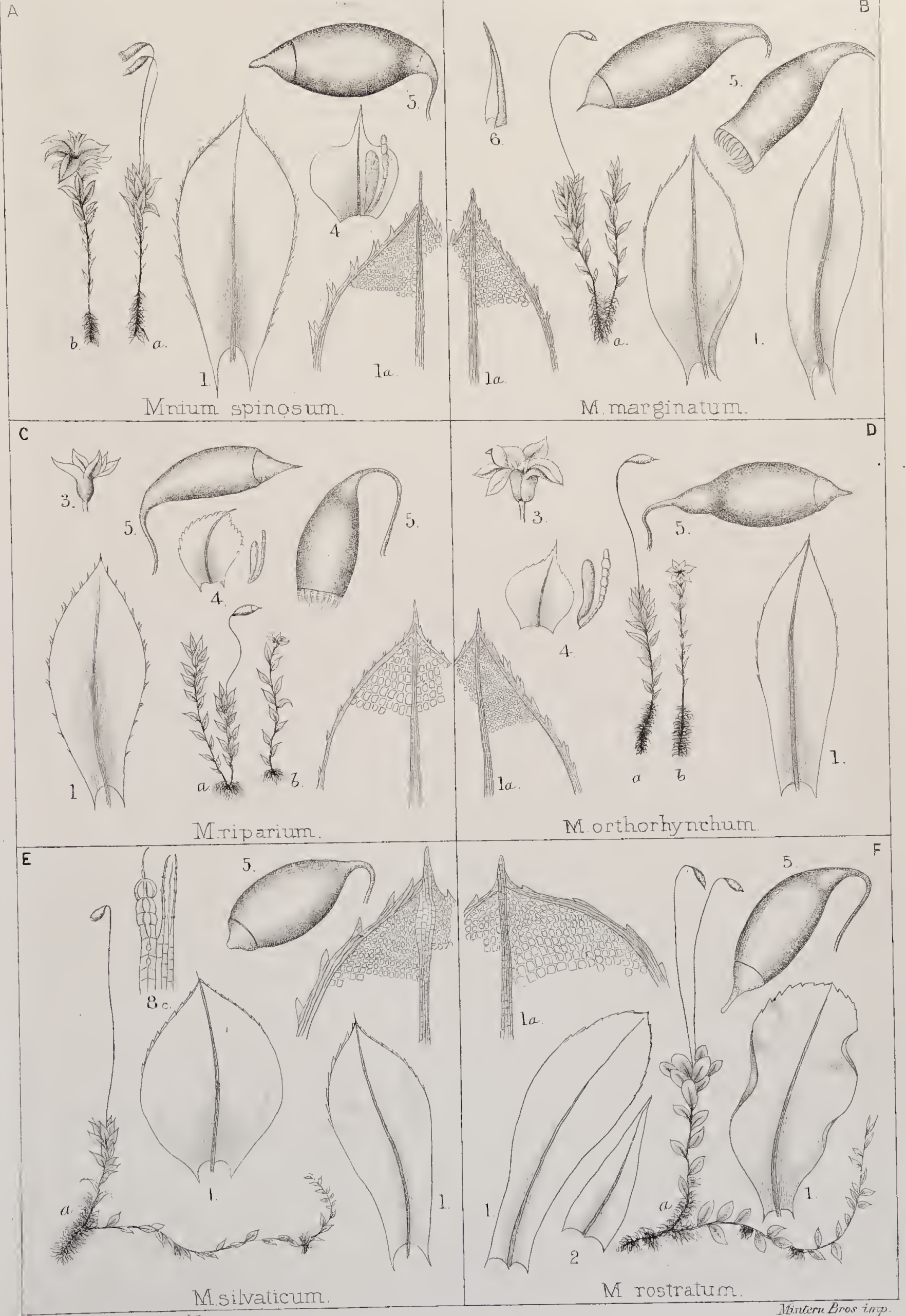




MNIACF.E

I. LXXXII

A
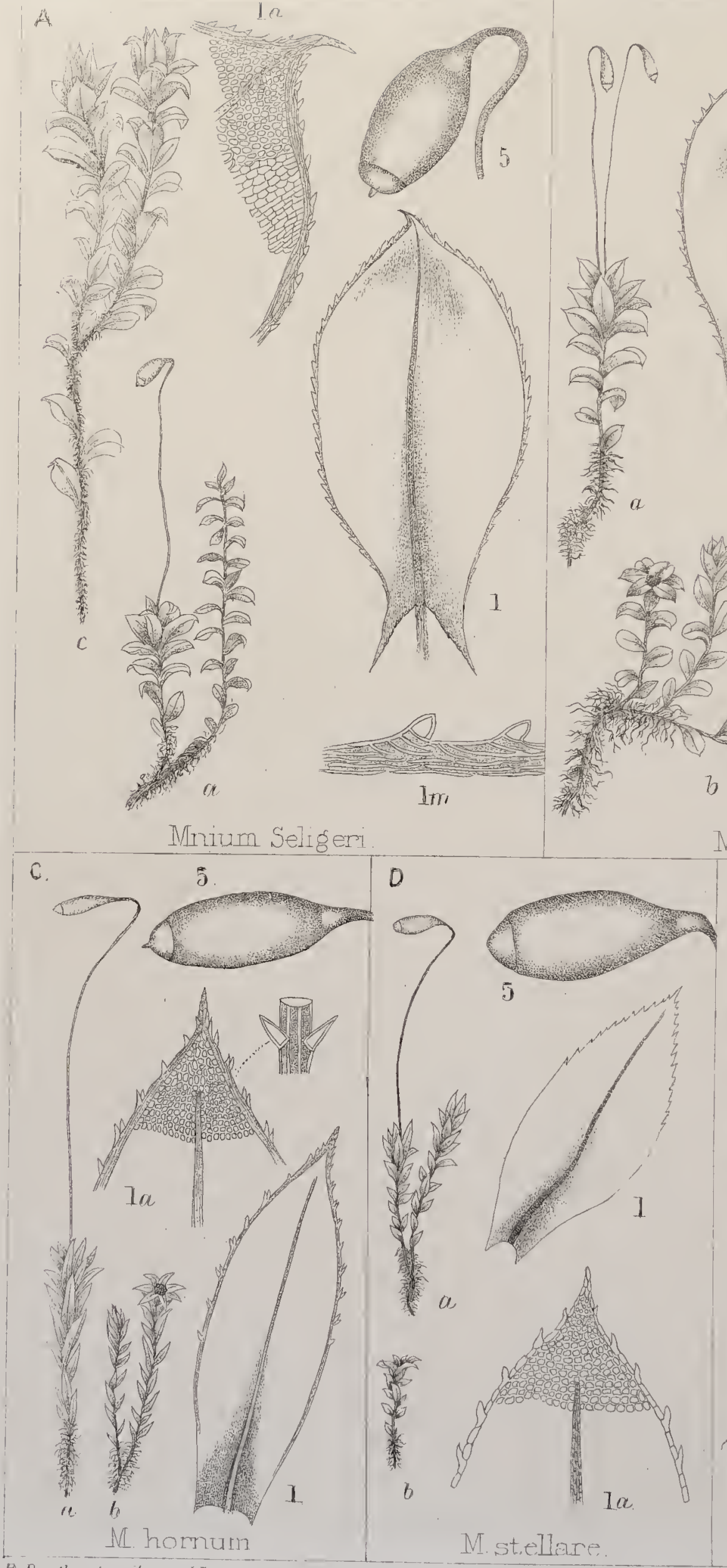

Mi cuspidatum
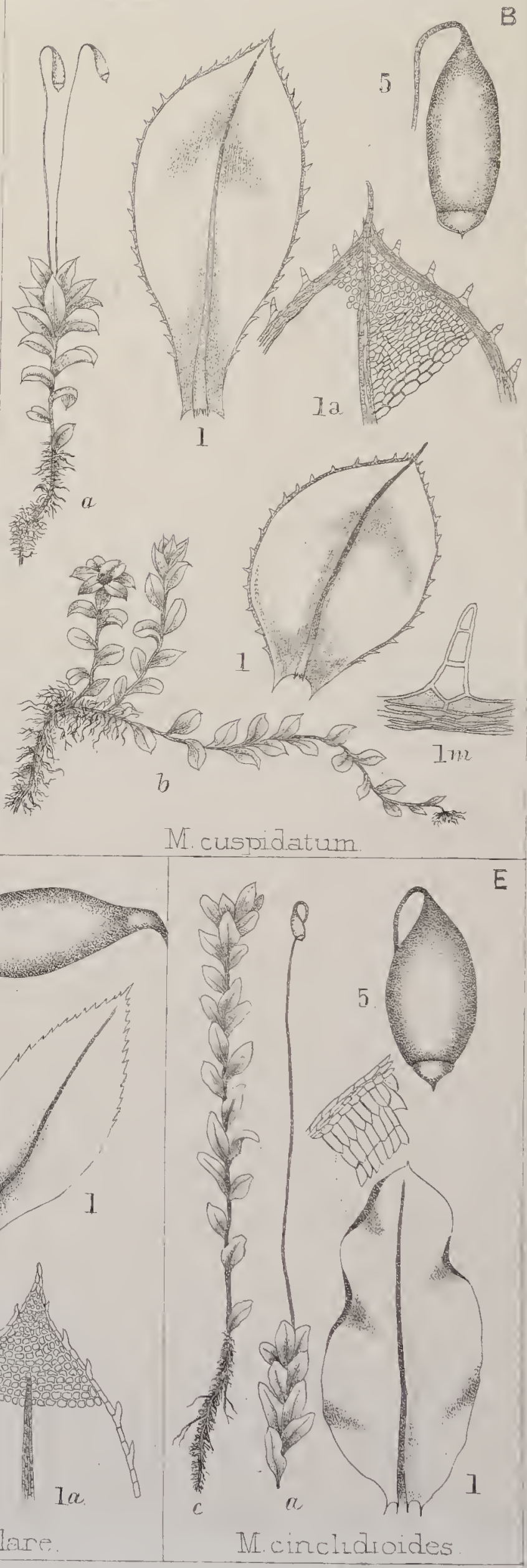

if. Brwethate ad, nat de 


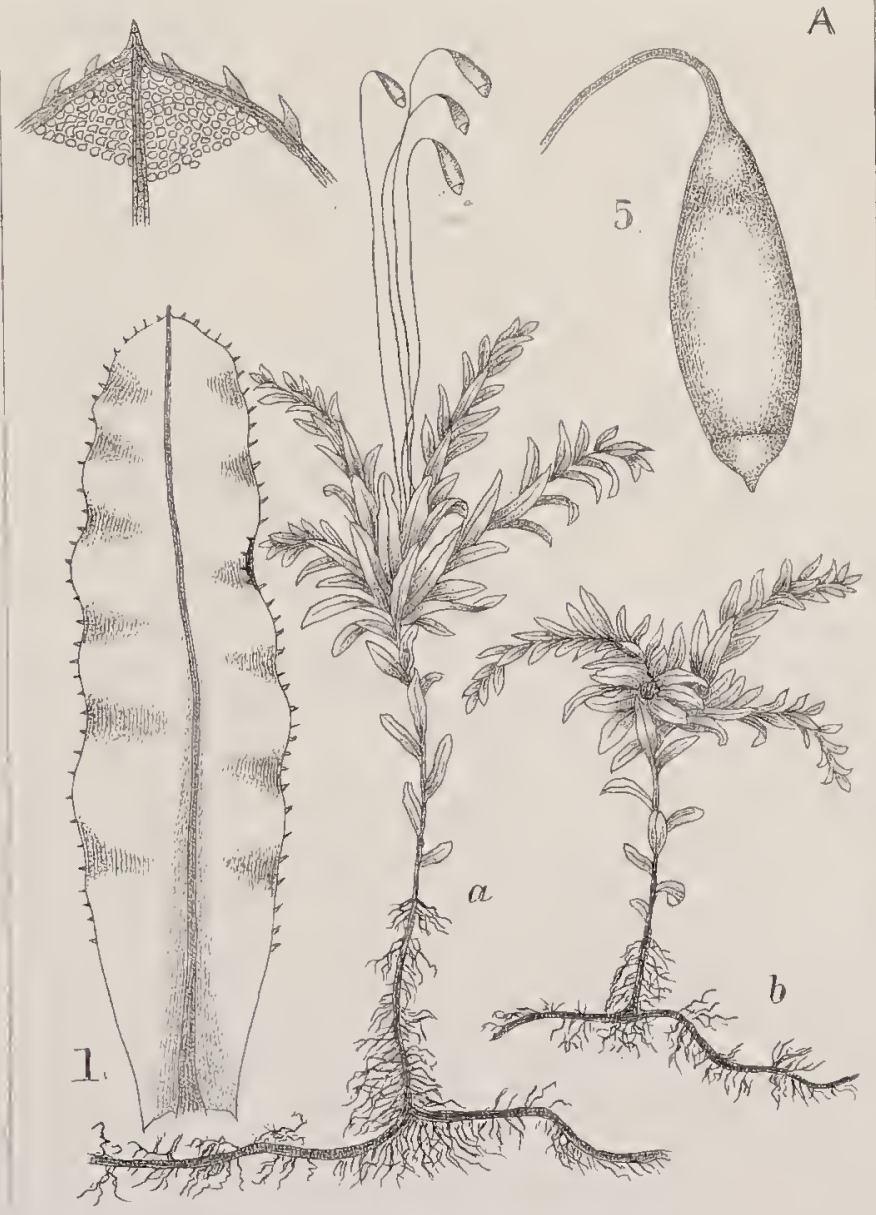

Mnium undulatum.
A

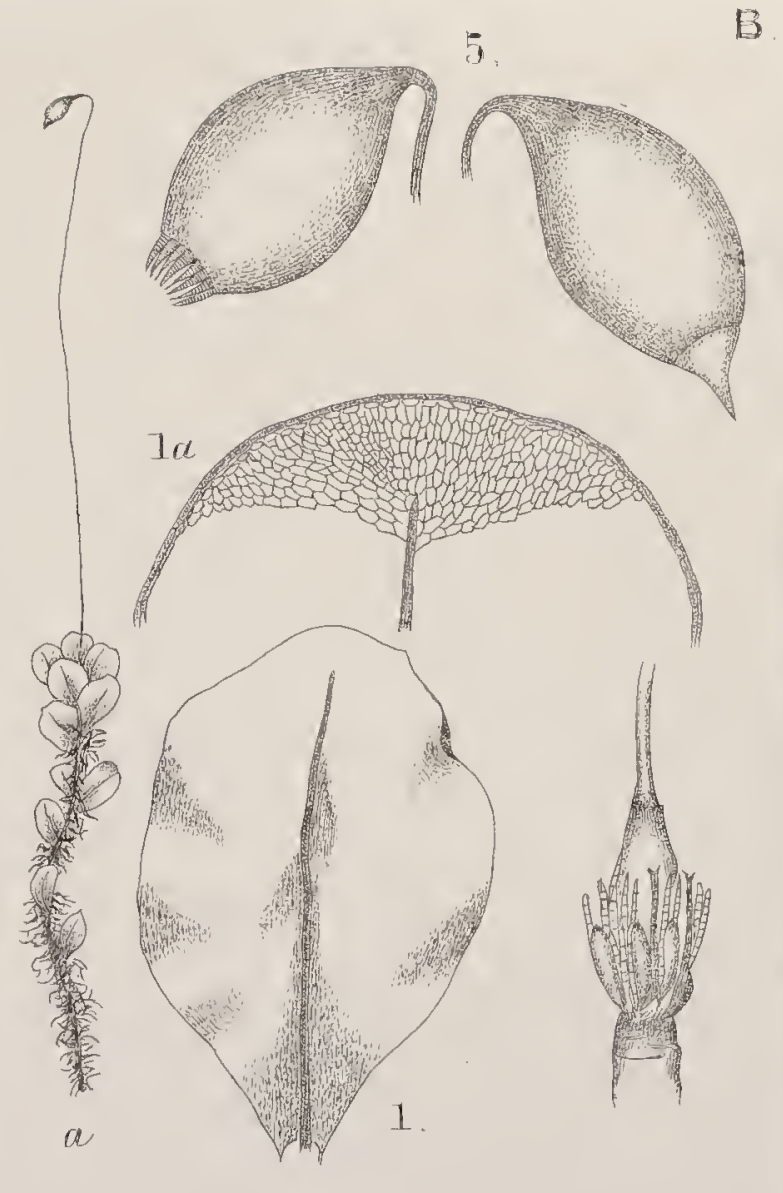

M.pscudopunctatum

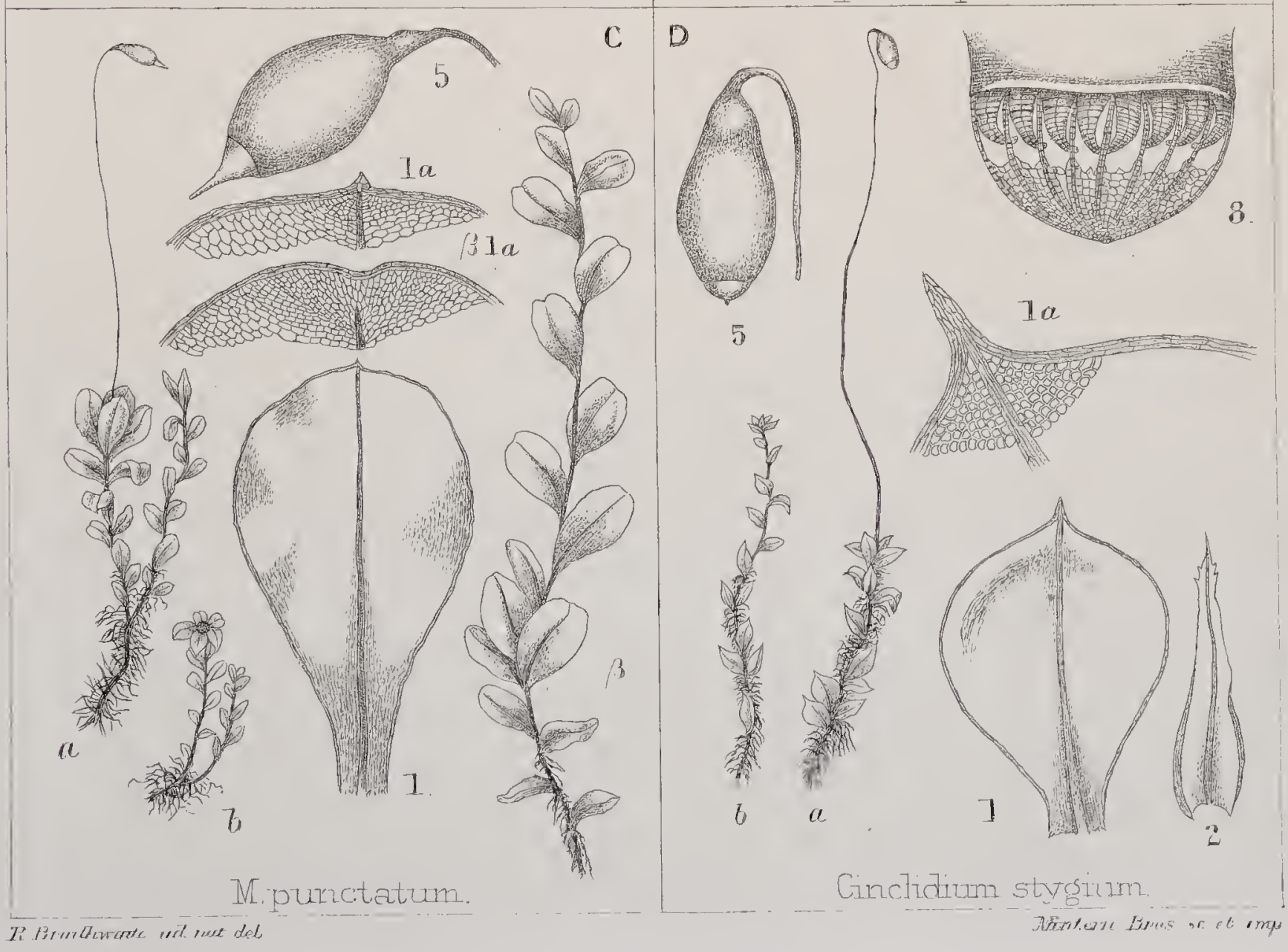





\section{S U P P L E M E T.}

\section{POLYTRICHACEA.}

\section{2*. CATHARINEA HAUSKNECHTII ( $\mathscr{f} u r$. Milde) Broth.}

Paroicous and synoicous; resembling C. undulata, but more slender; leaves more obtuse, capsulas narrower, $2-6$ in one perichætium. (T. LXXXIV, A.)

Syn.-Atrichum Hausknechtii JUr. Milde Verh. zool.-bot. Gesells. Wien 1870, p. 598.

Catharinea Hausknechtii Brotherus Etud. sur la distrib. des mouss. au Caucase 4 (I 834 Hagen in Rev, bryol. I89I, p. 3. Limpr, in D. kr. A. Laubm. ii, 595 (I894).

Catharinea anomala BryHn in Bot. Not. 1886, p. I57. LindB. ArNell in Kong. svensk. vetens. Akad. handl. xxiii, II (I89o).

Catharinea latcralis Vaiz. Ann. Bot. ii, 69 (rSSS).

Atrichun fortile Nawaschis in Hedwigia r 889 , p. 359.

Paroicous or polyoicous ; like C. undulata, but more slender and in looser tufts; the leaves more shortly acuminate and rather obtuse, lower distant, small and lingulate, upper suddenly larger, patent, the teeth at back smaller. At the centre of the terminal bud stand antheridia and bracts, and a row of archegonia encircle them, in others the two sets of organs are within separate bracts, and occasionally they are on separate plants. Fruit aggregated, $2-6$ in the same coma, rarely solitary, seta straw-coloured, flexuose, caps. narrowly cylindric, straight or slightly curved, sub-erect, purplish becoming yellow-brown by age, lid purple with a subulate beak, nearly as long as capsule; peristome as in C. undulata.

HaB.-Damp shady banks, rare. Fr. IO-I2.

On clay banks under beech trees near Broxbourne, Herts. (Vaizcy' I886)!!

This plant is found in Siberia, Finland, South Norway, North Hungary and in the Bavarian alps, but only sparingly, and it has probably not been clistinguished from the common species.

\section{DITRICHUM ZONATUM (Brid.) Limpr.}

Limpricht in his admirable "Laubmoose" $i$, 495, points out that this moss is distinct from $D$. homomallum and also from $D$. nivale, and is only known in 
the sterile state; the 2nd, $5^{\text {th }}$ and 6 th synonyms in Br. Moss-flora i, Ioo, belonging to the latter species. D. zonatum is found on most of the higher mountains of the Breadalbane range.

\section{DICRANUM UNDULATUM Ehrh.}

Figured on T. LXXXIV, B.

Fine sterile specimens have been found in Dupplin woods and VVoodhead wood, Perth (R. H. Meldnum I 89 $\mathrm{r})$ !! It is best distinguished from D. Bonjeani by the divergent leaves, having coarse sharp teeth standing out from the margin, and both these hare the leaf-cells shorter and not so narrow and linear as in D. scoparium.

\section{TORTULACEA:.}

\section{I4.* MOLLIA BREVIFOLIA (Sendtn.) Braithw.}

Dioicous; densely tufted. Leaves dense, from a lanceolate base, narrowly linear, obtuse. Caps. minute ovate; lid with a long very slender beak. (T. LXXXIV, D.)

Syn.-Trichostomum brovifolizm Sendtn. in litt. C. MUell. Synops. i, 572 (1849). Limpr. in RABENH. D. kr. f. Laubm. i, 575 (1888).

Dioicous; in densely cushioned tufts, fastigiate, dull green abọve, brown at base, the stems very slender, dense-leaved. Leaves short, from an erecto-patent base, slightly recurved, lanceolate, lineal and narrowed above, obtuse at point, the margins incurved, nerve yellowish, reaching apex or excurrent in an apiculus; cells at base minute rectangular, yellowish and transparent, above rounded-quadrate, opake, papillose on both sides. Perich. bracts sheathing, acuminate with a projecting point, the cells thin rhombic smooth. Seta reddish below, yellow above. Caps. very small, erect, ovate with a narrow mouth, jellowish-brown; lid long as capsule, with a long very slender beak; peristome yellow, teeth longish, geminate, very slender, roughish. Male infl. gemmiform, terminal, the 3 inner bracts ovate, pointed, nerveless, toothed at margin.

$\mathrm{H}_{\mathrm{AB}}$. - On rocks in limestone districts, rare. Fr. 6.

Upwey near Weymouth (Mitten I885)!! Near Swanage, Dorset (Mittcn I890), both sterile.

This has probably been mistaken for M. crispula, but differs in the leaf, which is much shorter, and not boat-shaped at the apex. 


\section{$9^{*}$. BARBULA ICMADOPHILA Schimf.}

Dioicous; slender, in dense olivaceous tufts. Leaves ovatolanceolate, acuminate with a long subulate excurrent nerve. Capsule subcylindric. (T. LXXXIV, E.)

SyN.-Barbula icmadophila Schimp. Bry. eur. fasc. 43, t. suppl. 2 (I850). Synops. 172 (I860), 2 ed. 2 II. C. Muell. Synops. i, 6I4 (I 849). Milde Bry. siles. II7 (I869). Juratz. Laubm. oest.-ung. I25 (I 882). Husn. Musc. gall. I06, t. 30 (I886). Limpr. in RABenh. D. kr. fl. Laubm. i, 625 (1888).

Tortula icmadophila Linde. de Tort. 249 (I864). DE Not. Epilogo 553 (I869).

Barbula abbreviatifolia H. Muell, in Verh. bot. Ver. Brandenb. I866, p. 58 .

Dioicous; in dense tufts, olivaceous green above, brown at base, the stems very slender, with short subcuspidate shoots. Leaves erectopatent, from an ovate base, lanceolate, suddenly acuminate, the brownish nerve excurrent in a long subulate straight point about $\frac{1}{4}$ the length of leaf, margin revolute with a longitudinal fold just within it; cells uniform, incrassate quadrate, shortly rectangular at base. Perich. bracts longer, sheathing. Seta reddish, caps. brown, erect, almost cylindric, lid with a short oblique beak; peristome purple, twice twisted to the left.

HAB.-Moist alpine rocks; rare and sterile. Fr. 8.

Quiraing, Isle of Skye, and above Loch-na-Chat, Ben Lawers (Dixon, July, I893)!!

This moss is very close to $B$. acuta, but has the leaves more suddenly narrowed above the middle, with the nerve much more excurrent. The fruit is very rare, but has been found at Krimmel fall, Salzburg.

\section{CINCLIDOTUS.}

\section{CINCLIDOTUS RIPARIUS (Host) Arnott.}

Dioicous; dull dark green. Leaves lingulate, obtuse with a short apiculus, scarcely keeled, limb of 5 rows of cells in several strata. Caps. exserted, longish, curved. (T. LXXXIV, C.)

SYN.-Gynnostomum riparium Hos't Syn. pl. austr. 563 (I797).

Trichostomum nigricans BRID. Sp. musc. I, 242 (1806).

Trichostommm riparium Web. MoHR Bot. Tasch. I20 (1807). SchisuhR D. kr. fl. P. II, 75 , t. 23 (I8Io). Schwaeg. Suppl. I, P. I, I58, t. 39 (I8II). Roeml. Deutsch, fl. iii, 64 (I8I3). FunCK Moost. 27, t. I8 (I82I).

Racomitrium rifarium Brid. Mant. So (1819), Bry. univ. i, 223 (1826). IUuleen. Musc. germ. 2 I3 (1833). 
Cinclidotus viparius Arnot M Mem. soc. d'hist. nat. Paris ii, 27I (IS25). DE Not. Syllab. 259 (1838), Epilogo 494 (I869). BR. Scr. Bry. eur. fasc. 16, p. Io, t. 2 (1842). RABENH. D. kr. f. ii, S. 3, 242 (1848). Schimp. Synops. I94 (1860), 2 ed. 235. Milde Bry. siles. I40 (1869). Husn. Mouss. n.-ouest 88 (I873), Musc. gall. I I9, t. 34 (I886). Juratz. Laubm. oest.-ung. I46 (I882). Boulay Musc. Fr. 401 (I884). Limpr. in Rabenh. D. kr. fl. Laubm. i, 699 (I888).

Guembelia riparia C. MUELL. Synops. ii, 65 I (185I).

Dioicous; in loose soft tufts, $I-3$ in. high, dark green at apex, black at base, often with a metallic gloss. Leaves erecto-patent, when dry slightly incurved and $t$ wisted or incumbent, from a narrower base longish lingulate, obtuse with a short apiculus, scarcely keeled, nerve lost in the point or excurrent as the blunt apiculus and confluent with the thickened limb which consists of five rows of cells in $2-5$ layers, the other cells smooth, rather small, dense and roundish. Seta about length of capsule, thick, orange; caps. exserted, longish oval, erect, somewhat curved, dark brown; calyptra conico-dimidiate, brownish, reaching middle of caps., lid conic, acuminate, incurved; peristome dark purple, the teeth irregular, in $2-4$ smooth filiform legs, united at base by transverse bars. Male plant more slender and fasciculate. $\mathrm{HAB}_{\mathrm{B}}-\mathrm{On}$ stones in streams, very rare and sterile. Fr. 7-8.

River Fergus at Ennis, Cu. Clare, Ireland (Stewart, July, I884)!! In the Teme near Ludlow, Salop (Wayman i 890 ) !! Both sterile.

So closely does this moss resemble Bavbula mucronata that it was long united with it, the Bavbula being regarded as a terrestrial variety. In the barren state $B$. mucronata may be known by the leaves having the upper cells papillose, and the basal ones more or less transparent, and the margin revolute and of 2 layers of cells; in fruit the long red seta immediately distinguishes it.

\section{BRYUM ALPINOM.}

Var. $\gamma$. viride Husnot.

Tufts pale green, the leaves shorter, acute, with a few small teeth at apex, nerve yellowish, slightly excurrent.

Syn.-Bryum alpinum Var. viride HUSN. Musc. gall. 247.

Hab.-Banlis of the Rattle brook, Dartmoor (Holmcs)!!

\section{BRYUM CAPILLARE.}

Var. $\eta$. elegans Nccs.

Tufts dense and soft, dull green above, ferruginous at base. Leaves dense, julaceously imbricated, very concave and spoon-shaped, broadly 
oval, margin flat, narrowly limbate, nerve yellow, excurrent in a smooth recurved hair.

Syn.-Bryum capillare Var. cochlearifolium Brid. Bry. univ. i, 666. Bry. eur. fasc. 6-9, p. 6r, t. $29 \eta$. C. Muell. Synops. Schimp. Synops. 372. Milde Bry. siles.

Bryum clegans Nees MSS. in Brid. Bry. univ. i, 849. Schimp. Synops. 2 ed. $45^{2}$. Limpr. Laubm. ii, 387 .

Bryum capillare $\delta$. late-vircns HueBen. Musc. germ. 442.

Bryum capillare* B. elegans Lindb. Musc. scand. i6 (I879). Boulay Musc. fr. 264.

HAB.-Alpine rocks in limestone districts.

Litton dale, Yorkshire (Whitehend and Ashton 1879)!!

A moss with very distinct aspect and much more worthy of specific rank than B. obconicum. Limpricht also transfers the Var. Ferchelii and Carinthiacum to $B$. elegans.

\section{TAB. LXXXIV.}

A. Catharinea Hansknchtii (Broxbourne, Vaizey). B. Dicranum undulatum. C. Cinclidotus riparins. D. Mollia brevifolia. E. Barbula icmadophila.

a. Fertile. c. sterile plant. I. leaf. Ia. apex. rb. base. Ix. section. 5. capsule. 6. calyptra. 8. peristome, ax, vertical section of apex of stem. 


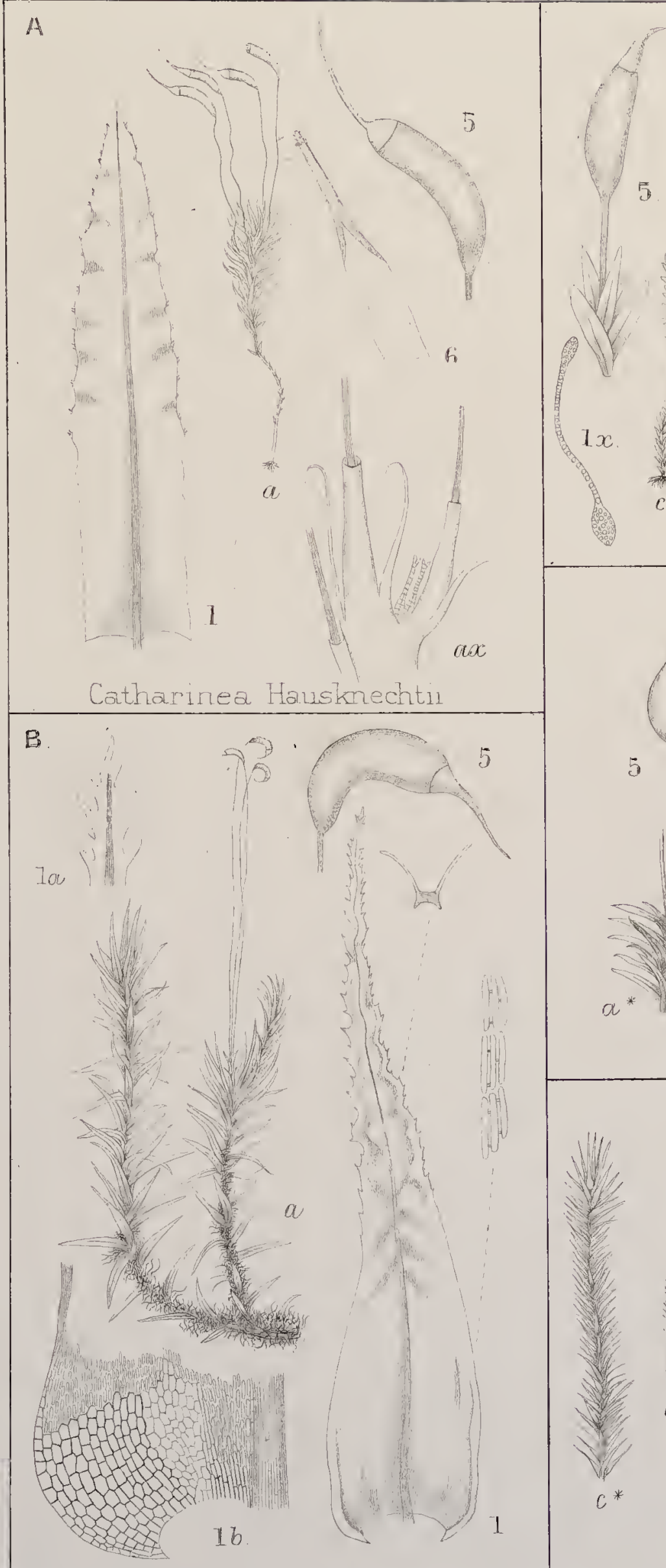

c.

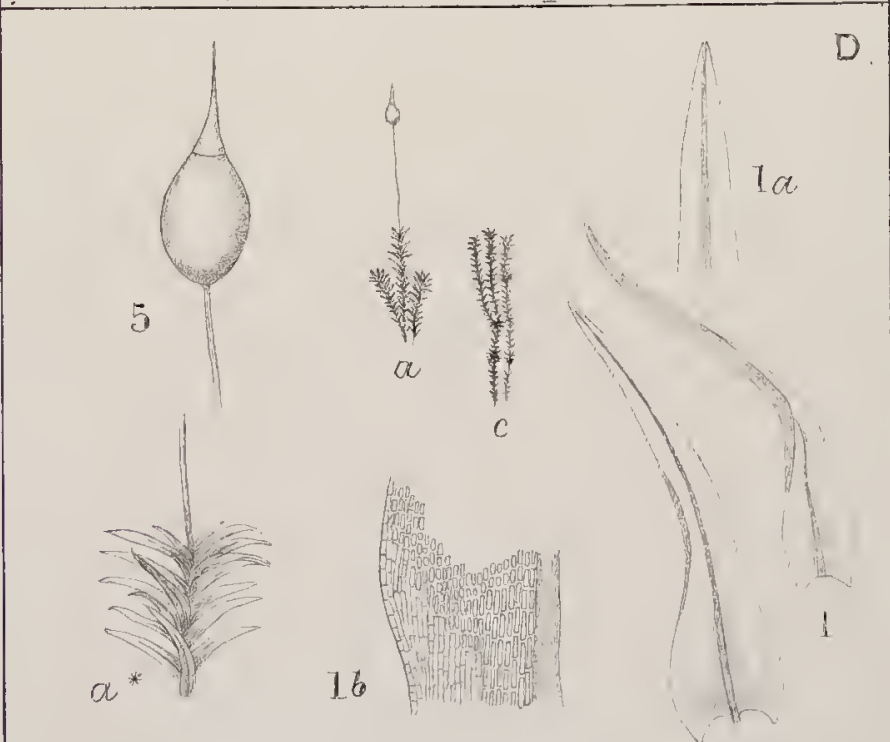

Mollia brevifolia.

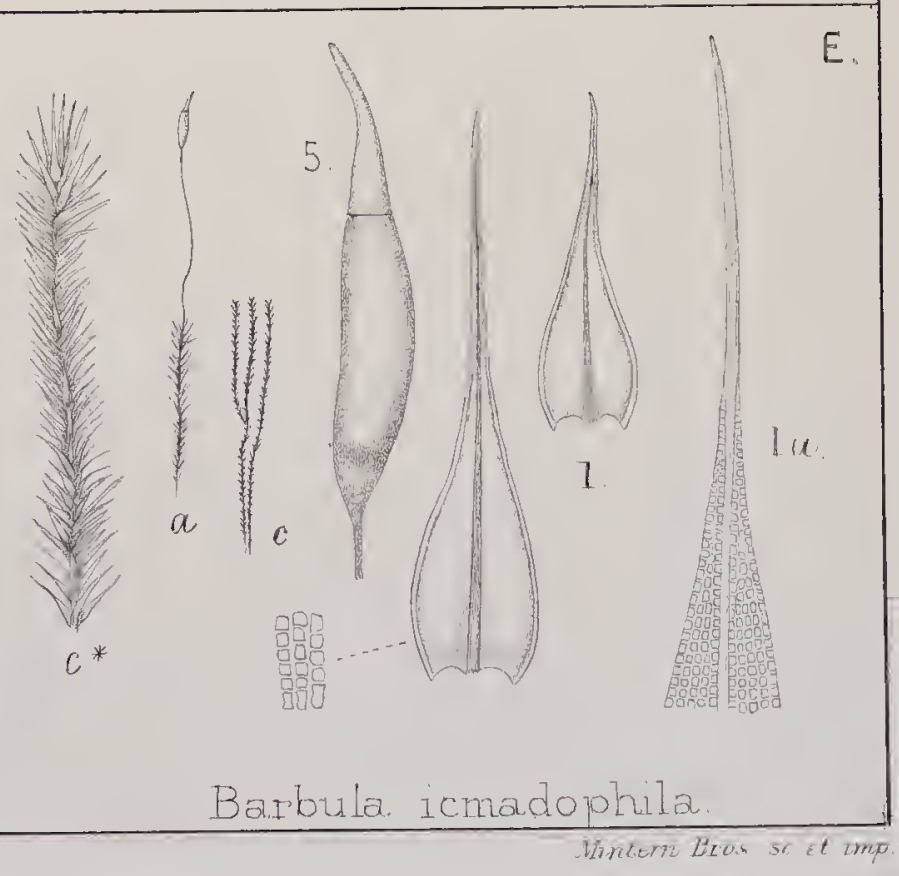





\section{A D D E N D A.}

Buxbaumia aplyylla. Fir wood, foot of Ben Lomond, Rowardennan (Patcrsoll). Otter wood, Kilfinan.

Catharinca crispa i. Two Bridges, Princeton, Devon (Dixon I894).

Oligotrichum incurvum Var. laxum. Gwynant, N. Wales (Dixon I888).

Fissidcns Curnozvii. Aber, N. Wales (Dixon I892). crigunus and tamarindifolius. Saltburn, Yorks. (Barnes).

cristatus. East gill, Kisdon Force, Hawnhy and Wensleydale, Yorks. (Barnes).

rufulus. In the Lune at Kirkby Lonsdale (Miss Tindall $\mathbf{1} 894$ ).

poly'plyllus. Nant Gwynant, N. Wales (Dixon I888).

Lellcobrynm minns. Under this name it appears that two species have been mixed up, and my valued friend, Mrs. Britton, having examined all the types, has, with her usual aciteness, cleared up the matter and kindly sent me the result. Of the two species only one is found in Europe, but both in America. The former will stand as

Lencobry'um albidum (BRID.) LINDI.

Syn.-Bryum albidtun ct glancum fragile minns, foliis crectis, sctis oblongis DiLL. Hist. musc. 546, t. 83 , f. 8 (I74I).

Dicrantm albidum Brid. Musc. rec. II, P. I, I67 (1798). Sp. musc. I, 205. Mant. 67.

D. glaucum Var. albidum WEв. Moнr Bot. Tasch. I66 (1807). BriD. Bry. univ. i, 409 (1826).

Leucobryum minus (non Hampe) Sulliv. Mosses U.S. 24 (1856). Lesq. James Moss. U.S. 9 I (I884). Braithw. Br. Moss-Fl. 295 excl. syn. (I887).

L. albidum Linds. in Oefv. K. vet. ac. Foerh. I863, No. 7 .

Exs.-Sull. Lesq. Musci bor.-amer. 2 ed. No. $9^{8}$ p.p. (1865). It has also been found in Italy, near Lago Maggiore.

The second species is

Lencobry'un pumilum (Michx.) BRITton.

Sys.-Dicranum glancun pumilum Michx. Fl. bor.-amer. ii, 297 (rSo3).

Leucobrynm vulgare $\beta$. mimus Hampe Linnæa xiii, 42 (I859). C. Muell. Linnæa xviii, 687 (1844), Synops. i, 75 .

L. scdiforme (non C. Muelz.) LesQ. James Moss. U.S. 9I (I884).

L. pumilum Britton Bull. Torr. Club xix, Igo (I8g2).

Exs.-Drumm. Musc. amer. 2 ed. Nos. 45-46 (I84I). Sulliv. Musci Allegb. n. I69 (I846). Sull. LesQ. Musci bor.-amer. 2 ed. n. 98 p.p. Austin Musci appal. n. 477 (I870).

Swartzia inclinata. Dunfanaghy, Donegal (Dixon I890). Coatham marshes, Yorks. (Barnes).

Seligeria pancifolia. On chalk blocks, Goodmanham, E. Yorks., with S. calcarca ( $\mathcal{F} . \mathcal{F}$. Marshall, I894.)

- acutifolia $\beta$. Kisdon Force and Richmond, Yorks. (Barnes).

trifaria. Kisdon Force, East gill and Blackburn gill, Upper Swaledale, and several falls in Wensleydale (Barnes).

Campylopus atrovircus Var. falcatus. Doocharry Bridge, Donegal (Dixon I89o).

$$
\text { Var. epilosus Penmaenmawr, N. Wales (Dixon I892). }
$$

Shawii. Sligichan, Skye (Binstead I885). Staffin, Skye (Dixon I893). 
Campylopus setifolius. Poisoned glen, Donegal (Dixon I89o). Widdy bank fell, Teesdale (Barncs). Schzearzii. Bowfell, Westmoreland (IBinstcad 1894 ). subulatus. Chipstable, Somerset (Binstead 1888). Rhyd Dhu, N. Wales (Binstcad 1 886).

Blindia trichodes. Naddle forest, Westmoreland and Black mountain, Brecon (Binstead 1893). Dicranum viridc. Ingestre and Blithfield hall, Trent. Alton, near Uttoxeter (Bagnall I894). - fagellarc and montanmm. Woods at Ruislip, \&c., near Uxbridge (Benbow I 894). schisti. Helvellyn (Dixon $\mathrm{r} 8 \mathrm{~g}$ ).

mncinatum. Dungeon Ghyll Force (Dixon I89I). Eskdale, Cumberland (Binstcad I 894). Limpricht in his admirable Laubmoose i, 409, figures this moss with a sparsely fringed calyptra. The fruit was found by Breidler near Schladming in Styria, and at St. Nicholas.

Oncophorus cremulatus. Far Easdale (Rev. H. G. Fameson $\mathrm{1} 889$ ) and Langdale, Westmoreland (Dixon $\mathrm{x} 89 \mathrm{I})$.

___ gracilescens. Mr. Whitehead sends me a typical specimen he detected in an old collection " N. Wales (E. Evans I 821 )."

Pottia latifolia. Craig Mhor, Glen Tilt (Barker r872). Craig Koynach, Castleton (Forgusson 1873). Tomintoul farm on Morrone, Banff. Breadalbane range (Tetlovv).

Tortula lamcllata. Kingsthorpe and Croughton, Northants (Dixon).

angustata. Darlington, Richmond, Saltburn, \&c., Yorks. (Barnes). princeps. Miller"s dale, Buxton (Ashton I87o).

Leptodontium rccurvifolium. $\mathrm{C}_{\mathrm{wm}}$ Bychan (Wild). Cynicht, $\mathrm{N}$. Wales, with abortive archegonia (Dixon I888). Creag Mhor, Tyndrum (Holmcs I888).

Pleurochatc squarrosa. Kendal and Wells; Somerset (Binstead 1887 ).

Mollia squarrosa. Saltburn (Barnes).

- rutilans. Saltburn and Lofthouse (Barnes).

inclinata. Bownes on Solway (Binstead $\mathbf{1} 890$ ). Barmouth and Bracelet Bay, Swansea (Binstead 1893).

tcnuirostris Var. Holtii. Widdy bank fell (Barnes).

Barbula rubclla Var. ruberrima. Aira Force, Scawfell Pike and Ulleswater (Dixon ISgr). Var dentata. Kintail, Ross (Dixon I893).

-_ reflexa. Teesdale, Swaledale and Wensleydale (Barncs). curvirostris Var. papillosa. Ben Lui (Dixon 1893).

Grimmia subsquarrosa. Considered by Limpricht to be a gemmiparous form of G. Muellenbeckii, just as G. Stirtoni is of G. trichophylla. Pen/ance (Dixon 1886). Brimmer head, Grasmere, by Rydal lake and Windermere (Binstertl IS93). Erwood, Radnor (Binstead I893).

- anodon. Near Kendal (Binstead I886).

montana $\precsim$. Honister Crag, Cumberland (Waterfall 1885 ). Braithwaite, Cumberland (Binstcad 1890). Tilberthwaite, Lanc. (Binstead I893). Summit of the Wrekin (Bcnson I893). Stanner rock (Binstcad I894).

¿__ncurva. Titterstone, Shropshire, and Summit of Scawfell Pike (Binstead I 893). ovalis. Stanner rock and Aberedw (Binstcad I893). Willersley, Hereford (Binstead I89o). Glasbury, Brecon (Binstead I89 I).

Hartmani. Fairhead, Antrim (Dixon I89o). Becky fall, S. Devon (Dixon I894).

elongata. Whiteside, Hobcarton crags', Cumberland (r889), and Grisedale Pike (Binstead 1894). 
Grimmia ovalis. Castle rocks, Lynton, N. Devon (Hoimes).

Coscinodon cribrosus. Wall at Staveley (Binstcad 1886). Barmouth, Merioneth (Binstead I89o). Tilberthwaite with Gr. montana (Binstead 1893). Portmadoc, N. Wales (Dixon).

Glyphomitrium Davicsii. Near Keswick, Cumberland (Carrington and Pearson 1884 ).

Zjgodon Forsteri, add Mitr. Ann. Mag. Nat. hist. 2 ser. viii, 32 I (I85I).

Orthotrichum obtusifolitum. Newbottle, Farthinghoe and Paulerspury, Northants (Dixun). Rokeby, Yorks. (Barnes).

Schimpcri. Kettering (Dixon I885). Rokeby (Barnes).

- pallcnis. Darlington and Rokeby (Barncs).

pulchellum. Hurstpierpoint and Midhurst (Mitten).

The Var. Winteri must be erased, being incorrect.

Wcissia Ancricana. Bodmin moors, Cornwall (Dixon I88I). Pont Aberglaslyn (I888). Errigal, Donegal (189o). Quiraing, Skye (1893).

- calvescolls (WILs.) Braituw, has precedence over W. Viltata. See Carrington in Trans. Bot. Soc. Edin. vii, 386 (I863). Poisoned Glen, Donegal (Diron I89o).

Tayloria tenuis. Near Watten, Caithness (Rcv. D. Lillic, IS94).

Ocdipodium Griffithii. Errigal, Donegal (Dixon 189o). Ben Ina (Stirton).

Discclium undum. Skipton, Yorks. (Holmcs). Banks of the Earn. Raven's seat, Swaledale (Barnes).

Amblyodon dcalbatus. Richmond, Coatham marshes and Widdy bank, Teesdale (Barnes).

Physcomitrclla patcns. Tunbridge Wells and near Stroud, Gloucester (Holncs). Abundant with its Var. Lucasii in 1893 about Manchester (Prof. Barkcr), Bourton, Warwick (Rev. W. O. Wait), and Waterford marsh, Hertford (H. Darton).

Funaria attcnuata. For T'. lxiv, C., read lxv, C., and for Plymouth reaf Boscastle, Falmouth (Holmes).

Stableria gracilis. On banks, Ardingly woods, Sussex (Davics IS70). Shaugh bridge, S. Devon (Holmes).

Pohlia cucullata. Kinder Scout, Derby (Whitchead, Holt, Dixon). coninutata. Helvellyn (Dixon I891).

Epipterygium Tozeri at p. 156 for Linde. l.c. read Linds. in Oefver. vet. ak. foerh. xxi, 577 (1864). N.E. Scotland (Fergusson).

Bryum concinnatum. Holwick Fell and High Force, Teesdale, Deepdale, and Wensleydale, Yorks. (Barnes). Far Easdale, Westmoreland, and rocks by the Wye, Aberedw, Radnor (Binstead I 893).

lacustre. Seaton Snook, Deepdale and Wensleydale (Barncs). Studland, Dorset (Mitten I893).

- calophyllnm. Seaton Snook and Lockwood beck, N. Yorks. (Bamucs).

rubcus. Salcey, Northants (Diton I893).

Mildci. Far Easdale (Di.run I8gr), rocks by a stream near Aber, N. Wales (1892), and Ben Lawers (I\$93). B. cavifolium. TAYL. MSS. must be added as a synonym.

alpinum Var. meridiouale. Kisdon Force (Barnes).

Duvalii. Quiraing, Skye (Dixon I893).

Conostomum boreale. Helvellyn (Dixon 1891).

Philonotis fontana Var. capillaris Lodore falls (Dixon I8gr), Staffin, Skye (1893). 



\section{N D E X.}

Amblyodon $P . B . \quad$. . . PAGE dealbatus (Dicks.) P. B. T. LXIV. 125

Anoectangium Hedro. . . . 55 Lapponicum Hedw. . . LIII. ${ }_{56}$

Mougeotii (Bruch) Lindb. . $\quad-\quad 57$

Barbula icmadophila Schpr. LXXXIV. 253

Bartramia Hedw. . . . 203

ithyphylla Brid. . . . . LXXVI. 207

norvegica (Gunn.) Lindb. . $\quad-206$

Oederi (Gunn.) Sw. . . . $\quad-203$

pomiformis (L.) Hedw. . . $\quad-205$

Var, crispa (Sw.) . . 206

stricta Brid. . . . LXXVII. 204

Breutelia Schimp. . . . 215

chrysocoma (Dic.bs.) Lindb. LXXVIII. -

Bryum Dill.. . . . . . 159

affine (Bruch) Lindb. . . LXXI. I72

Var. cirratum (Hsch.) . -

alpinum Huds. . . . . . LXXIII. 182

Var. meridionale Schimp . 183

— viride Husn. . . . 254

argenteum $L . \quad$. . . LXXII. I75

Var. majus $B . S . \quad$. . $\quad{ }_{176}$

- lanatum $(P . B$.$) . . -$

barbatum Wils. . . . LXXV. 194

bicolor Dicks. . . . . LXXII. I77

Var. gracilentum $T a y l . \quad$. $\quad{ }_{178}$

bimum Schreb. . . . LXXI. I7I

cæspiticium $L . \quad$. $\quad$. $\quad-\mathrm{I}_{74}$

Var. Kunzei $(H s c l$.$) . \quad 175$

- badium (Bruch) Brid. $\quad 196$

calophyllum $R . B r . \quad$. . LXX. I68

capillare $L . \quad$. . . . LXXIV. Igo

Var. macrocarpum $H u \varepsilon b . ~ . \quad$ IgI

- rosulatum Mitt.

— flaccidum Schimp.

- Ferchelii $\left(r_{u n c k}\right)$ B. S.

- obconicum (Hsch.) Hucb. elegans Necs.

cernutun (Sw Lindb. . . LXX. 167

concinnatum Spruce . . LXIX. I62

cyclophyllum (Schwacg.) B. S. LXXV. I89

Donii Grev. • • • • • - I92

Duvalii Voit • . . . LXXIII. I85

erythrocarpon Schwaeg. . LXXII. ${ }_{17} 8$

fallax Milde • • • . $\quad$ - 169 filiforme Dicks. PAGE

gemmiparum $D e$ Not. . . . LXXIII. I8I

inclinatum (Swo.) Bland. . LXIX. I64

intermedium Brid. . . LXX. I70

juliforme (Solnus) Schimp. . LXXV. 19j

lacustre (Bland.) Brid. . . LXIX. I63

Marratii Wils. • . . LXX, 168

Mildei fur. . . . . . LXXIII. I80

Muehlenbeckii B.S. . . . $\quad$ I8ז

murale Wils. $\quad$. . . LXXII. I79

Neodamense Itzig. . . . LXXIV. I88

pallens $S w . \quad . \quad$. . . .LXXIII. I $\delta_{4}$

Var. speciosum (Voit) Schp.

pallescens Schleich. . . LXXI. I73

Var. contextum (Hsch.) . $\quad 174$

pendulum (Hsch.) Schimp. . LXX. 165

proliferum (L.) Sibth. . . LXXV. I94

provinciale Phillib. . . . $\quad-\quad$ I93

purpurascens $(R . B r) B . S$. LXXII. I6

rubens Mitt. . . . . .LXXIII. I80

torquescens $B . S . \quad$. . . LXXI. I73

turbinatum (Hed.) Schwgn. . LXXIV. I86

Var. latifolium (Schleich.).

ventricosum Dicks. . . . $\quad$ - 187

Var. compactum B.S. . $\quad 188$

Warneum Bland. . . . LXX. 166

Catharinea Hausknechtii (Firr.

Milde) Broth. . . . LXXXIV. 25I

Catoscopium Brid. . . . 216 nigritum (Heil.) Brid. . LXXVII. -

Cinclidium Swart\%. . . . 249 Stygium $S$ w. . . . LXXXIII.

Cinclidotus riparius (Host) Arnl. LXXXIV. 253

Conostomum Swartz. . . . 201 boreale $S w . . \quad . \quad$. LXXVI. 202

Coscinodon Spreng. . . . 50 cribrosus (Hed.) Spruce . LIII. 5 I

Dicranum undulatum Eler. . LXXXIV. 252

Discelium Brid. . . . . . 123 nudum (Dicks.) Brid. : . LXIV.

Ditrichum zonatum (Brid.) Limpr. $\quad 25 \mathrm{I}$

Epipterygium Lindb. . . . . $\quad{ }_{156}$ Tozeri (Grev.) Lindb. . . . LXVIII.

Funaria Sclereb. . . . . $\quad$ I30 attenuata (Dicks.) Lindb. . LXV. 133 
calcarea Wahlcu. • ～LXV. 134

Var. patula $B . S$. . . _ _

fascicularis (Dicks.) Schp. . _ - $\quad$ I32

hygrometrica $(L$.$) Sibth. . \quad-\quad$ I35

Var. patula $B . S . \quad$. . 136

- calvescens (Schwgn.) Schp. $\quad$ I 37

microstoma B.S. ․ . _ - 135

obtusa (Dicks.) Lindb. . _ _ I3I

Glyphomitrium Brid.

Daviesii (Dicks.) Brid. . • 52

polyphyllum (Dicks.) Mitt. • — $\quad 53$

Saxicola $(W . M$.$) Mitt. \quad$. $\quad-\quad 54$

Grimmia Ehrh

acicularis $(L) C .$.$M .$

Var. denticulata $B$. S.

affinis (Schl.) Lindb.

Var. gracilescens (B. S.) Lindl.

alpestris Schleich. . . XLIX

anodon B.S. . . . XLVI.

apocarpa (L.) $\mathrm{Hcd}$. . . XLVI.

Var, alpicola Sw.

- - rivularis (Brid.) W. M.

- gracilis (Schl.) W.M.

_ pumila Sclip.

aquatica (Bricl.) C. M. . .

atrata Mielicll.

campestris Burch.

canescens (Timm) C. M.

Var. ericoides (Sclirad.) C. $M$.

conferta Funck . . . XLV

Var. pruinosa (Wils.)

crinita Brid. . . . . XLVII.

decipiens (Schultz) Lindb. . XLIX. 22

Var. robusta Ferg. . . $\quad 23$

Donii Sm. . . . . . - 24

Var. sudetica (Spreng.) . $\quad 25$

elatior Bruch. . . . . - 23

elliptica (Turn.) Arn. . . L. L. 35

elongata Kaulf . . XLVII. 30

fascicularis (Schrad.) C. M. . LII. 45

funalis (Schwg.) Schp. . . XLVII. I3

Hartmani Schp. . . .XLVIII, 20

heterosticha (Hed.) C. M. . LII. 43

hypnoides (L.) Lindb. . . - 47

incurva Schwg. . . . XLVII. I2

maritima Turu. . . . XLVI. Io

microcarpa (Gmel.) Lindb. .XLVIII. 3 I

montana B.s. . . . XLIX. 27

Muehlenbeckii $S c h p . \quad$. .XLVIII. I5

obtusa ( $\mathrm{Sm}$.) Lindl. . . LI. 40

Var. subsimplex Lindb. . $\quad 4$ I

orbicularis Brucl . . . . $\quad$ - 18

ovalis (Hed.) Lindb. . . . L. 29

Var.cylindrica (Hsch.) Hueb.

ovata Web. Mohr. .

L. 28

patens (Dicks.) B.S. . . . LI. $3^{6}$ pulvinata (L.) Sm. . .XLVIII. I7

Var. obtusa (Brid.) Hueb. I 8

ramulosa Lindb. . . . LI. 44

Stirtoni Sclp. . . . XLVII. I5

subsquarrosa Wils. . . XLIX. $2 \mathrm{I}$

Var. Edinensis $(F c r g$.$) . 22$

torquata $H$ sch. . . . XLVII. 14

trichophylla Grev. . . XLVIII. I9

unicolor Hook. . . . . L. 34

Gymnocybe Fries. . . . . 227

palustris (L.) Frics. . . LXXX. 228

Var. imbricata (Br.Sch.) . $\quad 229$

- fascicularis (Brid.) . -

-Cramosa (Huds.) . . . -

turgida (Wahlenb.) Linab. . _ $\quad-230$

Leptobryum Wils. . . . 142

pyriforme (L.) Wils. • . LXVI. -

Meesea $H c d w . \quad$. . . . 221

trichodes (L.) Sprucc . . LXXIX. --

Var. alpina (Funck.) . . 222

- miror (Brid.) . . -

Mnium Dill. L. . . . . . . 234

cinclidioides $(B / y t t) H. u \omega^{\prime}$. LXXXII. 246

cuspidatum $L . \quad$. . . $\quad$ 24I

Var. elatum (B.S.) . . $\quad 242$

- rugicum (Laur.) . -

hornum $L . \quad$. . . . $\quad-238$

marginatum (Dicks.) P. B. . LXXX1. 236

orthorrhynchum $B$.S. . . - 238

pseudopunctatum $B$. S. LXXXIII. 247

punctatum $L . \quad$. . . $\quad-247$

Var, elatum Schp. . . . 248

riparium Mitt. . . . LXXXI. 237

rostratum Schrad. . . . - 244

Seligeri $f u r . . \quad$. . LXXXII. $24 \mathrm{I}$

silvaticum Lindb. . . . .LXXXI. 240

spinosum (Voit) Schwg. . _ _ 235

stellare Reich. . . LXXXII. 245

undulatum $L . \quad$. . LXXXIII. 243

Mollia brevifolia (Sendtn.)

Braithe. . . . LXXXIV. 252

Nanomitrium Lindb. . . . 126 tenerum (Bruch) Lindb. . LXIV. -

Oedipodium Schrog. $\quad$. . . . II9 Griffithii (Dicks.) Schag. . LXIII. -

Oreas Brid. . . . . . . . $\quad 139$

Mielichhoferi (Funck) Brid. .

Orthopyxis P. B. . . . . 23I

androgyna (L.) P.B. . . LXXX. -

Orthotrichum $\mathrm{Hed}$. . . . . $6_{5}$

affine Schrad. . . LV. $7^{\mathrm{I}}$

Var. rivale Wils. . . . $\quad 72$ 
Var. fastigiatum (Bruch)

Hnsch. $\%$. , .

anomalum $\mathrm{Hed}$.

Var. cylindricum Schp. . $\quad 80$

cupulatum Hoffm. $\quad$. $\quad$ LVI. 77

Var. nudum (Dicks.) • 78

diaphanum Schrad. . . $\quad-76$

Lyellii $H k . T . \quad$. . . . $\quad-75$

obtusifolium (Schrad.) . . LV. 67

pallens Bruch . . . LVIII. 85

pulchellum Brunt. . . - 87

rivulare Turn. . . . LVII. 80

rupestre Schleich. . . . . LV. 68

Var. rupincola (Funck) Hnsch. $\quad 69$

- Sturmii (Hnsch.) Fur.

Schimperi Hamm.

LVII. 84

Shawii Wils. $\quad . \quad$. . LV, 70

speciosum Nees. . . . LVI. 73

Sprucei Biont. . . . LVII. 8 I

stramineum Husch. . . . $\quad-\quad 82$

Var. patens (Bruch) Vent. . $\quad \delta_{3}$

striatum (L.) Hed. . . LVI. 74

tenellum Bruch. . . . LVIII. 86

PaIudeIIa Ehrh. . . . . . 223 squarrosa Brid. . . . LXXIX. -

Philonotis Brid. .

adpressa Ferg.

crespitosa Wils.

calcarea Schp.

fontana (L.) Brid..

Var. falcata Brid.

- capillaris Lindb.

- compacta Schp.

rigida Brid. .

seriata Mitt.

Wilsoni (B.S.)

$\begin{array}{cc}\cdot & 208 \\ \text { LXXVIII. } & 2 \mathrm{I} 4 \\ \text { LXXVII. } & 2 \mathrm{IO} \\ \text { LXXVIII. } & 2 \mathrm{I} 3 \\ \cdot \quad- & 2 \mathrm{II} \\ \cdot & 2 \mathrm{I} 2 \\ \cdot & - \\ \text { LXXVII. } & 209 \\ \text { LXXVIII. } & 212 \\ \text { LXXVII. } & 208\end{array}$

Physcomitrella $B . S$. . . . . $\quad$ I27 patens (Hed.) B.S. . . LXIV. Var. Lucasii (Nees Hsch.) . -

Physcomitrium Bril. . . . $\quad 128$ pyriforme (L.) Brid. . . . - 129 spharicum (Ludw.) Brid. . _ - 128

PIagiobryum Lindb. demissum (Hsch.) Lindb. . LXIX. 158 Zierii (Dicks.) Lindb. . . - 157

Pleurozygodon Lindb. • • • LIV $\quad 5^{8}$ æstivus (Hedzo) Lindb. • LIV. Var. pellucidus (Wils.) • $\quad 59$

Pohtia Hedre. $\quad$. $\quad$. $\quad$. $\quad$. acuminata $H s c h . \quad$. . . LXVI. I44 albicans (Wahlcn.) Lind. . LXVIII. I55 Var. glacialis (Schlcich annotina (L.) Lindb. Var. tenuifolia Scinp. . LXVII. I5I - angustifolia Schp

69

osmundacea (Dicks.) Mohr. . LX. -

Splachnum $(L$.$) . . . . IO7$

ampullaceum $L$. . . $\quad$ LXI. 108

pedunculatum ( $\mathrm{H} u d$ s.) Lindb. $\quad$ - Iog

Var. sphæricum Swartz . IIO

vasculosum $L$. . . . . $\quad$ - $\quad$ I0g

StabIeria Lindb. . . . $\quad$ I 40 gracilis (Wils.) Lindb. . . LXVI. I4I

TayIoria, Hook. . . . . II3 tenuis (Dicks.) Schp. . . LXII. II4 lingulata (Dicks.) Lindb. ․ - $\quad$ II5

TetrapIodon $B$. S. . . . III bryoides (Zoega) Lindb. $\quad$. - Var. Breweri $(H c d w$.$) . \quad$ II2

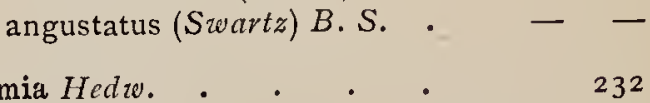

$\begin{array}{ccccc}\text { Timmia Hedw. } & \cdot & \cdot & \text { - } & 232 \\ \text { austriaca Hedw. } & \cdot & \cdot & \text { LXXX. } & 233\end{array}$ Norvegica $Z$ ett. . . . . $\quad$ - -

Weissia Ehrh. . . . . $\quad 88$ Americana $(P . B$.$) Lindb. . LVIII. 89$ Bruchii (Hsch.) Lindb. . . LIX. 92 calvescens (Wils.) Braithw. . - 95 coarctata (P.B.) Lindb. . LVIII. go Drummondii (Hk. Grcv.) Lindb. . . . . LIX. gI phyllantha (Brid.) Lindb. . - 96 ulophylla Ehr. . • • $\quad$ - 93 Var. intermedia (Schp.) . 94 crispula (Bruch) Hamm.

Zygodon $H k . T$. . $\quad$. $\quad$. $\quad$ • 59 conoideus (Dicks.) H. T. . LIV. 62 Forsteri (Dicks.) Mitt. . - $\quad-63$ gracilis Wils..$\quad$. $\quad . \quad-64$ Stirtoni Schpr. . . . $\quad-60$ viridissimus (Dicks.) Brown. $\quad-6$ I Var. rupestris Lindb. $\quad 62$ 



\section{CLASSIFIED LIST OF SPECIES.}

Fam. Io. GRIMMIACEA.

Subf. I. Grimmiece.

Grinima Elirh.

$\S$ I. Schistidium.

1. G. conferta Funck.

$\beta$. pruinosa Wils.

2. G. apocarpa (L.) Hedve.

$\beta$. alpicola (Sw.)

$\gamma$. rivularis (Brid.) W. M.

ס. gracilis (Schleich.) IV. M.

є. pumila Schimp.

3. G. maritima Tum.

$\S 2$. Eugrimmia.

4. G. anodon $B v$. Sch.

5. G. crinita Brid.

6. G. incurva Schwaeg.

7. G. funalis (Schwg.) Schimp.

8. G. torquata Homisch.

9. G. Stirtoni Schimp.

10. G. Muehlenbeckii Schimp.

11. G. pulvinata (L.) $S m$.

B. obtusa (Brid.) Hucb.

12. G. orbicularis Bmch.

13. G. trichophylla Grev.

14. G. Hartmani Schimp.

15. G. subsquarrosa Wils. B. Edinensis (Fcrg.)

16. G. decipiens (Schullz) Lindb. B. robusta (Firg.)

17. G. elatior Bvuch.

18. G. Donii Sm. $\beta$. sudetica (Spreng.)

19. G. alpestris Schleich.

20. G. montana B.S.

21. G. ovata $W . M$.

22. G. ovalis (Hcdw.) Lindb. B. cylindrica $(H s c h) H u c$.$b .$

23. G. elongata Kanlf.

24. G. microcarpa (Gmel.) Lindl.

25. G. campestris Burch.
\$ 3. Dryptodon.

26. G. atrata Miclich.

27. G. unicolor Hook.

28. G. elliptica (Tum.) Avn.

29. G. patens (Dicks.) B.S.

4. Trichostomum.

30. G. acicularis $(L) C,$.$M .$ $\beta$. denticulata $B . S$.

31. G. aquatica (Brid.) C. $M$.

32. G. obtusa $(S m$.) Lindb. B. subsimplex Lindl.

33. G. affinis (Schlcich.) Lindb. ß. gracilescens (B. S.) Lindb.

34. G. heterosticha (Hedw.) C. $M$.

35. G. ramulosa $L$ indb.

36. G. fascicularis (Schrad.) C. $M$.

37. G. hypnoides $(L$. $) L i n d b$.

38. G. canescens (Timm) C. $M$. B. ericoides (Sclurad.) C. $M$. Coscinodon Spreng.

1. C. cribrosus (Hcdw.) Sprace. Glyphomitrium Brid.

1. G. Daviesii (Dichs.) Brid.

2. G. polyphyllum (Dicks.) Mitt.

3. G. saxicola (W. M.) Mitt.

Subf. 2. Orthotrichece.

Aniectangium Hedie'.

1. A. Lapponicum Hedw.

2. A. Mougeotii (Bnnch) Lindb.

PLEUROZYGoDon Lindb.

1. P. æstivus (Hedw.) Lindl. $\beta$. pellucidus (Wils.) ZYGODON Hk. T.

1. Z. Stirtoni Schimp.

2. Z. viridissimus (Dicks.) Brown. $\beta$. rupestris $L i n d$.

3. $\mathrm{z}$ conoideus (Dicks.) Hh. T. 
4. Z. Forsteri (Dicks.) Mitt.

5. Z. gracilis Wils.

Orthotrichum Hedw.

I. Gymmoporus.

1. 0. obtusifolium Schrad.

2. 0. rupestre Schleich.

B. Iupincola (Funck) Hucb.

$\gamma$. Sturmii (Hsch.) $\mathscr{f} u r$.

3. 0. Shawii Wils.

4. 0. affine Schrad.

$\beta$. rivale Wils.

$\gamma$. fastigia tum (Bruch) Hucb.

5. 0. speciosum Nees.

6. 0. striatum (L.) Hed.

7. 0. Lyellii $H k$. $T$.

§. Calyptoporils.

8. 0. diaphanum Schrad.

9. 0. cupulatum $H o f f m$. $\beta$. nudun Dicks.

10. 0. anomalum Hedw. $\beta$. cylindricum Schimp.

11. 0. rivulare Turn.

12. 0. Sprucei Mont.

13. 0. stramineum Hornsch.

$\beta$. patens (Bruch) Vent.

14. 0. Schimperi Hamm.

15. 0. pallens Bruch.

16. 0. tenellum Brnch.

17. 0. pulchellun Brint.

Weissia Ehrh.

1. W. Americana (P. Beanv.) Lindb.

2. W. coarctata (P. B.) Lindb.

3. W. Drummondii (Hk. Grev.) Lindb.

4. W. Bruchii (Homisch.) Lindb.

5. W. ulophylla Ehwh.

$\beta$. intermedia (Schimp.) $\gamma \cdot$ crispula (Bruch) Hamm.

6. W. calvescens (Wils.) Braith.

7. W. phyilantha (Bvid.) Lindb.

Fan. I . SCHISIOSTEGACEE.

Schistostega Mohr.

1. S. osmundacea (Dicks.) Mohr.

Fam. I2. SPLACHNACER.

Splachnum $L$.

1. S ampullaceum $L$.

2. S. vasculosum $L$.

3. S pedunculatum (IIuds.) Lindb. $\beta$. sphæricun Swartz.
Tetraplodon B.S.

1. T. bryoides (Zoega) Lindb.

$$
\beta \text {. Breweri (Hedw.) }
$$

2. T. angustatus (Swartz) B.S.

TAyloria Hook.

1. T. tenuis (Dicks.) Schp.

2. T. lingulata (Dicks.) Lindb.

Fan. r3. OEDIPODIACEE. Oedipodium Schwg.

1. 0. Griffithii (Dicks.) Schw.

Fam. $I_{4}$ FUNARIACEÆ.

Subf. I. Disceliea.

Discelium Brid.

1. D. nudum (Dicks.) Brid.

Subf. 2. Amblyodonter.

Amblyonon $P . B$.

1. A. dealbatus (Dicks.) P.B.

Subf. 3. Funariea.

NANOMITRIUM Lindb.

1. N. tenerum $(B r u c h) L i n d b$.

Physcomitrella $B . S$.

1. P. patens ( $F I c d w$.) B.S.

B. Lucasii (Nees Hsch.) Schimp.

Physcomitrium Brid.

1. P. sphæricum (Ludw.) Brid.

2. P. pyriforme (L.) Brid.

Funaria Schreb.

\$. Eniosthodon.

1. F. obtusa (Dicks.) Lindb.

2. F. fascicularis (Dicks.) Schp.

3. F. attenuata (Dicks.) Lindb.

4. F. calcarea Wahlcnb.

B. patula B.S.

5. F. microstoma $B . S$.

6. F. hygrometrica (L.) Sibth.

$\beta$. patula $B$. S.

$\gamma$. calvescens (Schrog.) Schp.

Fam. I5. BRYACERE.

Subf. I. Oreadea.

Oreas Brid.

1. 0. Mielichhoferi (Funck) Brid. B. compacta (Horlisch.) 
Subf. 2. Bryece.

Stableria Lindb.

1. S. gracilis (Wils.) Lindb.

LePTOBRyum Wils.

1. L. pyriforme (L.) Wils.

$$
\text { PoHlia Hedw. }
$$

1. P. acuminata $H s c h$.

2. P. polymorpha $I I s c h$.

$$
\begin{aligned}
& \beta \text {. brachyearpa } H \text { sch. } \\
& \gamma \text {. gracilis } H \text { sch. }
\end{aligned}
$$

3. P. elongata Hedw.

4. P. cruda (L.) Lind.

5. P. cucullata (Schwo.) Bruch.

6. P. nutans (Schreb.) Lindb.

$$
\begin{aligned}
& \beta . \text { longiseta (Brid.) } \\
& \gamma \text {. bicolor (Hoppe) Hsch. }
\end{aligned}
$$

\%. P. carnea (L.) Lind.

8. P. aunotina $(L) L i n d$.$b .$

$\beta$. tenuifolia Sclipr. $\gamma$ angustifolia Schpr.

9. P. Ludwigii (Spreng.) Lindb. $\beta$. latifolia Schimp.

10. P. commutata (Schinip.) Lindb.

11. P. gracilis (Schleich.) Lindb.

12. P. albicans (Wahlenb.) Lindb.

$\beta$. glacialis Schleich.

Eipipterygium Lindb.

1. E. Tozeri (Gvev.) Lindb.

$$
\text { Plagrobryum Lindb. }
$$

1. P. Zierii (Dicks.) Linảb.

2. P. demissum (Hsch.) Lindb.

$$
\begin{gathered}
\text { Bryum Dill. } \\
\S \text { I. Sclevodictyon. }
\end{gathered}
$$

1. B. filiforme Dicks.

2. B. concinnatum Sprnce.

3. B. juliforme (Solnns) Schpr.

$$
\text { §. Cladodium. }
$$

4. B. lacustre (Bland) Brid.

5. B. inclinatum $(S . W$.$) Bland.$

6. B. pendulum (Hsch.) Schimp.

7. B. purpurascens $\left(R . B v_{\text {. }}\right) B . S$.

8. B. Warneum Bland.

9. B. cernuum (Sw.) Lindb.

10. B. Marratii Wils.

11. B. calophyllum $R . B r$.

12. B. fallax Milde.
13. B. intermedium Brid.

14. B. bimum Schveb.

15. B. affine (Bvuch) Lindl. B. cirratum (Hsch.)

16. B. torquescens $B . S$.

17. B. pallescens Schleich. $\beta$. contextum (Hsch.)

18. B. cæspiticium $L$.
B. Kunzei (Hsch.) $\gamma$. badium (Bruch) Brid.

19. B. argenteum $L$.

ß. majus B.S. $\gamma$. lanatum (P.B.)

20. B. bicolor (Dicks.)
$\beta$. gracilentum Tayl.

21. B. erythrocarpon Schreg.

22. B. murale Wils.

23. B. rubens Mitt.

24. B. Mildei $\mathcal{f} u \%$.

25. B. Muehlenbeckii $B . S$.

26. B. alpinum Huds. ß. meridionale Schp. $\gamma$. viride Husn.

27. B. gemmiparum De Not.

23. B. pallens $S w$.
B. speciosum (Voit) Schp.

29. B. Duvalii Voit.

30. B. turbinatum (Hed.) Schwer. $\beta$. latifolium (Schleich.)

31. B. ventricosum Dicks. $\beta$. compactum $B$. S.

32. B. Neodamense Itzig.

33. B. cyclophyllum (Schwg.) B.S.

34. B. capillare $L$.
$\beta$. macrocarpum $H u \in b$.
$\gamma$. rosulatum Mitt.
$\delta$. flaccidum $S c h p$.
€. Ferchelii (Funck) B. S.
ל. obconicum (Hsch.) Hueb. $\eta$. elegans Nees.

35. B. barbatum Wils.

36. B. Donii Grev.

37. B. provinciale Philit.

38. B. proliferum (L.) Sibth.

Fam. I6. BARTRAMIACEA.

Subf. I. Bartramiere.

Conostomum Ste.

1. C. boreale $S w$.

Bartramia Hcdw.

§. Oreadella.

1. B. Oederi (Gumm.) Sw. 
§2. Enbartramia.

2. B. stricta Brid.

3. B. pomiformis (L.) Hedw. B. crispa Sw.

\$ 3. Vaginella.

4. B. norvegica (Gunn.) Lindb.

5. B. ithyphylla $B$ rid.

Philonotis Brid.

$\S$ I. Plitlonotula.

1. P. Wilsoni (B.S.)

2. P. rigida Brid.

$\S 2$. Euphilonotis.

3. P. cæspitosa Wils.

4. P. fontana (L.) Brid. $\beta$. falcuta Brid. $\gamma$. capillaris $L$ ind $b$.

5. P. seriata Mitt. ס. compacta Schpr.

6. P. calcarea Schpr.

7. P. adpressa Fergus.

Breutelia Schimp.

1. B. chrysocoma (Dicks.) Lindb.

Subf. 2. Catoscopiere

Catoscorium Brid.

1. C. nigritum ( $H e d$.) Brid.

Fam. I7. MEESEACEÆ.

Meesea Hedw.

1. M. trichodes (L.) Spruce.

$\beta$. alpina (Funck).

$\gamma \cdot \operatorname{minor}($ Brid.)

Paludella Ehrh.

1. P. squarrosa (L.) Brid.

Fann. I8. MNIACEA.

Subf. I. Gymnocyber.

GrMNocyb Fries.

1. G. palustris (L.) Fries.

$\beta$. imbricata (B. S.) Lindb.

$\gamma$. fascicularis (Brid.) Lindb.

o. ramosa (Huds.) Lindb.
2. G. turgida (Wahlen.) Lindi.

ORTioprixis $P . B$.

1. 0. androgyna (L.) P. B.

Subf. 2. Timnirece.

Trmmia Hedw.

1. T. austriaca Hedw.

2. T. norvegica $Z$ ett.

Subf. 3. Mnice.

MniUm Dill. $L$.

1. M. spinosum (Voit) Schwaeg.

2. M. marginatum (Dicks.) P. B.

3. M. riparium $M$ itt.

4. M. orthorrhynchum B.S.

5. M. hornum $L$.

6. M. silvaticum $L i n d b$.

7. M. Seligeri $f u r$.

8. M. cuspidatum (L.) Neck.

$\beta$. elatum $B$. S.

$\gamma$. rugicum Laur.

9. M. rostratum Schraai.

10. M. undulatum $L$.

11. M. stellare Reich.

12. M. cinclidioides (Blytt.) Hueb.

13. M. pseudopunctatum $B$. $S$.

14. M. punctatum $L$.

$\beta$. elatum Schimt.

Cinclidium Swartz.

1. C. stygium Swartz.

\section{A D D E N A.}

2.* Catharinea Hausknechtii ( $f u$. Milde) Broth.

Ditrichum zonatum (Brid.) Limpr.

14." Mollia brevifolia (Sendtn.) Braithw.

9.* Barbula icnadophila Schpr.

2. Cinclidotus riparius (Host) A $\mathrm{m}$. 



Date Due

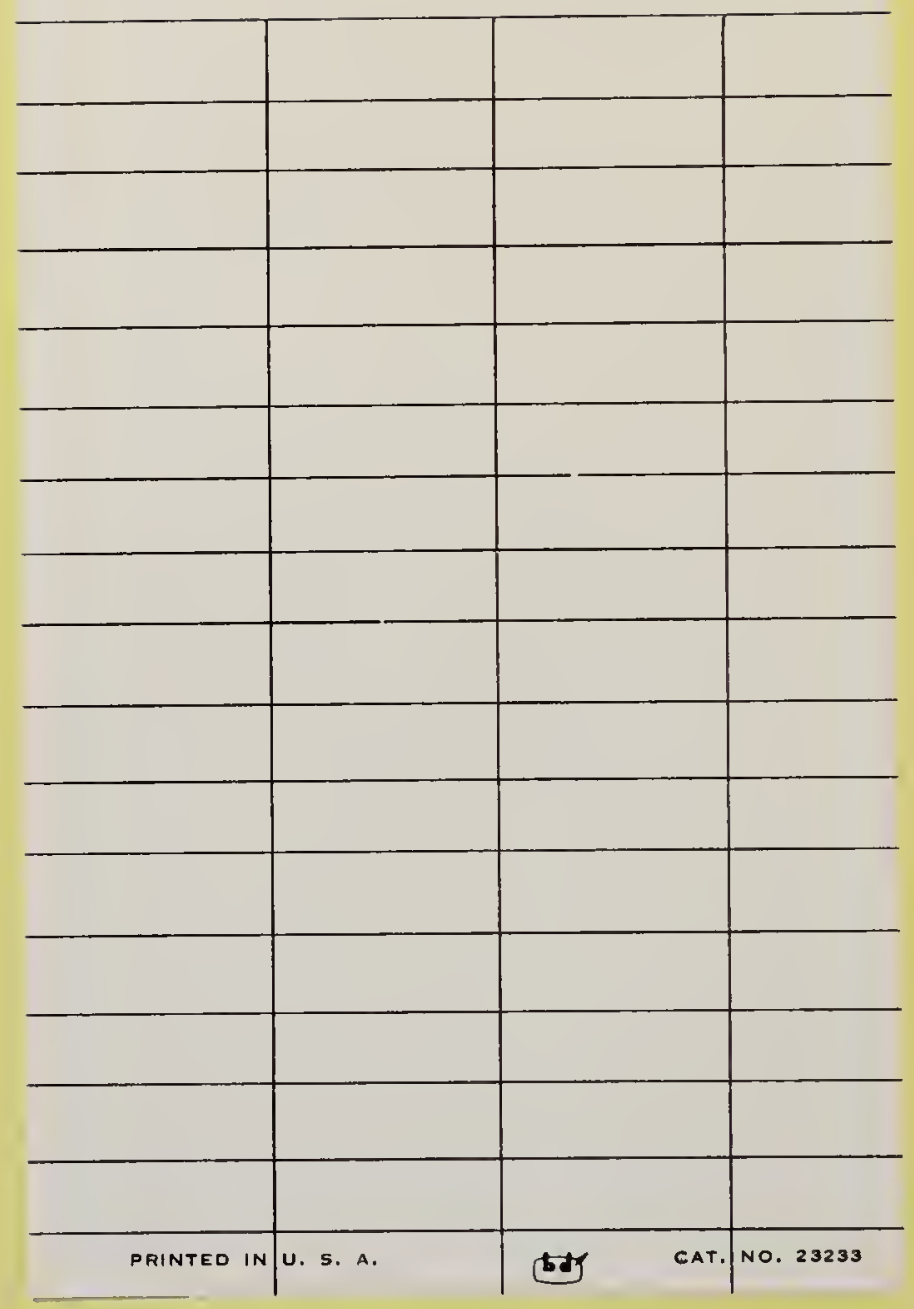




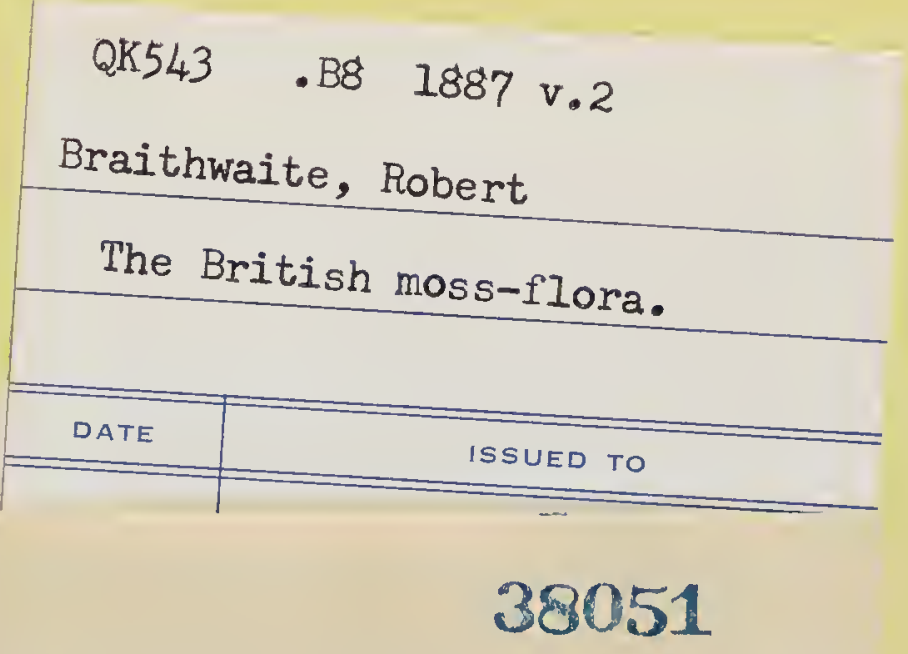


